VICTOR BORGES POLIZELLI

\title{
O PRINCÍPIO DA REALIZAÇÃO DA RENDA E SUA APLICAÇÃO NO IMPOSTO DE RENDA DE PESSOAS JURÍDICAS
}

Faculdade de Direito da Universidade de São Paulo São Paulo - 2009 


\title{
O PRINCÍPIO DA REALIZAÇÃO DA RENDA E SUA APLICAÇÃO NO IMPOSTO DE RENDA DE PESSOAS JURÍDICAS
}

\begin{abstract}
Dissertação apresentada como requisito para habilitação ao título de Mestre em Direito, sob a orientação do Prof. Dr. Luís Eduardo Schoueri, na subárea de Legislação Tributária, integrada ao Departamento de Direito Econômico e Financeiro da Faculdade de Direito da Universidade de São Paulo.
\end{abstract}

Faculdade de Direito da Universidade de São Paulo São Paulo - 2009 
DEDICATÓRIA

Para Juliana.

Dedico-lhe esta obra, com muito amor, como forma de retribuição mínima pela paciência e apoio incondicional. 


\section{AGRADECIMENTOS}

A Brandão Machado, por seu exemplo de dedicação, rigor e simplicidade. Sem seu auxílio e orientação, esta obra não teria sido possível. Ao anfitrião daquilo que ele mesmo chamava de "festa" do Direito Tributário, agradeço pela paciência por me buscar na porta e me apresentar à maior parte dos integrantes dessa festa, nas diversas tardes em que caminhamos juntos. Seu lugar na porta jamais será substituído à altura. Seu lugar na festa, ao lado de outros grandes estudiosos, certamente está garantido. À família de Brandão Machado e especialmente a Helena, sua esposa, por prolongar a vida de um ser humano sensacional e permitir nossa convivência.

A Luís Eduardo Schoueri, agradeço por todas as oportunidades concedidas, pela orientação constante, pelos diferentes desafios propostos ao longo dos últimos anos e pela amizade. Sua incansável busca pela excelência e pelo enriquecimento do Direito Tributário no Brasil é motivo de inspiração.

A Fernando Zilveti, influência direta no desenvolvimento do tema deste trabalho e também exemplo de dedicação profissional e acadêmica.

Agradecimentos especiais também aos meus tutores na vida profissional. A Fábio Piovesan, pelos primeiros passos na área tributária. A Henrique Lopes, especialmente, pelo suporte e estímulo irrestritos. A Carlos Toledo, pela revisão geral do texto, pelas críticas e pelo auxílio nos tortuosos caminhos da Contabilidade.

Aos Rotary Clubes de Ilha Solteira e Wil, por me permitirem engrandecer e conhecer amigos maravilhosos.

Agradeço, de coração, a meus pais, Marli Ribeiro Borges e Edwaldo Polizelli, e a minha família. Pais que nunca colocaram barreiras ao desenvolvimento de seus filhos e que, até mesmo por isso, não têm a felicidade de os ter por perto constantemente. 


\section{RESUMO}

No contexto do sistema tributário nacional brasileiro, uma apuração correta da renda tributável demanda o respeito a princípios abrigados pela Constituição Federal expressa ou implicitamente e, dentre estes, vale citar o princípio da realização da renda que, numa descrição simplificada, auxilia na deteç̧ão da capacidade econômica apta a sofrer tributação, uma vez que delineia diretrizes mais concretas para a identificação do momento adequado para que tal tributação se implemente. Este estudo enfoca o momento temporal em que se consideram ocorridos os fatos econômicos individuais que se ajuntam para compor a apuração da renda tributável. Não se trata, portanto, de uma abordagem direta acerca do aspecto temporal próprio da regra-matriz de incidência do imposto de renda, aquele que se identifica normalmente com o término do período de um ano. O tema é abordado com enfoque na tributação da renda, apresentando parâmetros para a conceituação do referido princípio e buscando delinear suas funções, bem como descrever seu âmbito de aplicação no Direito Tributário brasileiro, especialmente no que concerne à apuração do imposto de renda (sobretudo o de pessoas jurídicas). O princípio da realização é examinado sob três diferentes perspectivas. Primeiro, faz-se uma análise dos conceitos de renda (e noções correlatas de realização) fornecidos pelas ciências financeiras $e$ econômicas. Segundo, há uma análise sob a perspectiva histórica que apresenta a evolução deste princípio na Alemanha, nos E.U.A., no Reino Unido e também no Brasil. E, por fim, sob a perspectiva estritamente jurídica, enfocando-se o sistema normativo atualmente vigente no Brasil, discutem-se a posição sistêmica do princípio da realização e as limitações impostas pela Constituição Federal de 1988 e pelo Código Tributário Nacional. Ainda nesta última perspectiva, avaliam-se as funções desempenhadas pelo princípio da realização como integrante dos princípios de contabilidade geralmente aceitos e as relações entre Direito Contábil e Direito Tributário. O princípio da realização é examinado em seus diferentes elementos (cumprimento da obrigação, mudança da posição patrimonial, troca no mercado, mensurabilidade, liquidez e certeza). Por fim, propõe-se uma estrutura para classificação dos diferentes critérios que informam o princípio da realização à luz da legislação brasileira.

Palavras-chaves: 1. Direito tributário - Imposto de Renda. 2. Imposto de Renda - Direito tributário. 3. Imposto de Renda das Pessoas Jurídicas - Direito comparado. 4. Imposto de Renda - Princípio da realização da renda. 5. Renda - Princípio contábil. 6. Direito tributário comparado - Realização da renda. 


\begin{abstract}
In the context of the Brazilian tax system, a correct calculation of taxable income demands respect for the principles sheltered, expressly or implicitly, by the Federal Constitution and, among these, it is worth mentioning the realization principle. In a simplified description, said principle helps in the detection of the economic capacity that is able to suffer taxation, since it outlines more specific guidelines for identifying the right time where taxation may be implemented. This study focuses on the timing of the economic facts that are gathered up to comprise the basis for calculation of the taxable income. It is not, therefore, a direct approach on the temporal aspect of the basic rule of incidence of income tax (aspect which is usually identified with the end of the taxable period of one year). The issue is discussed with focus on taxation of income, showing parameters for the conceptualization of realization principle and seeking to outline its functions, as well as to describe its scope within the Brazilian Tax Law, especially on what concerns the calculation of the income tax (especially the corporate income tax). The realization principle is examined from three different perspectives. First, the study presents an analysis of the concepts of income (and related notions of realization) provided by the financial and economic sciences. Second, there is an analysis on the historical perspective that presents the evolution of this principle in Germany, the USA, the UK and also in Brazil. Finally, under a strictly legal perspective, focusing on the regulatory system currently in force in Brazil, it discusses the systemic position of the realization principle and the limitations imposed by the Federal Constitution of 1988 and the National Tax Code. With respect to the latter perspective, the study examines the functions performed by the realization principle as part of the generally accepted accounting principles and the relations between Accounting and Tax Law. The realization principle is examined in its different elements (achievement of the obligation, change in the property position, market exchange, measurability, liquidity and certainty). Finally, it proposes a structure for the classification of the different criteria that inform the realization principle in accordance with the Brazilian legislation in force.
\end{abstract}

Keywords: 1. Tax Law -Income Tax. 2. Income Tax - Tax Law. 3. Corporate Income Tax - Comparative Law. 4. Income Tax - Realization principle. 5. Income - Accounting Principle. 6. Comparative Tax Law - Income realization. 


\section{O Princípio da Realização da Renda}

\section{e sua Aplicação no Imposto de Renda de Pessoas Jurídicas}

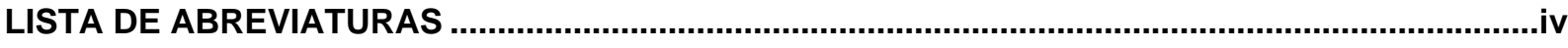

INTRODUÇÃO

CAPÍTULO 1 - EVOLUÇÃO E DEMARCAÇÃO DO PRINCÍPIO DA REALIZAÇÃO DA RENDA ....... 10

1. Aspectos gerais do princípio da realização da renda .................................................. 10

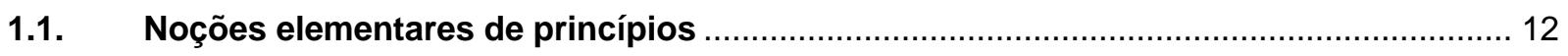

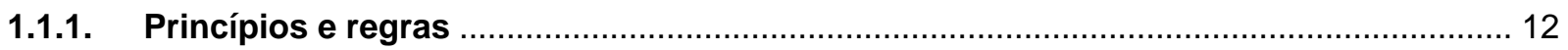

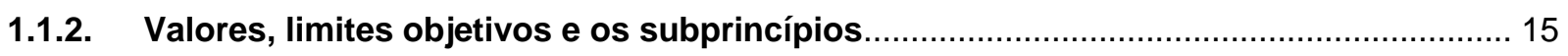

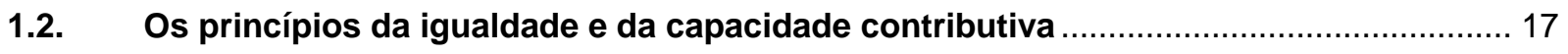

2. Conceitos de renda e noções correlatas de realização..................................................... 22

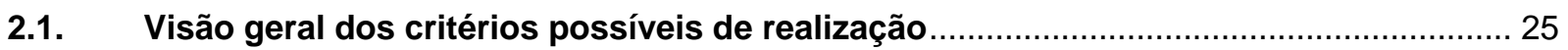

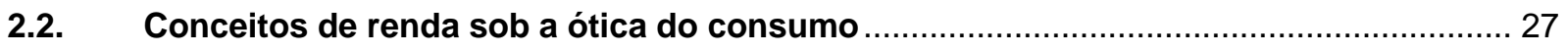

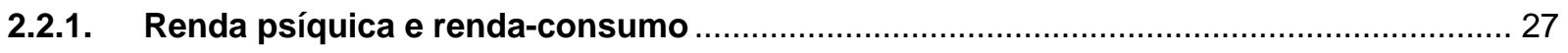

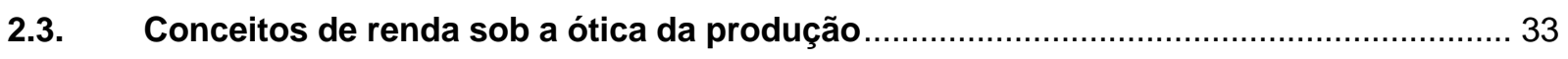

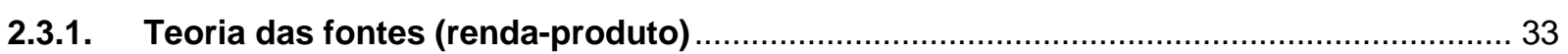

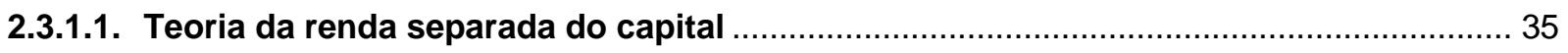

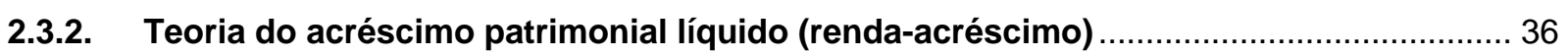

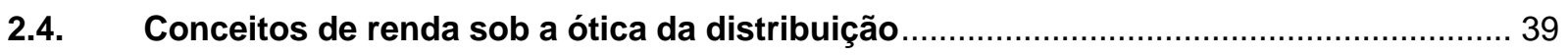

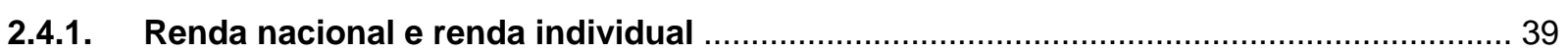

2.5. Restrições práticas à adoção de conceito abrangente de renda ................................... 40

3. Apontamentos sobre o princípio da realização da renda no direito comparado ............ 45

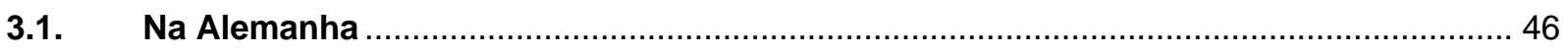

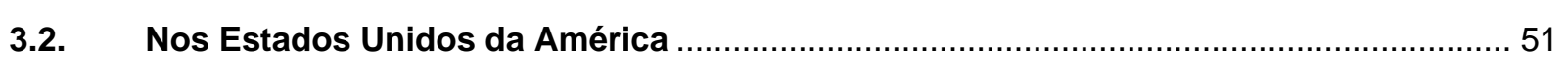

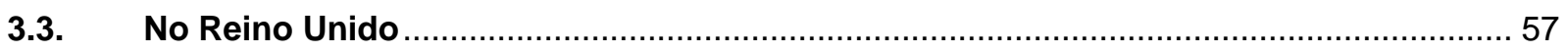

4. Breve histórico da evolução do princípio da realização da renda no Brasil.................... 63

CAPÍTULO 2 - O PRINCÍPIO DA REALIZAÇÃO DA RENDA NA CONSTITUIÇÃO FEDERAL E

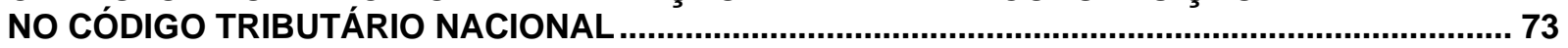

1. O princípio da realização da renda no sistema constitucional tributário......................... 73

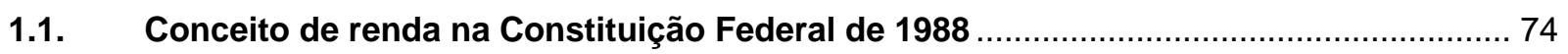

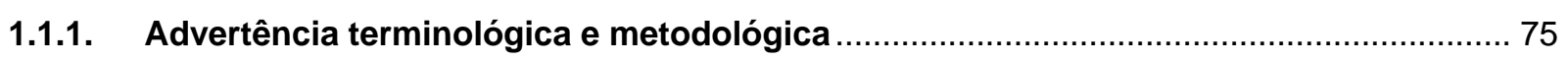

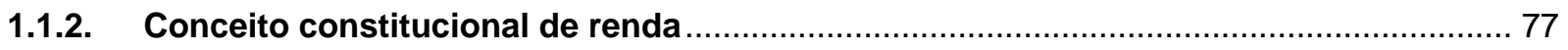

1.2. Princípios determinantes para a apuração da renda realizada ........................................ 85

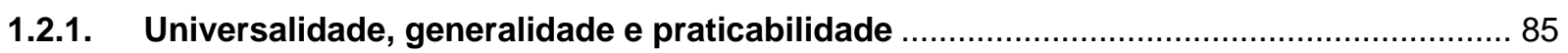

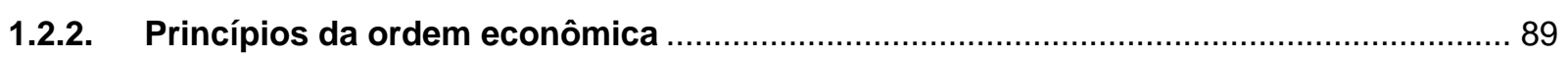

1.2.3. Monetarização, apuração periódica e renda líquida .................................................. 90

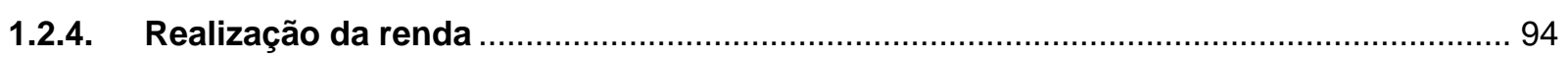

1.3. Conceito constitucional de renda conforme a visão do STF ...................................... 98

2. O princípio da realização da renda no Código Tributário Nacional ................................ 101 
2.1. Conceito de renda no Código Tributário Nacional.................................................. 102

2.2. Conceito de realização no Código Tributário Nacional .................................................. 107

2.2.1. As disponibilidades jurídica, econômica ou financeira ............................................. 108

2.2.1.1. Regimes de competência e caixa na legislação tributária ............................................ 113

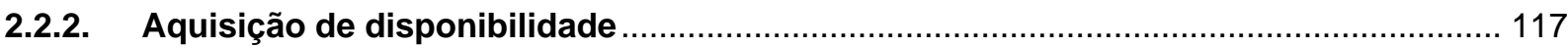

2.3. Artigos 109, 110, 116 e 117 e as relações com o Direito Civil...................................... 121

CAPÍTULO 3 - O PRINCÍPIO CONTÁBIL E TRIBUTÁRIO DA REALIZAÇÃO DA RENDA ............. 126

1. Visão geral da influência do Direito Contábil no Direito Tributário ............................... 129

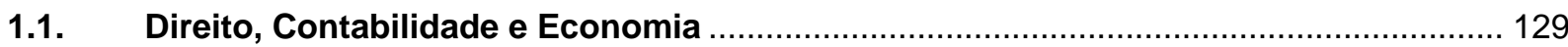

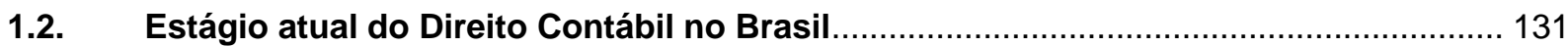

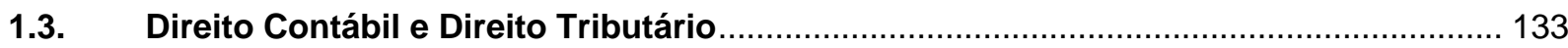

1.3.1. Princípio da congruência com os parâmetros contábeis ............................................. 134

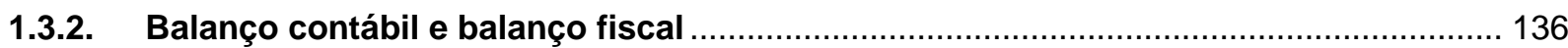

2. Princípios de contabilidade geralmente aceitos (PCGA) ........................................... 139

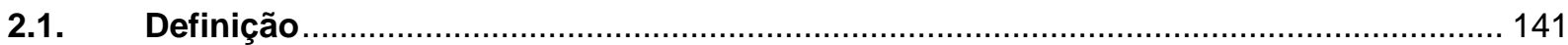

2.2. Objetivos vinculados à elaboração de demonstrações financeiras ............................... 144

2.3. Previsão legal e regulamentação dos PCGA no Brasil .............................................. 147

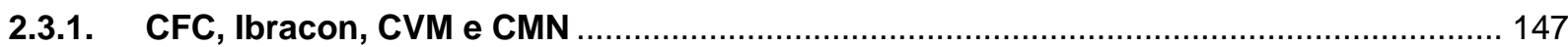

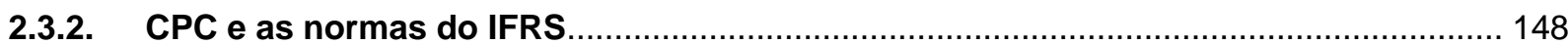

2.4. Princípios contábeis orientadores do princípio da realização ....................................... 149

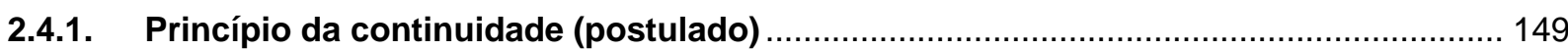

2.4.2. Princípio da prudência (convenção do conservadorismo) ............................................. 150

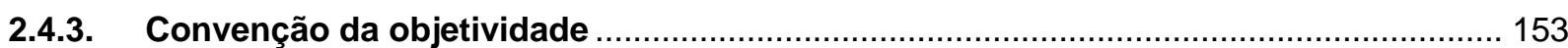

3. Fundamentos do princípio da realização da renda..................................................... 154

3.1. Reconhecimento do princípio no Direito Contábil ......................................................... 154

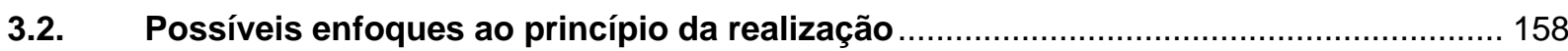

3.2.1. Enfoque no acréscimo de valor $x$ enfoque no evento crítico ....................................... 159

3.2.2. Enfoque no conservadorismo $x$ enfoque na apuração periódica ................................... 162

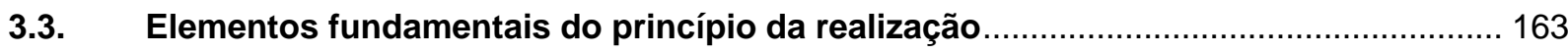

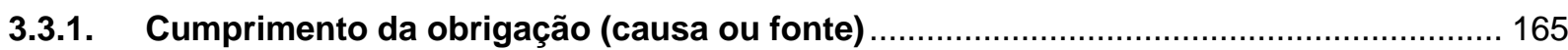

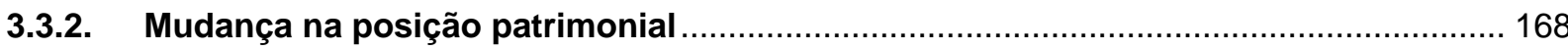

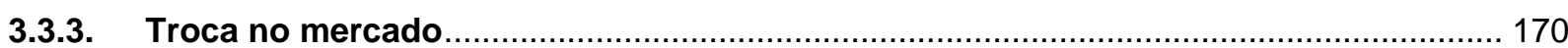

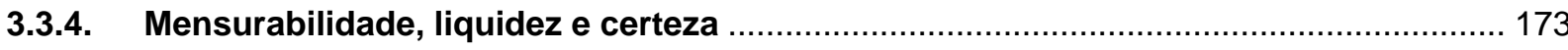

3.4. Outros princípios contábeis relacionados ao princípio da realização .......................... 176

3.4.1. Princípio do menor valor entre custo de aquisição ou mercado ............................... 176

3.4.2. Princípio do preço corrente (marcação a mercado) …................................................... 178

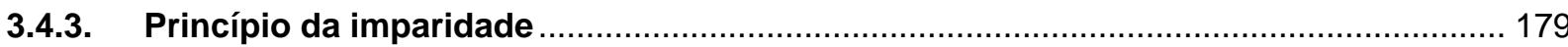

CAPÍTULO 4 - DEBATE SOBRE OS DIFERENTES MOMENTOS DE REALIZAÇÃO DA RENDA. 182

1. Realização no ato de fornecimento (ponto de venda) ............................................. 184

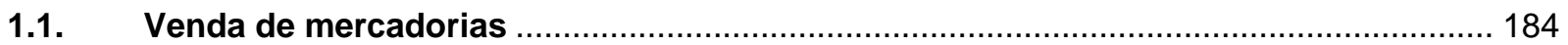




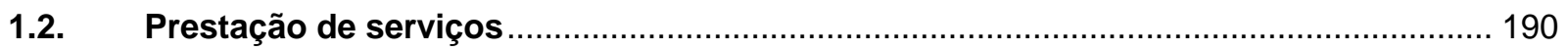

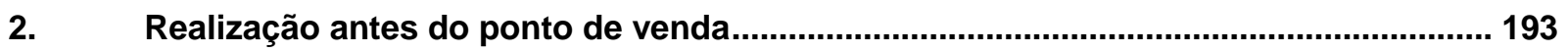

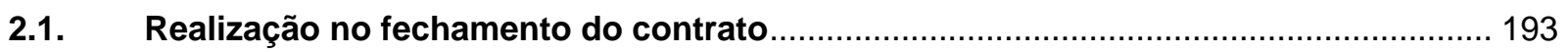

2.2. Realização durante o ato de fornecimento (andamento da produção) ............................ 196

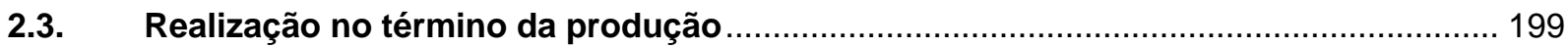

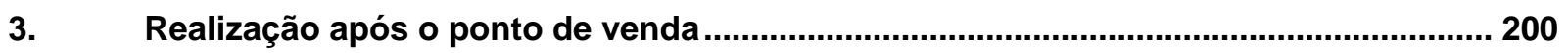

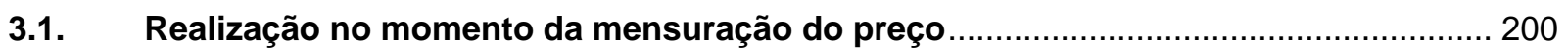

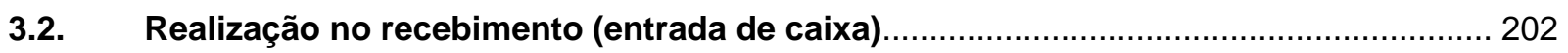

4. Realização com a passagem do tempo (pro rata temporis)............................................. 208

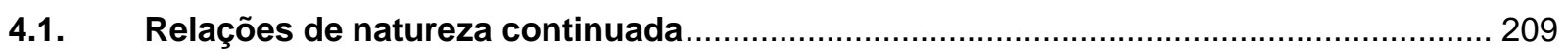

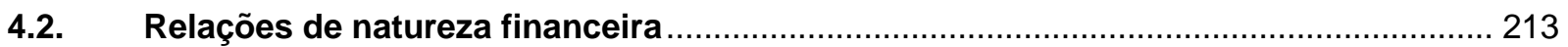

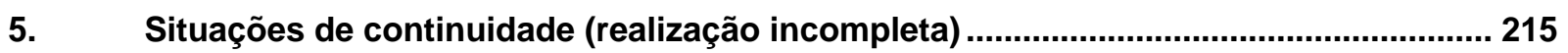

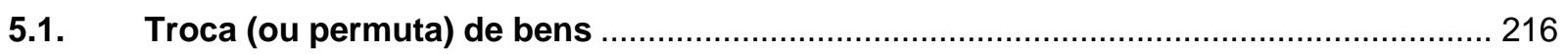

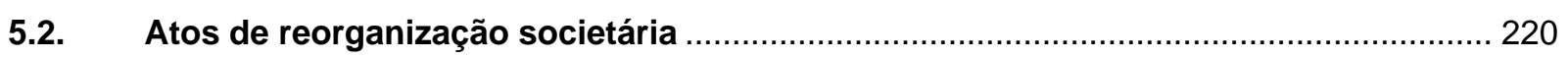

6. Realização na variação do valor de ativos e passivos inertes ........................................ 224

6.1. Atualização dos valores de ativos e passivos (mensurações subsequentes) ............. 224

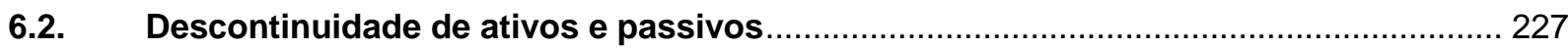

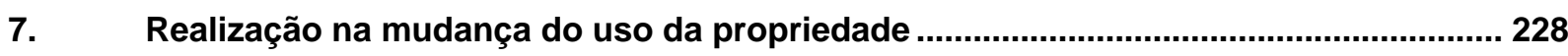

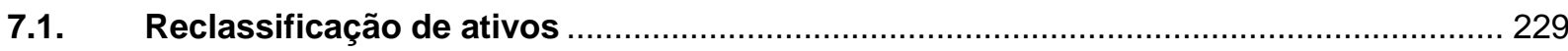

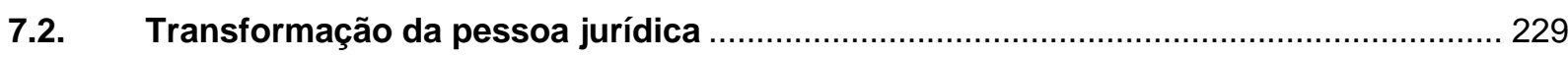

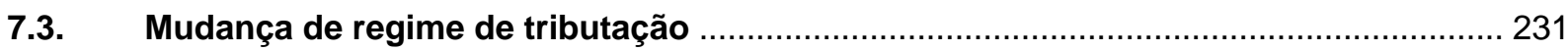

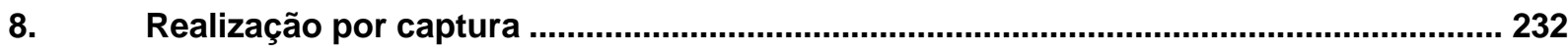

8.1. Falecimento, emigração ou transferência de bens para o exterior .............................. 233

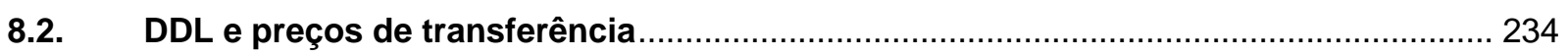

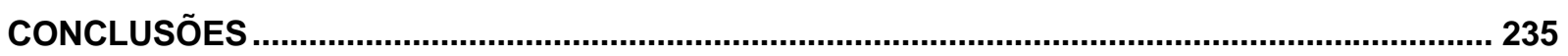

BIBLIOGRAFIA 


\section{LISTA DE_ABREVIATURAS}

ASC - Accounting Standards Committee (Comitê de Padrões Contábeis)

Bacen - Banco Central do Brasil

BFH - Bundesfinanzhof (Tribunal Financeiro Federal da Alemanha)

CC - Código Civil (Lei no 10.406/2002)

CF - Constituição Federal

CFC - Conselho Federal de Contabilidade

CMN - Conselho Monetário Nacional

Cosit - Coordenaria-Geral do Sistema de Tributação

CPC - Comitê de Pronunciamentos Contábeis

CSLL - Contribuição social sobre o lucro líquido

CST - Coordenaria do Sistema de Tributação

CTN - Código Tributário Nacional

CVM - Comissão de Valores Mobiliários

ECB - Estrutura Conceitual Básica da Contabilidade (Deliberação CVM no 29/1986)

ED - Exposure draft (memorando de discussão)

EEC - European Economic Community (Comunidade Econômica Europeia)

FASB - Financial Accounting Standards Board (Conselho de Padrões de Contabilidade Financeira)

GAAP - Generally accepted accounting principles ou generally accepted accounting practice (princípios ou práticas de contabilidade geralmente aceitas)

HMRC - Her Majesty Revenue \& Customs (Receita Federal e Aduana da Sua Majestade, órgão financeiro do Reino Unido)

HM-Treasury - Her Majesty Treasury (Tesouro da Sua Majestade, órgão financeiro do Reino Unido)

IAS - International Accounting Standard (Padrão Internacional de Contabilidade)

IASB - International Accounting Standards Board (Conselho de Padrões Internacionais de Contabilidade)

Ibracon - Instituto dos Auditores Independentes do Brasil

IFRIC - International Financial Reporting Interpretations Committee (Comitê Internacional de Interpretação [de Normas] de Relatórios Financeiros)

IFRS - International Financial Reporting Standards (Padrões Internacionais de Relatórios Financeiros)

ILL - Imposto (de Renda na Fonte) sobre o Lucro Líquido

IRC - Internal Revenue Code (Código Tributário Federal dos E.U.A.)

IRPJ - Imposto de renda de pessoas jurídicas 
LALUC - Livro de Apuração do Lucro Contábil

LALUR - Livro de Apuração do Lucro Real

LSA - Lei das Sociedades por Ações (Lei nº 6.404/1976)

MP - Medida Provisória

NPC - Normas e Procedimentos de Contabilidade

PCGA - Princípios de contabilidade geralmente aceitos

PFC - Princípios Fundamentais de Contabilidade (Resoluções CFC n ${ }^{0}$ 750/1993 e 774/1994)

PN - Parecer Normativo

REStG - Reichseinkommensteuergesetz (Lei do Imposto de Renda do Reino, da Prússia)

RIR - Regulamento do Imposto de Renda

RTT - Regime Tributário de Transição (instituído pela MP nº 449/2008)

SHS - Schanz-Haig-Simons (principais autores do conceito fundamental de renda)

SSAP - Statement of Standard Accounting Practice (Pronunciamento de Padrão de Prática Contábil)

STF - Supremo Tribunal Federal

UK-GAAP - United Kingdom generally accepted accounting practice (práticas de contabilidade geralmente aceitas no Reino Unido)

US-GAAP - United States of America generally accepted accounting principles (princípios de contabilidade geralmente aceitos nos E.U.A.) 


\section{INTRODUCÃ̃}

Numa visão da organização das pessoas em uma sociedade estruturada sob a forma de um Estado Democrático de Direito, a busca de um equilíbrio entre o poder de tributar e a justiça tributária aponta para um Direito Tributário que se orienta fundamentalmente pelo princípio da capacidade contributiva e respeita os limites impostos por direitos fundamentais protegidos constitucionalmente ${ }^{1}$.

Cada cidadão é chamado a contribuir com recursos financeiros para custear as despesas do Estado e, neste ponto, coloca-se o desafio da definição de parâmetros para avaliação do quanto cada membro da sociedade pode e deve aportar para o orçamento estatal. Nesse contexto é que ganha relevância o estudo das medidas adequadas (justas e praticáveis) que são voltadas para a identificação da aptidão dos indivíduos de pagar tributos.

Reconhecido como indicador adequado para expressar a capacidade contributiva $^{2}$, o elemento econômico "renda" apresenta-se como um dos fenômenos mais aceitos para a individualização do encargo tributário e, nesse passo, um instrumento apropriado para mensurar a riqueza suscetível a suportar o encargo da tributação. No contexto do sistema tributário nacional brasileiro, uma apuração correta da renda tributável demanda o respeito não só àqueles princípios abrigados pela Constituição Federal de forma expressa, mas também a determinados princípios subsidiários (subprincípios implícitos) que decorrem do ou se relacionam diretamente com o ideal de tributação conforme a capacidade contributiva. Dentre eles, vale citar o princípio da realização da renda que, numa descrição simplificada, auxilia na detecção da capacidade econômica apta a sofrer tributação, uma vez que delineia diretrizes mais concretas para a identificação do momento adequado para que tal tributação se implemente.

O presente estudo propõe-se, portanto, a uma abordagem deste tema sob a perspectiva da tributação da renda, apresentando parâmetros para a conceituação do

\footnotetext{
${ }^{1}$ Cf. TORRES, Ricardo Lobo. A legitimação da capacidade contributiva e dos direitos fundamentais do contribuinte. In: SCHOUERI, Luís Eduardo (coord.). Direito Tributário: Homenagem a Alcides Jorge Costa, vol. I. São Paulo: Quartier Latin, 2003, p. 432-435.

${ }^{2}$ Segundo o pensamento predominante, a renda é o melhor indicador de capacidade contributiva. Porém, conforme alerta Joachim Lang, deve-se mencionar também que pesquisas mais recentes contestam essa proposição, defendendo o elemento "consumo" como substrato ideal para a tributação. Cf. LANG, Joachim. Die Bemessungsgrundlage der Einkommensteuer: Rechtssystematische Grundlagen steuerlicher Leistungsfähigkeit im deustschen Einkommensteuerrecht. Köln: Otto Schmidt, 1988, p. 104 (nota de rodapé 346).
} 
referido princípio e buscando delinear suas funções, bem como descrever seu âmbito de aplicação no Direito Tributário brasileiro, especialmente no que concerne à apuração do imposto de renda (sobretudo o de pessoas jurídicas). Desde já se adianta que, embora a expressão "princípio da realização da renda" seja frequentemente empregada como sinônimo apenas de "realização da receita", sua abordagem neste estudo enfoca ambos os componentes essenciais à apuração do lucro: as receitas e as despesas. Sob essa perspectiva, o princípio em questão abrange e se desdobra em dois elementos principais de análise, quais sejam: o princípio da realização das receitas e o princípio da realização das despesas $^{3}$.

O princípio da realização da renda apresenta-se, assim, como preceito correlato ao princípio da capacidade contributiva, garantindo-lhe plenitude e servindo de parâmetro balizador do quanto cada cidadão pode oferecer ao Estado sem ser prejudicado em seu patrimônio e sem detrimento da fonte de produção de renda ${ }^{4}$.

Assim sendo, sob uma perspectiva investigativa mais ampla, o elemento central deste trabalho reclama uma exposição prévia e bastante pontual de determinados princípios gerais e valores que orientam a ordem jurídico-tributária nacional, haja vista que o princípio em exame deve guiar o legislador na formulação de regras que sejam coerentes com uma aplicação adequada do princípio da capacidade contributiva, possibilitando, no plano mais abstrato, a concretização dos valores de justiça e igualdade da tributação.

Em linhas gerais, o princípio da realização governa a formulação de regras para a determinação do momento temporal em que se consideram ocorridos os fatos econômicos individuais que se ajuntam para compor a apuração da renda tributável. Não se trata, portanto, de uma abordagem direta acerca do aspecto temporal próprio da regra-matriz de incidência do imposto de renda, aquele que se identifica normalmente com o término do período de um ano. $\mathrm{O}$ objeto de análise refere-se, mais propriamente, à manifestação temporal dos diversos fatos econômicos que ocorrem ao longo do período de incidência, buscando saber quais condições guiam o reconhecimento desses fatos como definitivos e

\footnotetext{
${ }^{3}$ Além destas, outras denominações são atribuídas ao princípio da realização da renda não só no campo do Direito Tributário, mas também no Direito Comercial (sobretudo nas regras contábeis de apuração do resultado comercial), tais como: "princípio da competência" e o binômio "princípio da realização das receitas e confrontação com as despesas".

${ }^{4}$ ZILVETI, Fernando Aurelio. Princípios de direito tributário e a capacidade contributiva. São Paulo: Quartier Latin, 2003, p. 314.
} 
permitem a sua vinculação a determinado período - i.e., quando se pode considerar que a atividade econômica geradora da renda se realizou, se aperfeiçoou, se concluiu ${ }^{5}$.

Porém, para qualquer tentativa de atribuir um conteúdo ao termo realização como parte integrante da apuração da renda de um determinado período deve-se, antes, indagar qual metodologia de mensuração da renda é a mais conveniente ${ }^{6}$. Tendo tal questionamento em vista, torna-se premente retornar aos conceitos de renda oferecidos pelas ciências financeiras e econômicas (cuja aplicabilidade no âmbito tributário já foi objeto de influentes estudos), para investigar qual conceito foi adotado pela legislação brasileira do imposto de renda e se haveria noções correspondentes de realização que deveriam necessariamente ser respeitadas.

Esta análise é apresentada no Capítulo 1 do presente trabalho. A partir de noções gerais sobre valores, princípios e regras, esboça-se um arcabouço teórico a respeito do princípio da realização da renda associado aos princípios de igualdade e da tributação conforme a capacidade contributiva. Após, apresenta-se uma análise acerca da evolução dos conceitos de renda, na qual se abordam não só os conceitos de renda mais difundidos no sistema brasileiro (renda-produto e renda-acréscimo), mas também os conceitos que estão relacionados com as perspectivas de consumo (renda psíquica e renda-consumo). Não se pretende oferecer exame exaustivo, mas tão-somente ressaltar os aspectos gerais importantes para a identificação de pontos de contato dessas teorias com noções correlatas de realização.

Nesse sentido, normalmente se pondera que o ideal para a incidência de tal exação seria que a renda tributável fosse apurada apenas ao final da vida de uma pessoa ${ }^{7}$, pois, com isso, evitar-se-ia o inconveniente de se tributarem indevidamente os resultados positivos de caráter meramente transitório. Todavia, razões mais preponderantes, sobretudo de ordem prática, demandam que a apuração da renda (ou mesmo dos resultados de um negócio ou atividade) seja dividida e demonstrada em períodos temporais menores.

\footnotetext{
${ }^{5}$ Para a importância do exame dos fatos isolados (geradores de rendimentos, despesas, perdas) ocorridos ao longo do ano e sua relação com a ideia de que o imposto de renda ocorre ao longo do período de apuração, ver AMARO, Luciano da Silva. Imposto sobre a renda e proventos de qualquer natureza. In: MARTINS, Ives Gandra da Silva (coord.). O fato gerador do imposto sobre a renda e proventos de qualquer natureza: Caderno de Pesquisas Tributárias, v. 11. São Paulo: Resenha Tributária, 1986, p. 393-395.

${ }^{6} \mathrm{Cf}$. CARSBERG, Sir Bryan; NOKE, Christopher. The reporting of profits and the concept of realisation. London: Research Board ICAEW, 1989, p. 21.

${ }^{7}$ Cf. a esse respeito, por exemplo, ARNOLD, Brian J. Timing and income taxation: the principles of income measurement for tax purposes. Toronto: Canadian Tax Foundation, 1983, p. 121. TIPKE, Klaus; LANG, Joachim. Steuerrecht. $18^{\text {a }}$ Köln: Otto Schmidt, 2005, p. $225(\S 9,44)$.
} 
Assim, ao longo do intervalo temporal definido para a incidência do imposto, verificam-se os fatos que contribuem para a formação do fato gerador e que se refletem em subunidades positivas (receitas) ou negativas (despesas) dotadas de autonomia relativa (porquanto dependem do encerramento do ciclo temporal para a apuração definitiva do imposto $)^{8}$. Todavia, não obstante tais fatos ganhem significância mormente na apuração final do imposto, a observação das condições e do momento em que se consideram efetivamente ultimados cada um desses fatos (e seus reflexos nas subunidades de receita e despesa) revela notória importância em matéria de imposto de renda.

Sendo a renda identificada, por exemplo, com o resultado líquido da confrontação de receitas e despesas pertinentes a negócios econômicos, bastaria a identificação isolada do momento em que ocorreram (ou se concluíram) tais atividades para que fosse feita a devida alocação dos resultados pertinentes aos períodos temporais correspondentes. Porém, essa distribuição da renda por ciclos temporais pode se revelar dificultosa quando envolver negócios econômicos mais complexos que, por exemplo, se desenvolvam em diversas etapas (caso dos contratos a longo prazo), sejam contratados mediante condições intrincadas de aceitação (e.g. vendas condicionadas), ou contenham peculiaridades na alocação de propriedade e riscos (e.g., arrendamento mercantil, venda com reserva de domínio, venda consignada), desdobrando-se em diferentes eventos que podem afetar mais de um período de incidência. Em tais situações, deve-se lançar mão de critérios capazes de efetuar uma alocação correta e justa da renda, sobretudo daquela que é submetida à tributação.

Nesse passo, o referido princípio impõe a formulação de regras que permitam vincular a cobrança do tributo de maneira coerente com a realidade complexa dos fatos econômicos subjacentes e, também, com as condições econômico-financeiras do contribuinte para efetuar o seu pagamento.

Tal como já anunciado, o princípio da realização da renda idealiza a distribuição adequada da renda auferida pelo contribuinte ao longo de sua vida ou existência, atenuando distorções, bem como planificando e estabilizando de maneira consistente os resultados tributáveis, alocando-os corretamente nos intervalos temporais definidos para a apuração da renda e a cobrança de tributos. Em geral, essa periodicização do lucro deve priorizar a apuração mais fidedigna possível da renda tributável, de forma a

\footnotetext{
${ }^{8}$ Pois apenas ao fim do período-base é que se fará uma apuração sintética do seu valor global que funcionará como base de cálculo do imposto.
} 
se verificarem respeitadas, essencialmente, a capacidade de pagar tributos e a praticabilidade da administração.

O tema não é particularmente novo e os estudos acerca dos limites e da forma de implementação do imposto de renda no contexto do sistema tributário brasileiro são numerosos e muitos deles já abordaram, direta ou indiretamente, a questão da realização da renda. Uma visão acerca dos diferentes conceitos de renda permite, destarte, avaliar criticamente a evolução da legislação tributária brasileira e apresentar as noções possíveis de realização da renda que podem ser adotadas pela legislação tributária em face do que dispõem a Constituição Federal de 1988 e o Código Tributário Nacional.

Nessas circunstâncias, o Capítulo 2 do presente trabalho presta-se à perquirição necessária: (i) dos aspectos constitucionais relevantes, divisando nos elementos mínimos de um conceito constitucional de renda os princípios correlatos (notadamente os princípios da monetarização, renda líquida, apuração periódica, realização); e (ii) dos contornos dados pelo Código Tributário Nacional, tanto na eleição dos eventos deflagradores da incidência do imposto de renda (aquisição de disponibilidade econômica e/ou jurídica) quanto na referência necessária ao Direito Civil (arts. 109, 110 e 116). Com isso, pretende-se reunir elementos suficientes para a identificação dos aspectos mais elementares do princípio ora enfocado no nível constitucional (seja no texto constitucional ou complementar).

Ademais, sendo a base de cálculo do imposto de renda, particularmente a do imposto exigido de pessoas jurídicas no regime do lucro real, uma grandeza que, embora definida de acordo com os ditames específicos da legislação tributária, tem por fundamento o valor do lucro líquido apurado pela contabilidade comercial ${ }^{9}$, outra questão de grande valor para o adequado encaminhamento deste estudo consiste na análise da interação entre o sistema normativo da contabilidade comercial e o sistema do Direito Tributário.

Isso porque, o princípio da realização da renda, tal como adotado para fins tributários, encontra grande similitude de conteúdo com um dos princípios de contabilidade geralmente aceitos (PCGA), qual seja, o princípio da competência (ou, mais propriamente, o princípio da realização das receitas e confrontação com as despesas). Nesse contexto, importa verificar qual influência os preceitos próprios da apuração da

\footnotetext{
${ }^{9}$ Cf. Artigos $6^{\circ}, \S 1^{\circ}$, e 67 , inciso XI, ambos do Decreto-Lei no $1.598 / 1977$. No mesmo passo, a apuração do lucro líquido sujeito à incidência da CSLL também parte do resultado apurado com observância da legislação comercial (cf. artigo $2^{\circ}$, $1^{\circ}$, alínea "c", da Lei nº 7.689/1988).
} 
renda sob a perspectiva do Direito Comercial (escrituração comercial) exercem sobre a apuração da renda tributável e, bem assim, sobre o princípio tributário da realização da renda.

Sob outra perspectiva, portanto, voltando-se agora para uma abordagem mais específica, verifica-se que o princípio da realização possui um grau de especificação maior em relação aos sobreprincípios que o orientam no plano superior. Por essa razão, torna-se factível uma definição mais precisa de seu objeto, alcance, posição sistêmica, funções e condições de aplicação. Dessa forma, no plano mais concreto da pesquisa que ora se explicita, envereda-se no Capítulo 3 pelo caminho do Direito Comercial, em busca das origens do princípio da realização, verificando sua pertinência ao conjunto dos princípios de contabilidade geralmente aceitos e a sua função como um dos principais elos de ligação entre o lucro apurado conforme os objetivos da legislação comercial (lucro comercial) e o lucro tributável (lucro fiscal).

Esta incursão no âmbito do Direito Contábil ${ }^{10}$ permitirá conhecer mais de perto os aspectos ou exigências específicos do princípio da realização (cumprimento da obrigação, conversão em direitos novos, transação de mercado, mensurabilidade, liquidez e certeza) e a integração imediata deste princípio com outros princípios relevantes pertencentes ao conjunto dos princípios de contabilidade geralmente aceitos (especialmente os princípio da continuidade e prudência, bem como o princípio do menor valor entre custo de aquisição ou mercado, o princípio do custo corrente e o princípio da imparidade).

Os conteúdos possíveis para o termo "realização", a serem refinados pelas regras que se orientam pelo princípio aqui estudado, já começam a ganhar corpo. Uma vez constatado que os objetivos colimados pelo Direito Contábil na apuração do lucro comercial (apuração do lucro passível de distribuição, proteção ao patrimônio da empresa e aos credores etc.) também são balizados por restrições de segurança jurídica e buscam demonstrar a renda derivada da atividade empresarial de maneira fidedigna (com maximização dos atributos de liquidez e certeza) conclui-se que há uma grande semelhança 
prévia entre o lucro comercial e o lucro fiscal, de forma a ser possível o aproveitamento, sem maiores reservas, de grande parte das discussões apresentadas por este ramo do Direito em matéria do princípio da realização.

Em termos teóricos, constata-se que o princípio da realização pode ser abordado conforme duas grandes perspectivas diferenciadas: o enfoque de acréscimo de valor, ou o enfoque do evento crítico. Tendo prevalecido até os tempos atuais o segundo enfoque, observa-se que, para a determinação do evento crítico, os seguintes critérios gerais devem ser atendidos, segundo a doutrina contábil, para a confirmação da realização da renda: (1) a atividade prestacional pode ser considerada encerrada/definitiva; (2) é possível a aferição do rendimento; (3) as despesas são conhecidas ou, pelo menos, mensuráveis com razoável certeza; e (4) há uma segurança razoável quanto ao efetivo fluxo de pagamento.

Com efeito, cristalizaram-se na literatura quatro pontos temporais principais que normalmente podem ser utilizados para preencher o conteúdo do princípio da realização: a entrada de caixa, o ato de faturamento, o progresso da produção e o término da produção ${ }^{11}$.

Tanto para o Direito Comercial quanto para o Tributário, são de suma importância eventos críticos que são determinados pelo próprio Direito Civil para o momento da aquisição dos direitos derivados da troca decorrente de negócios jurídicos (por exemplo, a tradição da mercadoria no negócio de compra e venda, a conclusão da prestação de serviço, a conclusão e entrega da obra etc.). E aqui o principal desafio é saber se o princípio da realização deve necessariamente ser preenchido com este conteúdo, ou se, em vista de outros objetivos igualmente preponderantes, poderia seguir caminho razoavelmente diverso (como exemplo deste dilema basta citar os regimes adotados pelo art. 10 do Decreto-lei $\mathrm{n}^{\mathrm{o}} 1.598 / 1977$ para contratos a longo prazo), definindo o momento temporal da realização pelo desempenho da atividade empresarial e buscando primar pela

\footnotetext{
${ }^{10}$ Sobre a consideração do conjunto de regras da contabilidade comercial como objeto juridicizado passível de reconhecimento, para fins da ciência do direito, como um subsistema normativo próprio, cf. MARTINEZ, Atonio Lopo. A Linguagem Contábil no Direito Tributário. 2002. Dissertação de Mestrado apresentada ao Programa de Pós-Graduação em Direito do Estado da Pontifícia Universidade Católica de São Paulo, São Paulo, 2002. Sobre a inclusão dos princípios contábeis no plano jurídico e considerações quanto à sua força normativa, ver RENCK, Renato Romeu. Imposto de renda da pessoa jurídica: critérios constitucionais de apuração da base de cálculo: uma proposta de interpretação sistemática do Direito. Porto Alegre: Livraria do Advogado, 2001, p. 121-127.

11 Cf. SCHRÖER, Thomas. Das Realisationsprinzip in Deutschland und Grossbritannien: eine systematische Untersuchung und ihre Aufwendung auf langfristige Auftragsfertigung und Währungsrechnung. Frankfurt am Main: Peter Lang, 1998, p. 200-202.
} 
planificação da renda, mediante o emparelhamento das receitas à realização das respectivas despesas $^{12}$.

Este é o fio condutor do Capítulo 4, que se volta para a legislação de regência do imposto de renda de pessoas jurídicas e encerra este trabalho com uma análise de situações específicas, enfocando os conteúdos que são adotados na prática para o princípio da realização. Essa investigação é importante para se observar de que forma o princípio da realização da renda interage com outros princípios para ser fortalecido ou flexibilizado e, ainda, como determinadas regras específicas de apuração do imposto de renda se correlacionam com a situação ideal preconizada abstratamente por este princípio.

A formulação do conteúdo possível do princípio da realização da renda no momento histórico atual depende, portanto, da análise de determinadas regras presentes na legislação tributária, principalmente do imposto de renda, para averiguarem-se, na aplicação concreta do referido princípio,

(i) quais escolhas a legislação retrata quanto aos métodos e regimes de apuração da renda aplicáveis a conjuntos específicos de contribuintes (e.g., regime de competência e regime de caixa);

(ii) quais são as variáveis de decisão envolvidas (liquidez, grau de precaução, redução de risco, mudança na posição patrimonial, participação de terceiros etc.);

(iii) quais relações há com os elementos jurídico-obrigacionais relevantes definidos pelo Direito Civil; e

(iv) quais seriam as alternativas existentes e aceitáveis, no âmbito de aplicação do princípio em tela, para se definir o ponto de realização da renda e o momento a partir do qual se reconhece como "ganho" o lucro, tornando-se exigível o imposto de renda.

Diferenças na aplicação do princípio podem decorrer não só de questões de praticabilidade, mas também da influência de normas indutoras, postergando o reconhecimento de receitas, por exemplo, para o momento da entrada de caixa (no caso de empresas de menor porte), ou permitindo-se que atos típicos de realização sejam desonerados para eliminar entraves ao desenvolvimento econômico (é o caso das regras

\footnotetext{
${ }^{12}$ Promovendo o chamado income averaging, que preza por uma demonstração regular da renda, sem concentrar receitas ou despesas em períodos desconexos.
} 
que concedem o afastamento da tributação em permutas de imóveis e atos de reorganização societária).

Por fim, convém salientar um limite importante ao escopo do presente estudo. Embora se reconheça que o conteúdo do princípio em tela, sobretudo no que respeita ao seu enfoque na realização das receitas, deva exercer influência sobre a conformação da base de cálculo dos tributos incidentes sobre a receita bruta ou o faturamento (notadamente as contribuições sociais "PIS" e "COFINS"), bem como dos tributos incidentes sobre produção e a circulação de mercadorias e serviços (ICMS, ISS e IPI), não consiste objeto deste trabalho examinar diretamente a aplicação do referido princípio a tais formas de tributação. 


\section{CAPÍTULO 1 - EVOLUÇÃO E DEMARCAÇ̃̃O DO PRINCÍPIO DA} REALIZAČ̃̃̃O DA RENDA

Neste capítulo serão debatidos, em essência, os aspectos gerais do princípio da realização da renda, questionando-se inicialmente a adequação de sua classificação enquanto princípio para, então, determinar sua posição e funções relativamente aos princípios da igualdade e da capacidade contributiva.

Nessa seara, ao enfocar os elementos nucleares do princípio da realização da renda, o debate pertinente à extensão do princípio da capacidade contributiva conduz à necessária abordagem do elemento renda, apresentando-se aqui a evolução desse conceito sob as perspectivas econômico-financeiras, bem como as restrições práticas que impediram a adoção de sua formulação no sentido mais amplo.

Desenhado esse plano geral, apresenta-se uma visão histórica da evolução do princípio da realização da renda nos sistemas tributários de três países especificamente selecionados por sua importância econômica histórica, quais sejam, os Estados Unidos da América, a Alemanha e o Reino Unido. Além disso, esboça-se um breve histórico da tributação da renda e das formas de realização adotadas pela legislação brasileira ao longo do último século.

\section{Aspectos gerais do princípio da realização da renda}

Uma postura possível para a análise dos princípios jurídicos consiste em destacar que, de maneira geral, eles possuem um conteúdo axiológico intenso, que remete o intérprete aos valores consagrados pela ordem jurídica e oferece um referencial para diferentes formas de se promoverem as finalidades e os resultados perseguidos pelo sistema. A investigação de um determinado princípio segundo esta perspectiva procura, antes, enaltecer os valores por ele protegidos, prescindindo-se de verificar, num primeiro momento, quais seriam precisamente os comportamentos indispensáveis à realização desses valores e quais os instrumentos metódicos essenciais à fundamentação controlável da sua aplicação ${ }^{1}$.

\footnotetext{
${ }^{1}$ Cf. ÁVILA, Humberto. Teoria dos princípios: da definição à aplicação dos princípios jurídicos. $6{ }^{\mathrm{a}}$, rev. e ampl. São Paulo: Malheiros Editores, 2006, p. 64.
} 
Segundo outra forma de abordagem inquisitiva, os princípios podem ser estudados em sua estrutura, a fim de detectar um procedimento racional de fundamentação que permita tanto especificar as condutas necessárias à realização dos valores por eles prestigiados quanto justificar e controlar sua aplicação mediante reconstrução de enunciados doutrinários e de decisões em casos concretos relevantes.

De maneira geral, este estudo procura atender de maneira satisfatória a essas duas correntes. Para a explanação de uma delas, apresenta, inicialmente aqui, um exame da relação do princípio da realização da renda com os valores de justiça e igualdade que, em última análise, são perseguidos pelo princípio da capacidade contributiva, do qual é decorrência imediata ${ }^{2}$. Mais adiante, em capítulo próprio $^{3}$, ressalta propostas para a compreensão de seu conteúdo, posição normativa e relações com os demais princípios que, direta ou indiretamente, contribuem para a concretização dos mesmos valores mediante uma apuração correta e justa da renda tributável. Para a análise da outra, avalia mais extensivamente as características próprias do princípio da realização da renda, por meio da observação de sua influência na elaboração das regras e na decisão de casos relevantes pertinentes ao momento adequado para reconhecimento da renda tributável, procurando sistematizar os parâmetros de sua aplicação em situações concretas ${ }^{4}$.

Assim sendo, traça-se, no presente item, um breve e indispensável arcabouço teórico acerca dos princípios jurídicos, expondo suas características e funções, bem como oferecendo subsídios para que a classificação do princípio da realização da renda como um princípio possa ser devidamente perquirida.

Tanto o estudo dos princípios quanto a categorização de alguma norma como tal são dois temas de difícil abordagem, razão pela qual se apresentam aqui algumas das principais formulações debatidas na atualidade para, a partir delas, analisar e criticar de forma objetiva a função normativa desempenhada pelo princípio da realização da renda.

Em complementação a esta análise quanto à posição e função normativas do princípio encimado, este item versa também sobre o desenvolvimento dos princípios correlatos da igualdade e da capacidade contributiva, esboçando a evolução histórica dos critérios adotados para a repartição do ônus da tributação e apresentando, afinal, alguns fundamentos da tributação da renda.

\footnotetext{
${ }^{2}$ Vide particularmente o item 1.2 deste Capítulo (e também as discussões quanto ao conceito apropriado de renda - desenvolvidas no item 2 mais abaixo).

${ }^{3}$ Vide o Capítulo 2 deste trabalho.
} 


\subsection{Noções elementares de princípios}

A colocação de um princípio como elemento central de um estudo aprofundado reflete, em certa medida, um movimento recente do pós-positivismo, voltado para a busca do sentido e da função dos princípios jurídicos. Essa valorização do estudo dos princípios,

a que o Prof. Humberto Ávila se referiu como o Estado principiológico ${ }^{5}$, deve ser aqui abordada com a devida cautela. É preciso, neste caso, avaliar se o princípio da realização da renda é mesmo uma espécie normativa que reúne as características de um princípio e comporta-se como tal ${ }^{6}$.

Essa identificação excessiva de princípios no sistema normativo decorre, em certa medida, da polissemia característica do vocábulo "princípio", reclamando, para os fins deste trabalho, a adoção coerente de uma proposta classificatória das espécies normativas, para que fique claro qual sentido se dá à palavra princípio quando se fala de um princípio da realização da renda.

\subsubsection{Princípios e regras}

Com efeito, observa-se que toda norma comporta-se ou como uma regra, ou como um princípio ${ }^{7}$. Princípios podem ser conceituados como normas que têm caráter finalístico acentuado e que impõem a busca ou a preservação de um estado ideal de coisas, o qual pode ser alcançado por meio de diferentes comportamentos aptos à sua concretização. A seu turno, as regras determinam com maior especificidade os comportamentos que devem ser adotados para efetivar as finalidades estabelecidas pelo princípio, antecipando ou resolvendo eventuais controvérsias e reduzindo a incerteza e arbitrariedade.

\footnotetext{
${ }^{4}$ Vide os Capítulos 3 e 4 deste trabalho.

5 ÁVILA, op. cit. (nota 1), p. 23.

${ }^{6}$ Críticas semelhantes ao exagero na formulação de princípios foram feitas pelo Professor e Ministro Eros Grau, para quem a época do "paradigma dos princípios" gerou a banalização da importância do estudo desta categoria normativa. Cf. GRAU, Eros Roberto. Ensaio e discurso sobre a interpretação/aplicação do direito. $3^{\text {a }}$ São Paulo: Malheiros Editores, 2005, p. 42, 135.

${ }^{7}$ A terminologia aqui empregada para discernir as proposições normativas cujos atributos de generalidade, abstração e finalidade são mais acentuados daquelas outras que são mais individualizadas, concretas e dirigidas a comportamentos segue a distinção que foi enfatizada decisivamente por Ronald Dworkin e divulgada no Brasil, por exemplo, por Humberto Ávila e Eros Grau. Cf. ÁVILA, op. cit. (nota 1), p. 35-40; GRAU, op. cit. (nota 6), p. 168-171.
} 
A coexistência dessas duas espécies normativas é essencial ao bom funcionamento do sistema normativo, pois, se, por um lado, os princípios remetem o intérprete a valores e a diferentes modos de promover os resultados almejados, por outro lado, a definição dos comportamentos adequados à concretização de tal situação ideal e a própria delimitação dos contornos normativos dos princípios ficam a cargo das regras (atos do Poder Judiciário, Legislativo e Executivo, sem os quais os princípios não adquirem normatividade) ${ }^{8}$.

Destacando-se sensivelmente de formulações anteriores, Ronald Dworkin propôs uma distinção entre princípios e regras fundada na estrutura lógica de tais espécies normativas, realçando mais intensamente suas diferenças relativamente a dois critérios: o modo de aplicação e o relacionamento normativo?.

Segundo sua concepção, as regras são espécies normativas que se aplicam de modo absoluto (tudo ou nada) e que não admitem ponderações ou sopesamento. Dito de outra forma, uma vez preenchida a hipótese de incidência de uma regra válida, a consequência normativa deve ser aceita. Mais ainda, situações de conflito entre regras terminam com uma delas sendo considerada inválida. Por sua vez, os princípios se aplicam de modo gradual (mais ou menos), isto é, não determinam absolutamente a decisão, estabelecendo apenas fundamentos que dependem da conjunção com outros fundamentos provenientes de outros princípios. Ademais, hipóteses de impasse na aplicação de princípios ${ }^{10}$ reclamam uma ponderação quanto às dimensões de peso atribuíveis aos princípios envolvidos na decisão e, em tal exame, determina-se o princípio que deve prevalecer, sem, no entanto, declarar(em)-se inválido(s) o(s) princípio(s) afastado(s) na situação específica ${ }^{11}$.

Dentre as contribuições doutrinárias que fomentaram a crítica e o aprimoramento da exposição de Dworkin, realça-se a formulação de Robert Alexy ${ }^{12}$, segundo quem os princípios são mandamentos de otimização que podem ser cumpridos em diferentes graus (normas que ordenam que algo seja realizado na maior medida possível,

\footnotetext{
${ }^{8}$ Cf. ÁVILA, op. cit. (nota 1), p. 64, 75-80, 91, 103, 118.

${ }^{9}$ Cf. DWORKIN, Ronald M. Is law a system of rules? In: DWORKIN, Ronald M. The philosophy of law. Oxford: Oxford University Press, 1977, p. 43-49. Este mesmo artigo foi reproduzido em DWORKIN, Ronald M. Taking rights seriously. Cambridge, MA: 1978, p. 22-28.

${ }^{10}$ Enquanto normas que estabelecem ideais a serem atingidos, os princípios não entram propriamente em conflito, haja vista seu entrelaçamento.

${ }^{11}$ Para bilhantes exposições desse tema à luz do sistema normativo brasileiro vide ÁVILA, op. cit. (nota 1), p. 36-37, 44, 51, e também GRAU, op. cit. (nota 6), p. 168-171.

${ }^{12}$ Cf. ALEXY, Robert. Theorie der Grundrechte. Frankfurt am Main: Suhrkamp, 1985, p. 75-79.
} 
dentro das possibilidades jurídicas e materiais existentes). Regras, pelo contrário, são cumpridas ou não (determinações no âmbito do fática e juridicamente possível). Quanto à questão dos confrontos entre si, as regras colidem na dimensão da validade, os princípios, na dimensão do peso ${ }^{13}$.

Tendo tais distinções de caráter geral em vista, cabe questionar se o preceito normativo que aqui denominamos de princípio da realização da renda exerce a função de um princípio ou de uma regra. Para sua admissão na categoria dos princípios, é necessário certificar se ele preconiza um certo estado ideal de coisas que admita sua implementação em diferentes graus. Ademais, em situações de confronto com outros princípios, deve-se avaliar se o princípio da realização permite sua relativização.

Na mesma linha de raciocínio, caso seja tomado como regra, o comando normativo que exige a tributação apenas depois de verificada a realização da renda deve prescrever algum comportamento específico, o qual tem que ser seguido sempre que preenchidos seus pressupostos fáticos, inadmitindo-se exceções ou ponderações de valor.

Nesse contexto, a observação do processo de formação e conclusão dos fatos econômicos que, individual ou agregadamente, contribuem para originar a renda tributável revela que há distintos momentos temporais que poderiam ser eleitos como determinantes da realização (produção, valorização, fechamento de contrato de venda, tradição, conclusão de atividade, efetivo pagamento, consumo etc.). Como se verá adiante, no item pertinente aos conceitos econômico-financeiros de renda ${ }^{14}$, tanto a evolução histórica como os debates teóricos acerca deste tema demonstram que a definição quanto ao momento da realização da renda varia bastante, conforme os aspectos conjunturais e o desenvolvimento de mecanismos práticos de mensuração, por exemplo.

Esse comportamento multiforme do fenômeno realização da renda aproxima-o mais de um princípio do que propriamente de uma regra, uma vez que se verifica haver uma certa diretriz ${ }^{15}$ (determinando a tributação da renda somente quando houver segurança da conclusão e permanência dos eventos que a deflagram), que pode ser concretizada em diversos níveis (valorização, ocorrência da atividade econômica prestacional, recebimento do pagamento, consumo etc.), a serem definidos por regras, de acordo com as condições fáticas e jurídicas próprias do ambiente histórico, cultural e jurídico de que se trata.

\footnotetext{
${ }^{13}$ A esse respeito, vide também ÁVILA, op. cit. (nota 1), p. 37-39, 44, 51-52, bem como GRAU, op. cit. (nota 6), p. 177-180.

${ }^{14}$ Vide item 2 deste Capítulo.
} 
É importante destacar também que a classificação do princípio da realização como um princípio e não uma regra depende ainda de se verificar se tal espécie normativa preserva as propriedades de um princípio: é de se questionar se o princípio da realização admite flexibilização ante outros princípios.

Também se nota que, em algumas hipóteses específicas, outros princípios ou ditames da ordem jurídica podem prevalecer perante o princípio da realização. Esta circunstância se mostra patente na formulação de determinadas regras (legislativas, jurisprudenciais ou executivas) que determinam a tributação independente de realização ou a postergam por razões de praticabilidade ou como forma de incentivo fiscal ${ }^{16}$.

\subsubsection{Valores, limites objetivos e os subprincípios}

Admitindo-se a qualificação do princípio, ora em exame, como tal, resta verificar ainda sua classificação e posição com relação a outros princípios. Nesse sentido, analisando especialmente os princípios pertinentes à matéria tributária, Paulo de Barros Carvalho alerta que um determinado princípio pode estar atrelado à perseguição de um valor ou, por outro lado, pode meramente formular limites objetivos ${ }^{17}$.

Para a identificação de um valor subjacente ao princípio, deve-se observar a presença dos elementos denotadores do caráter axiológico: bipolaridade, implicação recíproca, referibilidade, preferibilidade, incomensurabilidade, graduação hierárquica e objetividade $^{18}$. Por sua vez, um limite objetivo deve ser extremamente simples e de verificação pronta e imediata. Embora apontem para a realização de alguma meta ou finalidade que possa, esta sim, ser identificada como concernente a um valor, os limites objetivos devem ser de fácil comprovação e percepção ${ }^{19}$.

Indaga-se, então, se o princípio da realização da renda persegue algum valor específico, ou se, de outra forma, trata-se apenas de um limite objetivo. Conforme se aborda com mais vagar no item seguinte deste Capítulo, o princípio da realização encontra-

\footnotetext{
${ }^{15}$ Um estado ideal de coisas, ou um mandamento de otimização.

${ }^{16}$ Vide a esse respeito os itens 1.2.1 e 1.2.2 do Capítulo 2, bem como as situações discutidas nos itens 3,5 e 6 a 8 do Capítulo 4.

${ }^{17}$ Ademais disso, algumas variações na classificação dos princípios decorrem de seu grau de estruturação, de forma que um princípio pode ainda ser assinalado como norma de posição privilegiada, portadora de valor ou estipuladora de limites objetivos. Na mesma linha, pode-se tomar um princípio como valores ou limites expressos em normas de alta hierarquia, mas sem consideração particular com relação à estrutura normativa subjacente. Cf. CARVALHO, Paulo de Barros. Curso de direito tributário. 19a , rev. São Paulo: Saraiva, 2007, p. 158-159.

${ }^{18}$ Além da historicidade, inexauribilidade e atributividade. Cf. CARVALHO, op. cit. (nota 17), p. 159-162.
} 
se atrelado ao princípio da capacidade contributiva e, desse modo, procura implementar os valores atinentes a este último princípio (justiça e igualdade). Todavia, não se percebe um valor específico buscado pelo princípio da realização e, além disso, tampouco traduz um limite objetivo a norma que orienta a tributação no que concerne ao momento temporal adequado à verificação do fato econômico gerador da renda.

Entre um extremo e outro, não sendo pronta e facilmente identificado com um valor ou com um limite objetivo, apresenta-se conveniente, para classificar o princípio em estudo, a noção de que o sistema jurídico contempla sobreprincípios e subprincípios. Os primeiros exercem funções típicas dos princípios e contêm um forte conteúdo axiológico, ao passo que os últimos atendem às finalidades e aos valores dos primeiros, delimitando, com maior especificação, o comando mais amplo estabelecido pelo sobreprincípio axiologicamente superior. Os subprincípios desempenham, assim, uma função definitória que não se verifica nos sobreprincípios, pois estes atuam para ampliar ao invés de especificar $^{20}$.

Nesse diapasão, o princípio da realização da renda pode ser posicionado como corolário do princípio da capacidade contributiva e, neste sentido, ambos visam à promoção dos mesmos valores. O princípio da realização, portanto, atua ao lado de outros subprincípios, tais como o da renda líquida, o da imparidade etc., para substancializar, conferir concreção ao princípio da capacidade contributiva.

A despeito de sua maior especificação em relação ao sobreprincípio a que atende, o princípio da realização preserva o caráter finalístico, genérico e abstrato típico de um princípio, visto que não define os comportamentos necessários à realização do ideal por ele preconizado, qual seja, o de que a tributação aconteça apenas após verificadas certeza e segurança na ocorrência do evento deflagrador da renda. A determinação de quais são tais eventos, como já abordado aqui, depende de condições específicas a serem verificadas nas situações concretas e, outrossim, a seleção dos eventos deve variar também segundo condições de risco oferecidas pelo ambiente jurídico de que se trata.

Esse caráter de princípio vem sendo reconhecido em outros países, como é o caso da Alemanha, por exemplo, cujo Tribunal Financeiro já teve inúmeras oportunidades de se pronunciar sobre o tema. O relato histórico de Heinrich Beisse, Prof. e Juiz do Tribunal Financeiro, deixa claro que:

\footnotetext{
${ }^{19}$ Cf. CARVALHO, op. cit. (nota 17), p. 162-163.
}

${ }^{20}$ Cf. ÁVILA, op. cit. (nota 1), p. 98-99. 
“O BFH já repetiu enfaticamente que não há nenhum fato gerador geral $e$ superior da realização do lucro, mas sim apenas fatos geradores isolados. Estes estão espalhados em uma pluralidade de dispositivos legais, parcialmente sem um vínculo externo e imperfeitos, sobretudo em razão da referência aos princípios de contabilidade geralmente aceitos, os quais carecem de concretude e complementação."21.

\subsection{Os princípios da igualdade e da capacidade contributiva}

Constata-se que o princípio da realização restringe-se a traçar um estado ideal de coisas e, dessa forma, admite soluções diferentes para o problema da verificação e alocação temporal dos resultados tributáveis. È fácil, portanto, concluir que a seleção do evento crucial ou determinante, dentre os diversos eventos de realização identificáveis no conjunto dos fatos econômicos subjacentes e, principalmente, a fixação de momentos temporais diferenciados (em caráter de exceção) para situações e contribuintes específicos dependerão, enfim, de escolhas legislativas, administrativas e jurisprudenciais que, em última análise, remontam à aplicação dos sobreprincípios da igualdade e da capacidade contributiva. Isso porque a delimitação dos critérios de reconhecimento de receitas e despesas e, bem assim, das regras quanto à periodicização dos resultados pode, em circunstâncias específicas, reclamar soluções diferentes que terminem por diversificar o nível de carga tributária imposta a cada sujeito passivo, demandando justificativas em face dos princípios tributários destacados neste tópico.

O tema em debate exige, assim, a prévia identificação dos motivos que levam determinados contribuintes a pagar tributos de maneira diferenciada (em função de disparidades de alocação temporal) e, mais ainda, quais os critérios aceitáveis para se distinguirem os contribuintes entre si e determinar o quanto de carga tributária deve ser

\footnotetext{
${ }^{21}$ Tradução livre de: Der BFH hat wiederholt betont, dass es keinen übergeordneten allgemeneinen Tatbestand der Gewinnrealisierung, sondern nur bestimmte Einzeltatbestände gibt. Sie sind auf eine Mehrzahl von Gesetzen verstreut, teilweise ohne äusseren Zusammenhang und unvollständig, vor allem wegen der Verweisung auf GOB konkretisierungs- und ergänzungsbedürftig. Cf. BEISSE, Heinrich. Gewinnrealisierung - Ein systematischer Überblick über Rechtsgrundlagen, Grundtatbestände und grundsätzliche Streitfragen. In: RUPPE, Hans Georg (coord.). Gewinnrealisierung im Steuerrecht: Theorie und Praxis der Gewinnverwirklichung durch Umsatzakt und durch Steuerentstrichung sowie des Besteuerungsafuschubs. Köln: Otto Schmidt, 1981, p. 17-18.
} 
atribuída para cada um deles. Trata-se exatamente das questões que consumiram boa parte da história intelectual a respeito de tributação ${ }^{22}$.

Para sintetizar os principais pontos desse antigo debate, convém apontar que a discussão normalmente toma como marco inicial as reflexões de grandes pensadores, principalmente a partir do século XVIII ${ }^{23}$, época do desenvolvimento do liberalismo ${ }^{24}$.

A intensificação das formulações teóricas nesse período histórico associa-se com a consolidação do Estado moderno e com o surgimento de novas necessidades públicas que, atendidas por funções estatais correlatas, demandavam recursos financeiros em volume mais substancial do que outrora ${ }^{25}$. A geração de tais recursos passou gradativamente a depender mais da coleta de tributos e, com isso, aumentaram-se os conflitos entre contribuintes e Estado, germinando revoltas e anseios de igualdade e segurança jurídica na tributação ${ }^{26}$.

Dessa forma, a busca pelo ideal de igualdade na imposição físcal avança nessa época, tendo em Adam Smith um de seus mais expoentes defensores. Ao tratar das fontes tributárias de receitas públicas, o economista escocês sustentava que os cidadãos deveriam contribuir para as despesas públicas "tanto quanto possível, em proporção às suas respectivas capacidades, isto é, proporcionalmente à renda que eles usufruem sob a proteção do Estado",27.

\footnotetext{
${ }^{22}$ Cf. MCCAFFERY, Edward J. A new understanding of tax. In: Michigan Law Review, v. 103, 2005, p.

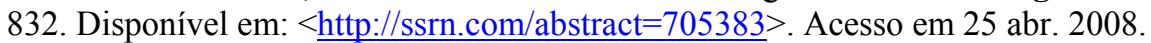

${ }^{23}$ Fernando Zilveti aponta para mais além, sugerindo como ponto de partida estudos realizados por filósofos gregos com relação ao sistema de tributação do Egito Antigo, que, desde aquela época, atenderia a preocupações quanto à capacidade contributiva. Cf. ZILVETI, Fernando Aurelio. Princípios de Direito Tributário e a Capacidade Contributiva. São Paulo: Quartier Latin, 2003, p. 142.

${ }^{24}$ Antes disso não haveria propriamente uma figura de tributo que pudesse ser identificada com os sistemas atuais. Cf. TORRES, Ricardo Lobo. Tratado de direito constitucional e financeiro tributário, v. II, valores e princípios constitucionais tributários. Rio de Janeiro: Renovar, 2005, p. 125, 288.

${ }^{25}$ Enquanto o Estado limitava-se a exercer, essencialmente, uma função de defesa, cada cidadão contribuía com sua própria força física. Com o crescimento da sociedade e o desenvolvimento de novas necessidades públicas, os gastos estatais de infraestrutura e manutenção monárquica/política aumentaram e foram, a princípio, custeados com base em doações, depois com base em espoliações de nações conquistadas e, enfim, com base em tributos. Cf. SELIGMAN, Edwin. R. A. Essays in taxation, $10^{\mathrm{a}}$ New York: Augustus M. Kelley, 1969, p. 1-2.

${ }^{26}$ Cf. NOGUEIRA, Ruy Barbosa. Curso de direito tributário brasileiro. $15^{\text {a }}$ ed., atualizada. São Paulo: Saraiva, 1999, p. 4-5.

${ }^{27}$ Ele sugeria a adoção de quatro máximas: igualdade, certeza, comodidade do pagamento e economia da tributação. O princípio da igualdade era formulado nos seguintes termos: "Os indivíduos de cada Estado devem contribuir para suporte do governo, tanto quanto possível, em proporção a suas respectivas capacidades; isto é, em proporção à renda que eles aproveitam respectivamente sob a proteção do Estado". Tradução livre de: The subjects of every state ought to contribute towards the support of the government, as nearly as possible, in proportion to their respective abilities; that is, in proportion to the revenue which they respectively enjoy under the protection of the state. SMITH, Adam. An inquiry into the nature and causes of the wealth of nations. New York: The Modern Library, 2000, p. 888.
} 
Inaugurava-se um critério legítimo para a concretização do princípio da igualdade $^{28}$ : a capacidade contributiva, permitindo-se uma distinção isonômica entre os contribuintes para fins de tributação. Como se sabe, o princípio da igualdade, por si só, é uma expressão vazia e depende da adoção de um critério de diferenciação para que efetivamente seja possível agruparem-se os iguais (igualdade horizontal) e distinguirem-se os desiguais (igualdade vertical), permitindo a comparação e, portanto, o estabelecimento de tratamento tributário adequado ${ }^{29}$. Não se pode deixar de mencionar que também ao princípio da capacidade contributiva foram dirigidas críticas semelhantes, no sentido de que seria um conceito vazio, dependente de outros conceitos para sua efetiva implementação. Tais críticas, todavia, foram superadas e não representam a opinião dominante da doutrina do Direito Tributário ${ }^{30}$.

Fato irrefutável é que o referencial de comparação declarado por Adam Smith restou consagrado na Declaração dos Direitos do Homem e do Cidadão da Revolução Francesa $^{31}$ e orientou as Constituições da grande maioria dos países ${ }^{32}$, sobrevivendo até os dias de hoje, sobretudo por atender perfeitamente às exigências reconhecidas para a justificação e implementação de um critério-medida que concretize devidamente o princípio da igualdade.

A capacidade contributiva proporciona uma distribuição igualitária da carga tributária porque apresenta os seguintes elementos essenciais: (i) identifica diferenças reais entre os destinatários da norma (razoabilidade, elemento discriminador ou relação entre os sujeitos), (ii) serve a uma finalidade encampada pelo ordenamento jurídico (fundamentação ou finalidade), e (iii) é reconhecida como elemento distintivo apropriado,

\footnotetext{
${ }^{28}$ Normalmente identificado com a diretiva de que "a lei deve tratar igualmente aos iguais e desigualmente aos desiguais, na medida de sua desigualdade" cuja autoria aristotélica seria questionável, mas que certamente foi proferida, no Brasil, por Rui Barbosa, na sua "Oração aos moços". Cf. FERRAZ, Roberto. Igualdade na tributação - Qual o critério que legitima discriminações em matéria fiscal? In: FERRAZ, Roberto (coord.). Princípios e limites da tributação. São Paulo: Quartier Latin, 2005, p. 451.

${ }^{29}$ Cf. FERRAZ, op. cit. (nota 28), p. 450-455 e 476-480; Cf. TORRES, op. cit. (nota 24), p. 236; Cf. ZILVETI, op. cit. (nota 23), p. 134; dentre outros.

${ }^{30}$ Para aprofundamento do tema, cf. ZILVETI, op. cit. (nota 23), p. 136-139.

${ }^{31}$ Cf. TIPKE, Klaus; LANG, Joachim. Steuerrecht. $18^{\text {a }}$ ed. Köln: Otto Schmidt, 2005, p. $225(\S 9,44)$, p. 83 $(\S 4,82)$.

${ }^{32}$ Cf. ZILVETI, op. cit. (nota 23), p. 144.
} 
pois guarda correspondência com a finalidade da norma que o fundamenta (nexo causal, decorrência lógica ou congruência) $)^{33}$.

Ademais, cumpre relevar que o pensamento de Adam Smith reflete a noção de que a capacidade econômica do indivíduo decorre de uma relação de benefício, sendo a tributação maior justificada por esse critério. Quem detinha mais capacidade contributiva deveria sofrer tributação mais agravada, contribuindo em maior medida para o financiamento do Estado.

Neste contexto, a tributação sobre a renda assume um papel importante, pois os benefícios que o indivíduo obtém da sua relação com o Estado podem ser associados à renda que ele aufere, tendo em vista que, em última análise, é a organização do Estado que oferece as condições para que os indivíduos exerçam atividades econômicas e obtenham renda para a satisfação de suas necessidades.

A despeito da ausência de uma indicação clara na legislação quanto ao critério ideal de apuração da capacidade de pagar tributos ${ }^{34}$, a doutrina normalmente identifica o atributo renda como o elemento indicador da capacidade contributiva por excelência ${ }^{35}$.

E a identificação da renda realizada, previamente à imposição da obrigação tributária, revela-se como um imperativo decorrente do princípio da capacidade contributiva e que vem a ser mais bem delineado pelo princípio da realização da renda ${ }^{36}$. O princípio da realização guia a determinação do momento temporal a partir do qual a renda está consumada e pode ser tributada, ou seja, orienta a marcação do instante, por exemplo, a partir do qual se verifica o acréscimo patrimonial e o imposto pode ser exigido ${ }^{37}$.

O princípio sob análise, portanto, conduz a produção das regras pertinentes à apuração da renda tributável, impedindo que a tributação atinja eventos econômicos que,

\footnotetext{
${ }^{33}$ As expressões entre parênteses são as mencionadas respectivamente por: SCHOUERI, Luís Eduardo. Normas tributárias indutoras e intervenção econômica. Rio de Janeiro: Forense, 2005, p. 276; BASTOS, Celso Ribeiro. Curso de direito constitucional. 16 a ed., ampl. e atual. São Paulo: Saraiva: 1995, p. 167-168; ÁVILA, Humberto. O princípio da isonomia em matéria tributária. In: TÔRRES, Heleno Taveira (coord.). Tratado de direito constitucional tributário: Estudos em homenagem a Paulo de Barros Carvalho. São Paulo: Saraiva, 2005, p. 407-410.

${ }^{34}$ A Constituição Federal Brasileira atual aponta para um conjunto de critérios: patrimônio, renda, atividades e operações comerciais.

35 Cf. ZILVETI, op. cit. (nota 23), p. 226. Cf. LANG Joachim. Die Bemessungsgrundlage der Einkommensteuer: Rechtssystematische Grundlagen steuerlicher Leistungsfähigkeit im deustschen Einkommensteuerrecht. Köln: Otto Schmidt, 1988, p. 104 (nota de rodapé 346).

${ }^{36}$ Cf. ZILVETI, op. cit. (nota 23), p. 242.

${ }^{37}$ Cf. OLIVEIRA, Ricardo Mariz de. Princípios Fundamentais do Imposto de Renda. In: SCHOUERI, Luís Eduardo; ZILVETI, Fernando Aurelio (coords.). Direito Tributário: Estudos em Homenagem a Brandão Machado. São Paulo: Dialética, 1998, p. 225.
} 
embora possam denotar a presença de renda tributável, não revelam as condições de certeza consideradas suficientes a deflagrar a incidência tributária. Nesse sentido, o princípio da realização exerce uma função bloqueadora, visto que afasta situações que sejam incompatíveis com o estado ideal de coisas a ser promovido ${ }^{38}$.

Por outro ângulo, se a justiça de um sistema tributário está fundada no princípio da capacidade contributiva, então, toda forma de renda deve ser considerada na formulação da base de cálculo. Partindo-se de uma noção ampla de igualdade horizontal, dever-se-ia necessariamente onerar a totalidade da renda, para evitar que alguns contribuintes com capacidade contributiva escapem da tributação ${ }^{39}$.

Nesse sentido, reitera-se que o princípio da realização traça tão-somente uma diretriz, uma noção geral a ser preenchida pelas regras pertinentes à apuração da renda tributável. Nesta tarefa de definição, determina-se com mais clareza o conteúdo do termo realização, preenchendo-o com algum ou mais dos elementos temporais pertinentes ao exercício do fato econômico tributável ${ }^{40}$.

A utilização de uma noção mais ampla de realização, abrangendo, por exemplo, o acréscimo patrimonial oriundo da mera valorização de ativos (sem transação com terceiro), bem como a restrição do conceito de realização à conclusão financeira das atividades econômicas (pagamento), à sua conclusão jurídica (tradição da mercadoria, execução do serviço etc.) ou qualquer outra concepção mais ou menos restritiva, todas essas decisões de política tributária dependem de condições práticas do sistema tributário de que se trata e da noção de renda que se considera justa e adequada.

Este processo de identificação e discernimento dos acontecimentos que são conexos ao fenômeno realização da renda (e adequados ao atendimento do princípio da tributação conforme capacidade contributiva), assim como a efetiva eleição dos eventos que são decisivos nas diferentes atividades econômicas, ambos, estão atrelados às teorias fornecidas pelas ciências econômicas e financeiras relativas ao conceito de renda. Dito de outra forma: definir qual o momento específico em que a renda se considera realizada depende de escolhas quanto ao conceito de renda que se considera adequado em vista das

\footnotetext{
${ }^{38}$ Sobre a função bloqueadora dos princípios, cf. ÁVILA, op. cit. (nota 1), p. 98.

${ }^{39}$ Cf. HOLMES, Kevin. The concept of income: A multi-disciplinary analysis. Amsterdam: IBFD, 2001, p. 25.

${ }^{40}$ Conforme já abordado, diferentes etapas do processo econômico poderiam ser consideradas determinantes da realização (produção, valorização, fechamento de contrato de venda, tradição, conclusão de atividade, efetivo pagamento, consumo etc.).
} 
condições fáticas e jurídicas e, igualmente, de um exame acerca da forma como se desenrolam os fatos econômicos submetidos à tributação ${ }^{41}$.

Para tanto, apresenta-se aqui uma análise de teorias influentes a respeito da evolução histórica e dos conceitos possíveis de renda fornecidos pelas ciências econômicofinanceiras.

\section{Conceitos de renda e noções correlatas de realização}

Durante a Idade Média, a tributação sobre a renda exercia um papel insignificante. Para as finanças públicas da época, eram de maior relevância os tributos sobre comércio e transportes e, no que respeita a uma tributação destinada a verificar diretamente a capacidade contributiva do contribuinte, os tributos sobre a propriedade ${ }^{42}$. Embora, nesse período, alguns tributos sobre a propriedade pudessem exibir características que denotassem tributação da renda ${ }^{43}$, foi apenas em período histórico mais recente, sobretudo na época da Revolução Industrial, que se verificou o surgimento de formas de imposto de renda com as características adotadas atualmente.

Identificam-se, destarte, na Grã-Bretanha ${ }^{44}$ de 1799 , as raízes históricas desse imposto que, adotado originalmente como forma temporária de exação destinada ao financiamento da guerra contra Napoleão Bonaparte ${ }^{45}$, passou a servir de sustentáculo a virtudes de reforma social e justiça distributiva, sobretudo no começo do século $\mathrm{XX}^{46}$.

A própria determinação do momento exato em que tenha surgido historicamente o imposto de renda já é uma tarefa que pressupõe a adoção de alguma definição prévia do que se entenda por renda. Na Grã-Bretanha, por exemplo, o imposto

\footnotetext{
${ }^{41}$ Como são executadas as atividades, como se estipulam pagamentos, como se distribuem riscos, todos esses fatores podem ser determinantes para a escolha do momento temporal em que a renda se considera seguramente consumada.

${ }^{42}$ Cf. SELIGMAN, op. cit. (nota 25), p. 41-42.

${ }^{43}$ Seligman exemplifica com o tributo sobre a terra que era exigido com base no valor presumido de locação do imóvel, porém, alerta ser equivocado ver semelhança entre essas formas de tributação e o imposto de renda. Cf. SELIGMAN, op. cit. (nota 25), p. 42-48.

${ }^{44}$ Usa-se neste trabalho a expressão "Reino Unido" para referência ao período posterior a 1801, a partir do qual, com a incorporação da Irlanda à Grã-Bretanha, esta expressão foi consagrada.

${ }^{45}$ Cf. FELIX, Günther. Einkommensteuer (verbete). In: STRICKRODT, Georg. Handwörterbuch des Steuerrechts: unter Einschluss von betriebswissenschaftl. Steuerlehre, Finanzrecht, Finanzwiss, $2^{\mathrm{a}}$ ed. München und Bonn: C.H. Beck'sche Verlagsbuchhandlung, 1981, p. 395 (item B).

${ }^{46}$ ARDANT, Gabriel. Histoire de L'impôt. Livre II - Du XVIII ${ }^{\mathrm{e}}$ au XXI ${ }^{\mathrm{e}}$ siècle. Paris: Fayard, 1971, p. 404-409.
} 
criado em $1797^{47}$ incidia sobre as despesas do indivíduo ${ }^{48}$ e, embora estas afetem uma grandeza econômica que corresponda à noção de renda aclamada por alguns autores ${ }^{49}$, convencionou-se identificar como marco inicial o imposto de guerra de 1799, porque se procura uma noção de renda semelhante àquela adotada hoje na maioria dos países ${ }^{50}$.

Apesar de sua experiência com o imposto de renda ser a mais antiga, a GrãBretanha não foi o berço de estudos econômico-financeiros significativos para o desenvolvimento de conceitos gerais de renda. Foi particularmente na Alemanha, Itália e E.U.A. que estudiosos se debruçaram perspicazmente sobre esse tema ${ }^{51}$, contribuindo com análises aprofundadas e concepções cuja influência perene se verifica ainda hoje no âmbito das mais variadas discussões a respeito do imposto de renda.

Os principais trabalhos publicados sobre a difícil conceituação do que seja renda datam do final do séc. XIX e começo do séc. XX. Por serem essas teorias fundamentais para a exposição dos demais tópicos deste trabalho, traça-se aqui uma exposição sucinta da forma como se desenvolveram os conceitos econômicos e financeiros de renda e da sua relação com as definições formuladas nas áreas econômica, contábil e jurídica $^{52}$.

Curiosamente, a exposição cronológica das definições de renda não se revela propriamente a mais adequada sob uma perspectiva sistêmica. Possivelmente porque, conforme pontua Edwin Seligman, quando do surgimento do imposto de renda, a ciência

\footnotetext{
${ }^{47} \mathrm{O}$ tributo proposto em 1797 por William Pitt (apurado pelo chamado Triple Assessment) e adotado em 1798 não costuma ser identificado com um imposto sobre a renda porque tomava como base as despesas do indivíduo e não seus recebimentos. Apenas ao final de 1798 é que William Pitt propõe o ato legislativo que criará um genuíno imposto sobre a renda. Cf. GROSSFELD, Bernhard; BRYCE, James D. A brief comparative history of the origins of the income tax in Great Britain, Germany and the United States. In: The American Journal of Tax Policy, v. 2. American College of Tax Counsel, 1983, p. 213-214.

${ }^{48}$ Cf. SELIGMAN, op. cit. (nota 25), p. 65-66, 79-80.

${ }^{49}$ Conforme se verá adiante, no item 2.2.1 deste Capítulo, há noções de renda do tipo dispositiva (disposition type), isto é, aquelas que se baseiam preponderantemente no consumo e resguardam a renda poupada do alcance da tributação. As noções de renda tradicionalmente discutidas no Brasil (renda-produto e rendaacréscimo patrimonial) são da tradição do acréscimo de valor (accrual type tradition).

${ }^{50}$ No Brasil, discussão semelhante foi abordada por Walter Barbosa Correa para indagar se o imposto de renda teria surgido: (i) com a décima urbana, em 1808, tributo incidente sobre os rendimentos de locação; (ii) com o imposto sobre lojas, em 1812, tributo incidente sobre as vendas realizadas em lojas, armazéns etc., (iii) com o imposto extraordinário sobre vencimentos, em 1843, ou (iv) se foi apenas em 1924, com a instituição de um imposto sobre a renda mais completo, com características semelhantes ao atual. Cf. CORREA, Walter Barbosa. Subsídios para o estudo da história legislativa do imposto de renda no Brasil. In: MARTINS, Ives Gandra da Silva (coord.). Imposto de renda: Conceitos, princípios e comentários (em memória de Henry Tilbery). $2^{\mathrm{a}}$ ed. São Paulo: Atlas, 1996, p. 205-206.

${ }^{51}$ Cf. WUELLER, Paul H. Concepts of taxable income I - The german contribution. In: Political Science Quarterly, v. LIII, n. 1. New York: Columbia University, mar.1938, p. 84-86.

${ }^{52}$ Para uma visão ampla dos diversos conceitos oferecidos por economistas, financistas e juristas, ver ZILVETI, Fernando Aurelio. O princípio da realização da renda. In: SCHOUERI, Luís Eduardo (coord.). Direito tributário: Homenagem a Alcides Jorge Costa, vol. I. São Paulo: Quartier Latin, 2003, p. 300-303.
} 
econômica ainda não havia oferecido análises satisfatórias dos conceitos e das relações de renda e capital ${ }^{53}$.

Como visto acima ${ }^{54}$, as primeiras manifestações históricas do imposto de renda concentravam-se em algumas expressões específicas de renda e não havia necessariamente uma forma de tributação abrangente da renda. Do mesmo modo, a base adotada para as imposições da renda observadas entre o final do século XIX e grande parte do século XX firmava-se numa concepção estritamente monetário-financeira da renda (no sentido de que importava apenas o fluxo de caixa) e, não raro, excluía da tributação algumas manifestações específicas de acréscimos patrimoniais: particularmente os ganhos eventuais.

Uma definição econômica mais ampla de renda, como sinônimo de benefício auferido pelos indivíduos e não restrita a transações prontamente redutíveis à expressão monetária, passou paulatinamente a ser discutida no começo do século XX.

Nesse passo, uma forma interessante de se principiar a exposição dos conceitos de renda foi proposta por Kevin Holmes, em obra recente sobre o tema ${ }^{55}$, e consiste em apresentar, por primeiro, uma concepção subjetiva, porém a mais abrangente: a renda psíquica.

A partir desta que é a noção mais abrangente, é possível tracejar um panorama sistemático dos conceitos econômico-financeiros de renda e também associá-los com as noções correlatas que podem ser adotadas para conceituar a realização da renda, haja vista estarem tais elementos, o conceito de renda e o momento temporal eleito como determinante para a realização, fortemente relacionados.

Destarte, como se verá na exposição adiante, confrontam-se, de um lado, as noções econômicas mais amplas de renda, que buscam concretizar o princípio do benefício em sua maior amplitude (apresentando-se a realização da renda, neste caso, como uma manifestação direta da satisfação recebida pelo indivíduo, ou do consumo de bens e serviços etc.), e, de outro lado, as noções econômicas, contábeis e jurídicas de renda que se identificam com um nível maior de certeza e de praticabilidade (refletindo a mensuração

\footnotetext{
${ }^{53}$ Cf. SELIGMAN, Edwin. Are stock dividends income? In: Studies in public finance. New York: Augustus M. Kelley, 1969 (reimpressão), p. 111.

${ }^{54}$ Vide notas 47 e seguintes e o texto que as acompanha.

${ }^{55} \mathrm{O}$ estudo que aqui se apresenta baseia-se na obra de três grandes compiladores das teorias sobre a renda: Paul H. Wueller (vide notas 51, 107 e 111), Horacio A. Garcia Belsunce (vide nota 86) e Kevin Holmes (vide nota 39$)$.
} 
da renda segundo critérios específicos e restritivos). Adotando-se a classificação sugerida por Alcides Jorge Costa, pode-se afirmar que, no primeiro grupo, encontram-se os conceitos de renda psíquica e renda-consumo (típicas conceituações de renda sob a ótica do consumo), e no segundo os conceitos de renda-produto e renda-acréscimo (renda sob a ótica da produção) e também os de rendas nacional e individual (renda sob a ótica da distribuição) $)^{56}$.

\subsection{Visão geral dos critérios possíveis de realização}

Observadas sob a perspectiva temporal, as definições de renda que são discutidas nos tópicos seguintes normalmente envolvem a eleição de um ou mais acontecimentos que refletem algum momento temporal pertencente ao desenrolar de cada atividade econômica. Teoricamente, qualquer um desses eventos pode ser tomado como terminativo do processo econômico e, portanto, determinante da realização da renda, uma vez que atenderia a alguma das noções de renda discutidas nas teorias econômicas.

Para ilustrar esse raciocínio com algumas formas de realização tratadas nas definições de renda discutidas abaixo, apresenta-se aqui uma linha do tempo simplificada que retrata uma sucessão de eventos, abrangendo desde a produção de uma mercadoria até a sua venda e o uso dos recursos financeiros para a compra de bens e serviços que serão consumidos $^{57}$.

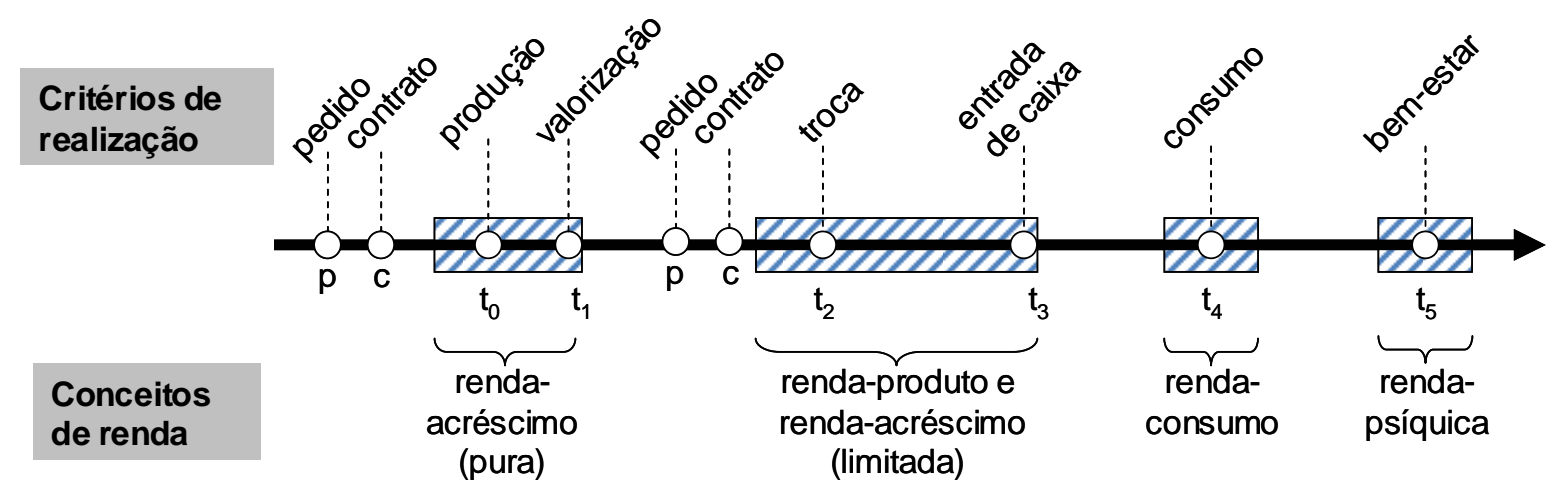

Quase que instantaneamente após a produção de uma mercadoria $\left(\mathrm{t}_{0}\right)$, verificase a sua valorização( $\left.\mathrm{t}_{1}\right)$, isto é, a pessoa que detém uma mercadoria produzida já

\footnotetext{
${ }^{56}$ COSTA, Alcides Jorge. Conceito de renda tributável. In: MARTINS, Ives Gandra da Silva (coord.). Imposto de renda - Conceitos, princípios e comentários (em memória de Henry Tilbery). $2^{\mathrm{a}}$ ed. São Paulo: Atlas, 1996, p. 25-27.
} 
experimenta um nível de riqueza maior (um acréscimo patrimonial) do que na situação anterior (em que os bens de produção ainda não foram organizados para a geração de valor econômico). A este evento de acréscimo de valor corresponde uma noção de renda segundo a teoria do acréscimo patrimonial líquido (em sentido puro e, portanto, mais amplo do que o normalmente adotado pelas legislações).

Depois da produção, seguem-se diversos atos (muitos deles não retratados na figura acima, tais como oferta, fechamento de contrato de venda, recebimento de adiantamento etc.) que poderiam, em tese, ser considerados eventos de realização. Para fins de simplificação, a figura apresenta o evento da troca $\left(\mathrm{t}_{2}\right)$, traduzido, de maneira geral, no evento crítico que, em geral, é definido conforme o Direito Civil (englobando a tradição da mercadoria, a execução do serviço etc.) e gera o surgimento do direito à contraprestação (sinalagma). A esta forma de realização, correlacionam-se os conceitos de renda-produto e renda-acréscimo (com as limitações práticas que lhe forem inerentes) adotados pela legislação tributária. Ao momento da troca corresponde também a noção de renda como competência (em sua visão tradicional: regime de competência ou disponibilidade jurídica da renda). Ao momento da entrada de caixa corresponde a noção de regime de caixa (ou disponibilidade econômica da renda) ${ }^{58}$.

Em torno das acepções ampla (pura) e restrita (limitada) de renda-acréscimo figuram também os eventos de pedido de compra e fechamento do contrato, os quais podem também ser considerados, em termos teóricos, como critérios possíveis para o princípio da realização, pois garantem ao contratante a aquisição de determinados direitos (por exemplo, o direito de, em caso de rescisão, ser ressarcido dos custos e despesas incorridos para o cumprimento do contrato).

Aos outros eventos relevantes dispostos na figura (o consumo dos bens e serviços adquiridos e o bem-estar decorrente do consumo) correspondem noções de renda tratadas nos itens seguintes (renda psíquica e renda-consumo).

Antes de continuar a exposição, faz-se aqui uma advertência terminológica: é importante ressaltar que o significado que se atribui neste trabalho à expressão princípio da realização (seja de renda, receita ou despesa) é o de um comando geral que permite sua

\footnotetext{
${ }^{57}$ Por extrapolar os limites deste trabalho, não se apresenta ou discute aqui o controverso tema da existência de consumo na pessoa jurídica, que passa pela justificativa da tributação das pessoas jurídicas e também por discussões sobre as relações e as formas de integração sócio-empresa.
} 
implementação, a ser definida pela legislação de regência do tributo, mediante a escolha de critérios de realização. Tais critérios são entendidos como fatos específicos que são eleitos para figurar como evento crítico, terminativo da atividade econômica geradora de renda. Esta distinção é apropriada, até mesmo para guiar a leitura de diversos textos que empregam a expressão princípio da realização para significar tanto uma quanto outra das definições apresentadas acima.

\subsection{Conceitos de renda sob a ótica do consumo}

Conforme anunciado, principia-se o estudo com a abordagem dos conceitos mais amplos de renda, os quais, não fossem os entraves de praticabilidade, seriam capazes de cumprir com os ideais de igualdade e tributação conforme a capacidade contributiva em sua máxima amplitude. Fala-se, assim, dos conceitos de renda que se baseiam em atributos de consumo.

\subsubsection{Renda psíquica e renda-consumo}

Embora tenha sido aperfeiçoado cronologicamente mais tarde, o conceito de renda como fruto de experiência psicológica ilustra perfeitamente a dificuldade prática envolvida no alcance pleno da capacidade contributiva. A noção de renda psíquica parte do princípio de que o Estado proporciona bem-estar ao indivíduo e depende de recursos para desempenhar suas funções, por conseguinte, nada mais justo que diferenciar os indivíduos de acordo com o bem-estar que o Estado lhes confere, impondo a tributação conforme este critério, pois aqueles que têm maior bem-estar também têm melhores condições de contribuir com as despesas do Estado.

Renda psíquica seria, então, o fluxo de satisfações que os indivíduos obtêm do consumo de bens e serviços na sociedade. Nessa acepção, portanto, renda não é o dinheiro, nem tampouco os bens e serviços que o dinheiro pode comprar ${ }^{59}$.

Idealmente seria esta uma das melhores maneiras de diferenciar as pessoas e impor-lhes tributação ajustada às diferenças de bem-estar subjetivas, algumas imperceptíveis à perspectiva baseada no monetarismo. Porém, a vagueza do termo bemestar e a difícil mensuração de elementos psíquicos já conduzem a uma necessária

\footnotetext{
${ }^{58}$ No capítulo 2 deste trabalho, discutem-se as noções de disponibilidade jurídica e econômica a partir da definição de renda proposta pelo Código Tributário Nacional, associando-a, preponderantemente, aos regimes de competência e caixa.

${ }^{59}$ Cf. HOLMES, op. cit. (nota 39), p. 36-37.
} 
simplificação da noção de renda, limitando-a a fenômenos objetivos observáveis e mais facilmente mensuráveis ${ }^{60}$.

Dentre outros relevantes autores ${ }^{61}$, destaca-se a formulação de Irving Fisher, para quem, segundo Wueller, a renda é uma série de eventos, e são esses eventos (as experiências psíquicas da mente humana) que constituem, em última análise, a renda do indivíduo $^{62}$. Segundo bem explica Holmes, em leitura da obra de Fisher ${ }^{63}$, se fosse praticável adotar uma tal concepção de renda, seu cálculo seguiria o seguinte caminho:

- do salário (W) deve-se deduzir o custo psicológico (P) incorrido com a realização de trabalhos, obtendo-se [ $\mathrm{W}-\mathrm{P}$ ];

- o salário (W) é utilizado, por exemplo, para comprar pão, o que gera serviços de alimentação $(\mathrm{O})$, ou serviços objetivamente desfrutáveis (que são fornecidos pelo exterior do corpo do indivíduo e estimulam funções psicológicas), gerando uma relação [ $\mathrm{O}-\mathrm{W}$ ]; e

- enfim, os serviços objetivos $(\mathrm{O})$ são transformados em satisfações psíquicas (S), ou seja, os benefícios psíquicos são obtidos ao custo dos serviços reais decorrentes do consumo de bens, de forma que [ $\mathrm{S}-\mathrm{O}$ ].

A composição desses elementos revela então a noção completa de renda psíquica $(\mathrm{Y})$, expressa nos seguintes termos: $\mathrm{Y}=(\mathrm{W}-\mathrm{P})+(\mathrm{O}-\mathrm{W})+(\mathrm{S}-\mathrm{O})$

Eliminando-se as duplas contagens, chega-se à conclusão de que a renda psíquica nada mais é que as satisfações obtidas pelo indivíduo, diminuídas do custo psicológico enfrentado para obtê-las: $\mathrm{Y}=\mathrm{S}-\mathrm{P}$

A dificuldade na aplicação dessa noção de renda é reconhecida pelo próprio Fisher $^{64}$ :

${ }^{60}$ Cf. HOLMES, op. cit. (nota 39), p. 5-14, 37.

${ }^{61}$ Holmes menciona Emil Sax, Umberto Ricci e William H. Hewett. Cf. HOLMES, op. cit. (nota 39), p. 3738.

${ }^{62}$ Cf. WUELler, Paul H. Concepts of taxable income II - The american contribution. In: Political Science Quarterly, v. LIII, n. 4. New York: Columbia University, dez.1938, p. 572.

${ }^{63}$ Cf. FISHER, Irving. The nature of capital and income. New York: Macmillan, 1906, apud HOLMES, op. cit. (nota 39), p. 39-41.

${ }^{64}$ Tradução livre de: FISHER, Irving. Comment on President Plehn's Address. In: American Economic Review, mar.1924, p. 64-65, apud HOLMES, op. cit. (nota 39), p. 41. O trecho original é: Theoretically, therefore, a meticulous income tax should pursue its victim to his dinning table and take toll from each mouthful, and should go with him to the theatre and tax every laugh. No tax which stops short of these final satisfactions can ever be a perfectly exact income tax. 
"Teoricamente, então, um imposto de renda meticuloso deveria perseguir sua vítima até a mesa de jantar e onerar cada garfada, e deveria segui-lo até o teatro e tributar cada risada. Qualquer tributo que se abstenha de tributar essas satisfações finais não poderá jamais ser considerado um imposto de renda perfeitamente exato."

A análise de Fisher voltada ao elemento consumo acabou influenciando outro professor da Harvard Law School, o Prof. William Andrews, notável propagador da teoria da renda-consumo, resultando na proposta de um imposto de renda baseado no fluxo de caixa $^{65}$. Tendo em vista a inviabilidade prática de se medir diretamente a quantidade de bens e serviços consumidos por um indivíduo, a observação das despesas monetárias desponta como uma medida viável do consumo ${ }^{66}$.

Descendo um degrau na escala de amplitude das noções de renda, essa proposta confere maior ênfase aos bens econômicos, não cuidando propriamente da satisfação que deles decorre. Além disso, embora os conceitos de satisfação psíquica ou do consumo de bens e serviços sejam de difícil aplicação, chega-se a um denominador de aplicação prática facilitada: o fluxo de caixa.

A proposta de Andrews para a tributação da renda num modelo de fluxo de caixa é considerada mais vantajosa porque o consumo aproxima-se mais da utilidade e esta seria a medida ideal de justiça distribucional. Um tributo sobre o consumo seria a melhor aproximação desse paradigma (de justiça distributiva baseada não em níveis de renda, mas sim em níveis de satisfação, bem-estar ou utilidade individual), uma vez que o fenômeno consumo, definido como o uso último ou a destruição de recursos econômicos (tal como ao se tomar uma taça de vinho), é o fenômeno observável mais próximo da utilidade ${ }^{67}$.

\footnotetext{
${ }^{65} \mathrm{O}$ chamado cash-flow consumption income tax. Cf. DODGE, Joseph M. The Story of Glenshaw Glass: Towards a Modern Concept of Gross Income. In. Tax Stories: An in-depth look at ten leading federal income tax cases. CARON, Paul L. New York: Foundation Press, 2003, p. 35.

${ }^{66}$ Cf. HOLMES, op. cit. (nota 39), p. 53.

${ }^{67}$ Cf. WARREN, Alvin. Would a Consumption Tax Be Fairer Than an Income Tax? In: The Yale Law Journal, v. 89, n. 6, maio de 1980, p. 1084, 1095-1096.
} 
De acordo com Andrews e seus seguidores ${ }^{68}$, a tributação da renda conceituada como consumo seguiria, grosso modo, o seguinte modelo de tributação voltado a atingir os gastos de consumo: todos os recebimentos, inclusive decorrentes de empréstimos, seriam incluídos na base do imposto e todos os gastos não relacionados a consumo, inclusive pagamentos do principal e juros relativos a dívidas, seriam deduzidos. O resultado de tal tributo sobre o fluxo de caixa ou tributo sobre o gasto (consumption tax), como costuma ser chamado, é o de que apenas o consumo seria tributado, mas segundo alíquotas que poderiam ser graduadas com base no consumo pessoal ${ }^{69}$.

Embora nos E.U.A. a discussão quanto à base ideal do imposto de renda (renda-consumo $\mathrm{x}$ renda-produto ou renda-acréscimo ${ }^{70}$ ) tenha consumido décadas $\mathrm{e}$ repercuta até os tempos atuais, no Brasil, sugestões quanto á tributação da renda-consumo passaram praticamente desapercebidas, tendo encontrado raras vozes, como foi o caso do trabalho do economista Carlos Alberto Longo, publicado em $1984^{71}$, e mais recentemente a tese defendida por Hiroshi $\mathrm{Nakao}^{72}$, que propugna por um modelo de tributação da renda conforme fluxos de caixa realizados. Bulhões Pedreira menciona rapidamente o ato de

\footnotetext{
${ }^{68}$ Bibliografia adicional sobre o tema pode ser encontrada em: KALDOR, Nicholas. An expenditure tax. London: Allen \& Unwin, 1955; ANDREWS, William, A Consumption-Type or Cash Flow Personal Income Tax. In: Harvard Law Review, v. 87, n. 6, abril de 1974, p. 1113-1188; WARREN, Alvin. Fairness and a Consumption-Type or Cash Flow Personal Income Tax. In: Harvard Law Review, v. 88, n. 5, mar. 1975, p. 931-946; ANDREWS, William. Fairness and the Choice Between a Consumption-Type or an AccretionType Personal Income Tax: A Reply to Professor Warren. In: Harvard Law Review, v. 88, n. 5, mar. 1975, p. 947-958; SCHACHAR, Avishai, From Income to Consumption Tax: Criteria for Rules of Transition. In: Harvard Law Review, v. 97, n. 7, maio de 1975, p. 1581-1609; SHAVIRO, Daniel. Replacing the Income Tax With a Progressive Consumption Tax, NYU Law School, Public Law Research Paper No. 70; e NYU, Ctr for Law and Business Research Paper No. 03-18, setembro de 2003. Disponível em: $<$ http://ssrn.com/abstract=444221>. Acesso em 18 nov. 2008; FLEMING, J. Clifton. Replacing the Federal Income Tax with a Postpaid Consumption Tax: Preliminary Thoughts Regarding a Government Matching Program for Wealthy Investors and a New Tax Policy Lens. In: Southern Methodist University Law Review, v. 59, 2006. Disponível em: <http://ssrn.com/abstract=940699>. Acesso em 18 nov. 2008.

${ }^{69}$ A progressividade pessoal é um aspecto crucial para justificar a adoção de uma tal tributação sobre o gasto, uma vez que um tributo de alíquota única (flat rate) sobre o consumo poderia ser facilmente cobrado sob a forma de um tributo sobre valor agregado, o qual não envolveria o encargo administrativo das declarações pessoais. É apenas a persistência por adotar um modelo de progressividade que diferencie elementos pessoais que separa este imposto de renda de um imposto sobre o valor agregado. Cf. WARREN, op. cit. (nota 67), p. $1082-1083$.

${ }^{70}$ Ver os itens 2.3 .1 e 2.3.2 deste Capítulo sobre renda-produto e renda-acréscimo, respectivamente.

${ }^{71}$ Longo escreveu sob a inspiração direta de seus professores em Harvard, defensores da teoria da rendaconsumo (Andrews, Warren, Schachar). Cf. LONGO, Carlos Alberto. Em defesa de um imposto de renda abrangente. São Paulo: FIPE-Pioneira, 1984.

${ }^{72}$ Vale ressaltar que o trabalho de Nakao, apesar de influenciado pela teoria de Irving Fischer, não se fundamenta diretamente na teoria da renda-consumo conforme formulada por Andrews, Warren et alli e apresenta diferenças relevantes quanto aos critérios propostos para a tributação (no modelo de Nakao empréstimos e aumentos de capital, por exemplo, não são considerados fluxos de caixa tributáveis, ao passo que, no modelo de Andrews, tais valores acrescem à base de cálculo). Cf. NAKAO, Sílvio Hiroshi. Um Modelo de Tributação da Renda por Fluxos de Caixa Realizados. 2003. Tese de doutorado apresentada ao Departamento de Contabilidade e Atuária da Faculdade de Economia, Administração e Contabilidade da Universidade de São Paulo, São Paulo, 2003.
} 
consumo como sinônimo de renda real, porém, inclina para o conceito de renda produzida $^{73}$.

A operacionalização do imposto de renda-consumo (no caso, para um contribuinte pessoa física) foi assim resumida por Longo ${ }^{74}$ :

"De fato, avalia-se o consumo pessoal pela simples observação do fluxo de caixa do contribuinte durante o exercício fiscal. Somam-se, de um lado, todos os seus recebimentos na forma de salários, juros, dividendos, o valor da venda de ativos físicos e financeiros, o valor das doações e heranças recebidas e o valor dos empréstimos pessoais obtidos no período. O total desses recebimentos deverá ser igual ao valor das despesas em consumo que são tributadas e ao dos investimentos, doações e heranças que são isentos. Despesas não tributadas incluem a compra de ativos físicos e financeiros, a amortização de empréstimos, bem como os ajustamentos necessários em qualquer estrutura tributária para refinar a base a ser tributada, tais como o abatimento de despesas médicas e contribuições filantrópicas, isenções para um nível mínimo de consumo e incentivos para atividades prioritárias. O imposto recai, progressivamente, sobre a diferença entre os recebimentos [totais] e os pagamentos não tributados e, portanto, o princípio da arrecadação é idêntico ao do imposto de renda: tributa-se a fonte das despesas e não as despesas em si. Todos os recebimentos são tributáveis, em princípio, menos aquela parte que é excluída explicitamente.”

Um tal modelo de tributação teria diversas vantagens em relação aos modelos de tributação da renda-produto ou renda-acréscimo, sendo uma diferença marcante o alívio da tributação sobre a poupança ${ }^{75}$. Explica-se: o modelo atualmente adotado (de tributação da renda-produto com uma certa dose de renda-acréscimo) não leva em consideração a utilização posterior que se dá para a renda (se ela é poupada, ou consumida). A diferença entre um imposto de renda do tipo acréscimo e um do tipo

\footnotetext{
${ }^{73}$ Cf. PEDREIRA, José Luiz Bulhões. Imposto sobre a renda: pessoas jurídicas. Rio de Janeiro: Justec, 1979, p. 169-170.

${ }^{74}$ Cf. LONGO, op. cit. (nota 71), p. 39-40.

${ }^{75}$ Warren cita ainda as seguintes virtudes de um modelo de tributação da renda-consumo: (i) o consumo aproxima-se mais da utilidade, a medida ideal de justiça distribucional; (ii) o IR discrimina os poupadores; (iii) a tributação sobre o consumo é preferencial sob uma perspectiva da distribuição da renda ao longo da vida inteira; (iv) o conceito de renda é inerentemente defeituoso; e (v) a tributação sobre o consumo interfere menos sobre a liberdade individual. Cf. WARREN, op. cit. (nota 67), p. 1094.
} 
consumo envolve apenas o tratamento da renda acumulada e é, em grande medida, tãosomente uma diferença de alocação temporal: se um item de renda acumulada não for considerado na base tributável, a competência tributária sobre esse valor não é renunciada, mas simplesmente diferida ${ }^{76}$.

Nesse sentido, Warren observa que uma justificativa para o imposto de renda (no modelo renda-produto e renda-acréscimo) é que a sociedade tem uma pretensão sobre o seu produto anual ${ }^{77}$. Todavia, deve-se ter em conta que o objetivo principal da atividade produtiva é servir ao consumo humano, de forma que o produto não consumido simplesmente não é relevante para o cálculo distribucional. Assim, sob um tributo sobre o consumo, a pretensão moral do cidadão é por uma fatia justa dos bens e serviços consumidos durante o período de contagem ${ }^{78}$.

Segundo esse raciocínio, seria inapropriado tributar uma pessoa antes do momento em que ela saque seus recursos para fins de consumo pessoal. $\mathrm{O}$ fato de se deixar a renda poupada incólume de tributação pode ser caracterizado como desejável socialmente, pois, com isso, sobram recursos na economia e o capital assim fornecido vai aumentar ambas: a produção futura e a produtividade futura dos trabalhadores ${ }^{79}$.

Para os fins do presente estudo, importa fixar que às noções de renda expostas acima correspondem eventos específicos de realização. Os eventos de realização relevantes seriam o bem-estar e o consumo. Ademais, a despeito da impraticabilidade de se adotar uma noção de renda psíquica ou renda consumo, essas circunstâncias específicas continuam a servir de paradigma para contrapor ou justificar noções mais amplas de renda que se distanciem do evento recebimento de dinheiro. Nesse sentido, são os argumentos de falta de liquidez, por exemplo, quando se pretende tributar ganhos decorrentes de mera valorização de $\operatorname{ativos}^{80}$.

\footnotetext{
${ }^{76}$ Cf. ANDREWS, William. A Consumption-Type or Cash Flow Personal Income Tax. In: Harvard Law Review, v. 87, n. 6, abril de 1974. Artigo parcialmente reproduzido em CARON, Paul L. et alli. Federal income tax anthology. Cincinatti: Anderson Publishing Co., 1997, p. 577.

${ }^{77}$ Pretensão esta que antecede às pretensões de seus cidadãos individuais. Cf. WARREN, op. cit. (nota 67), p. 1090.

${ }^{78}$ Cf. WARREN, op. cit. (nota 67), p. 1093.

${ }^{79}$ Cf. WARREN, op. cit. (nota 67), p. 1094.

${ }^{80}$ Ver o item 2.5 deste Capítulo.
} 


\subsection{Conceitos de renda sob a ótica da produção}

Passando adiante, expõem-se a seguir, os dois conceitos de renda sob a ótica da produção, que, a propósito, são os mais difundidos e largamente adotados, quais sejam, os conceitos de renda-produto e renda-acréscimo. Importa ressaltar também que esses foram os conceitos albergados nitidamente pelo artigo 43 do Código Tributário Nacional e, portanto, delimitam o rol de eventos possíveis para serem eleitos como critérios de realização.

\subsubsection{Teoria das fontes (renda-produto)}

Para abordar a segunda grande linha de formulações de renda, volta-se novamente à leitura da definição de Hermann, que, segundo Lang, menciona que os bens econômicos (que geram as satisfações) fluem com uma certa regularidade, sendo identificada como renda a soma dos bens econômicos que adentram a disponibilidade de um indivíduo dentro de um certo intervalo de tempo sem prejudicar a sua fonte de produção $^{81}$.

Dessa definição podem se extrair dois critérios (ou testes) fundamentais de identificação da renda que são bastante característicos das formulações de renda segundo a teoria das fontes, quais sejam, a periodicidade e a manutenção da fonte de produção.

Por periodicidade ${ }^{82}$ (ou reprodutividade) se entende a capacidade de repetir, recorrer, tornar a vir que a renda pode ter. Essa ideia de recorrência, repetição está ligada, de certa forma, à etimologia da palavra renda, associada ao vocábulo revenu que representa algo "que volta" (qui revient ${ }^{83}$ ), "algo que se repete e volta a dar-se" ${ }^{\text {" }}$.

A seu turno, o teste da manutenção da fonte identifica como renda a parcela dos acréscimos que se revela disponível para o indivíduo (para consumo ou outro

\footnotetext{
${ }^{81}$ Cf. LANG, op. cit. (nota 35), p. 36 (nota de rodapé 12).

${ }^{82}$ Embora sejam temas relacionados, não confundir o critério de periodicidade (usado como teste para definição de renda) com o princípio da periodicidade, que envolve a periodicização, ou apuração periódica da base de cálculo do imposto de renda (que pode não se limitar a incluir apenas rendas recorrentes). Para a definição do princípio da periodicidade cf. SCHMIDLIN, Lorenz. Das Prinzip der Periodizität in der Gewinnbesteuerung. Zürich und St. Gallen: Polygraphischer Verlag, 1956, p. 13-14.

${ }^{83}$ Cf. SOUSA, Rubens Gomes de. A evolução do conceito de rendimento tributável. In: Revista de direito público, ano IV, v. 14. São Paulo: Revista dos Tribunais, out-dez. 1970, p. 341 (item 11). Note que Rubens Gomes de Sousa contrapõe o critério de periodicidade como característica essencial com o argumento também linguístico de que income é o "que entra - comes in", sem necessidade de repetição periódica.

${ }^{84}$ Cf. ZILVETI, op. cit. (nota 23), p. 226-227.
} 
proveito), sem prejuízo ou dano de seu patrimônio líquido ${ }^{85}$. É bom registrar que a adoção de tais critérios naturalmente confere maiores restrições ao conceito amplo e ideal de renda apresentado acima.

Uma grande limitação encontrada com frequência nas definições de renda desse período é o critério da produtividade, que, aliado à periodicidade e manutenção da fonte, fundamentou a concepção de renda-produto ${ }^{86}$. Conforme a exposição de Wueller, Heinrich L. Biersack inaugurou esse critério ao apresentar sua noção de renda tributável como todos os recebimentos que fluem da aplicação da força produtiva de um indivíduo. Ou seja, para ser reconhecido como renda o recebimento deve derivar de alguma atividade econômica do indivíduo ${ }^{87}$. Foi, no entanto, com Wilhelm Roscher que o critério foi mais bem explicitado, sendo a renda identificada como a soma de produtos derivados da aplicação de trabalho ou investimento de capital ${ }^{88 \mathrm{e} 89}$.

Combinando-se, assim, os critérios de periodicidade, manutenção da fonte e produtividade, obtém-se uma noção simplificada ${ }^{90}$ do que se consagrou chamar de teoria das fontes para determinação da renda. O principal expoente dessa teoria foi Bernhard Fuisting, que influenciou a formulação da lei do imposto de renda da Prússia de $1891^{91}$. Trata-se, no entanto, de uma concepção bastante restrita de renda, vários degraus abaixo na escala de amplitude e bastante afastada da formulação ideal ${ }^{92}$.

Assim, a teoria das fontes logo foi abandonada na Alemanha, ou melhor, complementada quando da edição da Lei do Imposto de Renda do Reino de 1920,

\footnotetext{
${ }^{85}$ Cf. WUELLER, op. cit. (nota 51), p. 90 (nota de rodapé 35).

${ }^{86} \mathrm{Cf}$. BELSUNCE, Horacio A. Garcia. El concepto de rédito: En la doctrina y en el derecho tributário. Buenos Aires: Depalma, 1967, p. 52, 121-122.

${ }^{87}$ Segundo Wueller, Biersack não esclarece, todavia, qual noção de produtividade adota (se derivada apenas de trabalho, ou também de capital). Cf. WUELLER, op. cit. (nota 51), p. 91-92.

${ }^{88}$ Cf. BELSUNCE, op. cit. (nota 86), p. 52. Cf. WUELLER, op. cit. (nota 51), p. 92-93. Cf. HOLMES, op. cit. (nota 39), p. 94-95.

${ }^{89}$ Também os termos "trabalho" e "capital" estão sujeitos a interpretações mais ou menos restritivas. Segundo reporta Holmes, Gärtner, por exemplo, define renda como resultado do esforço laboral, porém, adota uma interpretação ampla, para tratar como esforço laboral até mesmo a tomada consciente de decisões estratégicas que levariam a um ganho na venda de um título negociável. Cf. HOLMES, op. cit. (nota 39), p. 107.

${ }^{90}$ Simplificada porque caberia acrescentar, quando menos, o critério do produto líquido, ou renda líquida (que demanda a dedução de determinadas despesas), citado por Belsunce em sua síntese da teoria da rendaproduto. Porém, como não se pretende tampouco aprofundar aqui as minudências do critério de manutenção da fonte, que seria a origem do critério do produto líquido, preferiu-se apresentar uma noção abreviada da teoria das fontes.

${ }^{91}$ Cf. JOST, Paul. Der Gewinnbegriff im Handels- und Steuerrecht: zugleich ein Beitrag zur Lehre von der Handels- und Steuerbilanz. Würzburg: Richard Mayr, 1940. p. 15. Cf. LANG, op. cit. (nota 35), p. 36-37.

${ }^{92}$ A restrição se deve, sobretudo, à noção de periodicidade na interpretação do beneficiário, que exclui ganhos extraordinários e até mesmo ganhos ocasionais com recorrência superior ao período convencionado para incidência do imposto.
} 
reconhecendo-se que, embora facilitasse a identificação da renda tributável tanto pelo contribuinte quanto pela administração, a teoria das fontes oferecia uma definição deficiente, não exaustiva e incapaz de acompanhar a rápida evolução das relações econômicas $^{93}$. A referida legislação passou a adotar (com certas restrições) a teoria do acréscimo patrimonial líquido, que será abordada no tópico seguinte.

Como última observação acerca da teoria das fontes, podenre-se que as críticas às limitações do conceito de renda dos alemães (sobretudo à teoria das fontes) devem ser balanceadas com o fato de que na Prússia do século XIX havia um tributo sobre o patrimônio (Vermögensteuer ${ }^{94}$ ) que era cobrado sobre o patrimônio líquido e tinha caráter complementar ao imposto de renda (Ergänzungsteuer $)^{95}$.

\subsubsection{Teoria da renda separada do capital}

Vale fazer uma digressão rápida aqui para enfatizar que ganhou força também nesta época, sobretudo no começo do séc. XX, a noção de que renda é algo separado do capital que a produz (teoria da renda separada do capital ou simplesmente teoria res $^{96}$ ). Foi Edwin Seligman o grande difusor da ideia de que a tributação depende da verificação dos atributos de realização e separação, os quais podem ser ilustrados pela metáfora do fruto e da árvore (embora já realizado, o fruto gerado pela árvore somente pode ser considerado renda quando separado dela $)^{97}$.

Em breve síntese, Seligman definia renda como "influxos", com o sentido de recebimentos regulares e recorrentes (trata-se do elemento de periodicidade descrito aqui acima) e tratava ganhos extraordinários como capital (deixando-os livre de tributação) ${ }^{98}$.

Sua teoria influenciou, dentre outras, as obras de Rubens Gomes de Sousa e Henry Tilbery, deixando marcas também em um dos mais influentes casos judiciais dos

\footnotetext{
${ }^{93}$ Cf. LANG, op. cit. (nota 35), p. 36-37.

94 Cf. SCHMÖLDERS, Günter. Geschichte der Besteuerung (verbete). In: STRICKRODT, op. cit. (nota 45), p. 622 (item D-2).

${ }_{95}$ Cf. WUELLER, op. cit. (nota 51), p. 88-89. Wueller informa que a justificativa para implementação dessa tributação complementar decorreu de uma convicção geral de que a renda (na sua acepção limitada) não era uma medida adequada de capacidade contributiva.

${ }^{96}$ Cf. DODGE, op. cit. (nota 65), p. 32-33.

${ }^{97}$ Seligman cita ainda os exemplos do vitelo (que deve ser separado da égua reprodutora para constituir renda), do aluguel (uma utilidade efetiva separada das utilidades potenciais de uma casa) e do salário (o talento do encanador é parte dele, mas, para assegurar a renda que chamamos de salário, ele deve transformar seu talento em algo fora e separado dele: ao prestar um serviço relativo à reparação do forno: o serviço é então algo separado do sujeito). Cf. SELIGMAN, op. cit. (nota 53), p. 98103.

${ }^{98}$ Cf. DODGE, op. cit. (nota 65), p. 32-33.
} 
E.U.A. ${ }^{99}$ Esse tratamento diferenciado entre renda e capital era, segundo Ascarelli, Sousa e Almeida, condizente com as disposições da lei brasileira da década de 40, pois definia a renda como um acréscimo de riqueza verificado durante um dado período de tempo, em oposição ao capital, que é uma quantidade de riqueza num dado momento. Associados a esta teoria, encontravam-se normalmente os elementos realização e separação ${ }^{100}$.

Ao rigor desta teoria, é de se questionar se a venda da árvore (com os frutos) representa renda tributável. Assim, os citados autores brasileiros esclareciam que o aumento do valor da árvore era considerado maior-valia do capital ${ }^{101}$; além disso, explicavam que a valorização de um imóvel, por exemplo, poderia ser considerada renda para alguém que profissionalmente compre e venda imóveis, ao passo que não será considerada renda para alguém que tem o prédio como investimento de capital ${ }^{102}$. Essa teoria parece ter sido uma das razões determinantes para que a tributação sobre ganhos de capital demorasse a ser introduzida, tanto no Brasil quanto em outros países, ou, ainda, assumisse regimes diferenciados (em relação à tributação do trabalho, por exemplo).

\subsubsection{Teoria do acréscimo patrimonial líquido (renda-acréscimo)}

Avançando no estudo dos critérios propostos para identificar a renda, outro importante economista alemão a abordar o tema, no século XIX, foi Georg von Schanz, cuja contribuição influenciou o desenvolvimento da teoria do acréscimo patrimonial líquido e também no que mais tarde passou a ser identificado como conceito fundamental de renda ${ }^{103}$ ou conceito acréscimo mais consumo ${ }^{104}$.

\footnotetext{
${ }^{99}$ Vide comentários sobre o caso Eisner v. Macomber, no item 3.2 deste Capítulo.

${ }^{100}$ Os requisitos da noção da renda vigente neste período eram: a) necessidade de se tratar de uma importância separada da fonte que a produziu; b) necessidade da importância ser realizada, isto é, efetivamente percebida pelo seu titular; e c) possibilidade de reprodução periódica do rendimento, decorrendo desta última circunstância a permanência da fonte, que não deve ficar diminuída pelo fato da separação. Cf. ASCARELLI, Tullio; SOUSA, Rubens Gomes de; ALMEIDA FILHO, João Batista Pereira de. Lucros extraordinários e imposto de renda. São Paulo: Martins, 1944, p. 101-102.

${ }^{101}$ Assumindo esta perspectiva, os autores classificam determinados tributos antigos como tributos sobre capital (pois atingem "fenômenos isolados e eventuais"). Assim, segundo tais autores um tributo colonial alemão de 1898, incidente sobre a valorização da terra (sobre a maior-valia imobiliária), deve ser classificado como tributo sobre o capital e não sobre a renda. Do mesmo modo que, o reversion duty inglês, cobrado à alíquota de $10 \%$ sobre o incremento do valor das terras arrendadas. Cf. ASCARELLI, et alli, op. cit. (nota 100), p. 12-13.

${ }^{102}$ Para este indivíduo, pode-se tributar os rendimentos decorrentes do imóvel, mas não a maior-valia, realizada na hipótese do proprietário vendê-lo. Cf. ASCARELLI, et alli, op. cit. (nota 100), p. 104.

${ }^{103}$ Ou modelo Schanz-Haig-Simons (SHS), cf. HOLMES, op. cit. (nota 39), p. 35-36.

${ }^{104}$ Cf. MUSGRAVE, R. A. In defense of an income concept. In: Harvard Law Review, v. 81, n. 1, nov.1967, p. 47-48.
} 
A proposta de Schanz tornou-se notável por enunciar o conceito mais abrangente formulado até então. Para ele, o conceito de renda está relacionado com o aumento do poder econômico do indivíduo durante um certo período de tempo, incluindo não só os lucros realizados a partir da troca de bens e outras transações comerciais, mas também os benefícios derivados da utilização de bens (bens de capital, de casas, jardins etc.) e também do lazer. Lang e Wueller ${ }^{105}$ ressaltam que a definição de Schanz pretende abranger a totalidade da renda, incluindo valorizações (ou apreciações) não realizadas de patrimônio, ganhos de capital, ganhos de loteria, heranças etc. e aproximando-se do conceito econômico ideal de renda ${ }^{106}$.

A amplitude pretendida com esse conceito restringe-se pela condição monetária (monetarização) exigida para torná-lo razoavelmente praticável. Assim, as variadas formas de renda devem ser passíveis de redução a um denominador monetário comum que permita um cálculo aproximado do total.

Na mesma linha, conforme nos informam Belsunce e Holmes, o economista norte-americano Robert Murray Haig propôs uma definição abrangente de renda que também se limitava pelo critério objetivo da conversibilidade em moeda. Para ele, renda é o acréscimo do poder de um indivíduo de satisfazer as suas vontades em um dado período, sendo esse poder consistente de dinheiro ou qualquer coisa suscetível de avaliação em dinheiro. Enfim, renda é o valor monetário do acréscimo líquido ao poder econômico de um indivíduo entre dois pontos do tempo. ${ }^{107}$.

Em comparação com o conceito ideal de renda (fluxo de satisfações), o próprio Haig, na leitura de Holmes, reconhece que sua proposta relaciona renda ao poder de satisfazer desejos econômicos, e não em relação às próprias satisfações ${ }^{108}$.

\footnotetext{
${ }^{105}$ Cf. LANG, op. cit. (nota 35), p. 38. Cf. WUELLER, op. cit. (nota 51), p. 102-106.

${ }^{106}$ Schanz afirma: "O conceito [de renda] se manifesta como acréscimo patrimonial líquido em um determinado período temporal, incluindo os benefícios e o valor monetário dos serviços prestados por terceiros [e não compensados financeiramente] [...] Nós somamos também à renda todos os rendimentos líquidos e benefícios, os valores monetários de serviços prestados por terceiros, todos os presentes, heranças, legados, ganhos de loteria, pecúlios e pensões de seguro, ganhos especulativos de toda sorte, e nós subtraímos todas as cobranças de juros e perdas de capital". Tradução livre de: Der Begriff erweist sich als Reinvermögenszugang eines bestimmten Zeitabschnitts inkl. der Nutzungen und geldwerten Leistungen Dritter. [...] Wir rechnen also zum Einkommen alle Reinerträge und Nutzungen, geldwerte Leistungen Dritter, alle Geschenke, Erbschaften, Legate, Lotteriegewinne, Versicherungskapitalien, Versicherungsrenten, Konjunkturgewinne jeder Art, wir rechnen ab alle Schuldzinsen und Vermögensverluste. SCHANZ, Georg von. Der Einkommensbegriff und dir Einkommensteuergesetze. In: Finanzarchiv, série antiga, v. 13/1. Stuttgart, 1896, p. 23-24.

${ }^{107}$ Cf. WUELLER, op. cit. (nota 107), p. 564. Cf. BELSUNCE, op. cit. (nota 86), p. 140-142.

${ }^{108}$ Cf. HOLMES, op. cit. (nota 39), p. 61-62.
} 
Como afirmado na apresentação do conceito de renda psíquica, a adoção de uma noção ampla de renda (e, portanto, de uma base de cálculo o mais abrangente possível para o imposto de renda) tem o propósito social muito claro de não gerar diferenças injustificáveis entre contribuintes ${ }^{109}$. A aplicação rigorosa de tal noção ampla de renda permite uma distribuição ideal da carga tributária, avaliando-se a capacidade contributiva relativa à renda de forma mais precisa ${ }^{110}$. Se o propósito é tributar conforme a capacidade contributiva, por conseguinte a definição deve ser a mais abrangente possível ${ }^{111}$.

De fato, verifica-se que o evento valorização de ativos pode, em princípio, ser eleito como critério da realização da renda (para fins de evidenciar ganhos de detenção). Numa sequência de eventos relativos à produção de mercadorias, o sobrevalor econômico atribuído aos bens que serão destinados à comercialização já existe desde o término do processo de produção. Nesse sentido, tanto o evento produção quanto o evento valorização que daí decorre podem exprimir o término do processo econômico gerador de renda ${ }^{112}$.

Entretanto, quanto à implementação prática de tal conceito amplo de renda, Haig admite que dificuldades administrativas poderiam prejudicar a apuração, por exemplo, de um ganho decorrente da apreciação de um ativo fixo enquanto este não for efetivamente realizado (particularmente mediante uma transação com terceiros, um ato de alienação). Porém, a justificativa para não se tributar tal valor não é porque não se trata de renda, mas sim porque há dificuldades de mensuração substanciais ${ }^{113}$.

Desenvolvendo um conceito similar aos anteriores, Henry Simons formulou uma noção de renda em função dos direitos de propriedade de uma pessoa, compreendendo a soma do (i) acréscimo no valor dos direitos de propriedade detidos dentro do período em questão e (ii) valor dos direitos exercidos no consumo ${ }^{114}$. Conforme sintetizam Holmes e Belsunce, trata-se da soma do consumo exercido no período com a riqueza ao final do período, subtraída da riqueza no começo do período ${ }^{115}$. Matematicamente: $Y=\Delta W+C$. Isto

\footnotetext{
${ }^{109}$ Cf. WUELLER, op. cit. (nota 107), p. 564.

${ }^{110}$ Cf. BITTKER, Boris I. A "comprehensive tax base" as a goal of income tax reform. In: Harvard Law Review, v. 80, n. 5, mar.-1967, p. 983-984.

${ }^{111}$ Cf. Umberto Ricci, citado por WUELLER, Paul H. Concepts of taxable income III - The italian contribution. In: Political Science Quarterly, v. LIV, n. 4. New York: Columbia University, dez.1939, p. 566.

${ }^{112} \mathrm{Na}$ figura apresentada no item 2 supra, trata-se dos momentos temporais $\left(\mathrm{t}_{0}\right)$ e $\left(\mathrm{t}_{1}\right)$.

${ }^{113}$ Cf. WUELLER, op. cit. (nota 107), p. 564-565.

${ }^{114}$ Cf. SIMONS, Henry C.. Personal income taxation: the definition of income as a problem of fiscal policy. Chicago: University of Chicago Press, 1938, p. 49-50.

${ }^{115}$ Cf. HOLMES, op. cit. (nota 39), p. 66-67. Cf. BELSUNCE, op. cit. (nota 86), p. 151.
} 
é, a renda $(\mathrm{Y})$ é igual ao consumo $(\mathrm{C})$ mais a diferença patrimonial $(\Delta \mathrm{W})$ verificada no período (que, no caso, é medida após o consumo).

Vale destacar que não há diferença entre Haig e Simons quanto ao resultado que alcançam. Porém, Haig propõe o conceito de renda com base na totalidade do acréscimo patrimonial e Simons, com base no consumo mais o (que restar de) acréscimo patrimonial após o consumo ${ }^{116}$.

Combinadas as noções de renda comentadas acima, obtém-se o chamado modelo Schanz-Haig-Simons (modelo SHS) que continua a servir de paradigma para a conformação de uma noção de renda tributável mais próxima do ideal ${ }^{117}$.

\subsection{Conceitos de renda sob a ótica da distribuição}

Existem ainda, e aqui se os faz rápida menção, os conceitos de renda sob a perspectiva distribucional (rendas nacional e individual). Embora normalmente ignorados, por sua aparente pouca influência, tais conceitos são às vezes utilizados implicitamente como forma de subterfúgio à teoria do acréscimo patrimonial líquido (como no caso da discussão sobre a intributabilidade das transferências patrimoniais ${ }^{118}$ ).

\subsubsection{Renda nacional e renda individual}

O principal divulgador desses conceitos econômicos, na área de imposto de renda, foi Bulhões Pedreira, que traduziu a renda nacional como "a soma de todas as remunerações pagas aos fatores de produção", identificando-a com "o resultado líquido da atividade econômica da sociedade calculado do ponto de vista de sua repartição pelos

\footnotetext{
${ }^{116}$ Holmes apresenta um exemplo ilustrado com gráficos para explicar as diferenças nas concepções. Em suma, o exemplo é o seguinte: uma pessoa tem um bem por $\$ 100$, o valor desse bem aumenta para $\$ 150$ e é vendido no mesmo período, sendo $\$ 30$ gastos para comprar comida. Tanto na concepção de Haig quanto na de Simons a renda foi de $\$ 50$, porém, enquanto Haig se preocupa com o incremento líquido de valor (de $\$ 100$ para \$150) sem consideração do consumo, Simons define a renda como a soma do consumo (\$30) mais o acréscimo patrimonial líquido (após o consumo). Cf. HOLMES, op. cit. (nota 39), p. 68-70 (gráficos nas p. 71 e 73$)$.

${ }^{117}$ Cf. LANG, Joachim. The influence of tax principles on the taxation of income from capital. In: ESSERS, Peter; RIJKERS, Arie. The notion of income from capital. Amsterdam: IBFD, 2005, p. 3, 14, 18.

${ }^{118}$ Retomada brevemente adiante, nos itens 2.1 do Capítulo 2 e 3.3.1 do Capítulo 3.
} 
fatores de produção" ${ }^{119}$. Segundo Misabel Derzi, os valores líquidos adicionados pela produção denominam-se também de produto interno ${ }^{120}$.

A renda individual é decorrência da renda nacional, pois advém da repartição (ou distribuição) da renda que foi produzida e remunerada pela sociedade. Disso decorre a denominação de "teoria da pizza" ("pie” theory), que consiste na ideia de que a renda individual é uma parcela percentual da "pizza” constituída pela renda nacional ${ }^{121}$.

Se a tributação tivesse como base os conceitos supramencionados, duas consequências deveriam ser levadas em conta: a adoção irrestrita do princípio da neutralidade para fins de IR e a intributabilidade das transferências patrimoniais. $\mathrm{O}$ primeiro repousa em que o tratamento tributário de uma parte na transação (inclusão, para fins de tributação, do rendimento recebido) define o tratamento tributário da outra parte na mesma transação (dedutibilidade do rendimento pago), ou seja, se a renda individual é uma parcela da renda nacional, então bastaria identificar o valor de renda nacional adicionado por cada indivíduo e tributá-la (sendo todos os seus gastos potencialmente dedutíveis, pois representam renda adicionada - e tributada - por outros indivíduos) ${ }^{122}$. Já a segunda consequência decorre do fato de que as transferências de renda (doações, subvenções etc.) não se identificam com atividades econômicas, i.e., não remuneram fatores de produção e, portanto, não compõem a renda nacional, sendo, outrossim, excluíveis da tributação ${ }^{123}$.

\subsection{Restrições práticas à adoção de conceito abrangente de renda}

De uma maneira geral, pode-se dizer que as interpretações sobre o que seja renda partiram de noções bastante subjetivas para chegar, enfim, a definições mais objetivas e praticáveis ${ }^{124}$. Uma noção bastante aceita sobre esse assunto é a de que, às vezes, uma regra tributária é adotada não por proporcionar o tratamento mais justo e igualitário, mas sim porque a regra mais justa e igualitária seria muito complexa de ser administrada $^{125}$. Quanto ao conceito de renda, a prática dos sistemas tributários tem

\footnotetext{
${ }^{119}$ PEDREIRA, op. cit. (nota 73), p. 169 e ss.

${ }^{120}$ Cf. DERZI, Misabel Abreu Machado. Justiça prospectiva no imposto sobre a renda. In: TÔRRES, Heleno Taveira (coord.). Direito tributário internacional aplicado, v. IV. São Paulo: Quartier Latin, 2007, p. 52.

${ }^{121}$ Cf. DODGE, op. cit. (nota 65), p. 36-37.

${ }^{122}$ Cf. DODGE, op. cit. (nota 65), p. 25, 36-37.

${ }^{123}$ Cf. DERZI, op. cit. (nota 120), p. 53.

${ }^{124}$ Cf. HOLMES, op. cit. (nota 39), p. 35.

${ }^{125}$ Cf. THURONYI, Victor. The concept of income. In: Tax Law Review, v. 45, 1990. Artigo parcialmente reproduzido em CARON, Paul L. et alli. Federal income tax anthology. Cincinatti: Anderson Publishing Co., 1997, p. 111.
} 
reafirmado a noção de que os conceitos consistentes de renda são impraticáveis, e os praticáveis, inconsistentes ${ }^{126}$.

Conforme já avençado, as restrições à aplicação de uma noção ampla de renda (uma que alcançasse ganhos de capital decorrentes da mera valorização de ativos já pertencentes ao patrimônio do contribuinte) estão relacionadas principalmente à indisponibilidade dos recursos (liquidez) e à fragilidade dos métodos de estipulação de valor (dificuldades de valoração). Tais inconvenientes para uma tributação abrangente da renda foram assim resumidos por Carlos Alberto Longo ${ }^{127}$ :

- o custo administrativo da declaração anual de tais ganhos de capital e a dificuldade técnica de determinar os valores dos ativos anualmente; e

- a dificuldade potencial do contribuinte em obter recursos para pagar impostos sobre ganhos auferidos, mas não realizados.

A tributação dos ganhos de capital com base no momento da sua ocorrência (no momento da valorização dos ativos) aumenta o custo administrativo (seja do fisco ou do contribuinte) pois, na ausência de uma referência direta de mercado (a troca do bem em uma transação de mercado direta), torna-se custosa a tarefa de valorar adequadamente seus ativos, uma vez que se deve lançar mão de informações, nem sempre disponíveis, relativas aos preços praticados em transações de mercado realizadas por terceiros ${ }^{128}$.

Para contornar esses problemas, o princípio da realização acabou sendo moldado para consagrar o evento crítico da transação com terceiros (troca) como elemento principal da realização, critério esse que seria capaz de superar o problema de valoração (pois se baseia em legítimo valor de mercado) e garantir a liquidez. Esta noção foi consolidada, sobretudo por influência da doutrina contábil, e acabou por ser incorporada, como regra geral, à legislação tributária de diversos países, dentre os quais o Brasil.

Dessa forma, conforme será abordado adiante em item específico ${ }^{129}$, a doutrina contábil, influenciada pelos princípios do conservadorismo e da prudência, adotou uma visão mais restritiva da apuração da renda, postergando seu reconhecimento até o momento em que acontecesse uma transação com terceiros. Isso porque o reconhecimento da renda

${ }^{126}$ Cf. MUTÉN, Leif. Treatment of capital gains and losses: a response. In. ESSERS, Peter; RIJKERS, Arie. The notion of income from capital. Amsterdam: IBFD, 2005, p. 217.

${ }^{127}$ LONGO, op. cit. (nota 71), p. 30.

${ }^{128}$ Segundo relembra LONGO, para ações e outros títulos negociados em Bolsa, haveria pouca dificuldade na obtenção desses valores, porém, para outros ativos, os custos de avaliação seriam elevados. Cf. LONGO, op. cit. (nota 71), p. 30 . 
antes deste momento está sujeito a incertezas e flutuações de valor. Tipicamente, é uma transação da entidade com terceiros que geraria a realização da receita, podendo esta assumir a forma de dinheiro recebido imediatamente ou a forma de um direito de obter dinheiro no futuro (crédito decorrente da venda) ${ }^{130}$.

Esse conceito transacional repousa, portanto, na contabilidade por custo histórico e não reconhece normalmente ganhos de mera detenção ${ }^{131}$, ou seja, o aumento no valor dos ativos já integrantes do patrimônio de uma pessoa não gera renda enquanto não for evidenciado (e, portanto, realizado) por uma transação com terceiros ${ }^{132}$. A introdução deste critério de realização representa, destarte, uma séria restrição à aplicação da noção fundamental ou ideal de renda (o modelo SHS discutido anteriormente).

Não obstante essa busca pela simplicidade na administração do conceito de renda seja um esforço constante, atualmente se discute, em determinados fóruns de debate, a viabilidade de métodos que permitiriam ultrapassar, por exemplo, os problemas de valoração e liquidez que, normalmente, são levantados para obstar a tributação de apreciações não realizadas de $\operatorname{ativos}^{133}$.

Esta busca por mudanças, e o consequente afastamento dos critérios tradicionais de realização baseados essencialmente em eventos de troca, justifica-se em razão dos problemas causados por um tal sistema e que, segundo Kavelaars, resumir-seiam no seguinte ${ }^{134}$ :

- distorções de comportamento econômico: o critério tradicional de realização gera perda de eficiência econômica, porquanto estimula, por exemplo, investimentos em

\footnotetext{
${ }^{129}$ Vide maiores detalhes no Capítulo 3 deste trabalho.

${ }^{130}$ Cf. HOLMES, op. cit. (nota 39), p. 112-114.

131 Apenas em casos excepcionais, a acumulação de valor no tempo pode ser considerada evento crítico para fins de tributação. Vide a esse respeito o exemplo do Reino Unido, no item 3.3 deste Capítulo e também os comentários feitos no item 3.4.2 do Capítulo 3 e no item 6 do Capítulo 4.

${ }^{132}$ Cf. DAVIDSON, Sidney. The realization concept. In: BACKER, Morton (coord.). Modern accounting theory. New Jersey: Prentice-Hall, 1966, p. 109.

${ }^{133}$ KAVELAARS, Peter. Accrual versus realization. In: ESSERS, Peter; RIJKERS, Arie. The notion of income from capital. Amsterdam: IBFD, 2005, p. 127-146. KORNHAUSER, Marjorie E. The Story of Macomber: the continuing legacy of realization. In: CARON, Paul L. Tax Stories: an in-depth look at ten leading federal income tax cases. New York: Foundation Press, 2003, p. 84-85.

${ }^{134}$ Cf. KORNHAUSER, op. cit (nota 133), p. 84-85.
} 
ativos que se apreciam sem realização tributária, bem como desestimula a venda de ativos valorizados $^{135}$;

- aumento de complexidade: diminui a certeza da tributação ao criar confusão quanto ao momento da realização uma vez que, como o diferimento é desejável, os contribuintes buscam promover operações complexas para evitar (ou simplesmente distorcer) o evento de realização, provocando a reação do governo para a criação de legislação adicional e regulamentações;

- violação da igualdade e alteração da distribuição de riquezas: a igualdade é comprometida porque dois contribuintes com a mesma quantia de ganho econômico podem sofrer tributação diferenciada por causa de diferentes critérios de realização e, além disso, propagam-se os desníveis na distribuição de riqueza, pois são os contribuintes mais ricos que têm mais condições de investir em ativos cujo ganho pode ser diferido.

Assim, alternativas são propostas para circundar os problemas de liquidez e dificuldades de valoração e, com isso, preservar um sistema de tributação justa, que alcance ganhos de detenção ${ }^{136}$. Quanto às dificuldades de valoração, Kavelaars noticia que nos países que adotam um tributo sobre a fortuna ${ }^{137}$ a valoração periódica do patrimônio requerida por esta espécie exacional não leva a custos adicionais, pois a informação necessária normalmente já está disponível ${ }^{138}$. Ademais, quanto à falta de liquidez, ressalta que o argumento é falacioso, pois se a tributação já é baseada em titularidade jurídica da renda, então não deveria ser importante saber se a renda está disponível na forma de ativos líquidos (ou se pode tornar-se líquida dentro de um certo tempo). De qualquer forma, propõe a adoção de facilidades de pagamento do tributo (de modo a garantir que a renda derivada das atividades operacionais sejam capazes de prover os recursos financeiros) e enfatiza que, na falta de outras rendas, pode-se, no limite, penhorar os ativos para realizar parte do seu valor acumulado e obterem-se os fundos necessários ${ }^{139}$.

\footnotetext{
${ }^{135}$ Causa o chamado efeito de acumulação (bunching effect), pois tais ativos carregam consigo reservas ocultas ou reservas latentes de valor que, caso se incorra no evento crítico de realização, devem ser oferecidas à tributação. Correlato ao efeito de acumulação, surge o efeito trava (lock-in effect), significando que, em razão da tributação potencial sobre tais ganhos acumulados, pessoas detentoras de tais ativos podem sentir-se desestimuladas a incorrer no evento de realização.

${ }^{136}$ Segundo já defendia Bittker, em 1967, tendo em vista que o distanciamento do conceito fundamental de renda é justificado por dificuldades administrativas (valoração, exigibilidade etc.), poder-se-ia buscar um modelo de second best. Mesmo que os problemas de valoração sejam tão importantes, uma estimativa grosseira porém imediata seria melhor do que nada. Cf. BITTKER, op. cit. (nota 110), p. 983.

${ }^{137}$ Como é o caso dos Países Baixos, onde leciona o citado professor.

${ }^{138}$ No caso dos Países Baixos, a valoração de bens imóveis para fins de outros tributos já é algo que acontece obrigatoriamente a cada 4 anos. Cf. KAVELAARS, op. cit. (nota 133), p. 130.

${ }^{139}$ Cf. KAVELAARS, op. cit. (nota 133), p. 128-133.
} 
A resistência à adoção de um modelo de tributação do ganho de capital baseado no momento temporal da ocorrência (formação) do ganho pode ser explicada por fatores psicológicos, uma vez que as pessoas tendem a tratar ganhos de maneira menos perdulária do que o fariam com suas rendas ordinárias ${ }^{140}$. Assim, não seria desmesurado tratar determinadas pessoas de maneira diferenciada, atribuindo-se um modelo de realização baseado na acumulação de valor para contribuintes que possam lidar melhor com flutuações e problemas de valoração (por exemplo, para investimentos em derivativos e outros títulos e valores mobiliários que tenham sua marcação a mercado facilitada) e um modelo de realização baseado na troca para os demais ${ }^{141}$.

Modelos de uma tributação baseada em valoração de ativos foram apresentados, por exemplo, por Alan Auerbach ${ }^{142}$ e David Bradford ${ }^{143}$, que sugeriram regimes de tributação retrospectiva, e David Weisbach ${ }^{144}$, que propôs um sistema parcialmente baseado em marcação a mercado. Segundo a sintética análise de Chorvat ${ }^{145}$, no caso da tributação retrospectiva, os ganhos ou perdas não são oferecidos à tributação até o momento da venda dos ativos ${ }^{146}$, porém tais ganhos ou perdas são considerados como ocorridos em um determinado ponto do tempo ${ }^{147}$ e, com isso, imputa-se a cobrança de uma certa taxa de juros sobre o imposto que deveria ter sido pago no momento da ocorrência ${ }^{148}$. Por sua vez, o sistema híbrido, ainda segundo a síntese de Chorvat, implicaria tributar determinados ativos (principalmente os financeiros) conforme a variação de seu valor de mercado e os demais de acordo com o sistema tradicional de realização, porém com alíquotas menores para os ativos marcados a mercado.

\footnotetext{
${ }^{140}$ Em outras palavras, as pessoas costumam tratar o ganho de capital como uma não-renda. Assim, elas devem gastar uma parcela mais significativa de suas rendas correntes do que um indivíduo que, com o mesmo nível de renda, não possua bens de capital. Cf. FREEDMAN, Judith. Tretament of capital gains and losses. In. ESSERS, Peter; RIJKERS, Arie. The notion of income from capital. Amsterdam: IBFD, 2005, p. 198-199.

${ }^{141}$ Cf. FREEDMAN, op. cit. (nota 140), p. 213.

142 AUERBACH, Alan J. Retrospective capital gains taxation. NBER Working Paper No. W2792. Setembro, 1991. Disponível em: <http://ssrn.com/abstract=447221>. Acesso em 12 nov. 2008.

${ }^{143}$ BRADFORD, David F. Fixing capital gains: symmetry, consistency and correctness in the taxation of financial instruments. NBER Working Paper No. W5754. Set. 1996. Disponível em: $<$ http://ssrn.com/abstract=4458>. Acesso em 12 nov. 2008.

${ }^{144}$ WEISBACH, David. A partial mark-to-market system. In: Tax Law Review, v. 53, 1999, p. 95 e ss; apud CHORVAT, Terrence R. Perception and income: the behavioral economics of the realization doctrine. George Mason Law \& Economics Research Paper No. 03-23, 2003, p. 4. Disponível em: $<$ http://ssrn.com/abstract $=407460>$. Acesso em 12 nov. 2008.

${ }^{145}$ CHORVAT, op. cit. (nota 144), p. 28-30.

${ }^{146}$ Suplantando-se, com isso, os problemas de valoração e liquidez.

${ }^{147}$ No sistema de Bradford, os ganhos são imputados desde o momento da aquisição do bem; já no sistema de Auerbach o ganho é alocado para todo o período da sua detenção pelo contribuinte.

${ }^{148}$ Diferente de outros modelos de tributação baseada em marcação a mercado, este sistema pode, em princípio, aplicar-se a todos os ativos cujo tempo de detenção possa ser controlado.
} 
Não obstante tais tentativas ${ }^{149}$, constatado que o modelo tradicional deverá permanecer por longo tempo e que ele causa um efeito de acumulação de valor potencialmente distorsivo das decisões dos agentes econômicos, faz-se necessário integrar, ao sistema tributário, disposições que permitam o diferimento da tributação para algumas situações econômicas relevantes (caso das permutas de bens imóveis e de determinados atos de reorganização empresarial que podem ser conduzidos a valor histórico ${ }^{150}$ ) ou amenizem a sua carga tributária (caso das alíquotas aplicáveis a ganhos realizados por pessoas físicas e das atualizações monetárias aplicáveis às vendas de imóveis residenciais) ${ }^{151}$.

O que importa ressaltar deste item, afinal, é que as conveniências do mundo moderno têm permitido superar alguns desses obstáculos (sobretudo os relativos a dificuldades de valoração), de forma que os critérios atuais de realização possam vir a permitir maiores aberturas para alcançar ganhos de detenção de ativos ${ }^{152}$. Trata-se naturalmente de medida polêmica, pois acarreta aumento da carga tributária em termos temporais, ou seja, adianta para o momento atual o pagamento de tributo que seria devido no futuro (quando praticado o evento mais conservador de realização previsto em lei), afora aumentar a complexidade do sistema ${ }^{153}$.

\section{Apontamentos sobre o princípio da realização da renda no direito comparado}

Expostos os principais debates acerca dos conceitos da renda e delineadas algumas formas alternativas de concretização do princípio da realização da renda, apresenta-se a seguir uma breve exposição a propósito do desenvolvimento do princípio da realização da renda na experiência verificada em três países específicos, enfatizando

\footnotetext{
${ }^{149}$ Conforme noticia Chorvat, a Itália havia adotado um sistema de tributação com marcação a mercado e este estava prestes a ser repelido integralmente. Cf. CHORVAT, op. cit. (nota 144), p. 3 (nota de rodapé 2) e p. 31-34. Menciona-se ainda neste trabalho, a crescente implementação de regimes específicos de tributação marcada a mercado no Reino Unido desde 2002 (ver item 3.3 deste Capítulo).

${ }^{150}$ Cf. Instrução Normativa SRF n ${ }^{\circ} 107 / 1988$ e arts. 21 a 24 da Lei no 9.249/1995.

${ }^{151}$ Henry Tilbery apresenta ainda outras duas alternativas para amenizar o problema de acumulação (e sua tributação na tabela progressiva de um único ano): a redistribuição pura e simples do ganho (spreading back) - que seria uma forma de tributação retrospectiva, a exigir a reabertura dos lançamentos do imposto de renda feitos em anos anteriores; e a técnica do cálculo "pro-rata" (prorating technique) - que consiste também numa forma de tributação retrospectiva, porém sem o inconveniente de se reabrirem períodos anteriores. Cf. TILBERY, Henry. A tributação dos ganhos de capital. São Paulo: Resenha Tributária/IBDT, 1977, p. 40-41.

${ }^{152}$ Especialmente os que a empresa detiver com a finalidade de venda (aplicações destinadas à negociação ou disponíveis para venda), conforme Lei $\mathrm{n}^{\circ}$ 6.404/1976, art. 183, inciso I, alínea "a", a despeito do tratamento dos ganhos e perdas pela contabilidade comercial acontecer sob a forma ajustes de avaliação patrimonial e não mediante trânsito por contas de resultado.
} 
pontos de polêmica e ressaltando as tendências que se formaram no tratamento do tema ao longo do tempo.

Os três países selecionados têm peculiaridades que merecem destaque. A Alemanha é tratada em primeiro plano por conter a mais antiga codificação do princípio da realização da renda, com a reforma da legislação de sociedades por ações promovida em $1884^{154}$. Os Estados Unidos da América apresentam um tratamento jurisprudencial e doutrinário relevantes da matéria e o Reino Unido oferece um contraponto interessante no desenvolvimento tardio, porém intenso, de regulamentação expressa sobre o tema (sobretudo na área da contabilidade comercial). A abordagem histórica aqui desenvolvida, portanto, focaliza principalmente os elementos que foram determinantes para $o$ reconhecimento e a moldagem do princípio da realização de acordo com o sistema normativo pesquisado. Assim, a análise jurisprudencial, por exemplo, é mais enfatizada nos itens pertinentes aos E.U.A. e ao Reino Unido do que no item da Alemanha, porque, em cada um dos países, jurisprudência ou codificação legislativa tiveram papéis mais ou menos importantes.

Além disso, tendo em vista que a análise de direito comparado (fundamentada em trabalhos produzidos no contexto dos três países ora selecionados) será retomada por diversas vezes ao longo deste trabalho, procurou-se enfatizar também algumas diferenças pontuais do sistema normativo de cada um desses países em relação ao sistema brasileiro, lançando as bases para comparações que serão exploradas em outros itens deste estudo.

\subsection{Na Alemanha}

Um comerciante do século XIX, estabelecido na Alemanha, que fizesse um levantamento de seus haveres conforme os critérios praticados pela maioria dos comerciantes organizados da época, provavelmente, adotaria um referencial de mercado para a valoração de seus ativos. Isto é, avaliaria seus bens de acordo com o valor que representassem na data do levantamento de contas supondo que fossem ser vendidos imediatamente (isso porque, na época, adotavam-se valores de saída para a apuração patrimonial). Com isso, um balanço comercial normalmente registrava resultados positivos

\footnotetext{
${ }^{153}$ Cf. FREEDMAN, op. cit. (nota 140), p. 213.

${ }^{154}$ É importante ressaltar, todavia, que, conforme se verá, a identificação da origem legislativa do princípio da realização da renda no ano de 1884 é objeto de acirrados debates, pois o que se codificou nessa época foi, essencialmente, o princípio do custo como base de valor.
} 
simplesmente em função deste rudimentar sistema de marcação a mercado, que aumentava virtualmente o patrimônio do comerciante e, consequentemente, antecipava o potencial de distribuição de lucros.

Considerando situações como essa, promoveu-se, em 1884, uma alteração na lei das sociedades por ações vigente à época ${ }^{155}$, para impor a tais sociedades a adoção do princípio do custo histórico, ou seja, a avaliação do patrimônio com base em valores de entrada $^{156}$. Essa medida intentava evitar que as sociedades distribuíssem lucros oriundos de resultados superestimados, o que poderia resultar em dano ao patrimônio da própria entidade $^{157}$.

Não obstante possam ser identificados traços mais antigos da adoção do princípio da realização em outros contextos ${ }^{158}$, a constatação de sua origem em 1884 é mais precisa em vista de sua obrigatoriedade e aplicação em caráter geral decorrer objetivamente da referida modificação legislativa. Embora não seja explícita a esse respeito, ao adotar o princípio do custo histórico, a legislação alemã teria, segundo Adolf Moxter, regulado precisamente a totalidade do conteúdo do princípio da realização da renda, uma vez que tais princípios normalmente identificam-se entre $\mathrm{si}^{159}$.

Quanto aos reflexos da adoção desses princípios para o Direito Tributário alemão, registra-se, como já apontado ${ }^{160}$, que a lei do imposto de renda da Prússia de 1891 sofreu a influência de Fuisting e adotava a teoria das fontes na conceituação da renda, fazendo expressa referência ao Direito Comercial para indicar as regras aplicáveis à apuração do lucro. Por essa razão, com a alteração legislativa de 1884, o princípio da realização ${ }^{161}$, na prática, passou a ser adotado também para o Direito Tributário desde esse período histórico ${ }^{162}$. A previsão expressa do princípio no âmbito da tributação veio

\footnotetext{
155 A alteração foi promovida pela Aktienrechtsnovelle (Modificação à Lei de Sociedades por Ações) de 1884.

${ }^{156}$ Ou princípio do registro pelo valor original.

${ }^{157}$ Cf. MOXTER, Adolf. Das Realisationsprinzip: 1884 und heute. In: Betriebs-Berater, Caderno 28. Frankfurt am Main: Recht und Wirtschaft, 1984, p. 1781.

${ }^{158}$ Moxter menciona o Código Prussiano (Allgemeines Landrecht) e práticas isoladas de comerciantes que, para não aparentar riqueza, procuravam evitar a valoração a mercado dos ativos. Cf. MOXTER, op. cit. (nota 157), p. 1786, nota de rodapé 3 . Para uma visão a respeito das origens mais remotas do imposto de renda na Alemanha, cf. LEONETTI, $O$ imposto sobre a renda como instrumento de justiça social no Brasil. Barueri: Manole, 2003, p. 9-11.

${ }^{159}$ Cf. MOXTER, op. cit. (nota 157), p. 1780.

${ }^{160}$ Vide item 2.3.1 neste Capítulo.

${ }^{161}$ Identificado com o princípio do custo histórico.

${ }^{162}$ Cf. JOST, op. cit. (nota 91), p. 20-21.
} 
somente depois, com a alteração legislativa de 1921 à Lei do Imposto de Renda do Reino de $1920^{163}$.

Reitera-se que, em todas essas situações, fala-se do princípio da realização como mero reflexo da adoção do princípio do custo histórico como base de valor. É importante destacar, por outro lado, que há autores, como Thomas Schröer ${ }^{164}$, que situam a origem legislativa histórica do princípio da realização em outro momento: no Código Comercial Alemão de $1985^{165}$.

Fato é que, durante muitas décadas, o princípio da realização era aplicado independente de sua previsão expressa na legislação comercial ou tributária. Nessa conjuntura, a apuração da renda tributável (que, como já dito, a partir de 1920, passou a adotar a fórmula amenizada do acréscimo patrimonial líquido ${ }^{166}$ ) apoiava-se nas regras comerciais, porém, já se reconhecia que os balanços comercial e tributário poderiam apresentar algumas diferenças, sobretudo quanto a despesas que fossem admitidas no primeiro e proibidas no segundo ${ }^{167}$.

\footnotetext{
${ }^{163}$ Embora a REStG de 1920 tenha sido identificada com a teoria do acréscimo patrimonial líquido de Schanz - o qual reconhecia uma noção ampla de renda, incluindo neste conceito, por exemplo, os ganhos de valorização de ativos (vide item 2.3.1 supra), a adoção explícita do princípio da realização (como custo histórico) deixou pouco da teoria de Schanz sobreviver, pois, ao se obrigar o uso do princípio do custo histórico (de aquisição ou produção), eliminaram-se as possibilidades de apuração de ganhos não realizados. Cf. JOST, op. cit. (nota 91), p. 20.

${ }^{164}$ Cf. SCHRÖER, Thomas. Das Realisationsprinzip in Deutschland und Grossbritannien: eine systematische Untersuchung und ihre Aufwendung auf langfristige Auftragsfertigung und Währungsrechnung. Frankfurt am Main: Peter Lang, 1998, p. 121.

${ }^{165}$ Cujo §252, item 1, número 4, diz: "Deve-se avaliar com prudência [...] Os lucros somente devem ser considerados, se, na data do fechamento do balanço, eles estiverem realizados". Tradução livre de: Es ist vorsichtig zu bewerten [...] Gewinne sind nur zu berücksichtigen, wenn sie am Abschlußstichtag realisiert sind.

${ }^{166}$ Vide item 2.3.1 supra.

${ }^{167}$ Cf. NEUMARK, Fritz. Theorie und Praxis der modernen Einkommenbesteuerung. Bern: A. Francke, 1947, p. 232-233.
} 
Neste aspecto é importante destacar que o sistema tributário alemão reconhece, preza e adota claramente o princípio da congruência com os parâmetros contábeis ${ }^{168}$ para fins de tributação, o que implica dizer que os princípios de contabilidade geralmente aceitos, tais como previstos na legislação comercial, se aplicam à apuração de tributos (exceto se houver conflito com alguma norma tributária expressa) ${ }^{169}$.

Assim, diferentemente do que normalmente se propaga, no sistema alemão os balanços comercial e tributário guardam forte proximidade e interdependência. Vale ressaltar, neste particular, todavia, que, em vez de de ignorar as práticas contábeis e partir para a estruturação de um balanço tributário próprio, o legislador tributário adotou um caminho intermediário: como se verifica, por exemplo, do $\S 5$ da Lei do Imposto de Renda atual, os princípios de contabilidade geralmente aceitos são determinantes na apuração da renda tributável (dentre eles o princípio da realização), porém, a legislação tributária pode criar regras especiais que "rompam" esta vinculação em alguns aspectos ${ }^{170}$.

Nessa seara, reconhecia-se, desde a época da Lei de 1920, que aplicar o princípio da realização (na sua forma tradicional) era a decorrência lógica do princípio contábil da prudência. Mais ainda, concedia-se uma certa liberdade ao contribuinte para adotar o princípio da imparidade ${ }^{171}$ na apuração da renda tributável, de forma que, por um lado, os ganhos não realizados não deveriam ser demonstrados, e, por outro lado, as perdas não realizadas relativas ao ativo circulante poderiam e aquelas relativas ao ativo imobilizado deveriam ser consideradas. Essa liberdade do contribuinte era moderada pela proibição do excesso, pois não se permitia que tal conduta gerasse evasão tributária (por

\footnotetext{
${ }^{168}$ Esta é uma tradução livre da palavra Massgeblichkeitsprinzip (tratando-se de termo de difícil tradução, anota-se aqui que em francês ele se denomina príncipe de déterminance e em inglês pode ser referido como authoritative principle, principle of bindingness, principle of congruency, principle of congruents). Para as referências em francês, ver GLAUSER, Pierre-Marie. IFRS et droit fiscal: Les normes true and fair et le principe de déterminance en droit fiscal suisse actuel. In: Archives de droit fiscal suisse, v. 74, 2006 , p. 529. Para as referências em inglês, ver BALL, Ray; KOTHARI, S. P.; ROBIN, Ashok. The effect of international institutional factors on properties of accounting earnings. University of Rochester Working Paper FR 99-12. Agosto de 1999. Disponível em: <http://ssrn.com/abstract=176989>. Acesso em 18 nov. 2008. BLAKE, John; AMAT, Oriol; FORTES, Hilary. The relationship between tax regulations and financial accounting: a comparison of Germany, Spain and the United Kingdom. Economics Working Paper Series No. 46: Universitat Pompeu Fabra, Outubro de 2003, p. 2-5. Disponível em: $<$ http://www.econ.upf.edu/docs/papers/downloads/46.pdf >. Acesso em 18 nov. 2008. NOBES, Christopher. A conceptual framework for the taxable income of businesses, and how to apply it under IFRS. London: Certified Accountants Educacional Trust / ACCA, 2003, p. 10 (nota de rodapé 1). Disponível em: $<\mathrm{http}: / /$ www.accaglobal.com/documents/tech_tp_n03.pdf $>$. Acesso em 18 nov. 2008.

${ }^{169}$ Cf. BLAKE; AMAT; FORTES, op. cit. (nota 168).

170 Cf. DAUBER, Desiree. Das Realisationsprinzip als Grundprinzip der steuerrechtlichen Gewinnermittlung. Frankfurt am Main: Peter Lang, 2003, p. 5.

${ }^{171}$ Sobre este princípio, ver item 3.4.3 do Capítulo 3.
} 
meio de manipulação e realocação de resultados para outros períodos, de modo a evitar uma tarifa progressiva mais elevada, por exemplo) ${ }^{172}$.

Data dessa época também a possibilidade de se utilizar, também para fins tributários, o princípio do custo histórico na sua máxima extensão (isto é, traduzido em princípio do menor valor entre custo histórico ou mercado $)^{173}$. Assim, itens componentes do ativo circulante e itens não depreciáveis do ativo imobilizado estavam adstritos a este princípio e o contribuinte possuía a faculdade de avaliá-los a valor de custo histórico (de aquisição ou produção) ou adotar um valor parcial (orientado pelo menor valor de mercado) ${ }^{174}$.

Esta possibilidade vigora até os tempos atuais e está regulada no §6 da Lei do Imposto de Renda de $2002^{175}$. Embora esteja confinada ao registro de perdas específicas, esta medida é digna de nota, pois a sua adoção denota um abandono do critério tradicional de realização e uma concomitante aproximação ao critério ideal de realização, qual seja, aquele que permite apurar o acréscimo patrimonial líquido de acordo com o conceito fundamental de renda (modelo SHS $)^{176}$.

Já no que respeita à consideração de perdas em atendimento ao princípio da imparidade, convém destacar que a alteração legislativa promovida de 1999 a 2002 admitiu a adoção ampla do critério de realização, trazendo, em sua exposição de motivos, a indicação clara de que as perdas deveriam ser reconhecidas quando ocorridas e não mais quando elas se tornassem prováveis de acontecer (o que representa uma guinada em relação à orientação anterior) ${ }^{177}$.

Nos tempos atuais, pode-se dizer que o princípio jurídico-contábil da realização continua a ser identificado como corolário do princípio da prudência, condição esta retratada pela própria lei ${ }^{178}$. Nesse diapasão, admite-se que, em razão de os critérios da realização não estarem detalhadamente explicitados na lei, sua aplicação em determinados casos pode depender do grau de prudência adotado. Nesta hipótese, deve-se cuidar para

\footnotetext{
${ }^{172}$ Cf. NEUMARK, op. cit. (nota 167), p. 233-234.

${ }^{173}$ Uma novidade que não encontra aplicação na legislação tributária atual brasileira, conforme se verá adiante, no item 3.4.1 do Capítulo 3.

${ }^{174}$ Fala-se de valor parcial (Teilwert), porque, ao fazer isto, o contribuinte deveria avaliar seus ativos de forma conjunta (assumindo a continuidade da empresa) e a partir daí encontrar a parcela correspondente ao ativo avaliado (não se podia, portanto, considerar o valor de cada ativo isoladamente sem considerar o seu contexto). Cf. NEUMARK, op. cit. (nota 167), p. 233-234.

${ }^{175}$ Alínea 1, parágrafos 3 e 4.

${ }^{176}$ Vide item 2.3.2 supra.

${ }^{177}$ Exposição de motivos transcrita e comentada em DAUBER, op. cit. (nota 170), p. 128.

${ }^{178}$ Vide nota 165 supra.
} 
que o livre-arbítrio (ou o julgamento) do elaborador das demonstrações financeiras não prejudique o nível de certeza da apuração de resultados. Por isso, considerando-se que a contabilidade de resultados periódicos lida com situações sujeitas a risco, o princípio da prudência requer que um certo grau de risco já tenha sido ultrapassado antes que o lucro decorrente da situação seja considerado realizado e demonstrado. Esse grau de risco é o descrito como quase certeza do fluxo de pagamento ${ }^{179}$.

\subsection{Nos Estados Unidos da América}

Apresentar a evolução histórica do princípio da realização no Estados Unidos da América é discorrer acerca de alguns dos casos mais influentes da jurisprudência daquele país em matéria tributária. Conforme se verá adiante, não havendo uma indicação clara, em textos legais (antigos ou atuais), quanto à adoção e os principais elementos deste princípio, restou ao Poder Judiciário o papel de modelá-lo e de confirmar a sua aplicação, sobretudo em matéria de imposto de renda. Nessa senda, apresenta-se aqui uma visão geral dos principais casos e discussões que pautaram o desenvolvimento e a flexibilização do princípio da realização da renda no país enfocado.

Embora na história da tributação estadunidense dos séculos XVIII e XIX verifiquem-se variados exemplos de tributos estaduais que gravavam manifestações específicas de renda ${ }^{180}$, e até tentativas rudimentares de introdução do imposto de renda no âmbito federal ${ }^{181182}$, foi apenas no início do século XX, após a aprovação da $16^{\mathrm{a}}$ Emenda Constitucional $^{183}$, que se criaram as condições constitucionais para a instituição de um

\footnotetext{
${ }^{179}$ Cf. SCHRÖER, op. cit. (nota 164), p. 129-130.

${ }^{180}$ Durante os séculos XVII e XVIII, as colônias estadunidenses introduziram isoladamente tributos sobre rendas arbitradas de propriedades e também de habilidades pessoais (fala-se de faculty taxes). Cf. SELIGMAN, Edwin. R. A. The income tax: A study of the history, theory, and practice of income taxation at home and abroad. $2^{\mathrm{a}}$ ed., rev. e ampl. (reimpressão). New York: Augustus M. Kelley, 1970, p. 367-386.

${ }^{181} \mathrm{O}$ primeiro imposto federal sobre a renda data de 1862, época em que os E.U.A. enfrentavam os primeiros anos da Guerra da Secessão. Foi cobrado apenas até 1872. Cf. POSIN, Daniel Q.; TOBIN, Donald T. Principles of federal income taxation of individuals. $7^{\mathrm{a}}$ ed. St. Paul: West Publishing Co., 2005, p. 12-13.

${ }^{182}$ Em 1894, foi instituído, pela primeira vez na história estadunidense, um imposto de renda em tempos de paz. Todavia, a Corte considerou inconstitucional tal cobrança (no julgamento do caso Pollock v. Farmers' Loan \& Trust Co.), uma vez que se tratava de um tributo direto e que, portanto, deveria ser repartido entre os Estados por força do artigo 1, seção 2, cláusula 3 Constituição dos E.U.A. Cf. KORNHAUSER, op. cit. (nota 133), p. 73.

${ }^{183}$ Esta Emenda incluiu o artigo XVI à Constituição dos E.U.A. para permitir a instituição de imposto federal sobre rendas sem necessidade de repartição de receitas entre os Estados: "O Congresso tem poder para instituir e cobrar tributos sobre a renda, derivados de quaisquer fontes, sem necessidade de repartição de receitas entre os diversos Estados e sem vinculação com qualquer censo ou proporção populacional". Tradução livre de: The Congress shall have power to lay and collect taxes on incomes, from whatever source derived, without apportionment among the several states, and without regard to any census or enumeration.
} 
imposto de renda de forma contínua e duradoura, de arrecadação puramente federal ${ }^{184} \mathrm{e}$ com características similares às atuais. Nesse sentido, a Lei orçamentária de 1913, que se seguiu à $16^{\mathrm{a}}$ Emenda, é reconhecida como o marco inicial do imposto de renda moderno nos E.U.A.

Um elemento bastante peculiar desta Emenda Constitucional ${ }^{185}$ é o de ter sido utilizado um verbo para qualificar a renda, sugerindo que a tributação deveria recair apenas sobre a renda "derivada" de alguma fonte ${ }^{186}$. Porém, a própria definição do conteúdo do vocábulo "derivada" não estava clara neste ato legislativo, de forma que a delimitação de algum conceito constitucional de renda mostrava-se propensa a discussões e, mais ainda, tratando-se de legislação editada em período de acirrados debates sobre os conceitos econômicos de renda e a base adequada para sua tributação ${ }^{187}$, não demorou que o Poder Judiciário fosse chamado a decidir sobre o tema.

Nesse contexto, é levada a julgamento uma discussão acerca da tributação de ações recebidas em bonificação por uma pessoa física. Tendo reunido boa parte dos temas tributários mais palpitantes daquela época e ganhado atenção inusitada da mídia ${ }^{188}$, este caso acabou se tornando um dos mais célebres e influentes julgamentos em matéria tributária nos E.U.A.: trata-se do caso Eisner v. Macomber ${ }^{189}$.

O principal tema abordado foi a constitucionalidade da tributação de dividendos que, em vez de distribuídos pela empresa, foram empregados para capitalização e emissão de novas ações em favor dos sócios. Não estava claro na legislação da época se os dividendos pagos com ações da própria empresa eram tributáveis. Em 1915, uma decisão administrativa havia dito que bonificações em ações não eram tributáveis e, no final do ano, voltou-se atrás, dizendo o contrário. A lei de 1916 expressamente dizia que

\footnotetext{
${ }^{184}$ É importante destacar que essa Emenda não concedeu competência tributária nova para o Congresso Federal, mas simplesmente eliminou uma restrição de ordem financeira (de que o produto da arrecadação de tributos diretos deveria ser repartido entre os Estados). Cf. KORNHAUSER, op. cit. (nota 133), p. 74.

${ }^{185}$ Este elemento permite uma comparação interessante com o sistema brasileiro, cuja Constituição Federal, ao contrário da estadunidense, não utiliza nenhum verbo para sinalizar alguma forma preferencial de aquisição da renda. Vide a esse respeito a discussão que se apresenta no item 2 do capítulo seguinte.

${ }^{186}$ A expressão é repetida na seção 61(a) do IRC, que define a renda bruta como "all income from whatever source derived" e presumivelmente limitaria a incidência do imposto de renda ao sentido no qual o termo renda é aplicado pela $16^{\mathrm{a}}$ Emenda. Cf. LOWNDES, Charles. Current conceptions of taxable income. In: Ohio State Law Journal, v. $25 \mathrm{n}^{\circ}$ 2, 1964, p. 158-162.

${ }^{187}$ Assim como sobre outro assunto importante: a identificação da justificativa para a tributação das pessoas jurídicas como entidade separada dos sócios. Cf. AVI-YONAH - Reuven S. Pessoas jurídicas, sociedade e o estado: uma defesa do imposto de renda das pessoas jurídicas. In: Revista de Direito Tributário Atual, v. 21. São Paulo: Dialética/IBDT, 2007, p. 37-38.

${ }^{188}$ A decisão foi publicada na primeira página do The New York Times e dominou as manchetes do dia. Cf. KORNHAUSER, op. cit. (nota 133), p. 53.
} 
tais bonificações pagas desde 1913 eram tributáveis. A Sra. Macomber, então, incluiu tais rendimentos em sua declaração e os tributou. Depois, ajuizou uma reclamação contra a tributação sofrida.

A Suprema Corte entendeu haver um conceito constitucional de renda implícito no texto da $16^{\mathrm{a}}$ Emenda e, na explicação de tal conceito, acabou por solidificar uma definição mais restritiva de renda que foi diretamente influenciada pelos ensinamentos de Edwin Seligman. Este autor, embora tenha apresentado em estudos anteriores uma noção abrangente de renda ${ }^{190}$, introduziu elementos limitadores em um estudo dirigido para o tema discutido no caso judicial em questão ${ }^{191}$ e tais restrições acabaram sendo acatadas pela Suprema Corte, definindo-se então os três ingredientes essenciais para a tributação da renda $^{192}$ : (1) deve haver um ganho, (2) que seja "derivado" ou realizado, (3) do capital ou trabalho, ou ambos combinados ${ }^{193}$.

No que respeita ao elemento da realização, ganhou força a ideia de que, para a identificação da renda tributável, seria necessária a verificação dos eventos de realização e separação conjugados, exigindo-se a efetiva segregação do rendimento com relação ao capital que o produziu ${ }^{194}$. Já que a tributação depende de realização, a identificação daqueles eventos que se qualificam como realização é algo crítico para o sistema tributário. Esta identificação nem sempre é fácil, pois o ganho econômico já terá ocorrido antes e a realização é apenas o evento artificial que é tratado como terminativo no processo econômico $^{195}$.

No caso Macomber, a Corte entendeu que tributar as ações recebidas em bonificação equivaleria simplesmente a tributar a apreciação em valor do investimento do acionista e isso não estaria autorizado, pois a renda correspondente ainda não estava separada do capital que a produziu.

\footnotetext{
${ }^{189} 252$ U.S. 189 (1920).

${ }^{190}$ Renda é o valor de riqueza que flui para um determinado indivíduo além de todas as despesas necessárias de aquisição e que está disponível para consumo. Cf. SELIGMAN, op. cit. (nota 25) p. 19-20.

${ }^{191}$ Cf. SELIGMAN, op. cit. (nota 53). A esse respeito vide especialmente o item 2.3.1.1 neste Capítulo.

192 Cf. LOWNDES, op. cit. (nota 186), p. 158-162.

${ }^{193}$ Ao declarar que renda decorria do capital, trabalho, ou de ambos combinados, assumiu-se que a renda tributável demandava o elemento contraprestacional. Porém, mais tarde, o julgamento do caso Glenshaw Glass Co. (348 US 426 - 1955) quebrou esse paradigma, deixando claro que o elemento contraprestacional não era essencial ao conceito de renda tributável (neste caso, a Corte decidiu que perdas punitivas são tributáveis como renda). Cf. LOWNDES, op. cit. (nota 186), p. 167-171.

${ }^{194}$ Cf. SELIGMAN, op. cit. (nota 53), p. 98 e ss. Teoria ilustrada pela metáfora do fruto e da árvore, cf. item 2.3.1.1 supra.

${ }^{195}$ Cf. KORNHAUSER, op. cit. (nota 133), p. 85.
} 
Além disso, ao considerar esse critério de realização como um aspecto constitucional do conceito de renda, a decisão, embora não tenha propriamente inventado o princípio da realização, anexou-o tão cedo e de maneira tão profunda na matriz do sistema tributário norte-americano, que qualquer tentativa de eliminá-lo encontraria obstáculos políticos e institucionais enormes ${ }^{196}$. Nesse sentido, a decisão colocou a Suprema Corte em rota de colisão com o Poder Legislativo (o Congresso), pois, ao tratar a definição de renda como um tema constitucional, ela se inseriu no processo legislativo do imposto de renda e, segundo a opinião de autores daquele país, frustrou um dos propósitos da $16^{\mathrm{a}}$ Emenda, que era o de evitar que a Corte tivesse de tomar decisões a respeito deste tema ${ }^{197}$.

Paulatinamente, porém, a visão da Suprema Corte em matéria de imposto de renda foi se tornando mais generosa e flexível. Nesse diapasão, algumas decisões que se seguiram ao caso Macomber resultaram num abrandamento e até mesmo abandono do critério da separação, possibilitando maior maleabilidade na definição da renda tributável $^{198}$.

Um dos casos que costuma ser indicado como o marco desta transformação no conceito de realização da renda é Helvering v. Bruun ${ }^{199}$, em que se decidiu que um ganho pode ser tributável mesmo que não esteja separado do capital. Permaneceu a ideia de que o ganho somente poderia ser tributado no momento da realização, porém o requisito de separação, também consagrado no caso Macomber, não era mais visto como um elemento necessário da realização.

No referido litígio, o Sr. Bruun detinha um imóvel rural, que foi alugado, em 1915, para um período de 99 anos. Em 1929, o locatário demoliu um prédio existente na propriedade e erigiu um novo cuja vida útil era menor do que o termo final do contrato de aluguel. Em 1933, o locatário deu causa à rescisão contratual e o Sr. Bruun retomou o imóvel. A discussão consistiu em saber quando o contribuinte (Sr. Bruun) deveria tributar o ganho líquido com relação ao novo imóvel (valor do novo imóvel menos o valor do imóvel antigo).

A realização poderia ter ocorrido em qualquer um de vários pontos temporais (para simplificar: 1915, 1929 ou 1933). Tomando-se, por um lado, a definição de renda

\footnotetext{
${ }^{196}$ CARON, Paul L. Introduction: Tax Archeology. In: Tax Stories - An in-depth look at ten leading federal income tax cases. CARON, Paul L. New York: Foundation Press, 2003, p. 4.

${ }^{197}$ Cf. KORNHAUSER, op. cit. (nota 133), p. 74.

${ }^{198}$ Cf. KORNHAUSER, op. cit. (nota 133), p. 86.

199309 U.S. $461-(1940)$.
} 
conforme o modelo Haig-Simons, segundo o qual os acréscimos de valor são renda quando eles ocorrem, poder-se-ia entender que o Sr. Bruun teria renda em 1915 no montante do valor presente dos aluguéis. Por outro lado, seguindo-se um conceito de realização que requeira separação em relação ao capital, a renda não teria ocorrido nem em 1915 (quando o contrato foi assinado), nem em 1929 (quando o prédio foi construído); além disso, segundo o contribuinte, não havia realização tampouco em 1933 (quando ele retomou a posse) porque a melhoria de riqueza observada não poderia ser separada do imóvel. A Corte, todavia, decidiu que o ganho não precisa ser separado do capital para que se verifique uma renda tributável ${ }^{200}$.

A partir da decisão deste caso, foi assentado que a realização não requer separação efetiva do ganho com relação à propriedade que o produziu, mas simplesmente exige um evento que congele ou fixe o ganho com um nível apropriado de certeza que justifique a imposição tributária ${ }^{201}$. Basta existir algum evento - uma transação completada - que manifeste objetivamente o ganho ${ }^{202}$. A interpretação da expressão constitucional indicativa do fato gerador "renda derivada" agora não mais significa renda separada do capital, mas tão-somente renda realizada.

Fala-se também que, depois do julgamento de Bruun, a Corte passou a defender firmemente que a realização não é um pré-requisito constitucional de renda ${ }^{203}$. Essa circunstância, antecipada no caso Bruun, veio a ser confirmada no julgamento do caso Helvering v. Horst ${ }^{204}$, realizado 10 dias depois. Este caso envolvia a tributação de rendimentos de um título detido por um pai e que foi doado para o filho (sendo a questão principal saber quem deveria ser tributado pela renda de tal título $)^{205}$. Na decisão, a

\footnotetext{
${ }^{200}$ Cf. KORNHAUSER, op. cit. (nota 133), p. 87. Depois desta decisão, o Congresso voltou atrás, regulandose (no atual artigo 109 do IRC) que não há ganho para o locador, no término do contrato, com relação ao valor da propriedade erigida no terreno.

${ }^{201}$ Cf. LOWNDES, op. cit. (nota 186), p. 180-182.

${ }^{202}$ Cf. MULLOCK Philip. The Constitutional Aspects of Realization. In: University of Pittsburgh Law Review, v. 31, nº 4, 1970, p. 618.

${ }^{203}$ Cf. DODGE, op. cit. (nota 65), p. 38.

${ }^{204} 311$ US 112, $116-(1940)$.

${ }^{205}$ Embora se trate mais propriamente de um problema de sujeição passiva do que de um problema de alocação temporal da renda, a Corte decidiu o caso com base no princípio da realização. Cf. KORNHAUSER, op. cit. (nota 133), p. 88.
} 
Suprema Corte claramente considerou que a realização era algo "fundado na conveniência administrativa"206.

Elucidar o significado desta colocação da Corte foi tarefa controversa durante algum tempo, pois não estava claro se a Corte havia abdicado de seu entendimento anterior quanto à posição constitucional do princípio da realização. A visão do Prof. Lowndes demonstra que, neste julgamento, a Corte deixou claro seu entendimento de que a realização não era um critério presente no texto constitucional e que deveria ser tratada apenas no nível legiferante administrativo ${ }^{207}$.

Segundo o Prof. Mullock, se tomarmos Macomber e Bruun em conjunto para concluir que a realização requer uma transação completada que objetivamente manifeste uma mudança mensurável na posição econômica do contribuinte, então pode-se considerar que Horst acrescentou a ideia de que uma mudança mensurável é, para fins de imposto de renda, algo que possa ser manuseado rotineiramente por fiscais de renda. Qualquer extensão do conceito de renda deve se justificar perante o critério de conveniência administrativa (sobretudo quanto aos requisitos de valoração e liquidez da renda ${ }^{208}$ ) para que o conceito de renda (e de realização) seja alargado ${ }^{209}$. Este seria o sentido da “conveniência administrativa" enunciada no caso Bruun.

Elucidar essa divergência era importante até mesmo para fins de definição da competência tributária em matéria de imposto de renda ${ }^{210}$. Entre 1962 e 1963, discutiram-

\footnotetext{
${ }^{206}$ Cf. KORNHAUSER, op. cit. (nota 133), p. 88. O trecho relevante da decisão é o seguinte: “[...] regra de que a renda não é tributável até que realizada nunca foi tomada com o significado de que o contribuinte, mesmo aquele sujeito ao regime de caixa, que tenha aproveitado integralmente o benefício do ganho econômico representado por seu direito de receber renda possa escaper da tributação pelo fato de não ter recebido pagamento dap arte do devedor. A regra, fundada na conveniência administrativa, é a de diferimento do tributo até o evento final de aproveitamento da renda, normalmente o recebimento desta pelo contribuinte, e não a de isenção de tributação nos casos em que o aproveitamento já s foi consumado por outro evento distinto do recebimento pessoal de dinheiro ou propriedade pelo contribuinte". Tradução livre de: [...] rule that income is not taxable until realized has never been taken to mean that the taxpayer, even on the cash receipts basis, who has fully enjoyed the benefit of the economic gain represented by his right to receive income, can escape taxation because he has not himself received payment of it from his obligor. The rule, founded on administrative convenience, is only one of postponement of the tax to the final event of enjoyment of the income, usually the receipt of it by the taxpayer, and not one of exemption from taxation where the enjoyment is consummated by some event other than the taxpayer's personal receipt of money or property. Grifo nosso.

${ }^{207}$ Cf. LOWNDES, op. cit. (nota 186), p. 181-182.

${ }^{208}$ Vide definições acima, no item 2.5 deste Capítulo.

${ }^{209}$ Cf. MULLOCK, op. cit. (nota 202), p. 617-621; 621-624.

${ }^{210}$ Para Lowndes, o IR poderia alcançar um ganho que não fosse considerado renda no sentido do termo aplicado pela $16^{\mathrm{a}}$ Emenda, tendo em vista que este ato apenas afastou a necessidade de repartição de receitas de um imposto direto. Ou seja, a competência tributária originalmente conferida ao Congresso não teria sido restringida pela $16^{\mathrm{a}}$ Emenda. Cf. LOWNDES, op. cit. (nota 186), p. 158-162. Para Mullock, a realização continuava então a ser vista como parte integrante do significado linguístico ordinário do conceito de renda contido na $16^{\mathrm{a}}$ Emenda. Cf. MULLOCK, op. cit. (nota 202), p. 617-621.
} 
se tentativas de cobrança de imposto de renda sobre ganhos não realizados ${ }^{211}$ e o possível conflito com o critério constitucional da realização, sem que, no entanto, a Corte se manifestasse claramente para confirmar o aspecto constitucional do referido princípio. Em um de seus pronunciamentos recentes sobre o tema ${ }^{212}$, ela reiterou que a realização é apenas um mandamento de ordem administrativa, porém, abdicou-se de revogar ou suplantar explicitamente a decisão dada no caso Macomber. Esta relutância em revogar definitivamente o aspecto constitucional da realização, anota Kornhauser, torna tal mudança até menos provável porque cria incerteza quanto aos poderes do Poder Legislativo de fazer mudanças radicais ${ }^{213}$. Não obstante, segundo aponta Dodge, a concepção que prevalece atualmente é a de que, no contexto da $16^{\mathrm{a}}$ Emenda, o Congresso tem liberdade para definir o que seja realização ${ }^{214}$.

Fato é que o princípio continua a ser moldado por mudanças legislativas naquele país. A Corte já reconheceu que a realização, embora não esteja definida expressamente na legislação, pode ser identificada em alguns dispositivos esparsos, como é o caso da seção 1001 (a) do atual Código (IRC de 1986), por exemplo, que diz que o ganho ou perda são realizados com a venda ou outras formas de disposição de propriedade. Esse elemento de troca, ínsito ao conceito de realização, veio também a ser aprimorado pela regulamentação do instituto da permuta, que posterga a tributação mesmo após a ocorrência de uma troca de ativos (disposição de propriedade), porém somente se aplica a bens que "se diferenciem materialmente, seja em espécie ou em extensão"215. Outros itens da legislação estadunidense que tangenciam o tema são os artigos 351 (integralização de capital em bens para aquisição de controle), 354 e seguintes (reorganizações empresariais), 1033 (conversão involuntária de bens em dinheiro ou em bens similares ${ }^{216}$ ), dentre outros. Alguns desses itens serão abordados ainda ao longo deste trabalho, quando pertinentes.

\subsection{No Reino Unido}

No Reino Unido, a regulação comercial surge já no século 19, porém, limita-se a oferecer instruções gerais, seguindo, outrossim, a filosofia do laisser faire. Por essa

\footnotetext{
${ }^{211}$ A tributação de acionistas sobre determinados lucros de subsidiárias estrangeiras e a tributação de ganho não realizado no momento da morte.

${ }^{212}$ Cottage Savings Assoc. v. Commissioner (499 U.S. 554 - 1991).

${ }^{213}$ Cf. KORNHAUSER, op. cit. (nota 133), p. 95.

${ }^{214}$ Cf. DODGE, op. cit. (nota 65), p. 22.

${ }^{215}$ Cf. KORNHAUSER, op. cit. (nota 133), p. 91-92.
} 
razão, ao lado do direito legislado, surgiram desde logo as decisões de tribunais como segunda fonte da regulamentação. Nesse sentido, a jurisprudência, sobretudo no contexto da preocupação com a correta determinação do lucro distribuível, foi de grande importância para a concretização e preenchimento de lacunas do Direito Comercial até a edição do Companies Act $1980^{217}$.

Um dos casos mais antigos a tangenciar a matéria foi Oxford Benefit Building and Investment Society (1886, 35ChD502), em que se afirmou que "nenhum dividendo deve ser pago, exceto se decorrer dos lucros realizados na atividade da empresa",218.

Inexistindo orientação concreta na legislação comercial (ou na regulamentação de temas de contabilidade comercial pelas associações profissionais) que esclarecesse o critério de realização determinante para fins de tributação, coube ao Poder Judiciário influente papel também na decisão de casos tributários limítrofes, que contribuíram para delinear os contornos deste princípio. Assim, já em 1904, em um julgamento acerca da tributação da maior-valia obtida por uma empresa com a venda de uma mina de cobre (adquirida ao custo de £24.000) contra recebimento de ações integralizadas de outra empresa (no montante de $£ 300.000$ ), definiu-se que a renda abrangia também os ganhos de capital e que a realização acontecia quando o vendedor recebia o preço. E a tributação independe da forma com que esse recebimento se materializa, há realização no recebimento seja em dinheiro ou em espécie (mesmo porque as ações recebidas poderiam ser transformadas em dinheiro, se o vendedor assim o quisesse $)^{219}$.

\footnotetext{
${ }^{216}$ Em razão de sua destruição (por incêndio, por exemplo), ou ainda por motivo de furto, apreensão, desapropriação etc.

${ }^{217}$ Mesmo assim, as decisões de tribunais furtavam-se a dar uma definição restritiva do lucro distribuível. O seguinte trecho de um acórdão judicial deixa claro tal circunstância: "os tribunais, especialmente após 1889, não desejavam "formular regras para condução e embaraço dos homens de negócio na condução de temas negociais". Tradução livre de: the courts, especially after 1889, were unwilling "to formulate rules for the guidance and embarassment of business men in the conduct of business affairs" - Dovey v. Cory, 1901 AC477. Cf. SCHRÖER, op. cit. (nota 164), p. 68-69 e 143 (nota de rodapé 154).

${ }^{218} \mathrm{Cf}$. CARSBERG, Sir Bryan; NOKE, Christopher. The reporting of profits and the concept of realisation. London: Research Board ICAEW, 1989, p. 7.

${ }^{219}$ Trata-se do caso Californian Copper Syndicate v. Harris, 1904, 5TC159, mencionado e transcrito parcialmente em CARSBERG; NOKE, op. cit. (nota 218), p. 62. O principal trecho do julgamento foi dado por Lord Trayner:

"Mas foi dito que o lucro - se fosse lucro - não estava realizado e, portanto, não era tributável. Eu entendo que o lucro estava realizado. Um lucro é realizado quando o vendedor recebe o preço pelo qual barganhou. Não há dúvida de que aqui o preço tomou a forma de ações totalmente integralizadas em outra companhia, mas, se não puder haver lucro realizado fora das situações em que o vendedor receber o preço em dinheiro, as ações eram realizáveis e poderiam ser transformadas em dinheiro se os apelantes assim quisessem. Eu não posso imaginar que [o imposto de] renda seja devida ou não conforme a maneira com que a pessoa que tiver o lucro deseje lidar com ele".
} 
Uma formulação mais explícita do conteúdo do princípio da realização foi dada no caso Willingale v International Commercial Bank Ltd (1978, 52TC242), desvinculandoo da ideia de recebimento de caixa e trazendo-o mais próximo do momento de fechamento do contrato, ou melhor, do momento temporal em que se trocam ativos, sendo que, no caso de prestação de serviços, o evento crítico seria o tempo em que o trabalho é concluído. Esclarecia-se, enfim, que o momento temporal de reconhecimento do lucro é aquele no qual o contribuinte se torna titular do direito de receber o pagamento ${ }^{220}$. Destacam-se nesta leitura os elementos de troca e cumprimento da obrigação, inerentes ao conceito de realização.

Outros casos determinantes para a matéria trataram: (i) de permuta de títulos de crédito, em que se assentou a ideia de que uma permuta de títulos seria o equivalente a uma venda do primeiro título com investimento do dinheiro no outro ${ }^{221}$; (ii) de ganhos ou perdas de variação cambial, tendo-se decidido que a tradução contábil de operações realizadas no exterior não deveria causar tributação apenas em razão de variação cambial

Tradução livre de: But it was said that the profit - if it was profit - was not realised profit and, therefore, not taxable. I think the profit was realised. A profit is realised when the seller gets the price he has bargained for. No doubt here the price took the form of fully paid shares in another company, but if there can be no realised profit, except when the seller gets the price in cash, the shares were realisible and could have been turned into cash if the Appellants had been pleased to do so. I cannot think that income is due or not according to the manner in which the person making the profit pleases do deal with it.

${ }^{220}$ Foram essas as palavras de Ormrod LJ: À primeira vista, pode-se supor que, para fins tributários, 'realizado' seria o equivalente a 'recebido' e que 'antecipar' seria usado no seu sentido próprio de 'antever' ou 'prenunciar', uma vez que o imposto de renda de pessoas físicas ou jurídicas é para ser pago anualmente com base na renda. Mas essa construção simplista ... não pode ser sustentada ... uma venda de bens durante o período contábil por um preço a ser pago no ano seguinte deve ser levado em conta no ano da venda e não no do recebimento. 'Realizado' não pode, portanto, ser equivalente a 'recebido'; para os fins da lei este lucro deve ser considerado como 'realizado' quando o contrato de venda for feito, isto é, quando os bens são substituídos na contabilidade do contribuinte por um débito. No caso de trabalho ou serviços, o valor do trabalho deve adentar a contabilidade relative ao ano no qual o trabalho é feito, ou os services são prestados, mas, presumivelmente, apenas se o contribuinte tiver completado o trabalho, ou feito algo suficiente para que lhe seja atribuído o direito de receber pagamento em algum momento futuro. Se esse arrazoado estiver correto, o lucro é realizado quando o contribuinte se torna titular do direito ao pagamento, aconteça este imediatamente ou em alguma data futura". Tradução livre de: At first sight, one might suppose that, for tax purposes, 'realised' was equivalent to 'received' and that 'anticipate' was used in its proper sense of 'to take before' or 'forestall', since income or corporation tax is intended to be paid annualy out of income. But this simplistic construction ... cannot be supported ... a sale of goods during the accounting period, por a price to be paid in the following year, must be brought into account in the year of sale, not of the receipt. 'Realised' cannot, therefore, be the equivalent of 'received'; for the purposes of the rule this profit must be regarded as 'realised' when the contract of sale is made, that is, when the goods are replaced in the taxpayer's books by a debt. In the case of work or services, the value of the work must be brought into the accounts for the year in which the work is done, or the services rendered, but, presumably, only if the taxpayer has completed the work, or done enough under the contract to entitle him in law to receive payment at some future time. If this reasoning is correct the profit is realised when the taxpayer becomes entitled to payment, either immediately or at some future date. Cf. CARSBERG; NOKE, op. cit. (nota 218), p. 64-66.

${ }^{221}$ Westminster Bank Ltd v Osler, 1933, AC139, cf. CARSBERG; NOKE, op. cit. (nota 218), p. 10 e 63. 
(ou seja, o resultado pode ser apurado em moeda estrangeira e a tradução em moeda nacional não pode gerar lucro se, na operação original, ele não ocorreu) ${ }^{222}$.

No nível legislativo, até o começo da década de 70, o conceito de lucros realizados vigia como exercício da boa prática comercial ${ }^{223}$, isto é, não era codificado, nem definido. A primeira codificação decorrente de autorregulamentação profissional remonta ao SSAP2 ${ }^{224}$, que ainda tem importância até hoje como padrão conceitual. Ao se definir o princípio da prudência, fala-se que:

"Receitas e lucros não são antecipados, mas sim reconhecidos pela inclusão na demonstração de resultados quando realizados sob a forma quer de dinheiro quer de outros ativos cuja realização última pode ser determinada com razoável certeza",225

Não obstante a regulamentação contábil começasse a se tornar influente neste período, foi apenas com a edição do Companies Act 1980 é que a apuração do lucro comercial, conforme o requisito da realização, ganhou maior substância ${ }^{226}$. É bastante curioso constatar isso, mas fato é que, antes da edição desse ato, não havia diferença se o lucro apurado no fechamento anual estava realizado ou não ${ }^{227}$. Foi com a adoção das Diretivas editadas no contexto da União Europeia que se positivou o comando para que apenas os lucros realizados fossem demonstrados em apuração de resultados ${ }^{228}$.

\footnotetext{
${ }^{222}$ Pattison v Marine Midland Ltd, 1983, 57TC219, cf. CARSBERG; NOKE, op. cit. (nota 218), p. 10 e $63-$ 64.

${ }^{223} \mathrm{Em} 1947$, após oito anos de discussões, inclusive com órgãos profissionais da área contabilidade, para reformas dos Companies Acts, foi editado o Companies Act 1947, que continha a obrigação para que as demonstrações financeiras seguissem uma visão fiel e verdadeira (true and fair view). Cf. SCHRÖER, op. cit. (nota 164), p. 70-71.

${ }^{224}$ De 1970 a 1990 os standards de contabilidade foram formulados no Reino Unido pelo Accounting Standards Steering Committee, mais tarde renomeado para Accounting Standards Committee (ASC). Este órgão emitiu memorandos de discussão chamados Exposure Drafts (ED) a respeito dos standards propostos, os quais, quando emitidos, foram chamados de Statements of Standard Accounting Practice (SSAP). BLAKE, et alli, op. cit. (nota 168), p. 20.

${ }^{225}$ Tradução livre do parágrafo 14 do SSAP2: Revenue and profits are not anticipated, but are recognised by inclusion in the profit and loss account only when realised in the form of either cash or of other assets the ultimate cash realisation of which can be assessed with reasonable certainty. Cf. SCHRÖER, op. cit. (nota 164), p. 144.

${ }^{226}$ Este ato incorporava as regras previstas na Segunda Diretiva do Conselho da União Europeia (77/91/EEC), no sentido de que "O montante a distribuir não pode exceder o montante dos resultados realizados" (art. 15, item 2, b da Diretiva).

${ }^{227}$ Cf. SCHRÖER, op. cit. (nota 164), p. 105.

${ }^{228}$ Tais Diretivas buscam a harmonização da matéria contábil na União Europeia. O Companies Act 1980 adotou a Segunda Diretiva do Conselho da União Europeia (77/91/EEC), o Companies Act 1981, a Quarta Diretiva (78/660/EEC) e o Companies Act 1985, a Sétima e Oitava Diretivas (83/349/EEC e 84/253/EEC).
} 
No Companies Act $1985^{229}$, menciona-se por diversas vezes o conceito de lucros realizados. Na Seção 4, parágrafo 12, por exemplo, lê-se:

"O valor de qualquer item deve ser determinado com prudência e, particularmente: (a) apenas os lucros realizados até a data de fechamento do balanço devem ser incluídos na demonstração de resultados"230

Mais adiante, no parágrafo 91 da mesma Seção do Companies Act 1985, observa-se que, para evitar a imposição de critérios imutáveis à noção de realização, ficou estabelecido que:

“... fica declarado por meio deste, para evitar dúvidas, que a referência nesta Seção a lucros realizados ... diz respeito àqueles lucros da companhia que forem tratados como lucros realizados para fins da contabilidade elaborada de acordo com os princípios geralmente aceitos relativamente à determinação do lucro para fins contábeis no momento em que tal contabilidade for preparada". ${ }^{231}$ Grifo nosso.

Disso se nota que o conceito de lucros realizados deve se adaptar às circunstâncias do ambiente dinâmico, podendo, portanto, ser redefinido, a cada momento, de acordo com os princípios de contabilidade geralmente aceitos vigentes na época ${ }^{232}$. Vale destacar, nesta definição, uma clara visão do princípio da realização que mais o aproxima de um princípio do que de uma regra ${ }^{233}$.

Nos tempos atuais, a legislação tributária preserva a referência à contabilidade comercial, aplicando o princípio contábil da realização sem grandes modificações ${ }^{234}$. Nesse particular, são dignos de nota o comando expresso na seção 42 do Finance Act 1998, demandando que o lucro tributário seja apurado com base em contabilidade que forneça uma visão fiel e verdadeira do lucro ${ }^{235}$, bem como a regra presente na seção 50 do Finance

\footnotetext{
${ }^{229}$ Ato que consolidou todos os Companies Acts de 1948 a 1981.

${ }^{230}$ Tradução livre de: The amount of any item shall be determined on a prudent basis, and in particular: (a) only profits realised at the balance sheet date shall be included in the profit and loss account.

${ }^{231}$ Tradução livre de: it is hereby declared for the avoidance of doubt that references in this Schedule to realised profits... are to such profits of the company as fall to be treated as realised profits for the purposes of those accounts in accordance with principles generally accepted with respect to the determination for accounting purposes of realised profits at the time when those accounts are prepared. Grifo nosso.

${ }^{232}$ Cf. SCHRÖER, op. cit. (nota 164), p. 145-147.

${ }^{233}$ A esse respeito ver o item 1.1.1 deste Capítulo.

${ }^{234}$ BLAKE, et alli, anotam que uma das áreas de grande divergência entre o lucro tributário e o comercial reside no tratamento de depreciações e apontam razões históricas para tanto. Cf. op. cit. (nota 168), p. 18-20.

${ }^{235} \mathrm{O}$ princípio do true and fair view.
} 
Act, que define o que se entende por práticas geralmente aceitas de contabilidade ${ }^{236}$. Com isso, percebe-se que, também no Reino Unido, os princípios de contabilidade são determinantes para a apuração do lucro tributável ${ }^{237}$.

A leitura proposta pelo órgão financeiro real $\left(\mathrm{HMRC}^{238}\right)$ também aponta neste sentido: se uma empresa seguir os padrões (standards) internacionais de contabilidade, ou até mesmo os standards dos E.U.A. (ditados pelo $\mathrm{FASB}^{239}$ ), desde que estes não entrem em conflito com as práticas contábeis aceitas no Reino Unido (UK-GAAP), e se tal procedimento refletir precisamente a realidade dos fatos, então ela estará de acordo com a legislação tributária ${ }^{240}$.

Maiores evoluções do sistema tributário do Reino Unido têm sido observadas desde 2002, com a introdução de regimes específicos de tributação marcada a mercado. Assim, após discutir publicamente as razões para uma reforma do sistema tributário ${ }^{241}$, editaram-se regras para permitir às empresas mudar de um sistema baseado no critério tradicional de realização para um regime de marcação a mercado (tema regulado nas seções 64 a 66 Financial Act 2002, que se aplicam a determinadas categorias de renda, relativas ao comércio, ao exercício de profissões e de talentos). É uma medida bastante ousada, mas que, segundo as teorias econômicas já debatidas aqui, contribui para afastar entraves tributários às decisões dos agentes e, sobretudo, para o desenvolvimento econômico.

\footnotetext{
${ }^{236}$ Ora se referindo às práticas geralmente aceitas de contabilidade do Reino Unido (UK-GAAP), ora aos padrões ditados pelo IASB, ora às regulações contábeis derivadas da União Europeia.

${ }^{237}$ Cf. ANTCZAK, Gina; WALTON, Kevin. Tolley's corporation tax 2005-06. $41^{a}$ ed. London: Lexisnexis, 2005, itens 53.2, 53.2 e 64.5, p. 803-806 e 943.

${ }^{238}$ Her Majesty Revenue \& Customs.

${ }^{239}$ Financial Accounting Standards Board, que desenvolve os princípios de contabilidade geralmente aceitos nos E.U.A. (US-GAAP).

${ }^{240}$ Cf. ANTCZAK; WALTON, op. cit. (nota 237), item 64.5, p. 943. Ver também o Business Income Manual (BIM), editado pelo HMRC (especialmente o BIM 31027, mas, para uma visão geral das relações entre direito tributário e contabilidade, ver BIM 31000-31120). Disponível em: $<$ http://www.hmrc.gov.uk/manuals/bimmanual/ index.htm>. Acesso em 14 nov. 2008.

${ }^{241}$ Apontando as vantagens e desvantagens de um sistema baseado no conceito tradicional de realização ou no conceito de marcação a mercado (discussão semelhante à que se apresenta aqui no item 2.5 deste Capítulo), os órgãos fazendários do Reino Unido solicitam a opinião dos interessados quanto ao impacto de uma tal mudança. Cf. HM-Treasury; Inland Revenue. Reform of corporation tax: A consultation document. Agosto de 2002, p. 7-9. Disponível em: <http://www.hmrc.gov.uk/consult_new/taxreform_final.pdf $>$. Acesso em 14 nov. 2008.
} 


\section{Breve histórico da evolução do princípio da realização da renda no Brasil}

Os próximos capítulos deste trabalho estão voltados para o estudo do desenvolvimento e da forma como vem sendo aplicado o princípio da realização da renda no Brasil. Neste ponto da exposição histórica, apresentar-se-á tão-somente uma visão ampla e sucinta da implementação e cobrança do imposto de renda no último século, considerando, como ponto de partida, a instituição do imposto de renda em 1922 e, como ponto de chegada, a introdução firme do regime de competência, realizada pelo Decreto-lei $n^{\circ} 1.598 / 1977$, com amparo na Lei $n^{\circ}$ 6.404/1976. Embora haja momentos legislativos importantes após 1977, esses dois atos legislativos lançaram as bases para o imposto de renda atual e conduziram a uma aliança tão duradoura entre a contabilidade comercial e o direito tributário do imposto de renda que, somente recentemente, com a edição da Lei $n^{\circ} 11.638 / 2007$ é que esta união foi posta em xeque ${ }^{242}$. Assim, algumas das principais modificações ocorridas após 1977 serão analisadas em outros tópicos deste trabalho. Ademais, o papel exercido tanto pela Constituição Federal de 1988 quanto pelo Código Tributário Nacional na moldagem do princípio da realização da renda terá lugar específico no Capítulo seguinte.

As principais indagações levantadas, com a presente análise histórica, ensejaram perquirir se havia alguma definição clara do princípio ou critério de realização, examinando-se, essencialmente, qual era o critério adotado no passado (isto é, se a renda só era computada após o efetivo recebimento, ou se havia alguma forma rudimentar de regime de competência ${ }^{243}$ ) e qual era a relação entre a apuração do lucro comercial e o lucro tributável pelo imposto de renda.

Introduzido em nosso País por meio da Lei $n^{\circ} 4.625$, de 31 de dezembro de 1922 , o imposto de renda somente veio a ser implementado no ano de $1924^{244}$. Avaliandose criticamente a regulamentação dada pelo Decreto no 17.390/1926 (o Regulamento do

\footnotetext{
${ }^{242}$ Vale notar que, com as alterações trazidas pela Medida Provisória ${ }^{\circ}$ 449/2008, pretende-se abrandar algumas das inovações da Lei $\mathrm{n}^{\circ}$ 11.638/2007 e reforçar o modelo de liderança da contabilidade comercial em face do Direito Tributário (eliminando-se a permissão, que havia sido inclú́da no art. 177, §2 , inciso II, da Lei ${ }^{\circ}$ 6.404/1976, para confecção de contabilidade puramente fiscal).

${ }^{243}$ A referência a regime de competência é feita aqui com relação a um regime de alocação de receitas e despesas orientado pelo critério da ocorrência dos fatos necessários para fazer nascer o direito ao seu recebimento. Quanto à ambiguidade da expressão regime de competência, vide o item 1.2.4 do Capítulo 2 (particularmente a nota 91 e o texto que a introduz).

${ }^{244}$ Cf. CORREA, op. cit. (nota 50), p. 206 e 214.
} 
Imposto de Renda de 1926 - RIR/26) ${ }^{245}$, verificam-se bons indicativos de que o legislador da época tenha elegido o efetivo recebimento ${ }^{246}$ da renda (seja em dinheiro ou bens) como fator relevante para a incidência do imposto ${ }^{247}$. O referido RIR/26 esclarecia ainda que, caso não fossem pagos em dinheiro, os rendimentos deveriam ser avaliados monetariamente, seja no momento da percepção ou quando tal avaliação fosse possível ${ }^{248}$.

A propósito, este último aspecto parece retratar um elemento fundamental do princípio da realização: a mensurabilidade ${ }^{249}$, pois, ainda que o evento crítico deflagrador da realização (o recebimento) já tivesse ocorrido, a falta de meios para medi-lo poderia justificar um diferimento da tributação (ou, melhor dizendo, o evento de realização somente se aperfeiçoa na presença de todos os seus elementos).

Ainda no exame dos primeiros Regulamentos do IR, é interessante destacar, desde já, a preferência demonstrada pelo legislador na escolha de determinados vocábulos para indicar critérios específicos de realização. Neste caso, embora o referido RIR/26 empregue os verbos auferir, derivar, provir e possuir para se referir à origem da renda, o legislador da época notoriamente priorizou o verbo perceber, assim como os verbos correlatos pagar e receber ${ }^{250}$. Esta prática parece denotar a eleição do evento recebimento,

\footnotetext{
${ }^{245}$ Trata-se do segundo Regulamento do Imposto de Renda; antes deste houve o Decreto ${ }^{\circ}$ 16.581/1924 (RIR/24), iniciativa repetida apenas outras 13 vezes na história do imposto de renda brasileiro: Decreto-lei $\mathrm{n}^{\mathrm{o}} 4.178 / 1942$ (RIR/42), Decreto-lei $\mathrm{n}^{\circ}$ 5.844/1943 (RIR/43), Decreto $\mathrm{n}^{\circ}$ 24.239/1947 (RIR/47), Decreto $\mathrm{n}^{\mathrm{o}} 36.773 / 1955$ (RIR/55), Decreto $\mathrm{n}^{\circ} 40.702 / 1956$ (RIR/56), Decreto $\mathrm{n}^{\circ} 47.373 / 1959$ (RIR/59), Decreto $\mathrm{n}^{\mathrm{o}} 51.900 / 1963$ (RIR/63), Decreto $\mathrm{n}^{\circ} 55.866 / 1965$ (RIR/65), Decreto $\mathrm{n}^{0} 58.400 / 1966$ (RIR/66), Decreto $\mathrm{n}^{\mathrm{o}} 76.186 / 1975$ (RIR/75), Decreto $\mathrm{n}^{\circ} 85.400 / 1980$ (RIR/80), Decreto $\mathrm{n}^{\circ} 1.041 / 1994$ (RIR/94) e o atual Decreto ${ }^{\circ} 3.000 / 1999$ (RIR/99).

${ }^{246}$ Recebimento é a denominação que se dá, do ponto de vista do credor, para o ato que, do ponto de vista do devedor, se chama de pagamento.

247 "Art. 22 - Consideram-se rendimentos brutos os ganhos derivados do capital, do trabalho ou da combinação de ambos, inclusive os que promanarem da venda e da permuta de propriedades.

Parágrapho único - Para os fins do imposto, não há distinção entre os rendimentos, quanto à espécie em que forem pagos." Grifo nosso.

248 "Art. $7^{\circ}$ - São tributáveis os interesses distribuídos aos accionistas, quer a distribuição tenha sido feita em dinheiro, quer sob outra fórma.

Parágrapho único - Quando o interesse não fôr em dinheiro, será declarado pelo valor que se lhe attribuir na data em que tiver sido recebido. Si nesta ocasião aquelle valor for desconhecido, será declarado no momento em que for possível determinal-o.

[...]

Art. 23 - Os rendimentos que não forem pagos em dinheiro, serão avaliados pelo valor que tiverem na data da percepção.

Parágrapho único - Si êste valor não puder ser determinado na data acima mencionada, será declarado e computado nos rendimentos brutos relativos ao exercício financeiro em que fôr possível determiná-lo." Grifo nosso.

${ }^{249}$ Sobre mensurabilidade e demais elementos essenciais do princípio da realização, ver item 3.3 do Capítulo 3.

${ }^{250}$ Ao longo do Decreto ${ }^{\circ}$ 17.390/1926, predomina a utilização dos verbos perceber (art. $2^{\circ}, 3^{\circ}, 10,11,17$, $19,20,22,24,29,57,69,90)$ e pagar/receber (art. $\left.7^{\circ}, 22,23,26,27,29\right)$ em relação a auferir (art. 12), derivar (art. 13, 22, 25, 38), provir (art. $9^{\circ}, 90$ ) e possuir (art. $1^{\circ}, 30,38,39$ ).
} 
em dinheiro ou em espécie (ou seja, indica a adoção de um regime de caixa) ${ }^{251}$, como evento crítico para a realização da renda. Confirmam essa interpretação da legislação diversos julgados da época ${ }^{252}$

Embora as pessoas jurídicas estivessem sujeitas à tributação sobre os lucros apurados em balanço da contabilidade comercial, a regulamentação contábil da época era incipiente $^{253}$ e a legislação tributária também empregava o verbo perceber nos dispositivos pertinentes à tributação de pessoas jurídicas. A legislação comercial, por um lado, ordenava a inclusão de direitos de crédito no ativo do balanço comercial ${ }^{254} \mathrm{e}$, por outro, ela própria indicava preferência por um sistema de contabilidade fundado em operações de caixa (recebimentos e dispêndios) ${ }^{255}$.

A esse respeito, importa trazer à colação outras expressões empregadas pela legislação do começo do século passado, mais propriamente, as expressões originado e disponibilidade jurídica. Segundo o RIR/42, na apuração do imposto pertinente a determinado ano, devem-se computar os rendimentos que estiverem juridicamente à disposição do contribuinte, ainda que tais rendimentos tenham sido originados em época anterior $^{256}$. Esse Regulamento repetia a fórmula do RIR/26 (usando diversas vezes o verbo perceber), porém trazia esses dois novos conceitos.

${ }^{251}$ A propósito, trata-se do mesmo vocábulo empregado pela legislação atual para definir o momento temporal da realização no que concerne a rendimento sujeitos ao imposto de renda de pessoas físicas. Cf. art. $8^{\circ}$, inciso I, da Lei no 9.250/1995. Sobre a assimilação deste vocábulo como sinônimo de regime de caixa, ver TILBERY, Henry. O novo imposto de renda do Brasil: comentário à Lei $\mathrm{n}^{\circ}$ 7.713/88, ajustado aos novos métodos de atualização monetária. São Paulo: IOB/IBDT, 1989, p. 34.

252 "Juros creditados fóra do ano-base, embora a esses se refiram, são considerados percebidos na data em que se positivou o credito (Ac. n. 1445, R.F., 936, n. 15)"; "não incide o imposto sobre os juros perdoados pelo credor deante da impossibilidade ou inconveniencia em recebe-los (Ac. n. 3517, D.O. de 21-1-37)". Cf. BALEEIRO, Aliomar. O impôsto sobre a renda: prática, doutrina e legislação. Salvador: Livraria Editora Baiâna, 1938, p. 118-119. "Emquanto não recebidas as vendas a prestações, não se póde computar lucro nelas", decisão do Supremo Tribunal Federal mencionada no número 188 da "Revista Fiscal" de 1933, cf. REZENDE, Tito. Manual prático do imposto de renda. Vol. IX da Biblioteca da Revista Fiscal e de Legislação da Fazenda, 2a ed. Rio de Janeiro: Sfreddo \& Gravina, 1939, p. 137.

${ }^{253}$ Estava baseada nos poucos dispositivos do Código Comercial (arts. 10 a 14 da Lei no 556/1850).

${ }^{254}$ Código Comercial "Art. 10 - Todos os comerciantes são obrigados: [...]

4 - a formar anualmente um balanço geral do seu ativo e passivo, o qual deverá compreender todos os bens de raiz móveis e semoventes, mercadorias, dinheiro, papéis de crédito, e outra qualquer espécie de valores, e bem assim todas as dívidas e obrigações passivas; e será datado e assinado pelo comerciante a quem pertencer." Grifo nosso.

255 “Art. 12 - No Diário é o comerciante obrigado a lançar com individuação e clareza toda as suas operações de comércio, letras e outros quaisquer papéis de crédito que passar, aceitar, afiançar ou endossar, e em geral tudo quanto receber e despender de sua ou alheia conta, seja por que título for, sendo suficiente que as parcelas de despesas domésticas se lancem englobadas na data em que forem extraídas da caixa. Os comerciantes de retalho deverão lançar diariamente no Diário a soma total das suas vendas a dinheiro, e, $\underline{\mathrm{em}}$ assento separado, a soma total das vendas fiadas no mesmo dia." Grifo nosso. Cf. PEDREIRA, op. cit. (nota 73), p. 165.

256 “Art. 22. A base do imposto será dada pelos rendimentos brutos, deduções cedulares e abatimentos correspondentes no ano civil imediatamente anterior ao exercício financeiro em que o imposto fôr devido. 
A palavra originado parece denotar a geração do rendimento em função do desenvolvimento de alguma atividade econômica, indicando que, em caso de realização da atividade econômica relevante em um determinado período de incidência e o efetivo recebimento da respectiva remuneração em outro período de incidência, vale este último evento para fins de apuração do imposto ${ }^{257}$. No que respeita, a seu turno, ao significado da expressão disponibilidade jurídica aí retratada, Luciano Amaro, comentando o dispositivo idêntico do Decreto-Lei $n^{0}$ 5.844/1943, ressalta que tal normativo expressou uma noção questionável de disponibilidade jurídica, pois equiparou erroneamente essa noção ao regime de caixa ${ }^{258}$. Frise-se: disponibilidade jurídica, nessa época, era sinônimo de efetivo recebimento do rendimento.

Com efeito, o evento deflagrador da incidência do imposto tendia mesmo a privilegiar o recebimento (ou a percepção) de recursos em dinheiro ou facilmente avaliáveis monetariamente. Esta era uma leitura válida para esses Decretos, embora, conforme se verá adiante no comentário ao RIR/47, eles já mencionassem, direta ou indiretamente, um certo critério de realização das receitas e confrontação com as despesas.

É verdade que, nos idos da década de 40, já se discutiam e difundiam no Brasil os diferentes conceitos de renda, havendo autores, como Ascarelli, Sousa e Almeida, que se mostravam contrários a um modelo de tributação da renda fundado no evento crucial de recebimento. Ao debater, em termos teóricos, se o imposto incidia no momento da realização efetiva (recebimento) ou já na simples aquisição do direito ao valor correspondente, os referidos juristas deixaram clara sua opinião de que ${ }^{259}$ :

“A solução (...) é em favor da segunda tese, devendo-se porém considerar no ano seguinte, sendo caso, a falta de realização efetiva como prejuízo. (...)

Em se tratando de precisar o momento da realização do lucro de balanço, quanto às mercadorias vendidas, pensamos que, aquele momento seja o da emissão da nota que deve obrigatoriamente acompanhar a mercadoria entregue: só a partir desse momento pode o vendedor creditar o importe da operação compensando-o com a baixa dos bens vendidos do ativo, de modo

Parágrafo único. Na determinação da base serão computados todos os rendimentos que, no ano considerado, estiverem juridicamente à disposição do beneficiado, inclusive os originados em época anterior." Grifo nosso.

${ }^{257}$ Cf. OLIVEIRA, Ricardo Mariz de. Fundamentos do imposto de renda. São Paulo: Revista dos Tribunais, 1977, p. 82-83.

${ }^{258}$ Cf. AMARO, Luciano. Imposto de renda: regimes jurídicos. In: MARTINS, Ives Gandra da Silva (coord.). Curso de direito tributário, v. 1. Belém: CEJUP/Centro de Extensão Universitária, 1993, p. 310. 
que a diferença constitue o lucro, ou renda, tributável. Inversamente, até esse momento o valor da coisa vendida deve permanecer na contabilização do estoque." Grifo nosso.

Com o passar dos anos, a legislação foi evoluindo em diversos aspectos e muitos dispositivos legais passaram a ser mais enfáticos quanto à adoção de um regime de competência para a alocação temporal de receitas e despesas. A Lei $n^{\circ} 154 / 1947$ foi um bom exemplo desta tendência, ao permitir que rendimentos recebidos acumuladamente, em virtude de decisão judicial ou administrativa, pudessem ser alocados temporalmente ao período a que se referissem ${ }^{260}$. Essa noção de referibilidade do rendimento a determinado período prioriza o tempo de geração do rendimento (i.e., a prática da atividade econômica que causou o direito a receber remuneração contraprestacional) em detrimento do evento de recebimento como evento crucial da realização.

O Regulamento do Imposto de Renda editado também naquele ano de 1947 repetiu alguns dispositivos legais que sinalizavam para a adoção de um regime de competência, levando respeitáveis doutrinadores da época a afirmar a existência de um princípio da competência do exercício pela legislação ${ }^{261}$.

Presente também nos RIR/42 e 43, o verbo realizar aparecia no RIR/47 como critério específico da alocação temporal das despesas ${ }^{262}$. A interpretação dada a este vocábulo atribuía-lhe o sentido de ocorrência concreta do fato subjacente (desvinculando-o

\footnotetext{
${ }^{259}$ Cf. ASCARELLI, et alli, op. cit. (nota 100), p. 102-103 (nota de rodapé 9).

${ }^{260}$ Lei $n^{\circ} 154 / 1947$ "Art $7^{\circ}$ Poderão ser redistribuídos, pelos exercícios financeiros a que se referirem, para efeito do pagamento do impôsto de renda, os rendimentos do trabalho recebidos cumulativamente, em virtude de sentenças judiciais ou administrativas."

261 "Uma das características do nosso impôsto de renda, sempre observada, e que constitui uma das maiores recomendações ao nosso sistema de impôsto reditual, é de estrita observância ao princípio da competência do $\underline{\text { exercício, }}$ isto é, do chamado sistema do ano-base. Por êste se estabeleceu que as rendas de um exercício seriam aquelas recebidas ou creditadas a uma pessoa, dentro do mesmo exercício, não importando mesmo que elas fôssem recebidas ou pagas posteriormente." CARNEIRO, Erymá. A nova lei do impôsto de renda, 1948, p. 21-22, apud BOUCHER, Hercules. Estudos de impôsto de renda e contabilidade: tributação das pessoas jurídicas. São Paulo: Saraiva, 1950, p. 89-90.

262 "Art. 37 - Constitui lucro real a diferença entre o lucro bruto e as seguintes deduções:

a) as despesas relacionadas com a atividade explorada, realizadas no decurso do ano social e necessárias à percepção do lucro bruto e à manutenção da fonte produtora." Grifo nosso. É importante ressaltar que no RIR/42 (art. 37) e RIR/43 (idem) o termo vinha no plural (realizadas) revelando sua relação mais direta com as despesas e não com a atividade.
} 
do mero pagamento) ${ }^{263}$. No mesmo Regulamento, a realização aparecia também, de maneira indireta, como critério de cômputo das receitas. Diz-se indiretamente porque ele constava da seção pertinente à apuração do lucro presumido ${ }^{264}$ e sua função como elemento portador do critério pertinente de realização dependia de alguma dose de construção interpretativa ${ }^{265}$.

No que concerne à legislação de contabilidade comercial, vale notar que também se verificou uma evolução neste período A referência da legislação tributária às normas contábeis também se foi incrementando e se tornando mais clara ${ }^{266}$. Já em 1940, o Decreto-lei $\mathrm{n}^{\mathrm{o}} 2.627$, que dispunha sobre as sociedades por ações, formalizava princípios contábeis importantes, tais como o princípio do menor valor entre custo histórico ou mercado (art. 129) e uma forma embrionária do regime de competência (arts. 132 e $\left.136^{267}\right)$.

A despeito deste encaminhamento da legislação tributária rumo à adoção de um critério diferenciado de realização (a substituição do regime de caixa pelo regime de competência), havia diversas válvulas de escape na legislação para que o contribuinte

263 "Como dissemos, o verbo realizar significa - tornar real, efetivo; efetuar. Ora, toda despesa paga é despesa efetuada. Se o pagamento se efetuou no decurso do ano social, parece ter sido observada a condição da lei. Não é essa, porém, a correta interpretação. Compreendendo que os gastos das firmas e das sociedades deveriam, necessariamente, ser apurados por meio da Contabilidade, de acordo com as suas normas e princípios, o legislador imprimiu significação contábil à redação do dispositivo, para que não houvesse dúvidas a respeito. Disse - despesas realizadas, como se dissesse - despesas certas do exercício, despesas corretamente agrupáveis dentro do ano-base, despesas que pertinem, enfim, à apuração do lucro num determinado espaço de tempo, que é o ciclo social. [...]Sendo lícito ao contribuinte deduzir da sua receita bruta os gastos vencidos e não pagos, é natural, "mutatis mutandi", que o fisco não lhe conceda dedução dos gastos pagos mas não vencidos, que se podem dizer "despesas antecipadas"." Cf. BOUCHER, op. cit. (nota 261), p. 105 e 113.

264 “Art. 40. O lucro presumido será determinado pela aplicação do coeficiente de $8 \%$ sôbre a receita bruta.

$\S \mathbf{1}^{\circ}$ Constitue receita bruta a soma das operações, realizadas por conta própria e das remunerações recebidas como preço de serviços prestados." Grifo nosso.

265 "Cabe, aí, ao verbo realizar, a mesma significação [a mesma apontada acima na nota 263] [...]Supomos serem devidos ao contribuinte alugueres de julho a dezembro, que todavia ainda não foram recebidos, devendo ser pagos de uma só vez no mês de janeiro. Nessa hipótese o fisco poderá reclamar sobre a formação da receita correspondente, realizada no exercício social. Existe o contrato que faz o locatário juridicamente responsável pelo débito vencido, o qual é exigível por todos os meios concedidos em direito. Isto na pior hipótese, imaginando-se que o devedor falte à sua palavra e o credor seja obrigado a recorrer à justiça. Sendo o débito exigível é ele um valor Ativo. Deve-se levá-lo à receita bruta do exercício, pondo-se em destaque a sua natureza." Cf. BOUCHER, op. cit. (nota 261), p. 114-115.

${ }^{266}$ RIR/47 "Art. 34 - Para os efeitos do impôsto sobre o lucro real, as pessoas jurídicas ficam obrigadas a escriturar seus livros na forma estabelecida pela legislação comercial, em idioma do país e de modo que demonstre, anualmente, o resultado de suas atividades no território nacional."

267 "Art. 132. Para que os haveres sociais possam entrar no cálculo dos lucros líquidos, não é necessário que se achem recolhidos em dinheiro à caixa; basta que consistam em valores definitivamente adquiridos ou em títulos ou papéis do crédito reputados bons. [...]

Art. 136. A demonstração da conta de lucros e perdas acompanhará o balanço e dela constarão: [...]

b) o produto das operações sociais concluídas no exercício e discriminadas pelas diversas fontes ou grupos de atividades afins;" 
manipulasse seus resultados e mantivesse a tributação circunscrita aos rendimentos efetivamente realizados (ou seja, recebidos). Assim, pode-se citar a relativa liberdade, decorrente de indefinição de critérios no registro de quotas de depreciação ${ }^{268}$, bem como na constituição de provisão para devedores duvidosos e também no registro de perdas por créditos considerados incobráveis ${ }^{269}$. Muitos dos Pareceres Normativos editados pelo Coordenaria do Sistema de Tributação durante a década de 70 procuravam preencher tais lacunas da legislação ${ }^{270}$.

Como se vê, a adoção ampla do regime de competência e uma aproximação forte entre as regras de contabilidade comercial e a regras tributárias de apuração do lucro são fenômenos relativamente recentes ${ }^{271}$ e somente aconteceram de forma plena quando, ao final da década de 70, a reforma na Lei das Sociedades por Ações provocou o início de profundas modificações na legislação do imposto de renda.

Encontra-se na obra de Wilson Batalha precioso testemunho dos acontecimentos da época. Relata o referido autor que, ao ensejo da elaboração da Lei $\mathrm{n}^{\mathrm{o}}$ 6.404, tornou-se palpável a inadequação dos dispositivos vigentes da legislação tributária do imposto sobre a renda, sobretudo no respeitante às demonstrações financeiras, à incorporação, fusão e cisão, às sociedades coligadas, controladoras e controladas, bem como aos grupos de sociedades. Com isso, o Ministério da Fazenda, em fins de 1977, empreendeu a ingente tarefa de reformular totalmente a legislação tributária do imposto de

\footnotetext{
${ }^{268}$ Embora a jurisprudência tenha se fixado em torno de uma taxa razoável de $10 \%$ ao ano, muitos julgados demonstram uma relativa facilidade na permissão para uso de taxas superiores: "Depreciação de moveis $e$ utensílios - Este Conselho tem limitado a dedução em 10\%, nenhuma circunstancia especial alegando a firma que justifique o abandono desse critério. (Acórdão do $1^{\circ}$ Conselho de Contribuintes. - "Revista Fiscal" de 1939, dec. n. 106) - No mesmo sentido: acórdãos na "Revista Fiscal" de 1936 [...] - Admitidos 15\% no caso de oficinas ("Revista Fiscal" de 1938, dec. n. 499). [...] Depreciação de maquinismos - Concedidos 10\% (acórdão do $1^{\circ}$ Conselho de Contribuintes - "Revista Fiscal" de 1936, dec. n. 641) - Inclusive no caso de uma lavanderia (idem, idem, de 1937, dec. n. 586) - Posteriormente, admitiram-se 20\% para depreciação de maquinismos (idem, idem, dec. n. 487 [...] Depreciação de automóveis e caminhões: admite-se a de $20 \%$ (acórdãos do $1^{\circ}$ Conselho de Contribuintes, na "Revista Fiscal" de 1936, dec. 53; de 1937, decisões 156, 271, 441 e 447; de 1938, dec. 498) - Admitida, entretanto, a de 25\%, num caso de caminhões que trafegam em zonas do interior, de estradas más (idem, idem, de 1938, dec. n. 498). Cf. REZENDE, op. cit. (nota 252), p. 140-141.

${ }^{269}$ Quanto aos créditos incobráveis: “A solução que a lei confere às dívidas incobráveis possui certos aspectos que não se harmonizam de todo com a prática, pois a rigor são pouquíssimos os casos em que se verifica, realmente, a impossibilidade da cobrança. Mal deixa um título de ser pago e já o contribuinte o tem por perdido e o debita a lucros e perdas." Cf. BOUCHER, op. cit. (nota 261), p. 159.

${ }^{270}$ A título de exemplo, vale mencionar os Pareceres Normativos CST 192/1972 e 74/1975, que cuidaram de alguns aspectos pertinentes a depreciação acelerada de bens do ativo imobilizado e da provisão para devedores duvidosos, respectivamente.

${ }^{271}$ Embora o item 3.2 do Parecer Normativo CST no 21/1984 sugira o contrário, que o regime de competência sempre foi o aplicável às pessoas jurídicas, este regime somente foi implementado nitidamente a partir de 1978.
} 
renda das pessoas jurídicas, tendo elaborado Anteprojeto com 289 artigos, o qual foi amplamente divulgado para o recebimento de sugestões ${ }^{272}$.

Dada a escassez de tempo para discutir com profundidade todas as recomendações recebidas, o Anteprojeto foi abandonado e foi necessário utilizar o recurso extremo do Decreto-lei para promoverem-se, com urgência, as indispensáveis adaptações dos dispositivos da legislação do imposto sobre a renda aos preceitos da Lei $n^{\circ}$ 6.404/76. Este é o contexto histórico em que surgiu o Decreto-lei $\mathrm{n}^{\mathrm{o}} 1.598 / 1977^{273}$.

O referido Anteprojeto trazia dois artigos para definir o que se entende por regime de competência e regime de caixa (art. 71 e 72$)^{274}$, determinando que o primeiro seria obrigatório para as sociedades por ações e, igualmente, para as sociedades por quotas de capital social superior a Cr\$100.000,00, ao passo que o segundo poderia ser adotado, opcionalmente, pelas demais sociedades. Esses preceitos não encontraram ressonância no Decreto-lei $n^{\circ} 1.598 / 77$, o qual, em regra, seguindo o art. 177 da Lei $n^{\circ} 6.404 / 1976$, adotou o regime de competência, e admitiu excepcionalmente o regime de caixa, e.g., em casos de empreitada ou fornecimento contratado com pessoa jurídica de Direito Público (art. 10,

272 “É óbvio que nada impedia a subsistência paralela de normas de direito mercantil e de direito tributário com pressupostos dessemelhantes e com diversos conceitos. Essa, entretanto, certamente não fora a ideia do legislador." Cf. BATALHA, Wilson de Souza Campos. A Lei das S.A. e o imposto de renda. Rio de Janeiro: Forense, 1978, p. VII e 1.

${ }^{273}$ A Exposição de Motivos do Ministro da Fazenda encaminhando o Projeto reformulado ao Presidente da República para a edição do Decreto-lei: "Tenho a honra de submeter à alta consideração de Vossa Excelência projeto de Decreto-lei que adapta a legislação do imposto sobre a renda das pessoas jurídicas domiciliadas no País à nova lei das sociedades por ações.

1. A Lei $n^{\circ} 6.404$, de 15 de dezembro de 1976 , contém diversas inovações em matéria de escrituração comercial, demonstrações financeiras, critérios de avaliação do patrimônio e correção monetária do balanço e cria novos valores mobiliários e institutos (como grupo de sociedades), cuja aplicação prática requer a adaptação da legislação do imposto de renda.

2. Era intenção deste Ministério aproveitar a oportunidade para consolidar, por ato legislativo, toda a legislação do imposto sobre lucro das pessoas jurídicas, a fim de tornar mais acessível aos contribuintes o conhecimento do sistema da legislação, que resulta de alterações esparsas introduzidas nos últimos 34 anos, no Decreto-lei $\mathrm{n}^{\circ} 5.844$, de 1943. Com esse objetivo, foi elaborado anteprojeto, divulgado para receber sugestões. O prazo exíguo concedido para análise do anteprojeto, assim como a quantidade de sugestões recebidas para modificação da legislação em vigor, recomendam o adiamento da consolidação legislativa para o próximo ano. $\mathrm{O}$ exame das sugestões recebidas requer revisão mais profunda da legislação e não apenas a consolidação dos preceitos cuja modificação não é exigida pela Lei das S.A.

3. O projeto de Decreto-lei ora submetido a Vossa Excelência abrange apenas as alterações na legislação do imposto consideradas necessárias para adaptá-la à Lei no 6.404, de 15 de dezembro de 1976. [...] Na definição dessa matéria houve a preocupação de, simultaneamente, assegurar funcionalidade à nova lei de sociedade por ações e, na regulação da base de cálculo do imposto, definir sistema coerente que possa se sobrepor à legislação em vigor sem o risco da multiplicação de problemas de interpretação. [...]

"33. Tratando-se de matéria da mais alta relevância e com caráter de urgência, e tendo em vista que não acarretará aumento de despesa, torna-se aconselhável a utilização de Decreto-lei para sua formalização, conforme facultado pelo artigo 55, item II, da Constituição." Transcrito em BATALHA, op. cit. (nota 272), p. 7-8.

${ }^{274}$ Esses dois artigos são discutidos adiante no item Erro! A origem da referência não foi encontrada. do Capítulo 2. 
$\S 3^{\circ}$ ), nas vendas a prazo ou em prestações (art. 29), nas vendas de longo prazo de bens do ativo permanente (art. 31, $2^{\circ}$ ), na alienação de bens desapropriados (art. 31, $4^{\circ}$ ), em determinadas operações de fusão, incorporação ou cisão (art. 34, inciso II).

Digno de nota é o fato de que, com a edição deste Decreto-lei, o direito tributário do imposto de renda e a contabilidade comercial se aproximaram em alto grau, podendo-se inferir, da leitura dos arts. $6^{\circ}, \S 1^{\circ}$ e 67 , inciso XI do Decreto-lei ${ }^{275}$, que se consolidava no Brasil o princípio da congruência com os parâmetros contábeis ${ }^{276}$. Em outras palavras, a apuração do imposto de renda de pessoas jurídicas deveria partir do lucro comercial e atender aos princípios de contabilidade geralmente aceitos, tal como previstos e aplicados na legislação comercial (resguardada a hipótese de previsão contrária da legislação tributária).

Essa orientação solidificava a técnica de tributação do imposto de renda de pessoas jurídicas com base na chamada teoria do balanço ou teoria do aumento do patrimônio líquido, segundo a qual compara-se o patrimônio no início e no fím do períodobase, incluindo-se todo e qualquer aumento do patrimônio líquido (abrange teoricamente inclusive a mais-valia de bens patrimoniais existentes). Trata-se de teoria vocacionada a realizar o conceito de renda-acréscimo. Opõe-se esta teoria ao cálculo segundo a teoria do resultado da exploração, o qual, assentado fundamentalmente no conceito de rendaproduto, considera apenas os lucros decorrentes das atividades operacionais de uma empresa $^{277}$.

A legislação tributária passava, assim, a se submeter claramente ao princípio da realização na forma como retratado no conjunto dos princípios de contabilidade geralmente aceitos, isto é, traduzido sob a forma do regime de competência (com as restrições pertinentes). Obedece-se aos arts. 177 e $187, \S 1^{\circ}$ da Lei $n^{\circ}$ 6.404/1976.

\footnotetext{
275 “Art $6^{\circ}$ - Lucro real é o lucro líquido do exercício ajustado pelas adições, exclusões ou compensações prescritas ou autorizadas pela legislação tributária.

$\S \mathbf{1}^{\mathbf{0}}$ - O lucro líquido do exercício é a soma algébrica de lucro operacional (art. 11), dos resultados não operacionais, do saldo da conta de correção monetária (art. 51) e das participações, e deverá ser determinado com observância dos preceitos da lei comercial." Grifo nosso. [...]

Art 67 - Este Decreto-lei entrará em vigor na data da sua publicação e a legislação do imposto sobre a renda das pessoas jurídicas será aplicada, a partir de $1^{\circ}$ de janeiro de 1978, de acordo com as seguintes normas:

$[\ldots]$

XI - o lucro líquido do exercício deverá ser apurado, a partir do primeiro exercício social iniciado após 31 de dezembro de 1977, com observância das disposições da Lei nº 6.404, de 15 de dezembro de 1976."

${ }^{276}$ A respeito do papel deste princípio vide o exemplo da Alemanha, comentado no item 3.1 deste Capítulo, e também maiores detalhes no item 1.3.1 do Capítulo 3.

${ }^{277}$ Cf. TILBERY, op. cit. (nota 151), p. 20-21 e 159-160.
} 
O regime de caixa era admitido apenas para fins tributários e em caráter de exceção (nas situações mencionadas acima). Direito Tributário e Direito Contábil passaram a caminhar juntos e, sendo este último dirigente do primeiro ${ }^{278}$, segregam-se da escrituração comercial os lançamentos feitos exclusivamente para fins fiscais, registrandoos no Livro de Apuração do Lucro Real (LALUR) ${ }^{279}$.

Como já adiantado, a união entre essas duas áreas de conhecimento do Direito tem sido duradoura, porém, a prática de se elaborarem demonstrações financeiras voltadas exclusivamente ao atendimento de regras tributárias tem impedido um desenvolvimento pleno da Contabilidade, um que fosse coerente com os princípios de contabilidade geralmente aceitos (e com a adoção irrestrita do regime de competência, por exemplo).

Por essas e outras razões, recentemente foi editada a Lei ${ }^{0} 11.638 / 2007$, para permitir a adoção de caminho diverso, isto é, ressaltou-se a possibilidade de descasamento entre demonstrações contábeis e fiscais. Para ser mais preciso, admitiu-se, pela primeira vez na legislação brasileira, a elaboração de demonstrações puramente para fins tributários, devendo as anotações dos lançamentos contábeis corretos serem feitas em livros auxiliares (o que se apelidou informalmente de "LALUC - Livro de Apuração do Lucro Contábil").

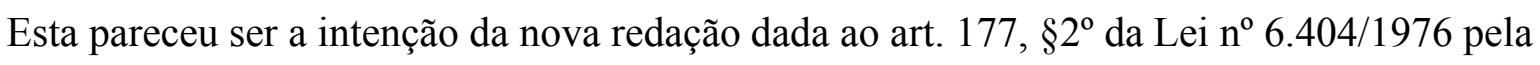
Lei $\mathrm{n}^{\circ} 11.638 / 2007$. Porém, mais recentemente, com as modificações promovidas pela Medida Provisória $\mathrm{n}^{\mathrm{o}} 449 / 2008$ no mesmo $\S 2^{\circ}$, volta-se ao modelo anterior: a Contabilidade domina a elaboração das demonstrações financeiras e as disposições da legislação tributária devem ser observadas em livros ou registros auxiliares ${ }^{280}$.

\footnotetext{
${ }^{278}$ O Direito Contábil "lidera" a regulação dos métodos e critérios de apuração do lucro, os quais têm validade direta para a apuração da renda tributável, salvo se o Direito Tributário expressamente dispuser de modo diverso

${ }^{279}$ Cf. artigo $8^{\circ}$, inciso I, do Decreto-lei ${ }^{\circ} 1.598 / 1977$.

${ }^{280}$ Volta-se a simplesmente permitir que sejam feitas "outras demonstrações financeiras". Porém, dada a ausência de previsão expressa na lei tributária que determine a elaboração de demonstrações puramente tributárias, a existência de um balanço fiscal no Brasil pode ser visualizada, quando muito, no conjunto dos livros e registros auxiliares exigidos pela legislação (dentre os quais, o LALUR). Mais a esse respeito pode ser visto no item 1.3.2 do Capítulo 3.
} 


\section{CAPÍTULO 2 - O PRINCÍPIO DA REALIZAC̄̃̃O DA RENDA NA CONSTITUIĈ̃̃O FEDERAL E NO CÓDIGO TRIBUTÁRIO NACIONAL}

Tendo em vista as diferentes teorias econômicas analisadas no primeiro capítulo deste trabalho, que delineiam conceitos de renda próprios e propiciam formas alternativas de implementação do princípio da realização da renda, o estudo que se apresenta neste capítulo busca identificar, nos níveis mais elevados do sistema tributário brasileiro, de que forma o princípio da realização da renda se manifesta, perscrutando-se a Constituição Federal de 1988 (CF 1988) e o Código Tributário Nacional (CTN) na busca dos principais requisitos, condições e limites fixados para referido princípio.

Nesse sentido, retomam-se aqui algumas das discussões específicas que já foram travadas na doutrina brasileira em torno da legislação suprema e complementar, voltando-se não apenas a uma compreensão da extensão do princípio da capacidade contributiva $^{1}$ e de seus subprincípios, mas também, e principalmente, enfocando-se as teorias econômicas acerca do conceito de renda, para verificar em qual medida o sistema tributário brasileiro admitiu a recepção de tais teorias e quais aspectos do conceito de renda foram efetivamente inseridos na ordem jurídica.

Em essência, portanto, a questão central examinada ao longo deste capítulo consiste em saber, na disciplina da matéria tributável pelo imposto de renda, quais parâmetros a CF 1988 e o CTN estabeleceram para a concretização do princípio da realização da renda.

\section{O princípio da realização da renda no sistema constitucional tributário}

Com esta proposta de análise são retomados alguns dos temas apresentados no Capítulo 1, estendendo-se o debate para a análise de princípios considerados integrantes do sistema constitucional brasileiro (explícita ou implicitamente) e que demonstrem relação intrínseca com o princípio da realização da renda.

Como primeiro passo nesta análise, percorre-se a discussão quanto à presença de um conceito ${ }^{2}$ de renda no texto constitucional, questionando-se acerca do(s) conceito(s) passíveis de adoção e as acepções correlatas e apropriadas de realização, pois se assume

\footnotetext{
${ }^{1}$ Tratado brevemente no item 1.2 do Capítulo 1.
} 
que, para cada conceito de renda que poderia ser adotado pelo sistema tributário brasileiro, haveria enfoques específicos para a implementação do princípio da realização.

Atenção especial é dada aos princípios e subprincípios que se congregam para o atendimento do princípio da capacidade contributiva no imposto de renda. Discorre-se principalmente sobre eventuais limites sistêmicos que impeçam a implementação do princípio da capacidade contributiva em sua máxima expressão, buscando, com isso, estruturar o princípio da realização a partir de prioridades que tenham sido antecipadas por princípios constitucionais atinentes à tributação da renda (como a universalidade, renda líquida, apuração periódica etc.). Nesse diapasão, por fim, atenção especial é dada ao princípio da praticabilidade, como elemento balizador a demandar simplicidade e objetividade na apuração da renda.

\subsection{Conceito de renda na Constituição Federal de 1988}

O uso da expressão "renda e proventos de qualquer natureza" para fins da atribuição de competência tributária é prática adotada desde a Constituição de $1934^{3}$, de modo que a ponderação acerca de seu conteúdo é tema com que já se ocuparam algumas das mentes mais brilhantes da área jurídica em nosso País. Por se tratar, assim, de assunto ampla e solidamente debatido pela doutrina, não se pretende rever os pressupostos da discussão, mas tão-somente realçar os componentes de uma tal noção constitucional de renda que possam ter vinculação com o princípio da realização e ser importantes para este estudo.

A discussão começa a ficar particularmente interessante a partir da edição do CTN, pois este sobreviveu a três mudanças substanciais de cartas constitucionais, de modo que a definição de renda esculpida em seu artigo 43 passou a ser o paradigma ao qual se contrapõem as previsões constitucionais pertinentes ao imposto de renda.

\footnotetext{
${ }^{2}$ No sentido de um conceito tipológico, uma noção mínima.

${ }^{3}$ Art. $6^{\circ}$, inciso I, item “c”. A mesma expressão foi utilizada pelas Constituições Federais e Emendas relevantes que se seguiram (CF de 1937, art. 20, inciso I, item "c"; CF de 1946, art. 15, inciso IV; EC $\mathbf{n}^{\mathbf{0}} \mathbf{1 8} / \mathbf{6 5}$, art. $8^{\circ}$, inciso II; CF de 1967, art. 22, inciso IV; EC $\mathbf{n}^{\mathbf{0}} \mathbf{1}$, 69, art. 21, inciso IV).
} 


\subsubsection{Advertência terminológica e metodológica}

Faz-se inicialmente aqui uma breve ressalva quanto à acepção que se atribui ao vocábulo conceito, especialmente quando o que se procura identificar é tão-somente um conteúdo mínimo, um conjunto de ideias dedicado à expressão renda e proventos de qualquer natureza empregada no artigo 153, inciso III, da atual Constituição Brasileira.

Buscando arrimo nas lições do Prof. e Min. Eros Grau, tem-se uma visão geral de conceito como uma suma de ideias, uma captação da essência mais simples dos objetos representados ${ }^{4}$. Ao se falar de um conceito de renda presente no texto constitucional, não se deve ignorar que o conceito, objeto de análise, deve comportar um grau relativo de indeterminação (o que o aproxima mais de um conceito jurídico tipológico, isto é, uma espécie de tipo, ou uma noção $)^{5}$.

Empenhando-se para afastar a convicção de que as hipóteses de incidência de tributos contemplam conceitos classificatórios (cerrados), Ávila propõe a substituição de um modelo antiquado, que demandava uma fixação absoluta dos fatos tributários na hipótese de incidência, por um que exija que os elementos essenciais da obrigação tributária sejam apenas "padronizadamente determináveis".

Tendo isso em vista, a identificação de um conteúdo mínimo, essencial, para os termos renda e proventos de qualquer natureza empregados pela Carta Constitucional aparenta resultar, mais propriamente, em um conceito jurídico tipológico (e não um conceito cerrado $)^{6}$. Como tal, deve limitar-se a descrever características gerais do que seja renda para fins de tributação, estando sujeito a algumas variações na sua definição, a serem

\footnotetext{
${ }^{4}$ A simplex apprehensio essentiae rei. Permite extrair do objeto referenciado sua aparência singular ou individual. O conceito é expressado através de um "termo" (um signo linguístico: uma palavra ou uma expressão) que, sendo impreciso ou ambíguo, pode demandar uma enunciação estipulativa, ou seja, uma "definição", uma explicitação dos elementos do conceito. Cf. GRAU, Eros Roberto. Ensaio e discurso sobre a interpretação/aplicação do direito. $3^{\mathrm{a}}$ ed. São Paulo: Malheiros Editores, 2005, p. 220-222.

${ }^{5}$ Eros Grau critica o uso da expressão conceito indeterminado, apontando que a indeterminação é característica dos termos e não dos conceitos a que eles se referem. Sugere ainda que o problema estaria relacionado à tradução imprecisa da expressão unbestimmter Rechtsbegriff: "Aqui se manifesta um problema de linguagem. É que a língua alemã usa a mesma palavra - Begriff - para conotar conceito e noção". Em algumas traduções francesas, utiliza-se, mais apropriadamente, la notion juridique indéterminée. Cf. GRAU, op. cit. (nota 4) p. 231-237.

${ }^{6}$ Em hábil manejo com os elementos de Teoria Geral do Direito, Humberto Ávila esclarece que, de maneira geral, o tipo representa uma "totalidade" "graduável" e "aberta", ao passo que o conceito constata uma "rígida" "soma de elementos distintivos". Porém, considerando-se os níveis reduzidos de "abertura" e "graduação" de determinados tipos e também a indeterminação linguística de determinados conceitos, essas categorias jurídicas podem se aproximar e se confundir. Ávila sustenta que o tipo é apenas uma espécie de conceito. Vide o percuciente estudo do renomado professor acerca da distinção entre conceitos e tipos e sua aplicação na definição de competências tributárias em: ÁVILA, Humberto. Sistema constitucional tributário: de acordo com a Emenda Constitucional n. 51, de 14.02.2006. $2^{\mathrm{a}}$ ed. rev. e atual. São Paulo: Saraiva, 2006, p. 159-213.
} 
determinadas pelo legislador competente no momento histórico pertinente, podendo absorver as concepções econômicas predominantes e, bem assim, as condições materiais de desenvolvimento da sociedade etc.

A propósito, é importante registrar que a perspectiva descrita acima - que procura salientar a abertura do conceito constitucional de renda - enfatiza, em certa medida, uma ideologia dinâmica da interpretação jurídica, a qual busca adaptar o direito às necessidades presentes e futuras da vida social e ameniza argumentos genéticos, que procuram aliar o significado da norma jurídica à vontade do legislador.

Por outro ângulo, não se pode perder de vista o entendimento que vem sendo consagrado pelo Supremo Tribunal Federal, no sentido de que a CF 1988 utiliza conceitos historicamente pressupostos. Em outras palavras, conforme pontua Humberto Ávila, a utilização de termos ou expressões no texto constitucional, que digam respeito a conceitos técnicos previstos no "direito infraconstitucional pré-constitucional", significa uma opção do legislador constituinte pela incorporação desse conceito legal ao ordenamento jurídico ${ }^{7}$.

Essa observação é relevante porque aponta para um grau razoavelmente elevado de determinação no conceito constitucional de renda, tendo em vista que a $\mathrm{CF}$ 1988, segundo esse raciocínio, teria incorporado os conceitos de renda que prevaleciam ao tempo de sua promulgação. Em outras palavras, a Carta Magna traria em seu bojo os conceitos de renda-produto e renda-acréscimo tal como retratados no CTN. E essa linha de pensamento parece coadunar-se com uma ideologia de interpretação diferente da exposta acima: trata-se da ideologia estática de interpretação jurídica, que preza pela segurança jurídica e certeza do direito ${ }^{8}$.

Afastando o trato maniqueísta da questão de interpretação do texto constitucional, a linha diretriz deste trabalho apoia-se nos conspícuos ensinamentos de Humberto Ávila, que fornece elementos para uma argumentação contrária à teoria da reserva constitucional material, pelos quais "a mera afirmação de que o conceito utilizado pela Constituição deve ser respeitado não resolve a questão crucial de saber qual conceito, entre todos aqueles possivelmente utilizáveis, foi efetivamente utilizado pela Constituição". Para tal raciocínio devem ser carreados argumentos preferencialmente de ordem linguística (que procurem evidenciar o significado das expressões contidas no

\footnotetext{
${ }^{7}$ Nesse sentido, o RE 166.772-9 sobre o conceito de salário para fins da cobrança de contribuição previdenciária; o RE 203.075-9, sobre o conceito de mercadoria para fins de ICMS na importação; e o RE 116.121, sobre o conceito de serviço para fins do ISS. Cf. ÁVILA, op. cit. (nota 6), p. 202-206.
} 
dispositivo constitucional) e sistemática (que prezem pela unidade e coerência do sistema jurídico), do que de ordem genética, histórica (que realcem a vontade do legislador ou o sentido que a norma tinha no contexto de sua produção) e meramente prática (que dependem de julgamento político, econômico ou ético) ${ }^{9}$.

Com isso, em face da indeterminação linguística da expressão renda $e$ proventos de qualquer natureza, deve o intérprete procurar, primeiramente, pautar-se por eventuais conceitos que tenham sido historicamente pressupostos (no caso, os conceitos de renda-produto e renda-acréscimo parecem adequados, haja vista constarem do direito infraconstitucional vigente ao tempo da promulgação da Nova Carta) e, após, persistindo a indeterminação, como de fato acontece, construir o conceito de renda tributável utilizando elementos do ordenamento constitucional de modo a preservar sua coerência.

\subsubsection{Conceito constitucional de renda}

Feitas tais ressalvas e passando à análise da questão colocada - perquirindo-se acerca dos elementos constitucionais do princípio da realização -, verifica-se que predomina, na doutrina brasileira, a opinião de que há um conteúdo mínimo atribuível para o conceito de renda ${ }^{10}$ no nível constitucional e, mais ainda, que a identificação deste conteúdo faz-se indispensável, particularmente em razão do modelo adotado pela Constituição Brasileira: o de distribuição rígida de competências tributárias.

Um dos arautos deste pensamento nos tempos atuais é o Prof. José Artur Lima Gonçalves, para quem o conceito de "renda e proventos de qualquer natureza" não pode ficar à disposição do legislador ordinário, porquanto a Constituição Federal de 1988 serviu-se da técnica de referir-se ao critério material da regra-matriz de incidência

\footnotetext{
${ }^{8}$ Para a referência a tais ideologias de interpretação, cf. GRAU, op. cit. (nota 4) p. 118-122.

${ }^{9}$ Tal preferência é ditada pelos princípios do Estado de Direito (notadamente em função da estabilidade e da segurança jurídica), da separação de poderes (vedando ao Poder Judiciário alterar os significados mínimos das normas instituídas pelo Poder Legislativo) e da legalidade (que coloca os enunciados prescritivos do Poder Legislativo em evidência). Cf. ÁVILA, op. cit. (nota 6), p. 160-162 e 208-213.

${ }^{10}$ Como pressuposto metodológico da presente análise não será enfocado o elemento "proventos de qualquer natureza" e suas acepções, pois se entende que a essência da tributação por este imposto já está compreendida no termo "renda". A respeito da função da expressão "proventos ...” cf. MOSQUERA, Roberto Quiroga. Renda e proventos de qualquer natureza - O imposto e o conceito constitucional. São Paulo: Dialética, 1996, p. 59-67. Para uma análise histórica da expressão, confluindo para sua definição residual como "outros acréscimos patrimoniais não decorrentes do capital nem do trabalho" e para a conclusão de sua prescindibilidade, cf. AMARO, Luciano da Silva. Imposto sobre a renda e proventos de qualquer natureza. In: MARTINS, Ives Gandra da Silva (coord.). O fato gerador do imposto sobre a renda e proventos de qualquer natureza: Caderno de Pesquisas Tributárias, v. 11. São Paulo: Resenha Tributária, 1986, p. 402408.
} 
tributária para proceder à repartição de competências tributária. Dessa forma, admitir o contrário seria equivalente a permitir que o legislador infraconstitucional pudesse bulir com o âmbito das competências tributárias impositivas constitucionalmente estabelecidas ${ }^{11}$.

Esse entendimento é compartilhado, por Bulhões Pedreira ${ }^{12}$, Roberto Quiroga ${ }^{13}$, Roque Carrazza ${ }^{14}$, João Francisco Bianco ${ }^{15}$, dentre outros brilhantes comentadores do imposto de renda de pessoas jurídicas que, perfilhando linhas similares de raciocínio, apontam para a existência, no Texto Supremo, de um conteúdo fundamental, uma noção mínima do termo linguístico "renda"16.

O conceito ou, mais propriamente, a noção constitucional de renda deve prezar pela divisão de competências tributárias engendrada pela CF 1988. Assim é que, visando superar a ambiguidade ou imprecisão do termo "renda", muitos dos comentadores lançam mão da técnica de conceituação por exclusão, ou seja, cotejam-se todos os demais termos empregados pela CF 1988 na atribuição de competências tributárias para, eliminando eventuais hipóteses de confluência, evitar que o conteúdo atribuído à renda conflite com outras noções constitucionais.

\footnotetext{
${ }^{11}$ A lógica é a de que o âmbito semântico dos veículos linguísticos adotados pela Constituição, para traduzir regras de competência tributária, não pode ficar à disposição de quem receber a outorga de competência. Segundo o referido autor: "A própria Constituição fornecerá, portanto, ainda que de forma implícita, haurível de sua compreensão sistemática, o conteúdo do conceito de renda por ela - Constituição - pressuposto." GONÇALVES, José Artur Lima. Imposto sobre a renda: pressupostos constitucionais. $2^{\mathrm{a}}$ tir. São Paulo: Malheiros, 2002, p. 170-171.

12 "A intenção dos redatores do CTN parece ter sido ampliar o conceito constitucional de "renda e proventos de qualquer natureza" para nele incluir as transferências de capital. A nosso ver, o CTN não define o conceito constitucional, mas conceito diferente - de "acréscimo de poder econômico". A constitucionalidade dessa definição ainda não foi submetida a qualquer teste." Cf. PEDREIRA, José Luiz Bulhões. Imposto sobre a renda: pessoas jurídicas. Rio de Janeiro: Justec, 1979, p. 110.

13 “ “...] no que se refere à regra matriz do imposto sobre a renda e proventos de qualquer natureza, não há campo de liberdade para o legislador federal em vista do sistema rígido de atribuição de competências". Cf. MOSQUERA, op. cit. (nota 10), p. 77.

14 “'[...] há na Constituição Federal conteúdos semânticos mínimos (noções genéricas) quer de renda, quer de proventos de qualquer natureza, a serem obrigatoriamente levados em conta na criação in abstracto do imposto em tela." Cf. CARRAZZA, Roque Antonio. Imposto sobre a renda: perfil constitucional e temas específicos. $2^{\mathrm{a}}$ ed., rev., ampl. e atualizada. São Paulo: Malheiros, 2006, p. 35.

15 "Quando a Constituição estabelece previamente a materialidade a ser tributada, pode ela ser um conceito determinado, definido pelo direito privado, ou um conceito com um certo grau de indeterminação, mas que apresenta um significado mínimo que não pode ser desconsiderado pelo legislador ordinário.” Cf. BIANCO, João Francisco. Imposto de renda da pessoa jurídica: uma visão geral. In: SANTI, Eurico Marcos Diniz de; ZILVETI, Fernando Aurelio (coords.) Tributação das Empresas. São Paulo: Quartier Latin, 2006, p. 318.

${ }^{16}$ Acerca da importância elevada do grau de rigidez das regras constitucionais de discriminação de competências tributárias, vide MOSQUERA, op. cit. (nota 10), p. 74-77.
} 
Segundo Lima Gonçalves, há diversos conceitos no texto constitucional que tangenciam ou influem no conceito de renda ${ }^{17}$. Carrazza envereda pelo mesmo caminho para dizer que os conteúdos semânticos mínimos presentes na Constituição Federal de 1988 permitem inferir que renda é uma grandeza diversa de rendimentos, patrimônio, importação, exportação, propriedade territorial rural etc. ${ }^{18}$. A partir da observação desses limites, os autores inferem conceitos mais ou menos precisos para o termo renda.

Neste ponto, cabe já uma ligeira observação. Quer nos parecer que a mera observação das fronteiras intransponíveis pela noção de renda, embora consista num certo exercício de definição (no sentido de “dizer os fins, os contornos”), pouco oferece de conteúdo específico quanto ao que seja renda. Tal exercício permite, quando muito, detectarem-se os pontos de efeito negativo (ou inibitório) inerentes à rígida distribuição constitucional de competência, concedendo argumentos para que se sustente, e.g., a intributabilidade de heranças e doações pelo imposto de renda, sob o argumento de que seria materialidade afeta à competência estadual ${ }^{19}$, ou que se afaste, por exemplo, um conceito de renda-consumo, por suposta invasão no campo de competência de outros tributos (ICMS, IPI, ISS etc.). Quer se reafirmar com isso que a formulação de uma noção de renda a partir do conhecimento dos limites da competência tributária parece resvalar, inevitavelmente, em um conceito-tipológico (aberto, indeterminado).

Nesse diapasão, Lima Gonçalves restringe-se a apontar parâmetros mínimos que ele reconhece serem genéricos e carregados de incertezas (as quais podem levar a abusos do legislador ordinário e, até mesmo, da administração) e que constituem o

\footnotetext{
${ }^{17}$ Faturamento: mero ingresso, soma dos valores das faturas - não há compromisso com a noção de resultado (positivo ou negativo); Capital: investimento permanente, de titulação de um patrimônio - noção estática que não se aproxima da noção dinâmica de renda (que aponta para um período); Lucro: (arts. $7^{\circ}$, XI, 172, 173, $\S 4^{\circ}$ e 195, I) resultado positivo da atividade empresarial - noção parcial com relação à renda, trata-se de uma espécie do gênero renda; Ganho: (arts. 201, $\S 4^{\circ}$ e $218, \S 4^{\circ}$ ) tem o sentido de ingressos de forma descompromissada da noção de saldo positivo; Resultado: (arts. $7^{\circ}, \mathrm{XI}, 20, \S 1^{\circ}, 71, \mathrm{VII}, 77, \S 3^{\circ}, 109, \mathrm{~V}, 111$, $\S 2^{\circ}, 176, \S 2^{\circ}, 195, \S 8^{\circ}, 231, \S 3^{\circ}, 235$, IX e $12, \S 1^{\circ}$ do ADCT) significa a situação terminal de um processo, sem qualificação valorativa relativamente à manifestação de capacidade contributiva; Patrimônio: conjunto estático de bens e direitos titulados por uma pessoa; Fortuna: sentido semelhante ao de patrimônio. Cf. GONÇALVES, op. cit. (nota 11), p. 177-179.

${ }^{18}$ Cf. CARRAZZA, op. cit. (nota 14), p. 35-37.

${ }^{19} \mathrm{O}$ argumento de conflito de competência é utilizado por Carrazza e Misabel, por exemplo, para declarar uma hipótese de não-incidência de IR, em situação que é tratada pela legislação de IRPF como sendo uma isenção e ignorada pela legislação de IRPJ (que considera as doações como renda tributável, por exemplo). Cf. CARRAZZA, op. cit. (nota 14), p. 86. Cf. DERZI, Misabel Abreu Machado. Imposto "causa mortis" e ganho de capital. In: BALEEIRO, Aliomar. Direito tributário brasileiro, atual. por Misabel Abreu Machado Derzi. $11^{\mathrm{a}}$ ed. Rio de Janeiro: Forense, 2001, p. 267.
} 
conteúdo semântico mínimo do conceito constitucionalmente pressuposto de renda ${ }^{20}$. Tais elementos resumiriam a renda ao:

“(i) saldo positivo resultante do (ii) confronto entre (ii.a) certas entradas e

(ii.b) certas saídas, ocorridas ao longo de um dado (iii) período".

Numa primeira leitura, tal definição parece sintetizar a essência da noção de renda apoiada nos princípios da renda líquida e apuração periódica ${ }^{21}$ sem grandes limitações conceituais aparentes. Particularmente ao explicitar o item "saldo positivo", o referido autor destaca que: "renda haverá quando houver sido detectado um acréscimo, um plus; tenha ele, ou não, sido consumido; seja ele, ou não, representado por instrumentos monetários, direitos, ou por bens, imateriais ou físicos, móveis ou imóveis"22.

Uma tal acepção ampla de acréscimo aparenta ser adequada a um conceito constitucional aberto, por ser vasta o suficiente para abrigar diversas das formulações econômico-financeiras de renda discutidos no Capítulo 1 deste trabalho. A leitura singela desta concepção de renda indica, ademais, que não se afasta, de plano, um conceito (a ser definido pelo legislador no exercício da competência tributária) que restringisse a materialidade do tributo à renda consumida ou a estendesse para atingir acréscimos patrimoniais decorrentes da mera valorização de ativos ou benefícios derivados da utilização de bens próprios ${ }^{23}$.

Ao explicar o que seriam as "entradas e saídas", não se afigura tão claro se o que o referido jurista denomina de "acréscimos e decréscimos", "aumentos e diminuições" do patrimônio ao longo do tempo abrangeria também meras mutações de valor de bens detidos pelo contribuinte (valorizações de patrimônio ou ganhos de detenção) ${ }^{24}$. E sabe-se que a imposição de um tal limite obstacularizaria a adoção plena do conceito de rendaacréscimo do modelo Schanz-Haig-Simons (modelo SHS ou conceito fundamental de

\footnotetext{
${ }^{20}$ Cf. GONÇALVES, op. cit. (nota 11), p. 179.

${ }^{21}$ Abordados com mais vagar no item 1.2.3 deste Capítulo.

${ }^{22}$ Cf. GONÇALVES, op. cit. (nota 11), p. 180-181.

${ }^{23}$ Ao acurar mais sua proposta conceitual, Lima Gonçalves afirma que "nem todo ingresso é relevante para o conceito de renda - por exemplo, o ingresso decorrente de financiamento ou aumento de capital pelos sócios são totalmente descompromissados com a noção de acréscimo", aparentando afastar uma noção de rendaconsumo. Cf. GONÇALVES, op. cit. (nota 11), p. 182.

${ }^{24}$ É possível afirmar, todavia, que o referido autor não teria afastado uma noção ampla de acréscimo patrimonial, pois ele se apoia na definição de patrimônio, explicitada por Bulhões Pedreira, no sentido de conjunto de direitos "cujo conteúdo está sujeito a frequentes modificações em razão de mutação, acréscimo ou exclusão de elementos" (grifos nossos), e poderia aceitar, portanto, a mutação patrimonial (sem acréscimos de elementos novos) como relevadora de uma entrada ou saída para fins do conceito de renda. Cf. GONÇALVES, op. cit. (nota 11), p. 182.
} 
renda), impedindo a efetivação ampla dos ideais de igualdade e de distribuição ideal da carga tributária conforme o princípio da capacidade contributiva ${ }^{25}$.

Para atribuir maior detalhamento ao conceito constitucional de renda, predomina na doutrina brasileira, e os exemplos tomados aqui partem das lições de Carrazza, Quiroga e Mariz de Oliveira, a ideia de que o intérprete deve ir além, buscando, nos conceitos de renda historicamente pressupostos ${ }^{26}$, os elementos essenciais da noção de renda, sugerindo-se, com isso, uma elevação dos conceitos de renda-produto e rendaacréscimo ao nível constitucional (não, porém, com toda a abrangência que um modelo SHS exigiria ${ }^{27}$ ). Carrazza fala que renda são "os ganhos econômicos do contribuinte gerados por seu capital, por seu trabalho ou pela combinação de ambos e apurados após o confronto das entradas e saídas verificadas em seu patrimônio, num certo lapso de tempo" ${ }^{28}$. Quiroga, de forma semelhante, vale-se das teorias das fontes e do acréscimo patrimonial líquido para descrever a noção constitucional de renda ${ }^{29}$.

Ricardo Mariz de Oliveira, fundamentando solidamente sua teoria no pressuposto de que a essência do fato gerador do imposto de renda resume-se ao gravamento do acréscimo patrimonial, chega a sugerir que o conceito de patrimônio ${ }^{30}$ teria sido absorvido implicitamente pela definição constitucional de competência tributária ${ }^{31}$. Após mencionar os recursos de interpretação histórica e de interpretação baseada em argumentos linguísticos (neste caso, a perquirição de um sentido substancial à expressão renda e proventos de qualquer natureza), Mariz aponta para a predominância do recurso interpretativo que busca o sentido dos termos técnicos empregados pela CF 1988 tal como

\footnotetext{
${ }^{25}$ Sobre a harmonia do princípio da capacidade contributiva com o modelo SHS, vide item 2.3.2 do Capítulo 1 .

${ }^{26}$ Vide o item 1.3 deste Capítulo sobre o entendimento do STF acerca dos conceitos historicamente pressupostos pela Constituição Federal de 1988.

${ }^{27}$ Sobre tais conceitos de renda e a abrangência demandada pelo modelo SHS, vide itens 2.3 .1 e 2.3.2 do Capítulo 1.

${ }^{28}$ Cf. CARRAZZA, op. cit. (nota 14), p. 37. O autor usa este "núcleo formador da renda" para justificar a intributabilidade de doações, pois uma tal exação seria insuscetível de enquadrar-se na "noção constitucional de rendimento" - doação seria transferência patrimonial e não renda, pois não é produto do capital e/ou trabalho, cf. op. cit., p. 87.

29 "Daí porque propomos a definição da palavra "renda" e da expressão "proventos de qualquer natureza" como a mutação patrimonial que se constitui num acréscimo de seus elementos, acréscimos estes originados do trabalho, do capital, da aposentadoria ou de qualquer outra fonte geradora de riqueza nova." Cf. MOSQUERA, op. cit. (nota 10), p. 110. Segundo Quiroga, as justificativas para a assimilação dos conceitos de renda-produto e renda-acréscimo enquanto sinônimos de "somatória de rendimentos", "rendimento do trabalho" e "produto do capital" são retirados do próprio texto constitucional (nos artigos 151, inciso II; 153, $\S 2^{\circ}$, inciso II - atualmente revogado; 157 , inciso I; 158 , inciso I; 201 , $\$ 5^{\circ}$ - na redação original), cf. op. cit., p. $52-59$.

${ }^{30}$ Definido pelo Direito Civil (no papel de direito infraconstitucional pré-constitucional).

${ }^{31}$ Cf. OLIVEIRA, Ricardo Mariz de. Fundamentos do imposto de renda. São Paulo: Quartier Latin, 2008, p. 54.
} 
eles se encontravam no mundo jurídico ao tempo da promulgação do Texto Maior ${ }^{32}$. Tratase de método interpretativo válido e aceito pela doutrina e jurisprudência brasileira ${ }^{33}$.

No que concerne às situações limítrofes do conceito de renda, uma das principais controvérsias que podem influenciar a moldagem de um princípio da realização no nível constitucional (e o conhecimento de suas formas alternativas de implementação) reside no tratamento dos ganhos de detenção (já tangenciado acima). Caso se conclua que a Constituição Federal de 1988 impôs uma barreira à tributação dos ganhos de detenção, dever-se-ia igualmente conceder que o legislador constitucional teria repelido as acepções pertinentes de realização da renda, quais sejam, aquelas que consideram o aumento patrimonial no tempo ${ }^{34}$.

Diversos juristas renomados como Modesto Carvalhosa ${ }^{35}$, Alcides Jorge Costa $^{36}$, Ives Gandra ${ }^{37}$, Quiroga ${ }^{38}$, dentre outros, se mostram contrários a tal forma de

\footnotetext{
${ }^{32}$ Sugere que esta orientação, afora ser prevalecente na doutrina e jurisprudência, teria sido incorporada ao direito positivo pela Lei Complementar n 95/1998, em seu art. 11, inciso I, alínea "a". Cf. OLIVEIRA, op. cit. (nota 31), p. 172-173.

${ }^{33}$ Nota-se que conceituações que recapitulam os conceitos de renda-produto e renda-acréscimo, procurando incorporá-los à noção constitucional de renda, deixam entrever, como já adiantado linhas acima, a aplicação de uma ideologia estática de interpretação jurídica que, retratando conceitos consolidados ao tempo da promulgação da Carta Magna, preza pela segurança jurídica na definição e aplicação dos termos presentes em textos normativos. Conforme se verá na segunda parte deste Capítulo, os conceitos de renda-produto e renda-acréscimo estão retratados no artigo 43 do Código Tributário Nacional e podem ser considerados prevalecentes no contexto da Constituição Federal atual.

${ }^{34}$ Com isso, afastada estaria, de pronto, a tributação de ganhos de variação cambial antes da liquidação das operações, e nem se cogitar poderia de tributar a renda econômica obtida no processo produtivo (antes de uma troca efetiva no mercado).

${ }^{35}$ É de se ressaltar que Carvalhosa estava fazendo uma leitura do texto constitucional orientado pelo art. 43 CTN: "Somente é tributável o acréscimo patrimonial quando ele é efetivamente verificável o disponível pelo seu titular. Exclui-se, dessa forma, a simples valorização do patrimônio como fato gerador do tributo, já que esta simples valorização nominal de um determinado patrimônio poderia desaparecer em momentos sucessivos pela desvalorização dêsse mesmo patrimônio, donde impossível mensurar o acréscimo patrimonial, já que êle não se efetivou e não pode estar disponível pelo seu titular". Cf. CARVALHOSA, Modesto. Imposto de renda. Conceituação no Sistema Tributário da Carta Constitucional. In: Revista de direito público, $\mathrm{n}^{\circ}$ 1, jul-set. 1967, p. 193.

36 "Parece importante esta conceituação inicial pois ela afasta, desde logo, a tributação de renda virtual ou ainda não realizada. Assim, a valorização de imóveis não pode ser tributada senão quando a renda dela decorrente possa ser utilizada, empregada, etc., o que só acontece quando ela deixar de ser virtual e se torna efetiva, como numa alienação de imóvel. Ou, em se tratando de sociedade, através de uma reavaliação, em que a disponibilidade ocorre indiretamente, através das ações que o acionista recebe gratuitamente." COSTA, Alcides Jorge. Imposto sobre a renda. A aquisição da disponibilidade jurídica ou econômica como seu fato gerador. Limite de sua incidência. (Relatório das XI Jornadas do Instituto Latino Americano de Derecho Tributário). In: Revista de Direito Tributário, ano 11, n ${ }^{\circ}$ 40. São Paulo: Revista dos Tribunais, abr-jun. 1987, p. 105.

${ }^{37}$ Cf. MARTINS, Ives Gandra da Silva. Imposto sobre a renda e proventos de qualquer natureza. In: MARTINS (Coord.), op cit. (nota 10), p. 286-291.
} 
tributação, sendo alguns deles enfáticos em afirmar de que tal matéria estaria fora do campo constitucional de competência relativo ao imposto de renda, pois este compreenderia somente a mutação patrimonial que representasse riqueza nova, i.e., a entrada de um novo elemento patrimonial. Notadamente no que respeita aos ganhos de detenção de bens imóveis, Ives Gandra alerta para o conflito de competência com IPTU e $\mathrm{ITR}^{39}$.

Todavia, com o devido acatamento, a construção de uma noção constitucional de renda não parece permitir a oposição de uma restrição tão específica. Não se pretende, com esta crítica, encontrar justificativas para opor um modelo de tributação que alcance todos os ganhos de detenção, nem tampouco validar as formas de tributação baseadas em valorização de ativos, tal como atualmente previstas na legislação de regência ${ }^{40}$, mas tãosomente explicitar quais vetores constitucionais contribuem para que uma tal restrição se sustente.

$\mathrm{Na}$ hipótese da renda decorrente da valorização de ativos, faltariam os elementos de certeza e liquidez, necessários para que se considere realizada essa renda? Ao se admitir o critério de riqueza nova, estar-se-ia apontando para alguma acepção específica do princípio da realização e, mais ainda, estar-se-ia constitucionalizando tal acepção? Essas questões parecem mais adequadas à aplicação da legislação a um caso concreto do que propriamente à explicitação dos limites da noção constitucional de renda.

O tema da existência de limites constitucionais ao conceito de renda-acréscimo foi amplamente discutido no XI Simpósio Nacional de Direito Tributário do Centro de Estudos de Extensão Universitária ${ }^{41}$ e, especialmente quanto à possibilidade de se tributar a valorização de bens do patrimônio ${ }^{42}$, alguns autores sustentaram a inexistência de

\footnotetext{
${ }^{38}$ Embora admita que o imposto de renda seja o único imposto vocacionado a atingir tal mutação patrimonial (ou seja, não haveria uma invasão da competência destinada a outro tributo), o aclamado professor firma-se no posicionamento de que, para se encaixar na materialidade prevista constitucionalmente, a mutação patrimonial deve decorrer de "trânsito de elementos patrimoniais", deve ser uma "mutação de elementos do patrimônio de uma pessoa" e não apenas a mutação em termos monetários. Em outras palavras, o conceito constitucional abarcaria apenas a riqueza nova como materialidade do imposto de renda. Cf. MOSQUERA, op. cit. (nota 10), p. 102-108.

${ }^{39}$ Cf. MARTINS, op cit. (nota 10), p. 290.

${ }^{40}$ Conforme será abordado em maior detalhe no item 6.1 do Capítulo 4 , a tributação de variações monetárias (regulamentada nos artigos 375 e seguintes do RIR atual) é um exemplo claro de que o conceito de renda tributável pode alcançar o acréscimo patrimonial não decorrente de uma transação de mercado em sentido estrito.

${ }^{41}$ Especialmente em razão da pergunta $\mathrm{n}^{\circ} 3.1$ dirigida a cada um dos expositores: "Existem acréscimos patrimoniais que não se enquadrem no conceito de proventos de qualquer natureza, referidos no artigo 21 , IV, da Constituição Federal?” In: MARTINS (Coord.), op cit. (nota 10).

${ }^{42} \mathrm{O}$ que se denomina, nesses trabalhos, como "renda virtual", "renda latente" ou "lucro potencial".
} 
competência constitucional para tanto ${ }^{43}$, invocando, no geral, as mesmas razões de falta de liquidez, incerteza e dificuldades administrativas discutidas no Capítulo $1^{44}$, ao passo que outros argumentaram haver espaço na noção constitucional de renda para o abrigo de uma concepção lata de renda, ressaltando alguns destes autores, todavia, que a decisão quanto à implementação de uma tal forma de tributação pode depender de reformulação da legislação complementar vigente ${ }^{45}$.

Sem a pretensão de resolver o problema, porque não há solução pronta e fácil para essa questão, o que parece possível sugerir para o direcionamento adequado da discussão é a desvinculação deste tema do nível constitucional. Não se afigura adequado impingir tal nível de especificação para um conceito constitucional de renda se, primeiro, a CF 1988 não oferece subsídios inequívocos que evidenciem sua preferência por um conceito particular de renda e, segundo, outros princípios constitucionais (como a universalidade e a generalidade) apontam exatamente para o contrário, isto é, demandam a imposição de tributação sobre todas as rendas, de todas as pessoas (e qualquer diferenciação, outrossim, demandaria justificativa clara, com apoio em outro valor ou princípio constitucional).

A noção constitucional de renda deve limitar-se a descrever as propriedades e características gerais do termo renda, abdicando-se de construir algum conceito muito específico ou erigir limitações definitivas que decorram da aplicação, em termos abstratos, de princípios constitucionais específicos ${ }^{46}$. Os aspectos gerais da noção constitucional de renda retratam o reconhecimento dos princípios da renda líquida, da realização, da apuração periódica e da monetarização da renda. Até aí se pode chegar na leitura do texto constitucional. Inferir algo além disso é sobejar o tema da distribuição rígida de

\footnotetext{
${ }^{43}$ Os textos de Gilberto de Ulhôa Canto et alli (itens 3.11-13), Antonio Manoel Gonçalez, Carlos da Rocha Guimarães, Gustavo Miguez de Mello, Ives Gandra da Silva Martins, Ricardo Mariz de Oliveira e Ylves José de Miranda Guimarães sustentaram tal posicionamento (mais ou menos nitidamente em alguns casos). In: MARTINS (Coord.), op cit. (nota 10), p. 34-35; 65-67 e 71; 152-153; 231; 286-291; 445-452; 562-563.

${ }^{44}$ Embora os argumentos a favor e contra a tributação do acréscimo patrimonial derivado de valorização de ativos já tenham sido adiantados no Capítulo 1, eles são retomados em alguns pontos deste Capítulo para ressaltar que alguns dos dilemas pertinentes a este tema envolvem o confronto de alguns princípios constitucionais (especialmente o conflito potencial entre universalidade e praticabilidade) e também para enquadrar as acepções pertinentes de realização perante os critérios de disponibilidade jurídica, econômica ou nenhuma das duas. Vide, a esse respeito, os itens 1.2.1 e 2.2.2 deste Capítulo.

${ }^{45}$ Deste lado se colocam Hugo de Brito Machado (item 6), José Eduardo Soares de Mello, Luciano Amaro, Wagner Balera e Waldir Silveira Mello. Textos publicados em MARTINS (Coord.), op cit. (nota 10), p. 259; 336; 402-409; 491-499; 544.

${ }^{46}$ Segurança jurídica e praticabilidade, por exemplo, poderiam ser os vetores prevalecentes em alguma situação concreta de ganhos de detenção, para fins de justificar o diferimento de sua tributação para um momento mais apropriado.
} 
competências e implica obscurecer a delegação dada pela própria CF 1988 ao legislador complementar para o trato da matéria.

\subsection{Princípios determinantes para a apuração da renda realizada}

Consoante já assinalado, a proposta que se desenvolve no presente trabalho é a de limitar a noção constitucional de renda aos seus elementos mais essenciais, mediante a segregação das características reconhecidas como presentes na noção constitucional de renda e abordando, então, cada princípio específico da tributação da renda que as reflete.

Segundo a exposição que se desenvolve nos próximos itens, as propriedades gerais da noção constitucional de renda refletem os princípios específicos da tributação da renda que já foram anunciados expressamente por Brandão Machado ${ }^{47}$ e Ricardo Mariz de Oliveira $^{48}$ (renda líquida, realização da renda), bem como outros elementos que costumam ser mencionados como integrantes do conceito de renda (apuração periódica, monetarização), mas que aparentam ser passíveis de enquadramento na categoria de princípios, haja vista traduzirem mandamentos (mais ou menos relativos) de otimização, isto é, diretrizes, que podem ser implementadas de diferentes maneiras pelo legislador, sem que, com isso, se entenda que houve afronta ao conceito constitucional de renda.

Antes, porém, abordam-se rapidamente aqui dois conjuntos de princípios que podem se combinar para contrabalançar a aplicação do princípio da realização em casos concretos, quer enfatizando sua importância (princípios da universalidade e generalidade), quer amenizando-a (princípios da ordem econômica).

\subsubsection{Universalidade, generalidade e praticabilidade}

Dentre os princípios constitucionais que orientam a cognição da noção adequada de renda para fins de tributação, interessa mencionar aqui, por primeiro, os princípios da universalidade e generalidade, cuja admissão na CF 1988 veio explicitada no

\footnotetext{
${ }^{47}$ Cf. MACHADO, Brandão. Breve exame crítico do art. 43 do CTN. In: MARTINS, Ives Gandra da Silva (coord.). Imposto de renda: Conceitos, princípios e comentários (em memória de Henry Tilbery). $2^{\mathrm{a}}$ ed. São Paulo: Atlas, 1996, p. 108.

${ }^{48}$ OLIVEIRA, Ricardo Mariz de. Princípios fundamentais do imposto de renda. In: SCHOUERI, Luís Eduardo; ZILVETI, Fernando Aurelio (coords.) Direito tributário: estudos em homenagem a Brandão Machado. São Paulo: Dialética, 1998, p. 224-226.
} 
artigo 153, $\S 2^{\circ}$, inciso $\mathrm{I}^{49}$. Mesmo reconhecendo se tratar de princípios fortemente relacionados entre si e que atuam em conjunto quase indissociável para um permitir a maior plenitude possível do outro, destacam-se especialmente aqui os princípios da universalidade e generalidade para retomar a discussão quanto aos limites do conceito constitucional de renda e, com isso, inferir a medida que pode ter um princípio da realização no sistema tributário nacional.

Como já afirmado algumas vezes aqui, o ideal de distribuição igualitária da carga tributária, orientado pelo princípio da capacidade contributiva, reclama a instituição de uma noção de renda que seja a mais ampla possível (e, portanto, uma base de cálculo igualmente abrangente). Nesse sentido, uma tributação equânime da renda conforme a capacidade contributiva é alcançada fundamentalmente apenas quando todos os cidadãos sejam tributados na totalidade de sua renda disponível ${ }^{50}$.

Assim, a universalidade é princípio que demanda a tributação da totalidade dos elementos positivos e negativos que compõem um determinado patrimônio, bem como a totalidade dos fatores que atuam para aumentar e diminuir esse mesmo patrimônio num dado período de tempo ${ }^{51}$. Na visão de Carrazza, essa avaliação global, caracterizada pelo alcance ideal de todos os ganhos ou lucros, alinha a tributação da renda aos princípios da igualdade e da capacidade contributiva ${ }^{52}$.

A seu turno, generalidade implica o alcance de todas as pessoas que consumarem o fato gerador do imposto de renda ${ }^{53}$. Significa tratar todas as situações sob uma norma geral, que seja aplicável a todos os contribuintes sem distinção. Implica tratar igualmente todo e qualquer tipo de renda (ou acréscimo patrimonial) $)^{54}$.

Em alguns estudos, as definições dadas para universalidade e generalidade se invertem, mas o importante é que a referência de um ou outro aponta para tributação da

\footnotetext{
${ }^{49} \mathrm{O}$ referido dispositivo abarca também do princípio da progressividade, tema não abordado aqui por sua menor relação com o princípio da realização.

50 Cf. LANG, Joachim. Die Bemessungsgrundlage der Einkommensteuer - Rechtssystematische Grundlagen steuerlicher Leistungsfähigkeit im deustschen Einkommensteuerrecht. Colônia: O. Schmidt, 1988, p. 167.

${ }^{51}$ Cf. OLIVEIRA, op. cit. (nota 48), p. 214.

${ }^{52}$ Cf. CARRAZZA, op. cit. (nota 14), p. 66-68.

${ }^{53}$ Cf. CARRAZZA, op. cit. (nota 14), p. 65-66.

${ }^{54}$ Cf. OLIVEIRA, op. cit. (nota 31), p. 253.
} 
totalidade das rendas e da totalidade das pessoas ${ }^{55}$. Em países como a Alemanha, por exemplo, o vocábulo universalidade é utilizado para expressar as duas ideias ${ }^{56}$.

À amplitude reclamada por esses princípios, contrapõe-se a viabilidade técnica para implementação de tributação com tais atributos. Fala-se assim de um princípio da praticabilidade, reconhecido e divulgado também por arguta doutrina nacional. Estribando-se na lição de Regina Helena Costa, podemos dizer que a praticabilidade aponta para o conjunto de técnicas que visam viabilizar a adequada execução do ordenamento jurídico. Sua gênese remonta aos cânones fundamentais da tributação que foram anunciados por Adam Smith nos idos de $1776^{57}$, especialmente o princípio da comodidade da tributação ${ }^{58}$.

O tema já vem sendo explorado há tempos, no Brasil, por Misabel Derzi, que sustenta a presença deste princípio no texto constitucional e destaca sua função como garantidor da efetividade das normas constitucionais ${ }^{59}$. Importa salientar que, do confronto deste princípio com os princípios da igualdade e da capacidade contributiva, normalmente resulta um abrandamento desses últimos ${ }^{60}$. Segundo Alfredo Augusto Becker, ao adentrar no mundo jurídico, o princípio da capacidade contributiva sofre algumas constrições, de modo a se tornar regra dotada de certeza e praticabilidade ${ }^{61}$.

\footnotetext{
${ }^{55} \mathrm{Cf}$. QUEIROZ, Mary Elbe. Imposto sobre a renda e proventos de qualquer natureza: princípios, conceitos, regra-matriz de incidência, mínimo existencial, retenção na fonte, renda transnacional, lançamento, apreciações críticas. Barueri: Manole, 2004, p. 35.

${ }^{56} \mathrm{O}$ princípio da universalidade contém um postulado orientado subjetivamente, no sentido de que todos os cidadãos devem pagar imposto de renda, e um postulado orientado objetivamente, no sentido de que o objeto da tributação da renda é o conjunto somado dos rendimentos. Nesse sentido, o princípio da totalidade se refere ao componente objetivo do princípio da universalidade, ou seja, à totalidade dos rendimentos. Cf. LANG, op. cit. (nota 50), p. 168-169.

${ }^{57}$ Cf. COSTA, Regina Helena. Praticabilidade e justiça tributária: exeqüibilidade de lei tributária e direitos do contribuinte. São Paulo: Malheiros, 2007, p. 53 e 89

${ }^{58}$ Formulado nos seguintes termos: "Todo tributo deve ser exigido do modo, ou no momento em que for mais provável a conveniência do contribuinte para pagá-lo. Tradução livre de: Every tax ought to be levied at the time, or in the manner, in which it is most likely to be convenient for the contributor to pay it. SMITH, Adam. An inquiry into the nature and causes of the wealth of nations. New York: The Modern Library, 2000 , p. 889.

59 “A praticabilidade não está expressamente em nenhum artigo da Constituição, mas está em todos, porque nada do que dissemos aqui teria sentido se as leis não fossem viáveis, exeqüíveis, executáveis e não fossem efetivamente concretizadas na realidade; portanto, a praticabilidade tem uma profunda relação com a efetividade das normas constitucionais." Cf. DERZI, Misabel Abreu Machado. Princípio da praticabilidade do direito tributário (segurança jurídica e tributação). In: Revista de Direito Tributário, ano 13, no 47. São Paulo: Revista dos Tribunais, jan-mar. 1989, p. 175.

60 "Os princípios da igualdade, no sentido de justiça individual, e da capacidade contributiva são abrandados (e frequentemente violados) por meio do princípio da praticidade ou praticabilidade." Grifo nosso Cf. DERZI, Misabel Abreu Machado. A praticidade, a substituição tributária e o direito fundamental à justiça individual. In: FISCHER, Octavio Campos (coord.). Tributos e direitos fundamentais. São Paulo: Dialética, 2004, p. 264.

${ }^{61}$ Cf. BECKER, Alfredo Augusto. Teoria geral do direito tributário. $3^{\text {a }}$ São Paulo: Lejus, 2002, p. 494-501 (item 132).
} 
Para os fins deste estudo basta registrar que, ao avaliar a dimensão da capacidade contributiva (em seu sentido objetivo ${ }^{62}$ ), o legislador se depara com manifestações de riqueza, vale dizer, fatos econômicos que demonstrem aptidão para concorrer para as despesas públicas. Destarte, na tarefa de definir a base tributável, o legislador se vale de conceitos fornecidos pela Ciência das Finanças, mas, em vista dos limites impostos pelo princípio da praticabilidade, ele deve decidir se há condições de adotar tal ou qual conceito em sua integralidade, ou se, de outro modo, melhor seria acolhê-lo parcialmente ou deformá-1o ${ }^{63}$.

Assim ocorre com o imposto de renda, pois, de um lado, o conceito econômico de renda-acréscimo, em conjunto com o princípio da universalidade, gera um vetor que aponta para o máximo de amplitude na formulação da renda tributável e, de outro lado, o princípio da praticabilidade gera um vetor contrário que requer a diminuição do campo de incidência para garantir exequibilidade da norma tributária.

Como já visto ${ }^{64}$, hipóteses de impasse na aplicação de princípios reclamam uma ponderação quanto às dimensões de peso atribuíveis aos princípios envolvidos na decisão. Neste caso, até que condições materiais favoreçam a implementação de um modelo de tributação baseado, por exemplo, em marcação a mercado ${ }^{65}$, o princípio da realização da renda dificilmente poderá ser orientado para tributar meras apreciações de valor. Nesse diapasão, normalmente se admite que dificuldades de valoração ou problemas administrativos demandem alguns afastamentos do ideal (deixando-se, e.g., de alcançar a apreciação não realizada) ${ }^{66}$. Não sendo a capacidade contributiva alcançável em sua expressão máxima para a tributação da renda, não se pode exigir que o critério escolhido pelo legislador para a implementação do princípio da realização corrija essa mitigação provocada pelo princípio da praticabilidade.

\footnotetext{
${ }^{62}$ Contrapõe-se à capacidade contributiva subjetiva, que respeita a um sujeito individualmente, ou seja, refere-se a sua aptidão econômica de contribuir concretamente, de absorver o impacto tributário. Cf. COSTA, op. cit. (nota 57), p. 114.

${ }^{63}$ Cf. COSTA, op. cit. (nota 57), p. 114-115.

${ }^{64}$ Vide item 1.1.1 do Capítulo 1.

${ }^{65}$ Convém ressaltar que um regime de tributação marcada a mercado foi, como visto, recentemente adotado no Reino Unido. Vide item 3.3 do Capítulo 1.
} 


\subsubsection{Princípios da ordem econômica}

Outros afastamentos do ideal de tributação abrangente da renda podem ser provocados pela intersecção de princípios relativos à ordem econômica, conduzindo a maneiras diferenciadas de implementação do princípio da realização mediante a permissão de critérios diferenciados de reconhecimento de receitas e despesas, normalmente destoantes do critério geral e universal que for adotado para a generalidade dos contribuintes.

Trata-se da manifestação do aspecto indutor das normas tributárias, que se traduz na formulação de normas tributárias com finalidade extrafiscal, normalmente voltadas a provocar intervenção sobre o domínio econômico para atender a algum ou mais dos princípios previstos na Constituição Econômica (CF, artigos 170 e seguintes) ${ }^{67}$. Sendo admitida a existência de normas tributárias com finalidade preponderante não-tributária, passa-se a permitir o estabelecimento de diferenças entre contribuintes sem que se tenha, como elemento discriminador essencial, o critério da capacidade contributiva.

Assim, como já afirmado, uma vez adotado um critério específico para a concretização do princípio da realização, ele deve ser aplicado indistintamente a todas as rendas de todos os contribuintes. Não obstante, mudanças no reconhecimento de receitas podem ser introduzidas em razão de uma intenção do legislador de estimular comportamentos econômicos, eliminar barreiras a ajustes negociais, aumentar a mobilidade laboral etc. ${ }^{68}$

Exemplo claro de diferenciação do critério de realização pode ser visualizado na adoção excepcional do regime de caixa para os contribuintes optantes pelos regimes de lucro presumido ou Simples Nacional ${ }^{69}$. Sendo a regra geral para a tributação das empresas a adoção da teoria do balanço ordenada pelo regime de competência, a instituição de critério diverso (postergando a tributação para o momento temporal do recebimento da renda) contraria o princípio da generalidade, mas atende ao objetivo fundamental de garantir o desenvolvimento nacional (CF, art. $3^{\circ}$, inciso II) e, em certa medida, apoia-se no

\footnotetext{
${ }^{66}$ Cf. BITTKER, Boris I. A “comprehensive tax base" as a goal of income tax reform. In: Harvard Law Review, v. 80, n. 5, mar.-1967, p. 932-933.

${ }^{67}$ A esse respeito, cf. SCHOUERI, Luís Eduardo. Normas tributárias indutoras e intervenção econômica. Rio de Janeiro: Forense, 2005.

${ }^{68}$ Cf. BITTKER, op. cit. (nota 66), p. 971-972.

${ }^{69}$ Para o regime lucro presumido, cf. Instrução Normativa SRF no 104/1998 (fundamentada remotamente no art. 45, parágrafo único da Lei $\left.\mathrm{n}^{\circ} 8.981 / 1995\right)$, para o regime de Simples Nacional, cf. Lei Complementar $\mathrm{n}^{\circ}$ 123/2006, art. $18, \S 3^{\circ}$ e também Resolução CGSN nº 38/2008 (válida a partir de 2009 - para os períodos anteriores havia vedação expressa prevista no art. $2^{\circ}, \S 3^{\circ}$ da Resolução CGSN n ${ }^{\circ}$ 5/2007).
} 
princípio de tratamento favorecido a empresas de menor porte (CF, art. 170, inciso IX), afora promover indiretamente o princípio da busca do pleno emprego $(\mathrm{CF}$, art. 170, inciso IX).

Iniciativas semelhantes e desvirtuamentos correlatos do critério de realização que é adotado como regra geral (i.e., afastamento do regime de competência) aparecem nas mais variadas formas de incentivos fiscais que posterguem o momento temporal de reconhecimento das receitas ${ }^{70}$ ou antecipem a dedução de despesas (e.g., os incentivos que concedem depreciação acelerada de ativos).

\subsubsection{Monetarização, apuração periódica e renda líquida}

Seguindo a linha de que a CF 1988, na definição do conteúdo semântico mínimo da conceito de renda, limitou-se a pronunciar princípios que, por sua natureza, não determinam absolutamente o formato final do que seja a renda tributável, abordam-se aqui três dos quatro princípios que parecem defluir do conceito constitucional de renda. $\mathrm{O}$ quarto elemento do conjunto é o princípio da realização da renda, enfocado no tópico seguinte.

Reafirma-se que o conceito constitucional de renda circunscreve apenas os atributos gerais do que seja renda e não oferece um conceito fechado/cerrado. Por essa razão, parece adequado desdobrar o conceito de renda e reconhecer nos seus elementos o reflexo de princípios que, por sua vez, limitam-se a estabelecer fundamentos que dependem da conjunção com outros fundamentos, provenientes de outros princípios, para servir de orientação ao legislador (ou ao aplicador da lei) na determinação conclusiva da renda tributável. O entrelaçamento dos princípios ora abordados oferece os elementos mínimos, que compõem a estrutura mais básica do imposto de renda. Conforme se verá, o reconhecimento de tais princípios se impõe mesmo na ausência de proclamação explícita pela Constituição Federal de 1988.

Encetando a exposição com o princípio da monetarização, recorda-se que este é um elemento tão evidentemente inerente à concepção de renda tributável, que, por vezes, 
ao ser tomado como pressuposto inquestionável, passa despercebido. Lembramos aqui, à guisa do que já se comentou no Capítulo $1^{71}$, que a perspectiva econômica baseada no monetarismo é causa de um dos primeiros cortes na noção mais ampla de renda, pois, sendo infactível tributar as pessoas com base nos níveis subjetivos de bem-estar (renda psíquica) - dada a inviabilidade de mensurar monetariamente os elementos psíquicos atrelados à satisfação -, o princípio da monetarização determina uma simplificação da noção de renda, limitando-a a fatos objetivamente observáveis e mais facilmente mensuráveis.

A despeito desta redução causada pelo princípio da monetarização, o conceito de renda continua a reclamar a maior monetarização possível das situações ensejadoras de renda. Assim, o pagamento de salário em espécie deve ser considerado renda para o trabalhador $^{72}$, ainda que a individualização do aspecto monetário dependa da utilização de critérios de aproximação ${ }^{73}$.

$\mathrm{O}$ aspecto da monetarização já foi destacado por Romeu Renck como um "postulado" da apuração da renda ${ }^{74}$. Propõe-se aqui a sua classificação como princípio porque ele simplesmente reclama a monetarização prévia das relações antes, que essas sejam tomadas como causa de tributação. Não se trata de regra que obriga a uma decisão. A monetarização simplesmente preconiza um estado ideal que pode ser implementado em diferentes graus. Tanto é assim que diversas situações, que poderiam ser traduzidas em

\footnotetext{
${ }^{70}$ Como já mencionado no Capítulo 1, o Decreto-lei no $1.598 / 1977$ já previu a adoção excepcional do regime de caixa em diferentes hipóteses (todas passíveis de justificação em princípios da ordem econômica). Tratase dos casos de empreitada ou fornecimento contratado com pessoa jurídica de Direito Público (art. 10, $\S 3^{\circ}$ ), de vendas a prazo ou em prestações (art. 29), de vendas de longo prazo de bens do ativo permanente (art. 31, $\S 2^{\circ}$ ), de alienação de bens desapropriados (art. $31, \S 4^{\circ}$ ), e de determinadas operações de fusão, incorporação ou cisão (art. 34, inciso II).

${ }^{71}$ Ver item 2.2.1 do Capítulo 1.

72 “O próprio princípio da igualdade sinaliza neste sentido, ou seja, impõe que as retribuições em espécie venham gravadas por meio de IR, do mesmo modo que as obtidas em dinheiro. [...]

Os rendimentos em espécie pressupõem, em primeiro lugar, o recebimento de um benefício não-consistente em moeda de curso forçado. Ademais, por força do princípio da capacidade contributiva, devem ser economicamente avaliáveis." Cf. CARRAZZA, op. cit. (nota 14), p. 79 e 81.

${ }^{73}$ Como acontece com a incorporação à remuneração do beneficiário de parcela do valor do veículo concedido pela empresa e que tenha utilização mista (serve na atividade operacional e no uso particular do beneficiário). Cf. Parecer Normativo Cosit no 11/1992.

74 “Quando um agente utiliza os serviços contidos num bem, v.g., comer, usar roupa, tomar um táxi, etc., efetivamente está consumindo renda no sentido concreto de fruição de serviço. Mas a economia não tem medida para quantificar a satisfação decorrente deste ato de consumo, e, por isso, adota como forma de medida econômica o valor dos bens que estão na origem do fluxo destes bens.
} 
termos monetários e tributadas na forma de renda imputada (serviços prestados a si próprio, valor locativo de imóvel próprio etc.), normalmente escapam da tributação por falta de critério objetivo de monetarização ${ }^{75}$. Renato Renck aponta a falta do elemento de troca no mercado (como sinônimo de realização) para que tais situações sejam alcançadas pela tributação ${ }^{76}$. Como se vê, os princípios da monetarização e realização podem causar entrechoques, a serem resolvidos pelo legislador na definição da base tributável.

Passando a discorrer sobre o princípio da apuração periódica, anota-se que este é também um elemento inafastável do conceito constitucional de renda, sendo praticamente impossível falar-se de renda como sinônimo de acréscimo patrimonial sem que se tenha em mente uma dimensão temporal para comparar o patrimônio no início e no fim deste período. Segundo Mariz de Oliveira, este elemento do conceito de renda figura como corolário do princípio da universalidade ${ }^{77}$.

Normalmente se pondera que o ideal seria que este período coincidisse com o tempo de vida de uma pessoa ${ }^{78}$, pois, com isso, evitar-se-ia o inconveniente de se tributar indevidamente os resultados positivos de caráter meramente transitórios. Todavia, razões mais preponderantes, sobretudo de ordem prática, demandaram que a apuração da renda (ou mesmo dos resultados de um negócio ou atividade) fosse dividida e demonstrada em

Aqui se está diante de um verdadeiro postulado, uma vez que, não havendo forma de medir economicamente a satisfação de cada um em particular, adotou-se um mecanismo que possibilita calcular o valor da renda consumido: o valor da renda consumida é o valor em moeda que está na origem do fluxo. Vale dizer, em outros termos, é o seu custo de aquisição.” Cf. RENCK, Renato Romeu. Imposto de renda da pessoa jurídica: critérios constitucionais de apuração da base de cálculo: uma proposta de interpretação sistemática do Direito. Porto Alegre: Livraria do Advogado, 2001, p. 108.

${ }^{75}$ Quanto ao exemplo do valor locativo de imóvel, vale notar que a legislação brasileira prevê isenção nas hipóteses em que o imóvel (para ser mais exato, "prédio construído") seja ocupado por seu proprietário ou cedido gratuitamente para uso do cônjuge ou de parentes de primeiro grau (cf. art. 39, IX do RIR/99). Porém, pode-se falar de uma renda imputada nas demais hipóteses de cessão gratuita (cf. art. 49, $\S 1^{\circ}$ do RIR/99) renda esta cujo valor, na falta de elemento monetário objetivo, foi fixado em $10 \%$ do valor venal do imóvel.

76 “Com isso se finca uma conclusão importante: a circulação econômica - que caracteriza troca patrimonial - é o ponto culminante da medição da produção de renda. Sem que ocorra a medição, não há condições de estabelecer a produção de renda nova. Começa a surgir neste contexto o princípio jurídico e contábil da realização de um recurso novo, que, para ser incluído no âmbito da renda como coisa nova, requer a circulação econômica. Aqui já se identifica o núcleo fundamental que irá orientar o critério de concretização material da renda; a troca no mercado, que se denomina realização.” Cf. RENCK, op. cit. (nota 74), p. 109.

77 “A propósito, note-se que o princípio da universalidade, estando expresso na Constituição, induz necessariamente a uma conseqüência que está implícita nele. [...]

Essa conseqüência é a periodicidade da incidência do imposto de renda, pois logicamente não há como proceder a uma apuração universal de aumento patrimonial sem referi-la a um determinado momento do tempo, o qual deve ser estabelecido pela lei ordinária.

Melhor dizendo e explicitando, a periodicidade não é propriamente um quarto princípio que estaria implícito na Constituição, autônomo do princípio da universalidade, mas é uma consequência, decorrência ou faceta implícita deste, uma espécie de subprincípio [...]." Grifo nosso. Cf. OLIVEIRA, op. cit. (nota 31), p. 263.

${ }^{78} \mathrm{Cf}$., por todos, ARNOLD, Brian J. Timing and income taxation: the principles of income measurement for tax purposes. Toronto: Canadian Tax Foundation, 1983, p. 121. TIPKE, Klaus; LANG, Joachim. Steuerrecht. $18^{\mathrm{a}}$ Köln: Otto Schmidt, 2005, p. 225 (§9, 44). 
períodos temporais menores. Não necessariamente este período deveria ser anual, porém, conforme ministra Misabel Derzi, em leitura de obra de Freitas Pereira, a regra anual foi adotada universalmente em razão de diversos fatores, que podem ser resumidos na preferência pelo ciclo sazonal de estações como critério adequado para a apuração e comparação de resultados ${ }^{79}$.

Tratando-se de um corte artificial na apuração da renda, a apuração periódica, quando aliada a um critério de realização baseado em trocas de mercado (e não em acréscimo de valor), causa os problemas citados no Capítulo anterior, dentre os quais se destaca o efeito de acumulação de valor ${ }^{80}$. Para sanar tais imperfeições de um regime de apuração periódica, faz-se premente a adoção de medidas de ajustes intertemporais (como a compensação de prejuízos, a dedução de créditos incobráveis etc.). Misabel Derzi reclama ainda a adoção do princípio da imparidade na área tributária, como medida de proteção do patrimônio da empresa e, portanto, de apuração correta da renda tributável ${ }^{81}$. Este assunto será comentado no Capítulo $3^{82}$.

Quanto ao princípio da renda líquida, destaca-se que ele reflete o ideal de que o imposto de renda afete apenas o acréscimo patrimonial real, isto é, retrata um mandamento para que sejam considerados, dentro do respectivo período de apuração, os

\footnotetext{
79 "Explica Freitas Pereira que a regra anual foi universalmente adotada, em razão dos seguintes fatores:

- o período não pode ser tão curto, que seus resultados não sejam significativos, nem tão longo que impeça sua renovação;

- a duração do período deve permitir a comparação entre exercícios sucessivos;

- o período deve integrar um ciclo completo de estações, de modo a neutralizar influências sazonais. E conclui:

'a adoção de uma base anual para a elaboração das contas preenche estes requisitos e reflete o juízo de uma longa experiência segundo a qual o ano nem é demasiado longo nem demasiado curto e, além disso, projeta o ritmo normal em que se desenvolve a vida econômica e social, toda ela marcada pelo ciclo de estações.' (Cf. A periodização do lucro tributável. Lisboa. Centro de Estudos Fiscais, 1988)". Cf. DERZI, Misabel Abreu Machado. Pressupostos da periodização anual. In: BALEEIRO, op. cit. (nota 19), p. 325.

${ }^{80}$ Ver item 2.5 do Capítulo 1. O efeito de bunching ou telescoping of income ocorre quando itens de receitas são incluídos num determinado período fiscal no qual a realização (troca de mercado) tenha acontecido, embora esta receita tenha se acumulado ou tenha sido "ganha" durante mais de um ano. O principal problema é que, com esta acumulação em um único período, mais tributo deverá ser pago do que se essas receitas fossem alocadas corretamente aos anos em que elas foram ganhas. Cf. ARNOLD, op. cit. (nota 78), p. 60.

81 "Como a periodização é um corte feito em uma atividade econômica ininterrupta - sendo a regra da continuidade da exploração um princípio contábil e de Direito Comercial universal -, dela resultam outras regras tecnicamente necessárias e reconhecidas pelos ordenamentos jurídicos em geral, tais como a uniformidade ou permanência de métodos utilizados; a especialização dos exercícios; $\underline{\text { a identidade entre o }}$ balanço de abertura de um exercício e o balanço de encerramento do exercício anterior; a cautela ou não paridade de tratamento entre lucro e prejuízo e a dedutibilidade dos prejuízos acumulados em períodos anteriores." Grifo nosso. Cf. DERZI, Misabel Abreu Machado. Justiça prospectiva no imposto sobre a renda. In: TÔRRES, Heleno Taveira (coord.). Direito tributário internacional aplicado, v. IV. São Paulo: Quartier Latin, 2007, p. 59.

${ }^{82}$ Ver item 3.4.3 do Capítulo 3.
} 
valores despendidos para produção de novos ingressos ${ }^{83}$. É esta uma das ideias centrais fixadas no conceito de renda formulado por José Lima Gonçalves ${ }^{84}$ (a outra seria a apuração periódica).

Uma definição simples deste princípio é dada na obra de Tipke e $\operatorname{Lang}^{85}$ : o princípio da renda líquida exige a consideração dos fluxos negativos de patrimônio para fins de apuração da base de cálculo do imposto de renda. Isso porque tais "efluxos" diminuem a capacidade contributiva. A ideia é que o imposto de renda alcance apenas rendimentos líquidos, concretizando, assim, o conceito de renda alinhado com a teoria do acréscimo patrimonial líquido. Vale dizer, o princípio da renda líquida demanda a apuração da capacidade contributiva com consideração das medidas de acréscimo e decréscimo de patrimônio $^{86}$.

Aliando-se o princípio de renda líquida ao de apuração periódica, obtém-se a diretiva para que sejam justapostas, dentro de um mesmo período, certas receitas e despesas. Todavia, seguindo além desta definição, parece possível inferir que não são quaisquer receitas e despesas que devem ser segregadas dentro de um período, mas sim as receitas e as despesas que se relacionam. Dessa composição de elementos positivos e negativos correlatos decorre o chamado enfoque na apuração periódica, aplicado ao princípio da realização para que ele atenda ao emparelhamento (de receitas e despesas), tema esquadrinhado no Capítulo $3^{87}$.

\subsubsection{Realização da renda}

Concluindo a exposição acerca dos quatro princípios que, consoante proposto, compõem o conceito constitucional de renda, chega-se, enfim, ao princípio da realização da renda, perquirindo-se, principalmente, se haveria algum requisito constitucional que demandasse a preferência por um evento/critério específico de realização. Nesse particular,

\footnotetext{
${ }^{83}$ Cf. OLIVEIRA, op. cit. (nota 48), p. 224.

84 “(i) saldo positivo resultante do (ii) confronto entre (ii.a) certas entradas e (ii.b) certas saídas, ocorridas ao longo de um dado (iii) período", conforme se comentou no item 1.1.2 deste Capítulo.

${ }^{85}$ Cf. TIPKE; LANG, op. cit. (nota 78), p. 228-229 $(\S 9,54)$.

${ }^{86} \mathrm{O}$ problema que decorre da intenção de se impor uma tributação igualitária, que apure a capacidade contributiva com base no princípio da renda líquida, é o de que a legislação do imposto de renda não aborda o acréscimo patrimonial líquido de maneira absolutamente universal, sem impor modificações de normas indutoras. Ou seja, algumas limitações/proibições de dedutibilidade de despesas, por exemplo, podem contrariar o princípio da renda líquida, se atenderem à realização de objetivos preconizados por outros princípios. Cf. TIPKE; LANG, op. cit. (nota 78), p. 224-225 (\$9, 43).

${ }^{87}$ Vide item 3.2.2 do Capítulo 3.
} 
retoma-se a afirmação feita no Capítulo anterior - de que ao princípio da realização caberia tal denominação, pois congrega meramente uma diretriz (de que a renda seja tributável quando concluídos e puderem ser considerados permanentes os eventos que a deflagram) concretizável em diferentes graus (mediante a escolha potencial de eventos como valorização, ocorrência da atividade econômica prestacional, pagamento, consumo etc.) procurando-se checar sua validade.

A elevação deste princípio ao nível constitucional é confirmada, na doutrina, por diferentes autores que o mencionaram como um dos aspectos essenciais do conceito de renda. Em trabalho recente, Humberto Ávila, apontando a exigência de que a capacidade contributiva seja graduada segundo a capacidade econômica, destaca que o substrato econômico de renda pressuposto pela CF 1988 limita-se às atividades relacionadas que sejam indicativas de expressão econômica, de forma que a "capacidade produtiva não deve

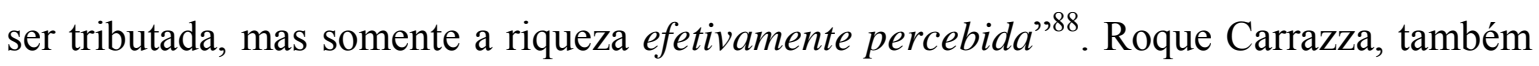
enfocando apenas as premissas básicas extraídas do texto constitucional, defende ser imperativo que a renda tributável esteja disponível para seu titular, isto é, que nada lhe obste o uso ou a destinação, e, mais adiante, arremata: "não sendo dado ao legislador federal mandar tributar a renda potencial, isto é, ainda não realizada" ${ }^{\prime 89}$.

Ao fazer uma análise dos princípios aplicáveis ao imposto de renda, Mariz de Oliveira salienta a presença do chamado princípio ou regime de competência dos exercícios ou períodos-base, ponderando que a falta de sua explicitação no texto constitucional não deve impedir seu reconhecimento como princípio ${ }^{90}$. Considerando-se o alerta feito por ele de que a expressão "regime de competência" é ambígua, uma vez que não esclarece qual o critério válido para atrelar receitas e despesas ao período competente $^{91}$, pode-se dizer que o princípio por ele visualizado na CF 1988 é o mesmo que aqui se convencionou chamar de princípio da realização.

\footnotetext{
${ }^{88}$ Cf. ÁVILA, Humberto. Teoria da igualdade tributária. São Paulo: Malheiros, 2008, p. 161.

${ }^{89}$ Cf. CARRAZZA, op. cit. (nota 14), p. 40-41.

90 "E, descendo ainda mais um degrau, para agora ter como objeto ainda menor o imposto de renda da pessoa jurídica (nível 4), está ele sujeito ao chamado "princípio ou regime de competência dos exercícios ou períodos-base", o qual não se aplica ao outro objeto menor, que é o imposto de renda da pessoa física. [...] Em primeiro lugar, a localização topográfica de uma disposição constitucional ou legal, sob um determinado título ou denominação de alguma divisão do texto constitucional ou legal, não é necessariamente relevante para se determinar se estamos ou não frente a um princípio ou norma." Cf. OLIVEIRA, op. cit. (nota 31), p. 238.

91 “A expressão "regime de competência” é ambígua, pois requer um elemento referencial para se determinar a que período "compete" uma determinada mutação patrimonial, seja esta positiva (receitas), seja negativa (custos, despesas).” Cf. OLIVEIRA, op. cit. (nota 31), p. 316.
} 
Dizer que a renda deve estar disponível, realizada, percebida para, só então, ser tributada não parece implicar a pressuposição de algum critério particular para a realização e significa, tão-somente, uma exigência de segurança na apuração da renda tributável, ou melhor, que a tributação deve alcançar situações concretizadas, concluídas e definitivas na órbita do Direito. Até esse ponto se pode falar de um princípio da realização, pois não se fixa a apuração da renda a nenhum critério específico ${ }^{92}$.

À legislação cabe a tarefa de escolher qual o ato mais adequado em vista das condições financeiras dos contribuintes, das atividades econômicas enfocadas e, bem assim, em razão de elementos conjunturais do sistema jurídico. Quanto às pessoas físicas, por exemplo, preferiu a legislação tornar mais imperativa a aplicação do princípio da realização, elegendo como ato deflagrador da aquisição da renda o recebimento em dinheiro (ou em bens) ${ }^{93}$. Com isso, dentre os diversos eventos possíveis para concretização do princípio da realização (fechamento do contrato, desenvolvimento e conclusão da atividade econômica etc.), escolheu-se o ato de recebimento por ser o que oferece maior certeza quanto à verificação concreta do ganho tributável.

Em termos teóricos, é possível afirmar que o princípio da realização é uma diretriz geral de alocação temporal dos ingressos (de receitas) e egressos (de despesas), que procurar atribuir tais elementos ao período-base em que são verificados os fatos substanciais que os geraram (condição de materialidade) sempre e quando exista um certo grau de objetividade na sua mensuração (condição de objetividade) e segurança na sua concreção (condição de prudência) $)^{94}$.

A melhor síntese do princípio da realização foi dada pelo saudoso Bulhões Pedreira, para quem o princípio da realização do lucro se caracteriza pelos seguintes elementos $^{95}$ : (a) sua conversão em direitos que acresçam ao patrimônio da empresa, (b) processamento desta conversão mediante troca no mercado, (c) cumprimento, pela

\footnotetext{
${ }^{92}$ Atribuir conteúdo específico ao princípio constitucional de realização pode se revelar desastroso. Ver a esse respeito a dificuldade que se enfrentou nos E.U.A. em razão de se ter considerado (durante muito tempo) como prevalecente a decisão dada em Macomber, atribuindo-se aspecto constitucional aos requisitos de realização e separação. Vide a esse respeito o item 3.2 do Capítulo 1.

${ }^{93}$ Cf. MACHADO, Brandão. Imposto de renda. Ganhos de capital. Promessa de venda de ações. In: Revista de Direito Tributário Atual, v. 11/12. São Paulo: Resenha Tributária/IBDT, 1992, p. 3201.

${ }^{94}$ Cf. VÉRON, Alberto Víctor. Estados Contables y Libros de Comercio. Buenos Aires: Depalma, 1976, p. 196-197, apud BATALHA, Wilson de Souza Campos. A Lei das S.A. e o imposto de renda. Rio de Janeiro: Forense, 1978, p. 31.

${ }^{95}$ Cf. PEDREIRA, op. cit. (nota 12), p. 279.
} 
empresa, das obrigações que decorrem dessa troca, e (d) mensurabilidade e liquidez dos direitos recebidos na troca.

É de se notar que os elementos "c" e "d" descritos por Bulhões Pedreira são, em grande medida, equivalentes às condições de materialidade e objetividade discutidas por Víctor Véron (valendo acrescentar ao item "d" de Bulhões o requisito de certeza no recebimento do valor). O elemento "a", que pode ser visto como mera decorrência de "c", parece atender ao requisito de segurança (condição de prudência), pois o acréscimo de direitos ao patrimônio é aquele que tenha os atributos de incondicionalidade e definitividade. Assim, é de se sublinhar, na ponderação de Bulhões Pedreira, a importância do elemento de troca (item "b"), que permite concluir que não bastaria a execução de atividades econômicas geradoras de renda (e.g., a produção de uma mercadoria demandada pelo mercado), seria necessária também a presença de uma transação de mercado, no sentido da efetivação de um negócio jurídico que tenha como objeto o cumprimento de uma obrigação com conteúdo econômico (trata-se da prestação, e.g., de entregar a mercadoria) em troca de direitos de conteúdo patrimonial (trata-se da contraprestação, e.g., pagamento em dinheiro ou em bens).

A extensão do elemento de troca e, bem assim, uma discussão mais aprofundada quanto aos demais serão objeto de tópico específico do Capítulo seguinte. Por ora, basta adiantar que a exigência do elemento de troca não é capaz, por si só, de afastar um modelo de tributação abrangente de renda (i.e, um que alcançasse meros acréscimos de valor, observáveis por marcação a mercado). Isso porque o elemento troca também é ambíguo e comporta um certo grau de indeterminação. Assim, uma tributação de ativos marcados a mercado também seria capaz de atender ao elemento troca, pois em vez de se basear nas trocas efetivamente realizadas pela empresa (transações de mercado em sentido estrito), utilizaria informações decorrentes de trocas realizadas entre terceiros (transações de mercado em sentido amplo).

Novamente se ressalta, contudo, que a definição do formato final do que seja renda tributável é tarefa incumbida ao legislador complementar. Para tanto, deve-se completar a análise feita até aqui com os limites impostos pelo CTN ao conceito de renda e, da mesma forma, ao princípio da realização.

É bem verdade que a Suprema Corte vem consagrando o entendimento de que a CF 1988 se ampara em conceitos historicamente pressupostos e que o CTN oferece ao intérprete a indicação de que relevantes são os conceitos de renda-produto e renda- 
acréscimo. Porém, essa perspectiva estática de interpretação não deve chegar ao ponto de solidificar no Texto Maior eventuais restrições dadas a esses conceitos pelo próprio CTN, sob pena de tornar inócua a delegação conferida pelo art. 146, III, "a" da CF ${ }^{96}$. Se o CTN, conforme se verá adiante, impede atualmente a tributação de ganhos de detenção (restringindo o alcance da renda-acréscimo), não parece adequado cristalizar tal obstáculo também no texto constitucional, pois isto trairia a intenção do legislador constituinte de atribuir a outro nível de discussão legislativa (elaboração de leis complementares) a tarefa de lapidar o conceito de renda-acréscimo, alargando ou restringindo-o.

\subsection{Conceito constitucional de renda conforme a visão do STF}

Finalizando a análise constitucional, não se pode passar ao largo do entendimento que o Supremo Tribunal Federal apresenta acerca do tema. Assim, realçamse, neste item, algumas das principais decisões proferidas, ao longo das últimas décadas, no respeitante à existência e dimensão de um conceito constitucional de renda. Alerta-se que a seleção dos acórdãos se baseia em referências citadas em textos de doutrina quanto às decisões importantes sobre o tema.

Espantosamente, há apenas 10 acórdãos relevantes (e um caso em andamento), dos quais apenas 5 abordam diretamente algum aspecto do conceito constitucional de renda $^{97}$. Dentre estes 5 casos, um não foi propriamente julgado ${ }^{98}$ e dois outros trataram da mesma matéria (tributação decorrente de correção monetária), porém, renderam decisões opostas $^{99}$. Quanto ao conteúdo das decisões, o que se antecipa é que o Tribunal Supremo

\footnotetext{
${ }^{96} \mathrm{Em}$ outros contextos constitucionais, em que não se identificava atribuição idêntica, poder-se-ia concluir que a Constituição teria adotado plenamente e de maneira definitiva o conceito dado pelo "direito infraconstitucional pré-constitucional". No sistema atual, entretanto, conclusão igual à de Carvalhosa não parece ser mais possível. Ao discorrer sobre o conceito de renda à luz da Constituição de 1967, Carvalhosa toma o conceito fornecido pelo $\mathrm{CTN}$, de que apenas rendas obtidas a título oneroso são tributáveis, e aplica-o no nível constitucional: "Portanto, do art. 22, IV, da nova Constituição, não se pode inferir a ampliação da incidência tributária aos acréscimos patrimoniais a título gratuito, mantida que foi a denominação do imposto constante das anteriores cartas, sob cuja vigência prevaleceu inquestionável o conceito oneroso da renda tributável." Cf. CARVALHOSA, op. cit. (nota 35), p. 191-192.

${ }^{97}$ O RE 41.431/SP, de 05.07.1959 (tributação de ágio na subscrição de ações), bem como os RE 72.014/SP, de 14.02.1975, RE 77.431/SP, de 14.02.1975, RE 92.253-9/SP, de 29.04.1980 (tributação sobre indenização decorrente de desapropriação), e o RE 172.058-1-SC, de 30.06.1995 (segundo caso de ILL), apenas tangenciam a questão (normalmente interpretando textos legais e não a Constituição) ou não acrescentam elementos novos à discussão (o segundo caso do ILL não aprofunda a discussão quanto a um conceito constitucional de renda). Porém, vale a menção a eles como julgamentos relevantes do STF em matéria de conceito constitucional de renda.

${ }^{98} \mathrm{RE}$ 195.059-5/SP, de 02/05/2000 (IR sobre férias não gozadas). Recurso não conhecido por falta de prequestionamento.

${ }_{99}$ Os RE 89.791-7/RJ, de 3.10.1978, e RE 201.465-6/MG, de 02/05/2002.
} 
não apresenta nenhuma teorização sistematizada do que seria um conceito constitucional de renda ${ }^{100}$.

Três acórdãos relevantes levavam em conta fatos ocorridos no período anterior à CF 1988 e sugeriam que o conceito de renda era equivalente ao de acréscimo patrimonial. O RE 71.158/GB, de 1972, refere-se a uma liberdade relativa do legislador disciplinar o conteúdo de renda, porém estabelecem-se limites tênues e, por se tratar de caso em que se discutia a viabilidade de tributação na fonte, a principal conclusão que se pode formular é que despesa não é renda ${ }^{101}$. O RE 89.791-7/RJ, de 1978 (o primeiro sobre correção monetária), deixava claro que o conceito de renda coincide com o de acréscimo ao patrimônio ${ }^{102}$. A terceira decisão aconteceu em 1993, tratando da tributação sobre o lucro líquido (ILL) ${ }^{103}$. Este julgamento, além de assimilar renda a acréscimos patrimoniais, parece tê-los limitado às situações que decorram de relações contratuais (relações externas

\footnotetext{
100 "Notadamente, o STF jamais se preocupou em formalizar uma tese sistematicamente encadeada, relativa a um procedimento verificatório definido, que pudesse se prestar como um paradigma, um modelo, um standard de verificação. Sempre analisou um aspecto isolado, e nos processos em que diversos critérios de cálculo eram atraídos à observação, estes foram aplicados como elementos não-estruturantes de um procedimento único, sem que os previamente inserisse numa estrutura hermenêutica competente, que se prestasse a uma delimitação, em tese, do que é renda tributável no país." Cf. RENCK, Renato Romeu. Paradigmas de racionalidade e as decisões do STF nas questões relativas à base de cálculo do imposto de renda: pessoa jurídica. 2006. Tese de doutorado apresentada ao Programa de Pós-Graduação em Direito do Estado da Pontifícia Universidade Católica de São Paulo, São Paulo, 2006, p. 286-287.

${ }^{101}$ Transcrição do voto do Sr. Ministro Oswaldo Trigueiro, proferido no RE 71.158/GB, de 14.6.1972, p. 307. "Quaisquer que sejam as nuanças doutrinárias sobre o conceito de renda, parece-me acima de toda dúvida razoável que, legalmente, a renda pressupõe ganho, lucro, receita, crédito, acréscimo patrimonial, ou, como diz o preceito transcrito, aquisição de disponibilidade econômica ou jurídica. Concordo que a lei pode casuisticamente dizer o que é renda ou o que não é renda tributável, mas não deve ir além dos limites semânticos, que são intransponíveis. Entendo, por isso, que ela não pode considerar renda, para efeito de taxação, o que é, de maneira incontestável, ônus, dispêndio, encargo ou diminuição patrimonial, resultante do pagamento de um débito."

${ }^{102}$ Além disso, o argumento para refutar a tributação da correção monetária aparece fundado nas teorias de renda-produto e de renda separada do capital (ressaltando os atributos de periodicidade e manutenção da fonte). Transcrição do voto do Sr. Ministro Cunha Peixoto (relator), proferido no RE 89.791-7/RJ, de 3.10.1978, p. 565-566: "Na verdade, por mais variado que seja o conceito de renda, todos os economistas, financistas e juristas se unem em um ponto: renda é sempre um ganho ou acréscimo do patrimônio. [...] Ora, a correção monetária, realmente, não constitui rendimento, porque lhe faltam elementos constitutivos deste, principalmente a reprodutividade. A renda se destaca da fonte sem empobrecê-la. Tal não ocorre na correção monetária, onde o capital continua o mesmo; apenas é atualizado para o valor do dia do pagamento."

${ }^{103}$ Imposto (de Renda na Fonte) sobre o Lucro Líquido, instituído pelo art. 38 da Lei no $4.506 / 1964$, afetava distribuições de lucros aos sócios.
} 
à empresa), pois ressaltou que renda é o auferimento de algo a título oneroso ${ }^{104}$. Renda, ou melhor, acréscimo patrimonial é definido como a entrada de algo ao patrimônio ${ }^{105}$.

Quanto aos dois acórdãos que envolvem questões ocorridas sob a égide da $\mathrm{CF}$ $1988^{106}$, tem-se que no RE 195.059-5/SP, de 2000, destacou-se a liberdade relativa dada ao legislador para definir renda ${ }^{107}$, ao passo que no RE 201.465-6/MG, de 2002 (o segundo caso sobre correção monetária), tal liberdade, embora identificada com limites na capacidade contributiva e na praticabilidade ${ }^{108}$, não foi propriamente questionada ou afastada, prevalecendo, no caso concreto, a estipulação legal de renda ${ }^{109}$.

Tratando-se de um julgamento anômalo por sua ênfase na liberdade do legislador para definir o que seja renda ${ }^{110}$, o STF agora tem a oportunidade de elucidar seu entendimento com o julgamento do RE 582.525/SP ${ }^{111}$. Até o momento, tem-se notícia dos votos dos Srs. Ministros Marco Aurélio e Joaquim Barbosa. Destaque-se que Barbosa tem a tendência de considerar os princípio de renda líquida e apuração periódica como

\footnotetext{
104 "Rendas e proventos de qualquer natureza: o conceito implica reconhecer a existência de receita, lucro, proveito, ganho, acréscimo patrimonial, que ocorrem mediante o ingresso ou auferimento de algo, a título oneroso.", ementa do RE 117.887-6/SP, de 11.2.1993, p. 786. A respeito desta leitura do acórdão, vide OLIVEIRA, op. cit. (nota 31), p. 41 e s.

105 Transcrição do voto do Sr. Ministro Carlos Velloso (relator), proferido no RE 117.887-6/SP, de 11.2.1993, p. 803: "Noutras palavras, nada teria entrado no patrimônio da contribuinte, ora recorrente, com a distribuição das ações, ou nenhuma renda teria sido percebida por ela, conforme, aliás, esclarecido na sentença. [...] não houve acréscimo pecuniário entre dois momentos, já que nada entrou no patrimônio do contribuinte, nada ganhou o contribuinte;"’

${ }^{106}$ Convém ressaltar que, embora o RE 172.058-1-SC, de 30.06.1995 (segundo caso de ILL), trate de situação ocorrida sob a CF 1988, não se discute, neste caso, o conceito constitucional de renda. A decisão ampara-se no art. 146 da CF 1988 para trazer o CTN ao debate e concentra-se, outrossim, no tema das disponibilidades jurídica e/ou econômica da renda.

${ }^{107}$ Transcrição do voto do Sr. Ministro Moreira Alves (relator), proferido no RE 195.059-5/SP, de 02/05/2000, p. 413: "renda, para o efeito do artigo 153, III, da Constituição é questão constitucional, como entendeu o acórdão recorrido, até porque não pode a Lei infraconstitucional definir como renda o que insitamente não o seja".

${ }^{108}$ Transcrição do voto-vista do Sr. Ministro Nelson Jobim, proferido no RE 201.465-6/MG, de 2.5.2002, p. 399: "o conceito de renda é fixado livremente pelo legislador, segundo considerações pragmáticas, em função da capacidade contributiva e da comodidade técnica da arrecadação". Esta colocação, conforme referencia o Sr. Ministro, foi retirada da obra de Aliomar Baleeiro, Direito Tributário Brasileiro, 11 ${ }^{\text {a }}$ São Paulo: Forense, 2000 , p. 284.

${ }^{109}$ Transcrição do voto-vista do Sr. Ministro Nelson Jobim, proferido no RE 201.465-6/MG, de 2.5.2002, p. 398-399, 404: "Isso tudo demonstra que o conceito de LUCRO REAL TRIBUTÁVEL é um conceito decorrente da lei. Não é um conceito ontológico, como se existisse, nos fatos, uma entidade concreta denominada de "LUCRO REAL". Não tem nada de material ou essencialista. É um conceito legal. [...] Para efeitos tributários, não há que se falar em LUCRO REAL que não seja o decorrente da definição legal. [...] Ambos pretendem que a Constituição tenha determinado a indexação das demonstrações financeiras das empresas para efeitos de apuração do LUCRO TRIBUTÁVEL. Como se viu, o LUCRO TRIBUTÁVEL é um conceito legal."

${ }^{110}$ Mariz se refere ao RE 201.465-6/MG como "um julgado de triste lembrança”, cf. OLIVEIRA, op. cit. (nota 31), p. 180. Bianco menciona que o entendimento do STF sofreu um "forte abalo" com tal julgado, cf. op. cit. (nota 15), p. 318.

${ }^{111} \mathrm{O}$ caso trata da dedução da Contribuição Social sobre o Lucro Líquido na apuração do IRPJ.
} 
integrantes do conceito constitucional de renda ${ }^{112}$, repetindo a fórmula de renda proposta pela doutrina de José Lima Gonçalves ${ }^{113}$.

Acerca do princípio da realização, pode-se mencionar que os RE 72.014/SP, RE 77.431/SP, e RE 92.253-9/SP, julgados entre 1975 e 1980, tangenciavam o tema ao exigir a ocorrência de uma venda (uma troca no mercado) para fins de tributação ${ }^{114}$. É de se lembrar, todavia, que tais casos tratavam de indenização decorrente de desapropriação e havia outros aspectos legais envolvidos ${ }^{115}$. Por isso, a nosso ver, é difícil sustentar que tenha havido menção aos elementos desse princípio nos referidos julgamentos. Em vista deste quadro de decisões, parece mais razoável concluir que tanto a identificação dos elementos mínimos do conceito constitucional de renda quanto a identificação dos contornos de um princípio da realização ainda não foram suficientemente abordados pela Suprema Corte.

\section{O princípio da realização da renda no Código Tributário Nacional}

Passando os olhos sobre o raciocínio desenvolvido nos tópicos acima, nota-se que o conceito constitucional contempla tão-somente as características gerais do que seja renda tributável, cabendo ao legislador complementar, em vista da competência que lhe foi conferida pelo art. 146, III, "a" da CF, a tarefa de definir o fato gerador do imposto de renda. É neste nível normativo que o conceito de renda deve ser emoldurado, ganhando contornos mais nítidos.

Como já foi bem apontado por Brandão Machado, em erudito estudo sobre o art. 43 do $\mathrm{CTN}^{116}$, o Código Tributário, embora recepcionado como lei complementar em face da CF 1988, falha na tarefa ordenada pelo artigo 146, III, "a" para apresentar a definição do fato gerador e da base de cálculo dos impostos discriminados na Carta Magna.

\footnotetext{
${ }^{112}$ Notícia do Informativo STF relata voto do Min. Joaquim Barbosa: “[...] afirmou que, para análise das questões postas no recurso, seria suficiente considerar quatro aspectos para a definição da base de cálculo possível do imposto sobre a renda: a) acréscimo patrimonial resultante do cômputo de certos b) ingressos e de certas c) saídas, ao longo de um dado d) período de tempo, e que esses critérios poderiam ser deduzidos das normas gerais em matéria tributária construídas a partir do CTN (artigos 43 e 44)." Disponível em $<$ www.stf.jus.br>. Acesso em 18 nov. 2008.

${ }^{113}$ Vide item 1.1.2 deste Capítulo.

${ }^{114}$ Comentando o primeiro acórdão: "Consta-se então que neste acórdão estão aplicados os critérios técnicos do: 1) registro do valor da aquisição, 2) a realização do valor da alienação, 3) a necessária presença de um negócio jurídico de venda, 4) e finalmente a contraposição entre os elementos do ativo (realizado pela alienação) deduzido do valor de compra, o que foi gasto para adquirir o bem vendido." Cf. RENCK, op. cit. (nota 100), p. 242.

${ }^{115}$ A presença do termo "venda" no dispositivo legal que previa a tributação na alienação de imóveis e também o fato de a lei tratar como isentos apenas os ganhos de desapropriação percebidos por pessoas físicas.
} 
Em vez de propor uma definição real, o Código oferece uma noção-quadro de renda. As duras críticas do saudos mestre chegam a acusar o CTN de desconhecer princípios relevantes da tributação da renda, dentre eles o da realização, o da renda líquida e o da capacidade contributiva ${ }^{117}$.

A tarefa que se propõe neste tópico da exposição apresenta-se, assim, em aparente contradição com os ensinamentos de Brandão Machado, uma vez que se procura identificar, no conceito de renda dado pelo CTN, eventuais indicações ou até limitações ao princípio da realização comentado acima, o qual se identificou como pertencente ao conceito constitucional de renda (e com contornos bastante amplos). Diz-se "aparente" porque, de fato, o CTN não enuncia claramente tal princípio e tampouco explicita o conceito de renda líquida. A identificação desses elementos nos dispositivos legais do CTN decorre de esforço interpretativo, notadamente voltado à busca de coerência sistemática (sobretudo com o conceito constitucional de renda). Assim, depreende-se das palavras de Brandão Machado a reclamação, também feita por Mariz de Oliveira, de que os artigos do CTN poderiam ser melhorados, pois simplificam demais tema tão complexo ${ }^{118}$.

\subsection{Conceito de renda no Código Tributário Nacional}

Retomando a discussão, apresentada no Capítulo 1, concernente à evolução do conceito de renda, que partiu da noção mais ampla (renda psíquica) para se conformar à mais restritiva (renda realizada), examina-se, a seguir, a definição legal de renda fixada pelo Código Tributário Nacional há mais de 40 anos, podendo-se conferir, com maior rigor técnico, os critérios adotados pelo seu artigo $43^{119}$.

Verifica-se evidente a adoção de uma noção combinada de renda-produto (inciso I) com renda-acréscimo (inciso II) ${ }^{120}$. É bem verdade que determinadas

\footnotetext{
${ }^{116}$ Cf. MACHADO, op. cit. (nota 47), p. 99-100.

${ }^{117}$ Cf. MACHADO, op. cit. (nota 47), p. 108.

${ }^{118}$ Cf. OLIVEIRA, op. cit. (nota 48), p. 224.

119 "Art. 43. O imposto, de competência da União, sobre a renda e proventos de qualquer natureza tem como fato gerador a aquisição da disponibilidade econômica ou jurídica:

I - de renda, assim entendido o produto do capital, do trabalho ou da combinação de ambos;

II - de proventos de qualquer natureza, assim entendidos os acréscimos patrimoniais não compreendidos no inciso anterior."

${ }^{120}$ Cf. COSTA, Alcides Jorge. Conceito de renda tributável. In: MARTINS, Ives Gandra da Silva (coord.). Imposto de renda - Conceitos, princípios e comentários (em memória de Henry Tilbery). $2^{\text {a }}$ São Paulo: Atlas, 1996, p. 30.
} 
obscuridades no texto legal dão margem a divergências de interpretação ${ }^{121}$. Todavia, visando à simplificação desta análise, distancia-se de algumas dessas controvérsias (muito bem expostas nos textos doutrinários aqui mencionados) e toma-se como pressuposto deste trabalho, a ideia de que uma leitura razoável dos incisos I e II do CTN indica sua preferência pelos conceitos de renda-produto e renda-acréscimo.

Não obstante isso, ressalta-se rapidamente que é também bastante indefinida na doutrina brasileira a questão pertinente a saber se o CTN teria adotado também os conceitos de renda nacional e renda individual. Aponta-se que algumas discussões específicas (como a exclusão de transferências patrimoniais - doações, heranças e subvenções) do campo de tributação parecem sugerir a presença desses conceitos no sistema, pois uma justificativa para a não-tributação desses valores seria a sua origem em patrimônios alheios ${ }^{122}$. Ademais, também o conceito de renda separada do capital costuma ser suscitado com frequência (normalmente implicitamente), não só na jurisprudência $^{123}$, mas também em textos doutrinários que procuram enfatizar o elemento separação da renda, ou citar a metáfora do fruto e da árvore para explicar o momento temporal da realização. É questionável se tal elemento faria parte do conceito de renda ${ }^{124}$. Com mais razão, referir-se à separação significa apenas um modo eficaz de ilustrar a necessidade de que a tributação atinja a renda e não o capital (patrimônio), sob pena de

\footnotetext{
${ }^{121}$ Por exemplo, tanto a palavra disponibilidade quanto a palavra produto podem dizer respeito a noções de ingresso líquido. A primeira por poder denotar que o objeto da tributação é apenas renda a disponível (no sentido de livre, isto é, a parcela não destinada a cobrir dispêndios essenciais), e a segunda por potencialmente significar incremento líquido. Quanto ao termo disponibilidade como sinônimo de renda líquida, cf. SOUSA, Rubens Gomes de. IMPOSTO DE RENDA: Despesas não dedutíveis pelas pessoas jurídicas [...]. In: Pareceres - 1: imposto de renda. São Paulo: Resenha Tributária, 1975, p. 69-70. Para a equivalência de produto com o incremento líquido, cf. CANTO, Gilberto de Ulhôa. A aquisição de disponibilidade e o acréscimo patrimonial no imposto sobre a renda. In: MARTINS, Ives Gandra da Silva (Coord.). Imposto de renda: conceitos, princípios e comentários (em memória de Henry Tilbery). $2^{\mathrm{a}}$ São Paulo: Atlas, 1996, p. 36.

${ }^{122}$ Para a justificativa, cf. OLIVEIRA, op. cit. (nota 31), p. 182, 285.

${ }^{123}$ Como se viu do RE 89.791-7/RJ, cf. nota 102 supra.

124 "Mas a verdade é que este conceito [separação] não é inerente ao conceito de "renda", e a afirmação de que o fruto não destrói nem desfalca o bem que o produz não é absoluta, pois somente se aplica quando a fonte produtora remanesce, tal como a matriz bovina que dá cria, ou a árvore que dá o fruto, ou a máquina que produz a coisa.

Já em outras situações, não há a separação, pois a colheita do resultado importa na própria destruição da fonte produtora ou no seu desfalque.

Assim ocorre, por exemplo, com a árvore que não rebrota e que é cortada pela madeira que nela existe, e não pelo fruto que dá, ou com a jazida mineral que se reduz a cada extração, até se consumir." Cf. OLIVEIRA, op. cit. (nota 31), p. 376.
} 
invasão de competência ${ }^{125}$. Uma constatação é certa: a adoção do conceito de rendaacréscimo exclui, de plano, os conceitos de renda psíquica e renda consumo ${ }^{126}$.

Enfim, enfocando os conceitos mais comuns, destaca-se que, em obra recente sobre o tema, Mariz de Oliveira sublinha ser entendimento majoritário da doutrina brasileira (aparentemente alinhado com as poucas decisões que o STF proferiu sobre o tema) o de que, em essência, o CTN teria adotado o conceito de renda-acréscimo. Isso porque a definição dada pelo inciso II do CTN seria mais abrangente - pois manda incluir na base de cálculo todos os acréscimos patrimoniais não compreendidos no inciso anterior - e tenderia a englobar, ou até tornar dispensável o conceito de renda-produto referido no inciso $\mathrm{I}^{127}$.

Pois bem, pode-se realmente afirmar que a essência da definição de renda desenhada pelo CTN consiste no acréscimo patrimonial. Porém, não se pode obscurecer a presença do conceito de renda-produto na legislação brasileira, pois ele é importante, sobretudo, para justificar a tributação de rendimentos que, decorrentes do capital ou do trabalho, fluem regularmente para o patrimônio do indivíduo ${ }^{128}$ e podem não ser alcançados pelo conceito de renda-acréscimo pelo simples fato de terem sido consumidos no período, ou por se sujeitarem à tributação em regime apartado ${ }^{129}$. Contudo, sendo de maior relevância para o presente estudo o conceito de renda-acréscimo, as considerações feitas daqui por diante concentram-se em definir o que seja acréscimo patrimonial.

Nesse sentido, Modesto Carvalhosa já sugeria, em 1967, que o conceito de renda estava intrinsecamente ligado ao conceito de patrimônio ${ }^{130}$. Contudo, detalhes mais esclarecedores seriam revelados no percuciente estudo de Brandão Machado e, após, aprimorados na obra de Mariz de Oliveira: o patrimônio é uma universalidade composta

\footnotetext{
${ }^{125}$ Cf. DERZI, Misabel Abreu Machado. Conceito de renda na Constituição de 1988. Regras de competência In: BALEEIRO, op. cit. (nota 19), p. 290.

${ }^{126}$ Nas palavras de Mariz de Oliveira "Com isto, o art. 43 está afastando outros critérios teoricamente possíveis para a tributação da renda, tais como o da renda consumida, ou o da renda empregada, ou o da renda capitalizada, para se fixar no critério da renda adquirida." Cf. OLIVEIRA, op. cit. (nota 31), p. 287.

127 "lendo-se o art. 43 do CTN na sua literalidade, sem preocupação crítica, fica-se com a nítida impressão de que ele adotou as duas correntes. Ou então, se partirmos da constatação, feita já no primeiro capítulo deste livro, de que, para o CTN, o fato gerador do imposto de renda consiste sempre na ocorrência de acréscimo patrimonial, pode-se chegar a pensar que ele adotou a corrente da renda-acréscimo, que afinal absorve a corrente da renda-produto. Não são poucos os juristas que assim se posicionam. [...]

E, se o inciso II afirma que os proventos são os acréscimos patrimoniais não compreendidos no inciso I, está necessariamente dizendo que a renda também é acréscimo patrimonial, pois sua diç̧ão textual equivale ao seguinte: proventos são acréscimos patrimoniais não compreendidos nos acréscimos patrimoniais compreendidos no inciso anterior." Cf. OLIVEIRA, op. cit. (nota 31), p. 182, 285.

${ }^{128}$ Sobre as características do conceito de renda-produto (teoria das fontes), vide o item 2.3.1 do Capítulo 1.

${ }^{129}$ Tributação exclusiva na fonte.

${ }^{130}$ Cf. CARVALHOSA, op. cit. (nota 35), p. 189.
} 
unicamente de direitos, de forma que o acréscimo patrimonial de que fala o CTN é sempre um acréscimo de direitos ${ }^{131}$.

E mais ainda, sendo o patrimônio um conceito emanado do Direito Privado, haveria impedimentos para que o legislador tributário alterasse tal conceito, sob pena de violação à rígida distribuição constitucional de competências ${ }^{132}$. Definir o que seria acréscimo patrimonial e, enfim, renda tributável, é tarefa que, em última análise, resvala para o Direito Civil. Tendo isso em vista, deve-se perquirir o conceito de acréscimo patrimonial segundo o tal ramo do Direito ${ }^{133}$, donde se infere preliminarmente que, à luz do Código Civil atual ${ }^{134}$, patrimônio é o complexo das relações jurídicas de uma pessoa que tiverem valor econômico.

Da leitura da obra de Pontes de Miranda ${ }^{135}$, verifica-se que os direitos de uma pessoa podem ser: (i) reais (sobre coisas, de caráter absoluto), (ii) pessoais (contra pessoas, de caráter relativo), (iii) de personalidade, e (iv) direitos a adquirir direitos (direitos em formação), que se subdividem em (iv-a) formativos (dependem da vontade do titular - o direito a formar-se depende do exercício do direito formativo gerador) e, (ivb) expectativos (direitos em formação, independem da vontade do titular - o direito expectado surge com o passar do tempo ou com a verificação de algum acontecimento).

Porém, no patrimônio só entram direitos que tenham conteúdo patrimonial, sendo esta patrimonialidade vinculada ao valor econômico ${ }^{136}$, como bem salientado, aliás, pelo artigo 91 do Código Civil ("Constitui universalidade de direito o complexo de relações jurídicas, de uma pessoa, dotadas de valor econômico.”). Disso concluem Brandão Machado e Mariz de Oliveira que o patrimônio é composto de direitos reais e pessoais e que a incidência do imposto de renda se dá quando verificado o acréscimo de direitos desta

\footnotetext{
${ }^{131}$ Cf. MACHADO, op. cit. (nota 47), p. 101.

${ }^{132}$ Cf. esclarece o artigo 110 do CTN, comentado no item 2.3 deste Capítulo.

${ }^{133}$ Tarefa que já foi mais extensa e brilhantemente feita por Pontes de Miranda (cf. MIRANDA, Pontes de. Tratado de direito privado, tomo V, Campinas: Bookseller, 2000, §596, p. 415 e s.) e retomada tanto por Brandão Machado quanto por Mariz de Oliveira nos estudos citados.

${ }^{134}$ Não havendo no Código Civil atual nenhum conceito didático de patrimônio ou sua referenciação direta a uma universalidade (como havia no Código Civil de 1916, com o art. 57), tem-se como melhor definição de patrimônio o artigo 91, que diz: “Constitui universalidade de direito o complexo de relações jurídicas, de uma pessoa, dotadas de valor econômico.”

${ }^{135}$ Cf. MIRANDA, op. cit. (nota 133), capítulos II e III, p. 287-357.

${ }^{136}$ Cf. MACHADO, op. cit. (nota 47), p. 101.
} 
natureza ${ }^{137}$. Mariz de Oliveira assim se pronuncia (acrescentando o necessário enfoque das obrigações integrantes do patrimônio) ${ }^{138}$ :

“Ora, se o patrimônio é um agregado de direitos e obrigações, as suas mutações necessariamente importam em mais ou menos direitos, ou em mais ou menos obrigações, da pessoa titular do patrimônio, ou seja, todas as mutações patrimoniais derivam de relações jurídicas do titular do patrimônio, ou, em outras palavras, as mutações na universalidade patrimonial operam-se apenas pelo ingresso de novos direitos, ou pelo contraimento de novas obrigações, ou pela saída de direitos ou obrigações antes existentes no patrimônio."

Como se vê do excerto acima, o acréscimo patrimonial, na visão de Mariz de Oliveira e também, segundo ele, na de alguns julgados do STF $^{139}$, seria traduzido essencialmente pelo acréscimo de algo novo, um direito novo adentrado ao patrimônio. Excluída estaria, em princípio, a possibilidade de se tributarem meros acréscimos de valor de itens patrimoniais, pois estes já fazem parte do patrimônio. Tal acréscimo não traduziria a entrada de "algo novo".

Este é um ponto bastante importante e merece ser mais bem explorado. Com efeito, uma questão fundamental, que tem permeado este trabalho e deve ser renovada aqui, consiste em saber em que amplitude o CTN albergou o conceito de renda-acréscimo, principalmente para questionar se seria possível adotar um critério de realização que acusasse renda tributável em situações de mero acréscimo de valor de bens patrimoniais (ganhos de detenção). Além disso, importa saber se os eventos de fechamento de contrato ou aceitação de oferta firme, por exemplo, seriam eventos aptos a figurar como critério de reconhecimento da receita correspondente.

Pressupondo-se que a renda é acréscimo de patrimônio, a referência ao Direito Civil é realmente obrigatória e indispensável. Todavia, não se pode afirmar que a questão se resolva absolutamente com sua transposição ao Direito Civil, pois, com isso, apenas transfere a indeterminabilidade de um conceito (renda) para a de outro (patrimônio). $\mathrm{O}$ próprio Pontes de Miranda admitia, por exemplo, que determinados direitos sobre direitos

\footnotetext{
${ }^{137}$ Brandão sugere, a propósito, que o CTN poderia ser mais simplificador se dissesse que "Fato gerador do imposto de renda é a aquisição da disponibilidade econômica ou jurídica de acréscimos de direitos reais ou pessoais". Cf. MACHADO, op. cit. (nota 47), p. 101.

${ }_{138}$ Cf. OLIVEIRA, op. cit. (nota 31), p. 73-74.

${ }^{139}$ Particularmente no RE 117.887-6/SP, pois os julgados mais recentes parecem não se fixar em um tal conceito. Vide acima, item 1.3.
} 
pudessem adquirir o atributo de patrimonialidade ${ }^{140}$. Além disso, o erudito civilista também não afastava a possibilidade de que aos elementos do patrimônio fosse atribuído valor econômico independentemente de uma relação de troca efetiva ${ }^{141}$. Não parece existir um requisito no Direito Civil, portanto, para que a realização de valor se concretize por uma troca no mercado.

Conforme se verá adiante, as soluções para algumas dessas questões relativas aos limites do princípio da realização são traçadas pelo próprio CTN. Outras dependem ultimamente dos efeitos das relações jurídicas verificadas em casos concretos e, portanto, da disciplina do Direito Civil (algumas delas serão analisadas nos Capítulos seguintes deste trabalho).

\subsection{Conceito de realização no Código Tributário Nacional}

Retomando considerações feitas acima, recorda-se que, na identificação do princípio da realização como um dos elementos nucleares do conceito constitucional de renda, asseverou-se que era possível falar desse princípio como uma diretriz geral de alocação temporal de receitas e despesas, que observa condições mínimas de materialidade (ocorrência dos fatos relevantes), objetividade (possibilidade de mensuração de seu valor) e prudência (segurança na sua apuração). Além disso, com Bulhões Pedreira, detectou-se o elemento de troca no mercado como um requisito adicional indicado pelo princípio da

140 "Resta saber-se quando há patrimonialidade na situação daquele que "expecta" algo de outrem.

Sempre que o efeito mínimo ou o de irrevogabilidade se produz, firma-se a situação do titular do direito patrimonial; de modo que esse é o critério para se saber se essa situação entrou ou não no patrimônio. $\mathrm{O}$ critério da probabilidade de realizar-se a expectativa, a que desesperadamente recorreu A. von Thur (Der Allgemeine Teil, I, 318), é insustentável: não se poderia conhecer onde começa a probabilidade inseridora, nem onde acaba; a afirmação de que a expectativa da herança de pessoa viva não entra no patrimônio porque é demasiado problemática há de ser repelida (318, nota 24), - essa expectativa não dá direito nenhum e, tratando-se de testamento, é revogável e sem qualquer efeito vinculativo antes da morte do decujo, que é condicio iuris.” Grifo nosso. Cf. MIRANDA, op. cit. (nota 133), §596, item 2, p. 420.

141 "2. Modos de avaliação. Há valor: a) espontâneo individual (A oferece o bem $a$ por $x$, B oferece $x$ por $a$ ); b) individual provocado (A é encarregado de dizer qual o valor de $a$ e fixa-o em $x$ ); c) tarifário legal (a lex specialis fixou em $x$ o valor dos bens da classe $a$ e o bem, de que se trata, entra em $a$, cf. o que estatuíra o Decreto-Lei $\mathrm{n}^{\circ}$ 7.036, de 10 de novembro de 1944, arts. 16-21); d) tarifário regulamentar (segundo a lei, a fixação em tarifa é feita por autoridade pública); e) espontâneo comissional ou pericial (A, B, e C fixam em $x$, dependendo de apreciação negocial ou judicial o aproveitamento da fixação); f) comissional ou pericial provocado (a junta de avaliadores fixa em $x$; os avaliadores oficiais ou em que se louvaram os interessados fixa em $x$ ). O valor em bolsa entra na classe e), salvo quando foram provocados para a avaliação, in casu, corretores. $[\ldots]$ 
realização ${ }^{142}$. Todos esses elementos carecem de melhor definição, haja vista serem ambíguos e comportarem indeterminação. Com isso, verifica-se que cabe ao legislador complementar concluir a moldagem do princípio da realização, opondo limites ou indicando metodologias ao legislador ordinário (este, sim, terá a incumbência de escolher o critério final apto a materializar os fins indicados por este princípio em situações concretas).

Este item do trabalho focaliza, portanto, os principais artigos do CTN que encerram comandos relacionados com a definição do momento temporal do reconhecimento de receitas e despesas e, enfim, da renda tributável. Posto que não contenha uma formulação explícita do princípio da realização, o artigo 43 do CTN oferece indicativos razoáveis para que se assimilem, por exemplo, os regimes de competência e de caixa como métodos contábeis apropriados para a apuração da renda.

Além do mais, outros dispositivos do CTN (arts. 109, 110 e 116) apontam para o forte elo de conexão que entrelaça o Direito Tributário ao Direito Privado e apresentam subsídios suficientes para o conhecimento dos preceitos que comandam a verificação dos efeitos dos atos ou negócios jurídicos que são o objeto da tributação pelo imposto de renda. É sobre esses temas que se discorre a seguir.

\subsubsection{As disponibilidades jurídica, econômica ou financeira}

O Código Tributário indicou o momento temporal que deflagra a ocorrência do fato gerador do imposto de renda: a aquisição da disponibilidade econômica ou jurídica de renda e proventos de qualquer natureza. Constatado que o elemento renda e proventos de qualquer natureza equivale fundamentalmente a acréscimo patrimonial, tem-se então que a realização da renda acontece no tempo da aquisição de tais disponibilidades de acréscimo patrimonial. Destarte, basta conhecer o conteúdo desses vocábulos para se ter uma percepção mais exata do conteúdo do princípio aqui estudado.

Reservando este primeiro subitem para o estudo das disponibilidades jurídica e econômica, mencionadas pelo CTN, e também para a menção à disponibilidade financeira,

4. Valor de preço. De ordinário, o valor dos bens é dado pelo que, transferindo-se, por eles se adquire. Daí ter-se procurado definir patrimonialidade por transferibilidade: bens transferíveis seriam patrimoniais. A definição seria defeituosa, porque há bens patrimoniais que são intransferíveis; então, basta o valor de uso, pois não há, ex hypothesi, valor de troca; o que de si só demonstra que o valor de uso é mais geral e está à base mesma do valor de troca. Ora o uso é pela própria pessoa, que tem o valor, ora é por outra, para que aquela receba contraprestação, ora o uso é deixado para mais tarde, pela pessoa que tem o valor, ou por outrem.” Cf. MIRANDA, op. cit. (nota 133), §601, itens 2 e 4, p. 448-449.

${ }^{142}$ Vide item 1.2.4 supra. 
que não foi tratada no CTN, mas que frequenta as discussões sobre este assunto, verifica-se que um dos grandes desafios em matéria de interpretação jurídica, na órbita do imposto de renda de pessoas jurídicas no Brasil, consiste em saber o que o legislador complementar pretendeu com o uso dessas expressões.

Por ser um tema amplamente abordado na doutrina nacional e por não se pretende aqui "reinventar a roda", o enfoque empreendido a seguir procura sintetizar e sistematizar as principais linhas de pensamento e, ao final, indicar aquela que prevalece, sublinhando os elementos necessários à identificação do princípio da realização.

O primeiro ponto de divergência digno de nota advém da constatação de que o CTN utilizou dois adjetivos, econômica ou jurídica, para qualificar uma mesma situação, a de disponibilidade. Não está claro se seriam duas formas absolutamente distintas de disponibilidade (existem atos que geram disponibilidades só econômicas e outros, só jurídicas) ou se seriam dois momentos distintos de uma mesma disponibilidade (toda disponibilidade é plenamente jurídica, mas pode ser econômica depois de verificado algum evento econômico relevante, e.g. o pagamento). Deste impasse decorre a classificação das opiniões dos autores em corrente unificadora x corrente dicotômica ${ }^{143}$.

Brandão Machado é um dos que entende supérflua a menção à disponibilidade econômica $^{144}$ e poderia, portanto, ser incluído na corrente unificadora ${ }^{145}$. Porém, ele mesmo impinge, mais adiante em seu estudo, uma conceituação razoavelmente dicotômica para as disponibilidades jurídica (propriedade de renda) e econômica (posse de renda) ${ }^{146}$.

Dentre os autores que procuram distinguir sensivelmente as duas espécies de disponibilidades, destaca-se a opinião daqueles que associam a disponibilidade jurídica com a renda derivada de atos lícitos e a econômica, com aquela oriunda de atos ilícitos (pois aí sim se verifica um ato que é só econômico - a posse de renda decorrente de roubo,

\footnotetext{
${ }^{143}$ Sobre a classificação das principais opiniões dentro desses grupos e suas variações, ver LEMKE, Gisele. Imposto de renda: os conceitos de renda e de disponibilidade econômica e jurídica. São Paulo: Dialética, 1998. Excelentes e esclarecedores resumos podem ser vistos em ABE, Cesar Henrique Shogi. Disponibilidade econômica de renda. In: Revista de direito tributário atual. v. 21. São Paulo: DialéticaIBDT, 2007, p. 191-210; e SILVEIRA, Ricardo Maitto. O princípio da realização da renda no direito tributário brasileiro. In: idem, p. 317-344.

144 "Todo acréscimo de direitos (reais ou pessoais e, portanto, patrimoniais) estará necessariamente disponível, pelo fato singular de que os direitos acrescem ao patrimônio. Aquela expressão [disponibilidade econômica] é excrescente e tem uma gênese que, afinal, pode encontrar-se na sistemática que o autor de seu anteprojeto pretendia imprimir no Código Tributário Nacional, sob a inspiração do direito tributário alemão, que dá maior relevo ao aspecto econômico do que ao jurídico na conceituação da hipótese de aplicabilidade da norma tributária e do vínculo entre a hipótese e o sujeito passivo." Cf. MACHADO, op. cit. (nota 47), p. 101.

${ }^{145}$ Cf. ABE, op. cit. (nota 143), p. 194-195; SILVEIRA, op. cit. (nota 143), p. 327-328.

${ }^{146}$ Cf. MACHADO, op. cit. (nota 47), p. 105-106.
} 
por exemplo, não é jurídica porque não é protegida pelo Direito). São deste pensar, Mariz de Oliveira e José Eduardo Soares de Mello ${ }^{147}$. Convém apontar que tal entendimento não está isento de críticas ${ }^{148}$.

Além dos binômios posse/propriedade e lícito/ilícito, devem-se destacar as formulações que divisam nas referidas disponibilidades os elementos de realização e separação, para significar qualquer uma das duas disponibilidades, em qualquer ordem. Parece absurdo, mas esta inversão dos termos e de seus significados pode ser constatada em estudos do próprio autor do anteprojeto que resultou no texto atualmente vigente do CTN.

Assim, em um de seus primeiros trabalhos, Rubens Gomes de Sousa apoia-se claramente na terminologia proposta por Seligman ${ }^{149}$ para "distinguir entre a realização, traduzida pela disponibilidade econômica de uma riqueza, e a separação, traduzida pela sua disponibilidade jurídica". A realização é entendida como a "verificação, efetiva ou potencial, de um acréscimo patrimonial" e a separação, como a "possibilidade de se dispor desse acréscimo independentemente e separadamente do capital que o produziu" 150 . Observe-se que esta noção de disponibilidade jurídica como sinônimo de "efetivo recebimento do rendimento" foi a que imperou durante boa parte do século passado ${ }^{151}$.

Em um de seus pareceres mais contemporâneos, o aclamado autor parece ter cometido uma reviravolta em seu pensamento ${ }^{152}$, equiparando a realização (e, portanto, a disponibilidade econômica) ao "dinheiro em caixa" 153 . Contudo, em parecer posterior, Rubens voltou a definir realização e separação de maneira coerente com seus estudos $\operatorname{prévios}^{154}$.

O que interessa notar é que, sejam eles identificados com os elementos de disponibilidade jurídica, econômica ou vice-versa, os critérios de realização e separação

${ }^{147}$ Cf. textos publicados em MARTINS (Coord.), op cit. (nota 10), p. 304-305 e 427. Em sua mais recente obra, Mariz manteve e enriqueceu seu ponto de vista, cf. OLIVEIRA, op. cit. (nota 31), p. 314.

${ }^{148}$ Com precisão contundente, Luís Eduardo Schoueri alerta que "Não é este o espaço para o exame crítico desta tese, mas deve ser mencionado que se o fruto da atividade ilícita não for protegido pelo direito, i.e., se o direito não assegurar aquela disponibilidade, então não parece correto falar em acréscimo patrimonial e, portanto, não parece acertado cogitar de imposto de renda." Cf. SCHOUERI, Luís Eduardo. Prefácio. In: OLIVEIRA, op. cit. (nota 31), p. 5.

${ }^{149}$ Vide item 2.3.1.1 do Capítulo 1.

${ }^{150}$ Cf. SOUSA, Rubens Gomes de. A evolução do conceito de rendimento tributável. In: Revista de direito público, ano IV, v. 14. São Paulo: Revista dos Tribunais, out-dez. 1970, p. 341 (item 11), p. 344.

${ }^{151}$ Ver a esse respeito a análise histórica empreendida no item 4 do Capítulo 1.

${ }^{152}$ Contradição apontada por MACHADO, op. cit. (nota 47), p. 107, e também por AMARO, Luciano. Imposto de renda: regimes jurídicos. In: MARTINS, Ives Gandra da Silva (coord.). Curso de direito tributário, v. 1. Belém: CEJUP/Centro de Extensão Universitária, 1993, p. 310.

${ }^{153}$ Cf. SOUSA, op. cit. (nota 121), p. 70. 
identificam-se, na visão dos autores que os empregam (observadas as peculiaridades ressaltadas por cada um deles), com os regimes de competência ou caixa.

A discussão sobre as disponibilidades ganhou influentes contribuições por ocasião do XI Simpósio Nacional de Direito Tributário do Centro de Estudos de Extensão Universitária, já referido aqui ${ }^{155}$. Dos 12 trabalhos apresentados, 1 sustentou os conceitos de posse/propriedade ${ }^{156}, 2$ outros seguiram a linha divisória entre lícito/ilícito ${ }^{157}$, e todos os demais conceituaram as disponibilidades jurídica/econômica como sinônimos de regime de competência e regime de caixa ${ }^{158}$.

A despeito das respeitáveis opiniões que formulam os conceitos de posse/propriedade e lícito/ilícito, parece mais razoável concluir que a referência a duas formas de disponibilidades no CTN tem relação com os métodos contábeis (regimes de competência ou caixa) admissíveis para fins de verificação das receitas e despesas componentes da renda tributável ${ }^{159}$. Sem estender muito este ponto, registra-se que as teorias de posse/propriedade e lícito/ilícito aparentam conter inconsistências insanáveis. Aceitar a primeira delas seria assumir uma contradição no artigo 45 do $\mathrm{CTN}^{160}$ (que trata da posse como algo adicional às disponibilidades do art. 43 do CTN), ao passo que aceitar a segunda implica negar que o fato gerador do imposto de renda seja o acréscimo de direitos (não sendo o fruto de roubo um direito, não haveria incidência do imposto) ${ }^{161}$.

Por sua vez, no que respeita à expressão disponibilidade financeira, posto que não utilizada pelo CTN, algumas manifestações identificam este fenômeno como hipótese de incidência do imposto de renda de pessoas jurídicas. Exemplo de tal pensamento pode

\footnotetext{
${ }^{154}$ Cf. SOUSA, Rubens Gomes de. IMPOSTO DE RENDA: Ações gratuitas provenientes da capitalização [...]. In: Pareceres - 1: Imposto de renda. São Paulo: Resenha Tributária, 1975, p. 117-118.

${ }^{155}$ Sobretudo em razão da pergunta $\mathrm{n}^{\circ} 1$ dirigida a cada um dos expositores: "Que se entende por aquisição de disponibilidade econômica ou jurídica de renda ou proventos de qualquer natureza?" In: MARTINS (Coord.), op cit. (nota 10).

${ }^{156}$ Cf. o artigo de Carlos da Rocha Guimarães. In: MARTINS (Coord.), op cit. (nota 10), p. 79-84.

${ }^{157}$ Trata-se de José Eduardo Soares de Mello e Ricardo Mariz de Oliveira. In: MARTINS (Coord.), op cit. (nota 10), p. 304-305, 427.

${ }^{158}$ Deste lado se situam Gilberto de Ulhôa Canto et alli, (itens 1.9-10), Antonio Manoel Gonçalez, Gustavo Miguez de Mello, Hugo de Brito (itens 3.1-6), Ives Gandra, Luciano Amaro, Wagner Balera, Waldir Silveira Mello), Ylves José de Miranda Guimarães (item 10). In: MARTINS (Coord.), op cit. (nota 10), p. 5-6; 49-50; $237-239 ; 249-253 ; 272,275 ; 387-393 ; 460-462 ; 539 ; 556$.

${ }^{159}$ A prevalência desta visão é confirmada até por quem defende formulação distinta: "Tradicionalmente, a doutrina entende que a aquisição da disponibilidade jurídica se constitui na aquisição do direito à renda, sem ter havido ainda a sua percepção em dinheiro ou em valores suscetíveis de avaliação em dinheiro.

Em complemento, o fato de o dinheiro da renda estar em caixa, isto é, no bolso do contribuinte, representaria a disponibilidade econômica da respectiva renda." cf. OLIVEIRA, op. cit. (nota 31), p. 292.

160 "Art. 45. Contribuinte do imposto é o titular da disponibilidade a que se refere o artigo 43, sem prejuízo de atribuir a lei essa condição ao possuidor, a qualquer título, dos bens produtores de renda ou dos proventos tributáveis."

${ }^{161}$ Conforme apontado acima (vide especialmente a nota de rodapé 148).
} 
ser visto em Zuudi Sakakihara que, em coletânea de comentários ao $\mathrm{CTN}^{162}$, alerta que a disponibilidade financeira não pode ser confundida com a econômica, uma vez que traduz tão-somente a existência (ou o recebimento) física dos recursos. Esclarece ainda que a legislação ordinária tem a liberdade de adotar o critério de disponibilidade financeira, como de fato o faz para as pessoas físicas ao permitir a adoção do regime de caixa com relação à maioria de suas rendas.

A polêmica causada pela confusão entre esta expressão com um dos regimes permitidos pelo CTN (o regime de caixa) pode ser explicada pelo fato de autores como Ricardo Mariz de Oliveira mencionarem a disponibilidade financeira para se referir ao mero recebimento dos recursos. Deve-se esclarecer que, pelo entendimento do referido autor, não se considera a disponibilidade financeira como deflagradora da incidência, por si só, pois um recebimento de recursos pode configurar, por exemplo, um adiantamento por entrega futura de mercadorias ou prestação futura de serviços (situação na qual fica o recipiente obrigado a devolver os recursos, caso não cumprida sua obrigação) ${ }^{163}$. Na visão do respeitado especialista (coerente com sua defesa dos conceitos de lícito/ilícito), o recebimento de recursos apenas pode resultar na incidência do imposto naquelas situações não regidas pelo direito, pois o recebimento seria, neste caso, o elemento denotador da disponibilidade econômica (que acontece simultaneamente) ${ }^{164}$.

Por fim, deste brevíssimo panorama acerca do tormentoso tema das disponibilidades, denota-se que o princípio da realização encontra no CTN um balizamento maior, pois excluem-se definitivamente os conceitos amplos de renda (psíquica e consumo), erigindo-se, para o alcance da renda-produto e da renda-acréscimo, a orientação do princípio da realização pelos regimes de competência ou caixa.

Contudo, apesar de tal direcionamento, não se pode ainda dizer que o princípio da realização da renda foi propriamente definido, isto é, ao se firmar o entendimento de que os eventos deflagradores da renda são considerados realizados conforme o regime de competência, por exemplo, o que se obteve foi a mudança do problema para outra expressão ambígua. O próximo passo consiste em definir o que se entende por regime de competência, isto é, qual é o critério determinante para se considerar que determinada receita ou despesa pertence a este ou àquele período. Dependendo do critério que se adotar

\footnotetext{
${ }^{162}$ Cf. SAKAKIHARA, Zuudi. Comentários aos arts. 43 a 45. In: Código Tributário Nacional comentado: doutrina e jurisprudência, artigo por artigo, inclusive ICMS (LC 87/1996 e LC 114/2002) e ISS (LC 116/2003). $2^{\mathrm{a}}$ rev., atual. e ampl. São Paulo: Revista dos Tribunais, 2004, p. 154-155.

${ }^{163}$ Cf. OLIVEIRA, op. cit. (nota 48), p. 206.

${ }^{164}$ Cf. OLIVEIRA, op. cit. (nota 48), p. 206-209.
} 
(produção, valorização, fechamento de contrato, troca de mercado, recebimento do direito, recebimento do dinheiro), o regime de competência pode até se identificar com o regime de caixa $^{165}$.

Tendo em vista que o regime de competência, também chamado de princípio da competência ou princípio da realização das receitas e confrontação com as despesas, é um princípio concernente à apuração do lucro comercial, o que se pode concluir do CTN é que se delegou ao Direito Comercial, ou mais propriamente, ao conjunto dos princípios de contabilidade geralmente aceitos, a tarefa inicial de determinar o critério pertinente de realização. Esta vinculação ao Direito Comercial retrata, conforme já se anotou aqui, a adoção do princípio da congruência com os parâmetros contábeis, fato este confirmado pelo vínculo entre o Decreto-lei n ${ }^{\circ} 1.598 / 1977$ e a Lei no 6.404/1976 ${ }^{166}$. Antes da edição deste Decreto-lei, houve, porém, a tentativa de se incluir na legislação fiscal a disciplina dos regimes de competência e caixa. A esse respeito, vale fazer aqui um pequeno aparte.

\subsubsection{Regimes de competência e caixa na legislação tributária}

Embora os regimes de competência e caixa sejam objeto de comentários mais específicos nos dois próximos Capítulos deste estudo (centrando-se em aspectos da legislação comercial), vale mencionar aqui alguns pontos relevantes da legislação tributária relativa a esses dois regimes.

Introduzido no Brasil, como se viu ${ }^{167}$, definitiva e inquestionavelmente com a Lei $n^{\circ} 6.404 / 1976$, o regime de competência não continha formulação inequívoca na legislação comercial ${ }^{168}$, de forma que uma das preocupações retratadas no Anteprojeto elaborado pelo Ministério da Fazenda, para fins de adaptação da legislação tributária, era a

\footnotetext{
${ }^{165}$ Completando com as palavras de Mariz de Oliveira "A expressão "regime de competência" é ambígua, pois requer um elemento referencial para se determinar a que período "compete" uma determinada mutação patrimonial, seja esta positiva (receitas), seja negativa (custos, despesas).

Realmente, se os elementos referenciais forem o ingresso de receitas no caixa da pessoa jurídica e a saída do caixa para pagamento de despesas ou custos, "competente" é o período em que esses eventos ocorrem." Cf. OLIVEIRA, op. cit. (nota 31), p. 316.

${ }^{166}$ Vide a esse respeito o item 4 do Capítulo 1.

${ }^{167}$ Vide a esse respeito o item 4, do Capítulo 1.

${ }^{168}$ Lei n ${ }^{\circ}$ 6.404/1976 - "Art. 177. A escrituração da companhia será mantida em registros permanentes, com obediência aos preceitos da legislação comercial e desta Lei e aos princípios de contabilidade geralmente aceitos, devendo observar métodos ou critérios contábeis uniformes no tempo e registrar as mutações patrimoniais segundo o regime de competência." - Grifo nosso.

"Art. 187. A demonstração do resultado do exercício discriminará: $\S \mathbf{1}^{\circ} \mathrm{Na}$ determinação do resultado do exercício serão computados:

a) as receitas e os rendimentos ganhos no período, independentemente da sua realização em moeda; e
} 
de tornar mais tangível a definição dos regimes de competência e caixa. Assim estavam redigidas as explicações do que seriam esses dois regimes sob a perspectiva da legislação tributária:

\section{Regime de competência}

“Art. 71 - Na determinação do lucro real devem ser computados em cada período-base de incidência:

I - as receitas e os rendimentos, cuja disponibilidade seja adquirida no período pela ocorrência de todos os fatos necessários para fazer nascer o direito ao seu recebimento e cujo valor possa ser determinado com aproximação razoável, ainda que não tenham sido recebidos em dinheiro;

II - os custos, as despesas e as perdas correspondentes a obrigações nascidas no período, desde que seu valor possa ser determinado com aproximação razoável;

III - os encargos de depreciação, amortização ou exaustão e as provisões que competirem ao período.

$\$ 1^{\mathbf{0}}$ As receitas e os rendimentos recebidos antecipadamente poderão ser computados no período a que competirem.

\$2 ${ }^{\mathbf{o}}$ Deverão ser computados no mesmo período:

a) as receitas de vendas de bens ou serviços e os respectivos custos;

b) os demais rendimentos ou receitas e as despesas diretas a eles correspondentes.

§3 $^{\mathbf{0}}$ As despesas pagas antecipadamente deverão ser computadas no período a que competirem."

\section{Regime de caixa}

“Art. 72 - A apuração do resultado da prestação de serviços poderá ser procedida computando-se, em cada período-base de incidência:

I - as receitas ou rendimentos efetivamente recebidos, ou colocados à disposição do contribuinte em condições de serem por ele recebidos, à sua vontade;

II - os custos ou despesas efetivamente pagos;

b) os custos, despesas, encargos e perdas, pagos ou incorridos, correspondentes a essas receitas e rendimentos." Gifo nosso. 
III - os encargos de depreciação ou amortização e as provisões que competirem ao período.

Parágrafo único. O disposto neste artigo não se aplica a pessoas jurídicas que tenham a forma de:

a) sociedades por ações; ou

b) sociedades por quotas de responsabilidade limitada, cujo capital social seja superior a Cr\$100.000,00."

Alguns aspectos são dignos de nota.

No regime de competência, o reconhecimento das receitas deve-se guiar pela verificação da ocorrência dos fatos necessários para fazer nascer o direito ao seu recebimento. A esta orientação pode-se atribuir a doutrina do princípio da realização orientado pelo enfoque no evento crítico (em oposição ao enfoque no acréscimo de valor), isto é, não se considera realizada a renda no momento da geração do valor mediante atos internos da empresa, mas sim após a realização de algum evento crítico (que pode ser fechamento de contrato, o ato de faturamento, recebimento de dinheiro etc. $)^{169}$.

Ainda no regime de competência, ao se falar de aproximação razoável (incisos I e II do art. 71), denota-se claramente o elemento de mensurabilidade (ou critério de objetividade) do princípio da realização. Ao se tratar de provisões que competirem ao período (inciso II do art. 71), não se cogita de limites fiscais ao registro de provisões, podendo-se, no contexto deste artigo, até falar de adoção do princípio da imparidade ${ }^{170}$. E, ainda, a busca pela vinculação das receitas e dos rendimentos e seus respectivos custos e despesas ( $\S 2^{\circ}$ do art. 71$)$ reflete uma preocupação com o emparelhamento (isto é, retrata fielmente um enfoque na apuração periódica e um princípio da realização das receitas e confrontação com as despesas) ${ }^{171}$.

Quanto ao regime de caixa, sublinha-se um aspecto da disponibilidade definida pelo inciso I do art. 72: considera-se como receita de um determinado período os rendimentos colocados à disposição do contribuinte em condições de serem por ele recebidos, à sua vontade. Este aspecto do regime de caixa parece extrapolar os limites do mero recebimento de recursos como evento de realização (em sua definição estrita) e passa

\footnotetext{
${ }^{169}$ Os dois enfoques de abordagem do princípio da realização e suas diferentes variações são tema do item 3.2.1 do Capítulo 3.

${ }^{170}$ Tratado adiante no item 3.4.3 do Capítulo 3, este princípio preconiza o registro cauteloso de despesas (antecipação de prejuízos futuros prováveis) e receitas (consideração apenas de receitas seguramente realizadas).

${ }^{171}$ Vide a discussão a respeito do emparelhamento no item 3.2.2 do Capítulo 3.
} 
a cogitar de um recebimento implícito como uma extensão do conceito de recebimento (definição ampla de recebimento).

Assumindo-se então que o regime de caixa permite ao contribuinte controlar o aspecto temporal da realização da renda por meio de aceleração ou postergação do recebimento e pagamento de diversos itens ${ }^{172}$, parece pertinente uma tal extensão do conceito de recebimento como meio de evitar a manipulação de resultados. É de se questionar, todavia, se o regime de caixa atualmente adotado no Brasil contempla essa extensão. O tema será mais bem explorado em item específico adiante ${ }^{173}$, bastando, por ora, sublinhar a definição dada pelo Parecer Normativo CST nº 85/1977, que parece refletir a adoção de tal critério:

"2.1 Com relação às receitas, todavia, no caso específico de rendimentos derivados da atividade agrícola, adota-se o regime financeiro ou de caixa, considerando-se como declaráveis no exercício financeiro a que se referir o ano em que foram as receitas recebidas ou colocadas à disposição do declarante, em condições de ser por ele realizadas, à sua vontade.” 174

Retomando o conteúdo dos referidos artigos do Anteprojeto, repete-se que a escassez de tempo para sua discussão e a urgência quanto à introdução de regras tributárias de adaptação à Lei nº 6.404/1976 tornaram necessária a adoção de via legislativa excepcional, o que resultou na edição do Decreto-lei no 1.598/1977. Porém, este ato legislativo não contemplou definições próprias do que seriam os regimes de competência e caixa.

Esta ausência de esclarecimentos quanto ao alcance dos referidos regimes, no entanto, acabou sendo suprida, no âmbito da legislação tributária, pelos diversos Pareceres Normativos editados, antes e depois do Decreto-lei, e que aproveitavam nitidamente a linguagem empregada no texto do Anteprojeto. Exemplo disso pode ser visto na explicação

\footnotetext{
${ }^{172}$ Cf. BITTKER, op. cit. (nota 66), p. 965.

${ }^{173}$ No item 3.2 do Capítulo 4, ao se abordarem os eventos de pagamento/recebimento como critérios de realização, comenta-se acerca do recebimento implícito e a teoria do constructive receipt discutida em outros países.

${ }^{174}$ Vale registrar também outro item do PN CST no 85/1977, o qual demonstra que o regime de caixa pode provocar o descasamento de receitas e despesas: "3.1 No exercício financeiro relativo ao ano da colheita, seguida da estocagem do respectivo produto, não há que se falar em receita, consoante o subitem 2.1 deste Parecer, embora os seus custos devam ser considerados como despesas de custeio do ano em que foram incorridos ou consumidos.

Desta forma, somente quando a produção, ou parte dela, for vendida, e cujo preço tenha sido recebido ou esteja à disposição do declarante é que haverá receita, cujo resultado, apurado segundo a forma a que estiver sujeito, será incluído como rendimento tributável na declaração de rendimentos do exercício financeiro correspondente."
} 
dada pelo PN CST n ${ }^{\circ}$ 58/1977 (editado pouco antes do Decreto-lei) ao que se entende por regime de competência:

“4.3- Finalmente, regime de competência costuma ser definido, em linhas gerais, como aquele em que as receitas ou despesas são computadas em função do momento em que nasce o direito ao rendimento ou a obrigação de pagar a despesa."

Além disso, o expediente dos Pareceres Normativos, embora possa ser considerado reprovável ${ }^{175}$, possibilitou eliminar muitas das controvérsias que decorreram da eleição dos regimes de competência e caixa como critérios de reconhecimento de receitas e despesas. O próprio PN CST n $n^{\circ}$ 58/1977 trazia mais detalhes sobre o que se considerava como nascimento do direito ou da obrigação ${ }^{176}$, esclarecendo ser relevante o atributo de incondicionalidade da receita ou da despesa e que tal aspecto deveria ser checado no contexto das relações jurídicas pertinentes. O balizamento dado pelos Pareceres Normativos a uma série de temas específicos será objeto das discussões que se apresenta adiante, no Capítulo 4, a respeito dos diferentes eventos de realização.

\subsubsection{Aquisição de disponibilidade}

Feita uma análise acerca do elemento disponibilidade econômica ou jurídica, e identificando-se tal fenômeno com os regimes contábeis de apuração (competência ou caixa), tem-se, até aqui, que o fato gerador do imposto de renda acontece no momento da aquisição de acréscimo patrimonial apurado por meio dos regimes de competência ou caixa. Falta-nos ainda compreender o sentido e a extensão do vocábulo aquisição.

Para tanto, convém retomar um exercício de pesquisa histórica para enfatizar os argumentos de ordem genética e histórica - que dão destaque à vontade do legislador e ao sentido que a norma tinha no contexto de sua produção -, para esclarecer a leitura que muitos autores dão ao vocábulo aquisição no art. 43 do CTN.

\footnotetext{
${ }^{175}$ Pois potencialmente atenta contra a separação de poderes.

176 “5. A primeira questão a examinar é a abrangência do que se entende por despesas pagas ou incorridas (art. 162. $\S 1^{\circ}$, do RIR/75), em cotejo com o momento em que nasce a obrigação de pagar a despesa, relativo ao regime de competência referido no item anterior.

6. Temos por assente que a obrigação de pagar determinada despesa (enquadrável como operacional) nasce quando, em face da relação jurídica que lhe deu causa, já se verificaram todos os pressupostos materiais que a tornam incondicional, vale dizer, exigível independentemente de qualquer prestação por parte do respectivo credor. Invariavelmente, tal despesa tem seu valor determinado ou facilmente quantificável. Este tipo de despesa guarda correspondência com o conceito de despesa consumida no mesmo exercício social, perfilhado por alguns compêndios de contabilidade."
} 
Voltando a atenção aos primórdios do artigo 43, nota-se que a redação proposta por Rubens Gomes de Sousa no Anteprojeto de CTN, elaborado em 1953, definia o momento temporal da tributação apenas com a expressão aquisição da disponibilidade de riqueza nova (sem referência aos atributos econômica ou jurídica) e totalmente atrelada ao conceito de renda-produto (teoria das fontes). O artigo proposto estava formulado nos seguintes termos:

“Art. 40. Compete privativamente à União instituir impôsto sôbre a renda e proventos de qualquer natureza, tendo como fato gerador da respectiva obrigação tributária principal a aquisição da disponibilidade de riqueza nova, em dinheiro ou suscetível de avaliação em dinheiro, proveniente do capital, do trabalho, ou da combinação de ambos".

Após as discussões em torno deste primeiro projeto, chegou-se a outra formulação para a incidência do imposto de renda:

“Art. 28. O impôsto sôbre a renda e proventos de qualquer natureza (...) tem como fato gerador a aquisição de riqueza nova produzida pelo capital, pelo trabalho, ou pela combinação de ambos"

Sobressai da leitura destas duas propostas a preservação das expressões aquisição e riqueza nova. Outrossim, é interessante observar que esta segunda formulação, elaborada em 1954, omitia a palavra disponibilidade, por entender que o tema já estava suficientemente esclarecido e regulamentado em outro artigo do Código ${ }^{177}$. No Relatório redigido por Rubens Sousa ${ }^{178}$, confirmava-se que os autores do Projeto tinham a intenção de conceituar como acréscimo patrimonial apenas aquilo que se obtivesse a título oneroso, isto é, como resultado da exploração do patrimônio. A expressão riqueza nova traduzia esta intenção, mas, na redação final, foi eliminada, por se considerar excrescente ${ }^{179}$.

Apesar de Rubens Sousa ter ressaltado que a ideia de renda como resultado de remuneração do patrimônio estava atrelada aos vocábulos proventos e disponibilidade, a

\footnotetext{
${ }^{177} \mathrm{O}$ artigo que teria tratado desta matéria resultou no artigo 116 do atual CTN, regulando o momento da ocorrência do fato gerador em situações de fato (inciso I) e em situações jurídicas (inciso II).

178 "Mas quanto a êsses ganhos [ganhos puramente gratuitos] não seria, de qualquer forma, aplicável o conceito de rendimento, nem mesmo o de "proventos", que traz implícita a ideia de remuneração. [...] Foi ao contrário aditada, como qualificativa de riqueza nova tributável, a circunstância de dever tratar-se de riqueza "produzida". Êsse esclarecimento, ligando a percepção do ganho ao elemento volitivo do seu titular na exploração do patrimônio de que decorre, contém, com efeito, implícitos os três fundamentos da conceituação teórica." MINISTÉRIO DA FAZENDA. Trabalhos da Comissão Especial do Código Tributário Nacional. Rio de Janeiro: Ministério da Fazenda, 1954, p. 128-129.

${ }^{179}$ Os trabalhos da Comissão que reexaminou o Projeto de CTN em 1964 não foram publicados, mas se tem o testemunho de Rubens Gomes de Sousa para afirmar que a Comissão entendeu dispensável a menção à riqueza nova, entendendo que elementos como disponibilidade já traduziam a ideia central. Cf. SOUSA, op. cit. (nota 153), p. 69-70.
} 
atenção da doutrina recaiu sobre o elemento aquisição. Nesse sentido, Carvalhosa afirma que "ao se falar em aquisição de disponibilidade, fala-se em acréscimo efetivo ao patrimônio do titular de uma determinada renda. Somente é tributável o acréscimo patrimonial quando ele é efetivamente verificável ou disponível pelo seu titular. Exclui-se dessa forma, a simples valorização do patrimônio como fato gerador do tributo, já que esta simples valorização nominal de um determinado patrimônio poderia desaparecer em momentos sucessivos pela desvalorização desse mesmo patrimônio, donde impossível mensurar o acréscimo patrimonial, já que ele não se efetivou e não pode, portanto, ser disponível pelo seu titular.",180

Ives Gandra também ressalta esta interpretação acerca do vocábulo aquisição, traduzindo a renda tributável como o acréscimo patrimonial derivado de um influxo ${ }^{181}$. Para tal conclusão, o jurista apoia-se nos ensinamentos de Bulhões Pedreira, que era enfático ao afirmar que a noção de renda adequada ao nosso sistema consistia no fluxo, assim entendido como algo que acresce, que entra no patrimônio, algo que é recebido ${ }^{182}$. Uma tal noção de renda parece remontar à noção linguística mais elementar de renda: aquela que recorda que a etimologia de income é o "que entra - comes in"183.

Mariz de Oliveira verifica afinidade entre a aquisição de disponibilidade e a realização da renda ${ }^{184}$. Mais ainda, aludindo ao conceito de receita, que, afinal, é um dos elementos integrantes da apuração da renda tributável, o consagrado especialista também frisa a ideia de influxo, ou entrada de algo no patrimônio como componente fundamental ${ }^{185}$ :

"receita é qualquer ingresso ou entrada de direito que se incorpore positivamente ao patrimônio, e que represente remuneração ou contraprestação de atos, atividades ou operações da pessoa titular do

\footnotetext{
${ }^{180}$ Cf. CARVALHOSA, op. cit. (nota 35), p. 193.

${ }^{181}$ Com as palavras do referido autor: "O fato gerador é a aquisição da disponibilidade econômica ou jurídica, que se realiza na ocorrência da elevação patrimonial de valores, bens ou direitos relativos. Por essa razão, explicita o legislador complementar que a renda e os proventos implicam, necessariamente, uma aquisição. A aquisição corresponde a algo que se acrescenta, que aumenta a patrimonialidade anterior, embora outros fatores possam diminuí-la. Por isto, o aumento como sinônimo de fluxo, lhe é pertinente.” Cf. MARTINS, op. cit. (nota 37), p. 265-266.

182 "No seu sentido vulgar, tanto a expressão "renda" quanto a "proventos" implica a ideia de fluxo, de alguma coisa que entra, que é recebida. Essa conotação justificaria, por si só, a afirmação de que melhor se ajustam ao nosso sistema constitucional são da renda como fluxo, e não de acréscimo (ou acumulação) de poder econômico ou de patrimônio líquido.” Cf. PEDREIRA, José Luiz Bulhões. Imposto de renda. Rio de Janeiro: APEC, p. 2-21, apud MARTINS, op. cit. (nota 37), p. 266 (nota de rodapé 5).

${ }^{183}$ Sobre tal associação linguística, cf. SOUSA, op. cit. (nota 150), p. 341 (item 11).

184 "Nesse sentido, a realização da renda confunde-se com a aquisição da disponibilidade econômica ou jurídica de renda ou de provento de qualquer natureza, pois essa aquisição marca o instante a partir do qual há acréscimo patrimonial e o imposto pode ser exigido [...]”. Cf. OLIVEIRA, op. cit. (nota 31), p. 372.
} 
mesmo, ou remuneração ou contraprestação do emprego de recursos materiais, imateriais ou humanos existentes em seu patrimônio ou por ele custeados, de modo que a receita ainda traz consigo esta característica de

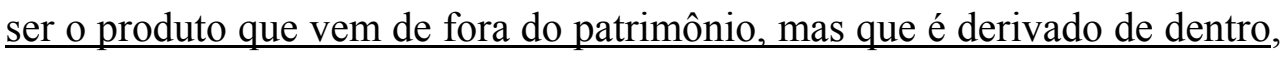
por derivar de atos, operações ou atividades da pessoa titular do patrimônio, ou do emprego de recursos que compõem esse patrimônio, de que resulte algum benefício direto para a pessoa a qual, em contraprestação, o remunera por isso." Grifo nosso.

Além disso, ao definir receita como "um novo direito - na sua existência, se se tratar de direito antes inexistente, ou na sua valoração por novo negócio jurídico bilateral ou multilateral, quanto a direitos anteriormente existentes", Mariz comentou em nota que o "aumento de valor que pode se constituir em receita é necessariamente aquele que derive de um negócio jurídico bilateral ou multilateral, e não de uma simples revalorização de saldos contábeis, procedida por ato interno do titular do patrimônio e meramente refletida na sua contabilidade." $" 186$

Consoante esse entendimento, o art. 43 do CTN, posto que tenha albergado o conceito de renda-acréscimo, seria avesso a uma tributação do acréscimo patrimonial derivado de aumento do valor dos bens já integrantes do patrimônio da pessoa (física ou jurídica), salvo se tal aumento se fundar em um negócio jurídico (leia-se, uma troca no mercado). Em outras palavras, reputando-se válido tal entendimento, é de se concluir que, embora a sistemática de renda-acréscimo, por sua natureza, envolva a comparação da situação patrimonial no início e no fim do período de apuração, não se podem computar as variações patrimoniais ocorridas no período, porque o conceito de renda expresso pelo CTN limita-se a onerar a renda oriunda de fora do patrimônio, ou cuja valoração seja certificada por fatos alheios ao patrimônio (troca no mercado).

Retomando mais uma vez o argumento genético, anota-se que, no Relatório da Comissão de 1954, após ter-se salientado a importância do caráter remuneratório da renda, mencionou-se que permanecia estranha à definição de renda a hipótese de reavaliação de ativo, "mas essa exclusão foi deliberada, porquanto só alcança as reavaliações puramente "monetárias" ou de reajustamento de valores contábeis, que efetivamente não têm conteúdo econômico; inversamente, as reavaliações que traduzem acréscimo patrimonial

\footnotetext{
${ }^{185}$ Cf. OLIVEIRA, op. cit. (nota 31), p. 89-90.

${ }^{186}$ Cf. OLIVEIRA, op. cit. (nota 31), p. 104 (e nota de rodapé 29).
} 
efetivo continuam no campo da incidência, como ganhos provenientes do capital" ${ }^{\text {"187 }}$. Logo, o legislador não ignorava a possibilidade de se tributar a renda decorrente de acréscimo de valor dos ativos (ganhos de detenção), mas condicionava a incidência à verificação de acréscimo patrimonial efetivo.

De todo o exposto, pode-se afirmar que a expressão aquisição de disponibilidade alude ao princípio da realização. Contudo há restrições legais, impostas pelo conceito de renda do CTN, para que este princípio eleja, como critério relevante do reconhecimento de receitas e despesas, o evento acréscimo (ou decréscimo) de valor. Tais variações somente podem ser reconhecidas na apuração da renda tributável caso traduzam acréscimo (ou decréscimo) patrimonial efetivo, isto é, se houver segurança na sua constatação. Este último requisito enfatiza o critério da prudência, ínsito ao princípio da realização.

\subsection{Artigos 109, 110, 116 e 117 e as relações com o Direito Civil}

Já se informou aqui a prevalência, na doutrina e na jurisprudência brasileira, da noção de que a renda tributável é essencialmente sinônimo de acréscimo patrimonial e, dos ensinamentos de Pontes de Miranda, Carvalhosa, Brandão Machado e Mariz de Oliveira ${ }^{188}$, destacou-se que esta noção remete ao conceito de patrimônio tal como definido no âmbito do Direito Civil. Além disso, sendo o patrimônio uma universalidade formada com os direitos que possuam valor econômico, o acréscimo patrimonial tributável pelo imposto de renda necessariamente implicaria a constatação de que houve a entrada de direitos novos ao patrimônio do contribuinte ${ }^{189}$.

Pois bem, tendo-se assentado que o conceito de renda tributável está atrelado ao conceito de patrimônio, o qual é dado pelo Direito Civil, pode-se afirmar que, na CF 1988, a referência ao elemento renda como delimitador de competência tributária da União pressupõe, ainda que indiretamente, o conceito de acréscimo patrimonial dado pelo Direito Civil (particularmente em matéria da forma e do momento da aquisição de direitos). Em vista disso, o sistema tributário brasileiro impõe sólidas barreiras para que o legislador tributário não extrapole a definição dada pelo Direito Civil, pois definir como renda algo

\footnotetext{
${ }^{187}$ Cf. Trabalhos ..., op. cit. (nota 178), p. 129.

${ }^{188}$ Vide item 2.1 acima.

189 Potencialmente, o acréscimo de valor dos direitos pré-existentes também deveria revelar acréscimo patrimonial, mas esta forma de tributação enfrenta um certo impedimento em vista do CTN ter restringido a tributação ao acréscimo de riqueza nova. Sobre este tema e a possibilidade de se tributar determinados acréscimos de valor efetivos, vide o item 2.2.2 deste Capítulo.
} 
que não o seja pode resultar em invasão de competência tributária alheia 190 (particularmente a competência atribuída aos Estados, Municípios e à própria União para tributar o patrimônio $\left.{ }^{191}\right)$.

Este é o espírito do arts. 109 e 110 do $\mathrm{CTN}^{192}$, que retiram do legislador tributário a competência para definir os institutos, conceitos e formas de Direito Privado, particularmente aqueles que se mostrem presentes (ainda que implicitamente) na distribuição de competências promovida pela Constituição Federal de 1988. Os dois artigos são interdependentes, pois o conteúdo genérico do art. 109 desdobra-se no $110^{193}$.

Por isso, a definição de patrimônio deve ser buscada no Direito Privado ${ }^{194}$. É importante recordar, nesse diapasão, a observação, já adiantada aqui acima, de que a submissão ao Direito Privado pode não afastar completamente a indeterminação do conceito de renda, haja vista que, mesmo no âmbito do Direito Privado, a definição, por exemplo, quanto à patrimonialidade, de direitos sobre direitos (direitos formativos e expectativos) é controversa ${ }^{195}$.

De todo modo, a referência ao Direito Privado (e ao Direito Civil em particular) permite concluir que o princípio da realização, orientado por um enfoque no evento crítico, obedece prioritariamente aos eventos definidos pelo Direito Civil como determinantes da aquisição de direitos (entrada de direitos ao patrimônio). Em outras palavras, o momento da aquisição do direito definido segundo os ditames de Direito Civil é o critério que informa a determinação do evento crítico relevante para o reconhecimento de receitas e despesas na órbita do Direito Tributário.

$\mathrm{Na}$ exposição singela de João Francisco Bianco, enfocando dispositivos do Código Civil atual, tem-se que se considera "adquirido o direito quando definitivamente

\footnotetext{
${ }^{190}$ O tema é bem explorado por Misabel Derzi. Cf. DERZI, op. cit. (nota 125), p. 284-291.

${ }^{191}$ CF de 1988, arts. 153, VI e VII, 155, III e 156, I.

192 "Art. 109. Os princípios gerais de direito privado utilizam-se para pesquisa da definição, do conteúdo e do alcance de seus institutos, conceitos e formas, mas não para definição dos respectivos efeitos tributários.

Art. 110. A lei tributária não pode alterar a definição, o conteúdo e o alcance de institutos, conceitos e formas de direito privado, utilizados, expressa ou implicitamente, pela Constituição Federal, pelas Constituições dos Estados, ou pelas Leis Orgânicas do Distrito Federal ou dos Municípios, para definir ou limitar competências tributárias."

${ }^{193}$ Cf. BALEEIRO, op. cit. (nota 19), p. 685.

${ }^{194}$ Segundo o magistério de Mariz de Oliveira: "Exatamente por isso, a lei tributária não pode agregar ao conceito de "patrimônio" algo que não seja participante do patrimônio segundo a lei privada, ou retirar dele qualquer dos seus componentes, ainda segundo esta lei, porque, se o fizer, estará esbarrando num elemento intrínseco à própria competência constitucional para a cobrança do imposto de renda. [...]

Ou seja, violar o conceito de "patrimônio" seria violar um conceito do direito privado absorvido implicitamente pela definição constitucional de competência tributária (embora expressamente pelo CTN) e, neste caso, aplica-se o art. 110, que se refere textualmente a conceitos de direito privado utilizados "implicitamente" pela Constituição Federal para definir ou limitar competências tributárias." Cf. OLIVEIRA, op. cit. (nota 31), p. 53-54.
} 
incorporado ao patrimônio do seu titular; quando não mais estiver pendente de condição suspensiva (art. 125 do Código Civil); quando não for direito eventual (art. 130); ainda que sujeito a termo (art. 131). Ocorre o fato gerador do imposto de renda, portanto, quando o direito à renda estiver definitiva e incondicionalmente adquirido pelo seu titular"196.

Nesse particular, a matéria de Direito Civil pertinente à existência, validade e eficácia dos negócios jurídicos, bem como à aquisição e exercício dos direitos é ampla e não se pretende aqui abordar extensivamente os detalhes deste tema. $\mathrm{O}$ conhecimento dos aspectos gerais quanto à aquisição de direito parece suficiente para o direcionamento da discussão, reservando-se a abordagem de alguns aspectos específicos de determinados negócios jurídicos para a exposição que se desenvolve no Capítulo $4^{197}$.

Tomando de empréstimo algumas das conclusões apresentadas no minucioso estudo feito por Mariz de Oliveira, para que se conheça, de maneira geral, o momento da aquisição de um direito (e, portanto, o momento temporal da realização), não se pode prescindir de examinar alguns artigos do Código Civil de 1916 que, mesmo sem encontrar equivalentes no Código Civil atual, são de grande importância didática ${ }^{198}$.

Assim, o artigo 74 do antigo Código Civil esclarecia que os direitos se adquirem por ato do adquirente ou por intermédio de outrem e são divisados em atuais e futuros, conforme seu estágio de aquisição (saõ atuais os completamente adquiridos e os futuros, aqueles cuja aquisição ainda não se completou). Quanto aos direitos futuros, eles podem ser deferidos (quando sua aquisição pende somente de arbítrio do sujeito) e não deferidos (quando se subordina a fatos ou condições falíveis) ${ }^{199}$.

Os artigos 118 e 123 do antigo Código Civil e, bem assim, o artigo $6^{\circ}, \S 2^{\circ}$ da Lei de Introdução ao Código Civil (que trata da proteção ao direito adquirido) também são importantes para o deslinde da matéria ${ }^{200}$. Nos dois primeiros se nota que o direito não está

\footnotetext{
195 Tema já adiantado acima, no item 2.1 deste Capítulo.

${ }^{196}$ Cf. BIANCO, op. cit. (nota 15), p. 321.

${ }^{197}$ Especialmente sobre a existência de direitos expectativos na situação em que o direito estiver sujeito à condição suspensiva. Vide a esse respeito o item 2.1 do Capítulo 4.

${ }^{198}$ Cf. OLIVEIRA, op. cit. (nota 31), p. 134-135.

${ }^{199}$ Código Civil de 1916 - “Art. 74. Na aquisição dos direitos se observarão estas regras:

I - adquirem-se os direitos mediante ato do adquirente ou por intermédio de outrem;

II - pode uma pessoa adquiri-los para si, ou para terceiros;

III - dizem-se atuais os direitos completamente adquiridos, e futuros os cuja aquisição não se acabou de operar.

Parágrafo único. Chama-se deferido o direito futuro, quando sua aquisição pende somente do arbítrio do sujeito; não deferido, quando se subordina a fatos ou condições falíveis."

${ }^{200}$ Código Civil de 1916 - "Art. 118. Subordinando-se a eficácia do ato à condição suspensiva, enquanto esta se não verificar, não se terá adquirido o direito, a que ele visa.

Art. 123. O termo inicial suspende o exercício, mas não a aquisição do direito."
} 
adquirido quando submetido a condição suspensiva e, por outro ângulo, está adquirido quando sujeito a termo inicial. O artigo citado da Lei de Introdução parece refletir, em largas linhas, a mesma ideia.

A noção geral de que a aquisição do direito pode ser afetada pela imposição de condições vem retratada também nos artigos 116 e 117 do $\mathrm{CTN}^{201}$. Segundo aponta Ives Gandra, o art. 116 é aquele que explicita o que seria a disponibilidade jurídica tributável para fins do imposto de renda ${ }^{202}$. A propósito, cabe frisar, como já apontado acima ${ }^{203}$, que, no entender da Comissão que discutiu o Anteprojeto de CTN, o artigo que resultou no atual artigo 116 era o que explicitava o conteúdo de disponibilidade jurídica de renda.

Fazendo-se a leitura dos dois artigos combinados no que respeita a situações jurídicas de que decorram efeitos tributários, observa-se que o fato gerador somente ocorrerá quando essa situação estiver definitivamente constituída de acordo com o direito aplicável (art. 116, inciso II). Além disso, o art. 117, inciso II, do CTN, informa que, sendo a situação jurídica sujeita à condição suspensiva, não há fato gerador enquanto esta não for implementada. No respeitante às situações meramente de fato, o inciso I do art. 116 declara que somente há fato gerador quando presentes as circunstâncias materiais necessárias a que produzam os efeitos que normalmente lhe são próprios, ou seja, quando esses fatos forem definitivos e efetivos ${ }^{204}$.

Em vista disso, verifica-se que o princípio da realização, identificado com os critérios de materialidade, objetividade, mensurabilidade e troca no mercado ${ }^{205}$, encontra no CTN não só a indicação de metodologias para sua implementação (os regimes de

Lei de Introdução ao Código Civil - "Art. $6^{\circ}$ A Lei em vigor terá efeito imediato e geral, respeitados o ato jurídico perfeito, o direito adquirido e a coisa julgada.

[...]

$\S 2^{\circ}$ Consideram-se adquiridos assim os direitos que o seu titular, ou alguém por êle, possa exercer, como aquêles cujo comêço do exercício tenha têrmo pré-fixo, ou condição pré-estabelecida inalterável, a arbítrio de outrem."

${ }^{201}$ Código Tributário Nacional - "Art. 116. Salvo disposição de lei em contrário, considera-se ocorrido o fato gerador e existentes os seus efeitos:

I - tratando-se de situação de fato, desde o momento em que o se verifiquem as circunstâncias materiais necessárias a que produza os efeitos que normalmente lhe são próprios;

II - tratando-se de situação jurídica, desde o momento em que esteja definitivamente constituída, nos termos de direito aplicável.

[...]

Art. 117. Para os efeitos do inciso II do artigo anterior e salvo disposição de lei em contrário, os atos ou negócios jurídicos condicionais reputam-se perfeitos e acabados:

I - sendo suspensiva a condição, desde o momento de seu implemento;

II - sendo resolutória a condição, desde o momento da prática do ato ou da celebração do negócio."

${ }^{202}$ Cf. MARTINS, op. cit. (nota 37), p. 269.

${ }^{203}$ Vide nota 177 e o texto que a introduz.

${ }^{204}$ Cf. OLIVEIRA, op. cit. (nota 31), p. 136-139.

${ }^{205}$ Vide item 1.2.4 supra. 
competência ou caixa, orientados pelo enfoque no evento crítico) e certas restrições (de que haja aquisição de riqueza nova - direito novo - ou, quando menos, efetividade do acréscimo patrimonial), mas também se depara com um elemento direcionador relevante, qual seja, o de que o momento da aquisição do direito deve ser orientado pelas regras de Direito Civil.

Assim, voltando-se à crítica de Brandão Machado, de que o CTN desconhece o princípio da realização ${ }^{206}$, pode-se agora afirmar, neste ponto da exposição, que o intérprete que busca nos dispositivos legais do CTN uma referência explícita a este princípio, seus contornos, suas formas de implementação, corre mesmo o risco de se frustrar. Como já dito, os dispositivos do CTN são amplos e imperfeitos, desatendendo nitidamente à tarefa incumbida ao legislador complementar para definir o fato gerador do imposto de renda. Porém, se o que se procura são indicações gerais da presença deste princípio, os principais vestígios de sua origem encontram-se no CTN.

Contudo, deve se dar razão ao erudito jurista quando se percebe que os principais elementos do princípio da realização foram definidos no âmbito do Direito Comercial, mais especificamente no contexto dos princípios de contabilidade geralmente aceitos (aos quais a legislação tributária do imposto de renda confessadamente se submete). Lá se verá também que, em última análise, o critério relevante para determinação do ponto temporal da realização obedece, em geral, às regras do Direito Civil. Com isso se confirma, portanto, que o referido princípio se constrói a partir de diversas regras, poucas delas integrantes do que se denomina para fins didáticos e científicos como sendo Direito Tributário.

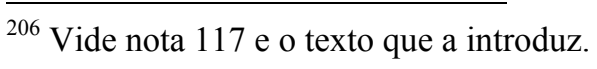




\section{CAPÍTULO 3 - 0 PRINCÍPIO CONTÁBIL E TRIBUTÁRIO DA} REALIZAČ̃̃O DA RENDA

Em essência, constatou-se, nos Capítulos precedentes, que o princípio da realização da renda congrega os atributos pertinentes à espécie normativa princípio, dado que se limita a traçar uma diretriz (de que a tributação ocorra no momento em que houver segurança suficiente da conclusão e permanência dos eventos geradores de renda) que pode ser implementada em diferentes graus Carece, portanto, de complementação por regras, estas sim encarregadas de definir o critério apropriado para a concretização do princípio, escolhendo dentre os diversos momentos temporais possíveis (acréscimo de valor, ocorrência da atividade econômica prestacional, recebimento de dinheiro ou bens, consumo etc.).

Os conceitos de renda formulados pelas Ciências das Finanças e da Economia oferecem alternativas correlatas de implementação do princípio da realização. Verifica-se, porém, que os conceitos mais justos de renda são também os mais impraticáveis, e os mais praticáveis, os menos justos. Dificuldades de valoração e liquidez na adoção de um conceito amplo de renda acabaram consagrando o fenômeno da troca realizada no mercado como evento crítico relevante da realização. Todavia, tal critério causa distorções no comportamento econômico, gerando os efeitos de acumulação e trava, aumentando a complexidade e violando a igualdade. Por isso, já se discutem atualmente propostas para contornar e amenizar tais problemas, mediante a adoção paulatina de regimes de tributação marcada a mercado (já uma realidade no Reino Unido).

No Brasil, o modelo rígido de distribuição constitucional de competências impõe a modelagem de um conceito de renda que não atinja o consumo e tampouco o patrimônio, sob pena de invasão de competências alheias ou próprias à União Federal. $\mathrm{O}$ conteúdo mínimo do conceito constitucional de renda reflete, assim, os atributos pertinentes aos princípios da monetarização, da apuração periódica, da renda líquida e da realização da renda. Ao definir os critérios pertinentes à concretização do princípio da realização, o legislador deve fazer escolhas, sopesando não só os princípios da universalidade, generalidade e praticabilidade, mas também considerando outros objetivos e princípios da ordem econômica.

O princípio da realização, assomado ao nível do conceito constitucional de renda, requer observância aos critérios de materialidade (ocorrência dos fatos relevantes), 
objetividade (possibilidade de mensuração de seu valor), prudência (segurança na sua apuração) e transacional (troca de mercado). Transplantado para o nível da legislação complementar, o princípio da realização encontra razoável embasamento para sua concretização por meio dos regimes de competência ou caixa. Tal orientação, confirmada pelo vínculo claro da legislação tributária com a apuração do lucro comercial, permite constatar que o CTN delegou aos princípios de contabilidade geralmente aceitos a tarefa de definir os critérios pertinentes de realização da renda. A interpretação sistemática do CTN permite concluir, ainda, que o princípio da realização da renda deve favorecer um enfoque no evento crítico e obedecer aos ditames do Direito Civil.

Assim, haja vista a amarração do Direito Tributário ao Direito Comercial, notase que o princípio da realização da renda, tal como adotado para fins tributários, deflui diretamente dos princípios de contabilidade geralmente aceitos (PCGA), assumindo, neste contexto, a forma do chamado princípio da competência (ou, mais propriamente, o princípio da realização das receitas e confrontação com as despesas). Importa, portanto, verificar que influência os princípios próprios da apuração do lucro comercial (contabilidade comercial) exercem sobre a apuração da renda tributável e, bem assim, sobre a modelagem do princípio tributário da realização da renda.

Sendo o conjunto de normas da contabilidade comercial passível de reconhecimento, para fins da ciência do Direito, como um subsistema normativo próprio (fundado na legislação comercial), pode-se considerar os princípios de contabilidade geralmente aceitos como pertencentes ao plano jurídico ${ }^{1}$. Não obstante trate-se de matéria também afeta ao Direito, o estudo dos princípios contábeis no Brasil tem recebido menor atenção das ciências jurídicas que das contábeis. Com isso, faz-se necessário o aproveitamento de estudos produzidos na área das ciências contábeis, incursão esta justificada pela notória vocação interdisciplinar do tema objeto de análise.

Aproveitando-se tal ponto de partida, uma das principais questões suscitadas neste capítulo consiste em saber se o princípio da realização adotado no contexto dos

\footnotetext{
${ }^{1}$ Sobre a consideração do conjunto de regras da contabilidade comercial como objeto juridicizado passível de reconhecimento, para fins da ciência do direito, como um subsistema normativo próprio, cf. MARTINEZ, Atonio Lopo. A Linguagem Contábil no Direito Tributário. 2002. Dissertação de Mestrado apresentada ao Programa de Pós-Graduação em Direito do Estado da Pontifícia Universidade Católica de São Paulo, São Paulo, 2002.

Sobre a inclusão dos princípios contábeis no plano jurídico e considerações quanto à sua força normativa, ver RENCK, Renato Romeu. Imposto de renda da pessoa jurídica - Critérios constitucionais de apuração da base de cálculo: uma proposta de interpretação sistemática do Direito. Porto Alegre: Livraria do Advogado, 2001, p. 121-127.
} 
objetivos perseguidos pela contabilidade comercial (prestação de contas, apuração do patrimônio e do lucro, proteção dos credores e cálculo dos pagamentos e dividendos) coincide com o princípio da realização que informa a legislação tributária (cujo objetivo maior é orientar a concretização do princípio da capacidade contributiva com respeito à segurança jurídica).

Como visto acima, o princípio da realização deveria fornecer padrões de conduta alternativos e igualmente viáveis na concretização de um certo estado ideal de coisas. Para o Direito Tributário parece certo que, dentre um conjunto de eventos possíveis de realização, diferenciados entre si conforme o grau de liquidez, certeza e risco que oferecem, o legislador tenha liberdade para escolher aquele que melhor se acomode à realidade econômico-financeira dos contribuintes. $\mathrm{O}$ ato de liquidação, por exemplo, pode constituir o evento de realização em determinadas hipóteses ${ }^{2}$. Em outras, poderá valer o ato que conferir certeza suficiente do contribuinte quanto à aquisição futura do ganho.

A proposição suscitada neste ponto do presente estudo é a de que o princípio da realização aplicado na legislação comercial e integrante dos PCGA também permite sua implementação em diferentes graus e demonstra similitude de conteúdo com o princípio tributário de realização. Conforme será evidenciado neste Capítulo, a implementação deste princípio na área contábil atende a requisitos semelhantes àqueles que imperam na área tributária, ou seja, o lucro apurado pela contabilidade comercial também se mostra restrito, exibindo apenas os acréscimos patrimoniais que carreguem os atributos de definitividade e incondicionalidade e sejam apurados consoante a realidade jurídica das relações e situações, sobretudo em consonância com os ditames do Direito Civil.

Para enfrentar tais questões e expor uma noção abrangente do princípio da realização, o presente Capítulo centra-se, primeiramente, na relação entre o Direito Tributário e o Direito Contábil para, em seguida, tratar dos princípios de contabilidade geralmente aceitos, identificando a relação do princípio da realização com outros princípios, postulados e convenções contábeis relevantes. Depois de tal bosquejo, passa-se à abordagem dos elementos fundamentais do princípio da realização e, ao final, discorre-se acerca dos princípios contábeis que mais se inter-relacionam com o princípio da realização. Em síntese, neste Capítulo, aborda-se a essência do princípio da realização, deixando para

\footnotetext{
${ }^{2}$ Cf. MACHADO, Brandão. Imposto de renda. Ganhos de capital. Promessa de venda de ações. In: Revista de direito tributário atual, v. 11/12. São Paulo: Resenha Tributária/IBDT, 1992, p. 3201.
} 
o derradeiro Capítulo a análise do(s) critério(s) de realização adotado(s) em algumas situações específicas.

\section{Visão geral da influência do Direito Contábil no Direito Tributário}

O forte vínculo do Direito Tributário, mormente em matéria de imposto de renda de pessoas jurídicas, com o subconjunto de princípios e regras do Direito Contábil incita o conhecimento prévio do funcionamento desta relação. Este item do estudo prestase, assim, a expor aspectos fundamentais da forma como Contabilidade e Direito Tributário interagem para guiar a apuração da renda tributável, enfocando-se o princípio da realização da renda e também os principais pontos de divergência entre essas duas áreas. Atenção especial é dedicada também aos novos rumos trazidos pela Lei nº 11.638/2007 e às recentes alterações promovidas pela Medida Provisória no 449/2008.

\subsection{Direito, Contabilidade e Economia}

Em linhas gerais, a Contabilidade é o ramo do conhecimento humano que se dedica a desenvolver um sistema de informação e avaliação destinado a prover seus usuários com demonstrações e análises de natureza econômica, financeira, física e de produtividade, referentes à entidade que é objeto de contabilização. Trabalha informações de natureza econômica, mas apresenta sua própria visão sobre tais fenômenos, potencialmente divergindo do tratamento proposto na Economia. Possui um grande relacionamento com os aspectos jurídicos que cercam o patrimônio e busca aplicar vigorosamente o princípio da essência sobre a forma, para evidenciar a realidade econômica subvertida por formatos inadequados ${ }^{3}$.

Quanto ao entrelaçamento da Contabilidade com a Economia e o Direito na abordagem do fenômeno renda, convém salientar um aspecto importante pertinente à orientação diferenciada que tais ramos de conhecimento possam privilegiar. Deve-se atentar, de primeiro, que determinadas análises econômicas, contábeis e financeiras estão necessariamente preocupadas com o futuro. Sua orientação é, por hipótese, ex ante. Porém, para fins tributários, a renda ex post é o que importa, isto é, a distribuição das obrigações

\footnotetext{
${ }^{3}$ IUDÍCIBUS, Sérgio de; MARTINS, Eliseu; GELBCKE; Ernesto Rubens. Manual de contabilidade das sociedades por ações: aplicável às demais sociedades. $7^{a}$ São Paulo: Atlas, 2007, p. 29-31.
} 
tributárias preocupa-se com o que efetivamente aconteceu e não com o que se podia esperar ${ }^{4}$.

Conforme aponta Misabel Derzi, a apuração da renda tributável por pessoas jurídicas é notadamente centrada na realização de uma justiça retrospectiva (tradicional) ${ }^{5}$. Está aí uma notável diferença entre o Direito, de um lado, e a Contabilidade, de outro. Enquanto a Contabilidade se preocupa com a continuidade da empresa e a efetiva preservação do capital social, o Direito Tributário do imposto de renda, embora também se ocupe de onerar a renda sem afetar o patrimônio ${ }^{6}$, ignora determinadas práticas que se preocupam em manter a empresa em funcionamento contínuo e viável. Misabel comenta que a busca por justiça prospectiva, i.e, orientada para o futuro, imporia a eliminação de barreiras, por exemplo, à compensação de prejuízos fiscais de períodos passados ou futuros ${ }^{7}$.

Uma maior conciliação entre as visões contábil e jurídica de renda demandaria, ademais, a adoção do princípio da imparidade ${ }^{8}$, a consideração do menor valor de mercado de ativos circulantes ${ }^{9}$, dentre outros mecanismos que são imprescindíveis a uma apuração fidedigna da renda, correta em termos tanto jurídicos quanto contábeis. É importante distinguir que não se pretende, com isso, trasladar conceitos próprios da Contabilidade

\footnotetext{
${ }^{4}$ Cf. WARREN, Alvin, Would a Consumption Tax Be Fairer Than an Income Tax? In: The Yale Law Journal, v. 89, n. 6, maio de 1980, p. 1117-1120.

5 “O sentido estático de renda, que somente se encontra encerrado em um período de tempo, é um artifício ou uma ficção legislativa, que tem como objetivo realizar a justiça retrospectiva ou tradicional, aquela que olha para os ganhos e despesas passados e presentes, sem divisar o futuro." Cf. DERZI, Misabel Abreu Machado. Justiça prospectiva no imposto sobre a renda. In: TÔRRES, Heleno Taveira (coord.). Direito tributário internacional aplicado, v. IV, São Paulo: Quartier Latin, 2007, p. 59.

${ }^{6}$ Tributar a renda sem onerar o patrimônio é mandamento que decorre da rígida distribuição constitucional de competências, como já se viu aqui nos itens 1.1 .2 e 2.3 do Capítulo 2.

${ }^{7}$ Cf. DERZI, Misabel Abreu Machado. Aquisição de disponibilidade econômica ou jurídica. O princípio da não-paridade de tratamento entre lucro e prejuízo. Compensação de prejuízos. In: BALEEIRO, Aliomar. Direito tributário brasileiro, atual. por Misabel Abreu Machado Derzi. 11 ${ }^{\mathrm{a}}$ Rio de Janeiro: Forense, 2001, p. 304-306.

${ }^{8}$ Permitindo-se, na apuração do lucro tributável, o cômputo das provisões aceitas pela legislação comercial. A respeito do princípio da imparidade vide o item 3.4.3 deste Capítulo.

${ }^{9} \mathrm{O}$ art. 183, inciso II, da Lei $\mathrm{n}^{\circ} 6.404 / 1976$ permite criar provisão para ajustar itens de estoque ao menor valor de mercado. Todavia, a proibição geral quanto à dedutibilidade de provisões no âmbito do imposto de renda contraria tal diretiva comercial. Cf. IUDÍCIBUS, et alli, op. cit. (nota 3), p. 107-108. O tema será também abordado no item 3.4.1, aqui adiante.
} 
Gerencial para a Contabilidade Comercial ou Financeira. As medidas apontadas acima são inerentes a uma Contabilidade Financeira dirigida pelas normas do Direito Comercial ${ }^{10}$.

\subsection{Estágio atual do Direito Contábil no Brasil}

No nível da legislação ordinária, o Direito Contábil está atualmente estruturado nos artigos 175 a 205 da Lei no 6.404/1976 (Lei das Sociedades por Ações - LSA), bem como nos artigos 1.177 a 1.195 do Código Civil (Lei $n^{\circ}$ 10.406/2002). Particularmente, quanto às disposições deste último, esclarece-se que, a despeito de alguns de seus dispositivos sugerirem avanços ${ }^{11}$, a interpretação que parece mais adequada, sistematicamente falando, é aquela que preza pela leitura integrada do Código Civil ao sistema normativo pré-existente, introduzido pela LSA. Do contrário, leituras isoladas do Código Civil poderiam conduzir à restauração de institutos contábeis ultrapassados, confusos e incoerentes ${ }^{12}$. Nesse sentido, pouca atenção se dedica aqui às regras e princípios refletidos pelo Código Civil ${ }^{13}$, centrando-se a análise na LSA.

A propósito, é no contexto da própria LSA que se têm engendrado as principais inovações em matéria de legislação contábil, especialmente em vista das recentes alterações promovidas pela Lei $n^{0} 11.638 / 2007$ (e também pela MP $n^{\circ} 449 / 2008$ ), que buscam a convergência do Direito Contábil brasileiro com os padrões internacionais de contabilidade adotados nos principais mercados de valores mobiliários ${ }^{14}$. Nesse diapasão, determinou-se à Comissão de Valores Mobiliários a elaboração de normas visando tal

\footnotetext{
${ }^{10}$ Uma coisa é a Contabilidade comportar também objetivos de ordem gerencial que conduzem à elaboração de cenários, simulações, e até mesmo apurações de lucro voltadas a ressaltar o resultado econômico (incorporando conceitos da geração contínua de valor): contabilidade baseada em valor. Outra coisa é a própria contabilidade financeira tradicional, baseada em critérios transacionais de apuração de lucro, servir-se de medidas recomendadas e práticas aceitas para uma apuração segura do lucro comercial. A respeito da Contabilidade baseada em valor e a gestão econômica de empresas, cf. CATELLI, Armando (coord.). Controladoria: uma abordagem da gestão econômica - GECON. São Paulo: Atlas, 1999.

${ }^{11}$ Os artigos 1.188 e 1.189 , por exemplo, ao dizerem, no primeiro caso, que o balanço deve exprimir com "fidelidade" a "situação real" da empresa, e, no outro, que o balanço apura "resultado econômico", poderiam indicar a adoção de um sistema de contabilidade baseada em valor, permitindo a mensuração de ativos e passivos a valores correntes. Cf. MARTINS, Eliseu. Atrocidades contábeis no novo Código Civil ( $1^{\mathrm{a}}$ parte). Boletim Temática Contábil e Balanços, $n^{\circ}$ 40. São Paulo: IOB, 2002, p. 1-3, 5-7.

${ }^{12}$ Cf. IUDÍCIBUS, et alli, op. cit. (nota 3), p. 12-14. Também sobre as "atrocidades" do Código Civil, cf. MARTINS, Eliseu. Atrocidades contábeis no novo Código Civil ( $2^{\mathrm{a}}$ e última parte). Boletim Temática Contábil e Balanços, $n^{\circ}$ 41. São Paulo: IOB, 2002.

${ }^{13}$ Porquanto, por ora, pode-se considerar tais dispositivos como veiculadores de normas jurídicas vigentes, porém desprovidas de eficácia social. Nas palavras dos líderes na área “[...] já dá para vermos as atrocidades contábeis cometidas nessa Lei $\mathrm{n}^{\circ} 10.406$, de janeiro de 2002, que entrou em vigor no início de janeiro de 2003, e, esses aspectos, felizmente, não têm sido observados pelos profissionais de contabilidade." Cf. IUDÍCIBUS, et alli, op. cit. (nota 3), p. 14.
} 
convergência (cf. novo $\S 5^{\circ}$ do art. 177 da LSA), permitindo, ainda, a criação de entidade técnica específica para auxiliar em tal tarefa (cf. art. 10-A da Lei nº 6.385/1976). Embora sejam de observância obrigatória apenas por sociedades por ações e sociedades de grande porte $^{15}$, muitas das inovações devem ser seguidas também por sociedades limitadas (e outras formas associativas), porquanto elas se apoiam na estrutura contábil básica definida a partir da LSA.

A própria MP $n^{\circ} 449 / 2008$ admite que os métodos e critérios contábeis que sejam inovados para adaptar o Direito Contábil brasileiro aos padrões internacionais (particularmente quanto ao reconhecimento de receitas, custos e despesas e, enfim, ao cômputo do lucro líquido) suscitam efeitos automáticos no âmbito tributário ${ }^{16}$, especialmente para as pessoas jurídicas sujeitas à tributação pelo regime de lucro real ${ }^{17}$.

É bem verdade que esta empreitada de convergência do Direito Contábil conta atualmente com a vantagem de não necessariamente causar efeitos tributários imediatos. $\mathrm{Na}$ penúltima alteração promovida à LSA (por meio da Lei $\mathrm{n}^{\circ} 11.638 / 2007$ ), inseriu-se dispositivo legal ( $\$ 7^{\circ}$ do art. 177 da LSA) que pretendia garantir que os ajustes contábeis efetuados exclusivamente para harmonização das normas contábeis não causassem impactos tributários ${ }^{18}$. Atualmente, no entanto, a perspectiva é outra. Com a edição da MP $n^{\circ} 449 / 2008$, revogou-se o citado $\$ 7^{\circ}$ do art. 177 da LSA ${ }^{19}$, instituiu-se um Regime Tributário de Transição (que permite aplicar os métodos e critérios contábeis vigentes em 31/12/2007 para o biênio 2008-2009) e prenunciou-se a edição de uma lei que "discipline os efeitos tributários dos novos métodos e critérios contábeis, buscando a neutralidade tributária",20.

\footnotetext{
${ }^{14}$ Leia-se: as normas do International Accounting Standards Board (IASB) - Conselho de Padrões Internacionais de Contabilidade. Cf. Resolução CFC no 1.055/2005.

${ }^{15}$ Conforme definição dada pelo art. $3^{\circ}$ da Lei ${ }^{\circ} 11.638 / 2007$.

${ }^{16}$ Para diferir o momento da adoção de tais critérios na apuração de tributos federais das pessoas jurídicas sujeitas aos regimes de lucro real ou presumido, a MP n $\mathrm{n}^{\circ} 449 / 2008$ criou a possibilidade de se adotar um Regime Tributário de Transição (RTT) para o biênio 2008-2009 (ou além). A esse respeito cf. artigos 15 a 22 da MP n ${ }^{\circ} 449 / 2008$.

${ }^{17}$ É evidente que a alteração em critérios de reconhecimento de receitas também afeta as pessoas jurídicas optantes pelos regimes de lucro presumido, Simples Nacional (e demais regimes que se fundamentam no elemento receitas). Não obstante isso, a MP $\mathrm{n}^{\circ}$ 449/2008 (artigo 20) estendeu o RTT apenas para as empresas do regime de lucro presumido.

${ }^{18}$ LSA “Art. 177 [...] \& $7^{\mathbf{0}}$ Os lançamentos de ajuste efetuados exclusivamente para harmonização de normas contábeis, nos termos do $\S 2^{-}$deste artigo, e as demonstrações e apurações com eles elaboradas não poderão ser base de incidência de impostos e contribuições nem ter quaisquer outros efeitos tributários." Convém salientar que tal dispositivo encontra-se atualmente revogado, por força do artigo 65, X, da MP nº 449/2008.

${ }^{19}$ É de se questionar se tal revogação seria capaz de produzir efeitos já em 2008, especialmente para as situações em que a adoção dos novos métodos e critérios contábeis provocar aumento da carga tributária.

${ }^{20}$ Vide artigo $15, \S 1^{\circ}$, da MP n ${ }^{\circ} 449 / 2008$.
} 
A despeito do quadro legislativo tributário comentado acima se mostrar inconstante, deve-se atentar para uma mudança firme no paradigma de produção normativa contábil, sendo digno de nota o fato de que a entidade técnica criada para auxiliar nesta tarefa (o Comitê de Pronunciamentos Contábeis - CPC) conta com poder de rever e reformular os princípios, normas e padrões de contabilidade de uma maneira geral, e não apenas para fins de harmonização ${ }^{21}$. Assim, espera-se uma verdadeira atualização dos princípios de contabilidade geralmente aceitos, com inovação particularmente dos critérios de reconhecimento de receitas e despesas ${ }^{22}$.

\subsection{Direito Contábil e Direito Tributário}

Como já tangenciado por diversas vezes aqui, é forçoso reconhecer que o conjunto das normas contábeis compõe um ramo específico do Direito. Além disso, repisase que, ao se admitir caráter normativo à Contabilidade, fala-se naturalmente da Contabilidade Financeira, ou seja, aquela voltada para a elaboração das demonstrações financeiras que, guiadas por objetivos próprios do Direito Comercial, fornecem informações relevantes decorrentes de fatos jurídicos praticados pela empresa (lucro passível de distribuição, quantidade e valor do patrimônio, distribuição do valor agregado). Esta necessária observância do Direito pela Contabilidade já era reconhecida por De Plácido e Silva ${ }^{23}$, sendo enfatizada também por Pfaltzgraff ${ }^{24}$ e outros autores que se ocuparam da matéria no passado mais recente ${ }^{25}$.

\footnotetext{
${ }^{21}$ A despeito do quanto apontado por Elidie Palma Bifano, o CPC não detém competência para emitir pronunciamentos contábeis que sejam de "obrigatória observância para todos os contadores e em todos os balanços". O que há é um forte compromisso dos órgãos reguladores (CVM, CFC, Bacen e SUSEP) para emissão de atos próprios, esses sim com força normativa, adotando os pronunciamentos do CPC. Cf. BIFANO, Elidie Palma. Aspectos contábeis da Lei 11.638/07: Reflexos legais. In: ROCHA, Sérgio André (coord.). Direito tributário, societário e a reforma da Lei das S/A. São Paulo: Quartier Latin, 2008, p. 50. Cf. IUDÍCIBUS, et alli, op. cit. (nota 3), p. 16.

${ }^{22} \mathrm{O}$ começo deste processo de maior elucidação e sistematização já pode ser visualizado no Pronunciamento Conceitual Básico que aprovou a "Estrutura para a Preparação e a Apresentação das Demonstrações Contábeis" (Framework for the Preparation and Presentation of Financial Statements - do IASB), transformado em norma jurídica pela Resolução CFC no 1.121/2008 e Deliberação CVM no 539/2008 (sobre o reconhecimento de receitas e despesas, vide itens 92 a 98 ).

23 "Razoàvelmente, pois, sendo a governadora de fatos econômicos, os quais se podem gerar de fatos jurídicos, ou dos quais se podem estabelecer negócios com relações jurídicas definidas, a Contabilidade, embora se apresente, fundamentalmente, uma disciplina de caráter econômica, não se pode afastar do Direito, mantendo com ele necessária subordinação.

[...] quando funciona, ditando as regras necessárias ao registro dos fatos econômicos, para que os valores referentes se encorporem ao patrimônio da entidade, há que atender às regras legais ou normais jurídicas dispostas para êsse fim. É que, nesta face, os fatos econômicos registráveis ou contabilizáveis se fundam em operações de tôda sorte, geralmente, importando em fatos ou negócios jurídicos, de que resultam obrigações ou deveres jurídicos a cumprir." Cf. SILVA, De Plácido e. Normas jurídicas na contabilidade. $2^{\mathrm{a}}$ Curitiba: Guaíra, 1950, p. 10.
} 


\subsubsection{Princípio da congruência com os parâmetros contábeis}

No Direito Tributário do imposto de renda, verifica-se uma situação de dependência com relação às normas contábeis. Tal como evidenciado no Capítulo 1 deste trabalho $^{26}$, a adoção da teoria do balanço pelo Decreto-lei $\mathrm{n}^{\mathrm{o}} 1.598 / 1977^{27}$ permite inferir a admissão do chamado princípio da congruência com os parâmetros contábeis. Nesse sentido, aproveita-se o arcabouço jurídico formado pelas normas contábeis relativas à apuração do lucro comercial (dentre elas, os princípios de contabilidade geralmente aceitos) para efetuar o cálculo do imposto de renda de pessoas jurídicas.

Esse modelo de ligação entre o Direito Contábil e o Direito Tributário é normalmente abordado com referência à liderança da Contabilidade. Outras formas de ligação entre as demonstrações contábeis e as demonstrações fiscais seriam: desconexão, identidade, liderança do Direito Tributário ou dominância do Direito Tributário ${ }^{28}$.

Fala-se de liderança da Contabilidade (e não dominância) porque, apesar deste vínculo, a legislação tributária pode considerar como não dedutíveis para o IRPJ determinadas despesas que tiverem sido consideradas pela Contabilidade e tratar como não tributáveis pelo IRPJ algumas receitas integrantes do lucro comercial. Para eliminar tais valores na apuração da base de cálculo do IRPJ, a legislação determina o ajuste do lucro comercial, mediante adições e exclusões, respectivamente. Isso, por si só, já responde por um certo descasamento entre os lucros comercial e fiscal.

\footnotetext{
24 "E, queiram ou não, a Contabilidade mantém íntimas relações com o Direito. Não se lhe pode tirar tais relações. Nem negar. Senão, vejamos: o Balanço decorre de uma contabilidade legal. Se não existir a legalidade da contabilidade, essa contabilidade não tem valor. É necessário que a contabilidade obedeça às regras de direito, para que tenha valor jurídico. Pode estar perfeitamente certa, sob o ponto de vista contábil, e errada sob o ponto de vista jurídico. Não terá valor. É necessário, repetimos, que os dois pontos - contábil e jurídico - se harmonizem, para que possamos dizer que a contabilidade está perfeita." Cf. PFALTZGRAFF, Rogério. Organização do balanço. Rio de Janeiro: Edições Minerva, 1958, p. 81.

25 “A doutrina jurídica da Contabilidade, que é o Direito Contábil, tornou-se necessária para diminuir as, talvez, inevitáveis manipulações sociais no comportamento dos tomadores de decisões econômicas via informações financeiras adulteradas, especialmente nos campos dos Direitos Comercial, Financeiro, Econômico e Tributário. [...]

Exemplo disso é o do Estado que, através da normatização jurídica da Contabilidade (Direito Contábil), ao estabelecer a estrutura e o conteúdo de uma demonstração financeira (contábil), objetiva coletar elementos para uma ação fiscalizadora (Direito Tributário), econômica (Direito Econômico) e social (Direito Social)." Cf. ROMEU, Alceu de Castro; MENDES, Celso; CARNEIRO, Paulo Baltazar; PISCITELLI, Roberto Bocaccio. Contabilidade tributária: doutrina e direito contábeis. São Paulo: ESAF/Atlas, 1985, p. 22.

${ }^{26}$ Vide o item 4 do Capítulo 1.

${ }^{27}$ Cf. particularmente os arts. $6^{\circ}, \S 1^{\circ}$ e 67 , inciso XI.
} 
Porém, o que importa gravar é que, definida a liderança do Direito Comercial relativamente ao Direito Tributário, aquilo que for admissível no primeiro, deverá sê-lo no segundo (salvo se, em hipótese excepcional, a legislação tributária expressamente dispuser de modo diverso). No que respeita à concretização do princípio da realização, por exemplo, pressupondo-se que a apuração do lucro comercial segue os ditames do Direito Civil e respeita critérios estritamente jurídicos, quando uma receita ou uma despesa for reconhecida pelo Direito Comercial, então não há impedimentos para que tal se estenda à apuração do lucro para fins fiscais ${ }^{29}$.

Esta relação entre o Direito Tributário e a Contabilidade pode ser ilustrada da seguinte forma:

Princípio da predominância do balanço comercial
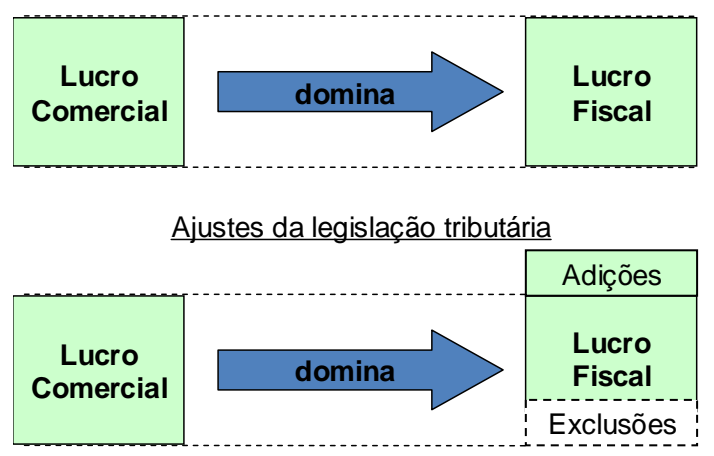

${ }^{28}$ Para aprofundamento quanto às diferentes formas de vínculo entre a Contabilidade e Tributação, ver NOBES, Christopher; OLIVERAS, Ester; PUIG, Xavier. The changing relationship between tax and financial reporting in Spain. Economics and Business Working Paper No. 782: Universitat Pompeu Fabra, Outubro de 2004. Disponível em: <http://ssrn.com/abstract=848667>. Acesso em 18 nov. 2008.

${ }^{29}$ A esse respeito, segundo nos informa Beisse, o Tribunal Financeiro Alemão tem a seguinte visão acerca do princípio da congruência com os parâmetros contábeis: "O BFH assumidamente interpreta o princípio da coongruência de maneira restritiva, o que muito se critica. O Tribunal restringe tal princípio essencialmente à compulsoriedade advinda do Direito Comercial. Traduzindo isso para o nosso tema, o Tribunal alude ao seguinte:

aa) quando o reconhecimento de um ganho para fins comerciais for obrigatório ou permitido, então se deve assumir que houve realização para fins tributários;

bb) se o reconhecimento de um prejuízo ainda não realizado for obrigatório para fins comerciais, então isso também vale para o balanço fiscal. Se o reconhecimento de um prejuízo para fins comerciais não for compulsório, mas apenas admitido, então ele só deverá ser reconhecido para fins tributários se for também admitido na órbita tributária e o contribuinte tiver efetivamente exercido seu direito de reconhecimento deste prejuízo na apuração comercial (o chamado princípio da congruência invertido)." Tradução livre de: Bekanntlich legt der BFH, was viel kritisiert wird, den Massgeblichkeitsgrundsatz eng auf. Er beschränkt ihn im wesentlichen auf zwingendes Handelsrecht. Er besagt, auf unser Thema übertragen: aa) Wenn handelsrechtlich Gewinnverwirklichung vorgeschrieben oder zugelassen ist, so muss steuerrerchtlich die Realisierung angenommen werden. bb) Ist der handelsrechtlich Verlustausweis nicht vorgeschrieben, aber zulässig, so wird er in der Steuerbilanz nur anerkannt, wenn er auch steuerrechtlich zulässig ist und der Steuerpflichtige von seinem handelsrechtlichen Verlustausweisrecht in concreto Gebrauch gemacht hat (sog. umgekehrter Massgeblichkeitsgrundsatz). Cf. BEISSE, Heinrich. Gewinnrealisierung - Ein systematischer Überblick über Rechtsgrundlagen, Grundtatbestände und grundsätzliche Streitfragen." In: RUPPE, Hans Georg (coord.). Gewinnrealisierung im Steuerrecht: Theorie und Praxis der Gewinnverwirklichung durch Umsatzakt und durch Steuerentstrichung sowie des Besteuerungsafuschubs. Köln: Otto Schmidt, 1981, p. 16. 
Atualmente, com a já citada convergência do Direito Contábil aos padrões internacionais de contabilidade (i.e., às normas do IASB), o patrimônio contábil será afetado por aumentos e diminuições, particularmente em decorrência de sua avaliação a valor justo. Essas variações, no entanto, devem ser registradas em contrapartida da conta de "ajustes de avaliação patrimonial", não afetando imediatamente o lucro comercial (cf. nova redação do art. $182, \S 3^{\circ}$, da LSA) e, portanto, não influenciam pronta e diretamente a apuração de tributos. São as mudanças em métodos e critérios de reconhecimento de receitas, custos e despesas que devem, estas sim, gerar impactos tributários relevantes ${ }^{30}$.

Em resumo, tem-se atualmente a seguinte relação entre esses dois contextos de apuração de lucros:

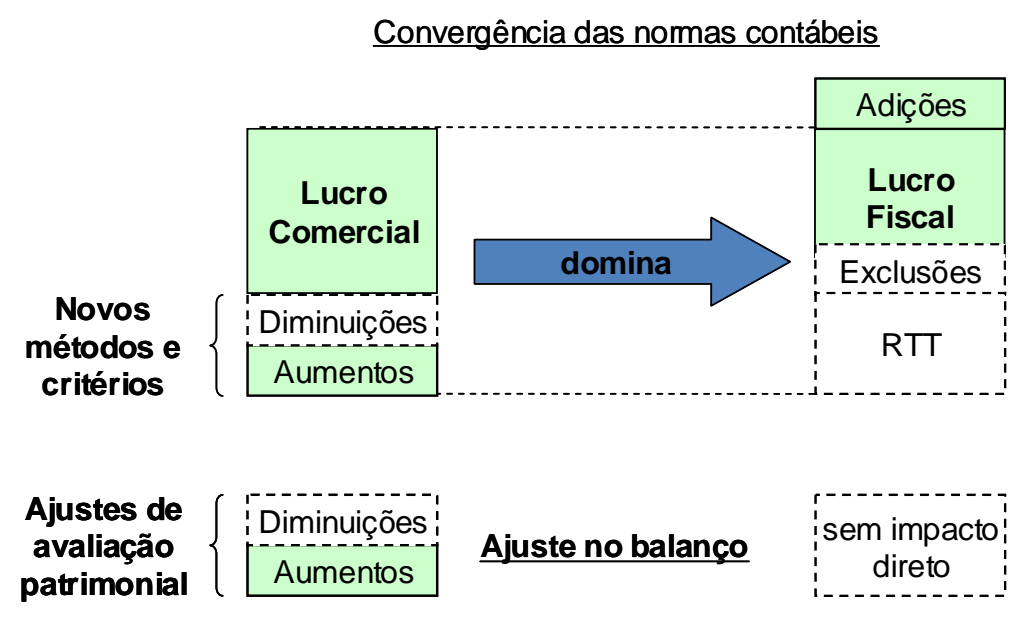

\subsubsection{Balanço contábil e balanço fiscal}

Concluindo este item, importa ressaltar ainda o que se entende por balanço fiscal e sua diferenciação com o balanço contábil. Primeiro, cumpre esclarecer que essa terminologia, bastante empregada na doutrina ${ }^{31}$, merece esclarecimento para uma melhor definição a respeito das demonstrações financeiras envolvidas ${ }^{32}$.

\footnotetext{
${ }^{30}$ Conforme se comentou acima, no item 1.2 deste Capítulo.

${ }^{31}$ A imprecisão conceitual é também um defeito visível no arts. 1.179, 1.186 e 1.189 do Código Civil, pois tais dispositivos empregam o termo balanço para se referirem à demonstração do resultado do exercício. Cf. IUDÍCIBUS, et alli, op. cit. (nota 3), p. 13.

32 Conforme alerta Erymá Carneiro: “Torna-se, pois, indispensável cuidado científico e jurídico em nos referirmos a balanço, pois não há balanço, há balanços. Daí as expressões que convém serem cuidadas distintamente, tais como Balanço de Exercício, Balanço Final, Balanço Fiscal, Balanço Extraordinário, Balanço Estático, Balanço Dinâmico, Balanço Oficial, Balanço Interno, Balanço Comercial e outras usadas de forma generalizada pelos diversos autores, mas que mostram situações distintas." Cf. CARNEIRO, Erymá. O balanço fiscal no direito e na contabilidade. Rio de Janeiro: S.N., 1950, p. 40-41.
} 
Quando se fala em balanço comercial, normalmente a referência diz respeito às duas demonstrações financeiras mais comuns: o balanço patrimonial e a demonstração de resultado do exercício.

O que se denominava de balanço fiscal não significava, até o começo de 2008, a obrigação de se elaborarem demonstrações financeiras específicas para atender ao usuário Fisco. O lucro fiscal sempre foi apurado com base em registros extracontábeis, demonstrativos auxiliares que não afetavam o balanço comercial $^{33}$. Isto era, inclusive, o que se prescrevia fundamentalmente no $\S 2^{\circ}$ do art. 177 da LSA, em sua redação original ${ }^{34}$, sendo válida a observação feita por Assis Tavares: "nos países onde a tributação das empresas é feita com base nos resultados do exercício, o balanço físcal não tem muito interesse" 35 .

Embora fosse possível prenunciar a necessidade de elaboração de balanço autônomo para o atendimento de exigências exclusivamente fiscais ${ }^{36}$, tal determinação fortaleceu-se somente em 2008 com as alterações promovidas pela Lei $n^{\circ}$ 11.638/2007 ao $\S 2^{\circ}$ do art. 177 da LSA (em particular, em seu inciso $\mathrm{II}^{37}$ ). Vigeu por curto tempo, todavia,

33 "O lucro que se apura em Balanço é o lucro comercial. Êsse lucro é um. Outro lucro é o chamado fiscal. Não quer dizer que tenhamos que levantar dois balanços, um comercial, outro fiscal, realmente, objetivamente. Não. Mesmo que se não levante, êsses balanços existem. Isto porque, de um lado as normas do direito positivo impõem regras a que se deve obedecer; de outro lado os estatutos ou os contratos também estabelecem normas. Êsses dois aspectos da questão formam e dão origem ao que pròpriamente chamamos de Balanço comercial, e, consequentemente, lucro comercial. De outro lado ainda, surge a lei do impôsto de renda, que determina normas também para a apuração do lucro. Quando se obedece a tais normas, então, eis que estamos dando vida ao lucro fiscal. E, por extensão, ao Balanço Fiscal. Não se preocupe o contabilista em realizar o seu Balanço Fiscal; que se realize o seu Balanço Comercial, êsse sim. Depois, se for preciso, em uma folha de demonstrativo especial para o Impôsto de Renda, face ao capítulo IV, art. 37 e seguintes, restabeleça ditos cálculos. Estará formado aí, o Balanço Fiscal." Cf. PFALTZGRAFF, op. cit. (nota 24), p. 85.

34 “Art. 177 [...] § $2^{\circ}$ A companhia observará em registros auxiliares, sem modificação da escrituração mercantil e das demonstrações reguladas nesta Lei, as disposições da lei tributária, ou de legislação especial sobre a atividade que constitui seu objeto, que prescrevam métodos ou critérios contábeis diferentes ou determinem a elaboração de outras demonstrações financeiras."

${ }^{35}$ Cf. TAVARES, Assis. Do balanço real ao balanço fiscal. $2^{a}$ Lisboa: Livraria Clássica, 1978, p. 101.

${ }^{36}$ Alberto Xavier menciona um "princípio da autonomia dos balanços" quando comenta que o tratamento dos juros sobre capital próprio, como despesas (para fins fiscais) e como distribuição de resultado (para fins contábeis), deveria demandar a elaboração de dois balanços autônomos. Cf. XAVIER, Alberto. Natureza jurídico-tributária dos "juros sobre capital próprio" face à lei interna e aos tratados internacionais. In: Revista dialética de direito tributário. v. 21. São Paulo: Dialética, junho de 1997, p. 10.

37 “§ $2^{\mathbf{0}}$ As disposições da lei tributária ou de legislação especial sobre atividade que constitui o objeto da companhia que conduzam à utilização de métodos ou critérios contábeis diferentes ou à elaboração de outras demonstrações não elidem a obrigação de elaborar, para todos os fins desta Lei, demonstrações financeiras em consonância com o disposto no caput deste artigo e deverão ser alternativamente observadas mediante registro:

I - em livros auxiliares, sem modificação da escrituração mercantil; ou 
este prenúncio de segregação entre Direito Tributário e Direito Contábil. Isso porque, com as modificações recentes, trazidas pela MP $n^{\circ} 449 / 2008$, retorna-se ao modelo anterior, de predomínio do Direito Contábil e utilização de registros ou livros auxiliares para demonstração de elementos relevantes à apuração de tributos ${ }^{38}$.

A elaboração de demonstrações financeiras outras, dedicadas exclusivamente ao atendimento da legislação tributária (balanço fiscal), volta a ser apenas uma possibilidade, prevista no $\S 2^{\circ}$ do art. 177 da LSA, dependente de regulamentação.

Diante dessa possibilidade, é de se questionar, no entanto, se a legislação brasileira atual já não determina a elaboração de demonstrações financeiras exclusivamente fiscais.

É verdade que não há dispositivo legal tributário que sistematize a elaboração de um balanço patrimonial. A maior preocupação da legislação tributária até aqui concentrou-se em regular elementos da ordem contábil dinâmica, tratando da passagem do lucro comercial ao fiscal. Porém, é de se ressaltar que diversas regras tributárias apontam para elementos contábeis estáticos, participantes de um balanço patrimonial. Basta enfatizar o exemplo dos juros sobre capital próprio ${ }^{39}$, que se calculam sobre um patrimônio líquido que não é propriamente o mesmo apontado na contabilidade comercial, pois a legislação tributária manda excluir a conta de ajustes de avaliação patrimonial (cf. MP $n^{\circ}$ 449/2008, art. 57). Diversos outros dispositivos da legislação tributária referem-se a itens do balanço patrimonial que podem não necessariamente decorrer da contabilidade comercial (mas sim de uma contabilidade comercial "ajustada" para atender a fins fiscais ${ }^{40}$ ). Apesar de tais dispositivos, não parece possível inferir a exigência para elaboração de um balanço patrimonial exclusivamente fiscal.

Ainda assim, vale sublinhar a ponderação de Natanael Martins, para quem a realização de dois balanços não afasta o balanço fiscal de atender aos princípios de

II - no caso da elaboração das demonstrações para fins tributários, na escrituração mercantil, desde que sejam efetuados em seguida lançamentos contábeis adicionais que assegurem a preparação e a divulgação de demonstrações financeiras com observância do disposto no caput deste artigo, devendo ser essas demonstrações auditadas por auditor independente registrado na Comissão de Valores Mobiliários."

${ }^{38}$ Vide a última alteração ao $\S 2^{\circ}$ do art. 177 da LSA, promovida pelo art. 36 da MP n ${ }^{\circ}$ 449/2004.

${ }^{39}$ Vide a menção à opinião de Alberto Xavier a esse respeito na nota de rodapé 36 supra (neste Capítulo).

${ }^{40}$ Nesse sentido, vale citar que alguns investimentos em sociedades coligadas ou controladas também olham para a conta de patrimônio líquido. O lucro arbitrado pode ser calculado sobre uma variedade de contas patrimoniais (por exemplo, sobre os ativos circulante, realizável a longo prazo e permanente), assim como uma série de operações de reorganização empresarial podem ser efetivadas a "valor contábil". 
contabilidade geralmente aceitos ${ }^{41}$. É a respeito de tais princípios que se passa a discorrer no próximo item deste trabalho, devendo-se assinalar, das constatações feitas acima, que o momento histórico da convergência das normas contábeis deverá gerar um maior aclaramento acerca do princípio contábil da realização e, conquanto sejam conforme o Direito, tais orientações deverão valer também para a apuração da renda tributável.

\section{Princípios de contabilidade geralmente aceitos (PCGA)}

Considerando-se que a legislação tributária expressamente indica os preceitos da lei comercial como de observância obrigatória na determinação da renda tributável ${ }^{42}$, este item tratará especificamente do papel exercido pelos princípios de contabilidade geralmente aceitos (PCGA) na ligação entre o lucro contábil e o lucro fiscal. Considerando-se que tais princípios compõem mandamentos imperativos fundamentais da contabilidade comercial $^{43}$, questiona-se aqui se os objetivos buscados pela apuração do lucro comercial identificam-se com aqueles preconizados na determinação do lucro sujeito à tributação, a ponto de se aceitar a ingerência da legislação comercial sobre a tributária neste aspecto.

Particular atenção será dedicada a entender o que são os PCGA, qual sua origem e natureza jurídica e, mais ainda, quais são os principais aspectos do princípio da realização identificados no conjunto normativo dos PCGA. Enfim, busca-se entender como os PCGA são identificáveis como fonte normativa do Direito Tributário e, em última análise, do princípio da realização.

Este enfoque se justifica em vista de diversas decisões administrativas que, pouco a pouco, vêm constatando a importância e reconhecendo a aplicação dos PCGA no âmbito da tributação. É o que se verifica, por exemplo, nos acórdãos n ${ }^{\text {os }}$ 101-96.073, de

\footnotetext{
${ }^{41}$ Cf. MARTINS, Natanael. A reforma da lei das sociedades anônimas: Lei 11.638/2007 e seus impactos na área tributária. In: ROCHA, op. cit. (nota 21), p. 362.

${ }^{42}$ Decreto-Lei $n^{\circ}$ 1.598/1977 - "Art. $6^{\circ}$ Lucro real é o lucro líquido do exercício ajustado pelas adições, exclusões ou compensações prescritas ou autorizadas pela legislação tributária.

$\S \mathbf{1}^{\mathbf{0}}$ - O lucro líquido do exercício é a soma algébrica do lucro operacional (art. 11), dos resultados não operacionais, do saldo da conta de correção monetária (art. 51) e das participações, e deverá ser determinado com observância dos preceitos da lei comercial." - Grifo nosso.

${ }^{43}$ Lei ${ }^{0}$ 6.404/1976 - "Art. 177. A escrituração da companhia será mantida em registros permanentes, com obediência aos preceitos da legislação comercial e desta Lei e aos princípios de contabilidade geralmente aceitos, devendo observar métodos ou critérios contábeis uniformes no tempo e registrar as mutações patrimoniais segundo o regime de competência."
} 
29/03/2007, e 107-07.458, de 04/12/2003, e 107-06.012, de 12/07/200044, emanados do Primeiro Conselho de Contribuintes, os quais trataram especificamente do confronto entre o princípio da competência (ou realização) e o princípio da prudência. A esse respeito, transcreve-se aqui um trecho do acórdão no 107-06.012 (voto do Conselheiro Relator Paulo Roberto Cortez) que torna evidente a aplicação dos PCGA em Direito Tributário:

"Não obstante as bem ponderadas considerações da recorrente postas nos autos do processo e em seus memoriais, penso que justamente em face dos princípios contábeis que reqem a contabilidade $e_{\text {, }}$ consequentemente, a apuração do lucro real e a base de cálculo da contribuição social sobre o lucro, o lançamento não deve prevalecer.

Com efeito, se é certo de que o regime que impõe a determinação do lucro líquido é o regime de competência, não menos certo é de que este pode e deve ser apurado pela aplicação de todos os princípios de contabilidade geralmente aceitos, dentre os quais o próprio princípio da competência (ou, mais especificamente, de realização da receita), balizado, temperado, pelo princípio da prudência ou do conservadorismo (convenção do conservadorismo, segundo alguns doutrinadores). (...)

Com efeito, se, de conformidade com o disposto do Decreto-lei 1.598/77 o lucro líquido, ponto de partida para a definição do lucro real, base de cálculo do IRPJ e, consequentemente, também da base de cálculo da contribuição social sobre o lucro, deve ser determinado com observância dos preceitos da legislação comercial (Art. $\left.6^{\circ}, \S 1^{\circ}\right)$, se, a teor do disposto na lei das sociedades anônimas, o lucro líquido da companhia deve ser apurado com obediência aos princípios de contabilidade geralmente aceitos (Lei 6404/76. art. 177), tem-se que todos esses princípios, sem exceção, foram juridicizados e não somente podem como devem ser observados, tanto pelo contribuinte quanto pelo fisco obviamente." Grifo nosso.

\footnotetext{
${ }^{44} \mathrm{O}$ conteúdo desses acórdãos será objeto de análise no item 2.4.2 deste Capítulo. Vale citar também o acórdão $n^{\text {o }} 108-08.319$, proferido pela $8^{\text {a }}$ Câmara do Primeiro Conselho de Contribuintes em 19/05/2005, que destaca a dominância dos princípios contábeis sobre a legislação tributária.
} 


\subsection{Definição}

O reconhecimento dos PCGA pela legislação brasileira efetivou-se por meio da LSA, que, em seu artigo 177, os reconhece expressamente e os integra ao sistema normativo jurídico-contábil ${ }^{45}$. A busca por princípios orientadores da atividade contábil reflete um movimento mundial iniciado desde a crise do mercado de ações de Nova Iorque em $1929^{46}$ e que teve, como elemento marcante, naquela época, a mudança de enfoque da contabilidade, deixando de atender exclusivamente ao público interno (administração), para passar a apresentar informações aos investidores e acionistas ${ }^{47}$.

No Brasil, a definição do que sejam tais PCGA em regulamentações e doutrinas contábeis tem se revelado incipiente para fins do estudo de seu conteúdo, funções e posição hierárquica jurídica, pois, conforme já bem apontado por Fábio Konder Comparato, o documento jurídico que define a "Estrutura Conceitual Básica de Contabilidade"48 não se ocupa em traçar o fundamento de validade jurídica dos PCGA ${ }^{49}$. Comparato, inconformado, como não poderia deixar de ser, com determinadas regras de

\footnotetext{
${ }^{45}$ Nenhum dos atos legais anteriores relativos à regulação da contabilidade (Lei ${ }^{\circ}$ 556/1850 - Código Comercial -, Decreto-lei $n^{\circ}$ 2.627/1940, e Decreto-lei $n^{\circ} 486 / 1969$ ) faziam menção a princípios da ordem contábil. O Parecer Normativo CST no 347/1970 falava de "princípios técnicos ditados pela Contabilidade". Foi, enfim, a Lei no 6.404/1976 que se os incluiu no sistema normativo (vide transcrição do art. 177 dessa Lei na nota de rodapé 43 supra neste Capítulo).

${ }^{46}$ Apontam-se, como alguns problemas das demonstrações financeiras da época, a falta de uniformidade e a ausência de regras para registro de depreciação e avaliação de ativos. Cf. HENDRIKSEN, Eldon S.; VAN BREDA, Michael F. Teoria da Contabilidade. $5^{\text {a }}$ Trad. Antonio Zoratto Sanvincente. São Paulo: Atlas, 2007 , p. 57-58. Reformas promovidas a partir da década de 30 tiveram por causa a descoberta de falsidades contábeis. As regras de publicidade não foram suficientes para promover o interesse dos credores. Assim, a reforma promovida em 1931, na Alemanha, teve por objetivos: (i) manutenção do capital como garantia de credores, (ii) determinação correta do ganho distribuível em favor do empresário e acionistas. Cf. JOST, Paul. Der Gewinnbegriff im Handels- und Steuerrecht, zugleich ein Beitrag zur Lehre von der Handelsund Steuerbilanz. Würzburg: Richard Mayr, 1940, p. 41. Sobre a origem da expressão em 1930, cf. PEDREIRA, Bulhões José Luiz. Finanças e demonstrações financeiras da companhia: conceitos fundamentais. Rio de Janeiro: Forense, 1989, p. 547.

${ }^{47}$ Cf. HENDRIKSEN; VON BREDA, op. cit. (nota 46), p. 75-76. Segundo Paul Jost: "Cresce assim a demanda pela determinação do ganho com precaução [...] o balanço comercial, ao contrário do balanço do comerciante, é um 'balanço de divisão do lucro"'. Tradução livre de: Daraus erwächst die Forderung den Gewinn vorsichtig zu ermitteln [...] die aktienrechtlich Bilanz ist im Gegensatz zu der des Kaufmanns eine “Gewinnverteilungsbilanz". Cf. JOST, op. cit. (nota 46), p. 41.

${ }^{48}$ Vide particularmente o item 3 da Estrutura Conceitual Básica de Contabilidade. Esta Estrutura decorreu de um estudo feito pelo IBRACON (antigo Instituto Brasileiro de Contadores e atual Instituto dos Auditores Independentes do Brasil) e aprovada pela CVM (Comissão de Valores Mobiliários) por meio da Deliberação $\mathrm{CVM} \mathrm{n}^{\circ}$ 29/1986, ainda vigente.

${ }^{49}$ Cf. COMPARATO, Fábio Konder. O irredentismo da "nova contabilidade" e as operações de "leasing". In: Revista de direito mercantil: industrial, econômico e financeiro. Nova Série, ano XXVI, no 68. São Paulo: Revista dos Tribunais, out-dez. 1987, p. 52.
} 
auditoria que claramente pretendiam afastar o império da lei em razão dos PCGA ${ }^{50}$, interpreta o art. 177 da LSA para sustentar que os PCGA são fontes subsidiárias do Direito que, não estando previstos expressamente em lei, seriam mais bem caracterizados como uma forma de costume, uma vez que decorrem de "prática geral, reiterada e uniforme de determinado comportamento, acompanhada da convicção de sua obrigatoriedade". E conclui, então, que, na qualidade de fontes subsidiárias do Direito Contábil, os PCGA têm aplicação unicamente nas matérias em que não haja lei expressa em contrário ${ }^{51}$.

As conclusões do respeitável comercialista são válidas, pois, como já muito se ressaltou aqui, a aplicação dos PCGA na área tributária, por exemplo, depende da inexistência de lei expressa veiculadora de regra específica. Porém, as duras críticas de Comparato parecem exagerar no ponto em que equiparam os PCGA a regras, parecendo sugerir que não conteriam normas de caráter finalístico ou mandamentos de otimização, mas tão-somente determinações específicas e claras de comportamento ${ }^{52}$. Tal análise obscurece o fato de que determinados PCGA, como é o caso do princípio da prudência, por exemplo, realmente têm a natureza de princípio geral e atuam como tal (afastando a aplicação de subprincípios ou regras mais específicas). A nosso ver, a lei pode escolher baixar regras em contrariedade a determinados princípios contábeis ${ }^{53}$ e, em tais casos, deve mesmo prevalecer a lei, todavia, isto não é indicativo de que o princípio não exista ou não deva servir de orientação para a resolução de situações concretas.

Outro ponto de destaque no estudo de Comparato é a menção à forma de produção e reconhecimento dos PCGA. O notável jurista aponta, com maestria, que, sendo reconhecidos juridicamente como costume, os PCGA devem decorrer realmente de aceitação geral, reiterada e uniforme das práticas contábeis para serem válidas e integrarem o âmbito de incidência legal (confirmando-se, inclusive, uma tradição do Direito Comercial, cujas raízes decorrem de prática mercantil $)^{54}$.

\footnotetext{
${ }^{50}$ Fala-se particularmente da Instrução CVM 38/1984 que afirmava, em seu artigo $5^{\circ}$, inciso V, que: "Ao emitir parecer de auditoria o auditor independente deve assinalar a inobservância, pela empresa auditada, de princípios contábeis geralmente aceitos, ainda que com fundamento em disposição legal ou regulamentar, quantificando seus efeitos sobre o patrimônio e os resultados, ou indicando as razões que impedem essa quantificação." Grifo nosso. Tal referência não consta da regulamentação atual (Instrução CVM no 204/1993).

${ }^{51}$ Cf. COMPARATO, op. cit. (nota 49), p. 53-54.

${ }^{52}$ A respeito de princípios e regras, vide o item 1.1.1 do Capítulo 1.

${ }^{53}$ A avaliação de ativos financeiros por meio de marcação a mercado, por exemplo, recém-introduzida pelo art. 183, I, da LSA, pode ser considerada, na visão de alguns, uma afronta ao princípio da prudência.

${ }^{54}$ Cf. COMPARATO, op. cit. (nota 49), p. 53-54.
} 
Preocupações semelhantes em perquirir a origem dos PCGA são também apresentadas por autores que se ocuparam com o tema em outras jurisdições. Brian Arnold $^{55}$ afirma que uma prática contábil é considerada geralmente aceita quando atende a pelo menos um e normalmente a mais do que um dos seguintes critérios: (i) a prática é realmente seguida em um número significativo de casos; (ii) o método tem suporte nos pronunciamentos de órgãos profissionais; (iii) o método tem suporte em estudos acadêmicos ou outros estudos. No Reino Unido, fala-se tanto de princípios quanto de práticas contábeis geralmente aceitas ${ }^{56}$. Schröer comenta que quando se fala de práticas, pensa-se em formulação de diretivas extraídas da prática, por meio do método indutivo ${ }^{57}$, e, por outro ângulo, quando se pensa em princípios, parte-se da ideia, predominante, de que os princípios decorrem de método dedutivo. Quanto ao que seria geralmente aceitos, aponta que pode ser tanto aquilo que a maioria faz quanto aquilo que o conselho profissional entende correto. Esta segunda corrente, segundo ele, é a que prevalece ${ }^{58}$.

Nessa controvérsia quanto à natureza jurídica dos PCGA, que podem assumir a forma de costume ou norma jurídica, parece ter razão Kruse, que já apontava extremos em tal discussão, pois ela costuma ser resolvida ao modo de "tudo ou nada". Sua proposta busca uma solução intermediária, divisando nos PCGA alguns elementos que realmente são retratados sob a forma de regras jurídicas ${ }^{59}$ e outros que decorrem simplesmente da prática $^{60}$ e podem ser mais bem caracterizados como costume ${ }^{61}$.

\footnotetext{
${ }^{55} \mathrm{Cf}$. ARNOLD, Brian J. Timing and income taxation: the principles of income measurement for tax purposes. Toronto: Canadian Tax Foundation, 1983, p. 7.

${ }^{56}$ Cf. DAVIES, Mike; PATERSON, Ron; WILSON, Allister. UK GAAP: generally accepted accounting practice in the United Kingdom. $6^{\text {a }}$ London: Tolley, 1999, p. 1-2.

${ }^{57} \mathrm{E}$ aponta que a principal crítica que se pode fazer é que, na verdade, a maioria das práticas contábeis não derivou propriamente da prática, mas sim de estudos acerca da prática, de racionalização da prática. Cf. SCHRÖER, Thomas. Das Realisationsprinzip in Deutschland und Grossbritannien: eine systematische Untersuchung und ihre Aufwendung auf langfristige Auftragsfertigung und Währungsrechnung. Frankfurt am Main: Peter Lang, 1998, p. 90-91.

${ }^{58}$ Cf. SCHRÖER, op. cit. (nota 57), p. 91-93.

${ }^{59}$ Exemplos disso no Brasil podem ser vistos no art. 183, II, da LSA (que integra ao sistema jurídico o princípio do menor valor entre custo de aquisição ou mercado), no art. 177 , caput e $\S 1^{\circ}$, da LSA (que reconhece o princípio - ou convenção - da consistência).

${ }^{60}$ Ao comentar um item específico da regulamentação contábil do PCGA, Mariz contrapõe a prática contábil como fonte genuína dos PCGA: "Esta generalização [item II da Resolução CFC n 750/1993], que coloca num único conjunto qualquer desaparecimento de passivo, sem distinguir situações e razões, se não é equivocada, ao menos é incompleta ou não está adequadamente exprimida. Nem contabilmente ela é aceitável, pois a prática contábil não ignora débitos ao passivo em contrapartida a créditos a contas de patrimônio líquido, mas juridicamente ela é totalmente inaceitável." Grifo nosso. Cf. OLIVEIRA, Ricardo Mariz de. Fundamentos do imposto de renda. São Paulo: Quartier Latin, 2008, p. 127, nota 40.

${ }^{61}$ Cf. KRUSE, Heinrich Wilhelm. Grundsätze ordnungsmässiger Buchführung: Rechtsnatur und Bestimmung. Köln: Otto Schmidt, 1978, p. 100-102.
} 
Para o que interessa aos fins do presente estudo, importa registrar que o princípio da realização (ou princípio da competência) deve atender com facilidade aos requisitos apontados aqui acima. Conforme se verá nos itens subsequentes, esse princípio encontra larga utilização na prática, costuma ser apontado com frequência em estudos acadêmicos e tem respaldo nos pronunciamentos dos órgãos contábeis. Além disso, a previsão legal do regime de competência e o esclarecimento de critérios gerais na legislação comercial afastam qualquer questionamento acerca da sua força enquanto norma jurídica.

Não se afirma, portanto, que os PCGA são obrigatórios simplesmente porque decorrem de ato editado pelo órgão contábil ${ }^{62}$, mas sim que o princípio da realização (com seus elementos de materialidade, objetividade, prudência e transacional) é prática ou princípio geralmente aceito, cuja força normativa é retratada na LSA e mencionada nos atos normativos da categoria profissional contábil. Para os fins da apuração, quer do lucro comercial, quer do fiscal, é sempre importante assinalar que o reconhecimento de receitas e despesas não pode se desviar dos aspectos jurídicos dos fatos e negócios que lhes são subjacentes ${ }^{63}$.

\subsection{Objetivos vinculados à elaboração de demonstrações financeiras}

Verificada a liderança da legislação comercial e, particularmente, dos PCGA no que concerne à apuração do lucro tributável, importa examinar de que forma o princípio da realização encontra-se estruturado neste seu contexto original, que é a apuração do lucro comercial ou empresarial. Para encetar dita análise, salientam-se os principais objetivos que envolvem a apuração do patrimônio empresarial e, em última análise, a demonstração de resultados periódicos para fins comerciais.

Nesse sentido, Schröer comenta que o Direito Contábil (a contabilidade regulada pelo Direito Comercial) atende aos seguintes objetivos principais: prestação de $\operatorname{contas}^{64}$, apuração do patrimônio e do lucro, proteção dos credores e cálculo dos

\footnotetext{
${ }^{62}$ Argumentação deste porte pode ser vista em RENCK, op. cit. (nota 1), p. 122-123.

${ }^{63} \mathrm{Com}$ as palavras de Mariz de Oliveira, pode-se afirmar que "a Lei n. 6.404 também vê o patrimônio com os olhos do direito, em sintonia com o que a propósito dispõe o Código Civil, tanto que o "caput" do seu art. 176 diz que as demonstrações financeiras devem exprimir com clareza a situação do patrimônio da companhia e suas mutações." E quanto ao reconhecimento de receitas conforme os PCGA "é impossível que algo que não seja receita segundo o direito possa ser considerado como tal sob a invocação de princípios geralmente aceitos ou qualquer outro conceito genérico." Cf. OLIVEIRA, op. cit. (nota 60), p. 47; 93-94.

${ }^{64} \mathrm{Ou}$ responsabilidade na prestação de contas (accountability).
} 
pagamentos e dividendos ${ }^{65}$. Não se afasta a possibilidade de a Contabilidade atender a outros interesses, sobretudo por se tratar de ciência voltada a diferentes grupos de usuários, com interesses às vezes conflitantes ${ }^{66}$. O que se salienta aqui são os interesses que a legislação buscou proteger ao regular a Contabilidade.

Dentre os objetivos citados, destaca-se, como primordial ao Direito Contábil, a proteção aos credores. Leffson aponta que o legislador interfere neste aspecto porque um dos objetivos do Estado é o de proteger os membros da sociedade contra arbitrariedades, prezando por uma ordem jurídica viável e o cumprimento das obrigações contratuais. Por isso, estabelecem-se regras para a elaboração de demonstrações contábeis que resguardem a massa de credores com relação às retiradas de ativos patrimonais, permitam o conhecimento das relações entre ativos e passivos do devedor e assegurem a força probatória dos livros contábeis ${ }^{67}$.

$\mathrm{Na}$ concretização da função de proteção aos credores, fala-se da necessária apuração do valor pagável/distribuível a título de lucro pela empresa (também chamada de função de cálculo dos pagamentos e dividendos) ${ }^{68}$.

A preservação do capital social como garantia mínima do cumprimento das obrigações pela empresa é o mote que conduz a preocupação quanto a uma apuração correta do lucro $^{69}$. A legislação contábil deve primar para que retiradas de lucros não afetem o capital social e, em última análise, o patrimônio da empresa. A apuração adequada do lucro procura, outrossim, evitar retiradas injustificadas de valores da empresa, revelando se o valor sacado corresponde a lucros genuínos do período, lucros de períodos anteriores, ou uma invasão no capital social da empresa ${ }^{70}$. As normas contábeis de apuração do lucro e preservação do patrimônio da empresa atendem ao interesse dos

\footnotetext{
${ }^{65}$ Cf. SCHRÖER, op. cit. (nota 57), p. 52-53.

${ }^{66}$ Sobre os principais tipos de usuários e as informações mais requisitadas por eles, cf. IUDÍCIBUS, Sérgio de. Teoria da contabilidade. $7^{\text {a }}$ São Paulo: Atlas, 2004, p. 23.

${ }^{67}$ Cf. LEFFSON, Ulrich. Die Grundsätze ordnungsmässiger Buchführung. $7^{\mathrm{a}}$, rev. e ampl. Düsseldorf: IDW, 1987, p. 41, 46.

${ }^{68}$ Cf. SCHRÖER, op. cit. (nota 57), p. 54-55.

${ }^{69}$ Essa já era a mensagem passada por Ascarelli, Sousa e Almeida: "O que pode ser distribuído como lucro - A questão de saber quais são os valores que podem ser distribuídos como lucro, e quando o podem ser, tem de ser resolvida pelo direito comercial, dada a evidente conexão do problema com a tutela dos credores, cujos direitos poderiam ficar prejudicados pelo depauperamento do patrimônio social decorrente de indevidas distribuições de lucro." Grifo nosso. Cf. ASCARELLI, Tullio; SOUSA, Rubens Gomes de; ALMEIDA FILHO, João Batista Pereira de. Lucros extraordinários e imposto de renda. São Paulo: Martins, 1944, p. 130.

${ }^{70}$ Cf. LEFFSON, op. cit. (nota 67), p. 52-53.
} 
credores, pois, sobretudo em sociedades de responsabilidade limitada, é tal patrimônio que responde pelas dívidas da empresa ${ }^{71}$.

Neste contexto, um dos fundamentos dos PCGA repousa no princípio da prudência, o qual serve à proteção dos credores e encontra sua concretização no princípio da realização, de forma a estabelecer um critério objetivo para restringir a arbitrariedade subjetiva na apuração do lucro ${ }^{72}$. Com efeito, três PCGA são fundamentais para atender aos objetivos de proteção aos credores e apuração correta do valor distribuível a título de lucros: os princípios da precaução, realização e imparidade.

A propósito, convém enfatizar que a busca de segurança jurídica e preservação do capital (em contraposição ao lucro - que, uma vez apurado, pode ser distribuído, tributado etc.) são metas comuns ao Direito Comercial e ao Tributário. Todavia, ao permitir a adoção do princípio da prudência em um grau mais elevado (inclusive com toques de imparidade) $)^{73}$, o Direito Comercial revela que a apuração do lucro contábil (lucro distribuível) demonstra uma visão até mais cautelosa do que aquela provida pela legislação tributária do imposto de renda ${ }^{74}$. Nessa perspectiva, o lucro submetido à tributação não é um lucro que a própria pessoa jurídica estaria disposta a distribuir a seus titulares, pois, se assim o fizesse, poderia afetar a proteção aos credores, a continuidade dos negócios e outros interesses que introduzem elementos prospectivos na apuração do lucro comercial $^{75}$.

Se para o cálculo da renda tributável importam os requisitos de segurança jurídica, objetividade e prudência, não há razão para se refutar o emprego do Direito Contábil, pois sua adoção no campo do Direito Comercial atende a todos esses requisitos ${ }^{76}$.

\footnotetext{
${ }^{71}$ Cf. GELHAUSEN, Hans Friedrich. Das Realisationsprinzip im Handels- und im Steuerbilanzrecht. Frankfurt am Main: Peter Lang, 1985, p. 68.

${ }^{72}$ Cf. SCHRÖER, op. cit. (nota 57), p. 128.

73 A respeito desses princípios, vide itens 2.4 .2 e 3.4.3 e deste Capítulo.

${ }^{74} \mathrm{Cf}$. CARSBERG, Sir Bryan; NOKE, Christopher. The reporting of profits and the concept of realisation. London: Research Board ICAEW, 1989, 31.

${ }^{75}$ A respeito das diferentes perspectivas (prospectiva e retrospectiva) na apuração do lucro, vide item 1.1 deste Capítulo.

${ }^{76} \mathrm{Na}$ visão de Mariz de Oliveira "Realmente, para a Lei n. 6404, o que interessa é o lucro líquido, isto é, o resultado líquido de todos os elementos positivos e negativos que atuam para promover e quantificar a mutação patrimonial ocorrida em determinado período de tempo.

Neste aspecto específico, o interesse da legislação do imposto de renda é o mesmo, eis que o substrato econômico para a sua incidência é o acréscimo patrimonial também apurado contabilmente." Cf. OLIVEIRA, op. cit. (nota 60), p. 161.
} 


\subsection{Previsão legal e regulamentação dos PCGA no Brasil}

Como já adiantado, os PCGA foram introduzidos no ordenamento jurídico por meio do art. 177 da $\operatorname{LSA}^{77}$. Sua explicitação foi sendo promovida por meio de pronunciamentos de órgãos profissionais (particularmente $\mathrm{CFC}$ e Ibracon) e órgãos governamentais específicos (Bacen e CVM). Mais recentemente, conforme já visto ${ }^{78}$, a Lei $n^{\text {o }} 11.638 / 2007$ abriu caminho para a convergência da contabilidade brasileira aos padrões internacionais e permitiu a criação de um novo órgão técnico, o $\mathrm{CPC}$, para agilizar o procedimento de integração das normas do IASB ao sistema jurídico-contábil brasileiro.

Neste item citam-se rapidamente os atos normativos produzidos por tais órgãos e que regulamentam os PCGA no Brasil. Comentários aos aspectos relevantes desses atos serão feitos adiante.

\subsubsection{CFC, Ibracon, CVM e CMN}

De todos esses órgãos, o Conselho Federal de Contabilidade (CFC) é o que detém maior abrangência normativa, pois regula a profissão contábil em sua plenitude. $\mathrm{O}$ Instituto dos Auditores Independentes do Brasil $\left(\right.$ Ibracon $^{79}$ ), embora tenha concentrado sua atenção nas atividades de auditores, também pretende ter abrangência a toda a classe profissional, todavia, não é órgão oficial (como o é o CFC), de forma que a regulamentação editada pelo Ibracon tem caráter meramente indicativo no que respeita à interpretação dos PCGA. A Comissão de Valores Mobiliários (CVM) e o Conselho Monetário Nacional (CMN) também editam atos com conteúdo jurídico-contábil, porém restritos à área regulamentar de abrangência desses órgãos.

Os PCGA de ordem geral são encontrados oficialmente, portanto, nos atos editados pelo CFC. Dentre ditos atos, destacam-se a Resolução CFC no 750/1993 ${ }^{80}$ (que explicita os "Princípios Fundamentais de Contabilidade" - PFC) e a Resolução CFC

\footnotetext{
${ }^{77}$ Vide a nota de rodapé 45 neste Capítulo e o texto que a introduz.

${ }^{78}$ Vide, neste Capítulo, as notas de rodapé 14 a 21 e o texto que as introduz.

${ }^{79}$ Originalmente a sigla era IAIB. Durante um período em que se buscou maior abrangência, o Instituto passou a se denominar Instituto Brasileiro de Contadores e mudou a sigla para Ibracon. Mais recentemente, mudou novamente de nome, mas preservou a consagrada sigla.

${ }^{80}$ Anteriormente, a Resolução CFC n $\mathrm{n}^{\circ}$ 530/1981 disciplinava a questão, contudo de maneira bastante incipiente. A respeito do princípio da competência, por exemplo, acrescentava muito pouco ao texto da LSA: "As receitas e despesas devem ser reconhecidas na apuração do resultado do período a que pertencerem e, de forma simultânea, quando se co-relacionarem. As despesas devem ser reconhecidas independentemente do seu pagamento, e as receitas somente quando de sua realização.” (item 1.4).
} 
$\mathrm{n}^{\mathrm{o}} 774 / 1994$, que aprova Apêndice sobre tais Princípios Fundamentais contendo importantes esclarecimentos teóricos acerca de sua abrangência.

A CVM editou também um estudo acerca dos PCGA que oferece bons subsídios teóricos para a sua interpretação: trata-se da chamada "Estrutura Conceitual Básica da Contabilidade” (EBC), tornada realidade pela Deliberação CVM nº 29/1986. Não sendo obrigatórios para todas as entidades, os atos da CVM também guardam apenas valor indicativo.

\subsubsection{CPC e as normas do IFRS}

O Comitê de Pronunciamentos Contábeis (CPC) foi criado pela Resolução CFC n $n^{0} 1.055 / 2005$ e tem por missão estudar, pesquisar, discutir e deliberar a emissão de pronunciamentos contábeis que auxiliem na uniformização das normas brasileiras de contabilidade. Busca a convergência aos padrões internacionais, mas este não é seu único objetivo.

O CPC não tem força normativa, porém, seus pronunciamentos deverão ser transformados em atos próprios das entidades que detêm competência para regulamentar a matéria contábil (CFC, CVM, Bacen) ${ }^{81}$. Embora a Lei no ${ }^{\circ} 11.638 / 2007$ não tenha explicitado isso, a convergência das normas brasileira aos padrões internacionais toma como parâmetro as normas do IASB, mais propriamente os IFRS (International Financial Reporting Standards - Padrões Internacionais de Relatórios Financeiros) ${ }^{82}$.

Até o momento, os trabalhos do CPC já resultaram, por exemplo, na aprovação da "Estrutura para a Preparação e a Apresentação das Demonstrações Contábeis", transformada em norma jurídica pela Resolução CFC n 1.121/2008 e Deliberação CVM $\mathrm{n}^{\mathrm{o}} 539 / 2008^{83}$. Interessantes contribuições ao conhecimento do princípio da realização (ou competência) devem vir, por exemplo, com a introdução do International Accounting Standard 18 (IAS 18 - Padrão Internacional de Contabilidade 18) sobre o reconhecimento de receitas e os atos que o interpretam e o Statement of Principles for Financial Reporting (Pronunciamento de Princípios de Relatórios Financeiros).

\footnotetext{
${ }^{81}$ Vide comentário na nota de rodapé 21 deste Capítulo.

${ }^{82}$ Cf. BIFANO, op. cit. (nota 21), p. 49.

${ }^{83}$ Sobre o reconhecimento de receitas e despesas, vide itens 92 a 98 do referido documento.
} 


\subsection{Princípios contábeis orientadores do princípio da realização}

Ainda quanto aos PCGA, apresenta-se aqui um breve delineamento dos principais princípios contábeis que orientam o princípio da realização num plano superior, quais sejam, os princípios da continuidade, prudência e objetividade. Fazendo já uma advertência terminológica, sublinha-se que, na linguagem da $\mathrm{ECB}^{84}$, há um esforço de classificação dos PCGA em postulados, convenções e princípios (retratando condicionamentos, restrições e orientações gerais, respectivamente) ${ }^{85}$. Tal metodologia não se repetiu na regulamentação dos $\mathrm{PFC}^{86}$. Essa distinção parece um tanto quanto arbitrária e dispensável para os fins aqui propostos. Adota-se, assim, para fins de coerência com o restante do trabalho, a divisão entre princípios e $\operatorname{regras}^{87}$, cabendo no primeiro grupo aqueles mandamentos de ordem mais genérica e aberta, como é o caso do princípio da realização e, no segundo, aqueles mais específicos, como ocorre quando o princípio da realização é concretizado por meio de algum critério de realização.

\subsubsection{Princípio da continuidade (postulado)}

O princípio da continuidade implica assumir que a empresa (ou entidade contábil) opera por prazo indeterminado e que continuará a produzir riquezas indefinidamente. Este princípio tem grande relação com o princípio da realização (ou competência) porque afeta diretamente a apuração do patrimônio e dos acréscimos patrimoniais $^{88}$. Tal princípio parte do pressuposto de que as apurações periódicas de lucros são uma ficção e que, portanto, grandes cuidados devem ser tomados na quantificação dos

\footnotetext{
${ }^{84}$ Deliberação CVM no 29/1986.

85 “os postulados ambientais enunciam, solenemente, condições sociais, econômicas e institucionais dentro dos quais a Contabilidade atua; [...] Os Princípios representam a larga estrada a seguir rumo a uma cidade. As Convenções (Restrições) seriam como sinais ou placas indicando, com mais especificidade, o caminho a seguir, os desvios, as entradas, as saídas etc." Cf. item 3.1.3 da ECB.

${ }^{86}$ Resoluções CFC n ${ }^{\circ} 750 / 1993$ e 774/1994.

${ }^{87}$ Vide a esse respeito o item 1.1.1 do Capítulo 1.

${ }^{88}$ Resolução CFC no 750/1993 “Art. 50 - A CONTINUIDADE ou não da ENTIDADE, bem como sua vida definida ou provável, devem ser consideradas quando da classificação e avaliação das mutações patrimoniais, quantitativas e qualitativas.

$\S 1^{\circ}$ - A CONTINUIDADE influencia o valor econômico dos ativos e, em muitos casos, o valor ou o vencimento dos passivos, especialmente quando a extinção da ENTIDADE tem prazo determinado, previsto ou previsível.

$\S 2^{\circ}$ - A observância do Princípio da CONTINUIDADE é indispensável à correta aplicação do Princípio da COMPETÊNCIA, por efeito de se relacionar diretamente à quantificação dos componentes patrimoniais e à formação do resultado, e de constituir dado importante para aferir a capacidade futura de geração de resultado."
} 
componentes patrimoniais e na formação do lucro, pois se assume que a capacidade de geração de resultados futuros não pode ser afetada por tais cortes temporais ${ }^{89}$.

Fortemente atrelados a este princípio, estão não só o princípio da realização, mas também o princípio do custo de aquisição, da imparidade e diversas exigências de ajustes intertemporais, consoante já se assinalou aqui com as críticas feitas por Misabel Derzi $^{90}$. Segundo tal autora, diversas normas do Direito Contábil remetem a este princípio e são de observância obrigatória no Direito Tributário ${ }^{91}$. Nesse sentido, a legislação tributária do imposto de renda é mais pobre, i.e., apura uma medida de renda com menor segurança do que aquela apurada para fins comerciais, tratando o resultado de cada ano com relativa independência dos demais ${ }^{92}$.

\subsubsection{Princípio da prudência (convenção do conservadorismo)}

Em muitos países o princípio da realização é visto como corolário do princípio da prudência ${ }^{93}$. Com efeito, este conceito, por estar diretamente atrelado a uma ideia conservadora na mensuração de ativos e passivos, inevitavelmente conduz à adoção de critérios os mais conservadores possíveis para a concretização do princípio da realização ${ }^{94}$. Em poucas palavras, tal princípio orienta registrar as perdas o quanto antes e pelo maior valor e, também, ter precaução no cômputo de receitas, mantendo o seu menor

\footnotetext{
${ }^{89}$ Cf. RENCK, op. cit. (nota 1), p. 129-130.

${ }^{90}$ Vide as notas 5 a 10 deste Capítulo e o texto que as introduz.

91 "Como a periodização é um corte feito em uma atividade econômica ininterrupta - sendo a regra da continuidade da exploração um princípio contábil e de Direito Comercial universal -, dela resultam outras regras tecnicamente necessárias e reconhecidas pelos ordenamentos jurídicos em geral, tais como a uniformidade ou permanência de métodos utilizados; a especialização dos exercícios; $\underline{\text { a identidade entre o }}$ balanço de abertura de um exercício e o balanço de encerramento do exercício anterior; a cautela ou não paridade de tratamento entre lucro e prejuízo e a dedutibilidade dos prejuízos acumulados em períodos anteriores." Grifo nosso. Cf. DERZI, op. cit. (nota 5), p. 59.

92 "A quantificação do Imposto sobre a Renda, segundo a lei ordinária vigente, parte do pressuposto de que o resultado de um período, uma vez estabelecido, quase perde o elo de vinculação com outros resultados periódicos, afirmando o princípio da independência dos exercícios sociais, no que incide em erro total." Cf. RENCK, op. cit. (nota 1), p. 130-131.

${ }^{93}$ Vide os exemplos da Alemanha e do Reino Unido nos itens 3.1 e 3.3 do Capítulo 1.

${ }^{94}$ Resolução CFC no 750/1993 “Art. 10 - O Princípio da PRUDÊNCIA determina a adoção do menor valor para os componentes do ATIVO e do maior para os do PASSIVO, sempre que se apresentem alternativas igualmente válidas para a quantificação das mutações patrimoniais que alterem o patrimônio líquido.

$\S 1^{\circ}$ - O Princípio da PRUDÊNCIA impõe a escolha da hipótese de que resulte menor patrimônio líquido, quando se apresentarem opções igualmente aceitáveis diante dos demais Princípios Fundamentais de Contabilidade.

$\S 2^{\circ}$ - Observado o disposto no art. $7^{\circ}$, o Princípio da PRUDÊNCIA somente se aplica às mutações posteriores, constituindo-se ordenamento indispensável à correta aplicação do Princípio da COMPETÊNCIA. $\S 3^{\circ}$ - A aplicação do Princípio da PRUDÊNCIA ganha ênfase quando, para definição dos valores relativos às variações patrimoniais, devem ser feitas estimativas que envolvem incertezas de grau variável."
} 
valor atual ${ }^{95}$. Deste princípio decorrem o princípio do menor valor entre custo de aquisição ou mercado ${ }^{96}$ e o princípio da imparidade.

A dualidade de critérios imposta pelo princípio da prudência reflete-se no princípio da realização e na sua combinação com o princípio da imparidade ${ }^{97}$. Os pensamentos básicos do princípio da realização, precaução e manutenção do capital, tornam importante a verificação de um grau de certeza substancial na demonstração do resultado. Nesse sentido, quando se observar, a partir da análise de riscos, a existência de diferentes momentos temporais possíveis de realização, tal escolha, tendo em vista aspectos de segurança, torna-se mais difícil e dependerá de avaliações subjetivas. Para as situações em que o critério do princípio da realização não estiver detalhadamente explicitado na lei, sua concretização depende do grau de prudência adotado ${ }^{98}$. Por isso, a aplicação do regime de competência para o reconhecimento de receitas merece ser sopesada em função de elementos circunstanciais (definidos no caso concreto), que sinalizem a necessidade de prudência na apuração de renda de forma a não extrapolar os limites da capacidade econômica da empresa de realizar seus ativos e, por conseguinte, fazer frente às suas obrigações (inclusive tributárias) ${ }^{99}$.

Não raro, as condições de determinados casos concretos podem realmente suscitar o afastamento da regra de realização pertinente (o critério de realização geralmente definido pela troca de mercado e orientado pelo Direito Civil) em vista de seu descompasso com o princípio da prudência. Assim é que, num caso em que se considerou

\footnotetext{
${ }^{95}$ Apresenta a ideia de que, no cômputo dos resultados, é melhor errar para menos do que para mais. Cf. SCHRÖER, op. cit. (nota 57), p. 172-173.

96 “Tendo em vista que o Direito Tributário, notadamente em razão do $§ 5$ seção 1 d EStG ( $\$ 5$ öEStG), se vincula aos princípios de contabilidade geralmente aceitos, decorre então do princípio da prudência que essencialmente apenas os ganhos realizados devem ser considerados (princípio da realização). Este princípio da realização é confirmado por meio do princípio do custo de aquisição ou produção citado no §6 EStG." Tradução livre de: Da das Steuerrecht indessen grundsätzlich über §5 Abs. 1 dEStG (\$5 öEStG) an die handelsrechtlichen Grundsätze ordnungsmässiger Buchführung anknüpft, ergibt sich über das Vorsichtsprinzip, das grundsätzlich nur realisierte Gewinne zu erfassen sind (Realisationsprinzip). Dieses Realisationsprinzip wird durch das Anschaffungswertprinzip des §6 EStG (i.V. mit §5 Abs. 4 EStG) bestätigt. Cf. TIPKE, Klaus. Rechtfertigung des Themas; Ziel der Tagung. In: RUPPE, op. cit. (nota 29), p. 3-4.

97 "Neste aspecto particular, a Lei n. 6.404 adotou uma visão pré-jurídica, transformando-a em norma jurídica, segundo a qual há uma variação de tratamento conforme se trate de pendência relativa a ganho e pendência relativa a perda.

Realmente, enquanto as receitas devem ser reconhecidas e registradas contabilmente quando definitivas e incondicionadas, exatamente de acordo com o que está exposto acima, as obrigações previsíveis mas ainda não definitivas devem ser contabilizadas, tanto quanto as definitivas, embora em contas de provisões. Tratase do princípio contábil da prudência, ou do conservadorismo, juridicizado pelo "caput" do art. 177 dessa lei e por outras disposições que serão mencionadas adiante.” Cf. OLIVEIRA, op. cit. (nota 60), p. 136-137.

${ }^{98}$ Cf. SCHRÖER, op. cit. (nota 57), p. 128-130.
} 
haver fundadas suspeitas quanto à capacidade de determinada pessoa adimplir obrigação reconhecida em processo judicial, decidiu-se que, por força do princípio da prudência, dever-se-ia afastar o critério de competência (assentado na constituição judicial do direito) relativo ao cômputo do correspondente direito de crédito ${ }^{100}$. Em mais duas oportunidades de julgamentos administrativos, outro critério de realização (desta vez fundado na passagem do tempo) foi preterido em razão da primazia do princípio da prudência. Nas duas situações analisadas, o contexto era de cômputo de encargos financeiros sobre créditos vencidos e não pagos por razões objetivamente verificáveis de inadimplência ${ }^{101}$.

\footnotetext{
${ }^{99} \mathrm{O}$ necessário exercício de sopesamento entre os princípios da competência (realização) e prudência já é evidenciado na própria regulamentação contábil (vide $\S \S 2^{\circ}$ e $3^{\circ}$, do art. 10 da Resolução CFC $\mathbf{n}^{0}$ 750/1993 transcrito acima na nota 94).

${ }^{100}$ Acórdão no 107-06.012, proferido pela $7^{\text {a }}$ Câmara do Primeiro Conselho de Contribuintes em 12/07/2000. Transcrição do voto do Conselheiro e Relator Paulo Roberto Cortez: "Todavia, não obstante nos autos da ação judicial tenha sido assegurado à recorrente o direito de regresso contra seu ex-diretor - pessoa que efetivamente praticou o delito da qual se viu condenada e obrigada a reparar para o seu cliente os danos que lhe causaram -, tal circunstância, à luz dos princípios que regem a contabilidade, em absoluto, a obriga, como quer a fiscalização, ao imediato reconhecimento desse potencial e incerto crédito.

De fato, o reconhecimento de uma receita, à luz dos princípios fundamentais da contabilidade, não se faz apenas porque alguém recebe a outorga de outrem, ainda que do Poder Judiciário, de um direito creditório exercitável contra terceiros. Pelo contrário, o reconhecimento de receita pressupõe a sua efetiva realização, no sentido de que não restem dúvidas acerca da real capacidade de auferimento do ganho. [...]

Pois bem, no caso concreto, o crédito que pretende a fiscalização deva, pela recorrente, ser reconhecido, decorre de sentença judicial em que o ex-diretor da empresa foi tido como responsável pelo dano causado a seu cliente, adquirindo esta, portanto, contra este, o direito de regresso. Trata-se portanto de credito, pela sua própria natureza, de difícil ou improvável realização, mormente diante da circunstância, como noticiam os autos do processo judicial, de ser o devedor pessoa interditada judicialmente (sua esposa, diante dos graves distúrbios sofridos pelo marido, obteve a sua curatela), sem nenhum bem registrado em seu nome e por esta mantido, conforme alega a recorrente, referindo-se ao processo judicial em que se requereu a curatela do seu ex-diretor."

101 "POSTERGAÇÃO DE RECEITA FINANCEIRA - JUROS MORATÓRIOS SOBRE DUPLICATAS A RECEBER - Não tem cabimento a aplicação pura e simples do regime de competência para apropriação de juros moratórios quan[d]o a situação de caracterizada inadimplência de clientes aponta a incerteza quanto ao seu efetivo recebimento." Acórdão $\mathbf{n}^{\mathbf{0}} \mathbf{1 0 7 - 0 7 . 4 5 8}$, proferido pela $7^{\text {a }}$ Câmara do Primeiro Conselho de Contribuintes em 04/12/2003.

"IRPJ E CSLL - LUCRO REAL - GLOSA DE DESPESAS NÃO COMPROVADAS - RENDIMENTOS DECORRENTES DE ENCARGOS FINANCEIROS DEVIDOS POR CLIENTES MUTUÁRIOS INCIDENTES SOBRE CRÉDITOS VENCIDOS NÃO APROPRIADOS AO LUCRO LÍQUIDO RETIFICAÇÃO DO PREJUÍZO FISCAL E DO SALDO NEGATIVO DA CSLL - O princípio do regime de competência, previsto no artigo $9^{\circ}$ da Resolução $\operatorname{CFC} n^{\circ} 750$, de 29 de dezembro de 1993, é o vigente em nosso sistema, importando no reconhecimento das receitas, custos e despesas quando de sua realização, não importando o seu recebimento em moeda.

No entanto, na mesma resolução, artigo 10, tem-se o denominado Princípio da Prudência que consiste na adoção do menor valor para os componentes do ativo e do maior para os do passivo, quando existam alternativas igualmente válidas para a quantificação das mutações patrimoniais que alterem o patrimônio líquido. Assim, se pela natureza do crédito restar dúvidas quanto a sua efetiva realização, em face do Princípio da Prudência, o regime de competência é preterido, devendo tal receita ser reconhecida contabilmente apenas quando efetivamente realizada, caso assim ocorra." Acórdão no 101-96.073, proferido pela $1^{\text {a }}$ Câmara do Primeiro Conselho de Contribuintes em 29/03/2007.
} 
No mesmo sentido, vale citar acórdão que trata de tema semelhante aplicado à realidade de empresas de factoring ${ }^{102}$.

\subsubsection{Convenção da objetividade}

Por último, encerra-se esta parte com a análise do princípio da objetividade ${ }^{103}$, o qual, sucintamente, repudia mensurações subjetivas, seja para o patrimônio, seja para o lucro. Para impor confiabilidade às demonstrações financeiras, restringe-se o universo da Contabilidade Comercial à utilização de valores que sejam comprováveis por documentos e critérios objetivos, e, apenas na falta destes é que se pode lançar mão de procedimentos de avaliação por pessoas qualificadas na profisssão. A própria enunciação do princípio na regulamentação contábil já fornece critérios para sua implementação ${ }^{104}$. Segundo Bulhões Pedreira, a Contabilidade adota o princípio de que a escolha de critérios de avaliação deve ser objetiva e verificável, para que qualquer avaliador que utilize o mesmo método alcance basicamente o mesmo valor atribuído ao elemento patrimonial ${ }^{105}$.

Este princípio guarda relação importante com o princípio da realização, pois é ele quem informa um dos seus principais elementos: o da mensurabilidade (possibilidade de quantificação do valor). Assim, reconhece-se que, em geral, o ponto de transferência é o mais objetivo para o reconhecimento da receita, pois o ato de troca no mercado fornece um valor que independe da subjetividade do avaliador.

102 "IRPJ - CRÉDITOS DE LIQUIDAÇÃO DUVIDOSA - INSTITUIÇÕES FINANCEIRAS APLICAÇÃO DA RESOLUÇÃO BACEN N ${ }^{\circ}$ 1748/90 - OFENSA AO REGIME DE COMPETÊNCIA IMPROCEDÊNCIA - O Decreto-lei 1.598/77, art. $6^{\circ}$, § $1^{\circ}$, na definição da base de cálculo do imposto de renda, determina que o lucro líquido do exercício, ponto de partida para o cálculo do lucro real (e, também, da base de cálculo da contribuição social sobre o lucro líquido), deve ser determinado com observância dos preceitos da lei comercial que, a seu turno, de conformidade com o que dispõe a Lei ${ }^{\circ} 6.404 / 76$, art. 187 , $\S$ $1^{\circ}$, c.c. art. 177 , impõe que, na sua apuração, a par da necessária aplicação do regime de competência, todos os demais princípios de contabilidade geralmente aceitos deverão ser observados. Inexiste, pois, incompatibilidade entre a lei do anonimato e a lei tributária, em cotejo com a norma do Banco Central que prescreve, às instituições financeiras (companhias de arrendamento mercantil, bancos etc.), em relação a créditos de liquidação duvidosa, em face do princípio da prudência, que estes, a partir do instante da caracterização de sua incerta realização, passem a ser reconhecidos à medida de seu efetivo recebimento." Acórdão no 101-94.769, proferido pela $1^{\text {a }}$ Câmara do Primeiro Conselho de Contribuintes em 11/11/2004.

${ }^{103}$ Ou convenção da objetividade, como é referido no item 3.6.1.1 da ECB (Deliberação CVM no 29/1986).

${ }^{104}$ Item 3.6.1.1) "Para procedimentos igualmente relevantes, resultantes da aplicação dos Princípios, preferirse-ão, em ordem decrescente: a) os que puderem ser comprovados por documentos e critérios objetivos; b) os que puderem ser corroborados por consenso de pessoas qualificadas da profissão, reunidas em comitês de pesquisa ou em entidades que têm autoridades sobre princípios contábeis".

${ }^{105}$ Cf. PEDREIRA, op. cit. (nota 46), p. 559. 
A ligação do princípio da objetividade com os demais é tão grande que a ECB não faz menção isolada a ele, tratando-o como um elemento do princípio da oportunidade $^{106}$, o qual, a propósito, confunde-se com o princípio da realização.

\section{Fundamentos do princípio da realização da renda}

Analisada a relação do Direito Contábil com o Tributário e, sobretudo, identificanda, no âmbito dos PCGA, a origem do princípio da realização, abordam-se, a seguir, os aspectos fundamentais do princípio da realização, discorrendo-se acerca dos critérios adotados pelo legislador para sua implementação, bem como dos diferentes enfoques e seus principais elementos definidores: a materialidade (desdobrado em cumprimento da obrigação e mudança na posição patrimonial), o elemento transacional (troca de mercado) e os atributos de objetividade e prudência (desenvolvidos no subitem pertinente à mensurabilidade, liquidez e certeza).

\subsection{Reconhecimento do princípio no Direito Contábil}

No Capítulo precedente a este já se constatou que o princípio da realização, quando identificado como um componente do conceito constitucional de renda, limita-se a demandar segurança na apuração da renda tributável, mediante a seleção de situações concluídas e definitivas segundo o Direito aplicável. Por ser a renda tratada fundamentalmente como sinônimo de acréscimo patrimonial, o princípio da realização exige, em termos amplos, a presença de um aumento de direitos ao patrimônio do sujeito enfocado. Este fenômeno é normalmente contraprestacional, ocorre no momento do cumprimento de obrigações (prestação) pelo titular da renda e exige o reconhecimento de receitas e despesas neste mesmo instante temporal, salvo se a renda derivada desta relação não for passível de mensuração ou houver impedimentos de liquidez e certeza.

O conceito de renda definido no CTN inclina-se pela adoção dos chamados regimes de competência ou de caixa para fins de implementação do princípio da realização. Contudo, tal como observado ${ }^{107}$, as expressões princípio da realização e regime de competência denotam mandamentos de otimização que, sendo

\footnotetext{
${ }^{106}$ Item 2.3.1 da Resolução CFC no 774/1994.

${ }^{107}$ Vide item 1.2.4 do Capítulo 2 (particularmente a nota 91 e o texto que a introduz).
} 
caracterizadamente ambíguos, comportam sua concretização em variados graus (daí serem tais expressões identificadas usualmente como sinônimas) ${ }^{108}$.

Nesse sentido, a previsão legal do regime de competência no art. 177 da $\mathrm{LSA}^{109}$, tomada isoladamente de seu contexto, não resolve a questão de saber quais os critérios apropriados de realização. Isso porque tal expressão não congrega, em si, as regras que devem ser seguidas para se decidir o momento temporal correto do reconhecimento de receitas e despesas para fins de cálculo do lucro. A ambiguidade da expressão é atenuada pela previsão expressa de critérios genéricos no art. 187 da LSA ${ }^{110}$, os quais, conforme já se destacou, poderiam ter sido mais bem explicitados, caso tivesse sido aprovado o Anteprojeto de 1977 para adaptação da legislação tributária à LSA ${ }^{111}$.

A propósito, para confirmar quão ambíguo é o vocábulo "ganha" na sua tarefa de determinar o momento da realização da renda, basta fazer a comparação com os vocábulos utilizados no Pronunciamento de Princípios do IFRS, explicados no memorando de discussão emitido em 1992, pois, neste contexto, renda ganha é renda ainda não realizada ${ }^{112}$. Ganhar e realizar a renda seriam, outrossim, dois momentos distintos. No

${ }^{108}$ Para Mariz de Oliveira, por exemplo, realização teria pelo menos dois sentidos, sendo o termo referido ora ao recebimento de dinheiro, ora aos efeitos que decorrem de diferentes eventos. Cf. OLIVEIRA, op. cit. (nota 60), p. 370-372.

109 “Art. 177. A escrituração da companhia será mantida em registros permanentes, com obediência aos preceitos da legislação comercial e desta Lei e aos princípios de contabilidade geralmente aceitos, devendo observar métodos ou critérios contábeis uniformes no tempo e registrar as mutações patrimoniais segundo o regime de competência." - Grifo nosso.

110 “Art. 187. A demonstração do resultado do exercício discriminará:

$\S \mathbf{1}^{\mathbf{0}} \mathrm{Na}$ determinação do resultado do exercício serão computados:

a) as receitas e os rendimentos ganhos no período, independentemente da sua realização em moeda; e

b) os custos, despesas, encargos e perdas, pagos ou incorridos, correspondentes a essas receitas e rendimentos." Grifo nosso.

${ }^{111}$ Vide a esse respeito o item 2.2.1.1 do Capítulo 2.

112 “(a) o lucro é ganho - isto é, não há uma transação material, contrato ou outro evento que deva ocorrer previamente ao registro da mudança nos ativos e passivos da entidade e que evidencie que o ganho terá ocorrido; e

(b) o ganho é realizado - isto é, uma das seguintes condições é atendida:

(i) ocorreu uma transação cujo valor é mensurável com confiabilidade suficiente. Ademais, para uma transação que envolva troca ou permute, os ativos e passivos trocados devem ser dissimilares ou monetários, ou

(ii) o ganho resulta de uma mudança num ativo ou passivo que não seja daqueles mantidos para uso continuo nos negócios da empresa e o ativo ou passivo resultante é prontamente conversível em quantidades conhecidas de dinheiro ou bens equivalentes a dinheiro; ou

(iii) o ganho resulta da expiração de um passivo, seu cancelamento ou qualquer outra forma de sua extinção". Tradução livre de: (a) the gain is earned - that is there is no material transaction, contract or other event that must occur before the change in the assets or liabilities of the entity inherent in the gain will have occurred; and

(b) the gains is realised - that is one of the following is met:

(i) a transaction whose value is measurable with sufficient realibility has occurr In addition, for a transaction involving an exchange, the assets or liabilities exchanged must be dissimilar or monetary; or 
limite máximo, se o regime de competência é direcionado pelo critério da receita ganha, esta deveria então ser registrada logo no momento da ocorrência do ganho econômico (independentemente de um ato de troca no mercado, isto é, de realização) ${ }^{113}$.

De todo modo, feita tal ressalva, é importante destacar que a interpretação dada ao art. 187 da LSA identifica nele a exigência de realização. A visão que prevalece é a de que, ao prescrever que as receitas ${ }^{114}$ devem ser reconhecidas quando ganhas (independentemente de sua realização em moeda) e as despesas, quando incorridas, a legislação jurídico-contábil filiou-se ao chamado "regime econômico" tradicional ${ }^{115}$. A regulamentação deste regime de competência ${ }^{116}$ em normativos infra-legais do Direito Contábil confirma a visão que muitos doutrinadores têm acerca do conteúdo dos termos "ganho"e "incorrido",117.

A receita é considerada ganha quando estiver definitiva e incondicionalmente adquirida $^{118}$; em outras palavras, quando se verificar o nascimento ou a aquisição de um direito patrimonial em conjunto com o poder de dispor desse direito ${ }^{119}$; ou, ainda, quando todo o esforço ("sacrifício" de ativos) para obter a receita já tiver sido desenvolvido e for possível aferir seu valor de mercado ${ }^{120}$.

A despesa é considerada incorrida quando estiver definitiva e incondicionalmente devida (ou, melhor dizendo, quando houver emprego de recursos despendidos pela empresa) ${ }^{121}$; vale dizer, no momento em que a empresa ficar

(ii) the gain results from a change in an asset or liability of a type not held for continuing use in the business, and the resultant asset or liability is readily convertible to known amounts of cash or cash equivalents; or

(iii) the gain results from a liability expiring, being cancelled or otherwise ceasing to exist." Grifo nosso. Cf. SCHRÖER, op. cit. (nota 57), p. 192-193.

${ }_{113}^{113}$ Sobre os momentos da preparação, ocorrência e realização do ganho, vide o item 3.2.1 deste Capítulo.

${ }^{114}$ Para fins de simplificação, não se fala aqui de receitas e rendimentos e tampouco de custos, despesas, encargos e perdas, mas tão-somente de receitas e despesas.

${ }^{115}$ Fala-se de "regime econômico" tradicional para procurar eliminar ambiguidades tanto da expressão "regime econômico" quanto da expressão accrual basis, normalmente usada para a referência ao regime econômico. Deve-se atentar para o fato de que accrual, por exemplo, é um termo ambíguo (pode significar o mero acréscimo de valor, isto é, o reconhecimento de renda no momento da sua ocorrência, ou pode dizer respeito ao regime tradicional de apuração de receitas e despesas). Cf. BITTKER, Boris I. A "comprehensive tax base" as a goal of income tax reform. In: Harvard Law Review, v. 80, n. 5, mar.-1967, p. 966 (nota de rodapé 9).

${ }^{116}$ Quanto à aproximação da expressão "regime de competência" com o princípio da realização da renda ver item 1.2.4 do Capítulo 2. Vale apontar ainda que, na regulamentação contábil, a expressão "regime de competência" é tomada como sinônimo dos princípios da realização da receita e da confrontação com as despesas (Deliberação CVM no 29/1986, item 3.1.5.4).

${ }_{117}$ Por todos, citam-se neste Capítulo as opiniões de Ricardo Mariz Oliveira e José Luiz Bulhões Pedreira.

${ }^{118}$ Cf. OLIVEIRA, op. cit. (nota 60), p. 137.

${ }^{119}$ Cf. PEDREIRA, op. cit. (nota 46), p. 489-490.

${ }^{120}$ Item 3.1.5.3 da ECB.

${ }^{121}$ Cf. OLIVEIRA, op. cit. (nota 60), p. 137. 
comprometida, ou, mais propriamente, no momento em que nascer a obrigação de pagar. Também se verifica na perda ou na diminuição do ativo, ou ainda quando se observar o aumento do valor da obrigação ${ }^{122}$; enfim, quando se verificar o consumo de ativos (no mesmo período ou adquiridos em períodos anteriores) ${ }^{123}$.

Essas definições ressaltam o aspecto operacional da geração de receitas e confrontação com as respectivas despesas. Em essência, realizar receitas e despesas é o equivalente a efetuar atividades produtivas com e para o mercado (exercício da atividade empresarial). As operações realizadas pela empresa provocam despesas e geram receitas que devem ser alocadas ao momento da realização das atividades operacionais ${ }^{124}$. Importa salientar que os atributos utilizados para descrever o momento em que receitas e despesas são reconhecidas acabam por confirmar os elementos peculiares do princípio da realização, quais sejam, o cumprimento da obrigação, a mudança na posição patrimonial, a troca no mercado e os atributos mensurabilidade, liquidez e certeza ${ }^{125}$.

A regulamentação dada ao tema pela Resolução CFC no 750/1993, posto que questionável em razão de sua incompletude ${ }^{126}$, é mais esclarecedora quanto à possibilidade de geração de receitas e despesas em razão de eventos diversos da atividade empresarial ${ }^{127}$. Os atos normativos contábeis esclarecem ainda uma série de aspectos da realização da renda, indicando critérios para sua implementação não só no momento da troca no mercado, mas também antes ou depois desta troca e, ainda, simplesmente em função da passagem do tempo. Ditos aspectos serão abordados oportunamente ${ }^{128}$.

\footnotetext{
${ }^{122}$ Cf. PEDREIRA, op. cit. (nota 46), p. 491.

${ }^{123}$ Item 3.1.5.4 da ECB.

${ }^{124}$ Interpretação semelhante era feita no Brasil para o vocábulo realizar empregado nos Regulamentos antigos. Registrar receita decorrente de atividades realizadas pela empresa era sinônimo de princípio de realização e sinalizava a adoção de um rudimentar regime de competência. Vide a esse respeito o item 4 do Capítulo 1 (especialmente as notas 262 a 265 e o texto que as introduz).

${ }^{125}$ Comentados adiante, nos item 3.3 deste Capítulo.

${ }^{126}$ Cf. OLIVEIRA, op. cit. (nota 60), p. 127 (notas 40 e 41).

127 “Art. $9^{\mathbf{0}}[\ldots]$ \& $\mathbf{3}^{\mathbf{0}}$ - As receitas consideram-se realizadas:

I - nas transações com terceiros, quando estes efetuarem o pagamento ou assumirem compromisso firme de efetivá-lo, quer pela investidura na propriedade de bens anteriormente pertencentes à ENTIDADE, quer pela fruição de serviços por esta prestados;

II - quando da extinção, parcial ou total, de um passivo, qualquer que seja o motivo, sem o desaparecimento concomitante de um ativo de valor igual ou maior;

III - pela geração natural de novos ativos independentemente da intervenção de terceiros;

IV - no recebimento efetivo de doações e subvenções.

$\S \mathbf{4 ^ { \mathbf { 0 } }}$ - Consideram-se incorridas as despesas:

I - quando deixar de existir o correspondente valor ativo, por transferência de sua propriedade para terceiro;

II - pela diminuição ou extinção do valor econômico de um ativo;

III - pelo surgimento de um passivo, sem o correspondente ativo."

${ }^{128}$ O Capítulo 4 deste trabalho é estruturado conforme os diferentes critérios de realização.
} 
Comenta-se, por derradeiro, que, apesar da possibilidade conferida pelo CTN para que sejam adotados os regimes de competência ou caixa, há nos tempos atuais uma nítida preferência da legislação comercial pela utilização do regime de competência, em vista de sua adequação à realidade dos fatos praticados pela empresa e que geram fluxos de riqueza. O Direito Contábil obriga todas as entidades a utilizarem este regime ${ }^{129}$ e o Direito Tributário segue a mesma linha (sobretudo em vista dos princípios da universalidade e generalidade da tributação da renda), permitindo a adoção do regime de caixa apenas em situações excepcionais ${ }^{130}$.

Este último regime tem como vantagens a simplicidade da escrituração e a segurança de tomar uma posição mais conservadora na apuração da renda, reconhecendo como lucro somente o valor que já estiver efetivamente à disposição da empresa. Seus pontos adversos são a potencial irregularidade na distribuição do lucro, uma vez que considera apenas os fluxos de caixa, sem levar em conta o momento em que ocorreram os fatos geradores de riqueza, e, ainda, a falha no emparelhamento de receitas e despesas ${ }^{131}$.

\subsection{Possíveis enfoques ao princípio da realização}

Como visto, a previsão do princípio da realização no Direito Contábil (como sinônimo de princípio da competência e, em certa medida, de regime de competência ${ }^{132}$ ) mantém a referência aos elementos básicos (cumprimento de obrigação, acréscimo de direitos patrimoniais, troca no mercado, mensurabilidade, liquidez e certeza) e não define momentos temporais específicos para que se considere efetivamente realizada a renda. Cabe fundamentalmente à disciplina do Direito Civil a tarefa de determinar quando se considera objetivamente ganho o acréscimo patrimonial.

Há uma preferência pelo ato de transferência (troca), porém, permite-se ao legislador a adoção de outros critérios em situações específicas. Nesse sentido, a implementação do princípio sob a forma de regime de caixa, por exemplo, confere particular importância ao momento do recebimento do dinheiro (ou bens de valor mensurável objetivamente).

\footnotetext{
${ }^{129}$ Interessante notar que não há espaço, no conjunto dos atos normativos superiores do Direito Contábil, para a adoção do regime de caixa. Todas as pessoas jurídicas (inclusive as de pequeno porte) estão obrigadas ao regime de competência.

${ }^{130}$ Vide a esse respeito o item 1.2.2 do Capítulo 2.

${ }^{131}$ Cf. PEDREIRA, op. cit. (nota 46), p. 485.
} 
Como já antecipado por Brandão Machado, diversas operações ou fatos podem servir de critério relevante para a realização da renda ${ }^{133}$. Outrossim, cabe ao legislador definir o momento temporal relevante da realização em situações concretas, vale dizer, o momento em que se considera definitivo o acréscimo patrimonial gerador de renda. Com relação a este aspecto, o princípio da realização pode ser implementado segundo enfoques diferenciados, que enfatizam a causa econômica geradora de renda (enfoque no acréscimo de valor) ou privilegiam momentos específicos da atividade econômica (enfoque no evento crítico).

Paralelamente a esses dois enfoques, verifica-se outra dualidade de orientações, neste caso motivada pela busca por um emparelhamento de receitas e despesas correlatas (i.e., realização da receita e confrontação com a despesa). Assim, pode-se privilegiar o conservadorismo e adotar critérios clássicos de realização - com forte ênfase nos aspectos jurídicos cruciais das relações - (enfoque do conservadorismo), ou privilegiar a alocação temporal correta do lucro aos períodos competentes (enfoque da apuração periódica).

\subsubsection{Enfoque no acréscimo de valor $x$ enfoque no evento crítico}

O enfoque no acréscimo de valor concentra-se no aspecto econômico da geração de lucros, elevando a própria atividade produtiva como principal aspecto para a demonstração de resultados. Para melhor compreensão deste enfoque é bastante pertinente a exposição de Beisse quanto à atividade geradora de lucros. Segundo referito magistrado, ela se subdivide em diversos estágios de causa, ocorrência e realização dos lucros, como segue $^{134}$ :

(a) preparação ou causa da ocorrência de lucros, verificada mediante compras vantajosas, fabricação de bens econômicos, desempenho parcial (do trabalho de

\footnotetext{
${ }^{132}$ Emprega-se a expressão regime de competência aqui em seu sentido estrito, isto é, de acordo com os critérios definidos no art. 187 da LSA.

133 “Operações ou fatos que podem conduzir à realização da renda, para o efeito de sua tributação, são, por exemplo, uma venda com recebimento do preço à vista ou a prazo, uma permuta, a extinção de uma dívida, a contabilização da chamada reserva oculta." Cf. MACHADO, Brandão. Breve exame crítico do art. 43 do CTN. In: MARTINS, Ives Gandra da Silva (coord.). Imposto de renda: Conceitos, princípios e comentários (em memória de Henry Tilbery). $2^{\text {a }}$ São Paulo: Atlas, 1996, p. 108. "Podem ser vários os momentos em que se dá a realização. Hans Luik, que tratou, no mesmo simpósio, do tema sob o ponto de vista do tempo, assinalou [...] que a realização do ganho pode ocorrer no momento da conclusão do contrato de alienação, ou na entrada da contraprestação, ou no vencimento dessa contraprestação, ou na tradição do bem alienado, ou na contabilização do negócio.” Cf. MACHADO, op. cit. (nota 2), p. 3203.

${ }^{134}$ Cf. BEISSE, op. cit. (nota 29), p. 19.
} 
empregados), continuidade/preservação do valor original de bens econômicos ou da totalidade do patrimônio empresarial;

(b) ocorrência de lucros, observada na geração de valor econômico no processo produtivo, mas ainda sem a sua realização efetiva (troca no mercado); e

(c) realização de lucros, que envolve atos praticados no mercado.

Diante desses três aspectos, o enfoque no acréscimo de valor entende já haver boas razões para se reconhecer o lucro no momento da sua ocorrência (prescindindo, em princípio, de uma troca no mercado).

Trata-se de enfoque vocacionado a realizar um conceito abrangente de renda ${ }^{135}$, pois leva em conta variações no valor de ativos como causa geradora de acréscimos patrimoniais (não fora pelas restrições já discutidas no Capítulo $2^{136}$ ). Sua aplicação, todavia, não pretende restringir-se aos ganhos de detenção e poderia alcançar até mesmo as relações tradicionais de compra e venda de bens. Para fins tributários, as situações de tributação de variação monetária e cambial bem explicitam a adoção deste enfoque em determinadas hipóteses ${ }^{137}$. Schröer menciona ainda as situações em que a realização se caracteriza pelo acúmulo de valor em razão da passagem do tempo ou em função do uso (juros, aluguéis), cuja atribuição ao período contábil competente é feita pro rata temporis ${ }^{138}$.

Por sua vez, o enfoque no evento crítico, embora reconheça que o lucro possa advir de atos e decisões passados (ou até de outros períodos anuais de apuração) ${ }^{139}$, prefere demonstrá-lo apenas no momento em for possível concluir, com maior segurança, que todas as condições geradoras do acréscimo patrimonial estão presentes ${ }^{140}$. Este ato determinante da realização opera-se por meio de uma troca no mercado, pois, neste caso,

\footnotetext{
${ }^{135}$ Ou modelo SHS, vide a esse respeito o item 2.3.2 do Capítulo 1.

${ }^{136}$ Vide item 2.2.2 do Capítulo 2, em que se conclui que a mais-valia de bens integrantes do patrimônio somente pode gerar tributação se apresentar o atributo de efetividade.

${ }^{137}$ Brandão Machado, a seu tempo, mencionava a contabilização do lucro inflacionário como hipótese de realização, posto que beneficiada por diferimento. Cf. MACHADO, op. cit. (nota 133), p. 108 (nota 51).

${ }^{138}$ Cf. SCHRÖER, op. cit. (nota 57), p. 199.

${ }^{139}$ Exemplo de tal postura pode ser vista em Mariz de Oliveira: "a realização significa que um acréscimo patrimonial se tornou efetivo, sempre instantaneamente, embora muitas vezes as causas geradoras do aumento tenham se formado antes, num único instante ou ao longo do tempo". Cf. OLIVEIRA, op. cit. (nota $60)$, p. 374.

${ }^{140} \mathrm{Na}$ linguagem do Pronunciamento de Princípios do IFRS: “5.34 - O evento crítico é o ponto de um ciclo operacional no qual haverá usualmente evidência suficiente de que o ganho existe e será usualmente possível mensurar tal ganho com confiabilidade suficiente". Tradução livre de: The critical event is the point in an operating cycle at which there will usually be sufficient evidence that the gain exists and it will usually be possible to measure that gain with sufficient reliability".
} 
tem-se maior certeza da mensuração do valor da receita (objetividade) e a maior parte dos riscos do negócio já foi ultrapassada ${ }^{141}$.

Nesse sentido, cristalizaram-se na literatura quatro pontos temporais geralmente aceitos para a constatação da troca ${ }^{142}$ : (i) a entrada de caixa, (ii) a troca de mercado, (iii) o andamento da produção, ou (iv) o final ou término da produção.

A primeira hipótese costuma ser aceita, em diversos países, para beneficiar empresas que não detêm volume substancial de créditos ou estoques, pois difere o reconhecimento de receitas para além do ponto de venda (podendo ser também aceita em situações nas quais há dúvida fundada quando à exequibilidade dos valores recebíveis). A segunda hipótese tem o condão de diferir o reconhecimento de receitas para um momento no qual a maior parte das incertezas do processo produtivo foram removidas. A terceira hipótese busca coincidir a apuração do lucro com o momento da sua efetiva ocorrência e, por fim, a quarta hipótese é normalmente debatida para aqueles produtos cujo risco de nãovenda é muito baixo, de forma que, concluída a produção, restaram riscos ínfimos a serem suplantados $^{143}$.

Considerando que o fato gerador definido para incidência do IRPJ repousa sobre um conceito de Direito Privado, a definição do evento crítico relevante segue prioritariamente o momento temporal do acréscimo de direitos, tal como definido pelo Direito Civil $^{144}$. Porém, em algumas situações específicas, o critério de realização pode ser definido com base em um enfoque de acréscimo de valor ou até mesmo um enfoque de evento crítico direcionado conforme o andamento da produção, sendo exemplos claros disso, no Brasil, os contratos de construção por empreitada ou de fornecimento, a preço

\footnotetext{
${ }^{141}$ A menção de Mariz aos "riscos aleatórios" dá uma ideia do quão importante é a passagem dos riscos do negócio: "Por exemplo, quando se adquire um bem por valor inferior ao que ele efetivamente vale no mercado, a compra assim feita acrescenta um valor "escondido" (latente, não declarado nem contabilizado) de acréscimo patrimonial, que se diz "não realizado" porque, para se tornar efetivo, depende da realização de um novo negócio pelo qual aquele ganho potencial se tornará efetivo e "realizado", isto é, o acréscimo patrimonial depende de uma venda por valor superior ao de aquisição.

Neste caso, o ganho de capital ocorrido e "realizado" nesta segunda operação já estava latente e potencial no patrimônio da pessoa desde o ato da compra do bem, mas dependia, primeiramente, de não haver uma reviravolta na sua cotação de mercado, e, em segundo lugar, da sua efetivação (concretização atual) pela venda a preço maior do que o da compra, ocorrência esta sujeita a vários fatores aleatórios, como, no mínimo, a não perda do bem, a negociação com este de um preço superior ao de compra, a conclusão satisfatória do negócio." Cf. OLIVEIRA, op. cit. (nota 60), p. 374.

${ }^{142}$ Cf. SCHRÖER, op. cit. (nota 57), p. 200-202.

${ }^{143}$ Segundo a ECB, por exemplo, produtos que tenham valor de mercado prontamente determinável e risco de não-venda praticamente nulo (como na mineração e lapidação de metais e pedras preciosas, bem como na produção de vinho e uísque) podem gerar, em circunstâncias bem determinadas, o reconhecimento de receitas antes do ponto de venda (i.e., antes da troca no mercado) Cf. item 3.1.5.3.3 da Deliberação CVM nº 29/1986. ${ }^{144}$ Quanto à intrínseca relação com o Direito Civil, vide especialmente o item 2.3 do Capítulo 2.
} 
predeterminado, de bens ou serviços a serem produzidos (art. 10 do Decreto-lei $\left.\mathrm{n}^{\mathrm{o}} 1.598 / 1977\right)$.

\subsubsection{Enfoque no conservadorismo $x$ enfoque na apuração periódica}

O exemplo dado no final do item anterior permite introduzir outra dualidade de posturas que podem dar encaminhamentos diversos ao princípio da realização. O dilema quanto à adoção de um ou outro enfoque acomete particularmente os negócios jurídicos mais complexos, notadamente aqueles que envolvam variadas prestações ou simplesmente prolonguem-se no tempo (de forma a afetar mais de um período de incidência).

Em fornecimentos mais comuns (venda de mercadorias e prestação de serviços), é particularmente um ato de entrega (alienação ou conclusão de serviço) que conduz à concretização do lucro para fins jurídico-comerciais - vale dizer, em situações simples, não se depende tanto do influxo financeiro da contraprestação, porque, na maioria das vezes, já ocorre a realização no momento da formação da pretensão à contraprestação (formando-se um ativo patrimonial no sentido jurídico-contábil do balanço). Via de regra, esta pretensão surge economicamente assim que o fornecedor cumprir com a sua obrigação e o risco de aceitação não for mais decisivo ${ }^{145}$.

O princípio da realização das receitas e confrontação com as despesas é, para essas situações, orientado principalmente pelo momento temporal da receita (a receita "puxa" a despesa para o seu período de realização). O enfoque no conservadorismo privilegia, outrossim, o momento temporal em que se obtém titularidade jurídica inquestionável sobre a receita.

No entanto, em contratos de longo prazo, por exemplo, é comum que o princípio jurídico-contábil da realização, derivado da convenção (ou princípio) do conservadorismo, vá de encontro ao princípio da atribuição correta da renda ao período competente (princípio do emparelhamento de receitas e despesas correlatas). Assim, a teoria e a prática da concretização do lucro em situações de fornecimento no contexto de negócios pendentes, especialmente os de execução prolongada no tempo, sofrem de uma antinomia entre duas formas de consideração: de um lado, a visão jurídica forte, que se orienta por um princípio da realização clássico, mais estático (que manda alocar a receita à conclusão do ato jurídico), e, de outro lado, uma visão orientada economicamente, segundo

${ }^{145}$ Cf. BEISSE, op. cit. (nota 29), p. 21-22. 
a qual a ideia de uma alocação temporal correta do lucro prevalece (e as receitas e despesas vão sendo alocadas conforme a realização da atividade econômica) ${ }^{146}$.

Da exposição de Beisse, nota-se que os princípios da prudência e da apuração periódica potencialmente conflitam, cabendo ao legislador antever tal dilema na elaboração das regras de realização. Nesse sentido é que, no Brasil, tal critério de realização acontece apenas na presença de fatores bastante peculiares (contrato com preço predeterminado, certeza do recebimento e estimativa de custos conhecida) ${ }^{147}$.

Assim, em situações como aquelas citadas acima (art. 10 do Decreto-lei $\mathrm{n}^{\mathrm{o}}$ 1.598/1977), o princípio da realização das receitas e da confrontação com as despesas privilegia o momento em que os recursos empresariais são consumidos (realização da despesa) para alocar as receitas conforme a realização das despesas (neste caso, a despesa "puxa" a receita, promovendo um emparelhamento mais correto). Aceita-se, por força do princípio da apuração periódica ${ }^{148}$, que o ponto de realização seja transportado para momento temporal anterior àquele que juridicamente seria o crucial para a aquisição definitiva dos direitos (contrariando o que seria um enfoque mais conservador) ${ }^{149}$.

\subsection{Elementos fundamentais do princípio da realização}

Neste tópico são abordados os principais elementos que as doutrinas contábil e tributária costumam identificar no princípio da realização. A subdivisão aqui proposta retrata a classificação formulada por especialistas da área jurídica ${ }^{150}$, porém, complementada com a regulamentação e discussão do tema na área juris-contábil.

\footnotetext{
${ }^{146}$ Cf. BEISSE, op. cit. (nota 29), p. 22, 37.

${ }^{147}$ ECB, item 3.1.5.3.2 e Apêndice aos PFC, item 2.6.3: "No caso das entidades que produzem produtos de longo período de maturação ou acabamento, é razoável, teórica e praticamente, o reconhecimento proporcional da receita pelos fatores acima considerados, observadas as seguintes condições:

a) o preço global do produto é determinado objetivamente mediante contrato ou determinável a partir da correção contratual de seu preço atual;

b) da mesma forma, a incerteza com relação ao recebimento em dinheiro da transação é mínima ou passível de boa estimativa;

c) os custos a serem incorridos para completar a produção são razoavelmente bem estimados."

${ }^{148}$ E também em prol do desenvolvimento econômico, uma vez que tal medida promove a planificação dos resultados, afastando os maléficos efeitos de acumulação ou trava. Afora diminuir o impacto da progressividade de tais contribuintes. Sobre tais questões, vide item 2.5 do Capítulo 1.

${ }_{149}$ Mais discussões a respeito das situações disciplinadas pelo art. 10 do Decreto-lei $\mathrm{n}^{\circ}$ 1.598/1977 podem ser vistas adiante, no item 2.2 do Capítulo 4.

${ }^{150}$ Seguem-se, essencialmente, os critérios conforme a divisão proposta por Bulhões Pedreira, acrescentandolhes aspectos decorrentes da obra de Mariz de Oliveira. Sobre tais critérios como componentes do conceito constitucional de renda, vide item 1.2.4 do Capítulo 2.
} 
Para se ter uma ideia da semelhança com os critérios adotados no Direito Contábil, veja-se o quadro comparativo abaixo quanto aos conceitos relevantes para reconhecimento de receitas e despesas em IFRS e na Contabilidade estadunidense ${ }^{151}$.

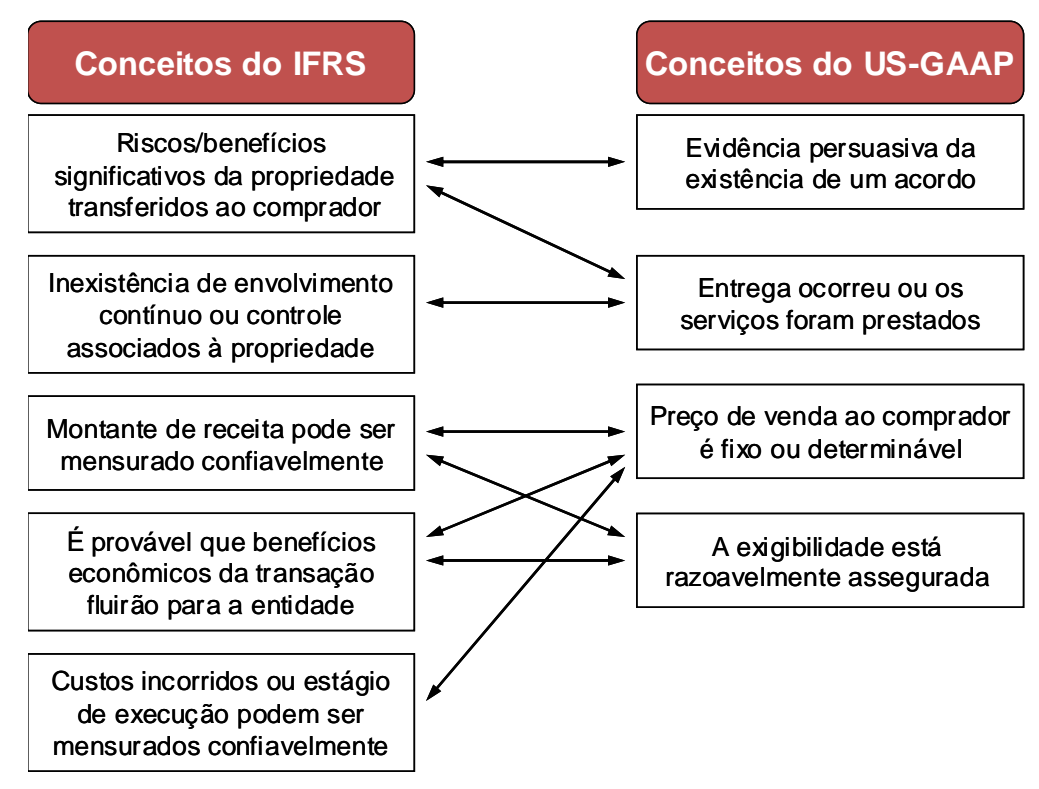

Alguns dos elementos fundamentais do princípio da realização da renda encontrados no Brasil (e discutidos nos items seguintes), aparentam ter maior relação com os conceitos da legislação contábil estadunidense (US-GAAP) do que com os de IFRS. Nesse particular, os três primeiros elementos (cumprimento da obrigação, mudança da posição patrimonial e troca no mercado) resumem-se no segundo conceito de US-GAAP referido acima (entrega). Ademais, a troca no mercado guarda uma certa relação com a existência de um acordo (primeiro conceito de US-GAAP), ao passo que os elementos de mensurabilidade e certeza ligam-se, respectivamente, aos conceitos de determinabilidade e exigibilidade (terceiro e quarto elementos de US-GAAP).

A perspectiva dada ao tema pelos conceitos de IFRS ainda tem pouca ressonância no Brasil, sendo digno de nota, a esse respeito, a inovação trazida pelo inciso IV, do art. 179 da LSA (conforme alteração da Lei $n^{\circ} 11.638 / 2007$ ), a qual introduziu oficialmente os conceitos de riscos, benefícios e controle como conceitos relevantes para fins de reconhecimento de ativos ${ }^{152}$.

${ }^{151}$ Quadro adaptado a partir de PRICEWATERHOUSECOOPERS. Revenue Recognition - Principles in Search of Guidance. In: VATTIPALLI, Kashyap; MUDRULA, E (coord.). Revenue Recognition in Financial Statements: an introduction. Hyderabad (India): ICFAI University Press, 2005, p. 69.

152 "Art. 179 - As contas serão classificadas do seguinte modo: [...] 


\subsubsection{Cumprimento da obrigação (causa ou fonte)}

Organizando os elementos do princípio da realização em uma ordem temporal normal dos acontecimentos que deflagram a incidência do imposto de renda ${ }^{153}$, tem-se, inicialmente, que a geração do lucro decorre (tem por causa ou fonte), em geral, da exploração dos recursos de uma empresa ${ }^{154}$. Em linha com o que se discutiu no Capítulo anterior, o acréscimo patrimonial tributável equivale a acréscimo de direitos ao patrimônio e, considerando-se que os direitos são efeitos de fatos jurídicos, é preciso verificar a ocorrência dos fatos pertinentes para que se considere realizada a renda ${ }^{155}$. Particularmente em relações jurídicas sinalagmáticas, o cumprimento da obrigação ( $1^{\circ}$ elemento) gera direitos que se acrescem ao patrimônio ( $2^{\circ}$ elemento), desde que sua troca no mercado seja certa ( $3^{\circ}$ elemento) e que tais direitos sejam mensuráveis, líquidos e certos ( $4^{\circ}$ elemento). Não necessariamente tais elementos acontecem nesta ordem, por isso, algumas inversões entre eles são também consideradas aqui.

A escolha do evento crítico da realização envolve, como se disse, uma análise de riscos. Assim, demandar que o reconhecimento de receitas e despesas dependa previamente do cumprimento da obrigação pelo fornecedor implica requerer que diversos riscos do negócio já estejam ultrapassados.

Nesse diapasão, pode-se dizer que a atividade empresarial envolve riscos pertinentes às atividades operacionais (riscos relativos à aquisição, produção, valorização e venda de ativos - sejam bens ou serviços), bem como, após a troca no mercado, riscos do pós-venda (riscos pertinentes à aceitação, riscos de crédito e garantia). Com o cumprimento da obrigação, já se terão ultrapassados os riscos das fases de aquisição e

IV - no ativo imobilizado: os direitos que tenham por objeto bens corpóreos destinados à manutenção das atividades da companhia ou da empresa ou exercidos com essa finalidade, inclusive os decorrentes de operações que transfiram à companhia os benefícios, riscos e controle desses bens;" Grifo nosso.

${ }^{153}$ É importante ressaltar que a identificação do momento temporal em que ocorre cada evento isolado (dentre todos os eventos aumentativos e diminutivos de patrimônio) não se confunde com o aspecto temporal do fato gerador do imposto de renda (apuração anual). Todavia, a definição do ponto de realização de cada evento é importante para se determinar a quais períodos de apuração pertencem tais ou quais receitas e despesas. A esse respeito, ver AMARO, Luciano da Silva. Imposto sobre a renda e proventos de qualquer natureza. In: MARTINS, Ives Gandra da Silva (coord.). O fato gerador do imposto sobre a renda e proventos de qualquer natureza: Caderno de Pesquisas Tributárias, v. 11. São Paulo: Resenha Tributária, 1986, p. 393-395.

${ }^{154} \mathrm{Com}$ a simplicidade e clareza que lhe eram comuns, Brandão Machado resume definitivamente este elemento com a seguinte colocação: "Tem de acontecer um fato econômico com revestimento jurídico como condição para que se dê a realização". Cf. MACHADO, op. cit. (nota 2), p. 3201.

${ }^{155}$ Vide o Capítulo 2, especialmente no item 2.3, em que se resumiu a questão, apontando que a realização é condicionada à constituição definitiva da situação jurídica geradora de obrigação tributária (art. 116, inciso II, do CTN) e à inexistência de condição suspensiva (art. 117, inciso II, do CTN). 
produção e, mais ainda, contratada a venda ( $3^{\circ}$ elemento), restam apenas os riscos de crédito e garantia, pois os riscos de aceitação já estarão potencialmente reduzidos ${ }^{156}$.

Ainda que o risco de não-venda seja amenizado pelo fechamento de um contrato prévio (prenunciando a presença do $3^{\circ}$ elemento), tal fato não costuma ser tomado como evento crítico. Embora a obrigação (de prestação de serviços ou fornecimento de mercadorias) esteja definida e o preço acertado, muitos riscos do negócio ainda subsistem (sobretudo da perspectiva da responsabilidade civil/contratual) ${ }^{157}$. Enquanto o fornecedor ainda tiver que honrar o objeto da relação jurídica ou produzir o bem, ele carrega os riscos inerentes à sua própria capacidade ${ }^{158}$.

Leffson aponta, com razão, que, após o implemento da obrigação contratual, não restam maiores dificuldades, pois, a partir daí, os riscos do fornecedor resumem-se à possível devolução (nos casos em que cabível), ao apontamento de defeitos e ao atraso no pagamento ou inadimplência. E esses riscos geralmente pertencem e devem ser quantificados num universo coletivo, quer mediante o uso de coeficientes médios empíricos, quer por meio do reconhecimento de perdas efetivas verificadas até o fechamento anual ${ }^{159}$ - ainda que tais perdas sejam oriundas de resultados tributados em períodos anteriores ${ }^{160}$. Logo, a atividade empresarial pode não ser tomada como realizada completamente quando ainda recaírem, sobre o fornecedor, obrigações fundamentais, ou quando o adquirente tiver o direito de devolução (do bem, por exemplo) ${ }^{161}$. Para Mariz de Oliveira, a receita é reconhecida quando se verifica um acréscimo de direito que não acarrete qualquer prestação para o fornecedor, que esteja pendente de cumprimento por ele $^{162}$.

Por essa razão, o cumprimento da obrigação é elemento fundamental da realização. Todavia, não se pode dizer que é elemento indispensável, pois, como a própria

\footnotetext{
${ }^{156}$ Cf. SCHRÖER, op. cit. (nota 57), p. 138. Para a menção a riscos na obra de Mariz de Oliveira, vide a nota de rodapé 141, neste Capítulo.

${ }^{157}$ Cf. SCHRÖER, op. cit. (nota 57), p. 136. Mais sobre o fechamento de contratos como evento de realização pode ser visto no item 2.1 do Capítulo 4.

158 Cf. DAUBER, Desiree. Das Realisationsprinzip als Grundprinzip der steuerrechtlichen Gewinnermittlung. Frankfurt am Main: Peter Lang, 2003, p. 135-136.

${ }^{159}$ Cf. LEFFSON, op. cit. (nota 67), p. 262-263.

${ }^{160}$ Nesta última situação (reconhecimento de perdas atuais por causa da tributação de resultados correlatos em períodos pretéritos) se identifica claramente um mecanismo de reconciliação. Cf. WHITE, Patricia D. Realization, Recognition, Reconciliation, Rationality and the Structure of the Federal Income Tax System, Michigan Law Review, v. 88, 1990. Artigo parcialmente reproduzido em CARON, Paul L et alli. Federal income tax anthology. Cincinatti: Anderson Publishing Co., 1997, p. 210.

${ }^{161}$ Cf. LEFFSON, op. cit. (nota 67), p. 263-264.

${ }^{162}$ Cf. OLIVEIRA, op. cit. (nota 60), p. 104.
} 
regulamentação contábil retrata, há outras situações que geram acréscimo patrimonial à empresa independentemente de uma prestação correlata, ou de um negócio bilateral ${ }^{163}$.

Defendendo, com autoridade, o conceito de renda como resultado da exploração do patrimônio empresarial ${ }^{164}$, Carvalhosa e Mariz de Oliveira sustentam a intributabilidade das transferências patrimoniais (doações, heranças etc.) em razão da gratuidade de tais acréscimos patrimoniais ${ }^{165}$. Quanto à hipótese de se verificar um acréscimo patrimonial em razão de redução ou extinção de obrigações (passivos) sem o sacrifício correspondente de ativos, Mariz de Oliveira, embora pareça, a princípio, exigir a concomitante exploração do patrimônio como elemento essencial ao reconhecimento de receita nesses casos ${ }^{166}$, acaba por concluir pela prescindibilidade do elemento "cumprimento da obrigação"167.

Ademais, a despeito de não previsto plenamente no art. $9^{\circ}, \S 3^{\circ}$ da Resolução CFC $n^{\circ} 750 / 1993$, dispositivo que, como se disse, padece de incompletude, o acréscimo

\footnotetext{
${ }^{163}$ É de se notar que, na Resolução CFC no 750/1993, por exemplo, apenas os itens I e II parecem decorrer do cumprimento de obrigações pela empresa: "Art. $9^{\mathbf{0}}[\ldots]$ \& $\mathbf{3}^{\mathbf{0}}$ - As receitas consideram-se realizadas:

I - nas transações com terceiros, quando estes efetuarem o pagamento ou assumirem compromisso firme de efetivá-lo, quer pela investidura na propriedade de bens anteriormente pertencentes à ENTIDADE, quer pela fruição de serviços por esta prestados;

II - quando da extinção, parcial ou total, de um passivo, qualquer que seja o motivo, sem o desaparecimento concomitante de um ativo de valor igual ou maior;

III - pela geração natural de novos ativos independentemente da intervenção de terceiros;

IV - no recebimento efetivo de doações e subvenções." Grifo nosso.

${ }^{164}$ Vide a esse respeito o item 2.2.2 do Capítulo 2.

165 "Não é tributável, portanto, a renda acrescida ao patrimônio de uma determinada pessoa a título gratuito, por doação, herança etc. Assim, os acréscimos patrimoniais gratuitamente trazidos à titularidade de uma certa pessoa, são intributáveis sob o aspecto do Imposto de Renda, já que constituem capital e não renda." Cf. CARVALHOSA, Modesto. Imposto de renda. Conceituação no Sistema Tributário da Carta Constitucional. Revista de direito público, $\mathrm{n}^{\circ} 1$, jul/set, 1967, p. 190. "[...] a receita vem de fora, mas por efeito de ações desenvolvidas pela pessoa ou pelo emprego do seu patrimônio, enquanto que as transferências patrimoniais são originadas de fora da empresa, pois vêm de patrimônios alheios, mas não são decorrências de ações do patrimônio ao qual se agregam, ou do seu titular.” Grifo nosso. Cf. OLIVEIRA, op. cit. (nota 60), p. 124-125. ${ }^{166}$ Empenhado em justificar a intributabilidade das transferência patrimoniais, Mariz afirmar que a "redução ou extinção de obrigação, sem pagamento ou qualquer outro comprometimento de ativos, também pode ser considerada receita, o que ocorre se for possível identificar nela uma forma de remuneração ou contraprestação do patrimônio; ao contrário, não se tratará de receita se tal redução de passivo for uma hipótese de transferência de dívida para o patrimônio líquido, como pode ocorrer com a transferência de créditos dos sócios contra a pessoa jurídica, para um aumento de capital ou absorção de prejuízos acumulados, além dos casos em que o perdão de dívida perante os sócios ou terceiros se constituir numa gratuidade, que importa em situação típica de doação" Grifo nosso. Cf. OLIVEIRA, op. cit. (nota 60), p. 104105.

167 "Seria possível excluir as reduções não contraprestacionais de passivos do elenco das receitas se se pudesse afirmar que o direito somente reconhece como receitas as provindas de atividades da pessoa jurídica exclusivamente na exploração do seu objeto empresarial propriamente dito. Todavia, além de não encontrar qualquer definição legal que conduza a um tal estreitamento do conceito de receita, sabemos, pelo contrário, que, para fins das demonstrações financeiras (Lei n. 6.404, art. 187) e do imposto de renda (Decreto-lei $n$. 1.598 , art. 11), as receitas da pessoa jurídica são operacionais - as decorrentes da exploração de seu objeto social e outras assim definidas por lei - e não operacionais, que se constituem por todas as demais." Grifo nosso. Cf. OLIVEIRA, op. cit. (nota 60), p. 128.
} 
patrimonial pode decorrer também de eventos de origem externa, de ocorrência alheia à vontade do empresário, mas com efeitos sobre o patrimônio (e.g. mudanças nas taxas de câmbio, quebras de clientes, efeitos de catástrofes naturais) ${ }^{168}$.

\subsubsection{Mudança na posição patrimonial}

Também denominado de mudança na substância dos direitos ou, mais sintética e restritivamente, conversão em direitos novos, este elemento é às vezes difícil de ser dissociado do elemento discutido anteriormente, uma vez que, via de regra, o cumprimento da obrigação pelo fornecedor aperfeiçoa-se instantaneamente com o surgimento, para ele, do direito de crédito (materializando-se concomitantemente a correspondente obrigação do adquirente de pagar o preço) ${ }^{169}$.

$\mathrm{Na}$ visão da passagem dos riscos, verifica-se que, no referido momento temporal, não há mais riscos quanto à capacidade do fornecedor de cumprir o contrato e não se conta mais com o direito de renúncia do adquirente. Isso sempre pode ser afirmado quando o risco do recebimento do preço tiver sido suplantado ${ }^{170}$. Neste momento, gera-se um direito fungível que pode ser reconhecido como um ativo no balanço do fornecedor e ser cedido, emprestado, dado em garantia, ou descontado. Concluída a atividade empresarial de fornecimento, dela decorre um crédito, que é um negócio de outra natureza $^{171}$. A geração de um crédito é suficiente, para o balanço comercial, quanto ao critério de distribuição dos lucros sem prejuízo dos credores, porquanto os créditos decorrentes de fornecimento de bens e/ou prestação de serviços podem ser predominantemente compensados ou transformados em meios líquidos ${ }^{172}$.

Com isso, a realização da renda exige a mudança da posição patrimonial, ou, como resumido por Brandão Machado, a "mudança na forma ou na substância da propriedade do contribuinte (ou dos direitos)" ${ }^{173}$, isto é, "quando uma parcela do patrimônio do contribuinte dele se destaca jurídica e economicamente, produzindo um

\footnotetext{
${ }^{168}$ A Resolução CFC n n $^{\text {774 }}$ /1994 assim explica ao tratar do princípio da oportunidade (o qual se confunde com o princípio da realização). Vide item 2.3.1 do Apêndice aos PFC.

${ }^{169}$ Mariz de Oliveira, ao definir receita, menciona "receita é um novo direito adquirido pelo titular do patrimônio, que corresponda à obrigação para um terceiro [a obrigação do terceiro de pagar o preço], a qual surge necessariamente no mesmo momento da aquisição do direito por aquele titular, mas cujo cumprimento ou extinção não necessita ocorrer simultaneamente" Cf. OLIVEIRA, op. cit. (nota 60), p. 104.

${ }^{170}$ Cf. DAUBER, op. cit. (nota 158), p. 145.

${ }^{171}$ Cf. LEFFSON, op. cit. (nota 67), p. 262-263.

${ }^{172}$ Cf. SCHRÖER, op. cit. (nota 57), p. 136.

${ }^{173}$ Cf. MACHADO, op. cit. (nota 133), p. 108.
} 
acréscimo de valor, então se diz que ocorreu a realização" ${ }^{\text {174 }}$. Neste particular, Klaus Tipke menciona que a ausência de mudança na posição patrimonial costuma ser a justificativa para que determinadas operações de permuta de bens similares sejam eximidas de tributação, pois tais transações deixam o contribuinte na mesma posição patrimonial anterior $^{175}$.

Essa mudança na posição patrimonial deve ser diferenciada de outros fenômenos que, embora possam afetar internamente o patrimônio estático da empresa, não se qualificam como acréscimo patrimonial, porque não causam alteração do patrimônio líquido da empresa. Tais eventos são normalmente qualificados como permutações patrimoniais, pois envolvem variações, deslocamentos ou trocas, enfim, eventos neutros ocorridos no interior do patrimônio empresarial ${ }^{176}$. Outros eventos como, por exemplo, uma operação de mútuo, geram direito novo, que, contudo, não se qualifica como acréscimo patrimonial porque é contrabalanceado pela obrigação de restituir a coisa fungível mutuada (Código Civil, art. 586) ${ }^{177}$

Deve-se deixar claro, ainda, que não basta a verificação da entrada de um direito novo no patrimônio da empresa para que se conclua haver realização de renda. $\mathrm{O}$ acréscimo patrimonial depende da confrontação com as despesas, de forma que, tendo o novo direito e o antigo direito valores idênticos, não ocorrerá mudança da posição patrimonial $^{178}$.

Somente a mudança efetiva na posição patrimonial interessa. Coerentes com sua posição de que o mero acréscimo de valor de ativos patrimoniais detidos pela empresa não se qualifica como evento de realização para fins de tributação, Bulhões Pedreira e Mariz de Oliveira definem restritivamente este elemento da realização como equivalente à entrada de novos direitos ${ }^{179}$. Esse novo direito, alerta Mariz, deve representar direito certo,

\footnotetext{
${ }^{174}$ Cf. MACHADO, op. cit. (nota 2), p. 3202.

${ }^{175}$ Cf. TIPKE, op. cit. (nota 96), p. 8-9.

${ }^{176}$ Os exemplos dados por Mariz de Oliveira ilustram bem este ponto: "Daí se perceber que as permutações patrimoniais podem decorrer da mera redestinação de um bem (como nos exemplos da desativação de uma unidade e utilização de uma mercadoria antes destinada à venda), ou de substituição de um direito por outro (como no exemplo do direito de crédito por dinheiro em caixa ou banco), ou de substituição de uma obrigação por outra (como no exemplo em que a obrigação do devedor é paga pelo avalista), ou por uma saída simultânea de um direito e de uma obrigação (como no exemplo do empréstimo pago), ou pela entrada de um direito [...] simultânea à entrada de uma obrigação (como no exemplo da aquisição de um bem a prazo), ou ainda pela saída de um direito e a simultânea entrada de um outro direito (como no exemplo do pagamento do aval pelo avalista)" Cf. OLIVEIRA, op. cit. (nota 60), p. 84.

${ }^{177}$ Cf. OLIVEIRA, op. cit. (nota 60), p. 122-123.

${ }^{178}$ Cf. OLIVEIRA, op. cit. (nota 60), p. 88.

${ }^{179}$ Cf. PEDREIRA, op. cit. (nota 46), p. 561. Cf. OLIVEIRA, op. cit. (nota 60), p. 133. Ver também o item 2.2.2 do Capítulo 2.
} 
e não mera expectativa de direito, ou direito futuro, sujeito a um evento futuro e incerto ${ }^{180}$. A restrição é válida para fins de tributação, sobretudo em vista da limitação imposta pelo CTN para a incidência do imposto apenas na aquisição de disponibilidade (no sentido de acréscimo de riqueza nova $)^{181}$.

A seu turno, no que respeita às hipóteses de redução do passivo, também é possível visualizar nelas o acréscimo de direitos. Para tanto, recorda-se que, no momento original de constituição da obrigação, houve a concomitante entrada de um direito ao patrimônio da empresa (sem causar acréscimo patrimonial neste momento), de forma que a desoneração do passivo gera o reconhecimento tardio de um direito novo, cuja efetiva entrada ocorreu em momento anterior ${ }^{182}$.

Enfim, o ponto temporal em que ocorre a mudança da equação patrimonial é o que importa para fins de realização. Segundo já se apontou aqui, a definição deste momento da aquisição de direitos depende substancialmente dos aspectos jurídicos envolvidos, amarrando-se o Direito Tributário ao Direito Civil para a determinação do evento crítico da realização da renda ${ }^{183}$. A respectiva estrutura de Direito Civil é decisiva para observar o grau de redução de risco e, com isso, para a identificação do ponto temporal de realização da renda ${ }^{184}$.

\subsubsection{Troca no mercado}

Conforme já tangenciado por muitas vezes ao longo desta exposição, o elemento de troca ou transação no mercado restou consagrado como evento crítico tradicional para implementação do princípio da realização (ou de competência) ${ }^{185}$. Em

\footnotetext{
${ }^{180}$ Vide crítica a esta posição nos itens 2.1 e 2.3 do Capítulo 2.

${ }^{181}$ Vide a esse respeito o item 2.2.2 do Capítulo 2.

182 "Ainda que se imagine o aspecto, mais físico do que substancial, de ingresso de algo novo no ativo ingresso de dinheiro ou outros bens - como sendo um elemento presente nas receitas, ainda assim não haverá dificuldade em integrar a extinção ou redução de obrigação sem pagamento no conceito de receita, desde que observados os demais elementos deste.

Realmente, quando a obrigação foi constituída, necessariamente a sua contrapartida foi o ingresso de dinheiro ou alguma utilidade ou bem no ativo do devedor, de tal arte que, com a exoneração da obrigação, remanesceu no ativo aquele bem, agora sem contrapartida de prestação ou obrigação, o que resulta "em cheio" num dos componentes do conceito de receita.

Sob esse aspecto, o que ocorre apenas é um lapso temporal entre a entrada do bem no ativo e a sua incorporação ao patrimônio como direito novo e permanente, a qual ficou transferida para o momento da exoneração da respectiva obrigação.” Cf. OLIVEIRA, op. cit. (nota 60), p. 129-130.

${ }^{183}$ Vide a esse respeito as considerações feitas no item 2.3 do Capítulo 2.

${ }^{184}$ Cf. SCHRÖER, op. cit. (nota 57), p. 141.

${ }^{185}$ Vide especialmente os itens 2.1 e 2.5 do Capítulo 1, os itens 2.2.1 e 2.2.2 do Capítulo 2, bem como os itens 2.4 .3 e 3.2.1 deste Capítulo.
} 
razão da vinculação estreita do princípio da realização com o princípio da prudência, a determinação do ponto temporal de realização deve atender ao requisito de objetividade, o qual se verifica satisfeito geralmente por meio de uma transação de mercado ${ }^{186}$.

As razões mencionadas no Direito Contábil para a escolha deste momento da atividade econômica são as de que: (i) praticamente todo o esforço substancial para a geração de receita já foi desenvolvido; (ii) garante-se objetividade e exatidão ao valor atribuído à receita; e (iii) as despesas correlatas já são conhecidas ${ }^{187}$. Se considerado que os itens (i) e (iii) já teriam sido atendidos pelo critério do cumprimento da obrigação $\left(1^{\circ}\right.$ elemento discutido acima), a função do elemento transacional ora abordado ( $3^{\circ}$ elemento) seria essencialmente a de certificar ou assegurar que o negócio é representativo do valor de mercado.

Deve-se sublinhar, na observação de Bulhões Pedreira, que o valor de receita gerado pela troca pressupõe uma transação de mercado ${ }^{188}$, porque o princípio da objetividade somente é pleno quando presentes condições normais de mercado no negócio que realiza a renda ${ }^{189}$. A participação de um terceiro é também elemento enfatizado por Brandão Machado ${ }^{190}$, sugerindo-se igualmente o requisito de troca no mercado. Conforme nos ensina Beisse, ausente tal condição, acontece o fenômeno da realização por captura ${ }^{191}$, sendo uma de suas hipóteses exatamente aquela dos "fatos geradores de realização complementar sui generis", nos quais se verifica uma relação de troca que possa ser influenciada por fatores de vinculação ou proximidade entre as pessoas ${ }^{192}$.

Conforme já se salientou, de acordo com o pensamento dominante, o ponto de venda (troca efetiva no mercado) materializa geralmente o acontecimento relevante de realização, uma vez que, neste ponto do tempo, os riscos estão reduzidos a uma medida administrável (riscos de crédito e de garantia permanecem) ${ }^{193}$.

\footnotetext{
${ }^{186}$ Cf. SCHRÖER, op. cit. (nota 57), p. 204.

${ }^{187}$ Vide item 3.1.5.3.3 da ECB.

${ }^{188}$ Cf. PEDREIRA, op cit. (nota 46), p. 561.

${ }^{189}$ Cf. PEDREIRA, José Luiz Bulhões. Imposto sobre a renda - pessoas jurídicas. Rio de Janeiro: Justec, 1979 , p. 335-336.

${ }^{190}$ Cf. MACHADO, op. cit. (nota 133), p. 108.

191 Entstrickung, que são eventos de realização definidos fundamentalmente por razões próprias da sistemática tributária e acontecem normalmente em situações nas quais determinados ativos são colocados fora da jurisdição tributária de um determinado país, isto é, em uma posição tal que o alcance do imposto de renda sobre as reservas silentes não mais estará garantido. Cf. BEISSE, op. cit. (nota 29), p. 28-35. Vide a esse respeito o item 8 do Capítulo 4.

${ }^{192}$ Nesses casos, a legislação tributária prevê mecanismos próprios de correção (complementação) do valor de realização. Trata-se das regras de distribuição disfarçada de lucros e de preços de transferência. Vide a esse respeito o item 8 do Capítulo 4.

${ }^{193}$ Cf. SCHRÖER, op. cit. (nota 57), p. 138.
} 
Porém, já se disse também que a realização pode ocorrer antes do ponto de venda. Conforme se verifica da $\mathrm{ECB}^{194}$, em circunstâncias especiais, produtos cujo processo de produção ocorre por crescimento natural ou acréscimo de valor vegetativo e produtos que tenham valor de mercado prontamente determinável e risco de não-venda praticamente nulo podem gerar o reconhecimento de receitas antes do ponto de venda (conforme o andamento ou término da produção). Sob uma perspectiva de análise de riscos, a razão para antecipar o ponto de realização é que, nesses negócios, as atividades físicas de crescimento, nascimento, envelhecimento etc. respondem mais pela obtenção do lucro do que as atividades de venda e entrega ${ }^{195}$.Para tornar isso possível, a determinação do valor de avaliação deve ser fundada em amplo consenso de mercado, atendendo-se, assim, a uma das formas possíveis de implementação do princípio de objetividade ${ }^{196}$.

Esta hipótese de realização prévia ao ato de venda levanta questões interessantes, sobretudo se considerado que a função primordial da troca no mercado, como se viu, consiste em conferir objetividade ao valor da transação. A questão que se coloca é se a própria empresa deve ser vinculada à transação (transação de mercado em sentido estrito), ou se basta uma transação entre terceiros (transação de mercado em sentido amplo $)^{197}$. A esse respeito, Schröer informa que, embora a visão predominante seja a de que a empresa deve ser parte ela própria da transação, pode-se reconhecer, na posição adotada no Reino Unido, que este critério no futuro deverá ter uma menor importância ${ }^{198}$. Com efeito, segundo aqui já se reportou, vem sendo implementado um sistema de tributação marcada a mercado no Reino Unido, o qual prescindiria da transação de mercado em sentido estrito, afastando-se do critério tradicional de realização ${ }^{199}$.

A adoção de uma referência de mercado, ainda que ampla, justifica a importância do elemento de troca. Todavia, há situações em que não se troca nada, isto é, não há sacrifício de ativo para a aquisição do direito novo (e.g. doações, heranças e perdão

\footnotetext{
${ }^{194}$ Item 3.1.5.3.3 da Deliberação CVM no 29/1986.

195 Item 3.1.5.3.3, alínea "c", da Deliberação CVM no 29/1986.

${ }^{196}$ Vide nota de rodapé 104 neste Capítulo e o texto que a introduz.

${ }^{197}$ Quando os produtos vendidos são homogêneos, há um grande mercado e há pouco ou nenhum esforço associado à venda, há uma probabilidade próxima de $100 \%$ de que a empresa venda seus produtos a um valor de mercado. Cf. DAVIDSON, Sidney. The realization concept. In: BACKER, Morton (coord.). Modern accounting theory. New York: Prentice Hall, 1966, p. 104.

${ }^{198}$ Cf. SCHRÖER, op. cit. (nota 57), p. 204-205.

${ }^{199}$ Vide a esse respeito o item 3.3 do Capítulo 1.
} 
de dívida ${ }^{200}$ ), assim como há situações em que a troca não gera acréscimo patrimonial, ilustrando situações em que o elemento de troca sozinho não é suficiente para deflagrar a realização de um acréscimo patrimonial ${ }^{201}$, como de resto já se viu acima ${ }^{202}$.

A troca que interessa é essencialmente aquela que decorre de negócios jurídicos contraprestacionais, pois a renda que se tributa é aquela que decorre primordialmente da exploração do patrimônio empresarial.

\subsubsection{Mensurabilidade, liquidez e certeza}

Quanto aos aspectos de mensurabilidade e liquidez, pode-se dizer que são pressupostos essenciais à realização da renda que, via de regra, estão presentes no momento temporal da troca de mercado. Isso porque, como dito, o ato de troca de mercado é aquele que, em princípio, confere exatidão ao valor da operação (sobretudo quando a troca é contra dinheiro). Todavia, caso tal valor não seja prontamente mensurável ou haja problemas de liquidez, a realização não se concretiza, pois não atende satisfatoriamente aos princípios da precaução e da objetividade.

$\mathrm{O}$ aspecto de mensurabilidade tem, portanto, relação umbilical com o princípio da objetividade descrito acima, dado que exige a comprovação (direta ou indireta) do valor econômico atribuído aos bens e serviços transacionados ${ }^{203}$. Nos dizeres de Bulhões Pedreira, se "os direitos recebidos na troca são dinheiro, não há dúvida de que o lucro está realizado; mas se não têm valor em dinheiro determinável com precisão (...) ainda não há lucro real ou efetivo" 204 .

Liquidez é entendida aqui como a aptidão de outros bens que não o dinheiro serem transformados nele ${ }^{205}$. Quanto maior a liquidez, torna-se mais concreto falar em renda realizada; quanto menor, tanto maior é a chance de diferimento do ponto de

\footnotetext{
${ }^{200}$ Para a ilustração da hipótese do perdão de dívida: “[...] aumento patrimonial derivado de saída de uma obrigação existente no passivo patrimonial somente ocorre se, para extingui-la, não for utilizado qualquer ativo (como ocorre no perdão de dívida) ou for utilizado ativo de menor valor que o da obrigação (como pode ocorrer na dação em pagamento)." Grifo nosso. Cf. OLIVEIRA, op. cit. (nota 60), p. 88.

${ }^{201}$ Mariz de Oliveira menciona situações de permutação patrimonial que envolvem terceiros, porém não causam a realização da renda: "quando terceiros estejam envolvidos, a permutação decorre de que se troca um direito por outro, como o direito de receber pelo direito sobre o dinheiro recebido em pagamento, que, simultaneamente, no patrimônio do devedor, representa a troca do dinheiro dado em pagamento pela extinção da obrigação de pagar." Grifo nosso. Cf. OLIVEIRA, op. cit. (nota 60), p. 84-85.

${ }^{202}$ Vide as notas de rodapé 176 e 177 neste Capítulo e o texto que as introduz.

${ }^{203}$ Sobre os métodos de avaliação, vide a nota 141 e o texto que a introduz no Capítulo 2.

${ }^{204}$ Cf. PEDREIRA, op. cit. (nota 46), p. 562.
} 
realização para o momento em que possa ser tornado líquido o bem ou o serviço recebido em troca (e.g. permuta). Há que se falar ainda no aspecto da certeza, pois a incerteza sobre a possibilidade de recebimento é também elemento direcionador da decisão (tipicamente subjetiva e dependente das condições a serem avaliadas no caso concreto) quanto ao reconhecimento ou não da receita subjacente.

Tais requisitos são tratados na regulamentação contábil como requisitos específicos de alguns princípios. Assim, ao regular o princípio da oportunidade (que, como já se ressaltou, retrata determinados aspectos do princípio da realização), coloca-se a mensurabilidade como condição para o registro da variação patrimonial ${ }^{206}$, bem como, ao se tratar do princípio da competência, destaca-se que a realização da receita depende de compromisso firme por parte dos devedores (indicando o requisito da certeza) (207. $^{207}$

A propósito, a regulamentação contábil das situações em que se verifica a realização da renda em momento posterior à troca no mercado fundamenta-se, basicamente, em razões de falta de mensurabilidade e/ou liquidez. Fala-se, assim, do recebimento de ativo em troca de uma venda efetuada (sugerindo que uma permuta de ativos, por exemplo, não deveria gerar a realização de ganho ou perda para fins do balanço comercial $^{208}$ ), de negócios ou operações cujo risco de crédito é comprovadamente alto ${ }^{209}$, ou em que falta certeza quanto ao recebimento das prestações do preço ${ }^{210}$.

\footnotetext{
${ }^{205}$ Liquidez aqui, portanto, não se refere a um daqueles atributos do título executivo (liquidez, certeza e exigibilidade - cf. art. 586 do Código de Processo Civil), pois, se assim o fosse, liquidez seria sinônimo de mensurabilidade. Liquidez é tomada aqui no sentido do art. $178, \S 1^{\circ}$ da LSA.

${ }^{206}$ Resolução CFC $\mathbf{n}^{\mathbf{0}}$ 750/1993 “Art. 6º [...] § único - Como resultado da observância do Princípio da Oportunidade:

I - desde que tecnicamente estimável, o registro das variações patrimoniais deve ser feito mesmo na hipótese de somente existir razoável certeza de sua ocorrência;" - Grifo nosso.

${ }^{207}$ Resolução CFC no 750/1993 “Art. $9^{\circ}$ [...] § $3^{\mathbf{0}}$ - As receitas consideram-se realizadas

I - nas transações com terceiros, quando estes efetuarem o pagamento ou assumirem compromisso firme de efetivá-lo, quer pela investidura na propriedade de bens anteriormente pertencentes à ENTIDADE, quer pela fruição de serviços por esta prestados;" - Grifo nosso.

${ }^{208}$ ECB, item 3.1.5.3.4 "a) no caso de um ativo não monetário ser recebido em troca de uma venda efetuada, se esse ativo não tiver um valor reconhecido de mercado. Nesse caso, o custo do ativo vendido é transferido para o ativo recebido em troca e somente quando esse último for vendido é que reconheceremos um resultado;",

${ }^{209}$ ECB, item 3.1.5.3.4 "b) no caso de entidades que pratiquem a venda a prazo (comumente a prestação), quando a operação for de natureza tal que não seja possível estimar, mesmo que por experiência estatística do passado, a porcentagem de recebimentos duvidosos, passando o recebimento a ser a etapa mais difícil no processo de ganho da receita;"

${ }^{210} \mathrm{ECB}$, item 3.1.5.3.4 “c) nos casos de negócios altamente especulativos, em que os recebimentos são realizados em prestações e o recebimento das prestações finais é duvidoso. Em tais casos, pode ser justificado o diferimento da receita; as primeiras prestações serão consideradas como retorno ou cobertura dos custos incorridos e o lucro começa a ser registrado apenas após todos os custos terem sido recuperados.”
} 
Nesse particular, aliás, devem-se aplicar com parcimônia as conclusões do erudito parecer de Brandão Machado no que concerne à falta de liquidez de notas promissórias recebidas em pagamento como causa para diferir a realização da respectiva receita. Diz o brilhante jurista, esteando-se na opinião de autores estrangeiros ${ }^{211}$, que o recebimento de nota promissória a título de pagamento somente poderia causar a realização da renda se fosse altamente negociável. Todavia, é de se notar que tal inferência foi traçada para situações de contribuinte sujeitos ao regime de caixa (evento de realização conforme o recebimento). Para os contribuintes que apurem o imposto de renda com base em regime de competência, não é possível concluir da mesma forma, pois a nota promissória representa um compromisso firme de pagamento, demandando o registro da renda normalmente no momento da troca de mercado.

Tal nota promissória, bem como qualquer outro título de crédito ou compromisso de pagamento têm suas liquidez e certeza presumidas para os contribuintes do regime de competência. Não obstante isso, tal presunção pode também ser refutada, especialmente nas situações em que houver fundadas dúvidas quanto à possibilidade de realização efetiva (recebimento) de tais créditos (falta do requisito certeza). Nessa seara, a constatação de tais razões de ausência de certeza já foi motivo para o afastamento do critério pertinente de realização (orientado pelo ponto do reconhecimento judicial da pretensão resistida, pela passagem do tempo, pelo ponto da troca no mercado etc.) em diversos casos concretos levados a julgamento perante as instâncias administrativas ${ }^{212}$. Dentre outras razões para o diferimento da receita, pode-se citar a dúvida quanto à solvência do devedor pode ser motivo para a não realização da renda ${ }^{213}$, assim como a

211 “É razoável concluir que uma nota promissória não negociável na forma indicada no Código Comercial Uniforme não é, quase por definição, um equivalente em dinheiro, uma vez que ela não é livre e facilmente negociável a ponto de passar de mão em mão no comércio." (Diamond e Curtler, "Promissory notes for services: when are they taxable to a cash basis taxpayer?" in Journal of Taxation, vol. 26, 1967, págs. 6768.)" Cf. MACHADO, op. cit. (nota 2), p. 3210.

${ }^{212}$ Vide a nota 44 e o texto que a introduz, bem como o item 2.4.2 deste Capítulo.

${ }^{213}$ Acórdão no 107-06.012, proferido pela $7^{\text {a }}$ Câmara do Primeiro Conselho de Contribuintes em 12/07/2000. Transcrição do voto do Conselheiro e Relator Paulo Roberto Cortez: "Ora, se pelas características do crédito houver fundadas dúvidas quanto a sua efetiva realização, em face da aplicação do princípio da prudência, o regime de competência cede passo, devendo a receita ser reconhecida se e quando efetivamente realizada, como se dá nos casos de créditos de liquidação duvidosa em que o contribuinte pode e deve cessar a sua atualização quando porque incerta a sua realização, ou mesmo sequer se reconhecer o crédito quando desde logo se apresente inserta a sua realização.

Note-se que não obstante o subjetivismo da regra (sua aplicação depende da análise de cada caso concreto), a sua aplicação se impõe não apenas em face da ciência contábil mas também em razão do próprio ordenamento jurídico, cabendo naturalmente ao contribuinte a prova de sua correta adoção, isto é, de que o crédito não teria sido reconhecido em face de fundadas incertezas quanto a sua realização." - Vide também a nota 100 supra. 
caracterizada inadimplência ${ }^{214}$, sobretudo naquelas atividades empresariais para as quais a assunção do risco de crédito (sem regresso) constitui parcela essencial do negócio ${ }^{215}$.

\subsection{Outros princípios contábeis relacionados ao princípio da realização}

Concluindo a análise deste tópico, não se pode passar ao largo de três outros princípios integrantes dos PCGA que guardam relação estreita com o princípio da realização. Trata-se dos princípios do menor valor entre custo de aquisição ou mercado, do princípio do valor corrente e da imparidade.

\subsubsection{Princípio do menor valor entre custo de aquisição ou mercado}

Constata-se, frequentemente, na literatura que o princípio do custo como base de valor é o principal princípio conexo ao princípio da realização, de forma que todos os ativos patrimoniais devam ser valorados no máximo pelo seu custo de aquisição (ou produção) até o momento em que ocorrer a realização, evitando-se, com isso, a demonstração antecipada de lucros (especialmente lucros não realizados) ${ }^{216}$. Esses dois princípios operam em momentos diferentes do processo de geração e reconhecimento da renda, isto é, o princípio do menor valor impera, evitando o reconhecimento da variações positivas de valor, até o momento em que o princípio da realização (mediante o critério legal cabível) apontar para a definitividade da respectiva renda.

\footnotetext{
${ }^{214}$ Acórdão no 107-07.458, proferido pela $7^{\text {a }}$ Câmara do Primeiro Conselho de Contribuintes em 04/12/2003. Transcrição do voto-vista (vencedor) do Conselheiro Natanael Martins: "Tenho visto, ao longo de minha atividade neste Conselho, uma crescente idolatria ao princípio (regime) de competência como se este, embora de inegável peso, fosse o único dos princípios que devem nortear a Ciência Contábil e os trabalhos de seus operadores e, consequentemente, fosse o único a nortear a apuração do lucro (base do IRPJ/CSL) ou da receita tributável (base do PIS/COFINS).

Realmente, pouco debate se vê quanto à aplicação dos demais princípios que norteiam a contabilidade, sobretudo daqueles que conformam (ou informam) a aplicação de outros princípios. [...]

Entretanto há situações em que demais princípios que norteiam a contabilidade, especialmente o da prudência ou do conservadorismo, impedem a adoção plena do regime de competência.

Tal fato naturalmente ocorre quando se verificam fundadas dúvidas quanto à segura realização da receita, como se dá, v.g., quando a inadimplência do devedor restar caracterizada, como é o caso dos autos."

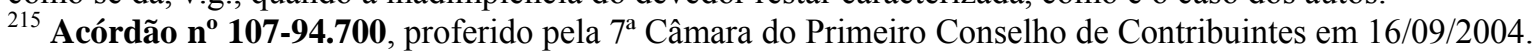
Transcrição do voto do Conselheiro e Relator Mário Junqueira Franco Junior: "[...] a operação de factoring convencional, sem regresso, como o caso ora em análise, configura uma operação de crédito, pois há antecipação de valores que serão recebidos futuramente. Por isso é que o custo de oportunidade está todo vinculado ao custo do dinheiro no tempo.

É uma verdadeira operação de desconto, com a característica específica do não-regresso, fator este que modifica a situação para o cedente, dado o seu caráter definitivo, mas não para o cessionário, cuja receita á auferida ao longo da operação.

Assim sendo, o regime de reconhecimento da receita auferida deve ser o mesmo do desconto de títulos, ou seja, pro rata tempore, conforme os artigos 317 do RIR/94 e 373 do RIR/99."
} 
Retratado na legislação contábil brasileira sob a denominação de "princípio do custo como base de valor" ou como "princípio do registro pelo valor original" ${ }^{217}$, o princípio do menor valor entre custo de aquisição ou mercado, assim designado neste estudo, é a diretiva que demanda a preservação do valor de troca (de transação de mercado) como uma aproximação razoável do valor mínimo de utilidade esperado para aquele ativo $^{218}$. A busca por este valor mínimo leva em consideração o custo de aquisição como ponto máximo e deve, por outro lado, registrar um valor menor para o ativo caso se verifique a impossibilidade de recuperação de parte ou de todo o valor despendido na transação. Possíveis motivos que podem gerar o reconhecimento de uma queda no valor do ativo são: fontes externas (valor de mercado, mudanças tecnológicas, econômicas e legais, taxas de juros, valor patrimonial da entidade), internas (obsolescência, dano físico, planos de descontinuidade, nova avaliação, desempenho ruim) etc. $^{219}$

Este princípio foi explicitado pelas leis comerciais pertinentes, nas quais se definiram também parâmetros para a apuração do valor de mercado (ou valor justo) ${ }^{220}$. É importante notar que as expressão valor de mercado, empregado na legislação pertinente, pode referir-se a um preço de saída ou um preço de entrada ${ }^{221}$. O mesmo se pode dizer do valor justo. Ao ser aplicado a ativos circulantes, normalmente se fala de custo de reposição $(\text { entrada })^{222}$, já com relação a determinados investimentos e também a itens do ativo imobilizado, a preocupação é com preço de venda ou valor realizável líquido (saída) ${ }^{223}$.

Assim, obtém-se, a partir deste princípio ${ }^{224}$, uma orientação para se reconhecerem as perdas decorrentes de variação negativa de determinados bens do patrimônio empresarial, inclusive com impacto no resultado ${ }^{225}$. Embora esta medida conduza a uma apuração mais correta do lucro, atualmente não se permite a adoção de tal

\footnotetext{
${ }^{216}$ Cf. SCHRÖER, op. cit. (nota 57), p. 131.

${ }^{217}$ Cf. item 3.1.5.1 da ECB e art. $7^{\circ}$ dos PFC.

218 A aplicação plena deste princípio para o reconhecimento de passivos é obstada parcialmente pelo princípio da imparidade, que, em função do princípio da prudência, manda aplicar critério inverso para os passivos. A esse respeito, vide itens 2.4 .2 e 3.4 .3 deste Capítulo.

${ }^{219}$ Cf. BIFANO, op. cit. (nota 21), p. 65.

${ }^{220}$ Vide a previsão do princípio na LSA, art. 183, II e IV, bem como $\S 3^{\circ}$, I (que após alteração promovida pela MP no 449/2008 passou a falar de "valor justo"), e também no Código Civil, art. 1187, II. Quanto à definição de valor de mercado, vide o Pronunciamento CPC 01 (juridicizado pela Resolução CFC $n^{\circ} 1.110 / 2007$, Deliberação CVM no 527/2007 e Resolução n ${ }^{\circ} 3.566 / 2008$ ).

${ }^{221}$ Cf. HENDRIKSEN; VAN BREDA, op. cit. (nota 46), p. 312.

${ }^{222}$ Vide art. 183, $\$ 1^{\circ}$, "a" da LSA.

${ }^{223}$ Vide art. 183, $\$ 1^{\circ}$, "c" da LSA e itens 22 e seguintes do Pronunciamento CPC 01.

${ }^{224}$ Principalmente também por força do princípio da prudência.

${ }^{225}$ Não é o caso, porém, da análise do valor recuperável de ativos, cuja contrapartida é lançada diretamente em conta de patrimônio líquido, mais propriamente na conta de "ajustes de avaliação patrimonial" (cf. art. $182, \S 3^{\circ}$ da LSA).
} 
prática para fins tributários no Brasil ${ }^{226}$. Em outros países, como na Alemanha, o reconhecimento do menor valor de mercado é aceito ${ }^{227}$.

\subsubsection{Princípio do preço corrente (marcação a mercado)}

A avaliação orientada pelo princípio discutido no item anterior apresenta, no entanto, a desvantagem de não refletir para a empresa os ganhos que se verificam ao longo do tempo, pois, como se viu, a interação com o princípio da realização impede o reconhecimento da receita até o ponto temporal adequado (definido pela legislação e orientado normalmente pela troca no mercado).

Em circunstâncias específicas, contudo, a legislação comercial permite que alguns ativos sejam avaliados pelo seu valor de saída sem impor o valor original de aquisição como limitador. É o que já havia em caráter opcional para "commodities",228 e o que se acaba de implantar, em caráter compulsório, para ativos financeiros destinados à negociação ou disponíveis para venda ${ }^{229}$. É possível apontar também tal possibilidade também para outros valores mobiliários, matérias-primas e outros bens destinados à alienação $^{230}$.

Verifica-se, nessas hipóteses, exemplo típico de realização por acumulação de valor, cujo elemento troca é referendado por uma transação no mercado em sentido amplo (i.e., sem a participação direta da empresa). Poder-se-ia, a exemplo do que se verifica atualmente no Reino Unido ${ }^{231}$, pretender a tributação de tais acréscimos de valor (típicos ganhos de detenção). Porém, o cenário brasileiro atual, refletido na legislação comercial e tributária, não parece vislumbrar segurança e definitividade suficiente nessa espécie de ganho para fins de considerá-lo realizado, nem para fins de distribuição de $\operatorname{lucros}^{232}$, nem

\footnotetext{
${ }^{226}$ Cf. art. 298, inciso IV do RIR/99. Para referência à possibilidade de se tomar tal dedução no passado, cf. BOUCHER, Hercules. Estudos de impôsto de renda e contabilidade: tributação das pessoas jurídicas. São Paulo: Saraiva, 1950, p. 205.

${ }^{227}$ Vide a esse respeito o item 3.1 do Capítulo 1.

${ }^{228}$ Cf. art. $183, \S 4^{\circ}$, da LSA.

${ }^{229}$ Cf. art. 183, I, da LSA.

${ }^{230}$ Cf. art. 1.187, inciso II do Código Civil, recordando-se aqui os problemas de eficácia social que os dispositivos deste diploma podem suscitar (vide notas de rodapé 11 a 13 neste Capítulo e o texto que as introduz).

${ }^{231}$ Vide item 3.3 do Capítulo 1.

${ }^{232}$ Cf. art. 182, $\S 3^{\circ}$ da LSA (o sobrevalor é direcionada para a conta de "ajustes de avaliação patrimonial" e de lá só sai quando realizado, para, passando pelo resultado, eventualmente tornar-se distribuível) e art. 1.187, inciso II do Código Civil (veda expressamente a distribuição desses sobrevalor sob a forma de lucros).
} 
para fins de tributação ${ }^{233}$. Mesmo no caso de "commodities" agrícolas, a orientação físcal é para o diferimento da realização ${ }^{234}$.

\subsubsection{Princípio da imparidade}

Muito já se falou aqui do princípio da imparidade, que, sendo corolário do princípio da prudência, impõe a adoção de requisitos distintos para o reconhecimento de receitas e despesas. Para ser mais exato, ele demanda que os prejuízos sejam reconhecidos ainda que não realizados e os ganhos, apenas quando realizados ${ }^{235}$. Assim, quando se fala desta dualidade de critérios, por um lado, o princípio da realização identifica-se mais com a abordagem dada para as receitas (pois somente se registram as realizadas). Por outro lado, com relação ao reconhecimento das despesas, o princípio da imparidade se demonstra como uma ruptura no princípio da realização (tendo em vista que se registram as perdas prováveis, mesmo que não realizadas), podendo ser visto até mesmo como um contraprincípio (eles são antagônicos neste ponto) ${ }^{236}$.

Trata-se, porém, de medida indispensável à apuração da renda real, correta tanto jurídica quanto contabilmente, de forma que se demonstre apenas o acréscimo patrimonial efetivo e, com isso, permita sua tributação ou distribuição sem causar dano ao patrimônio $^{237}$. Todavia, embora o princípio da imparidade devesse ter aplicação irrestrita na apuração do lucro tributável, principalmente para que se atendesse ao ideal de tributação conforme a capacidade contributiva (amenizando-se os efeitos adversos da periodização do

\footnotetext{
${ }^{233}$ Uma tal forma de tributação esbarraria, como se viu, na limitação ao princípio da realização imposta pelo CTN (apenas riqueza nova é tributável - vide item 2.2.2 do Capítulo 2).

${ }^{234}$ Cf. art. 297 do RIR/99 e Instrução Normativa SRF n ${ }^{\circ}$ 257/2002, art. 16.

${ }^{235}$ Vale ressaltar que o princípio da imparidade não impede a atuação do princípio do realização no que pertine ao emparelhamento de receitas e despesas, pois tais receitas e despesas que se alinham são normalmente aquelas relacionadas diretamente com a atividade da empresa. O princípio da imparidade atrai para si não essas despesas, mas aquelas outras que são extraordinárias.

${ }^{236}$ Cf. GELHAUSEN, op. cit. (nota 71), p. 14-16.

${ }^{237}$ Com as palavras de Mariz de Oliveira: "Esta dualidade de critérios entre o dever (passivo) e o ter (ativo) no patrimônio não passa, portanto, de expressão do princípio contábil do conservadorismo ou da prudência, juridicizado pela Lei n. 6.404 e, no que diz respeito aos direitos, está em perfeita consonância com o conceito jurídico de patrimônio, que é uma universalidade de direitos e obrigações com conteúdo econômico, somente acrescido por direitos que a ele se tenham incorporado definitiva e incondicionalmente." Cf. OLIVEIRA, op. cit. (nota 60), p. 137.
} 
lucro $)^{238}$, a proibição geral quanto à dedutibilidade de provisões no âmbito do imposto de renda contraria tal diretiva comercial ${ }^{239}$.

Visto isso, encerra-se este Capítulo com a ponderação de Moxter, segundo quem o princípio da imparidade procura corrigir fraquezas do princípio da realização e ajustar a tributação periódica à apuração correta do $\operatorname{lucro}^{240}$ :

"Com efeito, o lucro passível de distribuição, apurado conforme o princípio da realização, para ser orientado por períodos de faturamento, significa dizer que, dado um certo nível de despesas incorridas em anos de melhor situação de faturamento, considera-se como tendo sido demonstrado um volume maior de lucro distribuível nesses períodos do que em anos de pior situação de faturamento. Isso só pode valer com a seguinte condição fundamental: ignora-se a regra ancestral da Economia, de que os recursos obtidos em tempos de bonança devem ser retidos para tempos ruins. É verdade que o princípio da realização não repele tais retenções de recursos, porém também não as exige. O princípio da realização é corrigido parcialmente pelo princípio da imparidade [...]” Grifo nosso.

Voltando-se, assim, às reflexões que já foram apontadas aqui acima, quanto à disparidade de orientações do Direito, Contabilidade e Economia, e relembrando que a preservação do patrimônio empresarial (e a apuração segura do lucro) são metas comuns ao Direito Comercial e Tributário, conclui-se, também com Moxter, que o princípio da realização tende a ser orientado para o passado e que, além disso, é curiosamente o mesmo

238 “O princípio da cautela ou não paridade de tratamento entre lucro e prejuízo leva em conta a existência dos riscos inerentes à atividade empresarial, a necessidade de se proteger o capital social contra a distribuição de lucros fictícios e a urgência de se atenuar a ficção jurídica da periodização, passível de atentar contra a capacidade econômica. Assim, em cada exercício, subavaliam-se os lucros - desconsiderando-se os não realizados -, porém estimam-se os prejuízos meramente prováveis, embora ainda não efetivados. $\mathrm{O}$ princípio da cautela é a aplicação assimétrica do conceito de realização entre ganhos e perdas, assim como a superação do fracionamento em períodos no que tange aos prejuízos e ao direito de compensá-los, como referem-se os mais diversos autores." Cf. DERZI, op. cit. (nota 5), p. 71. Vide a esse respeito também o item 1.2.3 do Capítulo 2 (especialmente quanto ao princípio da apuração periódica).

${ }^{239}$ Art. 13, I, da Lei $\mathbf{n}^{\mathbf{0}} \mathbf{9 . 2 4 9 / 1 9 9 5}$.

240 Tradução livre de: Den verteilungsfähigen Gewinn, dem Realisationsprinzip entsprechend, an den Periodenumsätzen zu orientieren, heisst doch, bei gegebenen Aufwendungen in Jahren guter Umsatzsituation höhere Ausschüttungen für angezeigt zu halten als in Jahren schlechter Umsatzsituation. Das kann indessen nur mit wichtigen Vorbehalten gelten: die uralte ökonomische Regel, in guten Zeiten für schlechte Zeiten durch Mittelzurückbehaltungen vorzusorgen, wird ignoriert. Zwar schliesst das Realisationsprinzip solche Mittelzurückbehaltungen nicht aus, aber es erzwingt sie auch nicht. Partiell wird das Realisationsprinzip insoweit allerdings durch das Imparitätsprinzip korrigiert[...]. MOXTER, Adolf. Das Realisationsprinzip: 1884 und heute. In: Betriebs-Berater, Caderno 28. Frankfurt am Main: Recht und Wirtschaft, 1984, p. 1786. 
Direito que adota dualidade de critérios: uma postura mais rigorosa ao dispor regras sobre a distribuição dos lucros de uma empresa (conduzindo à apuração de menos lucro) e, por outro ângulo, uma postura menos rigorosa quando se trata de apurar o lucro que serve de base para a tributação (conduzindo à apuração de mais lucro) ${ }^{241}$.

\footnotetext{
241 "Essa já mencionada unilateralidade do princípio da realização decorre do fato de que ele é (por força da objetividade) orientado para o passado; a determinação da renda distribuível, feita por um empresário sólido, é, pelo contrário, orientada para o futuro. O princípio da realização sugere ao incauto uma quantia de renda distribuível que ao comerciante prudente pode em muitas situações parecer absurda. O legislador já reconheceu esta falha do princípio da realização há tempos, porém considerou-a apenas parcialmente, de forma que em determinados casos considera-se haver renda, mas nega-se a pretensão de distribuição de lucro aos empresários com base também no Direito. [...] O Direito Tributário é estranho a tais preocupações, ele se fundamenta na ideia da tributação fragmentada e por isso admite a tributação dos altos lucros excepcionais de um dado ano de atuação da empresa. Provisão para o futuro aqui vale não como uma questão da apuração do lucro, mas sim da utilização do lucro." Grifo nosso. Tradução livre de: Die gerade skizzierte Einseitigkeit des Realisationsprinzips beruht darauf, dass es (objektivierungsbedingt) vergangenheitsorientiert ist; die Ausschüttungsüberlegungen des soliden Kaufmanns sind dagegen zukunfstorientiert. Dem Unverständigen suggeriert das Realisationsprinzip einen ausschüttbaren Betrag, der dem umsichtigen Kaufmann in vielle Fällen als absurd erscheinen muss. Der Gesetzgeber hat diesen Mangel des Realisationsprinzips schon lange erkannt und, allerdings nur zum Teil, berücksichtigt; so wird etwa in bestimmten Fällen zwar Gewinn angenommen, aber ein Gewinnauszahlungsanspruch von Gesellschaftern mit Recht verneint. [...] Der Steuerrecht ist solche Vorsorge im wesentlichen fremd; es beruht auf der Idee der Abschnittsbesteuerung und erklärt infolgedessen auch den hohen Ausnahmegewinn eines Geschäftsjahr für vollbesteuerungspflichtig; Zukunftsvorsorge gilt insoweit nocht als eine Frage der Gewinnermittlung, sondern der Gewinnverwendung. MOXTER, op. cit. (nota 240), p. 1786.
} 


\section{CAPÍTULO 4 - DEBATE SOBRE OS DIFERENTES MOMENTOS DE REALIZAĈ̃̃ DA RENDA}

Enfim, apresentados os aspectos gerais quanto às noções econômicofinanceiras de renda e aos possíveis pontos correlatos de realização, bem como examinada a evolução do pensamento em torno do princípio de realização no sistema jurídico brasileiro e destacados os principais aspectos da ciência contábil pertinentes à análise do tema, passa-se, neste último capítulo do trabalho, a uma abordagem geral das diferentes formas de implementação do princípio da realização da renda. Examinar as alternativas existentes para a sua concretização, as variáveis de risco envolvidas e suas relações com os institutos pertinentes de Direito Civil são o mote de condução desta parte final do trabalho.

Para tanto, retomam-se aqui os pontos discutidos no Capítulo anterior, em que se enfatizaram os elementos fundamentais do princípio da realização e a sua origem nos princípios de contabilidade geralmente aceitos; verificou-se, ainda, que a formulação dada a este princípio na legislação comercial (sob a forma de regime de competência) não afasta plenamente a ambiguidade presente nos termos receitas ganhas e despesas incorridas, empregados pela Lei $\mathrm{n}^{\mathrm{o}} 6.404 / 1976$, de forma que cabe, afinal, ao legislador definir os eventos de realização que encerram os critérios apropriados para se dizer que uma receita ou uma despesa compete a este ou aquele período ${ }^{1}$.

A proposta do presente Capítulo consiste, então, na exploração de pontos específicos da legislação ordinária e também infralegal, selecionando determinadas situações que revelem a ampla variedade de critérios de realização adotados, em casos concretos, para alocar receitas e despesas ao período pertinente. Conforme se verá, o princípio da realização (ou regime de competência) pode realmente ser implementado de diferentes maneiras. Há, no mais das vezes, propostas igualmente válidas de alocação desses valores com vistas à apuração correta do lucro.

Nesse sentido, importa destacar que a expressão regime de competência, a despeito de sua ambiguidade, é normalmente utilizada como argumento definitivo resolutório, seja pelo julgador, seja pela autoridade administrativa, para justificar o cabimento de determinado critério reputado válido para deflagrar a realização da renda. Em tais circunstâncias, assume-se que a expressão denotativa do princípio tomou o lugar

\footnotetext{
${ }^{1}$ Particularmente sobre a ambiguidade das expressões regime de competência e receita ganha, vide o item 3.1 do Capítulo 3.
} 
do próprio critério, sendo utilizada como sinônimo da regra aplicável ao caso (e não propriamente do princípio) ${ }^{2}$. Porém, repete-se, pois é importante deixar assentado, que a expressão regime de competência e os demais termos empregados pela LSA para defini-lo comportam abertura suficiente para que se identifique neles, também, a explicitação do princípio da realização da renda.

Para sistematizar os diferentes critérios usados pela legislação para definir o regime de competência, a estrutura deste Capítulo parte das situações mais comuns, relacionadas à atividade operacional das empresas (venda de mercadorias e serviços) - em que o evento de realização normalmente se confunde com o próprio ponto temporal da venda -, para, pouco a pouco, apresentar situações mais complexas, que antecipam ou postergam a realização, ou, ainda, verificam-se com a simples passagem do tempo. Mais adiante, enfocam-se eventos não vinculados à atividade operacional, que demonstram combinações variadas dos elementos do princípio da realização discutidos no Capítulo 3 (ora amenizando a necessidade do elemento troca no mercado, ora enfatizando a ausência de mensurabilidade, liquidez ou certeza etc.). Para ilustrar tais situações, analisam-se, quando cabíveis, acórdãos pertinentes aos tópicos aqui explorados, proferidos no âmbito dos Conselhos de Contribuintes ${ }^{3}$.

Ciente de que a realidade apresenta tamanha variedade de situações e que alguns assuntos, dentre os aqui selecionados, têm peculiaridades tamanhas que mereceriam estudos mais aprofundados, alerta-se, desde já, que a abordagem realizada procura, nos limites da proposta deste estudo, tão-somente apontar e discutir a aplicação dos conhecimentos debatidos nos capítulos anteriores a diferentes situações do cotidiano empresarial.

Atenção especial é dada à forma como são combinados os elementos fundamentais do princípio da realização discutidos no Capítulo anterior (cumprimento da obrigação, mudança na posição patrimonial, troca no mercado e o conjunto de requisitos de mensurabilidade, liquidez e certeza). Assim, não se tem a pretensão de esgotar a matéria, pois se admite que os elementos jurídicos particulares de casos concretos (mesmo

\footnotetext{
${ }^{2}$ Fenômeno que também ocorre com a expressão princípio da realização, conforme já se apontou aqui no item 2.1 do Capítulo 1.

${ }^{3} \mathrm{O}$ enfoque nas decisões deste órgão se justifica por se tratar de instância que tem contribuído bastante na evolução do debate em torno do Direito Tributário do imposto de renda, suprindo a falta de justiça especializada na área tributária no Brasil.
} 
dentre alguns dos aqui analisados) podem provocar adoção de critérios de realização diferentes dos que são discutidos nesta abordagem geral do tema.

\section{Realização no ato de fornecimento (ponto de venda)}

A implementação do princípio da realização ou, até mesmo, a tradução do que se entende por regime de competência, normalmente é explicada por referência a transações tradicionais simples, de modo que se identifica o ponto de venda como o evento crítico relevante. Assim, costuma-se dizer que a realização ocorre com a entrega da mercadoria ou com a conclusão da prestação do serviço (conforme seja a atividade pertinente a uma ou outra forma de fornecimento) ${ }^{4}$. Tal explicação, no entanto, é tão simplista e incompleta - diante da variedade de aspectos jurídicos verificados no universo de relações empresariais - que não é capaz de resolver definitivamente nem mesmo algumas operações de venda de mercadorias ou serviços que destoem do modelo tradicional.

Tendo isso em vista, a abordagem deste Capítulo enfoca primeiramente essas relações mais básicas, de venda de mercadorias ou serviços, ressaltando, porém, algumas variações no modelo tradicional que podem fazer variar o ponto temporal de realização.

\subsection{Venda de mercadorias}

A exaltação do ato de entrega, ou tradição, de mercadorias como evento tradicional da realização tem sua justificativa, pois equivale ao ato mais comum de troca no mercado, situação na qual normalmente já terão sido ultrapassados os riscos do processo de fornecimento e se verão presentes todos os elementos do princípio da realização ${ }^{5}$.

O ato de tradição é, por excelência, conforme definição extraída do Direito Civil, o momento temporal no qual se verifica a aquisição do direito sobre as coisas móveis ${ }^{6}$, nascendo, neste mesmo momento, o direito do vendedor a receber o preço ${ }^{7}$ como

\footnotetext{
${ }^{4}$ Cf. ARNOLD, Brian J. Timing and income taxation: the principles of income measurement for tax purposes. Toronto: Canadian Tax Foundation, 1983, p. 124-125.

${ }_{5}^{5}$ Vide os comentários sobre a escolha do ato de troca no mercado no item 3.3.3 do Capítulo 3, pois as razões lá tratadas se aplicam também à tradição de mercadorias.

${ }^{6}$ Código Civil “Art. 1226 - Os direitos reais sobre coisas móveis, quando constituídos ou transmitidos por atos entre vivos, só se adquirem com a tradição."

${ }^{7}$ Passível de se caracterizar como riqueza nova, isto é, acréscimo patrimonial tributável.
} 
consequência imediata da entrega do bem ${ }^{8}$. A questão da passagem dos riscos é também explicitada pelo Código Civil, confirmando a importância da tradição ${ }^{9}$. Como já foi comentado, após o ato de troca no mercado, a receita pode ser reconhecida, pois subsistem apenas os riscos de crédito e garantia ${ }^{10}$.

Dessa forma, os atos ou negócios praticados antes da tradição da mercadoria geralmente não traduzem direito novo para o fornecedor e não costumam ser elegidos como critério da realização ${ }^{11}$. E, mais ainda, o fato de comprador e vendedor acordarem no objeto e no preço (CC art. 482) não causa realização da renda ${ }^{12}$, ainda que haja pagamento antecipado do preço (ou, mais propriamente, um adiantamento) ${ }^{13}$.

Ainda quanto ao ato de tradição de mercadorias, vale mencionar que este é geralmente identificado com a emissão da nota fiscal correspondente. Embora revogada, a orientação contida no item 3 , do artigo 200 , do Código Comercial ${ }^{14}$ poderá continuar a ser

${ }^{8}$ Cf. OLIVEIRA, Ricardo Mariz de. Fundamentos do imposto de renda. São Paulo: Quartier Latin, 2008, p. $98 ; 107-108$.

${ }^{9}$ Código Civil "Art. 492 - Até o momento da tradição, os riscos da coisa correm por conta do vendedor, e os do preço por conta do comprador."

${ }^{10}$ Bulhões Pedreira é enfático ao afirmar que a existência de obrigação de garantia não impede a realização da renda da venda: "Assim, é usual a venda de equipamentos com garantia de funcionamento ou qualidade, que cria custos para o vendedor durante algum tempo após a entrega e o recebimento do preço. A experiência da empresa permite, entretanto, prever esses custos, o que torna possível reconhecer o lucro por ocasião da entrega, computando-se como parte do custo das vendas (para efeito de determinar o montante do lucro) provisão para as despesas decorrentes da garantia contratual.” Cf. PEDREIRA, José Luiz Bulhões. Imposto sobre a renda: pessoas jurídicas. Rio de Janeiro: Justec, 1979, p. 299-300.

${ }^{11}$ Assim esclarece o Código Civil "Art. 1.267 - A propriedade das coisas não se transfere pelos negócios jurídicos antes da tradição."

${ }^{12}$ Dessa forma, equivocado parece ter sido o Acórdão $\mathbf{n}^{\mathbf{0}}$ 103-18.463, proferido pela $3^{\text {a }}$ Câmara do Primeiro Conselho de Contribuintes em 19/03/1997, cuja ementa está assim redigida: "POSTERGAÇÃO DE PAGAMENTO DE IMPOSTO - RECEITAS REGISTRADAS COMO ADIANTAMENTO DE CLIENTES

- Em se tratando de situação jurídica, o fato gerador do imposto implementa-se a partir do momento que esta esteja definitivamente constituída. No caso de compra e venda pura, como na espécie, seu implemento ocorre na concordância sobre preço e objeto (art. 1.126, Código Civil), data na qual deve-se oferecer o resultado à tributação."

${ }^{13}$ Conforme bem explicado por Mariz de Oliveira "o recebimento antecipado do preço, antes da entrega das mercadorias, não é receita para o vendedor, porque não há direito novo para ele. Pelo contrário, pende para ele a obrigação de entrega da mercadoria respectiva, derivada do contrato, a qual fica acrescida de uma nova obrigação derivada do recebimento do adiantamento do preço, que é a obrigação de devolução do valor recebido caso ele não entregue a mercadoria. Outrossim, nesse momento, há para o comprador direito ao recebimento da coisa e direito à devolução do preço se a coisa não the for entregue, e não a mera obrigação de pagar." Cf. OLIVEIRA, op. cit. (nota 8), p. 113-114.

${ }^{14}$ Código Comercial (dispositivos revogados pelo Código Civil, em 2002) "Art. 199 - A tradição da coisa vendida, na falta de estipulação expressa, deve fazer-se no lugar onde a mesma coisa se achava ao tempo da venda; e pode operar-se pelo fato da entrega real ou simbólica, ou pelo do título, ou pelo modo que estiver em uso comercial no lugar onde deva verificar-se.

Art. 200 - Reputa-se mercantilmente tradição simbólica, salva a prova em contrário, no caso de erro, fraude ou dolo: [...]

3 - a remessa e aceitação da fatura, sem oposição imediata do comprador;" 
seguida como uma forma não-regulada de presunção relativa, de modo que a emissão da fatura continue a constituir ato denotador de tradição simbólica ${ }^{15}$.

Ademais, João Bianco relembra a questão da responsabilidade pelo transporte: nas relações em que o frete for por conta do vendedor, a tradição ocorre somente com a entrega da mercadoria no estabelecimento do comprador. Sendo o frete por conta do comprador, a tradição já ocorre quando a mercadoria sair do estabelecimento do vendedor $^{16}$. Correspondendo a entrega da mercadoria, neste caso, a uma parcela essencial da obrigação da empresa fornecedora, ela ainda suporta riscos durante a fase de transporte ${ }^{17}$. Nesse sentido é a dicção do art. 494 do Código Civil ${ }^{18}$.

Como se vê, há boas razões para que o critério da realização na venda de mercadorias se resuma pela tradição. Contudo, outros elementos podem se agregar à relação jurídica e alterar o ponto de realização. Consoante já se disse ${ }^{19}$, a entrada do direito no patrimônio somente se aperfeiçoa quando ele estiver definitiva e incondicionalmente

\footnotetext{
${ }^{15}$ Decisões neste sentido, proferidas pelo Primeiro Conselho de Contribuintes (nenhuma, porém, analisou fatos posteriores ao Código Civil): Acórdão no 103-18.463, proferido pela $3^{\text {a }}$ Câmara em 19/03/1997, cuja ementa é "POSTERGAÇÃO DE PAGAMENTO DE IMPOSTO - RECEITAS REGISTRADAS COMO VENDA PARA ENTREGA FUTURA - A aceitação da fatura sem oposição imediata do comprador constitui tradição simbólica da mercadoria, sendo irrelevante o fato de a retirada da mercadoria se operar depois. $\mathrm{O}$ fato constitui tradição simbólica, nos termos do Código Comercial (art. 200, item 3)."; Acórdão no 10806.388, proferido pela $8^{a}$ Câmara em 25/01/2001, cuja ementa é "IRPJ - FATURAMENTO ANTECIPADO - A receita de venda é considerada realizada, ou "ganha", quando da tradição, real ou simbólica, dos bens vendidos. Não há tradição simbólica de bem ainda não produzido, portanto inexistente."; e Acórdão no $107-$ 08.544, proferido pela $7^{\mathrm{a}}$ Câmara em 27/04/2006 cuja ementa do acórdão a quo, confirmada pela Câmara é "VENDA PARA ENTREGA FUTURA. REGIME DE COMPETÊNCIA. Ocorrida a tradição simbólica da mercadoria com a emissão de fatura, deve ser reconhecida a receita proveniente da venda para entrega futura, segundo o regime de competência.”. Este último acórdão trata de um problema típico de realização, pois a fatura foi emitida no final de dezembro e a receita somente foi reconhecida no ano seguinte. Não tendo sido aventadas razões para tal descasamento (como a comprovação de que a entrega efetiva se deu no ano seguinte), a decisão prezou pela data constante na fatura.

${ }^{16}$ Segundo bem lembrado por ele "Esses detalhes podem à primeira vista parecer mero preciosismo, mas como o transporte pode levar até algumas semanas, é importantíssimo o estabelecimento de um critério determinado para a fixação do exato momento do reconhecimento da receita." Cf. BIANCO, João Francisco. Imposto de renda da pessoa jurídica: uma visão geral. In: SANTI, Eurico Marcos Diniz de; ZILVETI, Fernando Aurelio (coords.) Tributação das Empresas. São Paulo: Quartier Latin, 2006, p. 328-329.

${ }^{17}$ Cf. LUIK, Hans. Grundprobleme des Realisationszeitpunktes, dargestellt an den Fällen der Lieferung mit Rückgaberecht, des Umtauschgeschäftes und der Liquidation. In: RUPPE, Hans Georg (coord.). Gewinnrealisierung im Steuerrecht: Theorie und Praxis der Gewinnverwirklichung durch Umsatzakt und durch Steuerentstrichung sowie des Besteuerungsafuschubs. Köln: Otto Schmidt, 1981, p. 103.

${ }^{18}$ Código Civil “Art. 494 - Se a coisa for expedida para lugar diverso, por ordem do comprador, por sua conta correrão os riscos, uma vez entregue a quem haja de transportá-la, salvo se das instruções dele se afastar o vendedor."

${ }^{19}$ Vide o Capítulo 2, especialmente no item 2.3, em que se resumiu a questão, apontando-se que a realização é condicionada à constituição definitiva da situação jurídica geradora de obrigação tributária (art. 116, inciso II, do CTN) e inexistência de condição suspensiva (art. 117, inciso II, do CTN).
} 
adquirido pelo seu titular ${ }^{20}$. Sendo este o caso, a venda não se aperfeiçoa com a tradição da mercadoria, mas sim com o implemento da condição.

São exemplos clássicos de situações em que a venda se considera realizada em momento diverso da tradição ${ }^{21}$ : a venda a contento (que depende da aceitação ou decurso do prazo pertinente ${ }^{22}$ ); a venda sujeita a prova (que depende da averiguação da qualidade da mercadoria ou decurso do prazo $^{23}$ ); a venda em consignação (ou contrato estimatório ${ }^{24}$ ); e a entrega de produção do cooperado à cooperativa ${ }^{25}$ (nesses dois últimos casos, a realização acontece na venda feita por terceiros, e a relação entre vendedor e intermediário configura outorga de poderes aliada a depósito).

Nas vendas a contento e sujeita a prova, pode-se afirmar que não estão completos os requisitos de cumprimento da obrigação e troca no mercado, pois o vendedor ainda conserva o domínio sobre a coisa (tendo transferido apenas a posse ${ }^{26}$ ) e o adquirente ainda não manifestou sua concordância com a troca. Já nos casos de consignação e entrega da produção de sociedade cooperada à sua cooperativa, ausente está uma transação de mercado (e somente uma operação em condições de mercado realiza a renda) $)^{27}$.

Condições outras que não atentem contra os artigos 122 e 123 do Código Civil, tais como a instalação e correto funcionamento da máquina no estabelecimento do comprador $^{28}$, também podem postergar a realização para o momento da aceitação. Por

\footnotetext{
${ }^{20}$ Aspecto razoavelmente esclarecido pelo Parecer Normativo CST no 121/1973 (diz-se "razoavelmente", porque o parecer aborda apenas situação peculiar de pessoa física).

${ }^{21}$ Algumas dessas situações são comentadas por Bulhões Pedreira. Cf. PEDREIRA, op. cit. (nota 10), p. 298299.

${ }^{22}$ Código Civil "Art. 509 - A venda feita a contento do comprador entende-se realizada sob condição suspensiva, ainda que a coisa lhe tenha sido entregue; e não se reputará perfeita, enquanto o adquirente não manifestar seu agrado."

${ }^{23}$ Código Civil "Art. 510 - Também a venda sujeita a prova presume-se feita sob a condição suspensiva de que a coisa tenha as qualidades asseguradas pelo vendedor e seja idônea para o fim a que se destina."

${ }^{24}$ Regido pelos arts. 534 e seguintes do Código Civil. "Diversamente da compra e venda, na consignação a tradição da coisa móvel não opera a sua transferência, mantendo o consignante a propriedade sobre o bem e respondendo o consignado como depositário da coisa dada em consignação." Cf. ALVES, Jones Figueirêdo. Comentários aos arts. 421 a 839. In: SILVA, Regina Beatriz Tavares da (coord.). Código Civil comentado. Coord. até a $5^{\text {a }}$ Ricardo Fiuza, $6^{\mathrm{a}}$ rev. e atual. São Paulo: Saraiva, 2008, p. 487.

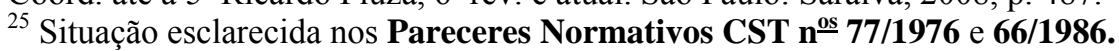

${ }^{26}$ Cf. ALVES, op. cit. (nota 24), p. 467-468.

${ }^{27}$ Particularmente para o caso da relação cooperado-cooperativa, este aspecto foi nitidamente ressaltado pelos Pareceres citados acima (nota 25) e tem amparo legal explícito: Lei $\mathbf{n}^{\mathbf{0}}$ 5.764/1971 "Art. 79. Denominam-se atos cooperativos os praticados entre as cooperativas e seus associados, entre estes e aquelas e pelas cooperativas entre si quando associados, para a consecução dos objetivos sociais.

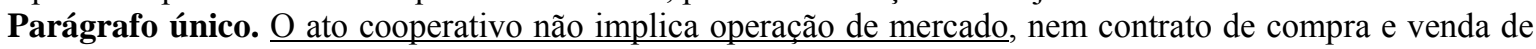
produto ou mercadoria." - Grifo nosso.

${ }^{28}$ Cf. BIANCO, op. cit. (nota 16), p. 329.
} 
outro lado, a condição isolada de que a passagem do título legal sobre o bem (a propriedade) se dará em momento futuro não posterga, por si só, o reconhecimento da receita. Nos casos, por exemplo, de venda com reserva de domínio e de alienação fiduciária em garantia tal não ocorre ${ }^{29}$. Nessas situações, já se transferiram ao comprador os riscos da mercadoria ${ }^{30}$ (e também os benefícios) e isso basta para considerar realizada a renda dessas operações.

Por serem tão variados os eventos que podem deflagrar a realização, a maioria dos autores, segundo Lüders, prefere se referir ao cumprimento/adimplemento da obrigação, conclusão do processo de fornecimento, passagem dos riscos etc., em vez de dizer simplesmente transferência, para denotar a completude dos eventos aqui comentados $^{31}$.

Ainda quanto à realização da renda na venda de mercadorias, convém destacar questões pertinentes à venda a prazo. Esta, conforme comenta Mariz de Oliveira, não impede a aquisição imediata do direito do vendedor ao preço, pois o(s) vencimento(s) da(s) parcela(s) é(são) considerado(s) termo inicial que suspende o exercício do direito, mas não a sua aquisição (cf. art. 131 do Código Civil) ${ }^{32}$.

No que concerne ao preço estipulado para a venda a prazo, embutir um acréscimo, a título de juros de mora, como forma de remuneração do dinheiro no tempo poderia suscitar o reconhecimento das parcelas de preço efetivo e de juros de maneira diferenciada. Contudo, tal questão foi elucidada no âmbito fiscal pelos Pareceres Normativos CST no ${ }^{\text {os }}$ 131/1975 e 21/1979, em que se definiu que os juros são considerados um subpreço da operação de venda, e não poderiam, portanto, ser reconhecidos conforme a passagem do tempo (pro rata temporis) ${ }^{33}$.

Não obstante tal direcionamento da questão, vale mencionar que esta discussão ganhou novo fôlego atualmente, com a publicação da Lei $n^{\circ} 11.638 / 2007$ e a

\footnotetext{
${ }^{29}$ Respalda esta conclusão o fato dos créditos decorrentes de tais transações serem tratados no art. $9^{\circ}$ da Lei $\mathrm{n}^{\mathrm{o}}$ 9.430/1996, que explicita o reconhecimento das perdas no recebimento de créditos (que já tenham sido tributados).

${ }^{30}$ Para a situação de venda com reserva de domínio, o Código Civil esclarece que "Art. 524 A transferência de propriedade ao comprador dá-se no momento em que o preço esteja integralmente pago. Todavia, pelos riscos da coisa responde o comprador, a partir de quando lhe foi entregue." - Grifo nosso.

${ }^{31}$ Cf. LÜDERS, Jürgen. Der Zeitpunkt der Gewinnrealisierung im Handels- und Steuerbilanzrecht. Köln: Otto Schmidt, 1987, p. 29.

${ }^{32}$ Cf. OLIVEIRA, op. cit. (nota 8), p. 300.

${ }^{33}$ Convém ressaltar que o critério da passagem do tempo (pro rata temporis) é atualmente utilizado para os juros das operações financeiras em geral (vide item 4 deste Capítulo).
} 
obrigatoriedade de se avaliar ativos de longo prazo a valor presente ${ }^{34}$. Em favor de uma mudança de perspectiva, poder-se-ia, com razão, dizer que, em relações de consumo, tais receitas de juros são de realização incerta, pois o consumidor pode utilizar seu direito de quitar a dívida à vista escoimada dos respectivos acréscimos ${ }^{35}$. Todavia, coerente com o que se vem debatendo aqui ${ }^{36}$, os riscos do pós-venda, particularmente os de crédito e garantia, não costumam ser determinantes para o diferimento da realização. Da mesma forma, o risco de que a receita de venda não se realize no tamanho do preço total definido não deveria afetar a sua realização ao tempo do fornecimento. Assim, o que fica pendente não é a incerteza do recebimento, mas sim a incerteza quanto ao registro de uma possível perda $^{37}$. Embora haja, a esse respeito, opiniões favoráveis ao tratamento de tais valores como receita financeira ${ }^{38}$, há autores que entendem que tal mecanismo não pode distorcer a natureza jurídica da operação (que é de compra e venda) ${ }^{39}$.

Tema semelhante a este é o do reconhecimento individualizado da parcela do preço que se destina a custear programas de recompensa/fidelização a clientes. No âmbito dos padrões internacionais de contabilidade, tal situação foi aclarada em ato do IFRIC $n^{\circ} 13 / 2007^{40}$, segundo o qual a segregação do preço é necessária, devendo tal parcela ser

\footnotetext{
${ }^{34}$ LSA, conforme alteração da Lei no $11.638 / 2007$, “Art. 183 - No balanço, os elementos do ativo serão avaliados segundo os seguintes critérios: [...]

VIII - os elementos do ativo decorrentes de operações de longo prazo serão ajustados a valor presente, sendo os demais ajustados quando houver efeito relevante." - Grifo nosso.

${ }^{35}$ Lei $^{\circ}$ 8.078/1990 (Código de Defesa do Consumidor) "Art. 52 [...]

$\$ 2^{\circ}$ É assegurada ao consumidor a liquidação antecipada do débito, total ou parcialmente, mediante redução proporcional dos juros e demais acréscimos."

${ }^{36}$ Vide, por todos, o item 3.3.1 do Capítulo 3.

${ }^{37}$ Nesse sentido decidiu o Acórdão $\mathbf{n}^{\mathbf{0}}$ 105-15.548, proferido pela $5^{\text {a }}$ Câmara do Primeiro Conselho de Contribuintes em 23/02/2006: "JUROS COBRADOS NA VENDA A PRAZO - RECONHECIMENTO COMO RECEITA - REGIME DE COMPETÊNCIA - Os juros embutidos no preço de venda a prazo compõem o resultado do período-base em que aconteceu a venda, sendo descabida sua apropriação em função do prazo concedido para pagamento.

PROVISÃO PARA "DESCONTOS A RECEBER" - GLOSA - Descontos condicionais, porquanto vinculados à condição de o cliente efetuar o pagamento antecipado, só podem ser levados a débito do resultado do exercício em que se implementar o pagamento antecipado com o desconto. No momento da venda, adquire-se o direito ao pagamento da totalidade do preço contratado, passível de redução se efetuado o pagamento antecipado e concedido o desconto." Grifo nosso.

${ }^{38}$ Ricardo Lodi e Adriana Clemente veem aqui uma oportunidade de planejamento tributário (pela postergação da realização das receitas financeiras). Cf. RIBEIRO, Ricardo Lodi; TAVARES, Adriana Clemente de Souza. "O planejamento fiscal pela metodologia de ajustes a valor presente - AVP - introduzida pela Lei n ${ }^{\circ} 11.638 / 2007$ ”. In: ROCHA, Sérgio André (Coord.). Direito tributário, societário e a reforma da Lei das S/A. São Paulo: Quartier Latin, 2008, p. 50. Cf. IUDÍCIBUS, et alli, op. cit. (nota 3), p. 452-460.

${ }^{39}$ Por exemplo, Ricardo Mariz, que alerta que, sendo caracterizados os juros como operação de natureza financeira, tal distorção causaria redução das bases de cálculo dos tributos que incidem sobre preço ou receita e, mais ainda, a parcela de receita financeira estaria sujeita a IOF. Cf. OLIVEIRA, Ricardo Mariz de. "Visão geral da Lei n. 11.638 e dos seus impactos na tributação". In: ROCHA, op. cit. (nota 38), p. 466-467.

${ }^{40}$ International Financial Reporting Interpretations Committee. (Comitê Internacional de Interpretação [de Normas] de Relatórios Financeiros)
} 
registrada em conta de "receitas a realizar (ou a apropriar)" (e ser considerada realizada apenas no momento em que a recompensa for resgatada). Este entendimento não encontra ainda reflexos na regulamentação contábil brasileira ${ }^{41}$, mas, se ou quando houver, a discussão no âmbito tributário provavelmente deverá encarar o dilema do enfoque no conservadorismo x enfoque na apuração correta do lucro, discutido no Capítulo anterior ${ }^{42}$ e retratado acima na abordagem da parcela dos juros que compõe o preço de venda.

\subsection{Prestação de serviços}

No que respeita à prestação de serviços, fala-se comumente da conclusão da prestação de serviços como evento crítico da realização. O critério para se saber quando o prestador adquire definitivamente o direito ao preço é o momento em que o serviço for prestado completamente ${ }^{43}$. O Código Civil repete, com a mesma simplicidade, a ideia de "serviço feito, serviço pago" conforme algum outro critério (por exemplo, conforme o tempo ou estágio de conclusão da obra) ao regular os efeitos de uma rescisão contratual (prevendo o pagamento da "retribuição vencida") ${ }^{45}$.

Com efeito, a realização da renda conforme a conclusão do serviço é critério que funciona bem para prestações de serviços compostas de um único ato. As dificuldades surgem quando a relação envolve o desempenho de uma série de atos (especificados ou não), que podem ser ou não similares, durante um período de tempo, o qual pode ou não ser limitado. Nesses casos, normalmente o critério apropriado para fins tributários é o mesmo utilizado para fins contábeis, qual seja, o da realização conforme o estágio de execução dos serviços. Com isso, as respectivas receitas podem ser alocadas proporcionalmente às etapas concluídas dos serviços (caso haja separação evidente dos

${ }^{41}$ Cf. CVM, Estudo sobre as diferenças e similaridades entre as Normas Internacionais de Contabilidade - IFRS e as Normas e Práticas Contábeis Brasileiras - IAS 18 - Reconhecimento de receitas. 2008, Resumo Executivo, item 1.G. Disponível em <http://www.cvm.gov.br >. Acesso em $01 \mathrm{dez}$. 2008.

${ }^{42}$ Vide a esse respeito o item 3.2.2 do Capítulo 3.

${ }^{43}$ Cf. BIANCO, op. cit. (nota 16), p. 329.

${ }^{44}$ Código Civil "Art. 597 - A retribuição pagar-se-á depois de prestado o serviço, se, por convenção, ou costume, não houver de ser adiantada, ou paga em prestações."

${ }^{45}$ Código Civil "Art. 602 - O prestador de serviço contratado por tempo certo, ou por obra determinada, não se pode ausentar, ou despedir, sem justa causa, antes de preenchido o tempo, ou concluída a obra.

Parágrafo único. Se se despedir sem justa causa, terá direito à retribuição vencida, mas responderá por perdas e danos. O mesmo dar-se-á, se despedido por justa causa.

Art. 603. Se o prestador de serviço for despedido sem justa causa, a outra parte será obrigada a pagar-lhe por inteiro a retribuição vencida, e por metade a que lhe tocaria de então ao termo legal do contrato." Grifo nosso. 
serviços e valores correspondente), confrontando-se as com os custos correspondentes, incorridos em cada etapa. O reconhecimento de receitas conforme a execução contratual será inapropriado, todavia, quando o respectivo contrato previr expressamente que o preço somente se adquire com a completude de todos os serviços ${ }^{46}$.

Bulhões Pedreira faz referência às relações de prestação de serviços continuadas em que o pagamento periódico é praticamente certo e a receita é considerada ganha mensalmente. Deve-se alertar que este é um caso de difícil classificação, pois, se a aquisição do direito for acompanhada de medições ou verificações periódicas, a realização fica postergada para o momento em que ocorrerem tais eventos ${ }^{47}$ e, mais ainda, se o contrato não previr medições nem pagamentos periódicos, a realização da renda poderá depender da execução completa dos serviços ${ }^{48}$.

Dessas manifestações se extrai que o elemento cumprimento da obrigação, ínsito ao princípio da realização, pode ser verificado e traduzido de diferentes formas, dependendo, para tanto, do acerto contratual que garanta a aquisição do respectivo direito (mudança na posição patrimonial), verificável por algum método cabível (mensurabilidade). Caso haja critério de identificação direta, vale dizer, o serviço é medido e cobrado conforme as horas de trabalho acumuladas no período (e.g. serviços de consultoria e de auditoria), pode-se utilizar este critério, permitindo o perfeito emparelhamento de receitas e despesas. Porém, caso não haja ligação direta entre o estágio de execução e o preço do serviço, deve-se lançar mão de critério de proporcionalização ${ }^{49}$. A NPC no 14/2001 do Ibracon esclarece a utilização de métodos de reconhecimento de receitas e despesas conforme o estágio de execução e conclui, enfim, que, quando os serviços forem compostos de um número indeterminado de atos ao longo de um certo

\footnotetext{
${ }^{46}$ Cf. ARNOLD, op. cit. (nota 4), p. 174-175.

${ }^{47}$ As prestações de serviços de natureza continuada seriam passíveis de enquadramento também no grupo daquelas receitas que se obtêm com a passagem do tempo (vide item 4.1 deste Capítulo), pois há situações em que o preço é fixo e a mensuração do cumprimento de obrigações periódicas pelo prestador pode ser estimada em razão do tempo. Todavia, quando tal mensuração é promovida efetivamente por meio de medições ou verificações constantes, tem-se a realização mais vinculada à efetiva entrega do serviço periódico. O fornecimento de água, gás e energia elétrica se enquadra melhor nesta segunda categoria, tendo em vista que são feitas medições na mesma frequência dos faturamentos.

${ }^{48}$ Cf. PEDREIRA, op. cit. (nota 10), p. 300.

${ }^{49}$ Cf. item 3.1.5.3.1 da ECB (Deliberação CVM no 29/1986) e item 2.6.3 do Apêndice aos PFC (Resolução CFC no 750/1993. Sobre a regulamentação contábil editada pela CVM e pelo CFC, vide item 2.3.1 do Capítulo 3.
} 
período e nenhum método de alocação for cabível, cabível é o método linear (alocação conforme a passagem do tempo $)^{50}$.

O estabelecimento de condições para a aquisição do direito ao preço também tem papel importante aqui. Nesse particular, vale citar o Parecer Normativo CST $\mathrm{n}^{\mathrm{o}} 7 / 1976$, que ratificou o diferimento do reconhecimento da receita (para o contratante) e da despesa (para o prestador) pertinente aos serviços de comissão, quando estes estiverem condicionados ao recebimento do preço de venda pelo contratante ${ }^{51}$. Trata-se genuinamente de uma condição, pois atende aos artigos 122 e 123 do Código Civil, não sendo, por exemplo, sujeita ao puro arbítrio de uma das partes ${ }^{52}$.

Em situação digna de nota, levada a julgamento perante o Primeiro Conselho de Contribuintes, o estabelecimento de uma condição específica foi rejeitado. Tratava-se do reconhecimento de receita referente à participação em empreitadas de loteamentos em imóveis de terceiros, correspondente a um percentual sobre o preço de venda de cada lote, que estava condicionada a uma prévia prestação de contas com relação aos pagamentos recebidos. Todavia, os pagamentos eram feitos ao próprio prestador dos serviços que, também, era encarregado de fazer tal prestação de contas e, após, repassar os valores ao proprietário, deduzidos de sua parcela percentual. O caso foi julgado desfavoravelmente ao contribuinte, por entenderem os Conselheiros que havia condições de mensurabilidade e liquidez dos direitos do prestador de serviço ${ }^{53}$. Vale acrescentar que a condição da prestação de contas, neste caso, parecia recair sobre fato arbitrário, de controle do próprio contribuinte, o que poderia favorecer a manipulação inaceitável do fato gerador do tributo.

\footnotetext{
${ }^{50}$ Item 27 da NPC (Norma e Procedimento de Contabilidade) no 14/2001. É importante destacar que os atos do Ibracon não possuem força normativa isoladamente (quando são aprovados mediante ato de órgão governamental - normalmente CVM ou CFC - é que se pode falar de obrigatoriedade jurídica).

${ }^{51}$ Parecer Normativo CST $\mathbf{n}^{\mathbf{0}}$ 7/1976 "4. Se, entretanto, o pagamento ou crédito da comissão está condicionado ao recebimento do valor da venda - não sendo, antes deste, exigível pelo representante, vendedor ou comissário -, não pode a importância correspondente ser considerada despesa incorrida no faturamento nem ser contabilizada como exigibilidade, dado que corresponde a meras expectativas: de obrigação, para a pessoa jurídica alienante do bem; e de direito, para o intermediário da transação comercial 5. O montante dessa despesa, enquanto não implementada a condição que mantém a obrigação e correlativo direito suspensos, melhor se contabilizaria em conta de compensação somente se tendo por incorrida tal despesa e constituída a exigibilidade após o recebimento do valor da venda que lhe deu causa."

${ }^{52}$ Código Civil "Art. 122 São lícitas, em geral, todas as condições não contrárias à lei, à ordem pública ou aos bons costumes; entre as condições defesas se incluem as que privarem de todo efeito o negócio jurídico, ou o sujeitarem ao puro arbítrio de uma das partes."

${ }^{53}$ Acórdão $\mathbf{n}^{\mathbf{0}}$ 101-95.152, proferido pela $1^{\text {a }}$ Câmara em 12/08/2005. Transcrição do voto do Conselheiro e Relator Paulo Roberto Cortez: "O fato gerador da obrigação tributária se dá no momento em que o direito ao recebimento de algo se torna liquido e certo, o que, no caso em tela, ocorre quando do recebimento pelo contribuinte, das prestações pagas pelos adquirentes dos lotes, reforçado ainda mais em virtude de cláusula contratual que permite ao prestador dos serviços reter, para si, das prestações recebidas, quantia igual ao percentual correspondente ao valor de seus serviços, até a total amortização de sua remuneração." - Grifo nosso.
} 
Os temas tratados no final do item anterior, relativamente à parcela do preço que seja explicada pela cobrança de juros (em cobranças a prazo) ou de valor destinado a programas de recompensa/fidelização a clientes, são igualmente aplicáveis aqui.

\section{Realização antes do ponto de venda}

Mencionou-se rapidamente no Capítulo anterior que a realização poderia ocorrer antes do ponto de venda ${ }^{54}$, especialmente com produtos agrícolas e minerais, cujo valor de mercado é prontamente determinável e risco de não-venda praticamente nulo (nesses casos a realização já pode ser identificada durante ou no final do processo produtivo e antes, portanto, de uma transação de mercado em sentido estrito). Para fins de sistematização, além dessas situações, reuniu-se, sob o item ora abordado, as discussões a respeito da realização no momento do fechamento do contrato.

\subsection{Realização no fechamento do contrato}

O fechamento de um contrato ${ }^{55}$ poderia ser escolhido como evento de realização especialmente no caso daquelas atividades empresariais para as quais o fechamento de um contrato responde pela maior parte do negócio (e.g. produtos com grande potencial de ganho e cuja venda é dificultosa) ${ }^{56}$. Todavia, conforme já se adiantou $^{57}$, tal fato não costuma ser tomado para evento crítico da realização, pois muitos riscos do negócio ainda subsistem neste ponto.

As críticas à escolha deste evento costumam ser as seguintes: (i) afora o esforço de venda, o cumprimento da obrigação econômica ainda não aconteceu; (ii) tratase de um negócio jurídico pendente, sendo o direito do fornecedor equilibrado contabilmente por uma obrigação de mesmo valor; e (iii) neste momento não se tem ainda uma visão segura das despesas envolvidas ${ }^{58}$.

Algumas dessas críticas, no entanto, poderiam ser afastadas caso se tratasse de mercadorias já produzidas. Leffson aponta que, neste caso, subsiste ainda o risco de não-

\footnotetext{
${ }^{54}$ Vide a esse respeito o item 3.3.3, bem como a nota 143 e o texto que a introduz, ambos do Capítulo 3.

${ }^{55} \mathrm{Ou}$ até mesmo o simples recebimento de um pedido de compra, nas relações econômicas em que não se costuma formalizar contratos para cada operação de fornecimento, pois a proposta de contrato obriga o proponente (art. 427 do Código Civil).

${ }^{56}$ Cf. GELHAUSEN, Hans Friedrich. Das Realisationsprinzip im Handels- und im Steuerbilanzrecht. Frankfurt am Main: Peter Lang, 1985, p. 91.

${ }^{57}$ Vide a esse respeito o item 3.3.1 do Capítulo 3.

${ }^{58}$ Cf. GELHAUSEN, op. cit. (nota 56), p. 93-97.
} 
entrega, pois pode ocorrer a perda do bem. É certo, reconhece o referido autor, que este risco poderia ser coberto por um contrato de seguro. Porém, ainda que o risco nesta situação seja menor do que naquela em que os bens ainda não foram produzidos, ambos os casos devem ser tratados igualmente, pois uma parte importante do processo de fornecimento ainda não ocorreu. Assim, concluem os autores aqui citados que o fechamento de contrato não pode ser tomado como evento de realização ${ }^{59}$.

Quanto aos bens não produzidos e aos serviços não prestados, argumenta-se que se trata de direito e obrigação de mesmo valor, com efeito neutro sobre a contabilidade da empresa ${ }^{60}$. Contrapõe-se a isso a ideia de que o registro do direito pode ser feito pelo valor da prestação contratada, ao passo que o valor da obrigação da empresa poderia ter por base as despesas correspondentes aos recursos que ela vai empregar na prestação ${ }^{61}$. Trata-se de um enfoque de ativo/passivo bastante comum nos IFRS ${ }^{62}$. Para o caso de uma prestação de serviços continuada, por exemplo, cujo valor é pago adiantadamente (assinatura de publicação, academia de ginástica etc.), a diferença entre o ativo e o passivo deveria ser tratada em conta de "receitas a realizar" 63.

Embora esta seja uma visão bastante funcional das relações jurídicas, pois observa os aspectos econômicos intrínsecos aos negócios, com atenção para a questão da incerteza e cuidados com o problema da mensurabilidade ${ }^{64}$, sua adoção para fins tributários deve também enfrentar os obstáculos já debatidos aqui quanto às parcelas de juros e programas de recompensa que efetivamente compõem o preço de venda ${ }^{65}$. Fala-se, assim, que, antes do cumprimento da obrigação, o que se tem é mero direito futuro e

\footnotetext{
${ }^{59}$ Cf. LEFFSON, Ulrich. Die Grundsätze ordnungsmässiger Buchführung. $7^{\mathrm{a}}$, rev. e ampl. Düsseldorf: IDW, 1987, p. 260-261. Cf. GELHAUSEN, op. cit. (nota 56), p. 100-103.

${ }^{60}$ Nesse sentido, a opinião de Mariz de Oliveira: "Mas, neste caso, necessariamente não haveria qualquer mutação patrimonial, pois cada direito deveria ser contrabalançado pela respectiva obrigação derivada da hipótese de descumprimento do contrato." Cf. OLIVEIRA, op. cit. (nota 8), p. 138.

${ }^{61}$ Cf. LÜDERS, op. cit. (nota 31), p. 23-24.

${ }^{62}$ Fala-se aqui do chamado asset/liability approach. Ver a esse respeito os itens 5.20 e 5.21 do Statement of Principles for Financial Reporting (Pronunciamento de Princípios de Relatórios Financeiros) do IASB. A respeito dos IFRS, vide o item 2.3.2 do Capítulo 3.

${ }^{63}$ Cf. HODGKINSON, Robert. Revenue and expense recognition. In: VATTIPALLI, Kashyap; MUDRULA, E (coord.). Revenue Recognition in Financial Statements - An introduction. Hyderabad (India): ICFAI University Press, 2005, p. 21. Hodgkinson apresenta quatro alternativas para mensuração da obrigação pela empresa em contrapartida ao valor de assinatura/associação recebido adiantadamente: "(i) o valor que a companhia seria obrigada legalmente a devolver ao cliente no caso de rescisão do contrato - caso o valor da assinatura não seja reembolsável, este registro tenderá a ser nulo; (ii) o custo marginal para prestar os serviços que se espera que o cliente usufrua durante o período de assinatura/associação; (iii) o custo total da prestação de serviços; (iv) o valor justo da obrigação, i.é, o montante exigido por outras empresas para assumir esta obrigação." - tradução livre.

${ }^{64}$ Para isso alertam os itens 5.14 e 5.17 do Pronunciamento de Princípios de Relatórios Financeiros.

${ }^{65}$ Vide a parte final do item 1.1 deste Capítulo.
} 
falível, mera expectativa de direito e, portanto, direito não completamente adquirido para fins do reconhecimento de renda ${ }^{66}$. Com o devido acatamento desta posição, deve-se recordar, das brilhantes lições de Pontes de Miranda, que os negócios sujeitos à condição suspensiva não impedem a aquisição de direito expectativo por seu $\operatorname{titular}^{67} \mathrm{e}$, mais ainda, não ignoram a atribuição do caráter de patrimonialidade a tal direito ${ }^{68}$. Confirma a existência de direitos àquele que contrata o próprio Código Civil, em seus arts. 129 e $130^{69}$.

Trata-se, porém, de discussão ainda embrionária, mas que deverá ser importante para definir se, uma vez promovida a convergência das normas brasileiras aos padrões internacionais de contabilidade, tal enfoque representaria uma inovação trazida exclusivamente por causa da harmonização das normas contábeis, ou se esses são aspectos jurídicos intrínsecos dos contratos que até então passavam despercebidos.

Ainda quanto ao evento de realização fechamento de contrato, aponta-se rapidamente que este é o critério válido nos casos de vendas de bens imóveis. A aquisição do direito ao preço ocorre com a assinatura da escritura definitiva de venda do bem, ou mesmo com a assinatura de instrumento particular de compra e venda, irrevogável e irretratável, desde que, pago o preço, o comprador possa adjudicar compulsoriamente a propriedade do bem, caso o vendedor se recuse a outorgar a escritura definitiva ao comprador $^{70}$. Além disso, o novo Código Civil reconheceu modalidade contratual em que a

\footnotetext{
${ }^{66}$ Mariz de Oliveira usa a terminologia do Código Civil de 1916 para denominar tal de direito futuro não deferido. Cf. OLIVEIRA, op. cit. (nota 8), p. 135-136. Vide a esse respeito o item 2.3 do Capítulo 2.

67 “O art. 118 [do CC de 1916, no CC atual trata-se do art. 125] é tautológico: se o direito é o efeito suspenso, não se adquiriu, ainda, o direito. Mas isso não quer dizer que não exista o direito expectativo: o que ainda não se adquiriu foi o direito, "a que ele (o negócio jurídico) visa" (art. 118); o negócio jurídico produz efeitos, dentre os quais está o direito expectativo; não produz o efeito, que é o direito "visado", ou de que decorrerá o direito "visado". O art. 118 de modo nenhum exclui que, nos negócios jurídicos em que se estabeleça depender da condição a eficácia e nessa eficácia se compreenda o direito, a que eles visam, ou dela decorra, não exista o efeito a que se chama "direito expectativo". Tal efeito se chama direito, porque direito é; não importa o nome (o art. 121 di-lo "eventual").

9. Exemplificação. São direitos expectativos: a) Os que se originam de negócios jurídicos a prazo (em se tratando de aquisição de bens), ou sob condição, porque, ao se atingir o termo, ou ao se realizar a condição, se adquire o direito expectado, de modo que não mais depende da vontade do outorgado o nascimento do direito; razão por que: o que se procura frustrar ou frustra a expectação a termo, ou sob condição, tem de reparar, e o que a frustra, tratando-se de condição, tem de sofrer que se tenha por ocorrida a condição (art. 120) [do CC de 1916, no CC atual trata-se do art. 129]; o outorgante tem o dever, nos atos de disposição, de não lesar o expectante; o direito expectativo é elemento do patrimônio do expectante, pode ser arrestado, penhorado, ou entrar em massa concursal, e se transmite entre vivos e a causa de morte." cf. MIRANDA, Pontes de. Tratado de direito privado. Tomo V, Campinas: Bookseller, 2000, §577, p. 335-336.

${ }^{68}$ Cf. no item 2.1 do Capítulo 2, especialmente a transcrição de Pontes de Miranda na nota 140.

${ }^{69}$ Código Civil "Art. 129 - Reputa-se verificada, quanto aos efeitos jurídicos, a condição cujo implemento for maliciosamente obstado pela parte a quem desfavorecer, considerando-se, ao contrário, não verificada a condição maliciosamente levada a efeito por aquele a quem aproveita o seu implemento.
}

Art. 130 - Ao titular do direito eventual, nos casos de condição suspensiva ou resolutiva, é permitido praticar os atos destinados a conservá-lo."

${ }^{70}$ Cf. BIANCO, op. cit. (nota 16), p. 329. 
venda se opera por documentos e o risco sobre a mercadoria se transfere independentemente da tradição ${ }^{71}$. Modalidade contratual indispensável para a consecução eficiente de negócios de comércio exterior ${ }^{72}$, o fechamento do contrato, nessas hipóteses, tem vocação para servir de evento crítico da realização da renda.

\subsection{Realização durante o ato de fornecimento (andamento da produção)}

Outras variações no ponto de realização da renda, desviando-se do ponto de venda como evento padrão da realização, costumam ser identificadas nas hipóteses de contratos de construção de longo prazo e nos acréscimos de valor em produtos agrícolas. Nessas situações, normalmente se observa um incremento gradual de valor, que se estende por um longo período de tempo. Deixar de reconhecer a receita competente pode resultar na demonstração parcial de renda com relação ao período de que se trata ${ }^{73}$.

O tema já foi pincelado em outras passagens deste trabalho ${ }^{74}$ e traduz o dilema do enfoque no conservadorismo x enfoque na apuração correta do lucro, que, conforme discutido no Capítulo anterior, retrata um potencial conflito entre os príncípios da prudência e da apuração periódica. Com efeito, colocam-se, de um lado, a orientação do princípio da realização pelo evento crítico do ponto de venda (atendendo à prudência) e, de outro, a orientação do princípio da realização pelo andamento da produção (atendendo à alocação temporal correta do lucro).

Comentando particularmente a situação dos contratos de construção por empreitada (uma das situações abrangidas pelo art. 10 do Decreto-lei nº 1.598/1977), Fábio Piovesan apresenta argutamente as razões favoráveis ao primeiro enfoque e defende uma visão jurídica mais rigorosa, aquela do princípio da realização em sua formulação clássica. Segundo tal autor, a obrigação do empreiteiro é de resultado e somente se aperfeiçoa pela entrega a contento da obra pronta e acabada, fazendo com que o registro de receitas e despesas fique protraído para o momento da aceitação da obra pelo dono ${ }^{75}$. Contribui para

\footnotetext{
${ }^{71} \mathrm{Da}$ lição de Sílvio Venosa, lê-se: “Cuida-se de modalidade criada pelos usos e costumes mercantis, dirigida à coisa móvel. Baseada na confiança em determinados ramos negociais, o comprador assume o risco maior, porque geralmente não examina a coisa.” Cf. VENOSA, Sílvio de Salvo. Direito civil: contratos em espécie. $8^{\text {a }} 2^{\text {a }}$ reimpr. São Paulo: Atlas, 2008, p. 76.

72 Cf. ALVES, op. cit. (nota 24), p. 483.

${ }^{73}$ Cf. BACKER, Morton; BELL, Philip W. The measurement of business income. Part 1 - The matching concept. In: BACKER, Morton (coord.). Modern accounting theory. New York: Prentice Hall, 1966, p. 87.

${ }_{75}^{74}$ Vide a esse respeito, particularmente, o item 3.2.2 do Capítulo 4.

75 "Nesse sentido, a tributação durante a fase de execução do contrato de empreitada, exigida pelo art. 10 do Decreto-lei n. 1.598, acaba por recair sobre parcela que, juridicamente, ainda não constitui renda ou receita,
} 
esta conclusão o art. 611 do Código Civil que disciplinou o tema de forma similar àquela mencionada acima, da venda a contento de mercadoria $^{76}$, esclarecendo também a questão pertinente à passagem dos riscos ${ }^{77}$.

Em situações como esta, no entanto, o legislador, ao permitir a distribuição eficiente dos resultados ao longo dos diferentes períodos envolvidos em tais modalidades contratuais, procura privilegiar o momento da "performance" contratual, isto é, aquele em que os recursos patrimoniais são consumidos. Com isso, promove-se a planificação da renda ao longo do tempo ${ }^{78}$ e o correto emparelhamento das receitas em razão da realização das respectivas despesas ${ }^{79}$.

Se adotado fosse o critério de realização tradicional, os custos do projeto iriam sendo ativados durante os primeiros anos; porém, despesas comerciais (que não são ativáveis) seriam lançadas contra despesa, de modo que os projetos de longo prazo acumulariam prejuízos até o ponto de realização, concentrando todo o lucro no último ano. Um método que permita demonstrar parcelas do lucro conforme o percentual de execução, por exemplo, não mostra uma curva de resultado com prejuízos ao começo e lucro ao final, mas sim uma divisão do resultado total do projeto nos períodos pertinentes em que ele se operacionalizou $^{80}$.

É importante lembrar que o critério de realização conforme o andamento da produção é excepcional e procura preservar os elementos de troca no mercado,

justamente porque a situação jurídica que subsidia a incidência tributária, aludida pelo inc. II do art. 116 do CTN, ainda não está completa.” Cf. BOZZA, Fábio Piovesan. Divergências na contabilização e regime de tributação dos contratos de empreitada de longo prazo. In: Revista dialética de direito tributário. v. 156. São Paulo: Dialética, set. 2008, p. 59.

${ }^{76}$ Vide item 1.1 supra.

${ }^{77}$ Código Civil “Art. 611 - Quando o empreiteiro fornece os materiais, correm por sua conta os riscos até o momento da entrega da obra, a contento de quem a encomendou, se este não estiver em mora de receber. Mas se estiver, por sua conta correrão os riscos."

${ }^{78} \mathrm{O}$ chamado income averaging.

${ }^{79}$ Comentando o art. 10 do Decreto-lei no 1.598/1977, Bulhões Pedreira explica que: "No reconhecimento do seu lucro pelo regime de competência duas soluções são possíveis: (a) considerar que o lucro apurado durante toda a execução da empreitada é ganho no exercício em que esta se completa e a obra ou o equipamento é entregue; ou (b) substituir o critério do momento da venda pelo da produção do bem ou serviço vendido.

A primeira solução era a adotada pela legislação anterior ao DL n ${ }^{\circ} 1.598 / 77$ [...]

$\mathrm{Na}$ maioria das atividades econômicas a empresa produz para estoque, e somente quando adquire o direito de receber o preço da venda há segurança sobre o valor dos seus produtos. Na empreitada, quando a produção é iniciada o preço de venda já é conhecido, porque contratado. Justifica-se, por isso, que o reconhecimento do lucro seja à medida em que o bem é produzido. [...]

$\mathrm{O}$ registro (nas contas de resultado de cada período) dos custos ou despesas incorridos na execução da obra ou na produção dos bens ou serviços obedece às regras gerais do regime de competência. A peculiaridade é o modo de dividir o preço total contratado entre os exercícios em que ocorre a execução do contrato." Cf. PEDREIRA, op. cit. (nota 10), p. 311-313.

80 Cf. CLEMM, Hermann. Grundprobleme der Gewinn- und Verlustrealisation bei langfristiger Auftragsfertigung und langfristiger Vermietung. In: RUPPE, op. cit. (nota 17), p. 119-120, 124-125. 
mensurabilidade, certeza e liquidez (pois só atinge situações em que o preço é predeterminado em contrato entre partes agindo no mercado, há razoável certeza do recebimento e a estimativa de custos é conhecida ${ }^{81}$ ), bem como o elemento cumprimento da obrigação (uma vez que manda reconhecer receitas em função do percentual de execução efetiva do contrato, ou dos custos incorridos até então), causando a mudança da posição patrimonial do contratado (visto que os riscos do negócio foram transformados em riscos jurídicos com toda a proteção inerente ${ }^{82}$ ).

Em caso de empreitada, o risco de não-aceitação da obra inexiste se a obra foi

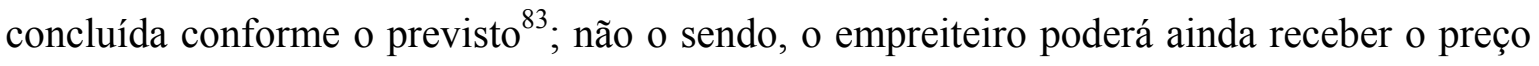
com abatimento ${ }^{84}$. E, mais ainda, havendo rescisão contratual por iniciativa do dono da obra, o empreiteiro terá direito a ser ressarcido das despesas e dos lucros relativos aos serviços já feitos, além de uma indenização razoável, calculada em função do que ele teria ganho se concluída a obra (art. 623 do Código Civil) ${ }^{85}$. É de ressaltar, aliás, que este último artigo do Código sugere que, com relação aos serviços já executados, o valor que o empreiteiro tem direito de receber é lucro do empreiteiro e não multa, indenização etc.

Como já se mencionou aqui, o modelo tradicional de realização causa efeitos distorsivos à economia, sobretudo em razão do efeito de acumulação de valor ${ }^{86}$, fazendo-se necessárias medidas que amenizem tal efeito. Para as situações em análise, o critério da realização conforme o andamento da produção suaviza a progressividade do IRPJ sobre os resultados de negócios de longo prazo e, sob a perspectiva do balanço contábil, diminui a perda do poder aquisitivo do lucro distribuído aos sócios (caso este fosse postergado para o término do projeto). Assim, somente é possível concluir que este critério seria um ônus

\footnotetext{
${ }^{81} \mathrm{ECB}$, item 3.1.5.3.2 e Apêndice aos PFC, item 2.6.3.

${ }^{82}$ Quanto à análise de riscos, Schröer relembra que o normal em negócios de fornecimento é que a realização se ocupe da passagem dos riscos aquisição, produção, valorização e venda, ao passo que os riscos de crédito e garantia são tratados, com prudência e segurança, pelo princípio da imparidade, mediante a criação de provisões. A particularidade dos contratos de longo prazo é que, com o fechamento de contrato prévio, ultrapassa-se o risco de valorização de forma decisiva para a realização do lucro. E, mais ainda, com a execução da tarefa encomendada, os riscos pertinentes às atividades operacionais são transformados em riscos jurídicos. Cf. SCHRÖER, Thomas. Das Realisationsprinzip in Deutschland und Grossbritannien: eine systematische Untersuchung und ihre Aufwendung auf langfristige Auftragsfertigung und Währungsrechnung. Frankfurt am Main: Peter Lang, 1998, p. 223-224.

${ }^{83}$ Código Civil "Art. 615 - Concluída a obra de acordo com o ajuste, ou o costume do lugar, o dono é obrigado a recebê-la. Poderá, porém, rejeitá-la, se o empreiteiro se afastou das instruções recebidas e dos planos dados, ou das regras técnicas em trabalhos de tal natureza."

${ }^{84}$ Código Civil "Art. 616 - No caso da segunda parte do artigo antecedente, pode quem encomendou a obra, em vez de enjeitá-la, recebê-la com abatimento no preço."

${ }^{85}$ Código Civil "Art. 623 - Mesmo após iniciada a construção, pode o dono da obra suspendê-la, desde que pague ao empreiteiro as despesas e lucros relativos aos serviços já feitos, mais indenização razoável, calculada em função do que ele teria ganho, se concluída a obra."

${ }^{86}$ Vide a esse respeito o item 2.5 do Capítulo 1.
} 
imposto ao contribuinte ${ }^{87}$, se os efeitos do dinheiro no tempo (diferimento da obrigação tributária para o período do término da obra) superassem os efeitos correlatos da maior progressividade do IRPJ, decorrente da acumulação dos resultados em um único período (efeito acumulação), e da perda do poder aquisitivo do lucro. Sendo tal balanceamento invertido, tal sistemática de planificação da renda poderia ser vista até mesmo como uma benesse fiscal. Vantagem essa que, contudo, deveria ter aplicação ampla, estendendo-se a todo e qualquer contrato que levar mais de um ano para ser completado ${ }^{88}$.

\subsection{Realização no término da produção}

Consoante o que já se adiantou ${ }^{89}$, as situações que poderiam ensejar a realização da renda já com o término da produção (produtos agrícolas e minerais) também comportam sua realização à medida do andamento da produção. Nesses casos, todavia, prescinde-se de contratação prévia e a realização ocorre por reconhecimento do acréscimo de valor de ativos afetados por fenômenos de crescimento natural ou de valor vegetativo (produtos agropecuários, vinho, reservas florestais, mineradoras), podendo se manifestar também para ativos que tenham seu valor justo ou de mercado prontamente determinável e risco de venda praticamente nulo (metais e pedras preciosas, ativos financeiros) ${ }^{90}$.

Para esses casos, a legislação comercial permite que os ativos sejam avaliados por seu valor justo ou de mercado ${ }^{91}$, antecipando o reconhecimento de ganhos. Porém, embora se possa falar de realização neste ponto, seu reconhecimento para fins tributários é claramente afastado para o caso das "commodities" agrícolas (diferindo-se a imposição fiscal para o ponto de venda) ${ }^{92} \mathrm{e}$, quanto às demais hipóteses, há bons indicativos na legislação que apontam para a falta de segurança e definitividade nessa apuração de ganho, de modo que se deva igualmente protelar a realização para fins fiscais ${ }^{93}$.

\footnotetext{
${ }^{87}$ Cf. BOZZA, op. cit. (nota 75), p. 57.

${ }^{88} \mathrm{Cf}$. BITTKER, Boris I. A "comprehensive tax base" as a goal of income tax reform. In: Harvard Law Review, v. 80, n. 5, mar.-1967, p. 964-965.

${ }^{89}$ Vide o item 3.3.3 do Capítulo 3 (particularmente as notas 194 a 196 e o texto que as introduz).

${ }^{90}$ Vide o item 3.1.5.3.3 da Deliberação CVM n ${ }^{\circ}$ 29/1986.

${ }^{91}$ LSA art. 183, inciso I (ativos financeiros) e $\$ 4^{\circ}$ ("commodities") e Código Civil art. 1.187, inciso II (tecnicamente aplicável a outros valores mobiliários, matérias-primas e outros bens destinados à alienação). Vide a esse respeito o item 3.4.2 do Capítulo 3.

${ }^{92}$ Cf. art. 297 do RIR/99 e Instrução Normativa SRF n ${ }^{\circ}$ 257/2002, art. 16.

${ }^{93}$ Vide maiores detalhes a esse respeito na parte final do item 3.4.2 do Capítulo 3.
} 


\section{Realização após o ponto de venda}

Razões relevantes podem carregar o evento crítico de realização para momento posterior ao ponto de venda. Já se mencionou que o evento entrada de caixa costuma ser adotado para beneficiar pessoas que não detêm volume substancial de créditos ou estoques, diferindo-se a realização para o momento de maior certeza e liquidez possível ${ }^{94}$. No Brasil, o regime de caixa é a regra para pessoas físicas, sendo facultativa para pessoas jurídicas optantes pelos regimes de lucro presumido e Simples Nacional e também para determinadas atividades.

Além disso, falou-se, no Capítulo anterior, que, mesmo para contribuintes que não sejam beneficiados com regras de exceção, a falta do elemento certeza no recebimento dos créditos pode fortalecer a prudência na escolha do evento de realização ${ }^{95}$. Embora o risco de crédito não deva, em princípio, afetar a identificação do ponto de realização, quando ele for um elemento relevante de determinado projeto ou ramo empresarial, pode ser justificada a postergação da realização para o momento da entrada de caixa.

Comentadas tais situações, em que a aplicação mais segura do princípio da realização se dá diante de circunstâncias particulares de casos concretos, fazem-se apontamentos, neste item, acerca das situações comuns de postergação do evento da realização, enfocando primeiramente os casos de indeterminação do preço para, depois, cuidar de aspectos específicos atinentes à escolha do evento entrada de caixa (ou rcebimento) como evento crucial da realização.

\subsection{Realização no momento da mensuração do preço}

Tradicionalmente se fala que os contratos de compra e venda são considerados válidos quando as partes convierem no preço e na coisa (donde se extraem os elementos constitutivos do contrato: coisa, preço e consentimento) ${ }^{96}$. Especialmente com atenção ao preço, Sílvio Venosa aponta que ele pode ser determinado ou determinável, sendo importante, para o último caso, que estejam fixados os parâmetros para sua determinação ${ }^{97}$. O preço não pode ser relegado ao arbítrio de uma das partes, havendo, portanto, a

\footnotetext{
${ }^{94}$ Vide a esse respeito o item 3.2.1 do Capítulo 3.

${ }^{95}$ Vide a esse respeito os itens 2.4.2 e 3.3.4 do Capítulo 3, bem como os acórdãos do Primeiro Conselho de Contribuinte lá comentados.

${ }^{96}$ Nesse sentido é o Código Civil “Art. 482 - A compra e venda, quando pura, considerar-se-á obrigatória e perfeita, desde que as partes acordarem no objeto e no preço."
} 
possibilidade da designação de terceiro para esta tarefa ${ }^{98}$. Consideradas algumas variações, este elemento se repete em grande parte das modalidades contratuais empregadas atualmente ${ }^{99}$.

O que importa destacar em tais situações é que, como o elemento mensurabilidade pode depender de eventos futuros para sua atuação e determinação do preço, a realização da renda fica postergada, mesmo que já se tenham verificados uma troca no mercado, o cumprimento da obrigação pelo fornecedor e o consequente acréscimo de direito novo para ele, e mesmo sendo o adquirente altamente solvente e sua obrigação de pagar esteja evidenciada em contrato (certeza).

O ponto temporal e o âmbito da realização são influenciados, neste caso, pela forma em que se estipula a contraprestação. A concretização do lucro pode ser diferida, quando o preço de venda for pagável na forma de percentuais, na forma de uma remuneração recorrente vinculada a elemento de risco etc. Nessas situações, o vendedor não pode ser forçado à realização imediata ${ }^{100}$.

Interessante situação foi analisada por ocasião da edição do Parecer Normativo CST $n^{\circ} 11 / 1976$, em que um contrato de arrendamento de terras a longo prazo estipulava duas formas distintas e complementares de preço: (i) prestações fixas e periódicas pelos 2 primeiros anos, e (ii) parcelas variáveis, determinadas mediante participação percentual de $5 \%$ nos resultados líquidos da exploração da área objeto do arrendamento, devidas a partir do quinto ano.

Assim, quanto à parcela variável, que interessa aqui (pois a outra é realizável tipicamente conforme a passagem do tempo), reconheceu-se que as receitas correspondentes estavam atreladas a evento futuro, de resultado incerto, e que, portanto, deveriam ser consideradas realizadas apenas quando sua disponibilidade jurídica se tornasse certa. A falta do elemento mensurabilidade foi, então, frisada pelo órgão administrativo: "Outra maneira de se proceder não seria viável, tendo em vista a

${ }^{97}$ Código Civil "Art. 487 - É lícito às partes fixar o preço em função de índices ou parâmetros, desde que suscetíveis de objetiva determinação."

${ }^{98}$ Cf. VENOSA, op. cit. (nota 71), p. 14. Nesse sentido é o Código Civil "Art. 485 - A fixação do preço pode ser deixada ao arbítrio de terceiro, que os contratantes logo designarem ou prometerem designar. Se o terceiro não aceitar a incumbência, ficará sem efeito o contrato, salvo quando acordarem os contratantes designar outra pessoa. [...]

Art. 489 - Nulo é o contrato de compra e venda, quando se deixa ao arbítrio exclusivo de uma das partes a fixação do preço."

${ }^{99}$ Cf. VENOSA, op. cit. (nota 71), p. 93, 122, 198, 211-212.

${ }^{100}$ Cf. BEISSE, Heinrich. Gewinnrealisierung - Ein systematischer Überblick über Rechtsgrundlagen, Grundtatbestände und grundsätzliche Streitfragen. In: RUPPE, op. cit. (nota 17), p. 25-26. 
impossibilidade de, previamente, serem determinados ou fixados seus valores e por não se encontrarem juridicamente disponíveis em tal momento"101.

É de se atentar que não se fala aqui da entrada de caixa como evento de realização, mas sim do momento em que a mensuração do preço for factível como ponto temporal relevante (assumindo-se, é claro, que estão presentes os demais elementos do princípio da realização).

\subsection{Realização no recebimento (entrada de caixa)}

Não raro, encontram-se vozes na doutrina que reclamam pela escolha da entrada de pagamento como momento temporal adequado da realização da receita e, por consequência, da renda. Por causa de sua garantia de liquidação, este momento tem a vantagem de concretizar ao máximo possível o princípio da prudência, já que os riscos essenciais são reduzidos ao mínimo ${ }^{102}$. Os argumentos mais extremados para justificar a entrada de caixa como evento primordial de realização partem do pressuposto de que o elemento liquidez é de maior importância no balanço fiscal do que no balanço comercial. Assim, para se evitar que a imposição tributária atinja a substância da empresa (seu patrimônio) e coloque sua existência a risco, dever-se-ia tomar o evento da entrada de caixa como ponto temporal da realização ${ }^{103}$.

Todavia, nenhum desses argumentos convence muito. Primeiro, não é possível dizer que a liquidez seja mais importante na apuração tributária do lucro do que na comercial, pois, como se viu, a função de proteção aos credores também impõe segurança na apuração do lucro passível de distribuição na sociedade ${ }^{104} \mathrm{e}$, mais ainda, o aspecto da liquidez dos créditos não realizados em caixa é zelado, no âmbito comercial, pela criação de reservas de lucros a realizar ${ }^{105}$. Segundo, o aspecto da liquidez não é tomado como pressuposto para a verificação e a determinação da capacidade contributiva. O Direito

\footnotetext{
${ }^{101}$ Cf. item 4.1 do Parecer Normativo CST n $\mathbf{n}^{\mathbf{1}}$ 11/1976.

${ }^{102}$ Cf. SCHRÖER, op. cit. (nota 82), p. 134.

103 Cf. DAUBER, Desiree. Das Realisationsprinzip als Grundprinzip der steuerrechtlichen Gewinnermittlung. Frankfurt am Main: Peter Lang, 2003, p. 132-133.

${ }^{104}$ Vide a esse respeito o item 2.2 do Capítulo 3.

${ }^{105}$ Nesse sentido são os ensinamentos de Bulhões Pedreira: "A importância prática da liquidez dos direitos recebidos na realização do lucro é demonstrada pelas normas da Lei $n^{\circ}$ 6.404/76 que criaram o dividendo obrigatório: para evitar a incompatibilidade entre esse dividendo e o regime de competência a lei foi obrigada a criar a "reserva de lucros a realizar" (art. 197, par. único), que exclui da base de cálculo dos dividendos a parte do lucro reconhecido nas contas de resultado ainda não realizada em dinheiro, ou representada por
} 
Tributário do imposto de renda preocupa-se apenas com o acréscimo de capacidade contributiva verificado ao final de um período ${ }^{106}$.

Se há tamanha precaução na apuração do resultado tributável, para não causar prejuízo aos recursos líquidos à disposição da empresa, então, para fins de coerência, o ponto temporal da realização deveria ser realocado para mais adiante, até que assegure que os recursos, uma vez recebidos, vão permanecer na empresa (pelo menos até o prazo de vencimento dos tributos devidos). Nessa linha de raciocínio, somente se poderia falar de realização quando fosse certo que o dinheiro recebido não seria devolvido em razão de quebra contratual, podendo se postergar o ponto de realização até que o risco de garantia esteja superado ${ }^{107}$. No contexto da legislação brasileira, dever-se-ia aguardar a passagem dos prazos para responder por vícios aparentes e redibitórios ${ }^{108}$.

Por razões como essa ${ }^{109}$ é que, mesmo sendo o chamado regime de caixa uma das formas previstas no Código Tributário Nacional para a apuração da renda tributável, este critério não é adotado como regra geral. Além disso, a implementação de critérios distintos para contribuintes e atividades diversas é medida que atenta contra os ideais de igualdade na tributação da renda e depende de justificativa apropriada perante outros princípios da ordem constitucional para se sustentar ${ }^{110}$.

Atualmente, apenas as pessoas jurídicas optantes pelos regimes de lucro presumido ou Simples Nacional usufruem dessa benesse com relação a qualquer ingresso de receitas oriundas da venda de bens ou serviços ${ }^{111}$, estando as demais pessoas jurídicas obrigadas ao regime de competência (salvo com relação a determinadas atividades que foram também contempladas com o evento de realização caixa). Muitas dessas hipóteses

direitos de crédito com vencimento após o término do exercício social subsequente." Cf. PEDREIRA, op. cit. (nota 10), p. 303.

${ }^{106}$ Cf. DAUBER, op. cit. (nota 103), p. 133. Segundo critica Lüders, nas circunstâncias atuais não é o fisco, com sua pretensão fiscal, que depende da liquidez dos contribuintes, mas sim o contrário, os contribuintes é que orientam a sua liquidez pela pretensão fiscal do Estado. Cf. LÜDERS, op. cit. (nota 31), p. 92.

${ }^{107}$ Cf. DAUBER, op. cit. (nota 103), p. 134.

${ }^{108}$ Em relações de consumo, os prazos previstos no Código do Consumidor.

${ }^{109}$ E outras comentadas nos Capítulos 1 (vide item 4) e 2 (vide itens 1.2.2, e 2.2.1).

${ }^{110}$ Conforme já se comentou no item 1.2.2 do Capítulo 2, o atendimento ao objetivo constitucional de garantir o desenvolvimento nacional (CF, art. $3^{\circ}$, inciso II) normalmente serve de justificativa, além do princípio de tratamento favorecido a empresas de menor porte (CF, art. 170, inciso IX), aplicável em alguns casos, bem como o princípio da busca do pleno emprego (CF, art. 170, inciso IX) podem ser invocados.

${ }^{111}$ Para o regime de lucro presumido, vide Instrução Normativa SRF no 104/1998 (cujo fundamento - art. 45, parágrafo único da Lei $n^{\circ} 8.981 / 1995$ - é pouco explícito a respeito dessa opção). Para o regime de Simples Nacional, vide Lei Complementar $n^{\circ} 123 / 2006$, art. 18, $\S 3^{\circ}$ e também Resolução CGSN nº 38/2008 (válida a partir de 2009 - para os períodos anteriores havia vedação expressa prevista no art. $2^{\circ}, \S 3^{\circ}$ da Resolução CGSN no 5/2007). 
foram previstas já pelo Decreto-lei $\mathrm{n}^{\mathrm{o}} 1.598 / 1977^{112}$ e outras foram sendo adicionadas ao ordenamento jurídico ao longo do tempo ${ }^{113}$.

Em todos esses atos normativos emprega-se o termo recebimento para designar o que seria o regime de caixa. Tendo sido frustrada a tentativa de regulamentar o tema em ato legal ${ }^{114}$, não há parâmetros legais claros sobre o que se considera recebimento, de forma que alguns questionamentos podem ser colocados quanto à operacionalização deste regime.

Primeiro, partindo-se de noções mais simples, verifica-se que o recebimento efetivo e físico não é necessário para se satisfazer o requisito de realização. Se o contribuinte tem controle sobre o valor, ele será considerado para fins de tributação. Por exemplo, valores depositados em conta bancária do contribuinte são considerados recebidos por ele. Além disso, nem mesmo o recebimento do valor integral é necessário, pois o recebimento do valor bruto do preço, por exemplo, é considerado para fins de tributação, ainda que tenha havido deduções que reduzam o valor efetivamente recebido ${ }^{115}$.

Questiona-se também se o recebimento de que falam os atos normativos restringe-se a recebimento de dinheiro.

Quando um contribuinte do regime de caixa recebe um cheque, por exemplo, o valor deve ser considerado tributável no momento do recebimento do cheque ou quando o cheque for descontado/liquidado? Para responder a esta pergunta, deve-se considerar que a legislação brasileira claramente trata o cheque como uma ordem de pagamento à vista. Mesmo os cheques pós-datados, isto é, com data posterior àquela em que efetivamente emitidos, são considerados pagáveis na data da emissão ${ }^{116}$. Assim, para fins do regime de caixa, a renda deve ser considerada realizada na data do recebimento do cheque ${ }^{117}$.

\footnotetext{
112 Trata-se dos casos de empreitada ou fornecimento contratado com pessoa jurídica de Direito Público (art. $10, \S 3^{\circ}$ ), de vendas a prazo ou em prestações (art. 29), de vendas de longo prazo de bens do ativo permanente (art. 31, $2^{\circ}$ ), de alienação de bens desapropriados (art. 31, $4^{\circ}$ ), e de determinadas operações de fusão, incorporação ou cisão (art. 34, inciso II).

${ }^{113}$ Como, por exemplo, no caso das atividades imobiliárias relativas a loteamento de terrenos, incorporação imobiliária, construção de prédios destinados à venda, bem como a venda de imóveis construídos ou adquiridos para revenda (art. 30 da Lei $\mathbf{n}^{\mathbf{0}} \mathbf{8 . 9 8 1 / 1 9 9 5 )}$.

${ }^{114}$ Vide o histórico do Anteprojeto que resultou no Decreto-lei no $1.598 / 1977$ nos Capítulos 1 (item 4) e 2 (item 2.2.1.1).

${ }^{115}$ Cf. ARNOLD, op. cit. (nota 4), p. 87.

${ }^{116} \mathrm{Cf}$. art. 32, parágrafo único da Lei $\mathrm{n}^{\mathrm{o}} 7.357 / 85$.

${ }^{117}$ Conforme já esclareceu a Solução de Consulta $\mathbf{n}^{\mathbf{0}}$ 263, emitida pela Superintendência Regional da Receita Federal da $7^{\text {a }}$ Região Fiscal em 28/08/2006: “IRPJ. LUCRO PRESUMIDO. REGIME DE CAIXA. CHEQUE PRÉ-DATADO. DUPLICATAS.Para fins de apuração da base de cálculo do lucro presumido calculado pelo regime de caixa, os pagamentos por meio de cheques pré-datados serão considerados à vista, uma vez que o cheque, ainda que apresentado para pagamento antes do dia indicado como data de emissão, é
} 
Como já se comentou antes, não é o recebimento de qualquer título que deflagra a realização por regime de caixa ${ }^{118}$. Consoante pontua Sílvio Venosa, o preço pode ser traduzido em títulos de crédito, devendo-se diferenciar as hipóteses de venda pro soluto (na qual a entrega do título representa pagamento definitivo e este se desgarra do negócio subjacente, tornando-se título autônomo com todas as características que lhe são peculiares) das vendas pro solvendo (nas quais o título é forma de garantia e o pagamento se considerará como ultimado quando liquidados efetivamente os valores dos títulos de crédito $)^{119}$. Tendo isso em conta, e sabendo-se que o recebimento é imagem reflexa do pagamento, deve-se concluir que a realização da renda ocorre já no recebimento do título que seja genuinamente autônomo da obrigação que lhe deu causa ${ }^{120}$.

Seguindo adiante, é de se perquirir sobre o recebimento em bens, ou até mesmo em serviços. Segundo Brian Arnold, um pagamento não feito em caixa, ou pagamento em espécie, constitui pagamento da mesma forma, cujo montante é o valor do bem ou direito transferido na data do pagamento. Teoricamente, este princípio deveria se estender para pagamentos em espécie que assumem a forma de serviços prestados ao beneficiário. Se um contribuinte adquire bens em contrapartida pela prestação de serviços ao fornecedor (vendedor), o custo de aquisição do bem deveria ser o valor dos serviços prestados ${ }^{121}$. A dúvida é pertinente, porque o instituto da dação em pagamento ${ }^{122}$ pode ter por objeto

pagável no dia da apresentação. O cheque não permite estipulação de prazo para pagamento, é ordem de pagamento à vista. As receitas provenientes de duplicatas descontadas e de transações relativas à troca de duplicatas de clientes por duplicatas de terceiros com vencimento futuro deverão ser tributadas à medida do recebimento, no caso de a pessoa jurídica ser optante pelo regime de tributação com base no lucro presumido e adotar o regime de caixa."

${ }^{118}$ Vide os comentários de Brandão Machado quanto ao recebimento de nota promissória não negociável. no item 3.3.4 do Capítulo 3 (particularmente a nota 211 e o texto que a introduz).

${ }^{119}$ Cf. VENOSA, op. cit. (nota 71), p. 15.

${ }^{120}$ Confirmam tal entendimento os seguintes acórdãos proferidos pelo Primeiro Conselho de Contribuintes (embora tratem de IRPF, suas conclusões estendem a todos que adotam regime de caixa): "IRPF - EXS. 1999 E 2000 - OMISSÃO DE RENDIMENTOS - ACRÉSCIMO PATRIMONIAL A DESCOBERTO - As prestações que constituem os contratos sob modalidade "pro solvendo" somente podem integrar a evolução patrimonial quando efetivamente pagas." Acórdão $\mathbf{n}^{\mathbf{0}}$ 102-45.968, proferido pela $2^{\text {a }}$ Câmara em 18/03/2003; "IRPF - GANHO DE CAPITAL - TITULOS PRO SOLUTO - DECADÊNCIA - Na venda a prazo efetuada com notas promissórias recebidas pro soluto, considera-se, para fins de apuração de ganho de capital, ocorrido o fato gerador na data da alienação do imóvel, já que o pagamento "pro soluto" é aquele que se dá quitação da dívida a que se refere, sem depender de qualquer evento posterior." Acórdão no 106-15.897, proferido pela $2^{\text {a }}$ Câmara em 18/10/2006; bem como o Acórdão $\mathbf{n}^{\mathbf{0}}$ CSRF/01-02.682, proferido pela Primeira Turma da Câmara Superior de Recursos Fiscais em 10/05/1999: "IRPF LUCRO NA ALIENAÇÃO DE IMÓVEIS. Comprovado que a alienação foi feita com parte do pagamento representado por notas promissórias vencíveis em exercícios subsequente ao da alienação, recebidas "pro soluto" cabível é a cobrança do imposto no exercício correspondente ao ano-base da alienação, sobretudo porque na escritura consta cláusula expressa dando completa e rasa quitação do preço de venda."

${ }^{121}$ Cf. ARNOLD, op. cit. (nota 4), p. 112-113.

${ }^{122}$ Previsto nos art. 356 e seguintes do Código Civil. 
qualquer tipo de prestação, positiva (dar e fazer) e negativa (não fazer), bens móveis e imóveis, direitos reais ou pessoais, cessão de crédito etc. ${ }^{123}$

Mariz de Oliveira sublinha que a dação em pagamento somente se distingue quanto ao meio legal de pagamento, não se afastando a tributação por este motivo. Em decorrência da dação, o que se verifica é que o direito de propriedade sobre o bem recebido em pagamento passa a figurar no ativo do vendedor pelo valor que antes constava da conta de duplicatas a receber, referente ao preço da venda que foi extinto pela dação ${ }^{124}$. Embora o brilhante especialista esteja se referindo ao regime de competência, o mesmo raciocínio se aplica aos pagamentos em espécie recebidos por contribuintes do regime de caixa ${ }^{125}$. Pouco se fala do recebimento sob a forma de prestação de serviços, porém, a esta modalidade se aplicam as mesmas conclusões pertinentes ao recebimento em bens.

Também devem ser consideradas, para fins da realização da renda tributável conforme o evento recebimento, as hipóteses de recebimento indireto, aplicável nas situações em que um valor que deveria ser incluído na apuração de renda do contribuinte, caso fosse recebido diretamente por ele, for de alguma forma aplicado em seu benefício ou à sua ordem. A situação clássica à qual se aplica a doutrina do recebimento indireto de renda é aquela na qual um pagamento é feito a um terceiro por ordem do contribuinte. Se o valor que é pago ou transferido a um terceiro tem a natureza de preço para o contribuinte, ele deverá ser considerado recebido por este ${ }^{126}$. Trata-se de hipótese que gera obrigações contrapostas no contexto de relação triangular, pois o devedor, ao pagar dívida do credor para com terceiro, torna-se credor desse montante (passando a figurar como credor e devedor). Assim, a extinção final da dívida original opera-se por meio de compensação, que depende de anuência do credor (fornecedor original) ${ }^{127} \mathrm{e}$, como tal, deflagra o evento de recebimento.

Além do recebimento indireto, cabe questionar também se o regime de caixa previsto na legislação brasileira contempla o instituto do recebimento implícito ${ }^{128}$, que se

\footnotetext{
${ }^{123}$ Cf. RÉGIS, Mário Luis Delgado. Comentários aos arts. 233 a 420. In: SILVA, op. cit. (nota 24), p. 318.

${ }^{124}$ Cf. OLIVEIRA, op. cit. (nota 8), p. 119-120.

${ }^{125}$ Conforme esclarece o acórdão $\mathbf{n}^{\mathbf{0}}$ 101-95.532, proferido pela $1^{\text {a }}$ Câmara do Primeiro Conselho de Contribuintes em 24/05/2006: "IRPJ - LUCRO PRESUMIDO - RECONHECIMENTO DE RECEITAS REGIME DE CAIXA - Na apuração do lucro presumido, as receitas podem ser reconhecidas pelo regime de competência ou quando do recebimento do pagamento. Nas alienações em que o pagamento ou parte dele não for em dinheiro, mas em bens ou direitos, a receita deverá ser reconhecida no momento do recebimento desses bens ou direitos, sendo descabido postergá-lo para o momento em que eles são revendidos."

${ }^{126}$ Cf. ARNOLD, op. cit. (nota 4), p. 87-88.

${ }^{127}$ Por se opor a tal procedimento o artigo 376 do Código Civil: “Art. 376. Obrigando-se por terceiro uma pessoa, não pode compensar essa dívida com a que o credor dele lhe dever."

${ }^{128}$ Refere-se aqui à chamada teoria do "constructive receipt" (que poderia ser traduzida também como atribuição de rendimentos ou rendimentos subentendidos).
} 
verifica nos casos em que o controle do contribuinte sobre um determinado valor é tão irrestrito que é mais apropriado considerar que ele recebeu o valor, embora ele não o tenha recebido fisicamente. Desenvolvida originalmente nos E.U.A., a teoria do recebimento implícito se aplica da seguinte forma: quando um montante de renda estiver imediatamente disponível para um contribuinte sujeito ao regime de caixa, esse valor será considerado como tendo sido a ele creditado, independentemente de sua opção por tomar ou não posse imediata do montante. Nesse sentido, uma quantia será considerada como imediatamente disponível para um contribuinte se ela tiver sido ganha (o cumprimento da obrigação e a mudança da posição patrimonial se verificaram), tiver um valor fixo (a retribuição estiver determinada - mensurabilidade) e a fonte pagadora tiver tanto a intenção quanto a capacidade de pagar (liquidez e certeza) ${ }^{129}$.

Se o sistema tributário previsse que a renda deveria ser reconhecida apenas mediante o recebimento real e físico do valor, os contribuintes seriam capazes de, em diversas situações, controlar o aspecto temporal do reconhecimento da renda e consequentemente, a obrigação tributária relativa a esta renda. Assim, a teoria do recebimento implícito se preocupa especialmente com aquelas situações em que o contribuinte tem a escolha entre receber a renda em um período, ou postergar o recebimento para o próximo ${ }^{130}$.

Conforme já tangenciado anteriormente ${ }^{131}$, o Anteprojeto que acabou lançando as bases para o Decreto-lei no 1.598/1977 continha previsão legal mais detalhada sobre o regime de caixa e lá se deixava claro que se consideravam, na base do imposto, não só as receitas ou rendimentos "efetivamente recebidos", mas também aqueles "colocados à disposição do contribuinte em condições de serem por ele recebidos, à sua vontade". Percebe-se aqui, nitidamente, a adoção da teoria do recebimento implícito. Embora não tenha ganhado corpo de lei, essa definição acabou sendo repetida em atos e decisórios administrativos, figurando claramente, por exemplo, na explicação dada ao que seria regime de caixa pelo Parecer Normativo CST no 85/1977:

"2.1 Com relação às receitas, todavia, no caso específico de rendimentos derivados da atividade agrícola, adota-se o regime financeiro ou de caixa, considerando-se como declaráveis no exercício financeiro a que se referir o ano em que foram as receitas recebidas ou colocadas à disposição do

\footnotetext{
${ }^{129}$ Cf. ARNOLD, op. cit. (nota 4), p. 91.

${ }^{130}$ Cf. POSIN, Daniel Q.; TOBIN, Donald T. Principles of federal income taxation of individuals. $7^{\mathrm{a}} \mathrm{St}$. Paul: West Publishing Co., 2005, p. 617.
} 
declarante, em condições de ser por ele realizadas, à sua vontade." Grifo nosso.

Assim, admitindo haver bons indícios de que o sistema tributário brasileiro recepcionou essa teoria, particularmente para evitar a manipulação de resultados por contribuintes sujeitos ao regime de caixa, pode-se dizer que, em situações de postergação de recebimento (em que o contribuinte tem o controle dos rendimentos a receber), as receitas são consideradas recebidas implicitamente ${ }^{132}$.

Resumindo, com as palavras de Brian Arnold, os três últimos temas aqui debatidos, conclui-se que a teoria do recebimento implícito refere-se à questão de quando se considera como tendo sido recebida em dinheiro a renda; ao passo que a teoria do recebimento indireto trata de saber quando o valor já foi recebido por alguém e procura determinar quem deveria ser tributado com relação àquela quantia; e, por fim, a teoria do recebimento em espécie preocupa-se com a quantia financeira que deve ser incluída na apuração da renda relativamente a recebimentos em bens ou serviços ${ }^{133}$.

\section{Realização com a passagem do tempo (pro rata temporis)}

Até este ponto da exposição, enfocaram-se, preponderantemente, atividades empresariais nas quais o cumprimento da obrigação consiste, de modo geral, em fornecer bens e/ou serviços concentrados em um ato isolado. Acontece que, numa variedade de relações contratuais verificadas na prática, a realidade é completamente outra. Passa-se a abordar, então, as relações obrigacionais continuadas, que são caracterizadas por fornecimentos desempenhados não em um único ato de fazer ou não fazer, mas sim em uma prestação que se prolonga por um certo intervalo temporal. A essa categoria de relações pertencem os contratos de locação, determinadas prestações de serviços, seguro, factoring, leasing e, bem assim, os contratos de licença de um modo geral.

Tais relações empresariais são implementadas de maneira continuada, de modo que a sua realização se revela não com a verificação de determinada data agendada, mas mais propriamente durante todo o tempo de sua existência. Como esses negócios não se

\footnotetext{
${ }^{131}$ Vide o item 2.2.1.1 do Capítulo 2 (especialmente as notas $172 \mathrm{e} 173$ e o texto que as introduz).

${ }^{132}$ Posin e Tobin esclarecem que, embora seja tema controverso, em sua opinião, a doutrina do recebimento implícito não necessariamente alcança o caso do acionista controlador de empresa que apurou lucros durante o ano (distribuíveis ao acionista controlador conforme a sua vontade), pois a distribuição depende ainda de atos formais (convocação de assembleia para deliberar a distribuição ou a constituição de fundos de reserva). Todavia, se o acionista controlador se declina a constituir fundos de reserva, ele estaria aparentemente numa situação de recebimento implícito dos dividendos. Cf. POSIN; TOBIN, op. cit. (nota 130), p. 618.

${ }^{133}$ Cf. ARNOLD, op. cit. (nota 4), p. 91.
} 
dissipam com a execução ou o cumprimento da obrigação, sua base normal de ocorrência é fundada mais adequadamente na passagem do tempo ${ }^{134}$.

Tendo isso em vista, e sem pretender examinar cada uma das modalidades contratuais que poderiam ser enquadradas neste tópico, selecionaram-se, para abordagem aqui adiante, alguns temas pertinentes à alocação temporal da renda enfocando-se dois grandes grupos de atividades negociais, as relações de natureza continuada e as relações de natureza financeira. Enquadram-se, no primeiro, as relações de locação, prestações continuadas de serviços e contratos de licença, e, no segundo, as concessões de crédito e outras relações que geram recebimento periódico de juros. Ambas têm em comum o pagamento de retribuição pelo uso de determinada coisa ou prestação de serviço efetiva ou potencial. Preferiu-se, porém, agrupá-las em dois tópicos distintos para facilitar a exposição.

\subsection{Relações de natureza continuada}

Comentam-se primeiramente os contratos de locação. Nesta modalidade contratual, a prestação econômica devida pelo locador não se consubstancia propriamente na simples entrega de uma coisa ${ }^{135}$, mas sim na concessão, ao locatário, do direito de uso durante um período de tempo acertado contratualmente ${ }^{136}$. Nesse sentido é a dicção do art. 565 do Código Civil $^{137}$. O cumprimento da obrigação do locador se verifica, assim, com a garantia do uso pacífico da coisa durante o prazo estipulado.

O valor total estipulado para o fornecimento dos direitos de uso e gozo corresponde à soma dos fornecimentos parciais autônomos, que são computados periodicamente. Assim, à medida que o tempo passa, são realizados os fornecimentos parciais, um após o outro ${ }^{138}$.

É importante sublinhar que as receitas de aluguéis devem ser consideradas realizadas proporcionalmente à passagem do tempo (pro rata temporis), primeiro, por ser retribuição que é naturalmente vinculada a esse fator e, segundo, por razões práticas de mensurabilidade. Não sendo possível estipular medida razoável das variações do uso e do

\footnotetext{
${ }^{134}$ Cf. LÜDERS, op. cit. (nota 31), p. 109.

${ }^{135}$ Prefere-se utilizar aqui a expressão empregada pelo Código Civil de 2002 para se referir tanto a bens móveis quanto a imóveis (embora se saiba que a locação de prédios urbanos tenha regulamentação complementar própria na Lei $\left.\mathrm{n}^{\mathrm{o}} 8.245 / 1991\right)$.

${ }^{136}$ Cf. LEFFSON, op. cit. (nota 59), p. 270.

${ }^{137}$ Código Civil "Art. 565 - Na locação de coisas, uma das partes se obriga a ceder à outra, por tempo determinado ou não, o uso e gozo de coisa não fungível, mediante certa retribuição.”

${ }^{138}$ Cf. LEFFSON, op. cit. (nota 59), p. 270.
} 
gozo do imóvel ao longo do prazo contratual, adota-se o método do desempenho proporcional.

Para a confirmação de que este é o critério adequado de aplicação do regime de competência às receitas de locação, volta-se ao caso discutido aqui acima ${ }^{139}$ e analisado no Parecer Normativo CST no 11/1976, desta feita para tecer maiores considerações sobre as parcelas fixas estipuladas com relação a um contrato de arrendamento de terras a longo prazo. Rememora-se que havia duas formas de remuneração previstas nesta relação contratual, sendo o preço dividido em: (i) prestações fixas e periódicas pelos 2 primeiros anos, e (ii) parcelas variáveis, determinadas mediante participação percentual de 5\% nos resultados líquidos da exploração da área objeto do arrendamento, devidas a partir do quinto ano.

Ainda que o contrato em questão não tenha deixado isso claro, o órgão administrativo entendeu, com acerto, que os valores mensais fixos recebidos durante os 2 primeiros anos diziam respeito a todo o período da primeira fase contratual (os primeiros 5 anos), devendo ser distribuídos pro rata temporis ${ }^{140}$.

$\mathrm{O}$ mesmo critério aplica-se às prestações continuadas de serviços, assim entendidas aquelas que são faturadas periodicamente e com preço certo ${ }^{141}$. Tais relações são caracterizadas pela ocorrência de um número específico de atos idênticos ou similares contratados por um determinado período ${ }^{142}$, ou um número não especificado de atos que devam ocorrer ao longo de um determinado período ${ }^{143}$. Nesses dois casos, o método de

\footnotetext{
${ }^{139}$ Vide o item 3.1 deste Capítulo.

${ }^{140}$ Os seguintes trechos são de relevante interesse: Parecer Normativo CST n 11/1976 “3. As receitas de arrendamento em face de suas características próprias, mesmo quando recebidos antecipadamente, podem ser apropriadas nos exercícios aos quais pertencem, consagrando-as o regime de competência ou econômico, que melhor traduz a distribuição dos valores pelos períodos de determinação. Devemos lembrar que a ocorrência da disponibilidade financeira não presume a competência da receita que a originou ao exercício do seu recebimento. Dúvidas não podem existir quanto a esse entendimento, o qual é reforçado pela obrigação do arrendatário em diferir as despesas com o arrendamento.

4. No caso, a peculiaridade do contrato consiste em que o pagamento não é feito em duas fases distintas, conforme já relatado no item 1, alíneas a e b; embora não conste, expressamente, no contrato, que o preço fixo corresponde à retribuição pela cessão do direito de uso durante o período que antecede à fase posterior, ressalta evidente essa condição e, portanto, os valores fixos, quando recebidos antecipadamente, podem ser diferidos para apropriação durante todo o tempo que corresponda à duração dessa fase." Grifo nosso.

${ }^{141}$ Vale alertar que há tratamento específico na legislação para os contratos de fornecimento de serviços com preço predeterminado e prazo superior a um ano. Para esses, os critérios válidos são aqueles definidos no art. 10 do Decreto-lei no 1.598/1977 (comentados aqui acima, no item 2.2 deste Capítulo).

${ }_{142}$ Por exemplo, a remoção de lixo realizada 1 vez por semana do estabelecimento do cliente.

${ }^{143}$ Por exemplo, os serviços prestados por uma academia de ginástica.
} 
alocação da renda ocorre proporcionalmente ao tempo como uma medida objetiva do desempenho ${ }^{144}$.

Conforme já assinalado ${ }^{145}$, Bulhões Pedreira chama a atenção para o fato de que, nos casos em que a prestação do serviço é continuada e o recebimento é periódico e praticamente certo, a receita é considerada ganha mensalmente, à medida que os serviços são fornecidos ${ }^{146}$. O referido autor, todavia, faz remissão ao serviço de energia elétrica. Essa pontuação é interessante porque permite distinguir o que se pretende classificar aqui como serviços cujas receitas são alocadas em função do tempo.

Nas situações de prestação de serviços em caráter continuado, em que se promovem efetivamente medições ou verificações em períodos coincidentes com os períodos de faturamento e cobrança e não há valor fixo de preço a ser aquinhoado em períodos temporais consecutivos, não se pode falar de alocação à medida da mera passagem do tempo, pois a cada nova medição estipula-se o preço correspondente pelo serviço. Fala-se de cobrança conforme a passagem do tempo, quando a alocação de receitas tiver por fundamento critério de mensuração mensal não baseada em medição efetiva, ou, até mesmo, quando se verificar a cobrança independentemente da utilização efetiva do serviço. Nessas hipóteses, tem-se um critério de realização mais atrelado à mera passagem do tempo. O fornecimento de energia elétrica, a nosso ver, suscita melhor enquadramento na categoria da realização conforme a prestação efetiva dos serviços e não tem relação ínsita com a passagem do tempo.

Analisando as duas categorias referidas acima, tem-se que, nas situações em que os serviços contratados a preço certo consistem de (a) um número certo e periódico de atos similares (b) a serem prestados por um período de tempo contratado, uma parcela proporcional de receita é registrada para cada ato realizado periodicamente. Isto significa que não se faz a alocação de receitas conforme a eventual variação de custos de um ou outro ato, pois presume-se que eles são similares e a alocação é mais atrelada ao elemento tempo (embora também seja relacionável ao andamento da produção) ${ }^{147}$. Caso os atos

\footnotetext{
${ }^{144}$ Cf. BRAGG, Steven M. Revenue recognition: rules and scenarios. New Jersey: John Wiley \& Sons, 2007, p. 142-143.

${ }^{145}$ Vide o item 1.2 deste Capítulo (especialmente as notas 47 e 48 e o texto que as introduz).

${ }^{146}$ Cf. PEDREIRA, op. cit. (nota 10), p. 300.

${ }^{147}$ É de se reconhecer que há uma mistura dos dois critérios (andamento da produção e passagem do tempo) aqui. Por um lado, a mera passagem do tempo sem a prestação efetiva do serviço no período pode prejudicar o reconhecimento da renda correspondente (demandando reposição futura do serviço ou até mesmo indenização). Por outro lado, a realização de mais serviço do que o programado (em razão de erro, negligência, imperícia etc.) não desgarra a alocação temporal conforme o cronograma temporal contratado.
} 
fossem diferenciados entre si, aí sim, a atribuição de receitas teria relação direta com o custo atribuído a cada ato individual ${ }^{148}$.

A situação que mais se identifica com a pura passagem do tempo, no entanto, é aquela em que a prestação de serviços em base continuada e preço predeterminado se identifica com (a) um número não especificado de atos (b) que deva ocorrer ao longo de um período fixo. O exemplo mais comum é o da academia de ginástica que cobra um valor pelo prestação dos serviços durante um prazo certo. A mensuração dos serviços efetivamente consumidos pelo usuário, neste caso, é bastante dificultosa e de materialidade (relação custo/benefício de se promover tal mensuração) baixa. Assim, sendo a cobrança do valor não necessariamente vinculada à efetivação de atos específicos (pois, o usuário pode dever o valor mesmo sem ter usufruído os serviços), reconhece-se, neste caso, um método linear conforme a simples passagem do tempo ${ }^{149}$.

Por fim, vale mencionar, muito ligeiramente, que contratos de licença de uso tendem a ter suas correspondentes receitas reconhecidas conforme a passagem do tempo, porquanto em muito se assemelham às relações de locação de coisas, visto que se destinam essencialmente a conceder direito de uso de determinada tecnologia, marca, software etc. durante prazo certo de tempo. Todavia, o valor cobrado a título de licença pode envolver outras prestações, como se verifica no caso das licenças de software, que normalmente incluem treinamento, atualizações, suporte técnico etc.

Nessas situações de contratos com múltiplos elementos, têm-se desenvolvido, no âmbito do Direito Contábil, uma série de critérios para divisão do preço cobrado e seu reconhecimento conforme o comportamento de cada um dos elementos envolvidos ${ }^{150}$. A aplicabilidade dessa perspectiva para o Direito Tributário, porém, deverá enfrentar as mesmas dificuldades que os demais temas comentados acima (de divisão do preço de venda para identificação dos juros e dos valores destinados a programas de recompensa) ${ }^{151}$.

Para sistematizar tais critérios, vide a proposta de árvore de decisão abaixo ${ }^{152}$ :

\footnotetext{
${ }^{148}$ Sendo os atos dissimilares, usa-se a proporção do custo direto do ato específico sobre os custos totais do contrato para verificar a parcela de receita pertinente a cada ato. Cf. BRAGG, op. cit. (nota 144), p. 142-143. ${ }^{149}$ BRAGG, op. cit. (nota 144), p. 143.

${ }^{150}$ Cf. BRAGG, op. cit. (nota 144), p. 155-158.

${ }^{151}$ Vide a parte final dos itens 1.1 e 1.2 deste Capítulo.

${ }^{152}$ Versão adaptada de BRAGG, op. cit. (nota144), p. 145.
} 


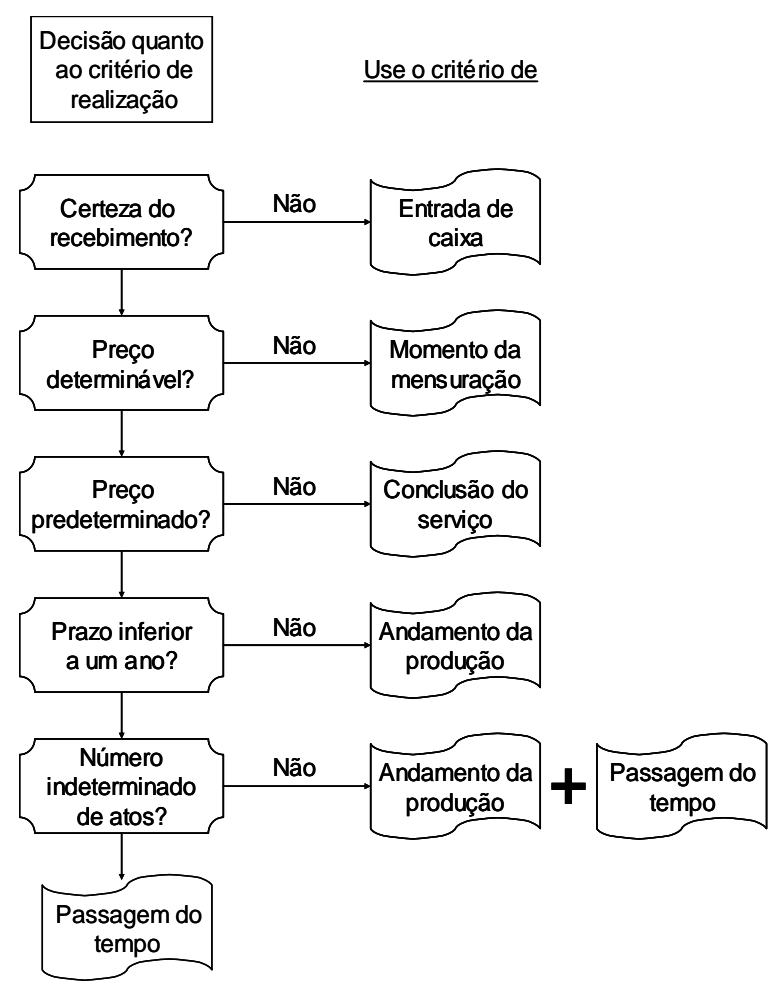

\subsection{Relações de natureza financeira}

Cuida-se, aqui, das relações de concessão de crédito mediante retribuição a título de juros. Essas receitas de natureza financeira têm forte vinculação com o elemento temporal, pois configuram remuneração periódica do capital em função da passagem do tempo. Assim, usando a terminologia de Bulhões Pedreira, pode-se dizer que o acréscimo patrimonial, ou melhor, o direito aos juros que vencem periodicamente nasce no exato momento do vencimento de cada prestação ${ }^{153}$.

Sendo mais explícito sobre o momento temporal em que se verifica o acréscimo de tais direitos ao patrimônio do contribuinte, o aludido especialista destaca que:

"O direito ao recebimento pode ser adquirido ao fim de cada período de contagem de juros, ou no vencimento (do contrato, do depósito ou título). O rendimento pode, entretanto, ser considerado ganho à medida em que decorre o período de contagem de juros (ou do contrato, depósito ou título) $[\ldots]^{\prime 154}$

\footnotetext{
${ }^{153}$ Cf. PEDREIRA, op. cit. (nota 10), p. 473.
}

${ }^{154}$ Cf. PEDREIRA, op. cit. (nota 10), p. 304. 
$\mathrm{O}$ assunto encontra-se disciplinado atualmente nos arts. 373 (receitas) e 374 do Regulamento do Imposto de Renda, e é importante mencionar também a obrigatoriedade de reconhecimento de juros sobre créditos vencidos (prevista no art. 342 do mesmo Regulamento), caso a empresa não tenha tomado as providências de caráter judicial para o recebimento do crédito.

No entanto, não é sempre que se deve apropriar as receitas de natureza financeira conforme a passagem do tempo. Reconhecia-se, no passado, por exemplo, que as aplicações financeiras cujo resgate antecipado causasse a perda do rendimento não geravam a obrigação de reconhecimento das respectivas receitas pro rata temporis ${ }^{155}$.

Além disso, como já se viu, a incerteza no recebimento dos próprios créditos de que derivam os juros pode ser justificativa para sua não contabilização em função da passagem do tempo ${ }^{156}$.

Ainda no que atine ao reconhecimento de rendimentos de relações financeiras, convém anotar que os negócios jurídicos das empresas de factoring tiveram regulamentação dada pelo Ato Declaratório Normativo Cosit n 51/1994 e, sem pretender descer a minudências quanto à tributação dessa atividade empresarial, aí se convencionou que as receitas financeiras obtidas por tais empresas deveriam ser reconhecidas no momento da aquisição dos créditos recebíveis (e não poderiam, portanto, ser reconhecidas em função da passagem do tempo $)^{157}$. Acontece que tais empresas, ao adquirirem créditos de terceiros no mercado, podem assumir integralmente os riscos de tais créditos e, para tanto, contam com o valor do dinheiro no tempo para a geração de lucros. Nessa linha, diferentes acórdãos proferidos pela $1^{\text {a }}$ Câmara do Primeiro Conselho de Contribuintes equipararam tais operações a relações de natureza financeira e afastaram a regra prevista

\footnotetext{
${ }^{155}$ Nesse sentido, os acórdãos de nos $\mathbf{1 0 1 - 9 2 . 6 3 5}$ e 101-92.961, proferidos pela $1^{\text {a }}$ Câmara do Primeiro Conselho de Contribuintes em 14/04/1999 e 26/01/2000, respectivamente: "APROPRIAÇÃO DE RECEITAS FINANCEIRAS - Aplicações financeiras realizadas em um exercício com resgate para o exercício seguinte, cuja percepção do rendimento está condicionado à observância da data prevista para o resgate, podem ter sua receita contabilizada na data do efetivo recebimento da receita."

${ }^{156}$ Vide a esse respeito os itens 2.4.2 e 3.3.4 do Capítulo 3, bem como os acórdãos do Primeiro Conselho de Contribuinte lá comentados.

${ }^{157}$ Ato Declaratório Normativo Cosit $\mathbf{n}^{\circ}$ 51/1994, que trata da alienação de duplicata a empresa de fomento mercantil (factoring): "O COORDENADOR-GERAL DO SISTEMA DE TRIBUTAÇÃO, [...] declara, em caráter normativo, às Superintendências Regionais da Receita Federal e aos demais interessados que:

I - a diferença entre o valor de face e o valor de venda oriunda da alienação de duplicata a empresa de fomento comercial (factoring), será computada como despesa operacional, na data da transação;

II - a receita obtida pelas empresas de factoring, representada pela diferença entre a quantia expressa no título de crédito adquirido e o valor pago, deverá ser reconhecida, para efeito de apuração do lucro líquido do período-base, na data da operação."
} 
no referido ato infralegal para fazer prevalecer o critério de realização conforme a passagem do tempo ${ }^{158}$.

Uma questão interessante salta aos olhos neste tratamento dado às partes envolvidas na venda de créditos mercantis a empresas de factoring: o critério de realização legítimo para uma das partes na transação não necessariamente será o mais apropriado para a outra parte. No caso enfocado, a empresa que aliena seus créditos futuros para a empresa de factoring, recebendo imediatamente um valor descontado, realiza a perda correspondente ao próprio tempo da transação (cf. item I do ADN Cosit n ${ }^{0}$ 51/1994). Já a empresa de factoring, que tem um ganho potencial relativo ao valor pago e o valor de face dos títulos, reconhece essa receita financeira pro rata temporis (consoante os acórdãos mencionados acima e contrariamente ao que se pretendeu impor com o item II do ADN Cosit no 51/1994) $)^{159}$.

\section{Situações de continuidade (realização incompleta)}

Focalizando situações que fogem ao escopo das atividades normais de uma empresa, mas preservando o fio condutor deste Capítulo, que consiste em identificar as diferentes formas de concretização do princípio da realização da renda, comentam-se agora alguns acontecimentos da vida empresarial que, embora tenham potencial para perfazerem todos os elementos do referido princípio (cumprimento da obrigação, mudança de posição patrimonial, troca no mercado, mensurabilidade, certeza e liquidez), não são tomados como eventos críticos de realização, porque alguns desses elementos não se completam com um grau adequado. Assim, as dificuldades de mensuração, a baixa liquidez e, por conseguinte, uma mudança de posição patrimonial diminuta (ou nula) normalmente são razões para que se reconheça que determinados eventos deixam o

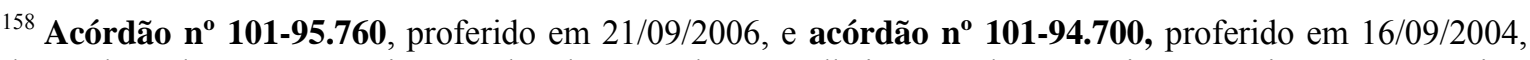
do qual se destaca o seguinte trecho do voto do Conselheiro e Relator Mário Junqueira Franco Junior: “Conforme se depreende da leitura da ementa e dos votos supra, a operação de factoring convencional, sem regresso, como o caso ora em análise, configura uma operação de crédito, pois há antecipação de valores que serão recebidos futuramente. Por isso é que o custo de oportunidade está todo vinculado ao custo do dinheiro no tempo.

É uma verdadeira operação de desconto, com a característica específica do não-regresso, fator este que modifica a situação para o cedente, dado o seu caráter definitivo, mas não para o cessionário, cuja receita á auferida ao longo da operação.

Assim sendo, o regime de reconhecimento da receita auferida deve ser o mesmo do desconto de títulos, ou seja, pro rata tempore, conforme os artigos 317 do RIR/94 e 373 do RIR/99."

${ }^{159}$ Este é um dos exemplos que faz questionar se o conceito de renda adotado pela legislação brasileira segue mesmo a "teoria da pizza" (renda nacional e renda individual), pois não se tem aqui uma aplicação irrestrita e
} 
contribuinte em posição similar àquela em que ele se encontrava antes, tornando incompleta a realização e justificando seu adiamento para ocasião futura.

Dentre as situações em que se observa o reconhecimento de uma situação de continuidade, pode-se falar que algumas delassão inevitáveis ao contribuinte, e outras são consideradas mais como eventos desagradáveis do que lucrativos ${ }^{160}$. Nas situações de indenização destinada a repor dano patrimonial, por exemplo, o contribuinte normalmente recebe caixa ou usa prontamente qualquer caixa recebido para repor os ativos que foram entregues ou sinistrados, de forma que qualquer imposição tributária, com relação a este evento, deverá forçá-lo a vender outros ativos (tomar dinheiro emprestado ou adotar algum comportamento econômico indesejado) para satisfazer a obrigação tributária ${ }^{161}$.

Outros motivos que podem justificar o diferimento da realização em algumas transações comerciais, já adiantadas aqui ${ }^{162}$, consistem no fomento ao desenvolvimento econômico $^{163}$, por meio da eliminação de barreiras a ajustes negociais, e o estímulo da mobilidade laboral ou de outros comportamentos econômicos desejados ${ }^{164}$. Enfim, o reconhecimento da realização da renda pode ser procrastinado para atender a propósitos não tributários, tais como o desenvolvimento de determinadas áreas de negócios, ou até mesmo porque o legislador estava incerto quanto a saber se a realização realmente ocorreu $^{165}$.

Tendo em vista este contexto, comentam-se brevemente aqui dois grupos de casos em que se pode reconhecer a existência de continuidade: trocas de bens e atos de reorganização societária.

\subsection{Troca (ou permuta) de bens}

Autores do peso de Klaus Tipke e Heinrich Beisse não afastam a possibilidade de se tributar o acréscimo patrimonial verificado em uma operação de troca de bens. Tipke,

imediata do princípio da neutralidade (o tratamento tributário de uma parte na transação define o tratamento tributário da outra parte na mesma transação). Vide a esse respeito o item 2.4 do Capítulo 1.

${ }^{160}$ Por exemplo, as indenizações de natureza patrimonial decorrentes de contrato de seguro.

${ }^{161}$ Cf. BITTKER, op. cit. (nota 88), p. 971-972.

162 Vide a esse respeito o item 2.5 do Capítulo 1.

${ }^{163}$ Sobre a atuação dos princípios da ordem econômica para a implementação diferenciada do princípio da realização, vide o item 1.2.2 do Capítulo 2 .

${ }^{164}$ Cf. BITTKER, op. cit. (nota 88), p. 972.

${ }^{165}$ Cf. KORNHAUSER, Marjorie E. The Story of Macomber: the continuing legacy of realization. In. Tax Stories: an in-depth look at ten leading federal income tax cases. CARON, Paul L. (coord.). New York: Foundation Press, 2003, p. 56. 
por exemplo, entende que, no caso de permuta (mesmo de bens similares), verifica-se um ato de comércio e um acréscimo de capacidade contributiva que pode acontecer na realidade, voluntária ou involuntariamente ${ }^{166}$. Beisse compartilha do mesmo entendimento, pois afirma que a permuta conduz essencialmente à concretização do ganho e, seguramente, de acordo com o valor ordinário do bem recebido em pagamento do preço de venda do bem trocado. Porém, referido autor deixa a salvo da tributação as permutas de bens similares, concluindo que o valor original de aquisição (valor contábil) registrado até então somente pode ser preservado quando os objetos permutados foram "economicamente idênticos" $" 167$.

Com efeito, se considerado que a mais-valia contida no bem permutado foi sendo gerada ao longo dos anos e que tal acréscimo patrimonial somente não vinha sendo tributado por razões de ordem prática ${ }^{168}$, os ideais de igualdade e tributação conforme a capacidade contributiva realmente apontam para a tributação de ganhos verificados em permuta. Todavia, razões práticas e, também, motivos relativos à estruturação incompleta do princípio da realização apontam para o sentido oposto, sugerindo a postergação da realização da renda.

Nesse sentido, Kornhauser informa que os motivos para o diferimento da tributação nas permutas focam-se em 3 aspectos centrais ao tema da realização: (i) mensurabilidade ou valoração (geralmente não é possível dizer o valor da propriedade recebida em troca); (ii) liquidez (as partes envolvidas no negócio não recebem dinheiro, portanto, podem ter dificuldades para pagar o imposto); (iii) continuidade do investimento (as partes têm um ganho meramente virtual, "de papel”, e o investimento inteiro continua sujeito a risco na propriedade recebida em espécie).

Quanto ao aspecto de mensurabilidade, Dodge complementa para informar que, em circunstâncias específicas, a Suprema Corte dos E.U.A. sustenta que o recebimento de direitos de propriedade cujo valor é tão contingente em relação a condições e circunstâncias futuras, de modo que não se possa determiná-lo razoavelmente, não pode ser considerado realizado enquanto tal valoração não se tornar razoavelmente possível.

\footnotetext{
${ }^{166}$ Cf. TIPKE, Klaus. Rechtfertigung des Themas; Ziel der Tagung. In: RUPPE, op. cit. (nota 17), p. 8.

${ }^{167}$ Cf. BEISSE, op. cit. (nota 100), p. 23.

${ }^{168}$ Conforme discutido no Capítulo 1, o ideal de tributação (modelo SHS) seria aquele que alcançasse todo o acréscimo patrimonial líquido verificado a cada período (inclusive considerando os ganhos de detenção, decorrentes da mera valorização de ativos já pertencentes ao patrimônio do contribuinte). Todavia, conforme lá se abordou, dificuldades relativas à indisponibilidade dos recursos (liquidez) para cumprir a obrigação
} 
Ademais, aponta-se também que operações de trocas de ativos não representam necessariamente uma mudança de posição patrimonial ${ }^{169}$.

Com efeito, para a legislação de alguns países, como é até hoje o caso dos E.U.A. ${ }^{170}$ e foi o da Alemanha até o final de $1998^{171}$, a troca de bens (inclusive participações societárias) que sejam economicamente similares não resulta na realização de ganhos de capital.

No âmbito da legislação tributária brasileira, o tema já foi objeto de Pareces Normativos na década de $70^{172}$, mas ganhou novos contornos com a previsão específica de não tributação no caso de permutas de unidades imobiliárias ${ }^{173}$ e continua a gerar controvérsias com relação a permutas de outras espécies de bens (sejam similares entre si ou totalmente diferentes).

Sobretudo diante da disciplina dada ao tema pelo novo Código Civil ${ }^{174}$, não se pode negar que uma operação de troca configura modalidade de alienação ${ }^{175}$, sendo em tudo comparável a duas operações de compra e venda contrapostas, com pagamento do preço mediante compensação recíproca ${ }^{176}$. É verdade que a legislação do imposto de renda das pessoas físicas foi mais explícita ao elencar a permuta como modalidade de alienação e, portanto, deflagradora da realização de ganho de capital ${ }^{177}$, porém, a ausência de tamanho didatismo na legislação pertinente às pessoas jurídicas não afasta, por si só, o alcance quanto às operações de permutas. O que se deve questionar é se as razões

tributária e à fragilidade dos métodos de estipulação de valor (dificuldades de valoração) impedem uma tal tributação ampla da renda. Vide a esse respeito o item 2.5 do Capítulo 1.

${ }^{169}$ Vide a esse respeito o item 3.3.2 do Capítulo 3.

${ }^{170} \mathrm{Cf}$. artigo 1031 do IRC.

${ }^{171} \mathrm{O}$ conceito de Tauschgutachten (troca de estimativas), criado desde muito cedo pela jurisprudência, restou superado pela reforma promovida na legislação do imposto de renda a partir de 1999. Para a referência ao instituto, cf. LÜDERS, op. cit. (nota 31), p. 131. Para a regulamentação da permuta atualmente, vide $\S 6$, itens 4 e 6 da EStG (Lei do Imposto de Renda) atualmente vigente.

${ }^{172}$ Parecer Normativo CST $\mathbf{n}^{\mathbf{0}}$ 232/1971 (que trata de permuta de ações realizada por pessoa física, reconhecendo que a mais-valia patrimonial obtida não é alcançada pela tributação), e Parecer Normativo $\operatorname{CST~}^{\circ}$ 504/1971 (que aborda o tema de pessoas jurídicas que realizam permuta de ações de mesmo valor). Os dois atos são de validade questionável em vista das alterações que se promoveram na legislação tributária e comercial desde então.

${ }^{173}$ Instrução Normativa SRF $n^{\circ} \mathbf{1 0 7 / 1 9 8 8 . ~}$

${ }^{174}$ Código Civil “Art. 533 - Aplicam-se à troca as disposições referentes à compra e venda, com as seguintes modificações:

I - salvo disposição em contrário, cada um dos contratantes pagará por metade as despesas com o instrumento da troca;

II - é anulável a troca de valores desiguais entre ascendentes e descendentes, sem consentimento dos outros descendentes e do cônjuge do alienante." Grifo nosso.

${ }^{175}$ Segundo Jones Alves: "O artigo utiliza o vocábulo "alienante", o que enquadra a permuta entre os atos de alienação do bem, resolvendo antiga controvérsia doutrinária.” Cf. ALVES, op. cit. (nota 24), p. 486.

${ }^{176}$ Cf. LÜDERS, op. cit. (nota 31), p. 129.

${ }^{177}$ Cf. art. $3^{\circ}, \S 3^{\circ}$, da Lei $\mathbf{n}^{\circ} 7.713 / 1988$. 
apontadas acima (falta de mensurabilidade e liquidez e uma possível continuidade da posição patrimonial) seriam suficientes para afastar o evento de realização por tradição dos bens trocados.

Quanto à situação de continuidade, a legislação parece sugerir, em alguns casos, que a permuta carrega em si mesmo o atributo de inalteração da posição patrimonial $^{178}$. Já no que respeita aos demais aspectos, cumpre dizer que, se a falta de mensurabilidade do valor recebido por qualquer das partes envolvidas na permuta, ou a falta de liquidez fossem considerados relevantes, não se deveria tampouco tributar os rendimentos recebidos em espécie ${ }^{179}$. Adotar essas razões aqui e não lá seria problema sério de inconsistência. É preciso entender por que no recebimento em espécie tais empecilhos são preteridos. E uma razão se apresenta para tanto: lá se tem uma estipulação de valor, há um consentimento entre as partes quanto ao valor da prestação de uma parte à outra (e.g., preço dos serviços prestados ou das mercadorias vendidas) e o bem em espécie vem apenas ocupar o espaço antes ocupado pelo item "duplicatas a receber", referente ao preço da venda que foi extinto pela dação ${ }^{180}$.

Nos casos de permuta, segundo pontua Sílvio Venosa, não há propriamente preço, porque os contratantes prometem entregar reciprocamente bens que não dinheiro. Assim, é necessário que a coisa seja o objeto predominante do contrato e não o montante em dinheiro, pois, se o valor em dinheiro for primordial, não existe troca, mas sim duas compras e vendas contrapostas ${ }^{181}$.

Nesse sentido, vale ressaltar que, no campo do Direito Contábil, a ECB mencionava que uma das situações excepcionais para reconhecimento de receita após a tradição era aquela de um ativo não-monetário sem valor de mercado reconhecido ser recebido em troca de uma venda efetuada. Nesta hipótese atribuía-se o custo do ativo transferido para o ativo recebido em troca, realizando-se o ganho ultimamente com a venda deste último ${ }^{182}$. Haveria aí uma razão para tratar de maneira diferenciada os recebimentos em espécie relativamente àquelas operações de troca em que a coisa trocada é mais importante que o valor a ela atribuído.

\footnotetext{
${ }^{178} \mathrm{O}$ art. 65 da Lei $\mathbf{n}^{\mathbf{0}} \mathbf{8 . 3 8 3 / 1 9 9 1}$ parece tomar como certo que permuta é um evento que não deflagra a tributação.

${ }^{179}$ Vide os comentários a esse respeito no item 3.2 deste Capítulo.

${ }^{180}$ Vide a esse respeito o item 3.2 supra (particularmente a discussão que acompanha as notas de rodapé 121 a 124).

${ }^{181}$ Cf. VENOSA, op. cit. (nota 71), p. 86-87.

${ }^{182}$ Vide item 3.1.5.3.4 da ECB (Deliberação CVM nº 29/1986).
} 
A definição deste tema continua bastante incerta no Brasil e a proposta do preente estudo não autoriza maior aprofundamento das questões emergentes dessa controvérsia $^{183}$. Menciona-se apenas que decisões recentes do Primeiro Conselho de Contribuintes têm chancelado a não tributação de mais-valias decorrentes de permutas (não necessariamente similares) ${ }^{184}$.

\subsection{Atos de reorganização societária}

Outras situações em que se reconhece a existência de continuidade da situação patrimonial, quer por força de previsões legais específicas, quer por interpretação sistemática, são verificadas em determinados atos de reorganização societária (assim entendidos como as hipóteses de integralização ou redução de capital e as operações de incorporação, fusão, cisão, extinção por liquidação e dissolução).

Pensa-se aqui na integralização ou redução de capital como atos que potencialmente não geram descontinuidade do ponto de vista do sócio da empresa, isto é, os bens por ele contribuídos ao capital continuam, de certa forma, a fazer parte de seu patrimônio, pois somente foram traduzidos em ou "trocados" por participação societária. No sentido inverso também, pois a redução de capital entrega ao sócio o bem que, de certo modo, já lhe pertencia remotamente (estava afetado à atividade empresarial, mas poderia ser resgatado, desde que atendidas as condições previstas em lei, protegidos os interesses de credores e dos demais sócios etc.).

A semelhança com as operações de permuta, neste particular, foi ressaltada por Beisse, pois, segundo ele, o aproveitamento dos fundamentos da permuta para as situações de integralizações de capital com bens econômicos, em troca de participações societárias, permite visualizar tais procedimentos como espécies de alienação capazes de realizar ganhos. Comentando o regime prevalecente na Alemanha, apenas para as sociedades de

\footnotetext{
${ }^{183}$ Para maiores subsídios acerca do tema, cf. MOREIRA JUNIOR, Gilberto de Castro. IRPF, IRPJ e Permuta de Participações Societárias. Disponível em: $<\mathrm{http}: / / \mathrm{www}$.fiscosoft.com.br $>$. Acesso em $04 \mathrm{dez}$ 2008.

${ }^{184}$ Nesse sentido são os acórdãos de nos $\mathbf{1 0 2 - 4 7 . 3 2 5 , ~ 1 0 2 - 4 7 . 6 8 1 , ~ 1 0 2 - 4 7 . 8 4 4 ~ p r o f e r i d o s ~ p e l a ~} 2^{\mathrm{a}}$ Câmara em 25/01/2006, 22/06/2006 e 17/08/2006, respectivamente. Quanto a este último, vale destacar trecho do voto do Conselheiro e Relator Leonardo Henrique Magalhães de Oliveira: "Essa Câmara firmou entendimento majoritário que não incide ganho de capital na permuta de bens, seja qual for a natureza desses (terrenos, participações societárias, veículos, etc.), conforme Acórdão $n^{\circ}$ 102-47.681, proferido na sessão de 22/06/2006. Entendeu o Colegiado que na operação de permuta não há acréscimo patrimonial do contribuinte; logo, a não incidência do ganho de capital não poderia ser restrita às operações entre imóveis mediante escritura pública de permuta."
} 
pessoas é que se permite a conferência de bens do sócio por seu valor original de custo.O fundamento para esta diferenciação é o de que o empresário não necessariamente é visto como um terceiro em relação a sua empresa. ${ }^{185}$.

No Brasil, a situação de continuidade foi reconhecida na hipótese de integralização de capital de empresa por pessoas físicas, permitindo que bens e direitos constantes da declaração de bens da pessoa física sejam transferidos à pessoa jurídica a título de integralização de capital pelo valor de custo de aquisição original (isto é, sem realização do ganho de capital) ${ }^{186}$. Previsão explícita como esta (de postergação da realização de possíveis ganhos latentes) não há para a situação do sócio pessoa jurídica que confira bens de seu patrimônio ao capital de outra pessoa jurídica. Dessa forma, em vista da controversa aplicação das regras de realização complementar ${ }^{187}$ relativas à distribuição disfarçada de lucros neste caso ${ }^{188}$, não é possível afirmar com segurança que a mesma concessão possa ser feita à pessoa jurídica ${ }^{189}$.

No movimento inverso, vale dizer, na redução de capital, também há previsão legal expressa que difere o ponto de realização para momento futuro ${ }^{190}$. Neste caso, porém, o reconhecimento se deu tanto para o sócio pessoa física quanto para o sócio pessoa jurídica. Ambos podem receber a propriedade de bens que antes estavam afetados ao patrimônio de uma pessoa jurídica, sem que tal transferência cause a realização de reservas ocultas (ganhos latentes) atreladas ao referido bem.

Embora não seja verificada de maneira tão evidente, a característica de continuidade patrimonial também está presente nas operações de incorporação, fusão $e$ cisão. Voltando a atenção para a própria empresa que será incorporada, fusionada ou cindida, pode-se falar de continuidade da situação patrimonial no sentido de que os patrimônios envolvidos, antes e depois das operações, continuarão a ser substancialmente os mesmos (com relação a seus elementos, embora, não quanto a seus titulares diretos), sem que se verifique qualquer acréscimo de direito novo ou transação com o mercado que

\footnotetext{
${ }^{185}$ Cf. BEISSE, op. cit. (nota 100), p. 23.

${ }^{186}$ Cf. Lei no 9.249/1995, art. 23.

${ }^{187}$ Sobre a realização complementar como uma hipótese de realização por captura, vide o item 8 deste Capítulo.

${ }^{188}$ No caso da pessoa física que integraliza capital de pessoa jurídica, as regras de DDL são afastadas expressamente pelo $\S 1^{\circ}$ do art. 23 da Lei $\mathrm{n}^{\circ}$ 9.249/1995.

${ }^{189}$ Mariz de Oliveira aparentemente concorda com a aplicação das regras de DDL neste caso: "Entretanto, a possibilidade de existência de DDL na conferência de bens por pessoas jurídicas não decorre da não inclusão destas na disposição do art. 23, mas, sim, da aplicação da primeira ou da segunda hipótese legal de DDL, conforme o valor da conferência seja notoriamente inferior ao de mercado, ou notoriamente superior, e, neste sentido, não lhes é estendida a exclusão do art. 23." Cf. OLIVEIRA, op. cit. (nota 8), p. 785.

${ }^{190}$ Cf. Lei no 9.249/1995, art. 22.
} 
pudesse gerar mudança da posição patrimonial. O aspecto da continuidade em tais eventos de reorganização societária é bem explicitado pelo Parecer Normativo CST nº 6/1985:

"2.1 - Segundo entendimento consagrado em atos normativos da Secretaria da Receita Federal, nos casos de incorporação, fusão e cisão não acontece descontinuidade na vida das empresas, tendo em vista que as obrigações tributárias das sucedidas continuam a ser cumpridas pelas sucessoras, como se não houvesse alteração nas firmas ou sociedades. Não há, a rigor, baixa de bens e direitos de um patrimônio e ingresso em outro, mas, sim, a transposição de patrimônio de uma para outra pessoa jurídica, que sucede a primeira nos direitos e obrigações."

Voltando-se a atenção para o ponto de vista do acionista, verifica-se haver, de fato, hipóteses em que ocorre uma substituição de ações da empresa incorporada, fusionada ou cindida por ações da empresa incorporadora ou resultante da fusão ou cisão. Porém, como já reconheceu o Parecer Normativo CST n ${ }^{\circ} 39 / 1981^{191}$, as quotas ou ações que venham a substituir títulos de participação societária, na mesma proporção das anteriormente possuídas, não podem ser consideradas novamente "subscritas ou adquiridas”.

Esse parecer, emitido para esclarecer se os eventos de incorporação, fusão ou cisão interferiam na contagem do prazo de 5 anos necessário para a aplicação de uma desoneração do imposto, valeu-se do instituto da sub-rogação para concluir que, nestas hipóteses, há mera substituição de uma coisa pela outra (novamente a similaridade com a permuta), mas sem que o patrimônio, ou os patrimônios, tenham deixado de ser, em qualquer momento, universalidades ${ }^{192}$.

Verificado haver continuidade da situação patrimonial em tais operações, importa destacar aqui que, a exemplo do que ocorre com as integralizações e reduções de capital, os eventos de incorporação, fusão e cisão também podem ser realizados com continuidade das reservas ocultas presentes nos patrimônios das empresas envolvidas ${ }^{193}$. Isto é, podem-se promover reorganizações societárias variadas sem que a tributação de tais ganhos latentes seja um elemento inibidor do rearranjo patrimonial.

\footnotetext{
${ }^{191}$ No que foi seguido por outros, inclusive o Parecer Normativo CST $\mathbf{n}^{\circ}$ 6/1985 aqui já mencionado. 
O dispositivo legal que contempla essa hipótese tem sua aplicabilidade questionada atualmente por respeitáveis autores ${ }^{194}$, em vista das alterações que vêm sendo feitas à legislação contábil ${ }^{195}$. Porém, considerando-se que referido acréscimo de valor não seja destinado ao lucro comercial e permaneça simplesmente destacado na conta de “ajustes de avaliação patrimonial”, parece mais convincente a visão daqueles que entendem que esta particular alteração nas normas contábeis afeta apenas o balanço contábil e não o fiscal ${ }^{196}$.

No que concerne às hipóteses de dissolução ou extinção da empresa por liquidação e, mais particularmente, à possibilidade de tais eventos resultarem na devolução de seu patrimônio aos sócios, tem-se aqui também uma situação de continuidade da relação entre o sócio e o patrimônio que estava afetado à empresa. Para não alongar a discussão neste ponto, anota-se brevemente que, embora fosse controverso o enquadramento de tais operações nas regras de distribuição disfarçada de lucros (o que ensejaria a utilização de valores próximos aos de mercado e, portanto, realização de ganhos latentes), atualmente tal querela é amenizada pela possibilidade, discutida acima, de redução de capital a valor contábil original.

Concluindo este item, além do aspecto da continuidade (ou inexistência do elemento mudança na posição patrimonial), importa destacar que tais medidas legais, que reconhecem a incompletude da realização, postergando-a para momento futuro, procuram, em última análise, corrigir os efeitos distorsivos provocados pela adoção de um princípio da realização orientado pelo enfoque no evento crítico (em vez de na acumulação de valor ao longo do tempo). O assunto já foi objeto de apontamentos em segmentos específicos deste trabalho e estão sendo retomados aqui para referência ${ }^{197}$.

\footnotetext{
${ }^{194}$ CARVALHO, Fábio Junqueira de; MURGEL, Maria Inês. A nova Lei das S/As e seus possíveis reflexos na tributação pelo imposto sobre a renda. In: ROCHA, op. cit. (nota 38), p. 116.

${ }^{195}$ Até a edição da MP n ${ }^{\circ} 449 / 2008$, esteve vigente o $\$ 3^{\circ}$, do art. 226 LSA (incluído pela Lei no 11.638/2007), que, passaria a exigir que determinadas operações de incorporação, fusão ou cisão fossem realizadas necessariamente a valor de mercado (e, portanto, incorrendo em evento de realização da renda relativa aos ganhos latentes). Atualmente, com a modificação dada pela MP n ${ }^{0}$ 449/2008, preferiu-se deixar a regulamentação do tema, em situações que envolvam companhia aberta, para a CVM (órgão que, todavia, possivelmente editará ato contendo orientação semelhante).

${ }^{196}$ Cf. MARTINS, Natanael. "A reforma da lei das sociedades anônimas: Lei 11.638/2007 e seus impactos na área tributária”. In: ROCHA, op. cit. (nota 38), p. 372. Cf. OLIVEIRA, op. cit. (nota 39), p. 485-486.

${ }^{197}$ Vide a esse respeito, por todos, o item 2.5 do Capítulo 1 e o item 3.2.1 do Capítulo 3.
} 


\section{Realização na variação do valor de ativos e passivos inertes}

Dentro da proposta aqui traçada, principiou-se a presente análise com as atividades mais elementares das operações do cotidiano empresarial para se chegar aos eventos de realização que afetam atividades não operacionais. Agora, neste ponto, abordam-se atividades que virtualmente independem de ações internas da empresa. Aludese aqui àquelas hipóteses de alteração do patrimônio que decorrem, no geral, de fatores externos, de ocorrência alheia à vontade do empresário (e.g. mudanças nas taxas de câmbio, quebras de clientes, efeitos de catástrofes naturais), podendo também estar relacionadas à descontinuidade de obrigações. Em todas essas situações, modificam-se (ou até eliminam-se) valores de ativos e passivos que estavam inertes.

Como já se sugeriu no Capítulo anterior ${ }^{198}$, há uma amenização do elemento cumprimento da obrigação neste caso, pois a causa ou fonte da variação patrimonial não decorre do emprego direto de recursos próprios.

Tendo isso em vista, foram arroladas, para sucintas considerações neste tópico, as situações de atualização dos valores de ativos e passivos, quer por iniciativa própria, quer por obrigação legal de se fazer atualizações periódicas (variações monetárias), bem como as hipóteses de descontinuidade de ativos e passivos.

Embora algumas das receitas e despesas ora enfocadas possam ser medidas periodicamente (particularmente as variações monetárias), suscitando seu melhor enquadramento no conjunto dos eventos de realização que ocorrem à medida da passagem do tempo, preferiu-se emoldurá-los aqui por sua afinidade com os demais eventos que provocam mudanças nos valores de ativos e passivos sem relação com fatores internos à empresa.

\subsection{Atualização dos valores de ativos e passivos (mensurações subsequentes)}

Decorre da própria legislação contábil-comercial, como se viu, a obrigação de se registrarem os ativos e passivos pelo seu custo de aquisição ou fabricação e, a partir daí, aguardar uma de duas coisas: (i) o evento de realização, ou (ii) para alguns casos de ativos, a verificação da queda de seu valor de mercado (hipótese na qual seria obrigatório o

\footnotetext{
${ }^{198}$ Vide a esse respeito o item 3.3.1 do Capítulo 3.
} 
registro por este menor valor - de mercado ou justo) ${ }^{199}$. Ademais, para algumas situações específicas, a orientação do Direito Contábil é para que se registrem (obrigatória ou opcionalmente) determinados ativos pelo seu valor provável de venda (princípio do custo corrente $\left.^{200}\right)$. Além das hipóteses hodiernamente vigentes, vale comentar que, até pouco tempo atrás, era possível efetuar-se a reavaliação de ativos (cf. art. 182, $\S 3^{\circ}$ da LSA, alterado pela Lei no $11.638 / 2007)$.

Esses atos de mensuração subsequente de ativos suscitam o reconhecimento de perdas ou ganhos em função de fatores externos e podem, assim, ser reconhecidos como eventos de realização para fins da legislação comercial ${ }^{201}$. Todavia, sua eleição como fato deflagrador da realização da renda tributável, segundo já apontado, encontra impeditivos previstos na própria legislação vigente ${ }^{202}$ ou restrições visualizadas no sistema da legislação comercial ${ }^{203}$.

A tributação da variação de valor de ativos inertes (ganhos ou perdas de detenção) é tema de que se ocupou este trabalho em diversas passagens dos Capítulos $1 \mathrm{e}$ 2, tendo-se verificado que a adoção do conceito de renda-acréscimo em sua maior amplitude (o modelo SHS) atenderia aos ideais de igualdade e tributação conforme a capacidade contributiva. Todavia, tal medida esbarra em sérias restrições práticas e, no presente caso, em impedimento decorrente da própria definição de renda dada pelo $\mathrm{CTN}^{204}$. Assim, embora seja plenamente possível afirmar que a verificação de acréscimo (ou decréscimo) patrimonial por marcação a mercado não contraria o princípio da realização ou o regime de competência (dado que ambos são abertos e passíveis de maior definição) $)^{205}$, a sua implementação no Brasil configura tarefa dificultosa.

\footnotetext{
${ }^{199}$ Vide a esse respeito o item 3.4.1 do Capítulo 3, sobretudo quanto às hipóteses a que se aplica tal princípio e os conceitos de valor de mercado (ou valor justo) conforme cada situação.

${ }^{200}$ Vide a esse respeito o item 3.4.2 do Capítulo 3.

${ }^{201}$ Relembra-se que apenas a utilização do princípio do menor valor entre custo de aquisição ou mercado afeta o lucro comercial, pois o princípio do custo corrente (sobretudo para ativos financeiros) é direcionado à conta de "ajustes de equivalência patrimonial" sem impacto inicial no resultado.

${ }^{202} \mathrm{O}$ art. 298, inciso IV, do RIR/99 impede o reconhecimento da perda decorrente do menor valor de mercado de ativos; e o art. 297 do mesmo diploma legal (mais a Instrução Normativa SRF n 257/2002, art. 16) protelam a realização do ganho decorrente da avaliação de "commodities" agrícolas a preços correntes.

${ }^{203}$ Vide comentário a esse respeito no item item 3.4.2 do Capítulo 3 (particularmente nas notas 232 e 233 e no texto que as introduz).

${ }^{204} \mathrm{O}$ fato de que somente se tributam as aquisições de riqueza nova. Vide a esse respeito o item 2.2.2 do Capítulo 2.

${ }^{205}$ Por ocasião da convergência das normas contábeis na Alemanha, tema semelhante é discutido por Desiree Dauber, sendo apontada, também naquele país, a controvérsia consistente em saber se a tributação das variações de valor de instrumentos financeiros ofendia o princípio da realização. A autora argumenta não haver tal contrariedade, inclusive com relação aos ativos mantidos com a finalidade de hedging. Cf. DAUBER, op. cit. (nota 103), p. 149-153.
} 
O curioso é que a tributação das variações monetárias, decorrentes de atualizações periódicas de ativos e passivos, tem suas raízes fincadas na legislação tributária e comercial desde muito tempo e as objeções para que tal mecanismo não interfira na apuração da renda tributável seriam um tanto quanto semelhantes: não há acréscimo de direito novo, trata-se de ganho meramente potencial ${ }^{206}$.

Nesse sentido, convive-se com a tributação de variações positivas ou negativas ${ }^{207}$ decorrentes de variações monetárias (cambiais ou inflacionárias) verificadas com relação aos direitos de crédito ou obrigações do contribuinte. Tais variações são explicadas também por fatores externos (de natureza macroeconômica) e estão fora do controle da empresa.

Atualmente, os critérios para seu registro periódico são, todavia, uma faculdade concedida ao contribuinte, podendo-se optar por reconhecer tais variações conforme o efetivo recebimento ou pagamento (regime de caixa) ou pro rata temporis (critério pertinente para implementação do regime de competência $)^{208}$. Vale apontar também que tais variações podem ser realizadas mediante a prática de eventos críticos específicos (o próprio recebimento ou pagamento, novação da obrigação, extinção da obrigação, conversão em capital, compensação etc. $)^{209}$.

No que concerne aos componentes do princípio da realização visualizados nas hipóteses acima delineadas, inexiste, ou tem grau de intensidade menor, o elemento cumprimento da obrigação. Ademais, o elemento troca no mercado, nesses casos, não é baseado em uma transação de mercado em sentido estrito (vinculada à própria empresa), mas sim em uma transação de mercado em sentido amplo (verificada mediante a observação de trocas realizadas por terceiros) $)^{210}$.

\footnotetext{
${ }^{206}$ Como inclusive confirma o Parecer Normativo CST $\mathbf{n}^{\mathbf{0}} \mathbf{8 6} / \mathbf{1 9 7 8}$ ao comentar o art. 18 do Decreto-lei $\mathrm{n}^{\mathrm{o}}$ 1.598/1977 (dispositivo que encetou a tributação de variações monetárias para fins do imposto de renda): "8. No que se refere à atualização dos direitos de crédito é óbvio que se o dever de inclusão, como determina o texto, se torna imperativo quando o ganho é apenas potencial, por melhores razões ele o será quando o ganho for realizado. [...]

9. A mesma ordem de considerações do item precedente é aplicável ao direito de dedução, consubstanciado no parágrafo único. Com efeito, em virtude disso, não só poderão ser deduzidos os encargos potenciais como, igualmente, os suportados, procedam de obrigações ou de créditos. [...]

10. Isto posto, concluímos que as perdas e ganhos, potenciais ou realizadas, constituem, respectivamente, faculdade e obrigação do contribuinte, no que se refere à computação ao lucro operacional, subordinadas ao regime de competência." Grifo nosso.

${ }^{207}$ A legislação classifica tais itens como "receitas" ou "despesas" financeiras - vide arts. 375 e 377 do RIR/99.

${ }^{208}$ Cf. Medida Provisória n ${ }^{\circ}$ 2.158-35/2001, art. 30.

${ }^{209}$ Vide o art. 378 do RIR/99.

${ }^{210}$ Vide a esse respeito o item 3.3.3 do Capítulo 3.
} 


\subsection{Descontinuidade de ativos e passivos}

Fatores externos como mudanças tecnológicas podem causar a obsolescência de máquinas e equipamentos; catástrofes naturais podem provocar dano físico a mercadorias ou a itens do ativo imobilizado; mercadorias podem ser furtadas ou se perderem integral ou parcialmente durante o processo produtivo (ou no manuseio e transporte). Em situações como essas reconhece-se que o ativo deve ser descontinuado, isto é, baixado do balanço patrimonial, ocasionando uma perda que, atendidas as condições previstas na legislação ${ }^{211}$, afeta também o lucro fiscal.

Quanto à descontinuidade de passivos, fala-se preponderantemente daquelas situações em que se verifica, na linguagem da Resolução CFC no $750 / 1993^{212}$, a extinção total ou parcial de um passivo sem o desaparecimento concomitante de um ativo de valor igual ou maior.

Já se comentou aqui que, em tais situações, não se verifica uma dependência forte da realização da renda com o requisito de cumprimento da obrigação ${ }^{213} \mathrm{e}$, tampouco, algum elemento visível de troca ${ }^{214}$. Todavia, é evidente a circunstância de ingresso de riqueza nova no patrimônio da empresa (ainda que sob a forma de reconhecimento postergado do direito novo que entrou ao tempo da constituição da obrigação original $)^{215}$. Mesmo que a classificação desse "ganho", como receita ou não, seja questionável, trata-se de um acréscimo patrimonial passível de tributação ${ }^{216}$.

Complementando o sentido da legislação contábil mencionada acima, o Apêndice dos $\mathrm{PFC}^{217}$ esclarece ainda que a extinção parcial ou total de uma exigibilidade compreende os casos "do perdão de multa fiscal, da anistia total ou parcial de uma dívida, da eliminação de passivo pelo desaparecimento do credor, pelo ganho de causa em ação

\footnotetext{
${ }^{211}$ Vide o art. 291 (quebras e perdas normais ou decorrentes de deterioração, obsolescência etc.) e art. 364 (prejuízos por desfalque, apropriação indébita e furto) do RIR/99.

212 “Art. $9^{\mathbf{0}}[\ldots] \S \mathbf{3}^{\mathbf{0}}$ - As receitas consideram-se realizadas: [...]

II - quando da extinção, parcial ou total, de um passivo, qualquer que seja o motivo, sem o desaparecimento concomitante de um ativo de valor igual ou maior;" Grifo nosso.

${ }^{213}$ Vide comentários específicos a esse respeito na parte final do item 3.3.1 do Capítulo 3.

${ }^{214}$ Vide comentários específicos a esse respeito na parte final do item 3.3.3 do Capítulo 3.

${ }^{215}$ Sobre o aspecto de ingresso de algo novo, vide especialmente a nota 182 do item 3.3.2 do Capítulo 3 e o texto que a introduz.

${ }^{216}$ Ao debater se a redução de despesa é receita tributável para PIS e COFINS, Greco afasta tal classificação, porém reconhece a existência de um "ganho". Cf. GRECO, Marco Aurelio. Cofins na Lei 9.718/98: variações cambiais e regime de alíquota acrescida. In: Revista dialética de direito tributário. v. 50. São Paulo: Dialética, nov. 1999, p. 130-131.

${ }^{217}$ Cf. item 2.6.3 da Resolução CFC no 774/1994.
} 
em que se discutia uma dívida ou o seu montante, já devidamente provisionado, ou outras circunstâncias semelhantes".

Como se verifica, o acréscimo patrimonial pode derivar não só do desaparecimento de uma obrigação, mas também ser motivado pela não-incursão em perdas ou em riscos para os quais se tenha constituído uma provisão na contabilidade ${ }^{218}$. O acréscimo patrimonial verificado com a baixa da provisão, contudo, não deve causar impactos ao lucro fiscal, tendo em vista que a despesa gerada ao momento de sua constituição tampouco afeta a base de cálculo do imposto de renda de pessoas jurídicas ${ }^{219}$.

Enfim, o que importa destacar diante da proposta deste Capítulo é que o evento relevante de realização, nesses casos, consiste na própria constatação do ato ou fato externo causador da descontinuidade do ativo ou passivo, ou no cumprimento das formalidades exigidas pela legislação para que tal constatação deflagre o reconhecimento da perda ou ganho.

\section{Realização na mudança do uso da propriedade}

Algumas situações peculiares de realização da renda podem decorrer também de fatos preponderantemente internos, relativos à mera mudança do uso da propriedade própria. Neste ponto da exposição, não se trata mais das atividades operacionais e tampouco das atividades estranhas aos objetivos sociais de uma empresa. As justificativas para que tais acontecimentos deflagrem a realização da renda estão mais ligadas a aspectos exclusivamente tributários.

Os eventos desta natureza que foram identificados em pesquisa da legislação tributária brasileira são aqui comentados em breve síntese. Convém ressaltar que, em termos teóricos, as situações aqui tratadas implicam sua classificação como eventos deflagradores da realização "por captura", isto é, fundados na simples razão de que a realocação de bens de uma posição patrimonial (regime jurídico ou tributário) para outra pode causar perda de base tributável ${ }^{220}$.

\footnotetext{
${ }^{218}$ Cf. REICH, Markus. Die Realisation stiller Reserven im Bilanzsteuerrecht. Zürich: Schulthess, 1983, p. 122.

${ }^{219}$ Em vista da proibição geral quanto à dedutibilidade de provisões (art. 13, I, da Lei $\mathbf{n}^{\mathbf{0}}$ 9.249/1995).

${ }^{220}$ A respeito desta possível classificação, vide o item seguinte (item 8) deste Capítulo.
} 


\subsection{Reclassificação de ativos}

De interesse apenas histórico, sublinha-se que vigeu até 31/12/1996 (por força do art. 35, §1", alínea "b”, item 1 do Decreto-Lei $n^{\circ}$ 1.598/1977) uma hipótese de realização que era provocada pela mera reclassificação de bens do ativo permanente para o ativo circulante ou realizável a longo prazo ${ }^{221}$.

Numa tal reclassificação de ativos é evidente a ausência dos elementos típicos ao princípio da realização (não se verifica nenhuma transação de mercado subjacente, nem tampouco o cumprimento de obrigações, acréscimo de direitos etc.). Nem sequer se poderia falar que tal movimentação interna teria a intenção de circundar os demais eventos de realização da reserva de reavaliação (itens $1,2,3$ do $\S 1^{\circ}$ do referido dispositivo), pois, em caso de venda (saída dos bens) da empresa, incorrer-se-ia no evento crítico de alienação. Mais ainda, evitar a realização periódica por depreciação traria mais prejuízos que benefícios.

A justificativa de tal evento crítico estava mais propriamente vinculada com a questão de correção monetária do balanço, pois, sendo os itens de ativo permanente relevantes para tal cálculo, a reclassificação do bem diminuiria o cômputo de receitas de correção monetária $^{222}$. Assim, verifica-se que tal hipótese de realização consistia em norma de caráter anti-elisivo.

\subsection{Transformação da pessoa jurídica}

Bastante comum em países cujas legislações contemplam diferenças marcantes no tratamento dos bens de capital (i.é, dos ganhos de capital) para fins do imposto de renda (conforme o bem esteja na propriedade de pessoa jurídica, de pessoa física, contemplando

\footnotetext{
${ }^{221}$ Decreto-lei no 1.598/1977 “Art. 35 A contrapartida do aumento de valor de bens do ativo permanente, em virtude de nova avaliação baseada em laudo nos termos do artigo $8^{\circ}$ da Lei $n^{\circ} 6.404$, de 15 de dezembro de 1976, não será computada no lucro real enquanto mantida em conta de reserva de reavaliação.

$\S \mathbf{1}^{\circ}$ - $\underline{\mathrm{O}}$ valor da reserva será computado na determinação do lucro real: [...]

b) em cada período-base, no montante do aumento do valor dos bens reavaliados que tenha sido realizado no período, inclusive mediante:

1 - alienação, sob qualquer forma;

2 - depreciação, amortização ou exaustão;

3 - baixa por perecimento;

4 - transferência do ativo permanente para o ativo circulante ou realizável a longo prazo." Grifo nosso. Vale lembrar que o dispositivo (item 4) encontra-se atualmente revogado.

${ }^{222}$ Cf. BATAlHA, Wilson de Souza Campos. A Lei das S.A. e o imposto de renda. Rio de Janeiro: Forense, 1978, p. VII e 1.
} 
ainda variações conforme o tipo societário adotado) ${ }^{223}$, o evento de transformação de um tipo societário a outro não é evento crucial da realização da renda no Brasil. Há apenas uma hipótese imprópria, em que se pode verificar a tributação por atos desta natureza: a transformação de associação sem fins lucrativos em sociedade simples ou empresária (com fins lucrativos), especificamente quando a avaliação do capital resultar em ganho.

Sem se deter a particularidades, vale frisar novamente que a transformação, por si só, não configura evento de realização, mesmo na hipótese excepcional acima citada. $\mathrm{O}$ que se observa é que, por se tratar da passagem de um tipo societário (associação) que, no regime do Código Civil de 1916, estava sujeito a registro em órgão específico (Registro Civil de Pessoas Jurídicas) distinto daquele próprio das sociedades (Junta Comercial), tal ato de transformação demandaria a extinção da associação e a constituição de uma sociedade nova (envolvendo atos de retirada e aporte de capital em uma e outra pessoas jurídicas). Embora, como já visto ${ }^{224}$, os atos de redução e integralização de capital revelem situações de continuidade (o que já seria um motivo para postergar o evento de realização), sua prática pode ser objeto de tributação quando os bens utilizados nessas transações sejam avaliados por valor acima do seu valor de registro original.

Hipótese bastante comum no setor de educação, intensificada principalmente após a instituição do Programa Universidade para Todos (PROUNI) - que previu expressamente tal possibilidade ${ }^{225}$-, o tema já foi objeto de Solução de Consulta proferida pela Cosit da Receita Federal do Brasil ${ }^{226}$.

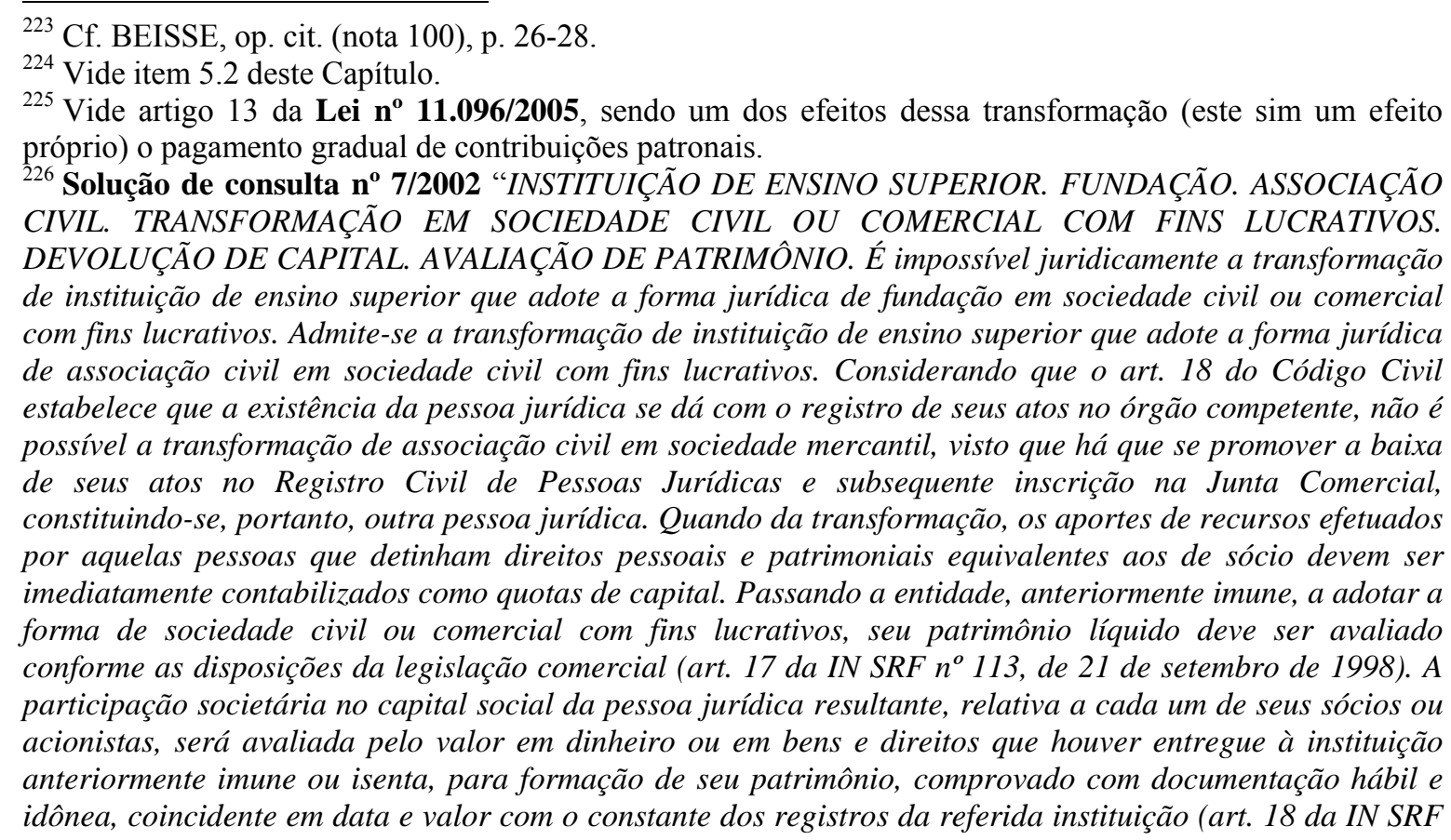


Considerando-se então que se trata, mais propriamente de situação que impele à realização dos atos de retirada e novo aporte de capital, a tributação potencialmente envolvida ocorre se os bens da associação forem devolvidos pelo associado por valor superior ao original ${ }^{227}$. No mais, por se tratar, enfim de hipótese que resvala naquelas hipóteses já discutidas de redução ou integralização de capital, aplicam-se aqui as mesmas considerações lá traçadas. É, contudo, importante mencionar que há quem sustente não ser tributável a hipótese de transformação aqui debatida, com base em argumentos relativos à existência de continuidade da situação patrimonial $^{228}$.

Enfim, embora seja tema conexo com os eventos de reorganização societária supra discutidos, preferiu-se abordar a transformação neste tópico por se tratar de evento em que, ao menos em princípio, não se muda a titularidade do patrimônio, mas tãosomente a forma de sua utilização.

\subsection{Mudança de regime de tributação}

Outras duas hipóteses que se sobressai por deflagrarem a realização da renda em virtude de mera decisão interna de alteração no uso da propriedade própria são relacionadas à mudança de regime de tributação aplicável ao IRPJ, particularmente na passagem do lucro real para o lucro presumido ${ }^{229}$ ou na mudança do regime de caixa para o regime de competência para apuração de tributos do Simples Nacional.

Nesse sentido, o artigo 54 da Lei ${ }^{\circ}$ 9.430/1996 manda tributar imediatamente os valores que tiverem sido diferidos por força de regras específicas aplicáveis ao regime

$n^{o} 113$, de 1998). Na ausência desses documentos comprobatórios, o valor da participação societária será considerado, para todos os efeitos tributários, igual a zero. Não há conflito entre os arts. 17 e 18 da IN SRF $n^{\circ} 113$, de 1998, pois um se refere à avaliação do patrimônio da entidade e o outro à avaliação das quotas de capital na pessoa física dos sócios. A transformação, de per se, não é fato gerador do imposto de renda. Os fatos geradores do tributo ocorrerão, por exemplo, à medida que se verificar a percepção de renda ou proventos de qualquer natureza, tal como definido na legislação tributária, pelos sócios. A pessoa jurídica deve avaliar seu patrimônio e classificar como capital social apenas a importância passível de comprovação com documentação hábil e idônea pelos sócios, sob pena de descumprimento não apenas da legislação tributária, mas também da legislação comercial e societária, em especial a Lei $n^{\circ}$ 6.404, de 1976 . $\underline{A}$ devolução de capital será tributada na pessoa jurídica que a está realizando, quando efetuada a valor de mercado (art. 22 da Lei $n^{\circ}$ 9.249, de 26 de dezembro de 1995). [...]” Grifo nosso.

${ }^{227}$ Neste caso, considerando-se que tais associações normalmente se beneficiavam de isenção, o tema foi tratado expressamente no art. 17 da Lei n ${ }^{\circ}$ 9.532/1997, estabelecendo-se uma tributação de $15 \%$ sobre o ganho potencialmente envolvido na operação.

${ }^{228}$ Cf. MOREIRA JUNIOR, Gilberto de Castro. Aspectos Tributários da Transformação de Associação sem Fins Lucrativos em Sociedade Simples ou Empresária. Disponível em: $<$ http://www.fiscosoft.com.br>. Acesso em 04 dez 2008.

${ }^{229}$ A hipótese também se aplica no caso em que a empresa do lucro real que for tributada com base no lucro arbitrado. 
de lucro real. Com isso, os valores que vinham sendo controlados na parte B do Livro de Apuração do Lucro Real (LALUR) realizam-se logo no primeiro período de apuração em que a pessoa jurídica mudar do regime de lucro real para o de presumido (ou for tributada com base no lucro arbitrado $)^{230}$. De maneira semelhante, a adoção do regime de caixa para fins de cômputo dos tributos devidos no regime de Simples Nacional pode ser alterada de ano a ano. Na passagem deste para o regime de competência, as receitas relativas a negócios já concluídos (mas que ainda não haviam sido recebidas) devem ser consideradas realizadas $^{231}$.

Para o que interessa, basta constatar aqui que a postergação da realização (quanto aos valores diferidos e controlados na parte B do LALUR, ou às receitas ainda não recebidas - respectivamente aos regimes de lucro real e Simples Nacional) pode ser interrompida por um evento específico de realização, que é a mudança de um regime tributário a outro. A justificativa evidente para tanto se assenta no fato de que os valores que haviam sido diferidos decorrem de fatos definitivos, que já geraram receita, de forma que ficariam fora do alcance da tributação se o contribuinte passasse a adotar regime de tributação que se foca preponderantemente nas receitas.

\section{Realização por captura}

Encerrando, enfim, a breve abordagem das diferentes formas de implementação do princípio da realização, mencionam-se rapidamente aqui as situações de realização por captura ${ }^{232}$. Trata-se de uma categoria de eventos de realização definidos fundamentalmente por razões próprias da sistemática tributária. Esses eventos acontecem normalmente em situações nas quais determinados ativos são colocados fora da jurisdição tributária de um determinado país, isto é, passam para uma posição tal que o alcance do imposto de renda sobre as reservas ocultas (ganhos potenciais ou silentes) não mais estará $\operatorname{garantido}^{233}$.

\footnotetext{
${ }^{230} \mathrm{O}$ tema foi regulamentado em maior detalhe pela Instrução Normativa SRF $\mathbf{n}^{\mathbf{0}} \mathbf{9 3 / 1 9 9 7}\left(\operatorname{art.} 36, \S \S 7^{\circ} \mathrm{e}\right.$ seguintes).

${ }^{231}$ Esta hipótese está regulada no art. $4^{\circ}$, inciso II da Resolução CGSN no ${ }^{\circ}$ 38/2008.

${ }^{232} \mathrm{Na}$ Alemanha usa-se a expressão Entstrickung para definir tais situações. Na língua inglesa se usa a expressão deemed realization. Preferimos não nos referir a "realização presumida" para não sugerir que todas as situações de realização por captura constituem presunção passível de afastamento mediante prova. Embora tal comprovação seja possível nos casos de DDL e preços de transferência, em outras ela não é (na maior parte das situações discutidas no item 7 supra, por exemplo).

${ }^{233}$ Cf. BEISSE, op. cit. (nota 100), p. 28-35.
} 
Partindo-se de tal definição, torna-se evidente que a referida categoria de eventos engloba também as situações discutidas no item anterior, pertinentes à mera mudança no uso da propriedade. Embora as hipóteses lá debatidas não envolvam a retirada de ativos da jurisdição tributária do País, a mera realocação de bens de um regime tributário a outro pode também ser considerada hipótese de realização por captura, fundada simplesmente em razões de ordem tributária.

Preferiu-se, todavia, fazer tal separação para que este tópico concentre apenas as situações que envolvem efetiva a perda efetiva de jurisdição sobre bens e, ainda, os casos de realização complementar (DDL e preços de transferência).

Conforme já adiantado ${ }^{234}$, existe uma relação íntima dos eventos de realização por captura, aqui tratados, com o elemento troca no mercado do princípio da realização. Isso porque, o evento que deflagra a realização é uma troca no mercado, isto é, em condições de mercado, preservada a condição de concorrência ${ }^{235}$.

\subsection{Falecimento, emigração ou transferência de bens para o exterior}

Praticamente inexistente no Brasil, a realização pode ocorrer simplesmente em razão do falecimento do titular de um patrimônio ou sua saída definitiva para outro país. Nessas duas situações, as legislações de alguns países inferem que tenha havido a realização dos bens detidos e exige a tributação correspondente ${ }^{236}$. Tal tributação na saída definitiva pode alcançar a mudança de domicílio de uma empresa ${ }^{237}$, bem como a mera transferência de bens de um país a outro, causando inclusive impactos nos arranjos internacionais quanto aos aspectos de dupla tributação ${ }^{238}$.

\footnotetext{
${ }^{234}$ Vide a esse respeito o item 3.3.3 do Capítulo 3.

${ }^{235} \mathrm{Ou}$, no dizeres de Bulhões Pedreira, que "não excluam a situação de competição". Cf. PEDREIRA, Bulhões José Luiz. Finanças e demonstrações financeiras da companhia - Conceitos fundamentais. Rio de Janeiro: Forense, 1989, p. 561.

${ }^{236}$ Focando-se na legislação do Canadá, Brian Arnold comenta diversas regras aplicáveis para a atribuição de rendimentos em caso de morte e a presunção de que, ao sair do país, o contribuinte tenha alienado seus bens a um valor justo de mercado. Cf. ARNOLD, op. cit. (nota 4), p. 196-198.

${ }^{237}$ Cf. ANTCZAK, Gina; WALTON, Kevin. Tolley's corporation tax 2005-06. $41^{\mathrm{a}}$ ed. London: Lexisnexis, 2005, item 58.7, p. 883-884.

${ }^{238}$ Kavelaars reporta que, nos Países Baixos, a emigração é evento de realização e que, embora o ato de imigração não o seja, dever-se-ia assumir que os bens trazidos pelo imigrante foram avaliados com base no seu valor econômico. Todavia, isso pode variar conforme o bem tenha ou não sido trazido, bem como do tratamento que o país de origem da pessoa tenha tributado tal valor e de acordo com qual regra de realização. Cf. KAVELAARS, Peter. Accrual versus realization. In. The notion of income from capital. ESSERS, Peter, RIJKERS, Arie (coord.). Amsterdã: IBFD, 2005, p. 135-136.
} 
No Brasil, nenhuma das duas hipóteses obriga à realização das reservas ocultas (ganhos latentes) relativas ao patrimônio do contribuinte ${ }^{239}$. Todavia, e já adiantando um aspecto pertinente ao tema do tópico seguinte, cabe questionar se, na hipótese de redução de capital de uma empresa, por exemplo, com entrega de ativos a seu sócio controlador estrangeiro, haveria uma típica hipótese de realização por captura. Concorrem para a solução desta questão as regras de preços de transferência, que exigem a atribuição de um valor de mercado para as operações de "venda" de bens efetuada com pessoa vinculada ${ }^{240}$, bem como a regra que permite a devolução de bens ao sócio, em redução de capital, com base no valor contábil original ${ }^{241}$. A primeira regra se baseia na perda de jurisdição (de certa forma assume uma perda de continuidade) como base para forçar a realização a valor de mercado, ao passo que a segunda permite o diferimento da realização (fundada na continuidade). Olhando por esse aspecto do princípio da realização, parece-nos mais coerente sugerir que prevaleça a regra de preços de transferência.

\subsection{DDL e preços de transferência}

Apenas para referência em seu tópico apropriado, reafirma-se aqui a existência de situações denominadas por Beisse como "fatos geradores de realização complementar sui generis", nos quais se verifica que o preço praticado numa relação de troca possa ter sido influenciado por fatores de vinculação ou proximidade entre as pessoas, de forma que uma delas renuncie à apuração de um lucro em favor da outra. Nesses casos, a legislação tributária prevê mecanismos próprios de correção (complementação) do valor de realização ${ }^{242}$. Trata-se exatamente das regras de distribuição disfarçada de lucros ${ }^{243}$ e de preços de transferência ${ }^{244}$.

\footnotetext{
${ }^{239}$ Reguladas pelo 15 da Lei n ${ }^{\circ} 9.250 / 1995$, as situações que causam entrega da declaração final de espólio e de saída definitiva não obrigam à tributação do valor dos bens patrimoniais tal como se vendidos foram.

${ }^{240}$ Cf. art. 19 da Lei $\mathbf{n}^{\mathbf{0}} \mathbf{9 . 4 3 0 / 1 9 9 6 . ~}$

${ }^{241}$ Cf. art. 22 da Lei $\mathbf{n}^{\mathbf{0}} \mathbf{9 . 2 4 9 / 1 9 9 5 .}$

${ }^{242}$ Cf. BEISSE, op. cit. (nota 100), p. 30-31.

${ }^{243}$ Previstas nos arts. 60 e seguintes do Decreto-lei $\mathbf{n}^{\mathbf{0}} \mathbf{1 . 5 9 8} / \mathbf{1 9 7 7}$.

${ }^{244}$ Previstas nos arts. 18 e seguintes da Lei $\mathbf{n}^{\mathbf{0}} \mathbf{9 . 4 3 0 / 1 9 9 6 .}$
} 


\section{CONCLUSÕES}

1. A observação dos fatos econômicos que geram a renda tributável revela que há distintos momentos temporais que poderiam ser eleitos como determinantes da realização (produção, valorização, fechamento de contrato de venda, tradição, conclusão de atividade, efetivo pagamento, consumo etc.), sendo que tanto a evolução histórica quanto os debates teóricos acerca deste tema demonstram que a definição quanto ao momento da realização da renda varia bastante conforme aspectos conjunturais e o desenvolvimento de mecanismos práticos de mensuração. Esse comportamento multiforme do fenômeno realização da renda aproxima-o mais de um princípio do que propriamente de uma regra, uma vez que se verifica haver uma certa diretriz (determinando a tributação da renda somente quando houver segurança da conclusão e permanência dos eventos que a deflagram), que pode ser concretizada em diversos níveis, a serem definidos por regras conforme as condições fáticas e jurídicas próprias do ambiente histórico, cultural e jurídico de que se trata.

2. O princípio da realização encontra-se atrelado ao princípio da capacidade contributiva e, desse modo, busca implementar os valores correspondentes (justiça e igualdade). Identificando-se na renda o elemento indicador da capacidade contributiva por excelência, torna-se imperativo apurar a renda realizada, de modo a impedir que a tributação atinja eventos econômicos incompletos ou incertos.

3. A escolha dos eventos decisivos para a realização da renda nas diferentes atividades econômicas é tarefa que depende dos elementos teóricos fornecidos pelas ciências econômicas e financeiras relativas ao conceito de renda. Avaliando-se metodicamente as noções de renda para identificar os momentos correlatos de realização, verificou-se que a tributação da renda psíquica seria o modelo ideal para otimização do princípio da capacidade contributiva. Ancorada explicitamente na teoria do benefício, esta noção de renda, caso fosse passível de implementação prática, diferenciaria os indivíduos conforme o bem-estar que o Estado lhes confere.

Dentre as proposições baseadas no consumo, destacam-se as que sugerem um modelo praticável de tributação. Sendo a renda identificada com o consumo (uma medida objetiva de bem-estar), seria inapropriado tributar uma pessoa antes do momento em que ela sacasse seus recursos para fins de consumo pessoal. As teorias comentadas no trabalho propõem uma tributação baseada em fluxo de caixa. 
4. São as noções de renda desenvolvidas sob a ótica da produção (renda-produto e renda-acréscimo) as mais difundidas e adotadas no Brasil e no mundo. Para ser genuinamente identificado com o restrito conceito de renda-produto, um rendimento deve derivar de uma atividade econômica, ter a capacidade de se repetir e estar disponível sem prejuízo da própria fonte de renda. Associada à noção de renda-produto, é de particular interesse a teoria da renda separada do capital, pois permite conhecer os atributos de realização e separação em sua expressão original.

A seu turno, o conceito de renda como sinônimo de acréscimo patrimonial líquido (renda-acréscimo), concentra-se no acréscimo de poder econômico de um indivíduo durante um dado período temporal. Todavia, a exigência de monetarização restringe a amplitude pretendida com esse conceito, de forma que se mede o poder econômico de satisfazer desejos e não as satisfações em si. Dificuldades práticas impedem que o evento valorização de ativos seja tomado como evento de realização.

Por fim, os conceitos de renda nacional e renda individual permitem conhecer o princípio da neutralidade para fins de IR e a intributabilidade das transferências patrimoniais.

5. De uma maneira geral, os conceitos de renda partiram de noções bastante subjetivas para chegar, enfim, a definições mais objetivas e praticáveis. As principais restrições à adoção de uma noção ampla de renda (uma que alcance os ganhos oriundos da valorização de ativos) estão relacionadas à indisponibilidade dos recursos (liquidez) e à fragilidade dos métodos de estipulação de valor (dificuldades de valoração). Isso justifica a consagração do evento crítico da transação com terceiros (troca), pois este critério permite superar razoavelmente os problemas de valoração e liquidez.

Todavia, os critérios tradicionais de realização baseados essencialmente em eventos de troca provocam distorções de comportamento econômico (por causa dos efeitos de acumulação e trava), aumento de complexidade, bem como violação da igualdade e alteração da distribuição de riquezas. Para combater tais efeitos maléficos, discute-se atualmente, em determinados fóruns de debate, a viabilidade de modelos de tributação que tomassem a acumulação de valor como critério de realização e resolvessem suficientemente os problemas de valoração e liquidez. 
6. A pesquisa em sistemas de direito comparado, que enfocou o desenvolvimento do princípio da realização da renda na experiência verificada em três países específicos (Alemanha, Estados Unidos da América e Reino Unido).

7. Na Alemanha, verifica-se o debate quanto à origem do princípio da realização da renda, que teria sido adotado em 1884, como decorrência da previsão legal do princípio do custo histórico (que lhe seria idêntico) na legislação comercial, ou se apenas em 1985, quando o Código Comercial editado na época previu-o expressamente. Além disso, observa-se o reconhecimento claro do princípio da congruência com os parâmetros contábeis (ingerência dos princípios de contabilidade geralmente aceitos na apuração de tributos) e a aplicação do princípio do menor valor entre custo histórico ou mercado também para fins tributários.

8. Nos Estados Unidos da América, o princípio da realização da renda teve sua modelagem desenvolvida e impulsionada por alguns dos casos mais influentes da jurisprudência daquele país em matéria tributária. A começar pelo julgamento do caso Eisner v. Macomber, no qual a Suprema Corte entendeu haver um conceito constitucional de renda e lhe atribuiu características bastante restritas, gerando dificuldades para a maleabilidade do conceito de renda tributável. Paulatinamente, porém, a visão da Suprema Corte em matéria de imposto de renda foi se tornando mais flexível. Nos julgamentos dos casos Helvering v. Bruun e Helvering v. Horst, a Suprema Corte passou a afastar o caráter constitucional da realização, considerando-a algo "fundado na conveniência administrativa" e garantindo, com isso, o maior liberdade do Poder Legislativo definir o que seja realização.

9. No sistema normativo do Reino Unido, o princípio da realização da renda também se desenvolveu a partir da jurisprudência, sobretudo em discussões pertinentes à correta determinação do lucro distribuível para fins comerciais, pois a legislação pertinente, ancorada na tradição do laissez-faire, limitava-se a oferecer instruções gerais. Julgamentos importantes assentaram os elementos de troca e cumprimento da obrigação, ínsitos ao princípio da realização da renda, esclarecendo que relevante é o momento em que o contribuinte se torna titular do direito de receber o pagamento. Em períodos mais recentes, intensifica-se a regulamentação comercial em torno do tema, sendo digno de nota o fato de que, desde 2002, introduziram-se naquele país regimes específicos de tributação marcada a mercado. 
10. O exame da evolução histórica do princípio da realização da renda no Brasil demonstra que o critério de realização prevalecente para fins do imposto de renda evoluiu de noções que se restringiam ao evento recebimento (ou entrada de caixa) para a vinculação da renda ao momento temporal em que fora originada. Em meados do século XX inicia-se um movimento de aproximação do Direito Tributário com relação ao Direito Contábil e também de ambos para um regime de competência mais evoluído. Pode-se afirmar que, com a edição do Decreto-lei $n^{0} 1.598 / 1977$, consolidou-se no Brasil o princípio da congruência com os parâmetros contábeis e, portanto, a vinculação do Direito Tributário aos princípios de contabilidade geralmente aceitos, tal como previstos e aplicados na legislação comercial (resguardada a hipótese de previsão contrária da legislação tributária).

11. No nível da Constituição Federal de 1988, enfocou-se o conceito constitucional de renda. Conceito é termo que se toma no sentido de conceito tipológico, um conteúdo ou noção mínima, dotado de um grau relativo de indeterminação. A esse respeito, predomina, na doutrina brasileira, a opinião de que há um conteúdo mínimo atribuível para o conceito de renda. É particularmente em razão do modelo de rígida distribuição de competências tributárias que a identificação desse conteúdo se faz indispensável.

A CF 1988 utiliza conceitos historicamente pressupostos, de modo a ser lícito concluir que os conceitos de renda-produto e renda-acréscimo tal como retratados no CTN agregam-se ao conceito constitucional de renda e lhe atribuem um grau maior de determinação. Não parece possível, todavia, impingir ao conceito constitucional de renda limitação tal que restrinja sua abrangência com relação aos ganhos de detenção (decorrentes da valorização de ativos). Se há restrições à adoção do formato mais amplo do conceito de renda-acréscimo, devem-se explicitar corretamente quais os vetores constitucionais que as embasam. Isso porque, princípios constitucionais como a universalidade e a generalidade demandam a imposição de tributação sobre todas as rendas, de todas as pessoas (e qualquer diferenciação demandaria justificativa clara, com apoio em outro valor ou princípio constitucional).

12. Num contexto mais amplo, o conceito econômico de renda-acréscimo, em conjunto com o princípio da universalidade, gera um vetor que aponta para o máximo de amplitude na formulação da renda tributável e, de outro lado, o princípio da praticabilidade gera um vetor contrário que requer a diminuição do campo de incidência para garantir exequibilidade da norma tributária. Outros afastamentos do ideal de 
tributação abrangente da renda podem ser provocados pela intersecção de princípios relativos à ordem econômica.

13. No que concerne aos princípios que concorrem para a noção constitucional de renda, viu-se na monetarização a exigência de se enfocarem fatos objetivamente observáveis e mais facilmente mensuráveis. Seus limites são ilustrados pelo conceito de renda imputada, presente em nossa legislação no exemplo do valor locativo de imóvel próprio cedido gratuitamente a terceiros. Na apuração periódica nota-se um corte artificial na apuração da renda, que causa problemas como o efeito de acumulação de valor, reclamando medidas de ajustes intertemporais (compensação de prejuízos, dedução de créditos incobráveis etc.). A seu turno, o princípio da renda líquida preconiza a tributação pelo acréscimo patrimonial real, demandando a consideração dos fluxos negativos de patrimônio (mormente dos valores despendidos para a produção de novos ingressos). Os dois últimos princípios, juntos, requerem o emparelhamento de receitas e despesas.

Quanto ao princípio da realização da renda, questiona-se, principalmente, se haveria preferência, no nível constitucional por um evento/critério específico de realização. Diversos autores ressaltam que a CF 1988 requer que a renda esteja disponível, realizada, percebida para, só então, ser tributada. Todavia, isso não parece implicar a pressuposição de algum critério particular para a realização e significa, tão-somente, uma exigência de segurança na apuração da renda tributável, ou melhor, que a tributação deve alcançar situações concretizadas, concluídas e definitivas na órbita do Direito. Até esse ponto se pode falar de um princípio da realização, pois não se fixa a apuração da renda a nenhum critério específico. Os elementos nucleares desse princípio demandam condições de materialidade, objetividade e prudência na apuração da renda tributável, além da necessária verificação de uma troca no mercado.

14. A pesquisa realizada envolveu também o exame dos principais acórdãos do STF quanto à existência e dimensão de um conceito constitucional de renda. As conclusões obtidas foram: (i) o Tribunal Supremo não apresenta nenhuma teorização sistematizada do que seria um conceito constitucional de renda; e (ii) quanto ao princípio da realização, pode-se inferir, com fragilidade, que dois acórdãos antigos tangenciavam o tema ao exigir a ocorrência de uma venda (uma troca no mercado) para fins de tributação.

15. Voltando-se ao exame do CTN, constata-se a evidente adoção de uma noção combinada de renda-produto com renda-acréscimo (incisos I e II do art. 43 do CTN). Mais relevante para a pesquisa foi o segundo conceito que, por ser mais abrangente, permite 
conhecer os parâmetros e limites do princípio da realização da renda. Assim, verificandose ser o acréscimo de que fala o CTN um acréscimo de direitos ao patrimônio, torna-se importante o estudo de conceitos de Direito Civil (patrimônio e direitos com atributo de patrimonialidade). A visão de muitos autores é a de que relevante para a tributação é o acréscimo de algo novo, de uma riqueza nova, oriunda de fonte externa ao patrimônio (excluindo, portanto, os ganhos de detenção).

16. Posto que não contenha uma formulação explícita do princípio da realização, o artigo 43 do CTN, ao falar das disponibilidades jurídica e econômica, oferece indicativos razoáveis para que se identifiquem métodos de apuração da renda. Afastando-se as formulações de posse/propriedade e lícito/ilícito, por serem inconsistentes, concluiu-se que a referência a duas formas de disponibilidades no CTN tem relação com os métodos contábeis (regimes de competência ou caixa) admissíveis para fins de verificação das receitas e despesas componentes da renda tributável. Contudo, apesar de tal direcionamento, não se pode ainda dizer que o princípio da realização da renda foi propriamente definido, pois a expressão regime de competência é também ambígua. Sendo o regime de competência (princípio da competência ou princípio da realização das receitas e confrontação com as despesas) um princípio concernente à apuração do lucro comercial, o que se pode concluir do CTN é que se delegou ao Direito Comercial, ou mais propriamente, ao conjunto dos princípios de contabilidade geralmente aceitos, a tarefa inicial de determinar o critério pertinente de realização.

Ao tempo da Lei $\mathrm{n}^{\mathrm{o}}$ 6.404/1976, formulou-se Anteprojeto que continha definições interessantes dos regimes de competência e caixa, permitindo enxergarem-se o enfoque no evento crítico, a exigência de mensurabilidade, os atributos de emparelhamento e recebimento implícito, bem como uma maior força ao princípio da imparidade. Embora não tenha sido aprovada, a redação desses dispositivos foi, após, reproduzida em diversos Pareceres Normativos, possibilitando afastar muitas das controvérsias relativas a tais regimes.

É na expressão aquisição de disponibilidade que se encontra uma restrição ao princípio da realização, pois, sendo a renda identificada como uma riqueza nova (um influxo, algo que acresce, que entra no patrimônio), afasta-se o evento acréscimo (ou decréscimo) de valor como critério relevante do reconhecimento de receitas e despesas.

17. Ainda no exame do $\mathrm{CTN}$, reafirma-se a ideia de que o conceito de renda tributável está atrelado ao conceito de patrimônio e, portanto, aos ditames de Direito Civil. 
O exame dos artigos 109 e 110 do CTN aponta neste sentido, retirando do legislador tributário a competência para definir patrimônio. É no Direito Civil, portanto, que se deve procurar a regulação quanto ao momento temporal da aquisição dos direitos. A esse respeito, encontram-se reproduzidas, nos artigos 116 e 117 do CTN, algumas noções basilares. Outros elementos são fornecidos pelo Direito Civil.

18. O forte vínculo do Direito Tributário com o subconjunto de princípios e regras do Direito Contábil suscitou o estudo prévio do funcionamento desta relação. O tema ganhou atenção recentemente por causa do movimento de convergência das normas contábeis (Direito Contábil) aos padrões internacionais de contabilidade adotados nos principais mercados de valores mobiliários. A mudança das normas contábeis trará impactos tributários, os quais, entretanto, vem sendo neutralizados por imposição ou opção concedida pela lei tributária.

A produção automática de efeitos tributários em razão da simples alteração das normas contábeis relativas ao reconhecimento de receitas, custos e despesas decorre da adoção do princípio da congruência com os parâmetros contábeis (e da teoria do balanço) pelo Decreto-lei $\mathrm{n}^{\mathrm{o}}$ 1.598/1977. Segundo este princípio, verifica-se uma liderança da Contabilidade em relação ao Direito Tributário. Portanto, aquilo que for admissível na apuração do lucro comercial, deverá sê-lo na apuração do lucro físcal (salvo se, em hipótese excepcional, a legislação tributária expressamente dispuser de modo diverso).

19. Centrando-se nos princípios de contabilidade geralmente aceitos (PCGA), verifica-se a referência a tal conjunto normativo no art. 177 da Lei no 6.404/1976. Pouco estudados no Brasil, discutiu-se se os PCGA seriam regras ou princípios e se seria adequada sua classificação como fontes subsidiárias do Direito que, não estando previstas expressamente em lei, seriam uma forma de costume. Quanto à natureza jurídica, sem afastar-se a origem como costume, notou-se que diferentes elementos dos PCGA estão estruturados em fontes primárias do direito positivo. Quanto ao conteúdo dos PCGA, constatou-se que alguns PCGA se comportam como princípio e não como regra (e.g. princípio da prudência). Outros apresentam características de regras.

20. Estando previsto na legislação comercial, verificou-se, ainda, que princípio da realização, tal como estruturado em seu contexto original, persegue objetivos similares àqueles prevalecentes no âmbito tributário. A contabilidade comercial atende aos seguintes objetivos principais: prestação de contas, apuração do patrimônio e do lucro, proteção dos credores e cálculo dos pagamentos e dividendos. Buscando-se particularmente a 
proteção aos credores, a legislação contábil prima para que retiradas de lucros não afetem o capital social e, enfim, o patrimônio da empresa. Para tanto, os princípios da prudência, realização e imparidade atuam juntos com vistas à preservação do capital. Verifica-se, outrossim, haver metas comuns ao Direito ao Direito Comercial e ao Tributário. Na verdade, ao permitir a adoção do princípio da prudência em um grau mais elevado (inclusive com toques de imparidade), a apuração do lucro comercial (lucro distribuível) demonstra uma visão até mais cautelosa do que aquela provida pela legislação tributária do imposto de renda.

Atenção especial foi dada, ainda, a detalhar as fontes dos PCGA no Brasil, comentando-se brevemente o papel de órgãos como CFC, Ibracon, CVM, CMN, CPC e sua função no contexto atual de convergência das normas contábeis aos IFRS.

21. Três princípios contábeis orientam o princípio da realização num plano superior, quais sejam, os princípios da continuidade, prudência e objetividade. O primeiro implica assumir que a empresa opera por prazo indeterminado e que continuará a produzir riquezas indefinidamente. Tendo em vista a fragilidade da apuração periódica do lucro, exige tal princípio a introdução de ajustes intertemporais. Por estar diretamente atrelado a uma ideia conservadora na mensuração de ativos e passivos, o princípio da prudência conduz à adoção de critérios os mais conservadores possíveis para a concretização do princípio da realização. Assim, para as situações em que o critério do princípio da realização não estiver detalhadamente explicitado na lei, sua concretização depende do grau de prudência adotado. Por fim, o princípio da objetividade impõe confiabilidade às demonstrações financeiras, reclamando a utilização de valores que sejam comprováveis por documentos e critérios objetivos.

22. Pode-se afirmar que o princípio da realização da renda é sinônimo do princípio da competência (regime de competência em sentido amplo), pois ambas as expressões são carregadas de ambigüidade e podem comportar critérios variados de realização (entrada de caixa, fornecimento, fechamento de contrato etc.). Previsto no art. 177 e razoavelmente explicado no 187 da Lei $\mathrm{n}^{\circ}$ 6.404/1976, tal princípio encontra critérios para considerar realizada a receita quando ganha e a despesa quando incorrida. Em linhas gerais, a receita é considerada ganha quando se verificar o nascimento ou a aquisição de um direito patrimonial em conjunto com o poder de dispor desse direito; ou, ainda, quando todo o esforço para obter a receita já tiver sido desenvolvido e for possível aferir seu valor 
de mercado. A despesa é considerada incorrida no momento em que a empresa ficar comprometida, ou, mais propriamente, no momento em que nascer a obrigação de pagar.

Tais orientações gerais fixam parâmetros dentro dos quais o legislador pode atuar para a definição do momento temporal da realização em situações concretas. Nesse particular, observa-se que o princípio da realização pode ser implementado segundo enfoques diferenciados, que enfatizam a causa econômica geradora de renda (enfoque no acréscimo de valor) ou privilegiam momentos específicos da atividade econômica (enfoque no evento crítico). Outra dualidade de orientações pode originar-se da pela busca por um emparelhamento de receitas e despesas correlatas. Assim, pode-se privilegiar o conservadorismo e adotar critérios clássicos de realização - com forte ênfase nos aspectos jurídicos cruciais das relações - (enfoque do conservadorismo), ou privilegiar a alocação temporal correta do lucro aos períodos competentes (enfoque da apuração periódica).

23. Focalizando-se o princípio da realização da renda, verificaram-se elementos que foram reunidos em 4 grupos. A lógica de tal divisão foi a de que, particularmente em relações jurídicas sinalagmáticas, o cumprimento da obrigação ( $1^{\circ}$ elemento) gera direitos que se acrescem ao patrimônio ( $2^{\circ}$ elemento), desde que sua troca no mercado seja certa ( $3^{\circ}$ elemento) e que tais direitos sejam mensuráveis, líquidos e certos ( $4^{\circ}$ elemento).

O elemento cumprimento da obrigação pode ser abordado a partir de uma visão de passagem dos riscos. Assim, demandar que o reconhecimento de receitas e despesas dependa previamente do cumprimento da obrigação pelo fornecedor implica requerer que diversos riscos do negócio já estejam ultrapassados. Notadamente, já se terão ultrapassados os riscos das fases de aquisição e produção e, mais ainda, contratada a venda ( $3^{\circ}$ elemento), restam apenas os riscos de crédito e garantia, pois os riscos de aceitação já estarão potencialmente reduzidos.

Instantaneamente com o cumprimento da obrigação verifica-se normalmente uma mudança na posição patrimonial. Neste momento, gera-se um direito fungível que pode ser reconhecido como um ativo no balanço do fornecedor e ser cedido, emprestado, dado em garantia, ou descontado.

Atendendo a exigências de prudência e objetividade, o elemento de troca ou transação no mercado restou consagrado como evento crítico tradicional para implementação do princípio da realização. Notou-se que a troca no mercado tem o papel precípuo de certificar ou assegurar que o negócio realizado é representativo do valor de 
mercado. Não obstante isso, aponta-se que a realização pode ocorrer antes da troca no mercado. Nesses casos, adotar-se-ia o referencial de uma transação de mercado em sentido amplo, em vez de uma transação de mercado em sentido estrito.

O último grupo de elementos congrega mensurabilidade, liquidez e certeza. A mensurabilidade exige a comprovação (direta ou indireta) do valor econômico atribuído aos bens e serviços transacionados. Liquidez é entendida aqui como a aptidão de outros bens que não o dinheiro serem transformados nele. Por fim, a certeza é também aspecto relevante, pois a incerteza sobre a possibilidade de recebimento é determinante na decisão quanto ao reconhecimento ou não da receita subjacente.

24. Completando a pesquisa relativa aos princípios de contabilidade geralmente aceitos, verificou-se no princípio do custo como base de valor uma forte conexão com o princípio da realização. Esses dois princípios operam em momentos diferentes do processo de geração e reconhecimento da renda, isto é, o princípio do menor valor impera, evitando o reconhecimento das variações positivas de valor, até o momento em que o princípio da realização (mediante o critério legal cabível) apontar para a definitividade da respectiva renda. Por sua vez, o princípio do preço corrente reflete os ganhos gerados dentro do processo produtivo, pois o elemento troca é referendado por uma transação no mercado em sentido amplo. Por fim, enfocou-se o princípio da imparidade, o qual demonstra uma ruptura no princípio da realização (tendo em vista que se registram as perdas prováveis, mesmo que não realizadas), podendo ser visto até mesmo como um contra-princípio ao princípio da realização.

25. Na última parte da pesquisa, apresentou-se uma proposta de classificação dos principais critérios de realização, ilustrando-a com a análise de diferentes situações e propondo, quando cabível, critérios alternativos de realização. Deu-se atenção especial os elementos fundamentais do princípio da realização (cumprimento da obrigação, mudança na posição patrimonial, troca no mercado e o conjunto de requisitos de mensurabilidade, liquidez e certeza) se combinaram em grande parte dos exemplos debatidos.

26. $\mathrm{O}$ ponto de venda encabeça lista dos diferentes momentos de realização da renda. $\mathrm{O}$ ato de tradição é, por excelência, o momento temporal no qual se verifica a aquisição do direito sobre as coisas móveis e, concomitantemente, o direito do vendedor a receber o preço. Após a troca no mercado subsistem apenas os riscos de crédito e garantia. A emissão da fatura ou nota fiscal constitui ato denotador de tradição simbólica. A tradição é afastada como critério de realização quando houver condições diferenciadas de negócio 
(e.g., venda a contento, venda sujeita prova, venda por cooperativa). Nas vendas a prazo e também nas situações em que parte do preço se destina a custear programas de recompensa/fidelização a clientes, há bons fundamentos para postergar a realização de parte da receita.

Na prestação de serviços, impera o critério de "serviço feito, serviço pago". Porém, circunstâncias específicas podem demandar a adoção do critério de realização conforme o tempo ou estágio de conclusão da obra. O estabelecimento de condições, quando genuínas, também pode causar a postergação da realização.

27. O fechamento do contrato, o andamento e o término da produção são exemplos de eventos de realização que se verifica antes do ponto de venda. Produtos com grande potencial de ganho e cuja venda é dificultosa são exemplo das poucas as situações em que o fechamento do contrato responde pela maior parte do negócio. Normalmente faltam os elementos de certeza e cumprimento da obrigação. A falta de mudança da posição patrimonial é questionável, pois direitos expectativos podem ter patrimonialidade. Nos casos da venda de bens imóveis e da venda por documentos a realização acontece no fechamento do contrato.

A realização conforme o andamento da produção foi visualizada nos contratos de construção de longo prazo. Faz-se presente, nesta hipótese, o dilema do enfoque no conservadorismo x enfoque na apuração correta do lucro, isto é, prudência (ponto de venda) x apuração periódica (desempenho do contrato). Por sua vez, reconhecer a renda no término da produção é comum a produtos agrícolas e minerais, porém, inadmitido para fins de tributação no Brasil.

28. A realização após o ponto de venda pode se dar no momento da mensuração do preço ou no recebimento (entrada de caixa). A ausência do elemento mensurabilidade é a característica marcante das situações em que a realização se posterga em função da mensuração do preço (comum quando o preço é pagável na forma de percentuais vinculados a evento futuro incerto). No que concerne ao evento crítico entrada de caixa, trata-se critério que otimiza os elementos certeza e liquidez, mas que só é adotado, no Brasil, em regime de exceção. O recebimento traz consigo questões intrigantes quanto ao momento da realização. Fala-se de recebimento implícito quando o contribuinte tem controle sobre a renda, embora não a tenha recebido efetivamente. A seu turno, diz-se recebimento indireto quando se verifica um pagamento a terceiro por ordem do 
contribuinte. E, por fim, verificou-se que p recebimento (de bens ou serviços) em espécie também deflagra a realização da renda.

29. Nas relações de natureza continuada (contratos de locação, determinadas prestações de serviços, seguro, factoring, leasing e contratos de licença de um modo geral) e nas relações de natureza financeira verifica-se a realização de receitas e despesas conforme a passagem do tempo (pro rata temporis). Razões para o uso desse critério derivam de dificuldades na mensurabilidade ou, no mais das vezes, da própria vinculação natural do fato econômico com a passagem do tempo. Em prestações continuadas de serviços este será o critério determinante, principalmente quando se tratar de relação que envolva um número não especificado de atos (e.g. academia de ginástica). Quando a prestação envolver um número certo e periódico de atos similares, pode ser adotado, alternativa ou conjuntamente, o critério de realização por andamento da produção. Nas relações de natureza financeira, ao analisar tema relativo a factoring, verificou-se que o critério de realização legítimo para uma das partes na transação não necessariamente será o mais apropriado para a outra parte.

30. Reconhece-se que a realização não se completa em situações de continuidade. Dificuldades de mensuração, baixa liquidez e, por conseguinte, uma mudança de posição patrimonial diminuta (ou nula) são razões para a postergação do evento crítico da realização. Operações de troca (ou permuta) de bens em que a coisa seja o objeto predominante do contrato (em vez do seu valor em dinheiro) revelam uma situação de continuidade. De maneira semelhante, diversos atos de reorganização societária não geram a mudança da posição patrimonial do contribuinte. Muitas dessas situações equivalem, em verdade, a uma troca de ativos (justificando a aplicação do mesmo tratamento dado às permutas). Em linhas gerais, verifica-se que, em integralizações ou reduções de capital, o sócio troca ativos por participação societária ou vice-versa. Em muitos atos de incorporação, fusão ou cisão, também se pode observar mera troca de ativos representativos de patrimônio que, em essência, não se altera.

31. A realização da renda pode ser causada por fatores externos à empresa (caso em que o elemento cumprimento da obrigação é amenizado). É o que se verifica na atualização dos valores de ativos e passivos, a qual pode decorrer de aplicação do princípio do menor valor de mercado ou também do princípio do custo corrente - sem efeitos tributários, porém. A tributação das variações monetárias é também exemplo desta modalidade de realização. Tais variações são explicadas também por fatores externos (de 
natureza macroeconômica) e geram ganho meramente potencial. Também se fala de descontinuidade de ativos e passivos como causa para realização da renda, apontando-se os exemplos do registro de perdas de ativos (por obsolescência, perecimento, deterioração etc.) e ganhos por extinção de passivos (por perdão, anistia, ganho de causa etc.).

32. Aspectos exclusivamente tributários podem ser a justificativa para determinados eventos de realização. Assim é que a mera reclassificação de um bem do ativo permanente para o ativo circulante já foi causa de realização apenas para evitar a distorção da correção monetária do balanço. Pode-se falar de evento de realização na transformação de um tipo societário a outro apenas em hipóteses muito específicas de transformação de entidade sem fins lucrativos. E, quanto à mudança de regime de tributação, esta pode ser causa de realização para alcançar valores de receitas diferidas que poderiam ficar de fora da tributação pelo novo regime.

Esses eventos guardam semelhança com eventos de realização por captura, pois a realização no falecimento, emigração ou transferência de bens para o exterior também fundamentam-se em razões exclusivamente tributárias. As regras de distribuição disfarçada de lucros e preços de transferência também se enquadram sob esta categoria. 


\section{BIBLIOGRAFIA}

ABE, Cesar Henrique Shogi. Disponibilidade econômica de renda. In: Revista de direito tributário atual. v. 21. São Paulo: Dialética/IBDT, 2007, p. 191-210.

ALEXY, Robert. Theorie der Grundrechte. Frankfurt am Main: Suhrkamp, 1985.

ALVES, Jones Figueirêdo. Comentários aos arts. 421 a 839. In: SILVA, Regina Beatriz Tavares da (coord.). Código Civil comentado. Coord. até a $5^{\mathrm{a}}$ ed. Ricardo Fiuza, $6^{\mathrm{a}}$ ed. rev. e atual. São Paulo: Saraiva, 2008, p. 375-749.

AMARO, Luciano da Silva. Imposto sobre a renda e proventos de qualquer natureza. In: MARTINS, Ives Gandra da Silva (coord.). $\mathbf{O}$ fato gerador do imposto sobre a renda e proventos de qualquer natureza: Caderno de Pesquisas Tributárias, v. 11. São Paulo: Resenha Tributária, 1986, p. 343-409. . Imposto de renda: regimes jurídicos. In: MARTINS, Ives Gandra da Silva (coord.). Curso de direito tributário, v. 1. Belém: CEJUP/Centro de Extensão Universitária, 1993, p. 310.

ANDREWS, William, A Consumption-Type or Cash Flow Personal Income Tax. In: Harvard Law Review, v. 87, n. 6, abril de 1974, p. 1113-1188. Artigo parcialmente reproduzido em CARON, Paul L. et alli. Federal income tax anthology. Cincinatti: Anderson Publishing Co., 1997, p. 575-582.

. Fairness and the Choice Between a Consumption-Type or an Accretion-

Type Personal Income Tax: A Reply to Professor Warren. In: Harvard Law Review, v. 88, n. 5, mar. 1975, p. 947-958.

ANTCZAK, Gina; WALTON, Kevin. Tolley's corporation tax 2005-06. $41^{\mathrm{a}}$ ed. London: Lexisnexis, 2005.

ARDANT, Gabriel. Histoire de L'impôt. Livre II - Du XVIII ${ }^{\mathrm{e}}$ au $\mathrm{XXI}^{\mathrm{e}}$ siècle. Paris: Fayard, 1971.

ARNOLD, Brian J. Timing and income taxation: the principles of income measurement for tax purposes. Toronto: Canadian Tax Foundation, 1983.

ASCARELLI, Tullio; SOUSA, Rubens Gomes de; ALMEIDA FILHO, João Batista Pereira de. Lucros extraordinários e imposto de renda. São Paulo: Martins, 1944.

AUERBACH, Alan J. Retrospective capital gains taxation. NBER Working Paper No. W2792. Setembro, 1991. Disponível em: $<$ http://ssrn.com/abstract $=447221>$. Acesso em 12 nov. 2008.

ÁVILA, Humberto. O princípio da isonomia em matéria tributária. In: TÔRRES, Heleno Taveira (coord.). Tratado de direito constitucional tributário: Estudos em homenagem a Paulo de Barros Carvalho. São Paulo: Saraiva, 2005, p. 407-410.

. Teoria dos princípios: da definição à aplicação dos princípios jurídicos. $6^{\mathrm{a}}$ ed., rev. e ampl. São Paulo: Malheiros Editores, 2006.

Sistema constitucional tributário: de acordo com a Emenda Constitucional n. 51, de 14.02.2006. $2^{\mathrm{a}}$ ed. rev. e atual. São Paulo: Saraiva, 2006. 
BACKER, Morton; BELL, Philip W. The measurement of business income. Part 1 - The matching concept. In: BACKER, Morton (coord.). Modern accounting theory. New York: Prentice Hall, 1966, p. 68-91.

BALL, Ray; KOTHARI, S. P.; ROBIN, Ashok. The effect of international institutional factors on properties of accounting earnings. University of Rochester Working Paper FR 99-12. Agosto de 1999. Disponível em: <http://ssrn.com/abstract=176989>. Acesso em 18 nov. 2008.

BALEEIRO, Aliomar. O impôsto sobre a renda: Prática, doutrina e legislação. Salvador: Livraria Editora Baiâna, 1938.

Direito tributário brasileiro. DERZI, Misabel Abreu Machado (Atualizadora). 11 ${ }^{\mathrm{a}}$ ed. Rio de Janeiro: Forense, 2001.

BALERA, Wagner. Imposto sobre a renda e proventos de qualquer natureza. In: MARTINS, Ives Gandra da Silva (coord.). $\mathbf{O}$ fato gerador do imposto sobre a renda e proventos de qualquer natureza: Caderno de Pesquisas Tributárias, v. 11. São Paulo: Resenha Tributária, 1986, p. 453-499.

BASTOS, Celso Ribeiro. Curso de direito constitucional. $16^{\mathrm{a}}$ ed., ampl. e atual. São Paulo: Saraiva: 1995.

BATAlHA, Wilson de Souza Campos. A Lei das S.A. e o imposto de renda. Rio de Janeiro: Forense, 1978.

BECKER, Alfredo Augusto. Teoria geral do direito tributário. $3^{\text {a }}$ ed. São Paulo: Lejus, 2002.

BEISSE, Heinrich. Gewinnrealisierung - Ein systematischer Überblick über Rechtsgrundlagen, Grundtatbestände und grundsätzliche Streitfragen. In: RUPPE, Hans Georg (coord.). Gewinnrealisierung im Steuerrecht: Theorie und Praxis der Gewinnverwirklichung durch Umsatzakt und durch Steuerentstrichung sowie des Besteuerungsafuschubs. Köln: Otto Schmidt, 1981, p. 13-43.

BELSUNCE, Horacio A. Garcia. El concepto de rédito: En la doctrina y en el derecho tributário. Buenos Aires: Depalma, 1967.

BIANCO, João Francisco. Imposto de renda da pessoa jurídica: uma visão geral. In: SANTI, Eurico Marcos Diniz de; ZILVETI, Fernando Aurelio (coords.) Tributação das Empresas. São Paulo: Quartier Latin, 2006, p. 317-332.

BIFANO, Elidie Palma. Aspectos contábeis da Lei 11.638/07: Reflexos legais. In: ROCHA, Sérgio André (coord.). Direito tributário, societário e a reforma da Lei das S/A. São Paulo: Quartier Latin, 2008, p. 43-74.

BITTKER, Boris I. A “comprehensive tax base" as a goal of income tax reform. In: Harvard Law Review, v. 80, n. 5, mar.-1967, p. 925-985.

BLAKE, John; AMAT, Oriol; FORTES, Hilary. The relationship between tax regulations and financial accounting: a comparison of Germany, Spain and the United Kingdom. Economics Working Paper Series No. 46: Universitat Pompeu Fabra, Outubro 
de 2003, p. 2-5. Disponível em: <http://www.econ.upf.edu/docs/papers/downloads /46.pdf $>$. Acesso em 18 nov. 2008.

BOUCHER, Hercules. Estudos de impôsto de renda e contabilidade: tributação das pessoas jurídicas. São Paulo: Saraiva, 1950.

BOZZA, Fábio Piovesan. Divergências na contabilização e regime de tributação dos contratos de empreitada de longo prazo. In: Revista dialética de direito tributário. v. 156. São Paulo: Dialética, set. 2008, p. 44-61.

BRADFORD, David F. Fixing capital gains: Symmetry, consistency and correctness in the taxation of financial instruments. NBER Working Paper No. W5754. Set. 1996. Disponível em: $<\mathrm{http}: / /$ ssrn.com/abstract=4458>. Acesso em 12 nov. 2008.

BRAGG, Steven M. Revenue recognition: rules and scenarios. New Jersey: John Wiley \& Sons, 2007.

CANTO, Gilberto de Ulhôa; MUNIZ, Ian de Porto Alegre; SOUZA, Antonio Carlos Garcia de. Imposto sobre a renda e proventos de qualquer natureza. In: MARTINS, Ives Gandra da Silva (coord.). O fato gerador do imposto sobre a renda e proventos de qualquer natureza: Caderno de Pesquisas Tributárias, v. 11. São Paulo: Resenha Tributária, 1986, p. 1-44.

CANTO, Gilberto de Ulhôa. A aquisição de disponibilidade e o acréscimo patrimonial no imposto sobre a renda. In: MARTINS, Ives Gandra da Silva (coord.). Imposto de renda: conceitos, princípios e comentários (em memória de Henry Tilbery). $2^{a}$ ed. São Paulo: Atlas, 1996, p. 34-40.

CARNEIRO, Erymá. O balanço fiscal no direito e na contabilidade. Rio de Janeiro: S.N., 1950.

CARON, Paul L. Introduction: Tax Archeology. In. Tax Stories - An in-depth look at ten leading federal income tax cases. CARON, Paul L. New York: Foundation Press, 2003, p. $1-14$.

CARRAZZA, Roque Antonio. Imposto sobre a renda: perfil constitucional e temas específicos. $2^{\text {a }}$ ed., rev., ampl. e atualizada. São Paulo: Malheiros, 2006.

CARSBERG, Sir Bryan; NOKE, Christopher. The reporting of profits and the concept of realisation. London: Research Board ICAEW, 1989.

CARVALHO, Fábio Junqueira de; MURGEL, Maria Inês. A nova Lei das S/As e seus possíveis reflexos na tributação pelo imposto sobre a renda. In: ROCHA, Sérgio André (coord.). Direito tributário, societário e a reforma da Lei das S/A. São Paulo: Quartier Latin, 2008, p. 103-119.

CARVALHO, Paulo de Barros. Curso de direito tributário. $19^{\mathrm{a}}$ ed., rev. São Paulo: Saraiva, 2007.

CARVAlHOSA, Modesto. Imposto de renda. Conceituação no Sistema Tributário da Carta Constitucional. In: Revista de direito público, nº 1, jul-set. 1967, p. 188-196. 
CATELLI, Armando (coord.). Controladoria: uma abordagem da gestão econômica GECON. São Paulo: Atlas, 1999.

CHORVAT, Terrence R. Perception and income: The behavioral economics of the realization doctrine. George Mason Law \& Economics Research Paper No. 03-23, 2003, p. 4. Disponível em: <http://ssrn.com/abstract=407460>. Acesso em 12 nov. 2008.

CLEMM, Hermann. Grundprobleme der Gewinn- und Verlustrealisation bei langfristiger Auftragsfertigung und langfristiger Vermietung. In: RUPPE, Hans Georg (coord.). Gewinnrealisierung im Steuerrecht: Theorie und Praxis der Gewinnverwirklichung durch Umsatzakt und durch Steuerentstrichung sowie des Besteuerungsafuschubs. Köln: Otto Schmidt, 1981, p. 117-135.

COMPARATO, Fábio Konder. O irredentismo da "nova contabilidade" e as operações de "leasing". In: Revista de direito mercantil: industrial, econômico e financeiro. Nova Série, ano XXVI, nº 68. São Paulo: Revista dos Tribunais, out-dez. 1987, p. 50-62.

CORREA, Walter Barbosa. Subsídios para o estudo da história legislativa do imposto de renda no Brasil. In: MARTINS, Ives Gandra da Silva (coord.). Imposto de renda: Conceitos, princípios e comentários (em memória de Henry Tilbery). $2^{\mathrm{a}}$ ed. São Paulo: Atlas, 1996, p. 204-215.

COSTA, Alcides Jorge. Imposto sobre a renda. A aquisição da disponibilidade jurídica ou econômica como seu fato gerador. Limite de sua incidência. (Relatório das XI Jornadas do Instituto Latino Americano de Derecho Tributário). In: Revista de Direito Tributário, ano 11, no 40. São Paulo: Revista dos Tribunais, abr-jun. 1987, p. 103-107.

. Conceito de renda tributável. In: MARTINS, Ives Gandra da Silva (coord.).

Imposto de renda - Conceitos, princípios e comentários (em memória de Henry Tilbery). $2^{a}$ ed. São Paulo: Atlas, 1996, p. 24-33.

COSTA, Regina Helena. Praticabilidade e justiça tributária: exeqüibilidade de lei tributária e direitos do contribuinte. São Paulo: Malheiros, 2007.

CVM, Estudo sobre as diferenças e similaridades entre as Normas Internacionais de Contabilidade - IFRS e as Normas e Práticas Contábeis Brasileiras - IAS 18 Reconhecimento de receitas. 2008, Resumo Executivo, item 1.G. Disponível em $<\mathrm{http}$ //www.cvm.gov.br>. Acesso em 01 dez. 2008.

DAUBER, Desiree. Das Realisationsprinzip als Grundprinzip der steuerrechtlichen Gewinnermittlung. Frankfurt am Main: Peter Lang, 2003.

DAVIDSON, Sidney. The realization concept. In: BACKER, Morton (coord.). Modern accounting theory. New Jersey: Prentice-Hall, 1966, p. 99-116.

DAVIES, Mike; PATERSON, Ron; WILSON, Allister. UK GAAP: generally accepted accounting practice in the United Kingdom. $6^{\text {a }}$ ed. London: Tolley, 1999.

DAUBER, Desiree. Das Realisationsprinzip als Grundprinzip der steuerrechtlichen Gewinnermittlung. Frankfurt am Main: Peter Lang, 2003. 
DERZI, Misabel Abreu Machado. Princípio da praticabilidade do direito tributário (segurança jurídica e tributação). In: Revista de Direito Tributário, ano 13, n ${ }^{\circ} 47$. São Paulo: Revista dos Tribunais, jan-mar. 1989, p. 166-179.

A praticidade, a substituição tributária e o direito fundamental à justiça individual. In: FISCHER, Octavio Campos (coord.). Tributos e direitos fundamentais. São Paulo: Dialética, 2004, p. 261-277.

Justiça prospectiva no imposto sobre a renda. In: TÔRRES, Heleno Taveira

(coord.). Direito tributário internacional aplicado, v. IV. São Paulo: Quartier Latin, 2007, p. 39-78.

DODGE, Joseph M. The Story of Glenshaw Glass: Towards a Modern Concept of Gross Income. In. Tax Stories: An in-depth look at ten leading federal income tax cases. CARON, Paul L. New York: Foundation Press, 2003, p. 15-51.

DWORKIN, Ronald M. Is law a system of rules? In: DWORKIN, Ronald M. The philosophy of law. Oxford: Oxford University Press, 1977, p. 38-65.

. Taking rights seriously. Cambridge, MA: 1978.

FERRAZ, Roberto. Igualdade na tributação - Qual o critério que legitima discriminações em matéria fiscal? In: FERRAZ, Roberto (coord.). Princípios e limites da tributação. São Paulo: Quartier Latin, 2005, p. 447-523.

FLEMING, J. Clifton. Replacing the Federal Income Tax with a Postpaid Consumption Tax: Preliminary Thoughts Regarding a Government Matching Program for Wealthy Investors and a New Tax Policy Lens. In: Southern Methodist University Law Review, v. 59, 2006. Disponível em: <http://ssrn.com/abstract=940699>. Acesso em 18 nov. 2008.

FREEDMAN, Judith. Tretament of capital gains and losses. In. ESSERS, Peter; RIJKERS, Arie. The notion of income from capital. Amsterdam: IBFD, 2005, p. 191-215.

GELHAUSEN, Hans Friedrich. Das Realisationsprinzip im Handels- und im Steuerbilanzrecht. Frankfurt am Main: Peter Lang, 1985.

GONÇALEZ, Antonio Manoel. [Respostas às questões do] XI Simpósio Nacional de Direito Tributário. In: MARTINS, Ives Gandra da Silva (coord.). O fato gerador do imposto sobre a renda e proventos de qualquer natureza: Caderno de Pesquisas Tributárias, v. 11. São Paulo: Resenha Tributária, 1986, p. 45-74.

GONÇALVES, José Artur Lima. Imposto sobre a renda: pressupostos constitucionais. $2^{\text {a }}$ tir. São Paulo: Malheiros, 2002.

GLAUSER, Pierre-Marie. IFRS et droit fiscal: Les normes true and fair et le principe de déterminance en droit fiscal suisse actuel. In: Archives de droit fiscal suisse, v. 74, 2006.

GRAU, Eros Roberto. Ensaio e discurso sobre a interpretação/aplicação do direito. $3^{\text {a }}$ ed. São Paulo: Malheiros Editores, 2005.

GRECO, Marco Aurelio. Cofins na Lei 9.718/98: variações cambiais e regime de alíquota acrescida. In: Revista dialética de direito tributário. v. 50. São Paulo: Dialética, nov. 1999, p. 110-151. 
GROSSFELD, Bernhard; BRYCE, James D. A brief comparative history of the origins of the income tax in Great Britain, Germany and the United States. In: The American Journal of Tax Policy, v. 2. American College of Tax Counsel, 1983, p. 211-251.

GUIMARÃES, Carlos da Rocha. O fato gerador do imposto de renda. In: MARTINS, Ives Gandra da Silva (coord.). O fato gerador do imposto sobre a renda e proventos de qualquer natureza: Caderno de Pesquisas Tributárias, v. 11. São Paulo: Resenha Tributária, 1986, p. 75-156.

GUIMARÃES, Ylves José de Miranda. Imposto sobre a renda e proventos de qualquer natureza. In: MARTINS, Ives Gandra da Silva (coord.). $O$ fato gerador do imposto sobre a renda e proventos de qualquer natureza: Caderno de Pesquisas Tributárias, v. 11. São Paulo: Resenha Tributária, 1986, p. 549-564.

FELIX, Günther. Einkommensteuer (verbete). In: STRICKRODT, Georg. Handwörterbuch des Steuerrechts: unter Einschluss von betriebswissenschaftl. Steuerlehre, Finanzrecht, Finanzwiss, $2^{\text {a }}$ ed. München und Bonn: C.H. Beck'sche Verlagsbuchhandlung, 1981, p. 394-402.

HENDRIKSEN, Eldon S.; VAN BREDA, Michael F. Teoria da Contabilidade. $5^{\text {a }}$ ed. Trad. Antonio Zoratto Sanvincente. São Paulo: Atlas, 2007.

HM-Treasury; Inland Revenue. Reform of corporation tax: A consultation document. Agosto de 2002. Disponível em: <http://www.hmrc.gov.uk/consult_new/ taxreform_final.pdf $>$. Acesso em 14 nov. 2008.

HODGKINSON, Robert. Revenue and expense recognition. In: VATTIPALLI, Kashyap; MUDRULA, E (coord.). Revenue Recognition in Financial Statements - An introduction. Hyderabad (India): ICFAI University Press, 2005, p. 11-30.

HOLMES, Kevin. The concept of income: A multi-disciplinary analysis. Netherlands: IBFD, 2001.

IUDÍCIBUS, Sérgio de. Teoria da contabilidade. $7^{\mathrm{a}}$ ed. São Paulo: Atlas, 2004.

IUDÍCIBUS, Sérgio de; MARTINS, Eliseu; GELBCKE; Ernesto Rubens. Manual de contabilidade das sociedades por ações: aplicável às demais sociedades. $7^{\mathrm{a}}$ ed. São Paulo: Atlas, 2007.

JOST, Paul. Der Gewinnbegriff im Handels- und Steuerrecht: zugleich ein Beitrag zur Lehre von der Handels- und Steuerbilanz. Würzburg: Richard Mayr, 1940.

KAVELAARS, Peter. Accrual versus realization. In: ESSERS, Peter; RIJKERS, Arie. The notion of income from capital. Amsterdam: IBFD, 2005, p. 128-146.

KORNHAUSER, Marjorie E. The Story of Macomber: the continuing legacy of realization. In: CARON, Paul L. Tax Stories: an in-depth look at ten leading federal income tax cases. New York: Foundation Press, 2003, p. 53-96.

KRUSE, Heinrich Wilhelm. Grundsätze ordnungsmässiger Buchführung: Rechtsnatur und Bestimmung. Köln: Otto Schmidt, 1978. 
LANG, Joachim. Die Bemessungsgrundlage der Einkommensteuer: Rechtssystematische Grundlagen steuerlicher Leistungsfähigkeit im deustschen Einkommensteuerrecht. Köln: Otto Schmidt, 1988.

. The influence of tax principles on the taxation of income from capital. In:

ESSERS, Peter; RIJKERS, Arie. The notion of income from capital. Amsterdam: IBFD, 2005, p. 3-31.

LEFFSON, Ulrich. Die Grundsätze ordnungsmässiger Buchführung. $7^{\mathrm{a}}$, rev. e ampl. Düsseldorf: IDW, 1987.

LEMKE, Gisele. Imposto de renda: os conceitos de renda e de disponibilidade econômica e jurídica. São Paulo: Dialética, 1998.

LEONETTI, $\mathbf{O}$ imposto sobre a renda como instrumento de justiça social no Brasil. Barueri: Manole, 2003.

LONGO, Carlos Alberto. Em defesa de um imposto de renda abrangente. São Paulo: FIPE-Pioneira, 1984.

LÜDERS, Jürgen. Der Zeitpunkt der Gewinnrealisierung im Handels- und Steuerbilanzrecht. Köln: Otto Schmidt, 1987.

LUIK, Hans. Grundprobleme des Realisationszeitpunktes, dargestellt an den Fällen der Lieferung mit Rückgaberecht, des Umtauschgeschäftes und der Liquidation. In: RUPPE, Hans Georg (coord.). Gewinnrealisierung im Steuerrecht: Theorie und Praxis der Gewinnverwirklichung durch Umsatzakt und durch Steuerentstrichung sowie des Besteuerungsafuschubs. Köln: Otto Schmidt, 1981, p. 97-115.

MACHADO, Brandão. Imposto de renda. Ganhos de capital. Promessa de venda de ações. In: Revista de direito tributário atual, v. 11/12. São Paulo: Resenha Tributária/IBDT, 1992, p. 3181-3220.

Breve exame crítico do art. 43 do CTN. In: MARTINS, Ives Gandra da Silva (coord.). Imposto de renda: Conceitos, princípios e comentários (em memória de Henry Tilbery). $2^{\mathrm{a}}$ ed. São Paulo: Atlas, 1996, p. 95-108.

MACHADO, Hugo de Brito. Imposto sobre a renda e proventos de qualquer natureza. In: MARTINS, Ives Gandra da Silva (coord.). $\mathbf{O}$ fato gerador do imposto sobre a renda e proventos de qualquer natureza: Caderno de Pesquisas Tributárias, v. 11. São Paulo: Resenha Tributária, 1986, p. 245-259.

MARTINEZ, Atonio Lopo. A Linguagem Contábil no Direito Tributário. 2002. Dissertação de Mestrado apresentada ao Programa de Pós-Graduação em Direito do Estado da Pontifícia Universidade Católica de São Paulo, São Paulo, 2002.

MARTINS, Eliseu. Atrocidades contábeis no novo Código Civil ( $1^{\text {a }}$ parte). Boletim Temática Contábil e Balanços, $n^{\circ}$ 40. São Paulo: IOB, 2002. Atrocidades contábeis no novo Código Civil ( $2^{\mathrm{a}}$ e última parte). Boletim Temática Contábil e Balanços, nº 41. São Paulo: IOB, 2002.

MARTINS, Ives Gandra da Silva. Imposto sobre a renda e proventos de qualquer natureza. In: MARTINS, Ives Gandra da Silva (coord.). O fato gerador do imposto sobre a renda 
e proventos de qualquer natureza: Caderno de Pesquisas Tributárias, v. 11. São Paulo: Resenha Tributária, 1986, p. 261-291.

MARTINS, Natanael. A reforma da lei das sociedades anônimas: Lei 11.638/2007 e seus impactos na área tributária. In: ROCHA, Sérgio André (coord.). Direito tributário, societário e a reforma da Lei das S/A. São Paulo: Quartier Latin, 2008, p. 341-377.

MCCAFFERY, Edward J. A new understanding of tax. In: Michigan Law Review, v. 103, 2005, p. 807-938. Disponível em: <http://ssrn.com/abstract=705383>. Acesso em 25 abr. 2008.

MELLO, Gustavo Miguez de. Imposto sobre a renda e proventos de qualquer natureza. In: MARTINS, Ives Gandra da Silva (coord.). $\mathbf{O}$ fato gerador do imposto sobre a renda e proventos de qualquer natureza: Caderno de Pesquisas Tributárias, v. 11. São Paulo: Resenha Tributária, 1986, p. 157-244.

MELLO, José Eduardo Soares de. Imposto sobre a renda e proventos de qualquer natureza. In: MARTINS, Ives Gandra da Silva (coord.). $O$ fato gerador do imposto sobre a renda e proventos de qualquer natureza: Caderno de Pesquisas Tributárias, v. 11. São Paulo: Resenha Tributária, 1986, p. 293-342.

MELLO, Waldir Silveira. Imposto de renda e proventos de qualquer natureza. In: MARTINS, Ives Gandra da Silva (coord.). $O$ fato gerador do imposto sobre a renda e proventos de qualquer natureza: Caderno de Pesquisas Tributárias, v. 11. São Paulo: Resenha Tributária, 1986, p. 501-548.

MINISTÉRIO DA FAZENDA. Trabalhos da Comissão Especial do Código Tributário Nacional. Rio de Janeiro: Ministério da Fazenda, 1954.

MIRANDA, Pontes de. Tratado de direito privado, tomo V, Campinas: Bookseller, 2000 .

MOREIRA JUNIOR, Gilberto de Castro. Aspectos Tributários da Transformação de Associação sem Fins Lucrativos em Sociedade Simples ou Empresária. Disponível em: $<$ http://www.fiscosoft.com.br>. Acesso em $04 \mathrm{dez} 2008$.

IRPF, IRPJ e Permuta de Participações Societárias. Disponível em:

$<$ http://www.fiscosoft.com.br>. Acesso em 04 dez 2008.

MOSQUERA, Roberto Quiroga. Renda e proventos de qualquer natureza - O imposto e o conceito constitucional. São Paulo: Dialética, 1996.

MOXTER, Adolf. Das Realisations prinzip: 1884 und heute. In: Betriebs-Berater, Caderno 28. Frankfurt am Main: Recht und Wirtschaft, 1984, p. 1780-1786.

MULLOCK Philip. The Constitutional Aspects of Realization. In: University of Pittsburgh Law Review, v. 31, no 4, 1970.

MUSGRAVE, R. A. In defense of an income concept. In: Harvard Law Review, v. 81, n. 1, nov.-1967, p. 44-62. 
MUTÉN, Leif. Treatment of capital gains and losses - a response. In. ESSERS, Peter; RIJKERS, Arie. The notion of income from capital. Amsterdam: IBFD, 2005, p. $217-$ 221.

NAKAO, Sílvio Hiroshi. Um Modelo de Tributação da Renda por Fluxos de Caixa Realizados. 2003. Tese de doutorado apresentada ao Departamento de Contabilidade e Atuária da Faculdade de Economia, Administração e Contabilidade da Universidade de São Paulo, São Paulo, 2003.

NEUMARK, Fritz. Theorie und Praxis der modernen Einkommenbesteuerung. Bern: A. Francke, 1947.

NOBES, Christopher. A conceptual framework for the taxable income of businesses, and how to apply it under IFRS. London: Certified Accountants Educacional Trust / ACCA, 2003. Disponível em: <http://www.accaglobal.com/documents/tech_tp_n03.pdf $>$. Acesso em 18 nov. 2008.

NOBES, Christopher; OLIVERAS, Ester; PUIG, Xavier. The changing relationship between tax and financial reporting in Spain. Economics and Business Working Paper No. 782: Universitat Pompeu Fabra, Outubro de 2004. Disponível em: < http://ssrn.com/abstract=848667>. Acesso em 18 nov. 2008.

NOGUEIRA, Ruy Barbosa. Curso de direito tributário brasileiro. $15^{\mathrm{a}}$ ed., atualizada. São Paulo: Saraiva, 1999.

OLIVEIRA, Ricardo Mariz de. Fundamentos do imposto de renda. São Paulo: Revista dos Tribunais, 1977.

Imposto sobre a renda e proventos de qualquer natureza. In: MARTINS,

Ives Gandra da Silva (coord.). $\mathbf{O}$ fato gerador do imposto sobre a renda e proventos de qualquer natureza: Caderno de Pesquisas Tributárias, v. 11. São Paulo: Resenha Tributária, 1986, p. 411-452.

. Princípios fundamentais do imposto de renda. In: SCHOUERI, Luís Eduardo; ZILVETI, Fernando Aurelio (coords.). Direito tributário: estudos em homenagem a Brandão Machado. São Paulo: Dialética, 1998, p. 197-227.

. Fundamentos do imposto de renda. São Paulo: Quartier Latin, 2008.

PEDREIRA, José Luiz Bulhões. Imposto sobre a renda: pessoas jurídicas. Rio de Janeiro: Justec, 1979.

. Finanças e demonstrações financeiras da companhia: conceitos fundamentais. Rio de Janeiro: Forense, 1989.

PFALTZGRAFF, Rogério. Organização do balanço. Rio de Janeiro: Edições Minerva, 1958.

POSIN, Daniel Q.; TOBIN, Donald T. Principles of federal income taxation of individuals. $7^{\text {a }}$ St. Paul: West Publishing Co., 2005.

PRICEWATERHOUSECOOPERS. Revenue Recognition - Principles in Search of Guidance. In: VATTIPALLI, Kashyap; MUDRULA, E (coord.). Revenue Recognition in Financial Statements: an introduction. Hyderabad (India): ICFAI University Press, 2005, p. $68-80$. 
QUEIROZ, Mary Elbe. Imposto sobre a renda e proventos de qualquer natureza: princípios, conceitos, regra-matriz de incidência, mínimo existencial, retenção na fonte, renda transnacional, lançamento, apreciações críticas. Barueri: Manole, 2004.

RÉGIS, Mário Luis Delgado. Comentários aos arts. 233 a 420. In: SILVA, Regina Beatriz Tavares da (coord.). Código Civil comentado. Coord. até a $5^{\mathrm{a}}$ Ricardo Fiuza, $6^{\mathrm{a}}$ rev. e atual. São Paulo: Saraiva, 2008, p. 205-375.

REICH, Markus. Die Realisation stiller Reserven im Bilanzsteuerrecht. Zürich: Schulthess, 1983.

RENCK, Renato Romeu. Imposto de renda da pessoa jurídica: critérios constitucionais de apuração da base de cálculo: uma proposta de interpretação sistemática do Direito. Porto Alegre: Livraria do Advogado, 2001.

Paradigmas de racionalidade e as decisões do STF nas questões relativas à base de cálculo do imposto de renda: pessoa jurídica. 2006. Tese de doutorado apresentada ao Programa de Pós-Graduação em Direito do Estado da Pontifícia Universidade Católica de São Paulo, São Paulo, 2006.

REZENDE, Tito. Manual prático do imposto de renda. Vol. IX da Biblioteca da Revista Fiscal e de Legislação da Fazenda, 2ª Rio de Janeiro: Sfreddo \& Gravina, 1939.

ROMEU, Alceu de Castro; MENDES, Celso; CARNEIRO, Paulo Baltazar; PISCITELLI, Roberto Bocaccio. Contabilidade tributária: doutrina e direito contábeis. São Paulo: ESAF/Atlas, 1985.

SAKAKIHARA, Zuudi. Comentários aos arts. 43 a 45. In: Código Tributário Nacional comentado: doutrina e jurisprudência, artigo por artigo, inclusive ICMS (LC 87/1996 e LC 114/2002) e ISS (LC 116/2003). 2a rev., atual. e ampl. São Paulo: Revista dos Tribunais, 2004, p. 150-167.

SCHACHAR, Avishai, From Income to Consumption Tax: Criteria for Rules of Transition. In: Harvard Law Review, v. 97, n. 7, maio de 1975, p. 1581-1609.

SCHANZ, Georg von. Der Einkommensbegriff und dir Einkommensteuergesetze. In: Finanzarchiv, série antiga, v. 13/1. Stuttgart, 1896.

SCHMIDLIN, Lorenz. Das Prinzip der Periodizität in der Gewinnbesteuerung. Zürich und St. Gallen: Polygraphischer Verlag, 1956.

SCHMÖLDERS, Günter. Geschichte der Besteuerung (verbete). In: STRICKRODT, Georg. Handwörterbuch des Steuerrechts: unter Einschluss von betriebswissenschaftl. Steuerlehre, Finanzrecht, Finanzwiss, $2^{\mathrm{a}}$ München und Bonn: C.H. Beck'sche Verlagsbuchhandlung, 1981, p. 617-626.

SCHOUERI, Luís Eduardo. Normas tributárias indutoras e intervenção econômica. Rio de Janeiro: Forense, 2005.

SCHRÖER, Thomas. Das Realisationsprinzip in Deutschland und Grossbritannien: eine systematische Untersuchung und ihre Aufwendung auf langfristige Auftragsfertigung und Währungsrechnung. Frankfurt am Main: Peter Lang, 1998. 
SELIGMAN, Edwin. R. A. Essays in taxation, 10a New York: Augustus M. Kelley, 1969; Are stock dividends income? In: Studies in public finance. New York: Augustus M. Kelley, 1969 (reimpressão), p. 99-123.

. The income tax: A study of the history, theory, and practice of income taxation at home and abroad. $2^{\mathrm{a}}$, rev. e ampl. (reimpressão). New York: Augustus M. Kelley, 1970.

SHAVIRO, Daniel. Replacing the Income Tax With a Progressive Consumption Tax, NYU Law School, Public Law Research Paper No. 70; e NYU, Ctr for Law and Business Research Paper No. 03-18, setembro de 2003. Disponível em: $<$ http://ssrn.com/abstract=444221>. Acesso em 18 nov. 2008.

SILVA, De Plácido e. Normas jurídicas na contabilidade. $2^{\text {a }}$ Curitiba: Guaíra, 1950.

SILVEIRA, Ricardo Maitto. O princípio da realização da renda no direito tributário brasileiro. In: Revista de direito tributário atual. v. 21. São Paulo: Dialética/IBDT, 2007, p. 317-344.

SIMONS, Henry C.. Personal income taxation: the definition of income as a problem of fiscal policy. Chicago: University of Chicago Press, 1938.

SMITH, Adam. An inquiry into the nature and causes of the wealth of nations. New York: The Modern Library, 2000.

SOUSA, Rubens Gomes de. A evolução do conceito de rendimento tributável. In: Revista de direito público, ano IV, v. 14. São Paulo: Revista dos Tribunais, out-dez, 1970, p. 339346.

. IMPOSTO DE RENDA: Despesas não dedutíveis pelas pessoas jurídicas [...]. In: Pareceres - 1: imposto de renda. São Paulo: Resenha Tributária, 1975, p. 59-95. . IMPOSTO DE RENDA: Ações gratuitas provenientes da capitalização [...].

In: Pareceres - 1: Imposto de renda. São Paulo: Resenha Tributária, 1975, p. 97-131.

TAVARES, Assis. Do balanço real ao balanço fiscal. 2ª Lisboa: Livraria Clássica, 1978.

THURONYI, Victor. The concept of income. In: Tax Law Review 45 (1990). Artigo parcialmente reproduzido em CARON, Paul L. et alli. Federal income tax anthology. Cincinatti: Anderson Publishing Co., 1997, p. 107-111.

TILBERY, Henry. A tributação dos ganhos de capital. São Paulo: Resenha Tributária/IBDT, 1977.

. O novo imposto de renda do Brasil: Comentário à Lei $\mathrm{n}^{\mathrm{o}} 7.713 / 88$, ajustado aos novos métodos de atualização monetária. São Paulo: IOB/IBDT, 1989.

TIPKE, Klaus. Rechtfertigung des Themas; Ziel der Tagung. In: RUPPE, Hans Georg (coord.). Gewinnrealisierung im Steuerrecht: Theorie und Praxis der Gewinnverwirklichung durch Umsatzakt und durch Steuerentstrichung sowie des Besteuerungsafuschubs. Köln: Otto Schmidt, 1981, p. 1-12.

TIPKE, Klaus; LANG, Joachim. Steuerrecht. 18ª Köln: Otto Schmidt, 2005. 
TORRES, Ricardo Lobo. A legitimação da capacidade contributiva e dos direitos fundamentais do contribuinte. In: SCHOUERI, Luís Eduardo (coord.). Direito Tributário: homenagem a Alcides Jorge Costa, vol. I. São Paulo: Quartier Latin, 2003, p. 429-456.

. Tratado de direito constitucional e financeiro tributário, v. II, valores e princípios constitucionais tributários. Rio de Janeiro: Renovar, 2005.

VENOSA, Sílvio de Salvo. Direito civil: contratos em espécie. $8^{\mathrm{a}} 2^{\mathrm{a}}$ reimpr. São Paulo: Atlas, 2008.

XAVIER, Alberto. Natureza jurídico-tributária dos "juros sobre capital próprio" face à lei interna e aos tratados internacionais. In: Revista dialética de direito tributário, v. 21. São Paulo: Dialética, junho de 1997, p. 7-11.

WARREN, Alvin. Fairness and a Consumption-Type or Cash Flow Personal Income Tax. In: Harvard Law Review, v. 88, n. 5, mar. 1975, p. 931-946.

. Would a Consumption Tax Be Fairer Than an Income Tax? In: The Yale Law Journal, v. 89, n. 6, maio de 1980, p. 1081-1124.

WHITE, Patricia D. Realization, Recognition, Reconciliation, Rationality and the Structure of the Federal Income Tax System, Michigan Law Review, v. 88, 1990. Artigo parcialmente reproduzido em CARON, Paul L. et alli. Federal income tax anthology. Cincinatti: Anderson Publishing Co., 1997, p. 208-212.

WUELLER, Paul H. Concepts of taxable income I - The german contribution. In: Political Science Quarterly, v. LIII, n. 1. New York: Columbia University, mar.1938, p. 83-110. . Concepts of taxable income II - The american contribution. In: Political Science Quarterly, v. LIII, n. 4. New York: Columbia University, dez.1938, p. 557-583. . Concepts of taxable income III - The italian contribution. In: Political Science Quarterly, v. LIV, n. 4. New York: Columbia University, dez.1939, p. 555-576.

ZILVETI, Fernando Aurelio. Princípios de direito tributário e a capacidade contributiva. São Paulo: Quartier Latin, 2003.

. O princípio da realização da renda. In: SCHOUERI, Luís Eduardo (coord.). Direito tributário: Homenagem a Alcides Jorge Costa, vol. I. São Paulo: Quartier Latin, 2003, p. 297-328. 